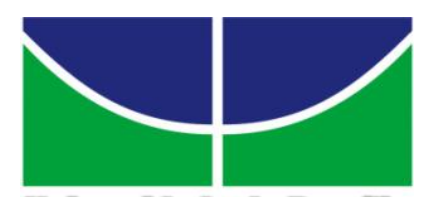

Tntucrsidacie do Brasilia

UNIVERSIDADE DE BRASÍLIA - UnB INSTITUTO DE CIÊNCIAS HUMANAS - IH DEPARTAMENTO DE GEOGRAFIA - GEA PROGRAMA DE PÓS-GRADUAÇÃO EM GEOGRAFIA

AS PAISAGENS REGIONAIS NA MICRORREGIÃO CERES (GO) DAS COLÔNIAS AGRÍCOLAS NACIONAIS AO AGRONEGÓCIO SUCROENERGÉTICO

Doutoranda: Lara Cristine Gomes Ferreira Orientador: Prof. Dr. Fernando Luiz Araújo Sobrinho

Brasília / DF 
LARA CRISTINE GOMES FERREIRA

\section{AS PAISAGENS REGIONAIS NA MICRORREGIÃO CERES (GO) - DAS COLÔNIAS AGRÍCOLAS NACIONAIS AO AGRONEGÓCIO SUCROENERGÉTICO}

Tese apresentada ao Programa de Pós-Graduação em Geografia, do Departamento de Geografia, da Universidade de Brasília, como Requisito para a Obtenção do Título de Doutora em Geografia.

Orientador: Prof. Dr. Fernando Luiz Araújo Sobrinho.

Brasília / DF, 30 de novembro de 2016. 


\section{AS PAISAGENS REGIONAIS NA MICRORREGIÃO CERES (GO) - DAS COLÔNIAS AGRÍCOLAS NACIONAIS AO AGRONEGÓCIO SUCROENERGÉTICO}

Tese apresentada ao Programa de Pós-Graduação em Geografia, da Universidade de Brasília, como parte dos requisitos para obtenção do título de Doutora em Geografia, aprovada em de de 2016, pela Banca Examinadora constituída pelos seguintes

Professores:

Prof. Dr. Fernando Luiz Araújo Sobrinho

Orientador - UnB

Profa. Dra. María José Piñeira Mantiñán

Universidade de Santiago de Compostela / Espanha

Prof. Dr. Adriano Rodrigues de Oliveira - IESA / UFG

Universidade Federal de Goiás - UFG

Prof. Dr. João Mendes da Costa Neto

Ministério do Planejamento

Prof. Dr. Juscelino Eudâmidas Bezerra

Universidade de Brasília - UnB 
Dedico esse trabalho à minha querida mãe, Maria Lúcia, à minha irmã Luciana e ao meu noivo Caio Sena, por simbolizarem o que realmente importa na vida: AMAR! Dedico também à minha avó, Juventina Carvalho, que saiu de Minas Gerais, na década de 1940, rumo à CANG, em busca de um futuro melhor. 


\section{AGRADECIMENTOS}

Saber agradecer é uma grande dádiva e, ao mesmo tempo, uma grande responsabilidade! Assim, inicio meus agradecimentos à Deus (ou a energia maior que nos move), por sempre direcionar meus caminhos, seja nos momentos difíceis, de dúvidas ou de alegrias.

Agradeço imensamente ao Departamento de Geografia (GEA), da Universidade de Brasília (UnB), que tão bem me acolheu nessa empreitada de quase quatro anos, e ao Programa de Pós-graduação em Geografia, em nome do Prof. Osmar Abílio Diniz. Agradeço também aos servidores do Programa, Jorge e Agnelo, pela presteza, simpatia e auxílios, sobretudo por telefone e e-mail, devido eu não residir em Brasília e necessitar, algumas vezes, de apoio à distância.

Agradeço aos professores vinculados ao Programa de Pós-graduação, em especial: Nelba Penna, Marília Peluso, Lúcia Cony e Osmar Abílio, que estiveram à frente das disciplinas por mim cursadas durante o doutoramento, e ao professor Everaldo Costa, pelo apoio e diálogos sobre o tema da pesquisa e sobre a vida.

Quero agradecer de forma muito especial ao meu querido orientador, Prof. Fernando Sobrinho, que de forma muito sábia soube conduzir a orientação, com reuniões, leituras, indicações e participação nos trabalhos de campo na microrregião Ceres. Para além da orientação acadêmica, tornou-se um grande amigo, apoiando minhas decisões e escolhas, principalmente durante a realização do Doutorado Sanduíche, na Espanha.

Agradeço aos membros da banca, os professores: Adriano Rodrigues, João Mendes, Maria José Piñeira e Juscelino Eudâmidas, por terem se disponibilizado prontamente a fazerem a leitura e avaliação desse trabalho. Reitero meus agradecimentos aos professores Adriano e João Mendes, pela participação também na banca de qualificação, em dezembro de 2014.

Agradeço aos amigos do Doutorado, sobretudo, Janaína Mourão, Edilene Américo e Roberto Pizarro, pelo carinho e momentos de descontração. Ao Roberto, meu "irmão" Chileno de orientação, muito obrigada pela parceria durante todo esse processo.

Agradeço também à Coordenação de Aperfeiçoamento de Pessoal de Nível Superior - CAPES, pela concessão de cinco meses de bolsa de estudos para a realização do estágio doutoral na Universidade de Santiago de Compostela (USC), Espanha. 
Aproveito para agradecer imensamente à Universidade de Santiago de Compostela, em nome da Profa. María José Piñeira Martiñan, por ter me coorientado durante a realização desse estágio. Obrigada por toda gentileza, cordialidade e diálogos enriquecedores! Agradeço aos professores Ruben Lóis e Xosé Santos pelas oportunidades concedidas: participação em trabalho de campo na Galícia e apresentação do meu projeto de tese aos alunos da disciplina de América Latina. Agradeço também à Angeles e Yamillé (do IDEGA), pelo apoio ao longo dos cinco meses na USC, bem como aos amigos brasileiros, Marco Mitidiero e Neila Coelho, amizades que Compostela trouxe para mim, por terem me "adotado" durante esses meses. Grata por todas as nossas aventuras europeias!

Agradeço aos colegas de trabalho do Laboratório de Estudos e Pesquisas das Dinâmicas Territoriais (Laboter) e do Instituto de Estudos Socioambientais - IESA / UFG, pelo apoio e compreensão durante esse processo. Agradeço à Direção do IESA, Profa. Celene Barreira, e à UFG por conceder minha licença para a realização do Doutorado Sanduíche. Meu muito obrigada aos colegas de trabalho: Charles Calisto, Ivonaldo Duarte, Romualdo Pessoa, Yuji Annoura, Denis Castilho e, especialmente, à Maria Geralda, pelo apoio e incentivo, desde meus primeiros pensamentos sobre a seleção de Doutorado na UnB; e, à Adriano Rodrigues, pela amizade, diálogos (acadêmicos ou frivolidades) e por tirar minhas várias dúvidas dentro da Geografia Agrária.

Por fim, agradeço e reitero meu carinho e admiração às pessoas que realmente estiveram ao meu lado nesse processo: minha família. Muito obrigada à todas e todos que sempre torceram e se preocuparam com minha pesquisa, mesmo que na maioria das vezes não compreendiam muito como é ser Doutora na Geografia, tamanha simplicidade e naturalidade.

Agradeço muito à minha mãe, Maria Lúcia, por todo empenho e dedicação em minha formação pessoal e educação. Agradeço pelo apoio, não só durante o período do doutorado, mas por tudo que significa em minha vida. Sem suas escolhas, decisões e luta jamais chegaria até aqui!

Agradeço também à minha irmã Luciana e a meu cunhado Mateus, que além de serem eternos apoiadores e pessoas queridas, foram essenciais durante o doutorado, acolhendo-me em sua casa e oferecendo todas as condições possíveis para que eu tivesse uma ótima estadia em Brasília.

Agradeço em especial ao meu noivo Caio Sena, um presente que a Geografia me deu, por todo carinho, apoio e por não medir esforços para me auxiliar no que fosse necessário durante o doutorado. Em momentos difíceis, como a retirada do visto para o 
estágio doutoral na Espanha, e em todos os momentos de alegria, esteve sempre ao meu lado. Gratidão e amor por tudo que construímos e construiremos a partir de agora.

À todas e todos que contribuíram para a realização dessa pesquisa, sejam: amigos, familiares, entrevistados, agentes sociais, enfim, àqueles que foram fundamentais para a conclusão desse trabalho.

Muito Obrigada! 
"Malditas sejam todas as cercas! Malditas todas as propriedades privadas que nos privam de viver e de amar! Malditas sejam todas as leis, amanhadas por umas poucas mãos, para ampararem cercas e bois e fazer da TERRA escrava e escravos os homens".

(Dom Pedro Casaldáliga) 


\section{RESUMO}

O tema da presente pesquisa versa sobre a territorialização do agronegócio sucroenergético na microrregião Ceres, Goiás, e como essa complexa atividade acaba por influenciar e dinamizar o campo e a cidade, bem como a região a qual está inserida. Parte-se do pressuposto que as problemáticas e os conflitos verificados, perpassam os limites dos municípios que possuem usinas implantadas, atuando, direta e indiretamente, nas dinâmicas socioeconômicas estabelecidas e nos efeitos materializados na paisagem regional. A pesquisa tem como principal recorte temporal a partir da década de 1940, que corresponde ao principal contexto de formação territorial da região, relacionado ao projeto das Colônias Agrícolas Nacionais (CANG), durante a Marcha para o Oeste. Entende-se assim, a importância de se considerar o recorte: das Colônias Agrícolas Nacionais ao momento atual, não somente pelo contexto de criação, consolidação e fragmentação municipal dessa região, mas também por representar duas temporalidades distintas: a CANG, enquanto estratégia de ocupação baseada na doação de lotes para a produção familiar e o momento atual, da lógica sucroenergética. Diante disso, o objetivo geral foi entender a produção do território na microrregião Ceres, a partir do contexto das CANG, ao agronegócio sucroenergético, na busca de identificar e compreender as dinâmicas socioespaciais, as redes estabelecidas, os agentes sociais envolvidos e as transformações na paisagem regional. Para tanto, foram necessárias etapas metodológicas relacionadas ao levantamento teórico-metodológico; realização do Doutorado Sanduíche, na Universidade de Santiago de Compostela (Espanha); realização de trabalhos de campo aos municípios da microrregião Ceres, para observação e entrevistas aos principais atores sociais envolvidos; além de tabulações, mapeamentos, análise e escrita de textos parcial e final. Como principais resultados, tem-se na atividade canavieira, um papel muito importante na (re) produção socioeconômica da microrregião Ceres, (re) funcionalização das redes técnica e urbana da região, assim como, a materialização das contradições socioespaciais na paisagem regional. Além disso, alguns elementos observados na microrregião Ceres como: a insuficiência da rede de objetos técnicos e de prestadoras de serviço, que contemplem a demanda da atividade sucroenergética atual, a sazonalidade da dinâmica socioeconômica, e a topografia acidentada de uma área relevante da região, que inviabiliza a mecanização total da colheita, contribuem para uma dinamização altamente concentrada e um desenvolvimento incompleto.

Palavras Chave: Agronegócio, Atividade Canavieira, Colônias Agrícolas Nacionais, Paisagem Regional, Desenvolvimento Incompleto, Mito do Progresso. 


\begin{abstract}
This research deals with the territorialization of the sugarcane agribusiness in Ceres microregion, Goiás, and clarify how this complex activity has an influence in the dynamic of countryside, city and region which is inserted. From the assumption that the problems and checked conflicts, beyond the limits of the municipalities that have sugarcane factories, because they act directly and indirectly, in the established socioeconomic dynamics and effects materialized in the regional landscape. This research fits temporally mainly from the 1940s, which is the context of territorial formation in the region, related with Colônia Agricola Nacional (CANG) during the Marcha para o Oeste. It is understood the importance of considering the temporal cut: Colônias Agricolas Nacionais to the present moment, not only the context of creation, consolidation and municipal fragmentation of the region, but also represent two different time frames: the CANG, while occupation strategy based on lots of donation or family production and the current time, with sugarcane logic. Thus, the general objective was to understand the production of territory in Ceres region, from the context of CANG, the sugarcane agribusiness, in order to identify and understand the socio-spatial dynamics, established networks, the social agents involved and the changes in the landscape regional. Therefore, it was necessary methodological steps related to the theoretical and methodological research; completion of the doctoral internship at the University of Santiago de Compostela (Spain); conducting field work in Ceres region municipalities, observation and interviews with key stakeholders involved; plus tabs, mapping, analysis and writing of partial and final texts. As main results, it has been in sugar production in a very important role in the (re) production socioeconomic of Ceres region, (re) functionalization of technical and urban networks in the region, as well as the materialization of socio-spatial contradictions in the regional landscape. In addition, some elements observed in Ceres region as: the failure of the network technical objects and service providers, that include the demand of the current sugarcane activity, seasonality of the socioeconomic dynamics, and the rugged topography of an area in the region, which infeasible the full mechanization of the harvest, contributing to a highly concentrated and an incomplete development.
\end{abstract}

Keywords: Agribusiness, Sugarcane Activity, Colônias Agrícolas Nacionais, Regional Landscape, Incomplete Development, Myth of Progress. 


\section{RESUMEN}

El tema de esta investigación se ocupa de la territorialización de la agroindustria de caña de azúcar en el región Ceres, Goiás, y cómo esta actividad tiene una influencia compleja y dinámica en el campo y la ciudad y la región que se inserta. Parte del supuesto de que los problemas y conflictos estudiados, sobrepasan los límites de los municipios que han establecido plantas industriales, que actúan directa e indirectamente, en la dinámica y en los efectos socioeconómicos materializados en el paisaje regional. La investigación tiene como principal recorte temporal el inicio de la década de 1940, que corresponde al contexto de formación territorial en la región, relacionado con el proyecto de las Colônias Agricolas Nacionales (CANG) durante la Marcha para el Oeste. Se entiende así la importancia de considerar el recorte: Colônias Agricolas Nacionales al tiempo presente, no sólo por el contexto de la creación, consolidación y la fragmentación municipal de la región, sino porque también representan dos marcos de tiempo distintos: La CANG como estrategia de ocupación basado en donación de lotes para la producción familiar y actualmente, la lógica de la caña de azúcar. Por lo tanto, el objetivo general es conocer la producción de territorio en el región Ceres, desde el contexto de CANG, la agroindustria de caña de azúcar, con el fin de identificar y comprender las dinámicas socio-espaciales, las redes establecidas, los agentes sociales implicados y los cambios en el paisaje regional. Por lo tanto, fueron necessários algunos pasos metodológicos, relacionados con el estudio teórico y metodológico; realización de una pasantía de Doctorado en la Universidad de Santiago de Compostela (España); la realización de trabajos de campo a los municipios de región Ceres, para la observación y entrevistas con actores sociales claves; además de tabulaciones, cartografía, análisis y escritura de textos parciales y finales. Como principales resultados, se observa que la producción de caña de azúcar tiene un papel muy importante en la (re) producción socioeconómica de la región Ceres, (re) funcionalizando las redes técnicas y urbanas, así como la materialización de las contradicciones socio-espaciales en el paisaje regional. Además, algunos de los elementos observados en la región Ceres, como la insuficiencia de la red de los objetos técnicos y proveedores de servicios que se ocupan de la demanda de la actividad de la caña de azúcar actual, la estacionalidad de la dinámica socioeconómica, y la topografía accidentada de un área relevante de la región, lo que impide la mecanización completa de la cosecha, lo que contribuye a una alta concentración y un desarrollo incompleto.

Palabras clave: Agroindustrias, Actividad de caña de azúcar, Colônias Agricolas Nacionales, Paisaje Regional, desarrollo incompleto, Mito del Progreso. 


\section{LISTA DE FIGURAS}

Figura 1 - Localização da microrregião Ceres em Goiás.

Figura 2 - Gráfico da evolução da produção brasileira de cana-de-açúcar. ..............................52

Figura 3 - Gráfico da evolução da produção brasileira de etanol........................................... 53

Figura 4 - Gráfico da evolução da produção brasileira de açúcar.......................................... 53

Figura 5 - Zoneamento Agroecológico da Cana-de-açúcar para Goiás .................................. 60

Figura 6 - Mapa da espacialização das usinas sucroalcooleiras de Goiás............................... 62

Figura 7 - Espacialização das usinas canavieiras, as principais massas d'água e os pivôs centrais no estado de Goiás.

Figura 8 - Projetos contratados no Produzir - Representatividade dos Investimentos por

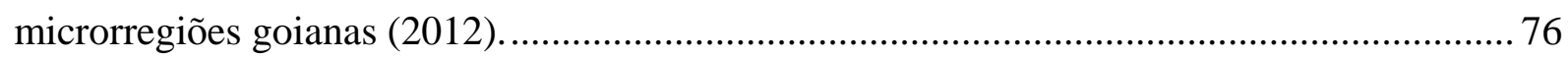

Figura 9 - Investimento fixo por ramo de atividade - Produzir .......................................... 76

Figura 10 - Faturamento (em R\$ bilhões) do setor industrial do Estado de Goiás - 1999 a

2010 . 78

Figura 11 - Espacialização das 18 microrregiões do estado de Goiás, segundo o IBGE......... 82

Figura 12 - Espacialização das 10 Regiões de Planejamento de Goiás, segundo a Segplan....84

Figura 13 - Escritório da CANG.

Figura 14 - Construção da ponte sobre o Rio das Almas, entre a CANG e o povoado de Barranca.

Figura 15 - População total, urbana e rural da CANG (até 1952) e Ceres (a partir de 1953).106

Figura 16 - Fragmentação territorial da microrregião Ceres e os principais contextos de emancipação.

Figura 17 - População urbana e rural da microrregião Ceres - anos 1980 a 2010.

Figura 18 - Espacialização das usinas sucroenergéticas implantadas na microrregião Ceres, em funcionamento e propostas.

Figura 19 - Fachada do Hospital São Pio X em Ceres, nos anos 1950. 126

Figura 20 - Principais rodovias (estadual e federal) da microrregião Ceres e os empreendimentos sucroenergéticos. 
Figura 21 - Programa de expansão ferroviária - trechos de expansão. 135

Figura 22 - Trechos das ferrovias concluídas e em construção - foco para Goiás. 136

Figura 23 - Linhas de transmissão de energia elétrica em Goiás e as usinas sucroalcooleiras implantadas.....

Figura 24 - Ilustração simplificada do processo de cogeração de energia elétrica nas usinas sucroenergéticas.

Figura 25 - Classes de declividade na microrregião Ceres. ................................................. 149

Figura 26 - Produção de cana-de-açúcar - Microrregião Ceres, 2000................................... 151

Figura 27 - Produção de cana-de-açúcar - Microrregião Ceres, 2007................................... 152

Figura 28 - Produção de cana-de-açúcar - Microrregião Ceres, 2011 .................................. 153

Figura 29 - Produção de cana-de-açúcar - Microrregião Ceres, 2012 .................................. 154

Figura 30 - Produção de cana-de-açúcar - Microrregião Ceres, 2015.................................. 155

Figura 31 - Área plantada (ha) com cana-de-açúcar na microrregião Ceres - 2013/2014.....156

Figura 32 - Usinas localizadas na Microrregião Ceres (período de 2009 a 2016)................. 161

Figura 33 - Colheita mecanizada no município de Itapaci................................................. 163

Figura 34 - Cana queimada para colheita manual no município de Carmo do Rio Verde..... 163

Figura 35 - Placa do Fomentar na usina Jalles Machado em Goianésia. ................................ 165

Figura 36 - Placa do Produzir na usina CRV Industrial em Carmo do Rio Verde................. 165

Figura 37 - Uso da vinhaça para fertirrigação em Goianésia................................................ 166

Figura 38 - Canal de vinhaça na usina Cooper Rubi.......................................................... 167

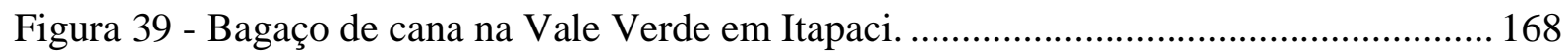

Figura 40 - Confinamento de gado pela Vera Cruz Agropecuária em Goianésia.................. 169

Figura 41 - Selos de certificação da Usina Jalles Machado. ............................................. 170

Figura 42 - Área de produção orgânica da usina Jalles Machado em Goianésia................... 171

Figura 43 - Pacotes com derivações de açúcar orgânico da marca Itajá. ............................... 171

Figura 44 - Vera Cruz Agropecuária, em Goianésia.......................................................... 172

Figura 45 - Produção de seringueira, em Goianésia......................................................... 172 
Figura 46 - Área urbana edificada de Carmo do Rio Verde e a usina CRV Industrial.......... 175

Figura 47 - Planta industrial da CRV Industrial, Carmo do Rio Verde. ............................... 176

Figura 48 - Lavoura de cana, rodovia e fumaça ao fundo, em Carmo do Rio Verde. ........... 176

Figura 49 - Treminhões para colheita de cana, Carmo do Rio Verde................................... 177

Figura 50 - Rodovia em péssimas condições devido o transporte de treminhões, Rubiataba.

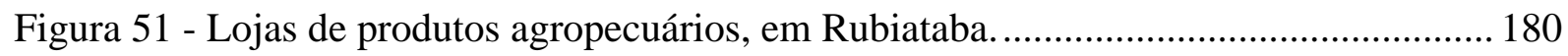

Figura 52 - Presença de loja Valtra Borgato, em Goianésia. ............................................. 180

Figura 53 - Ônibus utilizado para transporte rural, em Carmo do Rio Verde........................ 181

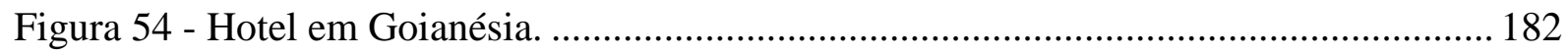

Figura 55 - Ônibus do SENAI, manutenção mecânica, em Carmo do Rio Verde.................. 183

Figura 56 - Ônibus do SENAI, manutenção de máquinas agrícolas, em Carmo do Rio Verde..

Figura 57 - A microrregião Ceres e a região de influência de Goiânia - REGIC 1978......... 197

Figura 58 - A microrregião Ceres e a região de influência de Goiânia - REGIC 1993......... 199

Figura 59 - A microrregião Ceres e a região de influência de Goiânia - REGIC 2007......... 200

Figura 60 - Espacialização das agências bancárias da microrregião Ceres - 2014................ 205

Figura 61 - Presença de SICOOB em Carmo do Rio Verde, Goiás ....................................... 207

Figura 62 - Gráfico com o percentual dos ocupados nos setores agropecuário, industrial e serviços, municípios da Microrregião Ceres, GO -2010 ................................................. 210

Figura 63 - Taxa de analfabetismo e percentual de pessoas sem fundamental completo e em ocupação informal - microrregião Ceres / 2010.

Figura 64 - Empresa/Distribuidora Saborelle - Rialma, Goiás.

Figura 65 - Localização dos municípios de Santa Isabel, São Luiz do Norte e Nova Glória na Microrregião Ceres, Goiás.

Figura 66 - Cultivo de cana-de-açúcar em Santa Isabel no período da entressafra - Santa Isabel, Goiás.

Figura 67 - Imagem de São Luiz do Norte e os talhões de cana-de-açúcar e pivôs centrais.. 220

Figura 68 - Treminhão no perímetro urbano - São Luiz do Norte, Goiás. 221 
Figura 69 - Imagem de Nova Glória e os talhões de cana-de-açúcar.

Figura 70 - Avião pulverizador de veneno utilizado nas lavouras de cana-de-açúcar - Nova

Glória, Goiás.

Figura 71 - Plantio de hortaliças na CANG................................................................ 233

Figura 72 - Produção de alimentos na CANG................................................................... 233

Figura 73 - Mercado municipal de Ceres, GO............................................................... 234

Figura 74 - Mercado municipal de Ceres internamente.................................................. 235

Figura 75 - Lavoura de cana-de-açúcar na Microrregião Ceres........................................... 236

Figura 76 - Plantio de mandioca em lote baldio, no município de Itapaci............................ 236

Figura 77 - Produção de mandioca na calçada em Itapaci.. ............................................... 237

Figura 78 - Colheita de café feita por mulheres, na CANG............................................ 238

Figura 79 - Técnicas rudimentares utilizadas na CANG.................................................. 238

Figura 80 -Transporte da colheita de forma mecanizada em Itapaci - GO......................... 239

Figura 81 - Transbordo da cana colhida na usina Jalles Machado, Goianéisa, Goiás........... 239

Figura 82 - Vegetação típica do “mato grosso de Goiás”................................................... 241

Figura 83 - Placa na rodovia indicando o intenso tráfego de treminhões entre os municípios de Rubiataba e Carmo do Rio Verde................................................................................. 242

Figura 84 - Parte de um treminhão abandonado em lote baldio, em Itapaci......................... 243

Figura 85 - Placas em agradecimento à família Lage em Goianésia.................................. 243

Figura 86 - Mapa síntese das Paisagens Regionais da Microrregião Ceres, Goiás............... 245

Figura 87 - Famílias assentadas em Goiás - série histórica. ............................................ 248

Figura 88 - Sede da Cooperativa de Agricultores Familiares - Cooperafi, Itapuranga......... 256

Figura 89 - Mulheres Rurais do Xixá, na Cooperafi, Itapuranga.. .................................... 257 


\section{LISTA DE TABELAS}

Tabela 1 - Destilarias em operação e produção de cana de açúcar, etanol e açúcar - 2005 2013, no estado de Goiás.

Tabela 2 - Projetos Contratados do Produzir por microrregiões - 2001 a Maio de 2012......... 77

Tabela 3 - População total dos municípios da microrregião Ceres - GO.

Tabela 4 - Produção de cana-de-açúcar para os municípios da Microrregião Ceres - 2000 a 2012 (toneladas).

Tabela 5 - Principais produtos agrícolas da microrregião Ceres - com exceção à cana-deaçúcar / 2015

Tabela 6 - Principais Atividades Econômicas Financiadas pelo Produzir na microrregião

Ceres $-\mathrm{GO}$.

Tabela 7 - Produto Interno Bruto (PIB) da Microrregião Ceres - GO.

Tabela 8 - Dados do IDH dos Municípios da Microrregião Ceres - GO.

Tabela 9 - Área, Produção e Produtividade de cana de açúcar, em série histórica -

Microrregião Ceres

Tabela 10 - Densidade Demográfica da Microrregião Ceres............................................... 203

Tabela 11 - Agências bancárias nos municípios da Microrregião Ceres - 2014 ..................... 204

Tabela 12 - Valor Adicionado Bruto a Preços Básicos (R\$ mil) / 2012 .............................. 208

Tabela 13 - Percentual da Renda Apropriada pelos 20\% mais ricos e Percentual de Pobreza

Microrregião Ceres / 2010.

Tabela 14 - Produção de cana-de-açúcar e área colhida nos município de Santa Isabel, São

Luiz do Norte e Nova Glória - 2013

Tabela 15 - Agricultores familiares e reforma agrária na microrregião Ceres - GO............ 250

Tabela 16 - Programa Nacional de Fortalecimento da Agricultura Familiar - PRONAF (2015)

Tabela 17 - Recursos Produzir para as usinas da Microrregião Ceres - GO 


\section{LISTA DE QUADROS}

Quadro 1 - Quadro esquemático dos capítulos da tese. 38

Quadro 2 - Contextos importantes de expansão e crise canavieira no Brasil. 49

Quadro 3 - Destilarias em Goiás e a Produção de Energia 66

Quadro 4 - Principais Programas de Governo para o Estado de Goiás e os Impactos Regionais.

Quadro 5 - Data de Emancipação e Municípios de origem - Microrregião Ceres - GO....... 108

Quadro 6 - Histórico de Implantação dos Empreendimentos Canavieiros na Microrregião

Ceres.

Quadro 7 - Potência de energia elétrica gerada pelos empreendimentos sucroenergéticos da microrregião Ceres - GO

Quadro 8 - Dados da Cogeração de Energia - Usina Jalles Machado ................................... 142

Quadro 9 - Detalhes de Produção - Usinas da Microrregião Ceres / GO. 164

Quadro 10 - Correspondência entre Categorias de Centros do REGIC para a Microrregião Ceres / 1978, 1993 e 2007 196 


\section{LISTA DE SIGLAS}

ANEEL - Agência Nacional de Energia Elétrica.

BUQI - Bureau Ventas Quality International.

$\mathrm{CAI}$ - Complexos Agroindustriais.

CANG - Colônia Agrícola Nacional de Goiás.

CAPES - Coordenação de Aperfeiçoamento de Pessoal de Nível Superior.

CELG - Centrais Elétricas de Goiás.

CENAL - Comissão Executiva Nacional do Álcool.

CHESP - Companhia Hidroelétrica São Patrício.

CNP - Conselho Nacional do Petróleo.

DAIA - Distrito Agroindustrial de Anápolis.

FACER - Faculdade de Ceres.

FCO - Fundo Constitucional de Financiamento do Centro-Oeste.

FOMENTAR - Fundo de Fomento a Industrialização do Estado de Goiás

GEE - Gases do Efeito Estufa.

IAA - Instituto do Açúcar e do Álcool.

IBGE - Instituto Brasileiro de Geografia e Estatística.

ICMS - Imposto sobre Circulação de Mercadorias e Serviços

IDH - Índice de Desenvolvimento Humano.

IFGOIANO - Instituto Federal Goiano.

IMB - Instituto Mauro Borges.

INCRA - Instituto Nacional de Colonização e Reforma Agrária. 
INPE - Instituto Nacional de Pesquisas Espaciais.

ISSQN - Imposto sobre Serviços de Qualquer Natureza.

LOER - Locadora Entre Ríos.

MAPA - Ministério de Agricultura, Pecuária e Abastecimento.

MME - Ministério de Minas e Energia.

PAA - Programa de Aquisição de Alimentos.

PAC - Programa de Aceleração do Crescimento.

PCH - Pequena Central Hidrelétrica.

PIB - Produto Interno Bruto.

PNAE - Programa Nacional de Alimentação Escolar.

PND - Plano Nacional de Desenvolvimento.

PNRA - Plano Nacional de Reforma Agrária.

POLOCENTRO - Programa de desenvolvimento dos Cerrados

PROÁLCOOL - Programa Nacional do Álcool.

PRODECER - Programa de Desenvolvimento do Cerrado.

PRODUZIR - Programa de Desenvolvimento Industrial de Goiás

PROINFA -Programa de Incentivo às Fontes Alternativas de Energia.

PRONAF - Programa Nacional de Fortalecimento da Agricultura Familiar

REGIC - Região de Influência das Cidades.

RPA - Regiões Produtivas do Agronegócio.

SEGPLAN - Secretaria de Gestão e Planejamento de Goiás.

SENAI - Serviço Nacional de Aprendizagem Industrial 
SICOOB - Sistema de Cooperativas de Crédito do Brasil

SIFAEG - Sindicato da Indústria de Fabricação de Etanol do Estado de Goiás

SUDAM - Superintendência de Desenvolvimento da Amanzônia.

SUDECO - Superintendência de Desenvolvimento do Centro-Oeste.

UEG - Universidade Estadual de Goiás.

UFG - Universidade Federal de Goiás.

UMESP - Universidade Metodista de São Paulo.

UNB - Universidade de Brasília.

ÚNICA - União da Indústria da Cana-de-açúcar.

UNINTER - Centro Universitário Internacional.

UNIP - Universidade Paulista.

UNOPAR - Universidade Norte do Paraná. 


\section{SUMÁRIO}

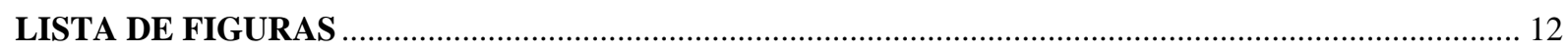

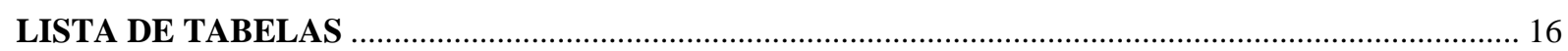

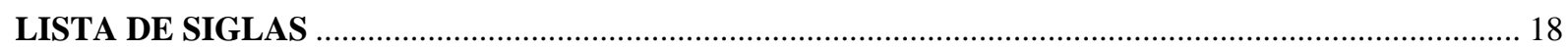

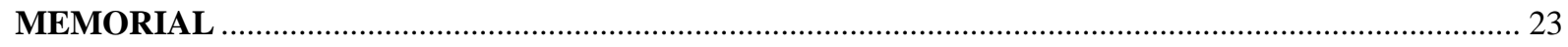

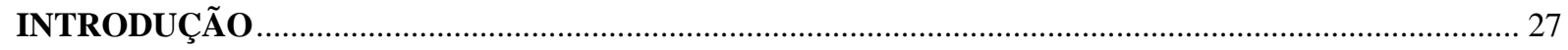

APRESENTAÇÃO DA PESQUISA - RECORTES E PROBLEMATIZAÇÃO …………………………... 32

CAPítulo I - O MOVIMENTO do CAPITAL E A TERRITORIALIZAÇÃo DA CANA-DE-

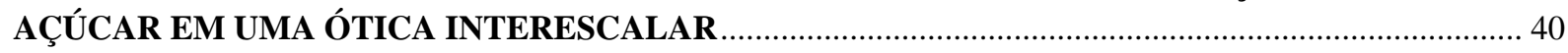

1.1 A TERRITORIALIZAÇÃO DA CANA-DE-AÇÚCAR NO BRASIL - CONTEXTOS DE EXPANSÃO ... 43

1.2 A PRODUÇÃO DO TERRITÓRIO GOIANO PELO AGRONEGÓCIO SUCROENERGÉTICO E O

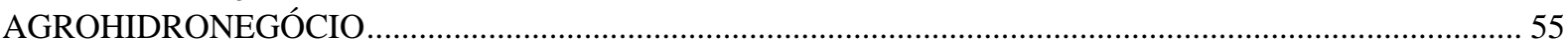

1.3 ESTADO E CAPITAL - UMA REFLEXÃO SOBRE O PAPEL DO ESTADO COMO AGENTE DE

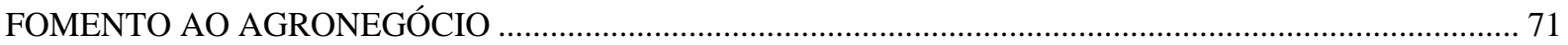

1.4 A ABORDAGEM REGIONAL NO DEBATE DO AGRONEGÓCIO SUCROENERGÉTICO ................... 79

CAPÍtulo II - A MiCRORREGIÃo CERES (GO): DAS COLÔNIAS AGRícolas AO

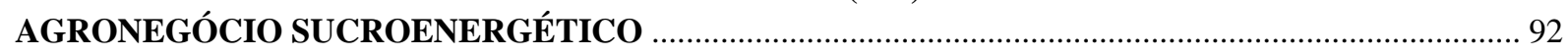

2.1. O PROCESSO DE CONSTITUIÇÃO HISTÓRICA DA MICRORREGIÃO CERES - GO ......................... 93

2.2. CARACTERIZAÇÃO SOCIOECONÔMICA DA MICRORREGIÃO CERES.......................................... 105

2.3. A CONFIGURAÇÃO DA REDE TÉCNICA NA MICRORREGIÃO CERES - A IMPORTÂNCIA DA

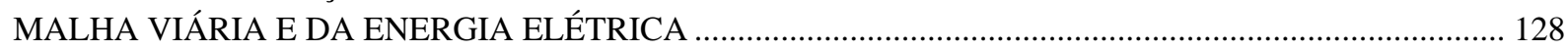

2.3.1 A LOGÍSTICA DOS TRANSPORTES - OBJETOS TÉCNICOS FUNDAMENTAIS PARA A CIRCULAÇÃO DO AGRONEGÓCIO.

2.3.2 A PRODUÇÃO DE ENERGIA ELÉTRICA PELA BIOMASSA DA CANA-DE-AÇÚCAR - A BASE

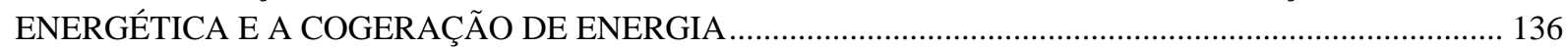

CAPÍTULO III - A ATIVIDADE SUCROENERGÉTICA, SUAS FORMAS E A RELAÇÃO CAMPOCIDADE NA MICRORREGIÃO CERES - GO 145

3.1 A DINÂMICA SUCROENERGÉTICA NA MICRORREGIÃO CERES E A RELAÇÃO CAMPO-CIDADE

3.2 AS USINAS SUCROENERGÉTICAS DA MICRORREGIÃO CERES - SEMELHANÇAS E ESPECIFICIDADES

3.3 AS FORMAS E AS DEMANDAS VINCULADAS AO SETOR SUCROENERGÉTICO NA MICRORREGIÃO CERES 
CAPÍTULO IV - A FORMAÇÃO DA REDE URBANA E O ORDENAMENTO TERRITORIAL PELA DINÂMICA CANAVIEIRA: A "NOVA" CONFIGURAÇÃO SOCIOESPACIAL …………………….... 186

4.1. A REDE URBANA E O ORDENAMENTO TERRITORIAL - ALGUNS APONTAMENTOS ............... 187

4.2. A "NOVA" CONFIGURAÇÃO SOCIOESPACIAL PELA DINÂMICA SUCROENERGÉTICA NA MICRORREGIÃO CERES

4.3. AS CIDADES QUE SERVEM AO AGRONEGÓCIO SUCROENERGÉTICO: O CASO DE SANTA ISABEL, SÃO LUIZ DO NORTE E NOVA GLÓRIA

CAPÍTULO V - A PAISAGEM REGIONAL E O MITO DO PROGRESSO - O DESENVOLVIMENTO INCOMPLETO DA MICRORREGIÃO CERES

5.1. A PAISAGEM REGIONAL DA MICRORREGIÃO CERES - DA CANG AO SETOR

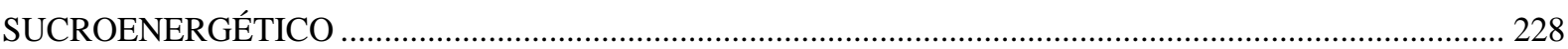

5.2. AS POLÍTICAS DE ACESSO À TERRA NA MICRORREGIÃO CERES: ALTERNATIVAS AO AGRONEGÓCIO CANAVIEIRO.

5.3. A MICRORREGIÃO CERES E O DESENVOLVIMENTO ECONÔMICO - O MITO DO PROGRESSO

REFERÊNCIAS 


\section{MEMORIAL}

Nasci na cidade de Goiânia, Goiás, no ano de 1986, filha de uma Carmo Rio Verdina e de um Ceresino (nascidos em Carmo do Rio Verde e Ceres, municípios do estado de Goiás), que se casaram no município de Rialma e vieram viver na capital Goiânia. Vivo na cidade de Aparecida de Goiânia, onde cursei todo o meu ensino básico e médio, na Escola Estadual José Alves de Assis.

A Geografia surgiu inicialmente, como uma disciplina muito interessante na escola, que mesmo sendo pública me deu bases, intelectuais e pessoais, que levarei para sempre. Posteriormente, no ano de 2004, essa disciplina passou a fazer parte do meu cotidiano, dos meus pensamentos, leituras e angústias, quando iniciei o curso de Geografia na Universidade Federal de Goiás.

Durante a graduação (2004 - 2007) apaixonei-me pela Geografia e pelas inúmeras possibilidades que surgiram. Participei de projetos de pesquisa e extensão nas áreas de Climatologia, Planejamento Urbano e Regional e Geografia física. Isso pode soar estranho para muitos acadêmicos, que começam a iniciação científica com determinado tema e com ele seguem até o doutoramento. Para mim, acredito que foi fundamental adentrar várias linhas de pesquisa na Geografia, pois possibilitou-me crescer enquanto Geógrafa, primeiramente, para depois ter mais clareza e maturidade para verticalizar na linha de pesquisa que estou atualmente. Destaco que esse caminho não foi o mais fácil!

No ano de 2006, fui selecionada para uma bolsa de Iniciação Científica (PIBIC), junto ao Prof. João de Deus, o qual coordenava um projeto de pesquisa que se preocupava em compreender a Formação Territorial de Goiás e a importância do planejamento urbano e regional. Para o desenvolvimento desse projeto, foi proposto pelo orientador, que os bolsistas (incluindo eu) elegessem uma microrregião do estado de Goiás (das 18 microrregiões propostas pelo Instituto Brasileiro de Geografia e Estatística - IBGE) para o recorte espacial das pesquisas individuais.

Nesse momento, logo me interessei em pesquisar a microrregião Ceres, que não era tão estranha aos meus olhos, visto que meus pais lá nasceram e desde a infância fazia parte das minhas férias, em visitas às avós e familiares. Mas, pesquisar requer muita responsabilidade, disciplina, interpretação científica e, muitas vezes, um olhar racional sobre as problemáticas verificadas. O que inicialmente fora movido por questões afetivas, passa a 
ter uma conotação profissional e a despertar angústias e questionamentos nunca levantados antes da Geografia.

Durante a realização da monografia, fui levada (pela minha curiosidade geográfica e participação no Laboratório de Geografia Física do IESA / UFG) a pesquisar a Alta Bacia do Rio Araguaia e os impactos ambientais decorrentes dos processos erosivos hídricos, que tinham uma susceptibilidade natural, mas eram potencializados pelo uso e ocupação, sobretudo, a agropecuária. A partir desse momento na graduação, percebi que o que realmente me movia geograficamente, era compreender os processos, as dinâmicas e os efeitos humanos no espaço geográfico. Assim, para o projeto de mestrado, propus o retorno aos estudos na microrregião Ceres, mas agora com o objetivo de pensar e compreender a expansão canavieira nessa região, algo tão perceptível durante minhas visitas a algumas cidades.

No mestrado (2008 - 2010), também realizado na Universidade Federal de Goiás, sob orientação do Prof. João de Deus, propus estudar a evolução da cana-de-açúcar e os impactos socioeconômicos na microrregião Ceres. Essa importante etapa foi concluída no ano de 2010, que culminou com minha aprovação em um concurso, para a função de Geógrafa, dentro do quadro técnico da UFG. Essa vaga era para atender ao Laboratório de Estudos e Pesquisas das Dinâmicas Territoriais (Laboter), do Instituto de Estudos Socioambientais (IESA).

Nesse momento, decidi que era fundamental colocar a Geografia em prática! Era momento de participar da dinâmica de um Laboratório acadêmico, envolver com as pesquisas, trabalhos de campo, organização de eventos acadêmicos e, além de desenvolver as funções que a mim cabiam enquanto servidora, aprender novas teorias, metodologias, bem como crescer com os desafios apresentados. O Laboter é um Laboratório bastante dinâmico dentro da Geografia da UFG, há importantes linhas de pesquisas que versam sobre: Geografia Cultural e Turismo, Geografia Agrária, Demografia, Geopolítica e Epistemologia da Geografia, e enquanto Geógrafa do mesmo, fui desafiada a trabalhar diretamente com algumas dessas linhas.

Nos primeiros anos, trabalhei diretamente com os projetos de pesquisa e extensão da Profa. Maria Geralda de Almeida, sobretudo, os relacionados aos efeitos do turismo em áreas de quilombolas Kalunga, no nordeste do estado de Goiás. Foi durante o desenvolvimento de um desses projetos, sob a coordenação da referida professora, em parceria com a Universidade de Brasília (UnB), que conheci os professores Fernando Sobrinho e Everaldo Costa, do Departamento de Geografia desta Universidade. 
A partir de 2012, com a vinda do Prof. Adriano Rodrigues de Oliveira, para o quadro de docentes do IESA / UFG, e sua inserção no Laboter, comecei a colaborar também nas atividades desenvolvidas por ele e, posteriormente, pelo Grupo de Pesquisa Trabalho, Território e Políticas Públicas (TRAPPU), e a contribuir e aprender com os projetos, eventos realizados e momentos ricos de debate, dentro da Geografia Agrária.

Por meio dos encontros proporcionados inicialmente pelos projetos da Profa. Maria Geralda, comecei a manter um diálogo profícuo com o Prof. Fernando Sobrinho, que além de estudos e pesquisas relacionadas ao turismo, também se interessava pela abordagem regional, tão cara às minhas pesquisas acadêmicas. Assim, no ano de 2013, candidatei-me ao processo seletivo de doutorado na Universidade de Brasília, o qual fui aprovada, sob orientação do Prof. Fernando.

Decidi no doutoramento, dar continuidade aos questionamentos e angústias que surgiram no mestrado, além de ampliar as discussões de uma agenda de pesquisa iniciada na Iniciação Científica da UFG. O projeto de doutorado foi se delineando, e hoje a tese está sendo apresentada à presente banca, com o intuito de compreender A Paisagem Regional na Microrregião Ceres (GO) - Das Colônias Agrícolas Nacionais ao Agronegócio Sucroenergético.

Durante o doutorado tive a oportunidade de realizar o estágio sanduíche, com bolsa CAPES, na Universidade de Santiago de Compostela, Espanha, sob supervisão da Profa. María José Piñeira Mantiñán, durante os meses de abril a agosto de 2015. Foi um momento ímpar na minha vida acadêmica e pessoal, que possibilitou diálogos com pesquisadores e literaturas estrangeiras, estabelecimento de redes de pesquisa, além da participação e apresentação de artigo científico, relacionado à temática da tese, no Congresso SETED (vinculado ao Grupo de Investigación: Estado, Territorio y Desarrollo), realizado em Santiago de Compostela, em julho de 2015.

Diante do exposto, destaco que tive a oportunidade de orientar trabalhos de monografia na graduação em Geografia e na especialização em Agroecologia, coordenada pelos Professores Marcelo Mendonça e Adriano Rodrigues, além de participar de algumas bancas de trabalho de conclusão de curso. Atualmente, assumi a vice-coordenação do Laboter, para a gestão 2016 - 2018, junto ao Prof. Romualdo Pessoa (coordenador), com o intuito de dar continuidade ao trabalho já desenvolvido pelo Laboratório, bem como contribuir com o fortalecimento das linhas de pesquisa existentes e com as atividades de pesquisa e extensão, que são marcas do trabalho coletivo nesse Laboratório. 
Diante desse memorial, ressalto que todas as atividades citadas contribuíram sobremaneira, para minha formação pessoal, acadêmica e profissional e, consequentemente, para o desenvolvimento da presente tese. Essa breve apresentação, teve o intuito de introduzir minha rápida trajetória na Geografia, para, a partir de agora, dar início ao desenvolvimento da pesquisa proposta. 


\section{INTRODUÇÃO}

O constante movimento do capital, juntamente aos processos e dinâmicas inerentes a ele, são responsáveis pela produção do espaço geográfico e muitas de suas problemáticas são materializadas no território, sendo possível verificá-las por meio da configuração da paisagem. Essas três categorias geográficas: Espaço, Território e Paisagem são fundamentais para compreender a realidade e as problemáticas postas. Com o advento das técnicas e, ao longo do tempo, com a modernização, houve a intensificação da acumulação, desenvolvimento da industrialização e expansão da fronteira agrícola (baseada em técnicas e insumos cada vez mais modernos), além do processo de urbanização.

Fica cada vez mais evidente a intensidade dos processos, a efemeridade das relações e a imanente intencionalidade com que os atores sociais (re) produzem a vida em sociedade. A formação socioespacial brasileira apresenta vários contextos chaves para se entender algumas transformações verificadas em seu território, nessa pesquisa parte-se da tentativa de se compreender a territorialização da atividade canavieira no Brasil e seus desdobramentos socioespaciais, em particular para a microrregião Ceres, localizada no estado de Goiás, por entender que a atividade canavieira, em seus primórdios, e a lógica sucroenergética atual, apresenta ricos elementos, "novos" e "velhos" de apropriação, que contribuem para o desvelar das contradições.

A atividade canavieira, que conjuga produção, processamento e circulação dos produtos, por meio de um sistema agroindustrial é bastante complexa, pois acaba por influenciar e dinamizar o campo e a cidade, o rural e o urbano, bem como a região a qual está inserida, sendo fundamental portanto, proceder à análise pela abordagem regional, pois essas problemáticas perpassam os limites municipais influenciando direta e indiretamente as dinâmicas socioeconômicas estabelecidas e os efeitos materializados.

Durante o período colonial brasileiro, o desenvolvimento da economia variou de acordo com os interesses e as oscilações da metrópole Portuguesa e do mercado internacional da época. Destacam-se três produtos nesse contexto: primeiro, o Pau-Brasil, seguido pelo açúcar e a mineração, sobretudo a extração do ouro. Durante esse período, cada um deles experimentou o seu momento de expansão e a sua fase de decadência, sendo que foi durante a República Oligárquica (1889-1930) que se verificou o auge e a decadência da atividade canavieira. 
Nos anos 1930 foi criado o Instituto do Açúcar e do Álcool no Brasil (IAA) e a intervenção estatal dominou praticamente toda a estrutura do setor, sendo responsável pelo ciclo de produção e comercialização, inclusive fixação de preços, cotas, exportação e importação (UNICA, 2007). Mas, foi no período pós-guerra, com a introdução de máquinas na agricultura, por meio da importação de tratores, de elementos químicos, como fertilizantes e defensivos agrícolas, e mudanças de ferramentas e de culturas ou incorporação de novas variedades de insumos, que as agroindústrias, de modo geral, desenvolveram-se.

Somado a esse contexto, destacam-se dois momentos fundamentais para o estímulo à produção canavieira e produção de álcool no Brasil: primeiramente, a crise mundial do açúcar e, logo em seguida, as sucessivas crises mundiais do petróleo (em 1975 e 1979); e a criação, no Brasil, do Programa Nacional do Álcool (Proálcool). Em decorrência desse contexto mundial a autossuficiência energética foi amplamente estimulada no Brasil (por ser um elemento geopolítico de suma importância), sobretudo pelos Planos Nacionais de Desenvolvimento (PND's) durante o Regime Militar. Diante disso, houve durante essa década, a intensificação da expansão canavieira e a territorialização de destilarias e/ou usinas ${ }^{1}$ em todo território nacional.

Além do Proálcool, um contexto mais recente merece atenção. Em meados dos anos 2000 houve um verdadeiro boom canavieiro, muito associado inicialmente com a crise global de energia, com a crescente preocupação ambiental, que propunha a produção de combustíveis alternativos à gasolina (principalmente após o Protocolo de Kyoto), o que culminou com o crescimento do uso de biocombustíveis (como o etanol) e de biodiesel, amparados no Brasil, pelo Plano Nacional de Agroenergia (2006 - 2011).

A partir do ano 2006 observou-se um incremento notável das áreas plantadas com cana-de-açúcar, do número de usinas em funcionamento e em processo de implantação e o desenvolvimento de políticas federais e estaduais importantes para o setor, já que despontava como maior produtor mundial de etanol derivado da cana. Os estados de São Paulo (maior produtor nacional), Minas Gerais, Goiás e Mato Grosso do Sul são os que apresentavam maior expansão em área plantada de cana-de-açúcar e instalação de empreendimentos. Destaca-se que após essa ascensão, o setor vem enfrentando novamente crises, com o fechamento de algumas usinas. De acordo com a União Nacional da Indústria de Cana-de-

\footnotetext{
${ }^{1}$ Geralmente o termo "destilaria” está associado à produção somente de álcool combustível, já o termo "usina” é mais amplo, designando a produção de açúcar, álcool e outros produtos.
} 
açúcar (ÚNICA, 2013), mais de 40 usinas deixaram de funcionar, entre 2008 e 2012, sendo 30 delas apenas entre 2011 e 2012.

A microrregião Ceres, localizada na mesorregião Centro Goiano, foi estudada em pesquisa anterior, e foi possível conhecer a expansão sucroalcooleira e os principais impactos socioeconômicos, frutos do complexo canavieiro, nos municípios-sede das usinas, ou seja, em cinco municípios da região: Goianésia, Itapaci, Itapuranga, Rubiataba e Carmo do Rio Verde. Contudo, observou-se que há uma refuncionalização dos equipamentos urbanos e da rede urbana local e regional para servir às demandas da atividade sucroenergética ${ }^{2}$. Desta forma, percebeu-se nos municípios que sofrem influência direta e indireta da atividade sucroenergética, uma produção do território diferenciada, que se realiza em prol das demandas do setor e das exigências do capital. As (re) configurações da rede urbana e da rede técnica local e regional também merecerão destaque nessa pesquisa.

Outra problemática verificada, foi que muitos municípios adjacentes aos municípios que possuem usinas implantadas, possuem uma alta produção de cana-de-açúcar para ser beneficiada no município com usina, além de apresentarem vários efeitos socioeconômicos produzidos pela dinâmica dos empreendimentos vizinhos. Esses são os casos, sobretudo, dos municípios de Nova Glória, Santa Isabel e São Luiz do Norte, que fazem limite com os municípios de Itapaci, Goianésia e Rubiataba, que possuem empreendimentos sucroenergéticos na microrregião Ceres. Ressalta-se, portanto, que as dinâmicas e os efeitos relacionados ao capital agroindustrial canavieiro, perpassam os limites municipais e também, em alguns casos, regionais. Sentiu-se também a necessidade de dar continuidade, aos estudos iniciados, utilizando-se de diferentes escalas, buscando um maior aprofundamento teórico e na discussão/resultados da pesquisa.

A presente tese possui como recorte espacial a microrregião Ceres (Goiás) e como principal recorte temporal a partir da década de 1940, que corresponde ao principal contexto de formação territorial da região, relacionado ao projeto das Colônias Agrícolas Nacionais (CANG), durante a Marcha para o Oeste do Governo Vargas. Entende-se assim, a importância de se considerar o recorte: das Colônias Agrícolas Nacionais ao momento atual, não somente pelo contexto de criação, consolidação e fragmentação municipal dessa região estarem

\footnotetext{
${ }^{2}$ Até recentemente utilizava-se o termo "sucroalcooleiro" para designar as usinas produtoras de açúcar e álcool. Atualmente o termo "sucroenergético" é mais usual, pois além da produção de açúcar e álcool, tem-se hoje nas usinas a produção de energia, por meio da biomassa da cana-de-açúcar, a qual se configura em um importante mercado para as usinas, que além de utilizarem a energia para consumo próprio, comercializam o excedente com a central elétrica local.
} 
diretamente associados a esse contexto, mas também por representar duas temporalidades distintas na região: a CANG, enquanto estratégia de ocupação baseada na doação de lotes para a produção familiar, e o momento atual, tão imerso na lógica do agronegócio sucroenergético.

Em síntese, faz-se importante compreender quais dinâmicas são verificadas por meio da relação estabelecida, que contextos são importantes para o desenvolvimento da atividade sucroenergética e quais os efeitos e transformações ocorreram na região estudada ao longo do tempo, tendo como principal "motor" a complexa atividade canavieira.

A tese teve como objetivo principal entender a produção do território da microrregião Ceres (GO), a partir do contexto das Colônias Agrícolas Nacionais ao agronegócio sucroenergético, na busca de identificar e compreender as dinâmicas socioespaciais, as redes estabelecidas (técnica e urbana), os agentes sociais envolvidos e as transformações na paisagem regional. Como objetivos específicos, pretendeu-se: a) Verificar como se deu a territorialização das agroindústrias sucroenergéticas em uma ótica interescalar e a importância do Estado para tanto, observando os contextos: brasileiro, goiano e microrregional; b) Compreender a microrregião Ceres a partir das Colônias Agrícolas Nacionais ao agronegócio sucroenergético, bem como o papel da rede técnica e da logística de transporte para a dinâmica canavieira; c) Identificar as semelhanças e especificidades entre as usinas implantadas na microrregião Ceres, bem como compreender as principais formas espaciais e a relação campo-cidade estabelecida; d) Verificar como se deu a formação da rede urbana e o ordenamento territorial pela dinâmica canavieira na microrregião Ceres, bem como observar os efeitos nos municípios que não possuem usinas implantadas, mas uma alta produção de cana-de-açúcar; e) Verificar o discurso do progresso e do desenvolvimento econômico vinculado ao agronegócio sucroenergético na microrregião Ceres, avaliando possíveis alternativas ao agronegócio canavieiro e os efeitos materializados na paisagem regional.

Para o desenvolvimento dos objetivos propostos, foram necessárias algumas etapas metodológicas, que podem ser sintetizadas em cinco grandes fases: 1) Levantamento teórico, metodológico e conceitual, ao longo do desenvolvimento da tese, e levantamento de dados primários e secundários (em órgãos competentes e instituições públicas e privadas relacionadas à temática da pesquisa; 2) Confecção e apresentação do relatório de qualificação da pesquisa em dezembro de 2014; 3) Realização do Doutorado Sanduíche, com cinco meses de bolsa CAPES, na Universidade de Santiago de Compostela - Espanha (de abril a agosto de 2015) para leituras, pesquisas e amadurecimento teórico-metodológico, sobretudo dentro dos conceitos de Ordenamento Territorial, Região e Paisagem; 4) Realização de trabalhos de 
campo aos municípios da microrregião Ceres, sobretudo aos municípios que contêm usinas implantadas e municípios vizinhos a estes, para observação e entrevistas aos principais atores sociais envolvidos (secretários de agricultura e diretores agrícolas, além de entrevistas às usinas). Foram realizados quatro trabalhos de campo, sendo: um em julho de 2014, aos municípios de Ceres e Carmo do Rio Verde; um em dezembro de 2015, aos municípios de Nova Glória, Santa Isabel e São Luiz do Norte; e dois trabalhos de campo no mês de maio de 2016, sendo o primeiro aos municípios de Goianésia, Carmo do Rio Verde e Itapuranga e o segundo aos municípios de Itapaci e Rubiataba. Nessa etapa, também se fez importante a tabulação dos dados levantados (prévios e de campo) e a elaboração de mapas, utilizando-se do SIG ArcGIS; 5) E por fim, foram realizadas análises das informações obtidas, construção de textos parciais, amadurecimento teórico-empírico, para posterior redação final e defesa da tese.

Com o desenvolvimento da presente tese, defende-se que a atividade canavieira tem uma importância ímpar na (re) produção socioeconômica da microrregião Ceres e, que com a aceleração do tempo e das técnicas, associada à lógica do agronegócio sucroenergético atual, houve uma intensificação da (re) funcionalização das redes técnica e urbana da região, bem como da materialização das contradições socioespaciais, que são verificadas na paisagem regional. Como a microrregião Ceres é focada em um segmento hegemônico do agronegócio (o canavieiro), vários municípios ficam reféns da falta de diversificação econômica, sobretudo aqueles que possuem grande produção de cana-de-açúcar para ser beneficiada em município vizinho.

Além disso, alguns elementos observados na microrregião Ceres como: a insuficiência da rede de objetos técnicos e de prestadoras de serviços que contemplem a demanda da atividade sucroenergética atual; a sazonalidade da dinâmica socioeconômica devido aos períodos de safra e entressafra; bem como, a topografia acidentada de uma área relevante da região, que inviabiliza a mecanização total da colheita, contribuem para uma dinamização altamente concentrada e um desenvolvimento incompleto. É importante ressaltar que há a inserção de novos elementos técnicos, há aumento no quantitativo de empregos diretos e indiretos (sobretudo no período da safra), há atração de mão de obra migrante, pois como ainda não é possível a mecanização total da colheita da cana, ainda existem muitos cortadores de cana na região (e suas várias especializações), entre outras características, contudo essa dinâmica se processa de forma extremamente frágil. 
O fato da microrregião Ceres estar focada no segmento canavieiro, fragiliza ainda mais a economia local e regional, não há muitas redes que se utilizam da lógica sucroenergética e vice-versa, muito menos redes autônomas à atividade canavieira, o que leva a crer que caso aconteça um fechamento sistemático das usinas, seja pela crise energética, seja pela licença funcionamento cassada, como aconteceu recentemente com a usina Vale Verde do município de Itapuranga ${ }^{3}$, a região passaria por sérios problemas socioeconômicos.

Por fim, defende-se que a dinamização concentrada e o desenvolvimento incompleto, são estimulados pelo mito do progresso, presente no discurso do agronegócio e nos altos incentivos provindos das políticas do Estado, bem como as contradições socioespaciais e conflitos fruto do agronegócio sucroenergético nessa microrregião, estão materializados no espaço geográfico e são perceptíveis pela paisagem regional.

\section{APRESENTAÇÃO DA PESQUISA - RECORTES E PROBLEMATIZAÇÃO}

O estado de Goiás é subdividido em cinco mesorregiões: Norte, Sul, Leste, Noroeste e Centro, que por sua vez são subdivididas em 18 microrregiões, segundo o Instituto Brasileiro de Geografia e Estatística - IBGE. A mesorregião Centro Goiano é formada pelas microrregiões Ceres, Anápolis, Goiânia, Anicuns e Iporá e é marcada historicamente pela construção das Capitais Goiânia e Brasília, pela densidade populacional e pela fragmentação dos municípios. A figura 1 mostra a localização da microrregião Ceres no estado de Goiás.

\footnotetext{
${ }^{3}$ A usina Vale Verde Empreendimentos, do município de Itapuranga, teve a licença funcionamento cassada e ficou sem funcionar por quatro anos (de 2010 a 2014). Agora, no ano de 2016, está em funcionamento, contudo não irá moer a cana-de-açúcar por problemas econômicos, sendo que toda a cana produzida, será beneficiada nas usinas do Grupo Farias, dos municípios de Itapaci e Uruaçu (informações obtidas em trabalhos de campo 2016).
} 


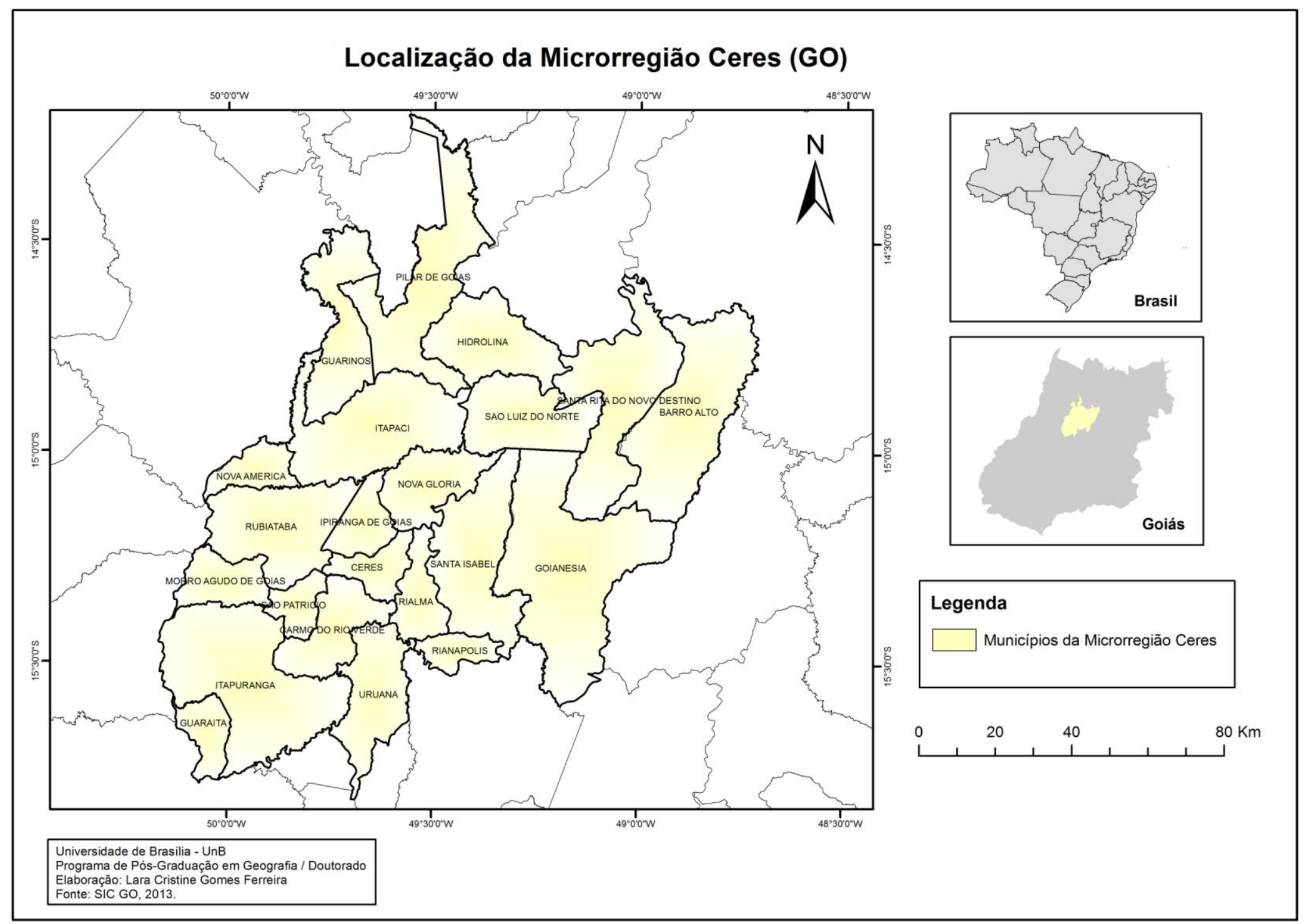

Figura 1 - Localização da microrregião Ceres em Goiás. 
A microrregião Ceres, leva o nome do município de Ceres, criado no contexto do Projeto das Colônias Agrícolas Nacionais (a Colônia goiana ficou conhecida por CANG), durante a década de 1940, cujo objetivo principal foi o de atrair agricultores de todas as partes do Brasil para ocupar o interior do país, baseado na doação de lotes e terras para moradia e produção agrícola familiar. Contudo, a partir da década de 1970, com a influência do Proálcool, algumas destilarias foram implantadas na região, alterando a estrutura de produção (antes baseada em colônias, depois para a estrutura agroindustrial e mais recentemente para a lógica do agronegócio) e também alterando a sua paisagem regional.

É importante ressaltar que a produção canavieira passou ao longo do tempo, por alguns contextos importantes de expansão no Brasil. Podem-se destacar o Proálcool, em meados da década de 1970, e a busca por combustíveis alternativos à gasolina, que culminou com o crescimento do uso de biocombustíveis (como o etanol e o biodiesel), em meados da década de 2000, como mencionado. Nesse último contexto, o estado de Goiás destacou-se, tanto na produção de cana-de-açúcar, quanto na implantação de empreendimentos sucroenergéticos e/ou previsão de implantação.

No ano de 2005 havia, no estado de Goiás, 14 usinas em operação, com uma produção de 15.642.125 toneladas (t) de cana-de-açúcar. No ano de 2007, havia 18 usinas em operação e aproximadamente 30 usinas em processo de avaliação. Muitas usinas tiveram o pedido negado para implantação e, atualmente, segundo dados do Instituto Mauro Borges (IMB), da Secretaria de Estado de Gestão e Planejamento de Goiás (SEGPLAN), existem 37 usinas sucroenergéticas implantadas e em funcionamento em Goiás, duas usinas com a licença suspensa temporariamente, quatro em processo de implantação e dez usinas em provável implantação (IMB, 2014). Mas, em síntese, verificou-se, por meio da observação de dados do estado de Goiás que, no período de 2005 a 2013, a produção de cana cresceu, assim como a produção de etanol e açúcar, salvo algumas pequenas oscilações.

Para a microrregião Ceres o Proálcool trouxe um rápido desenvolvimento das agroindústrias canavieiras, como por exemplo: a usina Pite S/A (Itapuranga), a Devale (Itapaci), a usina Goianésia e Jalles Machado (ambas em Goianésia) e a usina Carval (Carmo do Rio Verde), instaladas, a primeira, no final da década de 1970 e as demais no decorrer da década de 1980.

Dessas usinas, algumas foram desativadas quando da crise do Proálcool nos anos 1990, mas com o recente contexto de expansão canavieira, algumas foram reativadas e postas em funcionamento. $\mathrm{Na}$ microrregião Ceres mais quatro usinas estavam em processo de cadastro no ano de 2007, mas tiveram seus licenciamentos negados ou não foram construidas 
por problemas financeiros dos Grupos ${ }^{4}$. Assim, atualmente existem sete usinas em funcionamento na região, sendo três no município de Goianésia, uma em Itapaci, uma em Itapuranga, uma em Rubiataba e uma em Carmo do Rio Verde.

É importante mencionar que a implantação desses empreendimentos depende de uma série de fatores relacionados, sobretudo, à racionalidade do capital, materializados em determinado lugar, por meio de elementos como a malha viária, as redes de telecomunicações e a base energética, ou seja, à presença da técnica ou mediação técnica, como bem explicitou Lipietz (1988), que produz deslocamentos ou transferências de mercadorias e informações, bem como de estratégias econômicas, como a malha viária (fundamental para o escoamento da produção) e os programas de atração industrial, por meio de isenções fiscais e subsídios. Todas as usinas em funcionamento na microrregião Ceres receberam subsídios do governo dos programas de fomento à indústria em Goiás, o Fomentar e/ou o Produzir, para sua instalação e crédito, bem como as usinas propostas, mas não aprovadas, também tiveram subsídios aprovados.

A microrregião Ceres, diferente da região Sudoeste Goiano (onde predomina a topografia mais plana), possui em algumas áreas declives acentuados, o que inviabiliza a mecanização total do corte da cana, sendo ainda necessário o corte manual para este trabalho. Até o ano de $2009^{5}$ todas as usinas da microrregião Ceres, com exceção a usina Jalles Machado (Goianésia) tinha a colheita manual como maioria ou apresentava um alto percentual de colheita manual: usina Goianésia 67,29\%; Vale Verde de Itapaci 70\%; Vale Verde de Itapuranga 85\%; CRV Industrial 50\%; e Cooper Rubi 70\%. Somente na Jalles Machado, a colheita mecanizada era maioria, com cerca de $85 \%$ e, os restantes $15 \%$, eram colheita manual.

Diante do breve exposto, algumas questões de pesquisa foram fundamentais para nortear a investigação:

a) Quais as alterações verificadas na microrregião Ceres a partir do contexto das Colônias Agrícolas Nacionais ao agronegócio sucroenergético?

\footnotetext{
${ }^{4}$ Há duas versões para o fato das usinas terem sido propostas, em 2007 para a microrregião Ceres, mas não terem sido de fato construídas: a versão do Governo Estadual é que elas não obtiveram licença para funcionamento, contudo durante a realização de trabalhos de campo e entrevistas foi relatado que os Grupos Empresariais passavam por problemas financeiros, por isso essas usinas não foram efetivamente construídas.

${ }^{5}$ Dados defendidos na Dissertação de mestrado da autora (FERREIRA, 2010).
} 
b) Como a dinâmica sucroenergética (re) produz o território da região estudada, por meio da relação campo-cidade?

c) Que elementos técnicos foram incorporados ao espaço urbano microrregional e quais as ligações econômicas foram estabelecidas, por meio da dinâmica sucroenergética?

d) A implantação do complexo sucroenergético alterou ou (re) organizou a rede urbana microrregional?

e) Quais as formas espaciais verificadas, fruto da dinâmica canavieira, e como se configura a paisagem regional da microrregião Ceres?

A microrregião Ceres possui dois contextos interessantes a serem analisados. De um lado sua constituição histórica, por meio da política das Colônias Agrícolas Nacionais e, mais recentemente, o Plano Nacional de Agroenergia, que estimulou a territorialização das usinas sucroenergéticas na região. Essas usinas implantadas possuem demandas e relações multiescalares que vão desde o local ao internacional. $\mathrm{O}$ mercado internacional dita às normas, em consonância com o Estado, e acaba por movimentar a economia local e regional. Além disso, algumas dinâmicas da cidade, bem como os equipamentos urbanos e a infraestrutura local e regional são diretamente influenciados pela lógica sucroenergética.

Um relevante problema verificado é que a atividade canavieira apresenta uma sazonalidade na produção, devido ao fato de ser subdividida nos períodos de safra e entressafra. Com isso é visível, por meio da paisagem, que as cidades e a região são (re) produzidas de forma diferenciada, bem como se observa que há municípios que produzem cana para as usinas vizinhas, mas não usufruem de quase nenhum retorno socioeconômico, questiona-se então: o que fica para essas cidades? Quais efeitos podem ser verificados, sobretudo na rede urbana microrregional e em termos de desenvolvimento econômico?

Há de forma crescente uma discussão sobre as cidades do agronegócio e suas características, contudo a região estudada apresenta-se singular nessa discussão. A microrregião Ceres tem um passado agrícola, mas apresenta em sua morfologia uma topografia altamente propícia à atividade mineradora, que surgem (ou ressurgem ${ }^{6}$ ) em alguns municípios da região. Algumas usinas ainda persistem, mas percebe-se que a infraestrutura e

\footnotetext{
${ }^{6} \mathrm{O}$ município de Pilar de Goiás, pertencente à microrregião Ceres, possuía uma mineradora no contexto do ouro no Brasil (século XVIII). Essa mineradora foi desativada e recententemte uma empresa Canadense voltou a extrair ouro no município.
} 
as atuais demandas por produtividade não acompanham à lógica imposta pelo capital. Questiona-se novamente: é evidente pois, o agronegócio nessa região, mas há cidades do agronegócio? Como são materializadas as formas espaciais do agronegócio na paisagem regional da microrregião Ceres?

Assim, diante da problemática discutida, apresentam-se as seguintes hipóteses que nortearam a presente tese:

1. A dinâmica sucroenergética influencia diretamente a (re) produção do território dos municípios da microrregião Ceres, sendo fundamental a abordagem regional para essa análise, já que os efeitos e as contradições perpassam os municípios-sede das usinas, como verificado sobretudo, nos municípios de Nova Glória, São Luiz do Norte e Santa Isabel;

2. A microrregião Ceres passou a ter uma nova função na divisão territorial do trabalho com a instalação das usinas sucroenergéticas. Foram incorporados elementos ao espaço urbano microrregional derivados e demandados pela atividade canavieira, bem como percebeu-se uma evolução da rede urbana regional;

3. As cidades vinculadas à lógica do agronegócio canavieiro na microrregião Ceres, apresentam muitas deficiências quanto ao aparato técnico, prestadoras de serviço, comércio e infraestrutura, o que diferencia essa região de outras do estado de Goiás, que também possuem a mesma atividade econômica. Essas características são verificadas na paisagem regional, que sofreu várias alterações, sobretudo a partir do contexto das Colônias Agrícolas Nacionais;

4. Há um mito do progresso nos discursos do agronegócio e do Estado, que acaba por estimular e financiar as agroindústrias sucroenergéticas, contudo o desenvolvimento econômico verificado é altamente concentrado e incompleto, o que gera contradições socioespaciais e conflitos.

Diante dos objetivos, da abordagem metodológica proposta e das hipóteses que nortearam a pesquisa, a tese é apresentada em cinco capítulos. O quadro 1 mostra de forma esquemática, o tema central e o objetivo principal de cada capítulo, dentro da totalidade da tese, e os conceitos chaves utilizados. 


\begin{tabular}{|c|c|c|}
\hline \multicolumn{3}{|c|}{ QUADRO SÍNTESE - CAPÍTULOS DA TESE } \\
\hline Título do Capítulo & Objetivo Geral & Conceitos Chaves \\
\hline $\begin{array}{l}\text { Capítulo I: O Movimento do } \\
\text { Capital e a Territorialização da } \\
\text { Cana-de-açúcar em uma Ótica } \\
\text { Interescalar. }\end{array}$ & $\begin{array}{l}\text { Abordar os principais contextos de expansão } \\
\text { canavieira no Brasil, que contribuíram para a } \\
\text { territorialização } \\
\text { sucroenergéticas, bem como refletir sobre a } \\
\text { produção do território goiano pelo setor } \\
\text { sucroenergético, a importância do Estado para } \\
\text { tanto e introduzir à discussão sobre o } \\
\text { agrohidronegócio em Goiás. }\end{array}$ & $\begin{array}{l}\text { Território, Territorialização, } \\
\text { Abordagem Regional, } \\
\text { Estado, Agronegócio e } \\
\text { Agrohidronegócio. }\end{array}$ \\
\hline $\begin{array}{l}\text { Capítulo II: A Microrregião } \\
\text { Ceres - GO: Das Colônias } \\
\text { Agrícolas Nacionais ao } \\
\text { Agronegócio Sucroenergético. }\end{array}$ & $\begin{array}{l}\text { Abordar os principais contextos de criação e } \\
\text { fragmentação dos municípios da região, a partir } \\
\text { da CANG, passando pelos contextos do Proálcool } \\
\text { e do Plano Nacional de Agroenergia. Busca-se } \\
\text { conhecer as principais características } \\
\text { socioeconômicas da microrregião e a importância } \\
\text { das redes técnicas relacionadas à logística de } \\
\text { transporte e cogeração de energia elétrica. }\end{array}$ & $\begin{array}{l}\text { Colônias Agrícolas } \\
\text { Nacionais, Fragmentação } \\
\text { territorial, Fluidez, Rede } \\
\text { Técnica, Cogeração de } \\
\text { energia. }\end{array}$ \\
\hline $\begin{array}{l}\text { Capítulo III: A Atividade } \\
\text { Sucroenergética, suas formas e } \\
\text { a relação campo-cidade na } \\
\text { Microrregião Ceres - GO }\end{array}$ & $\begin{array}{l}\text { Entender como se realiza a dinâmica } \\
\text { sucroenergética na microrregião Ceres e a relação } \\
\text { campo-cidade. Identificar as principais } \\
\text { semelhanças e especificidades nas usinas } \\
\text { implantadas na região, além das formas espaciais } \\
\text { e demandas vinculadas à atividade canavieira. }\end{array}$ & $\begin{array}{l}\text { Relação campo-cidade, } \\
\text { Dinâmica canavieira, formas } \\
\text { espaciais. }\end{array}$ \\
\hline $\begin{array}{l}\text { Capítulo IV: A Formação da } \\
\text { Rede Urbana e o Ordenamento } \\
\text { Territorial pela Dinâmica } \\
\text { Canavieira: A "Nova" } \\
\text { Configuração Socioespacial }\end{array}$ & $\begin{array}{l}\text { Compreender como se deu a formação da rede } \\
\text { urbana da microrregião Ceres e como a dinâmica } \\
\text { sucroenergética pode ter influenciado a } \\
\text { configuração de uma "nova" configuração } \\
\text { socioespacial ou um "ordenamento territorial da } \\
\text { cana". Abordar os principais efeitos em } \\
\text { municípios que possuem alta produção canavieira, } \\
\text { mas não possuem usinas instaladas, como Nova } \\
\text { Glória, São Luiz do Norte e Santa Isabel. }\end{array}$ & $\begin{array}{l}\text { Rede urbana, ordenamento } \\
\text { territorial, "nova" } \\
\text { configuração socioespacial. }\end{array}$ \\
\hline \begin{tabular}{llrr} 
Capítulo V: A & \multicolumn{2}{c}{ Paisagem } \\
Regional e & o & Mito do \\
Progresso & \multicolumn{2}{c}{} & O \\
Desenvolvimento Incompleto \\
da Microrregião Ceres.
\end{tabular} & $\begin{array}{l}\text { Verificar como está configurada a paisagem } \\
\text { regional da microrregião Ceres, da CANG ao } \\
\text { contexto atual. Abordar o mito do progresso, } \\
\text { difundido pela lógica do agronegócio, e o } \\
\text { desenvolvimento incompleto verificado na região. }\end{array}$ & $\begin{array}{l}\text { Cidades do Agronegócio, } \\
\text { Paisagem Regional, mito do } \\
\text { progresso, Desenvolvimento } \\
\text { econômico. }\end{array}$ \\
\hline
\end{tabular}

Quadro 1 - Quadro esquemático dos capítulos da tese.

O capítulo I versa sobre o movimento do capital e a territorialização da cana-de-açúcar em uma ótica interescalar. Nesse primeiro capítulo, primeiramente, será realizada uma discussão sobre os principais contextos de expansão canavieira no Brasil, que contribuíram para a territorialização das agroindústrias sucroenergéticas. Posteriormente será abordada a produção do território goiano pelo setor sucroenergético e introduzida a discussão sobre o agrohidronegócio em Goiás. Entende-se, nesse momento, que o Estado tem uma importância singular para esse processo, assim será realizada uma reflexão sobre o papel do Estado como 
agente de fomento ao agronegócio. E por fim, será realizada uma discussão sobre a importância da abordagem regional no debate do agronegócio sucroenergético.

No capítulo II faz-se importante conhecer a região estudada: os principais contextos de criação e fragmentação dos municípios, voltados, sobretudo para o projeto das Colônias Agrícolas Nacionais (CANG), que originou o município de Ceres, que denomina a região, passando pelos contextos do Proálcool, Programas Nacionais de Desenvolvimento e o Plano Nacional de Agroenergia. É importante também conhecer as principais características socioeconômicas da microrregião Ceres e a importância da rede técnica, como: a malha viária (rodovias e ferrovias) e a rede de energia elétrica, dando ênfase a cogeração de energia pela biomassa da cana-de-açúcar, para a territorialização das agroindústrias sucroenergéticas.

O capítulo III faz uma abordagem sobre a dinâmica sucroenergética da microrregião Ceres e a relação campo-cidade. Nesse capítulo serão apresentadas as principais características das usinas em funcionamento na região, abordando as semelhanças, as especificidades, bem como as principais formas espaciais e as demandas da atividade canavieira, pretende-se também entender como se dá a relação campo-cidade nessa região.

O capítulo IV trata da formação da rede urbana da microrregião Ceres e sua relação com o agronegócio canavieiro. Nesse capítulo busca-se compreender como se deu a formação da rede urbana da microrregião Ceres e como a dinâmica sucroenergética pode ter influenciado uma "nova" configuração socioespacial ou um "ordenamento territorial da cana". E por fim, pretende-se abordar os principais efeitos socioespaciais verificados nos municípios com grande produção canavieira, que não possuem usinas em funcionamento, e que servem aos municípios usineiros.

E por fim, o capítulo $\mathrm{V}$ traz à discussão do desenvolvimento econômico na microrregião Ceres. Nesse capítulo será importante resgatar a discussão da formação territorial da região pelas Colônias Agrícolas, ou seja, o que permaneceu ou o que há de alternativa ao agronegócio canavieiro. Faz-se importante abordar como está configurada a paisagem regional da microrregião Ceres e qual paisagem ou paisagens podem ser verificadas dentro do contexto sucroenergético. E por fim, pretende-se discutir sobre o mito do progresso, difundido pela lógica do agronegócio, por meio da observação da realidade das cidades da microrregião Ceres, com base na tese de uma dinamização socioeconômica altamente concentrada e do desenvolvimento econômico incompleto, fruto do agronegócio sucroenergético. 


\section{CAPÍTULO I - O MOVIMENTO DO CAPITAL E A TERRITORIALIZAÇÃO DA CANA-DE-AÇÚCAR EM UMA ÓTICA INTERESCALAR}

O mundo está em constante movimento e transformação e, por meio da análise das dinâmicas e problemáticas materializadas no espaço geográfico, tem-se uma tentativa de compreender a realidade. Passamos por um processo de desenvolvimento descompassado, o que Neil Smith (1988), bem refletiu como desenvolvimento desigual, este é expressão geográfica sistemática das contradições próprias da essência do capital. Diante disso, compreender o processo histórico de produção e apropriação do espaço e das relações sociais, econômicas e políticas, utilizando-se de uma abordagem crítica, faz-se fundamental.

Para tanto é necessário partir da complexidade do modo de produção capitalista, o qual apresenta várias contradições e é essencialmente dialético nas suas formas de produção, reprodução, apropriação e expropriação dos recursos da natureza e do trabalho em sociedade.

Alguns autores são fundamentais para elucidar o funcionamento do "motor" do Capitalismo e para onde vai seu mover. Em diálogo com Smith (1988) verifica-se sua discussão referente a produção da natureza, o qual reflete sobre a forma em que a natureza era compreendida, durante a frente pioneira americana, por exemplo, vista sem nenhuma preocupação com o comprometimento ou até a finitude dos recursos naturais, não havia nenhuma preocupação ou reflexão sobre essas questões, naturalmente a natureza era desbravada e dominada pelo ser humano. Segundo esse autor, "a hostilidade da natureza exterior justificava sua dominação e a moralidade espiritual da natureza universal fornecia um modelo para o comportamento social” (SMITH, 1988, p. 45). Assim, por muito tempo, foi tradição enxergar a natureza somente como único meio de se produzir valor.

Isso não significa que atualmente seja muito diferente a visão dos capitalistas ou da sociedade em geral, em relação a natureza, pois mesmo com a consciência da finitude dos recursos e das consequências socioeconômicas, fruto dessas práticas, o objetivo final continua sendo a obtenção de lucros. Portanto, a produção capitalista e a apropriação da natureza é acompanhada pela satisfação de uma necessidade particular, o "motor" chama-se: lucro. O destino da natureza se dá a partir do preço estipulado, do 
valor de troca estabelecido. Ainda para Smith, o desenvolvimento desigual é a manifestação concreta da produção do espaço sob o Capitalismo e tem estampada no espaço a desigualdade social.

Soja (1993) reflete sobre a dinâmica do capital e, em alguns momentos, dialoga com Smith na busca de entender o desenvolvimento geograficamente desigual. Para Soja, a atividade normal dos capitalistas em busca de lucro, baseia-se intrinsecamente nas desigualdades regionais ou espaciais, como meio de sua sobrevivência. Soja utilizase de Harvey para fazer uma analogia muito interessante de como o capital assemelhase à música, às coreografias, no sentido de que as contradições internas do Capitalismo são regidas de acordo com essa música que a sociedade tem que dançar ininterruptamente.

Outro autor que muito tem contribuído com importantes reflexões na busca de compreender a perversidade do capital (seus enigmas) e suas repercussões na sociedade e no espaço geográfico é David Harvey. Para ele "o capital é o sangue que flui através do corpo político de todas as sociedades que chamamos de capitalistas, espalhando-se, as vezes, como um filete e outras vezes como uma inundação, em cada canto e recanto do mundo habitado" (2011, p. 7).

Para Harvey a natureza vem sendo gradativamente modificada pela ação humana e, desta forma, ao conceito de meio ambiente devem ser incluídos os lugares já modificados pela ação humana: os rios alvos de reengenharia, os sistemas de rede elétrica, redes de comunicação, grandes cidades, fábricas, destinos turísticos de massa, entre outros. Há pouco na superfície do planeta Terra que possa ser imaginado como uma natureza pura e intocada, ausente de qualquer alteração humana (HARVEY, 2011). Assim, um dos questionamentos de Harvey, na tentativa de desvendar os enigmas do capital é: como entender o desdobramento dialético da relação social com uma natureza que está ela mesma em evolução perpétua?

As relações entre sociedade e natureza são mediadas pela técnica e pelas formas organizacionais, sobretudo. Elas são construídas dentro de contextos geográficos e históricos demarcados. Desta forma, novas configurações e novas relações são produzidas constantemente, como uma nova rede técnica materializada nas pequenas cidades fruto da dinâmica do agronegócio, por exemplo, e isso após o desmatamento das áreas para a produção ou a substituição de outros cultivos. 
É por meio dos fluxos que as pessoas dão sentido a sua existência e vivem e sobrevivem em um sistema capitalista, onde a circulação do capital é a peça central. Milton Santos muito discutiu sobre a importância da circulação no âmbito da sociedade atual, para ele "não basta, pois, produzir. É indispensável pôr a produção em movimento. Em realidade, não é mais a produção que preside à circulação, mas é esta que conforma a produção" (2002, p. 186).

Nos dias atuais os empresários investem em pesquisas para conhecer o desejo de seus clientes e assim sempre estão atualizados em relação às "modas" criadas, e logo se alteram para satisfazer o comprador. Harvey (2011) bem explicitou que enquanto houver consumo, o Capitalismo estará vivo, pois ele se reinventa e se adequa ao contexto atual, transformando quase tudo em mercadoria.

Dentro dessa discussão, a técnica tem um papel fundamental pois, por meio dela, tem-se a principal forma de relação entre o homem e o meio. A técnica, segundo Santos (2002), é um conjunto de meios instrumentais e sociais, com os quais o homem realiza sua vida, produz e, ao mesmo tempo, cria o espaço. A técnica, muitas vezes, está materializada no espaço em forma de infraestruturas, que em sua maioria é resultado de um planejamento que interessa, sobretudo, aos agentes privados, que são hegemônicos nas relações econômicas em sociedade.

Assim, o espaço geográfico vai gradativamente sendo transformado pela técnica e, também, pela informação, o que possibilita a fluidez e rompe as barreiras temporais da comunicação, vencendo e convertendo, a partir da intencionalidade mercadológica, os lugares mais inóspitos em recursos, como expôs Arrais (2002). O desenvolvimento e uso da tecnologia promoveu o aumento dos fluxos de pessoas, mercadorias, dados, capitais, enfim, tornou os espaços cada vez mais inter-relacionados e interdependentes, tanto para suas construções, quanto para suas apropriações e expropriações feitas em sociedade.

As mutações e as adequações do sistema em acumular e se manter hegemônico nas sociedades mundiais mostram que o sistema adequa-se aos novos "habitats" históricos que a sociedade mundial constrói por meio das suas relações com a natureza, das características socioculturais, dos momentos políticos, enfim, a cada novo panorama, o Capitalismo se rearranja para consolidar-se cada vez mais como modo de produção dominante. Segundo Harvey (2011, p. 209), "o Capitalismo nunca vai cair por 
si próprio. Terá de ser empurrado. A acumulação do capital nunca vai cessar. Terá de ser interrompida. A classe capitalista nunca vai entregar voluntariamente seu poder. Terá de ser despossuída".

Mészáros (2011) também reflete sobre o fato do sistema capitalista escapar a um significativo grau de controle humano. Isso se deve ao fato do sistema capitalista ter surgido no curso da história como uma poderosa estrutura "totalizadora" de controle, a qual tudo deve se ajustar, inclusive os seres humanos, e assim provar de sua "viabilidade produtiva" ou perecer, caso não consigam se adaptar. É importante mencionar que a globalização, tão discutida atualmente, é uma tendência da própria natureza do capital. Para Mészáros (2011), na realidade, a globalização significa o desenvolvimento necessário de um sistema internacional de dominação e subordinação.

Essa breve reflexão sobre o movimento do capital, bem como trazer à tona elementos como a técnica, a informação e a fluidez das relações e do consumo são fundamentais para introduzir a discussão da territorialização da cana-de-açúcar no Brasil e seus contextos de expansão. É importante ter em mente que a lógica de expansão canavieira no Brasil esteve/está diretamente relacionada à geopolítica global, alguns contextos de expansão e crises na produção de açúcar e etanol estiveram/estão vinculados a contextos históricos mundiais importantes, que serão abordados a seguir.

\subsection{A Territorialização da Cana-de-açúcar no Brasil - Contextos de Expansão}

A territorialização da cana-de-açúcar no Brasil iniciou-se durante o período colonial, o plantio da cana e seu aproveitamento para a produção de açúcar foi uma das primeiras atividades econômicas implantadas por Portugal na colônia brasileira. As primeiras mudas de cana-de-açúcar foram trazidas da Ilha da Madeira (Portugal) por Martim Afonso de Souza, responsável pela instalação do primeiro engenho em São Vicente (atualmente São Paulo) no ano de 1532. Contudo, foi o litoral nordestino, sobretudo, Pernambuco e Bahia, o principal produtor canavieiro da colônia, tendo essa atividade baseada ainda no uso da mão-de-obra escrava, predominantemente negra (ANDRADE, 1986).

A maior proximidade do centro consumidor europeu, o regime de ventos que facilitava a navegação, o solo e as condições climáticas, bem como a presença de 
diversos rios que desembocavam no litoral foram condições apontadas como atrativas ao avanço dessa atividade em terras nordestinas (FERLINI, 1998).

A ocupação do Brasil, por meio da lavoura canavieira, inaugurava uma nova forma de colonização, já que normalmente a ocupação dos territórios conquistados limitava-se à comercialização de produtos encontrados nas terras colonizadas. Segundo Ferlini (1998), Portugal transformou a empresa colonial em um sistema produtivo, utilizando-se de técnicas e de recursos da metrópole, o que criavam fluxos constantes de produtos destinados ao comércio europeu, bem como a colônia dependia do abastecimento metropolitano, constituindo-se em mercado consumidor dos produtos manufaturados da Europa. Ainda segundo essa autora, ao final do primeiro século de colonização, o Brasil produzia aproximadamente 350 mil arrobas de açúcar ao ano. A produção brasileira de açúcar conheceria anos de glória até 1650, quando se inicia a concorrência das Antilhas e da América Central.

Nos anos seguintes, principalmente durante os anos do Primeiro Reinado (1822/1831), das Regências (1831/1840) e do Segundo Reinado (1840/1889), o açúcar brasileiro enfrentou a concorrência do açúcar das Antilhas no mercado mundial, este açúcar fabricado com a cana levada pelos holandeses que tinham sido expulsos do Brasil, além da competição com o açúcar de beterraba que, desde o século XVII, começou a ser largamente produzido na Europa. As pesadas taxas estabelecidas pelos diversos governos sobre as importações do produto constituíam forte obstáculo ao comércio (ÚNICA, 2007). Mas, foi durante a República Oligárquica (1889-1930) que houve o auge e a decadência dessa economia agroexportadora no Brasil.

A reorganização da estrutura produtiva do setor agroindustrial canavieiro no Brasil se deu logo no início dos anos 1930 e só se tornou possível pela intensa ação do Estado ao longo de pouco mais de seis décadas de forte intervenção pública. Exemplo disso foi a criação do Instituto do Açúcar e do Álcool (IAA), no ano de 1933, onde a intervenção estatal dominou praticamente toda a estrutura do setor, sendo responsável pelo ciclo de produção e comercialização, inclusive fixação de preços, cotas, exportação e importação (ÚNICA, 2007). O IAA teve o papel de incentivar o consumo e regular o mercado de açúcar e álcool no Brasil, sendo o principal mecanismo de regulação a implantação de cotas de produção. Também limitou a usina a produzir, no máximo, 
$60 \%$ de toda a cana em suas próprias terras, sendo o restante fornecido por produtores independentes.

Segundo Andrade (1986), a usina que já ganhara espaço e poder, iria agora ter a sua produção regulamentada, planejada e poderia se impor no espaço que disputasse. $\mathrm{O}$ governo a transformaria quase em uma empresa estatal, estabelecendo as normas que iriam regulamentar a sua vida econômica e a sua função social e política.

O objetivo do IAA era regionalizar a produção de açúcar, por meio do sistema de cotas de produção para cada estado e, nestes, para cada unidade produtiva. Os critérios utilizados para definir as cotas de participação eram: a média da produção nos últimos cinco anos; a capacidade de esmagamento da cana para as novas usinas; e a relação produção/consumo em cada estado. O objetivo era evitar que os estados produtores do sudeste do Brasil, sobretudo São Paulo, tivessem um crescimento exponencial, prejudicando os estados do Rio de Janeiro e do nordeste brasileiro, tradicionais na produção de açúcar (LIMA, 2001).

O IAA surgiu no contexto em que o governo brasileiro considerava que a produção somente de açúcar era excedente em relação à demanda do consumo, além de considerar a produção de etanol uma alternativa viável para assegurar o equilíbrio do mercado açucareiro mundial, o qual começava a se limitar.

Oliveira (1981) trouxe uma discussão muito interessante sobre o verdadeiro objetivo do IAA, que segundo ele, era estabelecer uma divisão regional do trabalho da atividade açucareira. Contudo, a ironia é que os membros da burguesia açucareira nordestina acabaram passando o eixo da produção do açúcar para a região industrial, comandada por São Paulo.

O grande problema é que o financiamento do IAA para a região industrial de São Paulo, poderia financiar tanto o capital variável, quanto o capital constante, ao contrário do nordeste açucareiro, que acabava financiando as relações de produção arcaicas e tornam nulas as possibilidades de modernização do capital constante das usinas (OLIVEIRA, 1981). Assim, em 1959, os usineiros paulistas criaram a Cooperativa Central de Produtores de Açúcar e Álcool de São Paulo (Copersucar), que 
passou a negociar empréstimos e ajudar na comercialização com a criação de novas marcas de venda final do açúcar ${ }^{7}$.

Em meados da década de 1970, o governo brasileiro criou o Programa Nacional do Álcool (Proálcool), que incentivou a produção do álcool, por meio de insumos, utilizando-se principalmente da cana-de-açúcar, contudo contou também com a participação do álcool da mandioca, por exemplo. A principal motivação para o lançamento do Programa foi a crise internacional do açúcar e, posteriormente, o forte impacto negativo na economia nacional causado pelos dois "choques do petróleo" em 1973 e 1979, respectivamente.

Na chamada "primeira fase do Proálcool" criou-se paralelamente, a Comissão Executiva Nacional do Álcool (Cenal) com o objetivo de definir as participações programáticas dos órgãos direta ou indiretamente vinculados ao Programa, com vistas a atender a expansão da produção de álcool, definir os critérios de localização a serem observados na implantação de novos projetos de destilarias, estabelecer a programação anual dos diversos tipos de etanol, especificando o seu uso, decidir sobre o enquadramento das propostas e/ou projetos para modernização, ampliação ou implantação de destilarias nos objetivos do Programa, e definir os critérios de localização a serem observados na implantação de unidades armazenadoras (ÚNICA, 2007).

Com os incentivos do Proálcool a produção de álcool combustível cresceu muito e houve ampliação de 555,6 $\mathrm{m}^{3}$ para 2.490,9 $\mathrm{m}^{3}$, entre os anos de 1975/76 e 1978/79, sendo 2.095,9 $\mathrm{m}^{3}(84,1 \%)$ de álcool anidro, portanto basicamente para uso na mistura à gasolina. Nesta fase, na chamada "segunda fase do Proálcool”, aproximadamente em 1979, o governo brasileiro decidiu estimular também a produção do etanol hidratado, que viria a ser usado diretamente em motores de veículos de passageiros (ÚNICA, 2007).

O Conselho Nacional do Petróleo (CNP) estabelecia a sistemática de alocação e faturamento dos volumes de etanol entre as companhias distribuidoras de derivados de petróleo e a Petrobrás, tendo em vista a dinâmica de abastecimento do mercado. Ficou

\footnotetext{
${ }^{7}$ Hoje essa cooperativa tornou-se a empresa Copersucar, que conta com 47 Unidades Produtoras Sócias, pertencentes a 24 grupos econômicos. Trata-se de um sistema integrado de distribuição de etanol, com a construção e desenvolvimento de polidutos, interligando as regiões produtoras aos maiores centros consumidores (COPERSUCAR, 2013).
} 
sob a responsabilidade da Petrobrás a aquisição dos volumes de etanol destinados à formação dos estoques de segurança. Assim, se ao encerramento do período de safra em cada região produtora, os estoques em poder da Petrobrás fossem superiores ou inferiores aos estoques de segurança, o CNP deveria promover os necessários ajustes nos faturamentos das unidades produtoras. Os estoques de segurança do sistema de abastecimento de etanol para fins combustíveis deveriam corresponder aos volumes mínimos de consumo de dois meses para o etanol anidro e hidratado, referentes às previsões de consumo do mês de encerramento de cada safra.

O IAA teve a sua extinção determinada em medida provisória no ano de 1990. Em meados de 1988, um Decreto-Lei ( $n^{\circ} 2.437$, de 24 de maio de 1988) já se encarregara de proibir, a partir de $1^{\circ}$ de junho de 1989 , o uso de recursos do Tesouro Nacional em operações de compra e venda de açúcar para exportação e determinava ao Poder Executivo que procedesse à reformulação da organização do setor sucroalcooleiro, com a redução da dependência da agroindústria canavieira de recursos do Tesouro Nacional e da intervenção do Governo no setor. A redução da ação estatal deu-se em ritmo inegavelmente acelerado, iniciado com a liberação das exportações de seus produtos em 1989, passando por liberações dos preços do açúcar e do etanol anidro e sendo concluída com a liberação dos últimos preços que ainda eram mantidos sob controle oficial: os da cana, os do açúcar e os do etanol hidratado (PINHEL JUNIOR, 2007).

A partir de 1983, com a chamada "crise das dívidas" na América Latina, a capacidade de endividamento do Estado brasileiro se esgotou e a redução da possibilidade de fornecimento de créditos subsidiados à agroindústria sucroalcooleira nos anos seguintes gerou um processo de falência e de fusões de diversas destilarias e usinas. Entre os anos de 1989 e 1990, houve uma crise de abastecimento que levou a população a perder a confiança nesse combustível e, em consequência, no carro à álcool, cujas vendas tiveram redução para 11,55\% (1990) em relação aos 52,5\% (1989) (PITTA, et al, 2014).

Passada essa crise, quando as vendas já davam sinais de recuperação (em 1992 e 1993, os veículos a álcool representaram média superior a $25 \%$ do total), novos padrões tecnológicos colocaram o carro a álcool definitivamente em desvantagem e como a relação de preços não era favorável ao álcool, a indústria automotiva concentrou sua 
pesquisa na geração de veículos a gasolina mais econômicos. Estes, em 1996, alcançaram $75 \%$ das vendas, enquanto a comercialização dos carros a álcool reduziu para menos de $1 \%$ (BRASIL, 2006).

Vian (2003) apresenta um quadro-síntese com os principais contextos de expansão e crise canavieira no Brasil, a partir do fim do século XIX, que culmina com a crise de superprodução e perda de espaço no mercado internacional pela competição com o açúcar das Antilhas e Europa, conforme mencionado, e vai até a extinção do IAA, nos anos 1990. O quadro 2 mostra os dados trabalhados por Vian (2003), com alguns detalhes acrescidos fruto da presente pesquisa, sobretudo relacionado ao Plano Nacional de Agroenergia.

No ano de 2006, o governo brasileiro, por meio do Ministério da Agricultura, Pecuária e Abastecimento - MAPA - e Secretaria de Produção e Agroenergia, lançaram o Plano Nacional de Agroenergia, no contexto mundial da busca por novas fontes de energia, principalmente renováveis (biocombustíveis) no intuito de ser uma fonte alternativa aos combustíveis fósseis, como a gasolina, por exemplo.

Foi a partir da realização da Conferência Eco 92 (na cidade do Rio de Janeiro/Brasil, no ano de 1992), que resultou no Tratado de Kyoto (em 1997), que a busca por energia menos poluente e renovável tornou-se uma prioridade em alguns países, como China e Japão, que passaram a adicionar álcool (etanol anidro) à gasolina, na busca de diminuir o uso do petróleo e a emissão de monóxido de carbono (CO), um dos gases responsáveis pelo efeito estufa.

A partir daí, iniciou-se uma fase de preocupação mundial pela proteção ambiental, por meio da criação de políticas e acordos internacionais, principalmente no que se refere ao aquecimento global, já que sua causa é derivada dos impactos humanos, ressaltando o uso de combustíveis fósseis como um dos importantes participantes. Segundo Pinhel Júnior (2007), contribuiu também para a revalorização do álcool, como real alternativa combustível em substituição ao petróleo, o surgimento do chamado veículo bicombustível ou flex, cujo motor pode utilizar tanto álcool quanto gasolina ou mesmo a mistura dos dois combustíveis em qualquer proporção. 
Quadro 2 - Contextos importantes de expansão e crise canavieira no Brasil.

\begin{tabular}{|c|c|c|c|}
\hline Períodos & Eventos Deflagradores & Políticas Adodatas & Resultados \\
\hline Final do Século XIX & $\begin{array}{l}\text { Crises de superprodução. } \\
\text { Perda de participação relativa } \\
\text { no mercado externo para } \\
\text { produtores mais modernos. } \\
\text { Emergência do } \\
\text { protecionismo europeu } \\
\text { (Antilhas, Europa). }\end{array}$ & $\begin{array}{l}\text { Desvalorização cambial, } \\
\text { subsídios para } \\
\text { implantação de engenhos } \\
\text { centrais, surgimento de } \\
\text { usinas. }\end{array}$ & $\begin{array}{l}\text { Engenhos centrais falham. } \\
\text { Apenas as usinas atingem } \\
\text { o objetivo de aumentar a } \\
\text { eficiência da produção. }\end{array}$ \\
\hline $1905 / 07$ & $\begin{array}{l}\text { Conflitos entre usinas e } \\
\text { refinadores/comerciantes } \\
\text { sobre o preço interno do } \\
\text { açúcar. }\end{array}$ & $\begin{array}{l}\text { Coligação do açúcar de } \\
\text { Pernambuco e coligação } \\
\text { do açúcar do Brasil. }\end{array}$ & $\begin{array}{l}\text { Estabilização dos preços } \\
\text { por dois anos-safra. } \\
\text { Comportamento } \\
\text { oportunista de usineiros de } \\
\text { Campos inviabilizou a } \\
\text { manutenção do acordo. }\end{array}$ \\
\hline $1929 / 33$ & $\begin{array}{l}\text { Crise mundial/superprodução } \\
\text { de açúcar. Litígios internos } \\
\text { (usinas x fornecedor, disputa } \\
\text { de mercado entre PE e SP) }\end{array}$ & $\begin{array}{l}\text { Pesquisas e incentivo ao } \\
\text { álcool. Criação do IAA } \\
\text { (cotas de produção, } \\
\text { controle preços). }\end{array}$ & $\begin{array}{l}\text { Controle da produção } \\
\text { nacional e estabilização } \\
\text { dos preços. }\end{array}$ \\
\hline $1939 / 45$ & $\begin{array}{l}\text { Guerra mundial e problemas } \\
\text { com abastecimento de } \\
\text { gasolina e açúcar no Brasil. }\end{array}$ & Incentivo ao álcool-motor. & $\begin{array}{l}\text { Aumento da produção } \\
\text { paulista. }\end{array}$ \\
\hline $1959 / 62$ & $\begin{array}{l}\text { Revolução Cubana. } \\
\text { Problemas sociais no } \\
\text { Nordeste e erradicação dos } \\
\text { cafezais em SP. }\end{array}$ & $\begin{array}{l}\text { Tentativa de } \\
\text { modernização da produção } \\
\text { nordestina. }\end{array}$ & $\begin{array}{l}\text { Exportação para os EUA. } \\
\text { Crescimento da produção } \\
\text { paulista. }\end{array}$ \\
\hline $1968 / 71$ & $\begin{array}{l}\text { Alta dos preços } \\
\text { internacionais, otimismo } \\
\text { sobre o mercado mundial de } \\
\text { açúcar. }\end{array}$ & $\begin{array}{l}\text { Ambicioso programa de } \\
\text { modernização } \\
\text { agroindustrial financiado } \\
\text { pelo IAA. }\end{array}$ & $\begin{array}{l}\text { Expansão da produção } \\
\text { paulista. }\end{array}$ \\
\hline $1974 / 75$ & $\begin{array}{l}\text { Queda dos preços mundiais } \\
\text { do açúcar. Primeiro choque } \\
\text { do petróleo. }\end{array}$ & Lançamento do Proálcool. & $\begin{array}{l}\text { Crescimento da produção } \\
\text { de álcool anidro. }\end{array}$ \\
\hline $1979 / 83$ & $\begin{array}{l}\text { Segundo choque do petróleo. } \\
\text { Estimativas quanto ao } \\
\text { esgotamento das reservas de } \\
\text { óleo. }\end{array}$ & Reforço do proálcool. & $\begin{array}{l}\text { Crescimento da produção } \\
\text { de álcool hidratado. }\end{array}$ \\
\hline $1985 / 89$ & $\begin{array}{l}\text { Reversão dos preços do } \\
\text { petróleo, crise nas finanças } \\
\text { públicas e falta de álcool. }\end{array}$ & $\begin{array}{l}\text { Investimento na produção } \\
\text { nacional de petróleo. }\end{array}$ & $\begin{array}{l}\text { Quebra da confiança no } \\
\text { álcool combustível. }\end{array}$ \\
\hline Pós - 1990 & $\begin{array}{l}\text { Extinção do IAA. (Brasil: } \\
\text { maior produtor mundial x } \\
\text { protecionismo/subsidios, } \\
\text { fontes e alternativas } \\
\text { energéticas). Superprodução } \\
\text { de álcool. Reestruturação } \\
\text { produtiva. Questão social e } \\
\text { ambiental. }\end{array}$ & $\begin{array}{l}\text { Medidas paliativas: pacto } \\
\text { pelo emprego, Brasil } \\
\text { álcool, Bolsa Brasileira de } \\
\text { álcool, Autogestão } \\
\text { setorial: Consecana, } \\
\text { grupos de comercialização } \\
\text { e redução do número de } \\
\text { entidades de representação } \\
\text { patronal. }\end{array}$ & $\begin{array}{l}\text { Preços e mercados } \\
\text { instáveis. Redução no uso } \\
\text { de mão-de-obra e } \\
\text { intensificação da } \\
\text { mecanização da } \\
\text { agricultura. Fusões, } \\
\text { entrada de empresas } \\
\text { estrangeiras e emergência } \\
\text { de novas estratégias. }\end{array}$ \\
\hline 2006/11 (atual) & $\begin{array}{l}\text { Criação do Plano Nacional de } \\
\text { Agroenergia (2006 2011). } \\
\text { Criação da Unidade Embrapa } \\
\text { Agroenergia. }\end{array}$ & $\begin{array}{l}\text { Arranjos institucionais } \\
\text { para estruturar pesquisa e } \\
\text { transferência de tecnologia } \\
\text { para o setor. } \\
\text { Processo de } \\
\text { internacionalização da } \\
\text { industrial de etanol no } \\
\text { Brasil. Co-geração de } \\
\text { energia pela biomassa da } \\
\text { cana-de-açúcar. }\end{array}$ & $\begin{array}{l}\text { Expansão canavieira sobre } \\
\text { áreas agricolas e não } \\
\text { somente pastos } \\
\text { degradados. Altos } \\
\text { subsídios públicos para } \\
\text { implantação e crédito para } \\
\text { os empreendimentos } \\
\text { sucroenergéticos. } \\
\text { Instabilidade finaceira } \\
\text { decorrente aos períodos de } \\
\text { crise econômica. }\end{array}$ \\
\hline
\end{tabular}

Fonte: Vian (2003); Ferreira (2016). Organizado pela Autora. 
Outro ponto relevante para a busca por fontes alternativas ao petróleo, refere-se a questões econômicas, políticas e estratégicas sobretudo, já que mais de $75 \%$ das reservas de petróleo estão localizadas no Oriente Médio e na Venezuela, áreas com fortes conflitos e disputas políticas. Assim, o Plano Nacional de Agroenergia no Brasil (2006/2011) visou:

(...) organizar e desenvolver proposta de pesquisa, desenvolvimento, inovação e transferência de tecnologia para garantir sustentabilidade e competitividade às cadeias de agroenergia. Estabelece arranjos institucionais para estruturar a pesquisa, o consórcio de agroenergia e a criação da Unidade Embrapa Agroenergia. Indica ações de governo no mercado internacional de biocombustíveis e em outras esferas (BRASIL, 2006).

No contexto do Plano Nacional de Agroenergia, foi amplamente difundido que o Brasil tinha uma série de vantagens que o qualificavam a liderar a agricultura de energia e o mercado da bioenergia - o biomercado - em escala mundial e o mercado do açúcar (a exportação do etanol brasileiro ainda é muito incipiente). A primeira delas foi a possibilidade de dedicar novas terras à agricultura canavieira, sem a necessidade de reduzir a área utilizada na agricultura de alimentos e com impactos ambientais e sociais socialmente aceitos. Com isso várias usinas foram propostas e muitas aprovadas para implantação em todo Brasil, sobretudo nos estados de São Paulo (maior produtor nacional de cana-de-açúcar), Goiás e Minas Gerais.

É importante destacar que dentro das diretrizes do Plano de Agroenergia, a expansão canavieira se daria em áreas de pastagens ou pastos degradados, contudo com a efetivação da expansão da cana foi verificado que a expansão se deu em áreas de produção agrícola, com algumas áreas de lavouras de alimentos sendo substituídas pela cana, e também áreas com soja, que é um dos principais produtos exportados pelo Brasil, sendo substituídas.

Atualmente, o Estado já não mais controla a produção e a comercialização da cana e de seus produtos, quem define seus preços são os mercados, as importações e exportações de açúcar e de etanol são realizadas sob total responsabilidade dos próprios empresários. Sabe-se da importância do papel do Estado, sobretudo em termos de políticas e programas de fomento às agroindústrias sucroenergéticas hoje, mas em relação ao mercado, a competitividade estrutural de uma produção está diretamente exposta ao mercado nacional e à concorrência internacional. 
Segundo Benetti (2009), o início do processo de internacionalização da indústria de etanol no Brasil remonta os anos 2000, quando o grupo francês Louis Dreyfrus adquiriu uma empresa nacional. A partir disso, vários outros grupos com matrizes nos Estados Unidos e em diferentes países europeus e asiáticos, passaram a investir no setor sucroenergético, podem-se citar: Adecoagro, de George Soros (Luxemburgo); Cargill (EUA); L. Dreyfus (França); Tereos (França); Noble (Cingapura); Infinity Bio-Energy (Rússia); ADM (EUA); e Evergreen (Rússia).

A crise econômica mundial em 2008 contribuiu para uma mudança no perfil do agronegócio brasileiro, pois estimulou a presença de empresas com capital internacional de setores distintos, não só agrícolas, mas também petroleiros, automotivos e financeiros. Isso aconteceu por meio, sobretudo, de fusões entre as empresas e corporações, o que facilita a concentração de capitais e, consequentemente, tem maior poder de compra de terras, insumos, maquinários, etc. (PITTA, et al, 2014).

Assim, a partir de 2008, alguns acontecimentos vieram instabilizar o mercado canavieiro, principalmente do etanol. Primeiramente a crise de 2008 trouxe uma "onda" de insegurança para a economia internacional como um todo, e quase que simultaneamente, com a descoberta de petróleo na camada de pré-sal no Brasil, retirouse, por um momento, os holofotes da produção de energias renováveis, como o etanol, mesmo porque foi uma euforia muito grande, difundindo-se que os problemas econômicos do Brasil estariam solucionados pela descoberta do pré-sal.

Também nesse contexto, começou a se intensificar a extração do gás de xisto nos Estados Unidos, que corresponde ao gás natural encontrado dentro das formações de xisto argiloso. A reserva americana é estimada em 2,7 trilhões de metros cúbicos e é vendido por US\$ 4 por milhão de $\mathrm{BTUs}^{8}$ - o menor preço do mercado mundial.

Desta forma, a extração e comercialização do gás xisto veio preocupando os produtores de etanol brasileiros, pois com a difusão do uso do gás, e por um preço relativamente baixo, a inserção do etanol brasileiro, como uma commodity internacional, está cada vez mais distante, já que a maior parte do etanol produzido no Brasil ainda é comercializado no mercado interno. Contudo, estudos recentes

\footnotetext{
${ }^{8}$ Valor referente ao ano de 2013, disponibilizado pela Administração de Informação sobre Energia (EIA).
} 
divulgaram que a emissão de metano pela extração do gás xisto é superior àquela do gás convencional, o que agravaria ainda mais o efeito estufa.

É importante destacar que até a crise de 2008, as principais empresas do setor canavieiro no Brasil eram de capital nacional, com excessão à Cosan. A partir desse período, houve grande abertura para o capital internacional e fusões de empresas. As corporações internacionais que têm se inserido no setor sucroenergético tem buscado principalmente novas áreas para o cultivo canavieiro. As empresas Raízen (Shell Cosan), Biofuels e ETH (Sojitz Corporation e Odebrecht Construtora), entre outras, têm concentrado suas atuações em áreas do Sul Goiano, Oeste e Noroeste Paulista, Leste do Mato Grosso do Sul e Triângulo Mineiro (PITTA, et al, 2014).

Esse breve panorama global sobre as fontes de energia faz-se fundamental para entender a lógica de mercado, que conforma a lógica de produção do etanol. Ainda não se sabe o fututo da produção sucroenergética no mundo, já que a extração do gás xisto é uma realidade e que preocupa os produtores de etanol brasileiros. Atualmente o Brasil é o maior produtor de etanol derivado de cana-de-açúcar do mundo, mas conforme mencionado, a maioria da produção fica no Brasil.

Segundo as figuras 2, 3 e 4 pode-se verificar a produção canavieira, de etanol e de açúcar no Brasil, respectivamente, a partir da década de 1940 até o ano de 2010/2011.

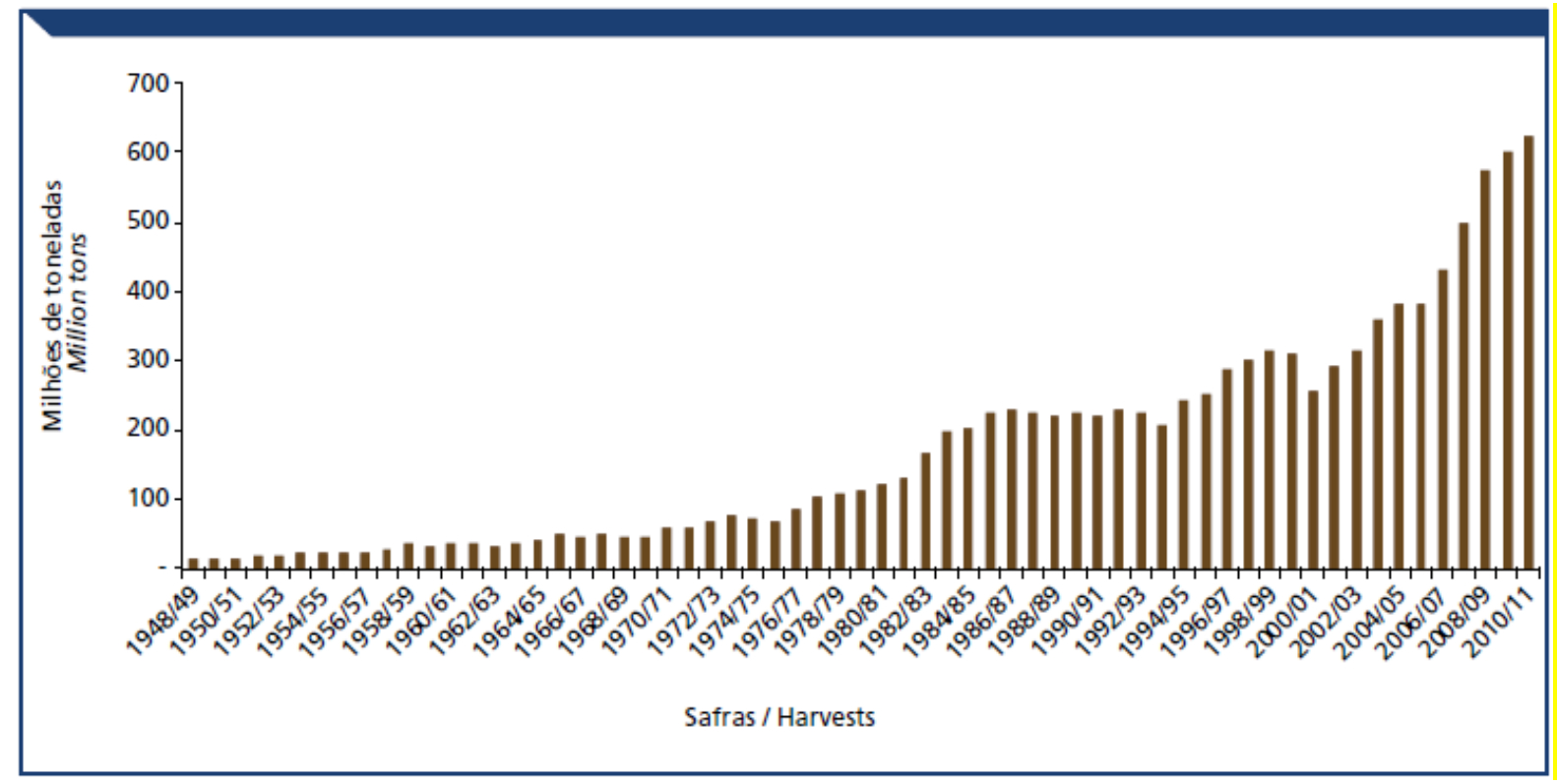

Figura 2 - Gráfico da evolução da produção brasileira de cana-de-açúcar. Fonte: Anuário Estatístico da Agroenergia (2012). 


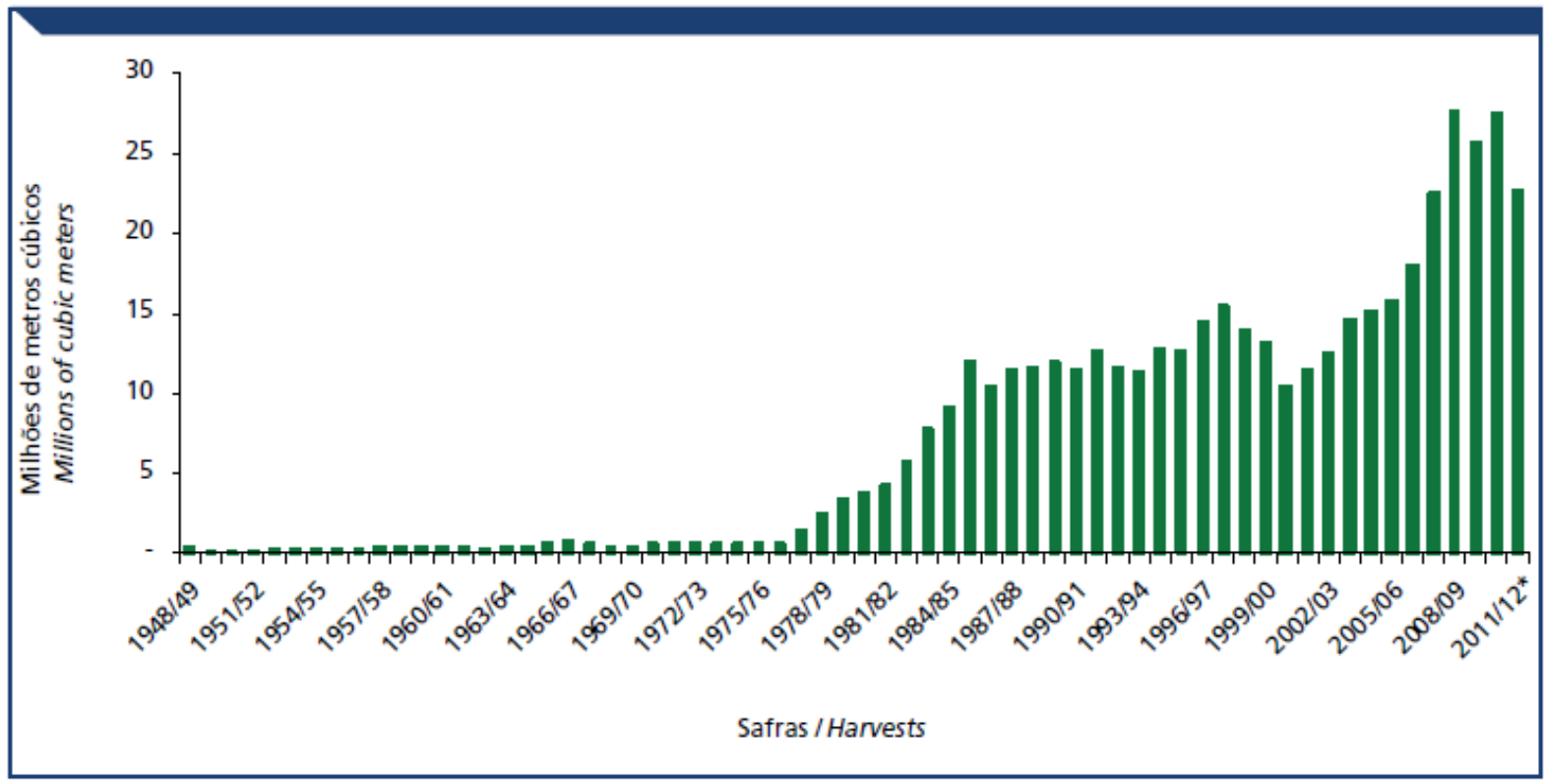

Figura 3 - Gráfico da evolução da produção brasileira de etanol. Fonte: Anuário Estatístico da Agroenergia (2012).

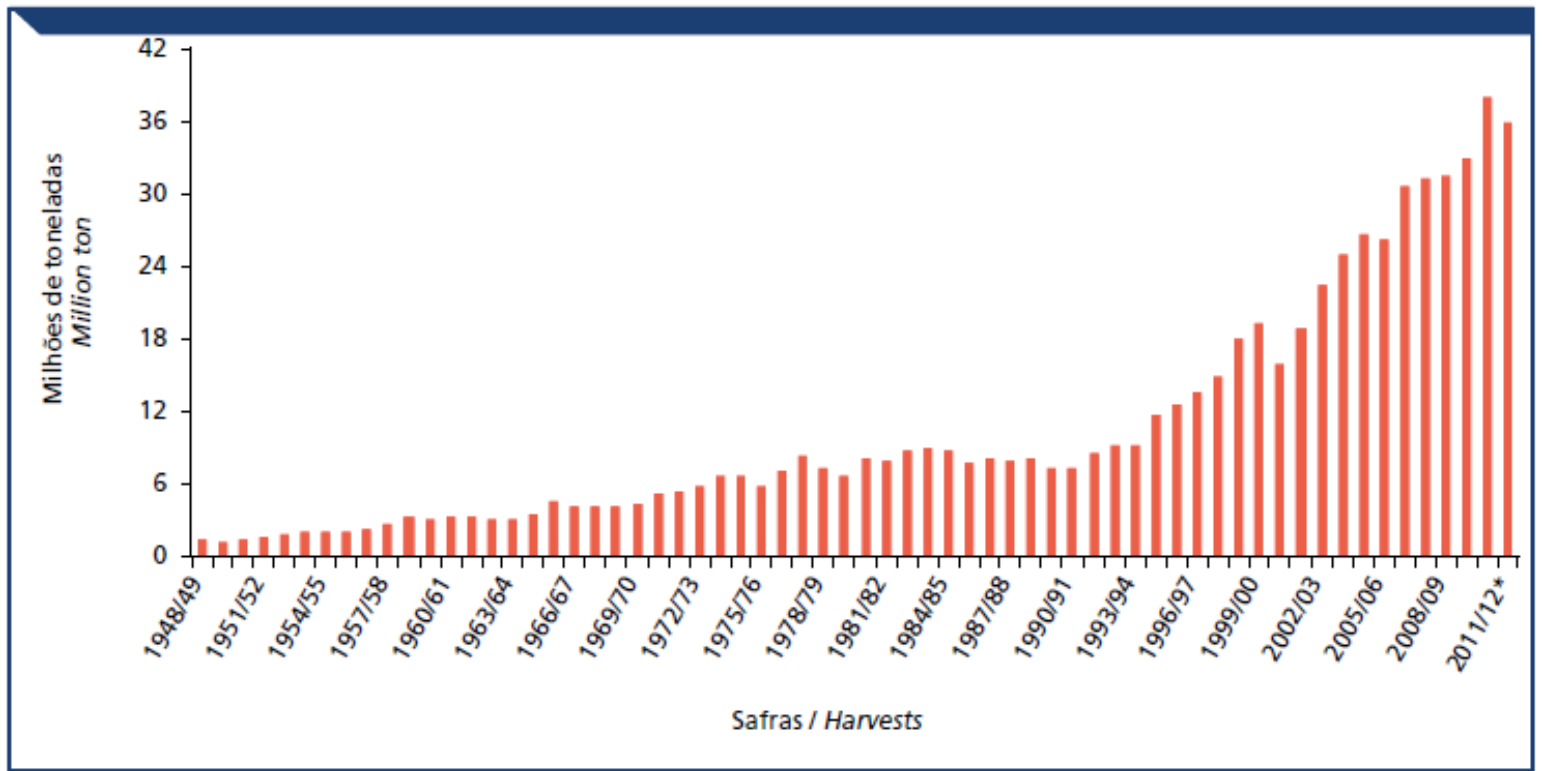

Figura 4 - Gráfico da evolução da produção brasileira de açúcar. Fonte: Anuário Estatístico da Agroenergia (2012).

A análise desses gráficos permite iniciar uma compreensão sobre a lógica de produção e mercado canavieiro no Brasil e compreender a importância das políticas públicas e programas de governo que estimularam a produção canavieira. Observa-se que houve um crescimento relevante da produção de cana-de-açúcar a partir do final da 
década de 1970 (figura 2), fruto dos incentivos do Proálcool, o que demonstra, em dados, o quão importante este Programa foi para a expansão canavieira no Brasil, tanto em área plantada de cana-de-açúcar, quanto de usinas implantadas em todo território nacional.

A queda na produção de cana e etanol principalmente a partir dos anos 1990 (figura 3), tem relação direta com a extinção do IAA e a crise do Proálcool, até culminar no ano de 2006 com o Plano Nacional de Agroenergia, que incentivou novamente a produção canavieira e de etanol no Brasil. É evidente que a produção de açúcar (figura 4) também segue esse padrão, mas é importante ressaltar que o mercado do açúcar brasileiro é mais estável que o do etanol, além de ser, em sua maioria, para exportação.

É importante mencionar que a expansão da agroindústria canavieira tem se concentrado na região Centro-Sul brasileira, com grande parte das áreas cultivadas com cana-de-açúcar localizadas no Oeste Paulista, Triângulo Mineiro, Centro e Sul de Goiás, Leste do Mato Grosso do Sul e Noroeste do Paraná. Em relação a área plantanda, o estado de São Paulo aparece em primeiro lugar, com 5566584 ha, seguidos de Minas Gerais, com 949801 ha, e Goiás com 882216 ha (IBGE, 2014).

Diante do panorama geral da territorialização das agroindústrias canavieiras no território brasileiro e a constatação do estado de Goiás como o terceiro maior produtor de cana-de-açúcar do país, faz-se importante entender como esta produção está espacializada nesse estado, bem como tecer algumas reflexões sobre a produção do território goiano pela dinâmica sucroenergética.

É importante também trazer à discussão o conceito do agrohidronegócio, que traz uma importante contribuição, pois talvez o elemento mais importante para a territorialização do setor sucroenergético, até mesmo em termos estratégicos e geopolíticos, seja a água, já que em praticamente qualquer tipo de solo pode-se produzir cana e com topografia acidentada a colheita pode ser realizada de forma manual, contudo sem água a produção canavieira e, consequentemente seus produtos: etanol, açúcar e energia, tornam-se inviáveis. 


\subsection{A Produção do Território Goiano pelo Agronegócio Sucroenergético e o Agrohidronegócio}

Para pensar a territorialização dos empreendimentos sucroenergéticos em Goiás é importante refletir brevemente sobre a categoria território. Há importantes contribuições de vários autores sobre essa categoria, que auxiliam no entendimento dos conflitos verificados pela dinâmica sucroenergética.

Destaca-se o conceito de Raffestin (1993), que entende o território como formado a partir do espaço e como sendo resultado de uma ação conduzida por um ator sintagmático ${ }^{9}$ em qualquer nível. Segundo Raffestin, ao se apropriar de um espaço, concreta ou abstratamente, o ator territorializa o espaço, sendo nessa perspectiva um espaço onde se projetou trabalho e que revela as relações de poder (RAFFESTIN, 1993).

No território, verifica-se a dialética estabelecida pelas relações de poder. Assim ele pode ser apreendido, de acordo com Oliveira (1999), como síntese contraditória, como totalidade concreta do processo / modo de produção / distribuição / circulação / consumo e com suas articulações e mediações supraestruturais (políticas, ideológicas, simbólicas, etc) em que o Estado desempenha a função de regulação.

Para pensar o território é necessário entender a relação estabelecida entre a sociedade e a natureza, as formas em que a primeira utiliza-se para apropriar-se da segunda. Assim, para tanto, faz-se importante considerar a indústria, a agricultura, a mineração, entre outras atividades econômicas. Para o presente estudo é fundamental compreender como a atividade agroindustrial produz os territórios, diante disso, pensar o campo e a cidade torna-se necessário.

Para Raffestin, "é pois evidente como a construção dos territórios foi muito influenciada, não somente pelas atividades agrícolas, mas também pelas políticas, pelas transformações das cidades e pelas mudanças nos hábitos de consumo" (2009, p. 22). Os territórios transformam-se de acordo com o ritmo das novas técnicas e isso é verificado tanto na cidade como no campo. A atividade agroindustrial está sujeita às modificações velozes, estabelecidas pelo tempo e materializadas na paisagem.

\footnotetext{
${ }^{9} \mathrm{O}$ termo ator sintagmático é de A. J. Greimas, e manifesta, com precisão, a ideia de processo e de articulações sucessivas no interior do processo. Assim, todas as organizações, da família ao Estado, são atores sintagmáticos.
} 
Por fim, destaca-se o conceito de "território usado" de Santos (2002), o qual é um todo complexo onde se tece uma trama de relações, sendo também entendido como a mediação entre o mundo e a sociedade local. Entremeados nesse conceito, estão os objetos, as ações, a importância da técnica, ou mediação técnica, e a constituição das redes. $\mathrm{O}$ autor, por meio desse conceito, enaltece o uso e o controle social cristalizado no território, sendo visto como uma totalidade. Partir do conceito de "território usado" auxilia na análise da problemática posta, na medida em que de um lado revela a estrutura global da sociedade e de outro a própria complexidade de seu uso.

O estado de Goiás apresenta contextos históricos e processos importantes de produção de seu território. Uma das atividades, na atualidade, que contribui para a (re) produção do território goiano é o agronegócio. Antes de abordar o conceito de agronegócio, faz-se importante compreender que a agricultura brasileira passou por um amplo processo de modernização, tendo na década de 1970 seu marco principal, e por um processo de industrialização da agricultura, cujas características principais estiveram presentes nos complexos agroindustriais (conhecidos como CAI's), nas décadas de 1970 e 1980.

Por modernização da agricultura entende-se o processo de mudança na base técnica da produção agrícola. Este processo ganhou dimensão nacional no pós-guerra com a introdução de máquinas na agricultura, por meio da importação de tratores; de elementos químicos, como fertilizantes e defensivos agrícolas; e mudanças de ferramentas e de culturas ou incorporação de novas variedades. $O$ processo de modernização ao mesmo tempo em que implicaria a integração técnica intrasetorial e a mercantilização da agricultura, promoveu a substituição de elementos internos do complexo rural para compras extrasetoriais, como máquinas e insumos, abrindo espaço para a criação de indústrias de bens de capital e insumos para a agricultura (KAGEYAMA, et al, 1996).

A modernização da agricultura teve seu marco na década de 1970, mas o processo de mecanização da agricultura no Brasil iniciou-se em meados da década de 1920, anterior a isso, a tração mecânica se restringia à lavoura canavieira (nos engenhos). A partir do crescimento das lavouras de trigo e arroz irrigado no Rio Grande do Sul e de cana-de-açúcar e café em São Paulo (década de 1940), que foram criadas condições concretas para a existência de um mercado de máquinas e implementos 
agrícolas, tornando-se necessária a importação destes equipamentos. Mas, foi a partir da expansão da lavoura de soja, nos anos 1960, que houve a possibilidade de difusão das máquinas ampliando os limites de mercado de equipamentos para a agricultura.

Assim, com a implantação da indústria de base (siderurgia, petroquímica, plásticos, bioquímica, etc.) nas décadas de 1950 e 1960, os setores que produziam insumos modernos, máquinas e equipamentos para a agricultura foram internalizados no Brasil, fazendo com que a capacidade de modernização da agricultura passasse a ser endógena.

Em síntese, foi a partir do pós-guerra que se verificaram os principais esforços para a modernização da base técnica agrícola no Brasil. Observou-se um forte crescimento extensivo da produção agrícola no país entre os anos 1930 e 1950, com a incorporação de 6.356 hectares; entre 1950 e 1960, de 9.617 hectares; e, na década de 1960, mais de 5.272 hectares, além de importações de tratores e fertilizantes que possibilitaram um aumento na produtividade agrícola (LIMA, 2001).

O desenvolvimento da agricultura, com a constituição dos CAI's, principalmente a partir da década de 1970, passa a depender da dinâmica da indústria, sendo seu funcionamento determinado de forma conjunta. Segundo Silva (2003), a implantação dos complexos agroindustriais tornou-se parte integrante da política de Integração Nacional e de abertura de fronteiras agrícolas capitalistas. Desse modo, o espaço agrário inseriu-se, cada vez mais, no modelo de acumulação urbano-industrial, consumindo insumos industriais e produzindo matérias-primas para as indústrias de tecnologias avançadas na área de processamento alimentar.

Mais recentemente no Brasil, tem-se utilizado o conceito de agronegócio para representar essas complexas relações existentes no complexo sistema agrário brasileiro. O termo agronegócio já foi compreendido de várias maneiras ao longo do tempo. A primeira formulação veio do agribusiness de Davis e Goldberg em 1957, os quais compreendiam um complexo de agricultura, indústrias, mercado e finanças. Mais recentemente, outros autores trabalharam com o conceito de agronegócio, aperfeiçoando-o.

Para Gasquez et al (2004, p. 8), o agronegócio é visto como a cadeia produtiva que envolve desde a fabricação de insumos, a produção nos estabelecimentos agropecuários, sua transformação, chegando até o consumo. Esta cadeia incorpora todos 
os serviços de apoio, desde pesquisas e assistências técnicas, bem como processamentos, transporte, comercialização, distribuidores, bolsas de valores, até o consumidor final.

Girardi e Fernandes (2004), trazem nove preceitos que seriam fundamentais para caracterizar o agronegócio: concentração de terras, uso intenso de tecnologia, elevados impactos ambientais, uso elevado de água para cultivo irrigado, produção de plantas e animais modificados geneticamente, concentração de capitais, financiamentos facilitados devido à propriedade da terra ser garantia dos mesmos, predomínio de trabalho assalariado, uso e dependência de insumos estrangeiros e a produção destinada na sua maior parte para o mercado externo.

Para Fernandes e Welch (2008) é importante mencionar que o agronegócio forma um modelo controlado por corporações transnacionais, que trabalham com uma ou mais commodities e atuam em outros setores da economia. Segundo os autores é evidente que essa condição confere às transnacionais do agronegócio um poder extraordinário que possibilita a manipulação dos processos em todos os sistemas do complexo.

Mendonça (2015), traz subsídios para ratificar, que o conceito de agronegócio,

(...) está relacionado a um conjunto de medidas impulsionadas por governos e instituições privadas que intensificaram a industrialização e a padronização da agricultura em nível internacional. Alguns dos elementos centrais deste modo de produção são a uniformidade e extensão dos cultivos, o uso de máquinas e insumos químicos, além da intensificação do uso de água e energia no processo produtivo (2015, p. 397).

O complexo canavieiro atualmente é um dos principais exemplos de agronegócio, pois possuem a produção agrícola altamente tecnificada, com a presença de insumos, implementos agrícolas, maquinários altamente modernos, além do processamento industrial da cana, com a produção, em suas várias formas, de açúcar (VHP, cristal, refinado K, orgânica), etanol (anidro, hidratado, em gel), energia (pela biomassa da cana: bagaço e palha), levedura, etc.. Além de todas as relações que se antecipam e que finalizam esse sistema, como as relações de circulação, transporte, logística, fomentos, mercado e consumo, enfim, as relações capitalistas e de poder envolvidas nesse processo. 
Como já mencionado, a expansão canavieira para o estado de Goiás teve seu primeiro marco durante a década de 1970, com os incentivos do Próalcool algumas destilarias foram implantadas no estado, dando início à territorialização da cana-deaçúcar em Goiás. Contudo, foi em meados dos anos 2000 que houve um verdadeiro boom canavieiro no estado, fruto do Plano Nacional de Agroenergia e do contexto nacional e internacional de bioenergia já mencionado.

No ano de 2005 havia 14 usinas em operação em Goiás, com uma produção de 15.642.125 toneladas (t) de cana-de-açúcar. No ano de 2007, havia 18 usinas em operação e aproximadamente 30 usinas em processo de avaliação. É importante ressaltar, que nesse contexto, o estado de Goiás foi visto como área de relevante interesse para a implantação de novos empreendimentos e expansão da cultura canavieira, sobretudo, por fatores econômicos, ambientais e de logística.

O estado de Goiás possui posição geográfica estratégica, razoável infraestrutura implantada e terras mais baratas se comparado ao estado de São Paulo (maior produtor de cana do Brasil), além de possuir, em sua maioria, solos e clima favorável ao cultivo de cana, além de uma área extensa do território goiano estar em áreas de chapadas, o que facilita a inserção de maquinários para plantio e colheita da cana-de-açúcar.

No ano de 2009, foi realizado pela Embrapa (solicitado pelo Ministério da Agricultura, Pecuária e Abastecimento - MAPA) o Zoneamento Agroecológico da Cana-de-açúcar. Ao excluir Áreas de Preservação Permanente, observou-se que o estado de Goiás apresenta somente áreas com alta e média aptidão agrícola para a produção canavieira (por classes de uso do solo), não existindo nenhuma área com baixa aptidão. A figura 5 mostra o zoneamento agroecológico da cana para Goiás.

Muitas usinas tiveram o pedido negado para implantação e, atualmente, segundo dados do Instituto Mauro Borges da Secretaria de Estado de Gestão e Planejamento de Goiás (IMB / SEGPLAN, 2014), existem 37 usinas sucroenergéticas implantadas e em funcionamento em Goiás, duas usinas com a licença suspensa temporariamente, quatro usinas em processo de implantação e dez usinas em provável implantação. 


\section{Zoneamento agroecológico da cana-de-açúcar Estado de Goiás}

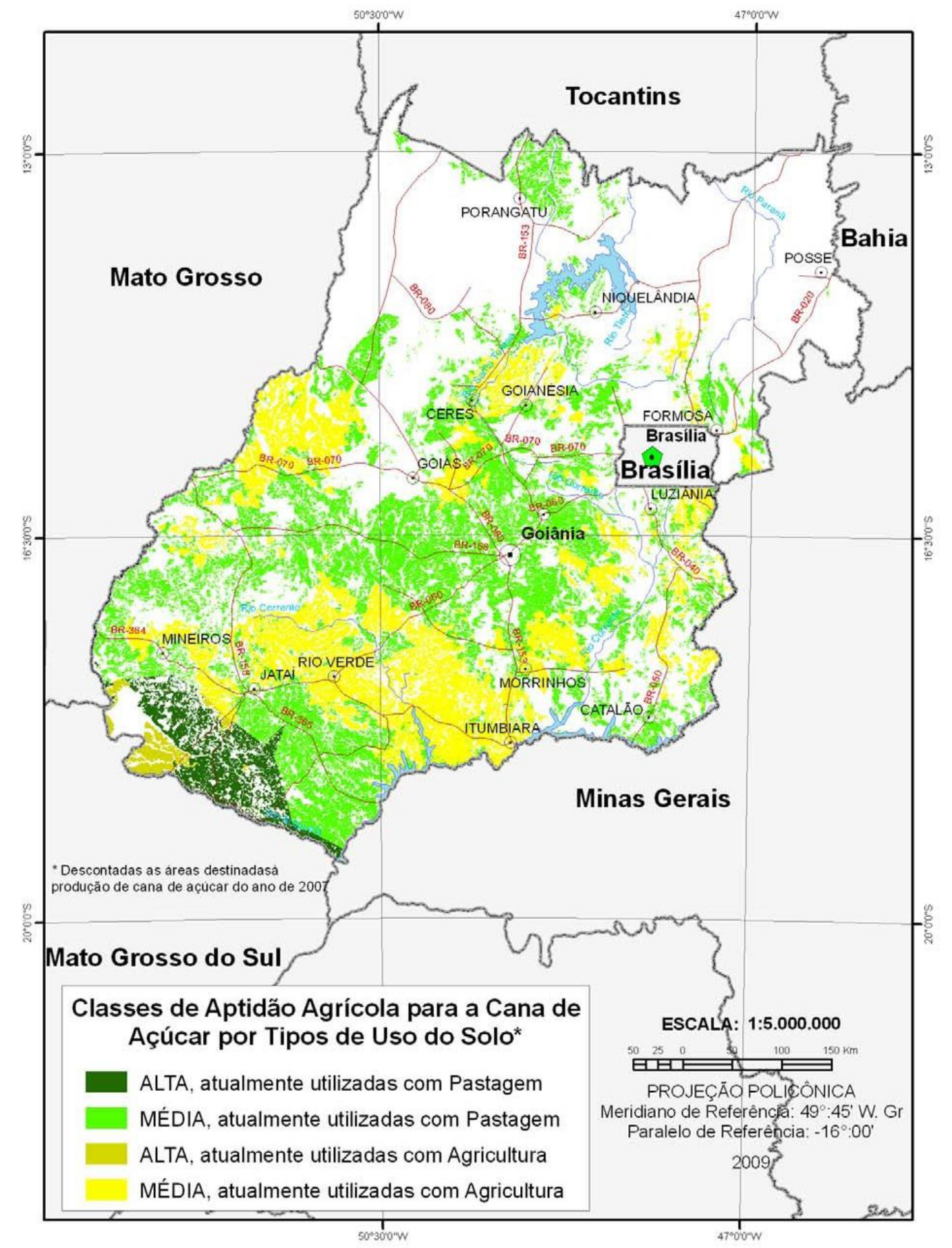

Figura 5 - Zoneamento Agroecológico da Cana-de-açúcar para Goiás. Fonte: Embrapa, 2009. 
A tabela 1 mostra dados do número de usinas em funcionamento, bem como os dados de produção canavieira, etanol e açúcar para Goiás, entre os anos 2005 a 2013. Por meio da observação desses dados, verifica-se que a quantidade de usinas mais que dobrou em apenas cinco anos e a produção de cana, assim como a de etanol e açúcar, cresceu consideravelmente ao longo do tempo, salvo algumas pequenas oscilações.

Tabela 1 - Destilarias em operação e produção de cana de açúcar, etanol e açúcar - 2005 - 2013, no estado de Goiás.

\begin{tabular}{c|c|c|c|c}
\hline Ano & $\begin{array}{c}\text { Destilarias/ } \\
\text { Usinas }\end{array}$ & $\begin{array}{c}\text { Produção Cana de açúcar } \\
(\mathbf{t})\end{array}$ & $\begin{array}{c}\text { Etanol } \\
(\mathbf{m i l} \text { litros })\end{array}$ & $\begin{array}{c}\text { Açúcar } \\
(\mathbf{t})\end{array}$ \\
\hline 2005 & 14 & 15.642 .125 & 728.979 & 749.838 \\
\hline 2006 & 15 & 19.049 .550 & 821.616 & 766.322 \\
\hline 2007 & 18 & 22.063 .677 & 1.213 .733 & 952.312 \\
\hline 2008 & 28 & 33.041 .559 & 1.922 .414 & 1.247 .039 \\
\hline 2009 & 35 & 43.666 .585 & 2.196 .179 & 1.384 .081 \\
\hline 2010 & 36 & 47.733 .283 & 2.895 .998 & 1.798 .457 \\
\hline 2011 & 34 & 54.903 .085 & 2.675 .292 & 1.752 .398 \\
\hline 2012 & 37 & 53.915 .572 & 3.130 .577 & 1.875 .260 \\
\hline
\end{tabular}

Fonte: Goiás em Dados, 2014.

Elaboração: Instituto Mauro Borges / Segplan-GO / Gerência de Sistematização e Disseminação de Informações Socioeconômicas - 2014.

A maioria das usinas implantadas em Goiás está geograficamente instalada num eixo centro norte - sul - sudoeste do estado, como pode ser observado na figura 6 . Esta lógica de espacialização também está associada à malha viária implantada nesse eixo, com destaque para a BR 153 que corta o estado de Goiás, de norte a sul, o que facilita logística e financeiramente o escoamento e a circulação da produção.

Na figura 6 há em destaque duas áreas pontilhadas, as quais representam, em azul, a região sudoeste de Goiás e, em vermelho, a região de Ceres. O sudoeste goiano é sem dúvida, a região do estado de Goiás que apresenta maior dinamismo econômico relacionado ao agronegócio, sobretudo, com a produção de grãos e proteína animal e, mais recentemente, a cana-de-açúcar. No sudoeste de Goiás há visivelmente uma disputa pela terra entre as culturas e também com as áreas de pastagens, como o caso do município de Quirinópolis, onde a área de produção de cana-de-açúcar aumentou $650 \%$ entre os anos de 2006 e 2009, na medida que o cultivo de arroz declinou $70 \%$ e da soja 16\%, como bem explicitou Arrais (2013). 


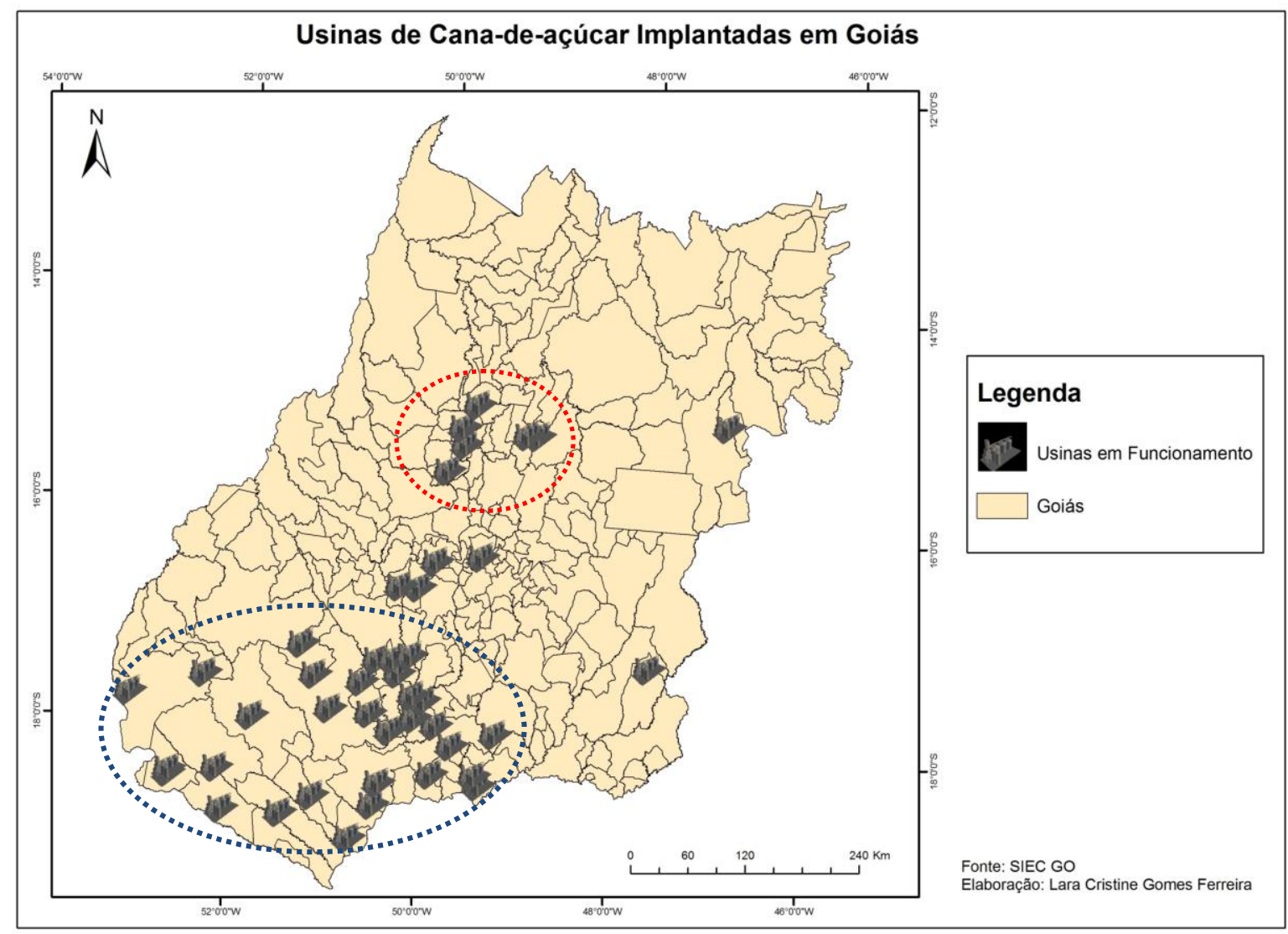

Figura 6 - Mapa da espacialização das usinas sucroalcooleiras de Goiás. Fonte: Instituto Mauro Borges / Segplan-GO - Goiás em Dados, 2012.

Ainda no sudoeste goiano, o caso do município de Rio Verde foi emblemático. No ano de 2006, no auge da expansão canavieira, o poder público local limitou a produção de cana, por meio da Lei Complementar $n^{\circ} 5.200 / 2006$, em até 50 mil hectares, ou seja, $10 \%$ do território do município, com a justificativa de a produção canavieira ameaçar uma cadeira produtiva já consolidada, que é todo complexo de grãos e carnes territorializada no município.

Nesse caso ocorrido em Rio Verde, ficaram evidentes as disputas territoriais entre o capital sojicultor (e todo o complexo grãos-carnes), já dominante até então em Rio Verde, e o capital canavieiro, que naquele contexto surgia com uma intensidade e rapidez assustadoras. Menos de dois anos depois, a Lei Complementar $n^{\circ}$ 5.200/2006 foi revogada pelo Tribunal de Justiça de Goiás, que considerou essa Lei inconstitucional, com o argumento de que a imposição de limites à propriedade é atribuição da União e 
não do poder local. E, naquele contexto, a expansão canavieira era tema de interesse nacional e internacional, com o país em pleno destaque na produção de biocombustíveis, sobretudo o etanol. A soja continua sendo a principal cultura em Rio Verde, mas o capital sojicultor e canavieiro ainda encontra-se em disputas territoriais e contam com pesados investimentos privados e do Estado (em sintonia com o mercado financeiro), já que o município de Rio Verde possui instaladas em seu território duas usinas de cana-de-açúcar: a usina Rio Verde e a Decal Açúcar e Álcool.

Outra região que se destaca na produção canavieira em Goiás é a região de Ceres, como pôde ser verificado na figura 6 , destacada com a linha pontilhada em vermelho. Essa região, diferente do sudoeste de Goiás, já possui usinas implantadas desde o final da década de 1960, a primeira usina de produção de açúcar implantada na região foi em Goianésia, no ano de 1969.

Atualmente são sete usinas implantadas na região de Ceres, nos municípios de Rubiataba, Itapaci, Itapuranga, Carmo do Rio Verde e Goianésia, sendo que neste último há três usinas em funcionamento. Essa região, ao contrário do sudoeste do estado, possui topografia acidentada o que dificulta a inserção total da mecanização da colheita da cana, o que traz para o município e região sérias problemáticas socioespaciais, bem como disputas e conflitos particulares que serão abordadas no decorrer desta pesquisa.

As usinas canavieiras passaram, ao longo do tempo, por algumas transformações industriais importantes. No contexto do Proácool, as usinas produziam somente álcool e eram denominadas de destilarias. Posteriormente, com o mercado do áçucar sempre ascendente, sobretudo, o mercado internacional, foram acopladas às destilarias o processamento industrial do açúcar. Atualmente, as usinas reaproveitam praticamente tudo o que era considerado rejeito (subproduto) do processamento industrial do álcool e do açúcar, como o bagaço e a palha da cana, a vinhaça e a torta de filtro. Para quase tudo tem-se mercado.

A vinhaça é o subproduto do processamento industrial do álcool e atualmente é utilizada como fertilizante na própria lavoura de cana, por meio da fertirrigação. A vinhaça é fonte de nutrientes, principalmente matéria orgânica e potássio, e pode trazer vantagens para a cultura canavieira, como a elevação do $\mathrm{pH}$, a disponibilidade de certos nutrientes (como magnésio, cálcio e potássio), melhoria da estruturação do solo, 
aumento na retenção de água e desenvolvimento da microflora e microfauna do solo. Entretanto, o uso da vinhaça deve obedecer aos limites técnicos, pois sua sobrecarga (geralmente em aplicações acima de $300 \mathrm{~m}^{3} / \mathrm{ha}$ ) pode trazer sérios impactos como salinização e contaminação do lençol freático.

A torta de filtro é o subproduto proveniente do processo de produção de açúcar. A torta de filtro, quando incorporada ao solo em doses elevadas (até $268 \mathrm{t} / \mathrm{ha}$ ) apresenta propriedades corretivas de acidez do solo, sendo sua vantagem sobre o calcário a de provocar menor alteração no balanço catiônico do solo. A torta de filtro, por ser um material orgânico por excelência, mostra elevada capacidade de retenção de água a baixas tensões e esta propriedade contribui tanto para aumentar a produtividade da canade-açúcar, especialmente em regime não irrigado, como para assegurar melhor brotação em plantios realizados em épocas desfavoráveis (SACAROSE ON LINE, 2009).

Outro resíduo da produção canavieira é o bagaço da cana, que durante muito tempo foi um grande problema para as usinas. Em cerca de uma tonelada de cana-deaçúcar restam, aproximadamente, $140 \mathrm{~kg}$ de bagaço. Atualmente o bagaço da cana é bastante utilizado e é sinônimo de renda para as agroindústrias, pois ele pode ser transformado em energia elétrica, por meio da cogeração de energia, bem como pode ser transformado em fibra de carbono, um material muito valorizado pela indústria, e em peças de carros, materiais para a indústria de petróleo e até armações de óculos (NOVA CANA, 2014).

Atualmente quase todas as usinas de cana-de-açúcar reaproveitam o bagaço ${ }^{10}$ para produção de energia, utilizando-a para o funcionamento da própria unidade industrial durante o período da safra (geralmente oito meses, de março a outubro) e em alguns casos há a comercialização do excedente de energia para a central elétrica local. Segundo definição da Agência Nacional de Energia Elétrica (Aneel) a cogeração de energia é o processo de produção combinada de calor útil e energia mecânica, geralmente convertida total ou parcialmente em energia elétrica. A cogeração trata-se da associação da geração simultânea combinada de dois ou mais tipos de energia, utilizando um único tipo de fonte energética. Em relação a produção de energia pelas

\footnotetext{
${ }^{10}$ Algumas usinas utilizam-se também da palha da cana para a cogeração de energia elética (biomassa da cana-de-açúcar).
} 
usinas, a fonte energética é o bagaço que, ao ser queimado, gera energia térmica em forma de vapor e energia elétrica.

O desenvolvimento da cogeração de energia, a partir da biomassa da cana-deaçúcar, foi impulsionado, sobretudo, pelo Programa de Incentivo às Fontes Alternativas de Energia Elétrica - PROINFA - que vem estimulando as usinas a não serem somente empreendimentos produtores de açúcar e álcool, mas verdadeiras biorrefinarias. O mercado da energia nas usinas canavieiras é bastante promissor e tão fortemente considerado que o setor, até recentemente, era conhecido por sucroalcooleiro, fazendo referência à produção de açúcar e álcool, mas atualmente é denominado de setor sucroenergético, referindo-se a produção de energia elétrica pela biomassa da cana.

O quadro 3 mostra a potência $(\mathrm{kW})$ dos empreendimentos sucroenergéticos em operação no estado de Goiás. Esse quadro ilustra o novo mercado do setor que é a produção de energia e a comercialização do excedente em alguns casos. Por meio desse quadro, pode-se destacar a Rio Claro Agroindustrial, localizada no município de Caçú (sudoeste do estado), com a produção de $130.000 \mathrm{~kW}$. Esta é uma empresa do grupo Odebrecht, uma empresa com origem brasileira, mas que possui participação e investimentos internacionais (Asmore, Inglaterra e Sojitz, Tóquio, por exemplo).

Para compreender o setor sucroenergético atualmente é necessário passar pela discussão do que está sendo denominado de agrohidronegócio. Esse conceito foi cunhado por Mendonça e Mesquita (2007) e, posterior a isso, trabalhado por outros autores, sobretudo Thomaz Júnior. Segundo Mendonça (2015), a terra e água passaram a ser, de forma conjunta, apropriadas para se transformarem em mercadorias, ao invés de serem consideradas bens públicos, conforme as necessidades humanas. 
Quadro 3 - Destilarias em Goiás e a Produção de Energia

\begin{tabular}{|c|c|c|c|}
\hline \multicolumn{4}{|c|}{ ESTADO DE GOIÁS: DESTILARIAS E GERAÇÃO DE ENERGIA / POSIÇÃO: AGOSTO/2013 } \\
\hline Municípios & Destilarias & Situação & Potência $(\mathrm{kW})$ \\
\hline Anicuns & Anicuns S/A Álcool e Derivados - Grupo Farias & Operando & - \\
\hline Cachoeira Dourada & Usj Açúcar e Álcool S/A Fl Ii & Operando & 80.000 \\
\hline Caçu & Rio Claro Agroindustrial (Odebrecht) & Operando & 130.000 \\
\hline Carmo do Rio Verde & Crv Industrial Ltda & Operando & 20.000 \\
\hline Chapadão do Céu & Usina Cerradinho & Operando & 70.000 \\
\hline Edéia & Tropical Bioenergia S/A (Bp) & Operando & 50.000 \\
\hline \multirow{3}{*}{ Goianésia } & Jalles Machado S/A & Operando & 40.000 \\
\hline & Jalles Machado S/A - Unidade Otávio Lage & Operando & 48.000 \\
\hline & Usina Goianésia S/A - Grupo J. Maranhão & Operando & 7.300 \\
\hline \multirow{2}{*}{ Goiatuba } & Bom Sucesso Agroindústria Ltda & Operando & 4.500 \\
\hline & Goiasa - Goiatuba Álcool Ltda & Operando & 46.520 \\
\hline Inhumas & Centroálcool S/A & Operando & - \\
\hline Ipameri & Lasa Lago Azul S/A & Operando & 3.992 \\
\hline Itapaci & Vale Verde Itapaci Grupo Farias & Operando & 6.952 \\
\hline \multirow[t]{2}{*}{ Itumbiara } & $\begin{array}{l}\text { Central } \\
\text { Alimentos Ltda (Bp) }\end{array}$ & Operando & 56.000 \\
\hline & Usina Panorama S/A & Operando & - \\
\hline Jandaia & Denusa - Nova União S/A & Operando & - \\
\hline Jataí & Cosan Centro Oeste S/A Açúcar e Álcool & Operando & 105.000 \\
\hline Mineiros & Brenco/Odebrechet (Morro Vermelho) & Operando & 72.700 \\
\hline Montividiu & Usina Serra do Caiapó & Operando & - \\
\hline Morrinhos & Central Energética Morrinhos & Operando & 12.000 \\
\hline Paraúna & Usina Nova Galia Ltda & Operando & 47.000 \\
\hline Perolandia & Brenco/Odebrechet (Perolândia/Água Emendada) & Operando & - \\
\hline Porteirão & Usina São Paulo (Antiga Usina Fortaleza) & Operando & - \\
\hline \multirow{2}{*}{ Quirinópolis } & Sjc - Usina São Francisco & Operando & 80.000 \\
\hline & Usina Boa Vista - Grupo São Martinho S/A & Operando & 80.000 \\
\hline Rio Verde & Usina Rio Verde Ltda $\quad($ Decal $)$ & Operando & - \\
\hline Rubiataba & Cooperativa Agroindustrial de Rubiataba Ltda & Operando & 21.000 \\
\hline \multirow{2}{*}{$\begin{array}{lll}\text { Santa } & \text { Helena } & \text { de } \\
\text { Goiás } & & \end{array}$} & Usina Santa Helena Açúcar e Álcool & Operando & 4.400 \\
\hline & Cambui Açúcar e Álcool Ltda & Operando & - \\
\hline $\begin{array}{|lll|}\text { Santo } & \text { Antônio } & \text { da } \\
\text { Barra } & & \\
\end{array}$ & Floresta S/A Açúcar E Álcool & Operando & - \\
\hline São Simão & Energética São Simão - Grupo J. Maranhão & Operando & 4.200 \\
\hline Serranópolis & Energética Serranópolis & Operando & 3.860 \\
\hline Turvelândia & Vale Do Verdão Açúcar e Álcool & Operando & 23.400 \\
\hline Uruaçu & Uruaçu Açúcar e Álcool Ltda & Operando & - \\
\hline Vicentinópolis & Caçu Com Ind Açúcar e Álcool Ltda & Operando & - \\
\hline Vila Boa & Alda Part e Agropecuária S/A & Operando & 18.100 \\
\hline
\end{tabular}

Fonte: SIFAEG; ANEEL, 2013.

Elaboração: Instituto Mauro Borges / SEGPLAN-GO / Gerência de Sistematização e Disseminação de Informações Socioeconômicas - 2013. 
Para a implantação das agroindústrias canavieiras alguns elementos são fundamentais, contudo, em termos geoambientais, talvez o mais importante deles seja a água. A disponibilidade hídrica é fundamental para as atividades relacionadas ao setor sucroenergético, como plantio, irrigação, uso nas atividades industriais, resfriamento de equipamentos, etc.. Neste sentido é importante não atribuir a territorialização do setor sucroenergético somente ao acesso a terra ou sua topografia, mas também a disponibilidade e controle da água.

Sabe-se que o solo e o relevo são fatores importantes para implantação das usinas, mas não decisivos. Para exemplificar essa afirmação, pode-se citar, no estado de Goiás, a cana produzida em "areia” (Neossolos Quartizarênicos) pela Energética Serranópolis, no município de Serranópolis (sudoeste de Goiás) ou mesmo o corte manual, ainda predominante, nas usinas da microrregião Ceres, devido a topografia mais acidentada que as áreas de Chapadas do sudoeste de Goiás (para a colheita mecanizada são necessários, geralmente, áreas com declives em até 12\%).

Diante disso, pode-se afirmar que a disponibilidade hídrica é um fator decisivo para a implantação das usinas, pois sem água é impossível alimentar o complexo sucroenergético. Primeiramente, a água é fundamental para o desenvolvimento da planta, pois em condições de déficit hídrico, há redução do crescimento radicular da cana-de-açúcar, assim a produtividade pode ser reduzida significativamente, mesmo em solos mais férteis. Além disso, a água tem papel fundamental no setor industrial das usinas. Durante a lavagem da cana colhida e levada para o processamento industrial são utilizados cerca de 2.000 a 7.000 litros de água por tonelada de cana. Também durante a produção de etanol e açúcar são utilizadas quantidades significativas de água, dentre outras funções, o resfriamento dos aparelhos da destilaria, por exemplo.

Thomaz Júnior (2010) traz à discussão o conceito de "Polígono do Agrohidronegócio" referindo-se principalmente ao oeste de São Paulo, leste de Mato Grosso do Sul, noroeste do Paraná, Triângulo Mineiro e sul-sudoeste de Goiás. Essa demarcação territorial contempla diferentes formas de agronegócio, com predomínio das culturas de soja, milho, eucalípto e cana-de-açúcar, sendo a área com maior área plantada de cana-de-açúcar do Brasil, bem como de empreendimentos implantados.

Ainda para esse autor, para o sucesso do empreendimento é necessário garantia de acesso a água, seja superficial (rios, reservatórios e lagos) e/ou subterrânea. $\mathrm{Na}$ área 
do "Polígono do Agrohidronegócio" estão os principais Aquíferos do Brasil, com destaque para o Aquífero Guarani. A discussão do agrohidronegócio é uma questão estratégica e geopolítica muito importante. Dispor de água, dentro da expansão do setor sucroenergético é dispor de condições fundamentais para a territorialização do capital canavieiro. Assim, a expansão do capital sucroenergético não se restringe à incorporação de novas áreas para o aumento da produção, mas também na busca pela água que seja de boa qualidade e que possa atender as necessidades hídricas dessa cultura (FREITAS; CLEPS JÚNIOR, 2012).

O acesso e controle da água são importantes não somente para a territorialização das usinas canavieiras. Uma outra discussão importante refere-se a "drenagem" e comercialização da água indiretamente, por meio da exportação de grãos, carnes e açúcar (e da grande quantidade de água contida no processo de plantio e produção), do Brasil para os países hegemônicos. Essa reflexão é bastante pertinente, realizada por alguns autores, mas tem como expoente Gonçalves. Para ele,

\footnotetext{
[...] Os conflitos quanto aos uso da água tendem, portanto, a se aguçarem no contexto de relações sociais e de poder desiguais que caracteriza o mundo contemporâneo. É preciso ficar atento porque, quanto à água, não será necessariamente sob forma de aquedutos ou de navios que veremos a água ser drenada das regiões e países periféricos para as regiões e países hegemônicos e, sim, pelo volume de grãos e de matérias semiindustrializadas numa geografia desigual dos proveitos para uns e dos rejeitos para a maioria (GONÇALVES, 2008, p. 198).
}

A figura 7 mostra as principais massas d'água no estado de Goiás, os pivôs centrais e as usinas implantadas. Observa-se que as usinas implantadas estão concentradas em áreas com influência direta das bacias do Paranaíba (sul-sudoeste goiano) e Tocantins (região de Ceres). Observa-se também, por meio da figura 7, uma quantidade relevante de pivôs centrais, sobretudo nesse eixo de implantação das usinas sucroenergéticas (eixo norte-sul do estado) e também na porção leste do território goiano, mas neste caso, a relação é direta com a cultura de grãos, especialmente soja e milho, na região do município de Cristalina. 


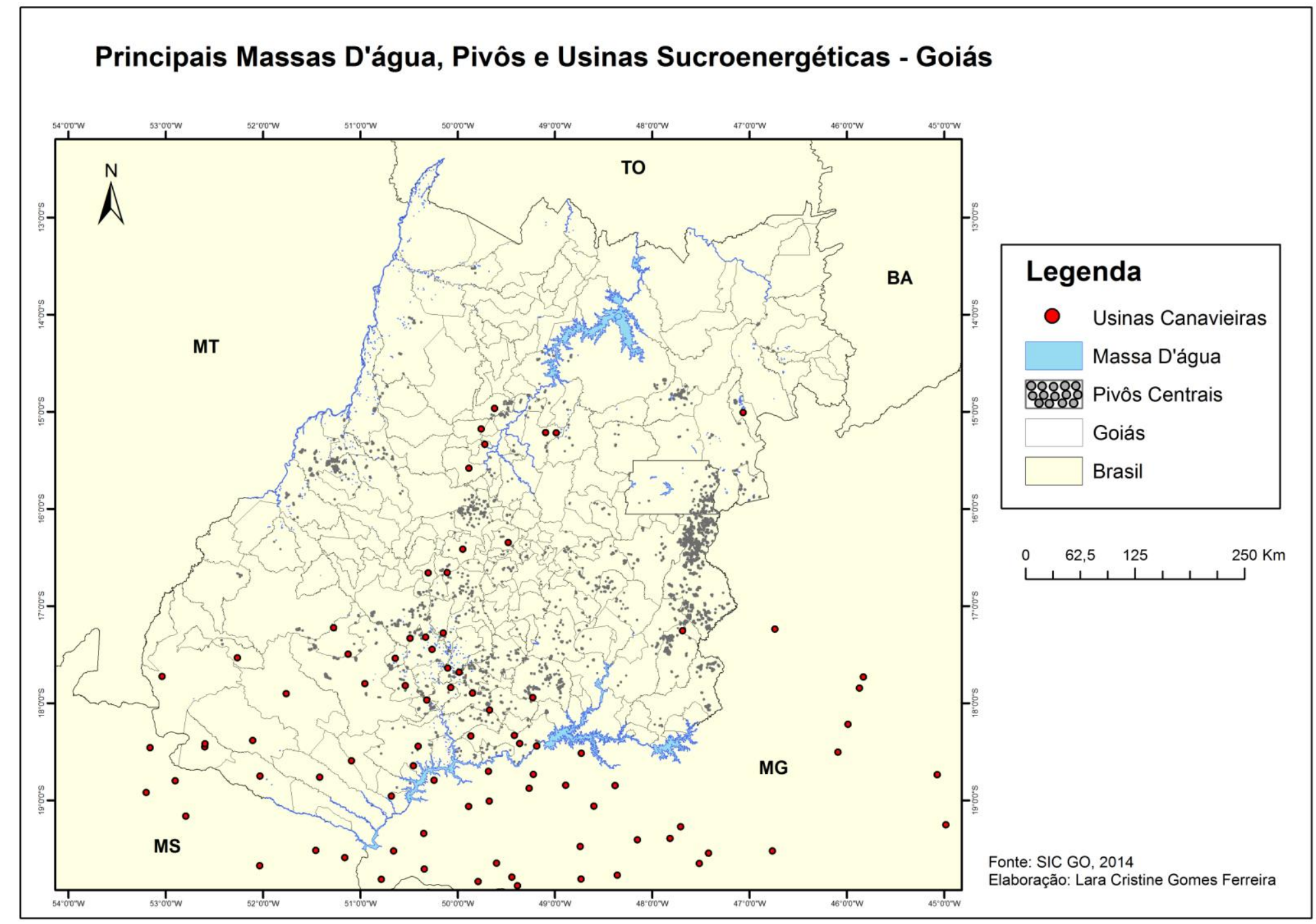

Figura 7 - Espacialização das usinas canavieiras, as principais massas d'água e os pivôs centrais no estado de Goiás. 
Essa breve reflexão vem somar à discussão que geralmente é feita para se entender a territorialização canavieira em Goiás. É importante considerar outros aspectos além da topografia e malha viária, que também são fundamentais, mas não únicos na estratégia de implantação do setor sucroenergético. A questão da água hoje é fundamental, pois é um elemento estratégico e geopolítico no agronegócio brasileiro, por isso a importância em se considerar os estudos sobre o agrohidronegócio, principalmente quando considerado a expansão canavieira, já que a água é um elemento fundamental para o plantio e processamento da cana-de-açúcar.

É importante considerar também que o complexo canavieiro pode causar sérios impactos no sistema hídrico superficial e subterrâneo, sobrecarregar os aquíferos, bem como contaminar os rios e lençol freático. Outro impacto inerente ao agrohidronegócio refere-se às disputas entre os capitalistas do agronegócio com os camponeses, que estão perdendo suas terras para o capital agroindustrial. Os pivôs centrais são utilizados para irrigação de monoculturas para exportação, muitas veredas são destruídas e em muitos rios são realizados represamentos para ser utilizados pelos empreendimentos.

Thomaz Júnior (2008) esclarece que não se trata somente de se posicionar contrariamente às técnicas ou a própria dinâmica sucroenergética, mas sim à lógica capitalista que estabele pressupostos de utilização e funcionalidade da água (e demais recursos) sem as devidas precauções e responsabilidade socioambiental. É preciso garantir que os interesses capitalistas não sobressaiam aos interesses do desenvolvimento socioeconômico, e não simplesmente crescimento econômico, e para isso é fundamental o papel do Estado na fiscalização das leis propostas, além da execussão de políticas e programas de inserção na dinâmica agrícola de alimentos dos agricultores familiares, bem como o respeito à terra e demais recursos, tão necessários ao trabalho e a vida desses trabalhadores. 


\subsection{Estado e Capital - Uma Reflexão sobre o Papel do Estado como Agente de Fomento ao Agronegócio}

Para a territorialização do agronegócio alguns agentes têm papel fundamental, pode-se destacar a ação do Estado para tanto. Parte-se da discussão realizada por Milton Santos, o qual entendia o Estado como principal agente de normatização e regulação da vida em sociedade. Assim, para entender tanto a territorialização dos empreendimentos do agronegócio em Goiás, quanto as políticas de financiamento e a logística que envolvem a produção e circulação dos produtos é fudamental entender a mediação do Estado.

Parte-se do entendimento que o Estado mantém uma legítima relação dialética com a sociedade capitalista, pois interfere e gera conflitos entre o novo e o velho, entre o externo e o interno, e as forças do mercado e a ação estatal, como expôs Santos (1985). Essa reflexão é fundamental para compreender o papel do Estado frente ao agronegócio, por exemplo. Como portador do "novo", o Estado garante a inserção de modernos maquinários, insumos e tudo isso tem influência direta com as redes internacionais de comercialização, vinculadas às bolsas de valores. Simultaneamente, o Estado garante a permanência do "velho", sobretudo no tocante ao social (SANTOS, 1985).

As "velhas" relações podem ser exemplificadas no agronegócio brasileiro, em algumas relações ainda latentes nas agroindústrias sucroenergéticas (por exemplo), como o corte manual da cana-de-açúcar, que propicia além da queima da cana (algo tão "velho" frente aos modernos maquinários de corte e colheita da cana), à migração de mão-de-obra para a colheita desta cana queimada, passando até por relações de trabalho análogo ao escravo ou trabalho escravo, como largamente discutido nos trabalhos de Maria Aparecida Moraes Silva.

Diante dessas breves reflexões, como pensar em compreender o papel do Estado de forma desconexa? É possível partir da ideia que há inseparabilidade entre os interesses do Estado e do mercado? ou, no caso estudado, da lógica do mercado sucroenergético atual? Acredita-se que é importante partir da relação dialética "mercado-Estado" e considerar, em primeiro plano, a dimensão do objeto analisado. 
Para Boaventura de Souza Santos (1982), o Estado é capitalista pelo seu papel constitutivo no processo de acumulação. E entende que cada atuação "do" Estado é uma atuação "no" Estado, pois o perfil de dominação e de legitimação é dinâmico e contraditório.

Concorda-se com Mészáros (2011) quando reflete que o Estado moderno é inconsebível sem o capital e este precisa do Estado como seu complemento necessário. Para este autor, o Estado deve ser entendido como parte integrante da própria base material do capital, pois ele contribui significativamente para a formação e consolidação de todas as grandes estruturas produtivas da sociedade, bem como para seu funcionamento ininterrupto (MÉSZÁROS, 2011).

Há atualmente pouquíssimos aspectos da produção e do consumo que não são afetados, de forma direta ou indireta, pelas políticas do Estado. O papel do Estado é central como agente do funcionamento da sociedade capitalista e esse papel não é recente na sociedade, como expôs Harvey (2005).

Quando se avalia a produção de certos produtos do agronegócio em Goiás, percebe-se algumas tendências de espacialização e, simultaneamente, uma "movimentação" dos agentes do capital e do Estado para conformá-lo e fomentá-lo, buscando, sobretudo o retorno pretendido por cada agente. Quando essa lógica é de alguma forma "ameaçada", o Estado tende a se posicionar no intuito de regular e ordenar, a favor de seus interesses. Exemplo disso em Goiás foi a Lei Complementar $\mathrm{n}^{\circ}$ 5.200/2006 que limitava a expansão canavieira no município de Rio Verde, referência na produção e beneficiamento de soja em Goiás, como mencionado anteriormente.

Segundo Arrais (2013) o Estado atua também na garantia da circulação, investindo em rodovias, ferrovias, hidrovias, aeroportos etc. e assim regula e investe diretamente no território, por isso é alvo de críticas em razão da "concepção do discurso neoliberal de que existe uma falsa separação entre os interesses imediatos do mercado e a regulação estatal" (ARRAIS, 2013, p. 16).

O papel do Estado é tão importante, que segundo Magdoff (1978) é o próprio Estado-nação que intermedia a relação entre a empresa capitalista com o sistema mundial. Isso pode ser verificado analisando as empresas multinacionais, que na verdade são organizações nacionais que funcionam em escala global. Ainda segundo este autor, 
O desenvolvimento das corporações multinacionais é meramente a última emanação da infatigável acumulação de capital e do impulso inato em direção a uma maior concentração e centralização do capital. (...) qualquer sucesso das políticas do governo resulta da manutenção ou restauração da saúde da economia por meio da promoção do poder de empresas gigantescas, pois sem a prosperidade dessas empresas a economia só pode ir ladeira abaixo (MAGDOFF, 1978, p. 187).

Concorda-se com Hirsch (2005) quando afirma que mercado e Estado estão relacionados entre si de forma indissolúvel, pois o Estado tem que intervir nas ações do do mercado e desta forma acaba, as vezes, por suprimi-lo. Ao mesmo tempo, o Estado segue dependendo fundamentalmente do processo de revalorização capitalista regulado pelo mercado. Hirsch infere que "o Estado em sua forma social específica só é capaz de se manter na medida que siga sendo garantida a reprodução econômica como processo de revalorização do capital” (HIRSCH, 2005, p. 169).

Por fim, o Estado é portanto sempre "Estado intervencionista", mas sem que possa fundir-se realmente com a sociedade. Estado e sociedade não só estão separados, mas ao mesmo tempo ligados, e essa separação-ligação se produz por meio de permanentes conflitos sociais ((HIRSCH, 2005).

Diante disso, como o agronegócio está diretamente propenso aos momentos de crises e euforias econômicas globais e do mercado internacional, o Estado tem o papel de intervir para estabilizar o setor, por meio do oferecimento de garantias políticas e econômicas. Cleps Júnior (2010) enfatiza que os planos-safra destinam recursos financeiros para a agricultura comercial e o BNDES (Banco Nacional de Desenvolvimento Social) também apresenta mecanismos a serviço da expansão do agronegócio. Um elemento muito importante a se compreender são os subsídios governamentais que em muitas vezes representam, além do fomento à atração e o crédito ao empreendimento, a negociação e o perdão de dívidas, bem como as isenções fiscais por um determinado período.

Para o estado de Goiás há dois programas que se destacam em incentivos fiscais, atração de empreendimentos e incremento no valor adicionado industrial de Goiás, que são o Fomentar e o Produzir. O Fomentar (Fundo de Participação e Fomento à Industrialização de Goiás) foi criado pelo Governo Estadual em 1984 e tinha como objetivo central atrair grandes empresas e indústrias para Goiás, baseado na isenção temporária do pagamento de $70 \%$ sobre o ICMS (Imposto sobre Circulação de 
Mercadorias e Serviço). Os financiamentos das empresas industriais e agroindustriais, beneficiadas com o Programa, deveriam ser resgatados no prazo de cinco anos, com dois anos de carência. Considerando-se que no ano de sua concepção a inflação já era superior a $223 \%$ ao ano, atribuir correção monetária a essa parcela praticamente se constituiria em isenção fiscal, pois a deterioração da dívida se tornava um benefício indireto concedido ao empreendedor (SILVA, 2002).

Ainda de acordo com este autor, com a estabilização monetária, ocorrida nos anos 1990, novos mecanismos se aplicaram ao Programa, mudando a forma do beneficiamento. As modificações na legislação do Fomentar atingiram as questões relativas aos prazos da protelação do pagamento e do tempo de fruição. Pode-se verificar o impacto da renúncia fiscal por meio da relação entre custos dos estímulos e a arrecadação tributária do ICMS. Tomando-se como base o período 1994 a 1999, percebeu-se que o Tesouro Estadual deixou de arrecadar 8,8\% do ICMS.

No ano 2000, foi criado o Produzir (Programa de Desenvolvimento Industrial de Goiás) que primeiramente teve a intenção de substituir o Fomentar, já que a princípio o prazo para este expirar era de apenas 10 anos. Mas, este prazo foi prorrogado para o ano 2020, tanto para o Fomentar quanto para o Produzir, segundo a Secretaria de Indústria e Comércio de Goiás (FERREIRA, 2010).

Em linhas gerais, o Produzir trata-se de um incentivo financeiro de apoio às indústrias, com base no faturamento e arrecadação tributária. O Produzir visa amparar principalmente projetos industriais direcionados à implantação de novos empreendimentos, expansão e diversificação da capacidade produtiva, modernização tecnológica, gestão ambiental e revitalização de unidade industrial paralisada. É importante ressaltar que estas características são basilares para a competitividade e a capitalização no campo, ou seja, estimulam a dinâmica e a lógica do agronegócio.

Em síntese, o Fomentar recolhia $30 \%$ e os restantes $70 \%$ (que o empreendimento ficava temporariamente isento) eram pagos em leilão, porém este percentual era negociado, o que acabava diminuindo muito o valor. Já o Produzir recolhe $27 \%$ e deixa de recolher $73 \%$, destes $10 \%$ vão para o Funproduzir, que corresponde ao Fundo da Agência de Fomento de Goiás que serão revertidos em outros Programas do Governo, relacionados ao esporte, cultura e para a própria Secretaria de Indústria e Comércio, para fornecer créditos aos empreendimentos e microempresas (Microproduzir). 
Assim, esses dois programas de incentivos fiscais, implementados em Goiás, estiveram orientados para o desenvolvimento de três grandes grupos de segmentos industriais: 1) Processamento de matérias-primas naturais e indústrias acessórias, como embalagens, adubos e rações; 2) Química, farmacêutica e automobilística, com a tentativa de diversificação da economia; 3) Setores tradicionais como de confecções, calçados e móveis, com objetivos de promover o adensamento de suas cadeias produtivas (ROMANATTO, et al, 2012).

É interessante observar que há uma desigualdade no financiamento das indústrias e agroindústrias, no território goiano, por esses programas de fomento. Em um artigo para a revista da Secretaria do Estado de Gestão e Planejamento de Goiás (SEGPLAN) Romanatto et al (2002) demonstraram estatisticamente muito bem essa disparidade. A porção sul do território goiano teve maiores investimentos pelo Fomentar e Produzir, enquanto a porção norte menos investimentos. A partir da análise proposta, os autores concluíram que nos primeiros três anos do Programa Produzir, apenas municípios da porção centro-sul de Goiás foram beneficiadas, sendo que as microrregiões de Anápolis e Goiânia tiveram $81 \%$ do investimento fixo. A partir do ano de 2003 houve investimento na porção norte goiana, contudo a porção centro-sul ainda absorvia $77 \%$ do investimento fixo.

Com base nos dados de 2012 a microrregião de Goiânia recebeu o maior número de projetos, seguida das microrregiões Sudoeste Goiano, Quirinópolis e Anápolis. Estes investimentos estão relacionados à expansão do setor sucroenergético para o sudoeste goiano e Quirinópolis (onde foram destinados vultosos investimentos para a instalação e crédito das usinas pelo Produzir) e no setor automotivo, aeronáutico e farmacêutico, para a microrregião de Anápolis.

As microrregiões Quirinópolis, Anápolis e Goiânia absorveram 60,38\% de todo o investimento previsto para o estado de Goiás. Já as Microrregiões de Anicuns, São Miguel do Araguaia, Iporá e Rio Vermelho receberam os menores investimentos e a microrregião Vão do Paranã (nordeste goiano) não captou nenhum recurso e a única empresa que usufruiu do benefício da microrregião originalmente seria instalada em outra (ROMANATTO, et al 2012). A figura 8 mostra o percentual de projetos contratados pelo Produzir (ano de 2012), por microrregiões em Goiás, o que ilustra o abordado anteriomente. 


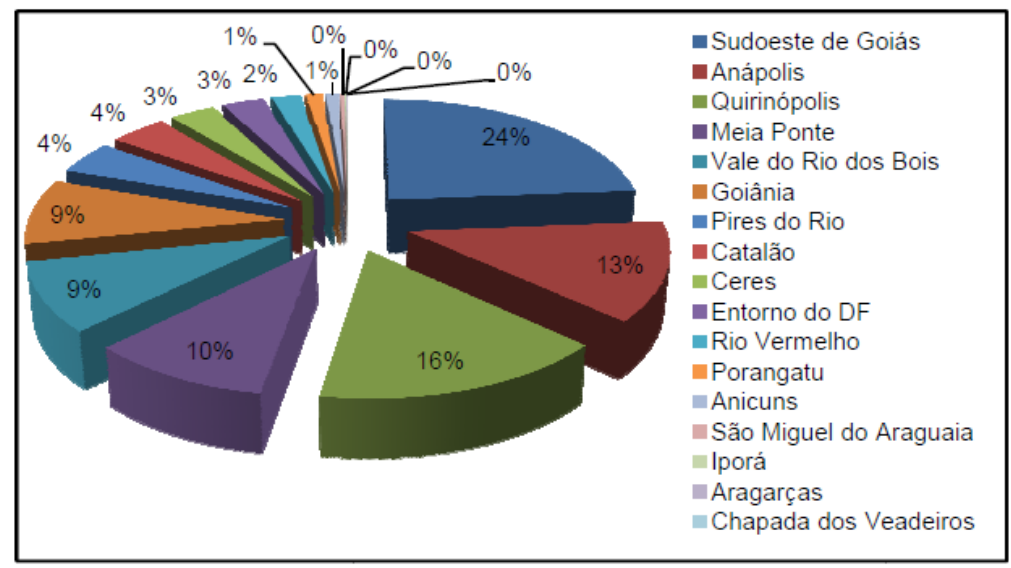

Figura 8 - Projetos contratados no Produzir - Representatividade dos Investimentos por microrregiões goianas (2012). Fonte: Romanatto, et al, 2012.

A figura 9 mostra os principais setores de atividades em que o Produzir está investindo no estado de Goiás, destacam-se: aeronáutica e destilaria, com $40 \%$ e $34 \%$ dos investimentos fixos, respectivamente. $\mathrm{O}$ investimento em aeronáutica está direcionado para o município de Anápolis (centro goiano), o qual tem instalado em seu território uma base áerea, e os investimentos em destilaria (setor sucroenergético) está direcionado principalmente para o centro-sul goiano.

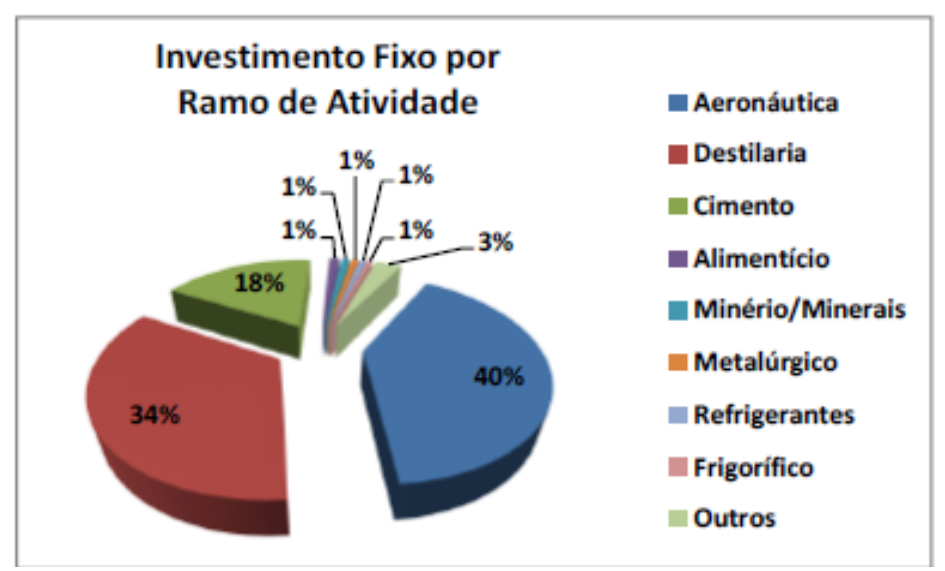

Figura 9 - Investimento fixo por ramo de atividade - Produzir. Fonte: Romanatto, et al, 2012.

É importante mencionar que muitos empreendimentos solicitam o investimento desses programas mesmo antes de serem aprovados, assim é comum verificar muitos projetos com recursos aprovados, contudo é um percentual muito inferior que é 
efetivamente aplicado. Isso ratifica mais uma vez o interesse do Estado na atração e financiamento de empreendimentos industriais.

A título de informação, desde a implantação do Fomentar foram aprovados 1.565 projetos, destes, 364 foram efetivamente implementados. Até o mês de maio de 2012 já haviam encerrado a utilização do benefício cerca de 224 projetos, e 140 ainda estavam dentro do período de utilização. Com o programa Produzir, no período de 2001 a maio de 2012 foram aprovados 1.399 projetos, sendo que 650 foram contratados contemplando 81 municípios em 17 das 18 microrregiões do estado (IMB, 2012). A tabela 2 mostra os detalhes descritos acima, com a quantidade de projetos aprovados pelo Produzir, a quantidade de empregos gerados e os investimentos concedidos por microrregiões de Goiás.

Tabela 2 - Projetos Contratados do Produzir por microrregiões - 2001 a Maio de 2012.

\begin{tabular}{|c|c|c|c|c|c|c|c|}
\hline Projetos & Microrregiões & Empregos & Repres. (\%) & Investimento $(\mathrm{R} \$)$ & Repres. (\%) & Benefício Concedido (R\$) & Repres. (\%) \\
\hline 46 & Sudoeste de Goiás & 27.220 & 15,4 & 2.728.234.368 & 23,3 & 11.896.757.466 & 16,4 \\
\hline 9 & Quirinópolis & 12.293 & 7,0 & 1.837 .915 .634 & 15,7 & 6.303.078.168 & 8,7 \\
\hline 49 & Meia Ponte & 17.504 & 9,9 & 1.137 .669 .675 & 9,7 & 6.692 .130 .796 & 9,2 \\
\hline 23 & Vale do Rio dos Bois & 16.968 & 9,6 & 1.053.096.974 & 9,0 & 4.570.947.407 & 6,3 \\
\hline 22 & Catalão & 8.188 & 4,6 & 682.030 .994 & 5,8 & 10.701.269.904 & 14,8 \\
\hline 10 & Pires do Rio & 8.806 & 5,0 & 505.786 .817 & 4,3 & 2.410 .866 .869 & 3,3 \\
\hline 14 & Ceres & 6.406 & 3,6 & 378.163 .461 & 3,2 & 3.865 .406 .194 & 5,3 \\
\hline 31 & Entorno do DF & 6.350 & 3,6 & 351.010 .795 & 3,0 & 1.722 .001 .345 & 2,4 \\
\hline 3 & São Miguel do Araguaia & 509 & 0,3 & 36.167 .550 & 0,3 & 185.680 .840 & 0,3 \\
\hline 5 & Iporá & 244 & 0,1 & 7.968 .150 & 0,1 & 127.412 .171 & 0,2 \\
\hline 4 & Aragarças & 147 & 0,1 & 4.660 .663 & 0,0 & 22.792 .485 & 0,0 \\
\hline 1 & Chapada dos Veadeiros & 12 & 0,0 & 207.300 & 0,0 & 27.261 .846 & 0,0 \\
\hline 650 & TOTAIS & 176.622 & 100 & 11.714 .692 .340 & 100 & 72.458 .065 .133 & 100 \\
\hline
\end{tabular}

Fonte: IMB (2012).

A figura 10 auxilia sobremaneira para entender o porquê dos vultosos investimentos do Estado, por meio dos programas de fomento analisados. O gráfico (figura 10) mostra o crescimento, ao longo do tempo, do faturamento com o setor industrial em Goiás. Nos anos em análise, de 1999 a 2009, houve um crescimento nominal de 592\% no período (IMB, 2012). 


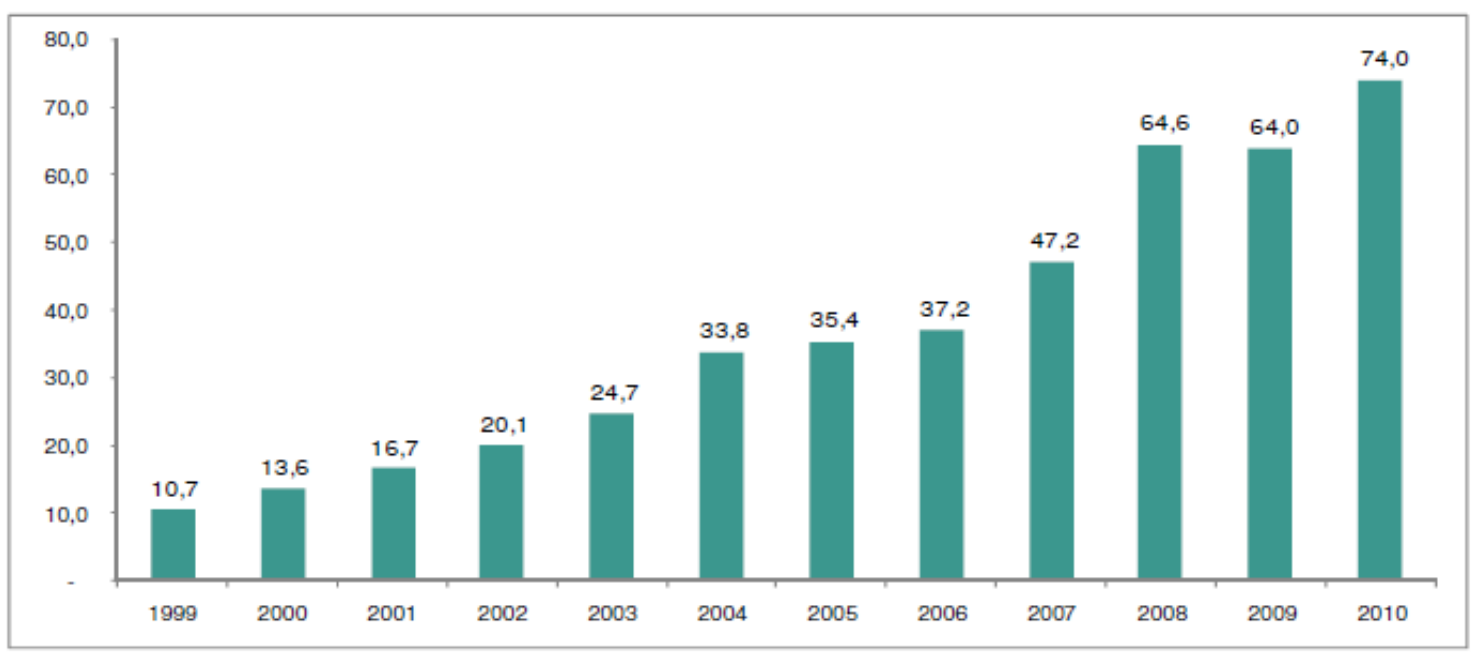

Figura 10 - Faturamento (em R \$ bilhões) do setor industrial do Estado de Goiás - 1999 a 2010. Fonte: IMB (2012).

Observando por meio de um olhar dialético é possível refletir sobre os grandes investimentos "do" Estado sendo retornados "ao" Estado, pelo grande faturamento, por exemplo. Mészáros (2011) fala em uma "reciprocidade dialética" entre o Estado e o capital. Essa reciprocidade torna-se essencial para o funcionamento permanente do sistema do capital, afetando tudo, desse o local, o mais imediato, até o nível mais abrangente, o mediato. A dialética se confirma não na relação de "troca" estabelecida: "investe-se, mas fatura-se", mas sim quando verifica-se que o faturamento financeiro é maior que o retorno em empregos, por exemplo, que seria, em tese, um dos pontos que o Estado deveria realmente se ater.

Outra reflexão importante está relacionada a concentração dos recursos em algumas microrregiões, o que contribui para a manutenção da concentração de renda na porção centro-sul do estado de Goiás. A falta de infraestruturas, de rodagem e informação, na porção norte-nordeste goiana (estes deveriam ser construídos pelo Estado) também contribuem para que os empreendimentos não demonstrem interesses em se materializarem nessas regiões.

Boaventura de Souza Santos (1982) fala da Teoria da Dialética Negativa do Estado Capitalista, a qual reflete que a função política geral do Estado é "dispersar as contradições e lutas sociais, de modo a mantê-las em níveis tensionais funcionalmente compatíveis com os limites estruturais impostos pelo processo de acumulação e pelas relações sociais de produção" (SANTOS, p.24). Assim, não se trata, portanto, de 
solucionar (superar) os problemas, mas antes de os manter em estado de relativa latência. Isso obriga o Estado a realizar constantes "ajustes" e mudanças no processo de dominação, mas sem superar as principais contradições em que essa dominação (re)produz.

Assim, em síntese, somadas às formas construídas e aos elementos da paisagem, a distribuição dos subsídios do governo, pelo território, acabam por reforçar a concentração de renda (no centro-sul goiano) e a pouca dinamicidade econômica industrial (no norte-nordeste goiano), já que a infraestrutura implantada e a possibilidade de mão-de-obra qualificada são dois fatores atrativos para os empreendimentos / capital privado.

\subsection{A Abordagem Regional no Debate do Agronegócio Sucroenergético}

Para compreender a problemática posta, será utilizada a abordagem regional por entender que o agronegócio e toda sua complexidade, relações e efeitos, não se materializam em um só município, mas sim acabam por influenciar diretamente os municípios vizinhos. Uma rede de produção, circulação, comercialização, etc. é criada, e estas perpassam os limites municipais e as vezes até regionais. Para pensar a região é preciso partir do entendimento do movimento do capital e do papel do Estado, temas já introduzidos nessa pesquisa. Para tanto, faz-se importante primeiramente refletir sobre a forma em que o conceito de região foi trabalhado em algumas fases da Geografia.

O conceito de região está diretamente ligado ao princípio de diferenciação de área, ou seja, à noção de que a superfície da Terra é construída por áreas diferentes e que essas diferenças foram materializadas em contextos históricos específicos e distintos.

A região teve grande importância para a Geografia durante o final do século XIX e início do XX, sobretudo com a concepção de "região natural" difundida por Ratzel, e as monografias regionais, de Vidal de La Blache. Já no decorrer do século XX, podemse citar os nomes de Hettner e Carl Sauer que valorizaram as formas regionais, por meio da região-paisagem, e Hartshorne que defendia o método regional para se tentar compreender a Geografia. 
A partir de meados dos anos 1930, com a Geografia sendo influenciada por uma concepção mais lógico-quantitativa, a região passou a ser utilizada como uma forma para se explicar padrões, por meio de teorias de crescimento e desenvolvimento. Nesse contexto, podem-se citar as Teorias das Localidades Centrais, de Christaller (1933) e dos Pólos de Crescimento, de Perroux (1950). Assim, a divisão regional, por essa concepção, pressupõe uma objetividade máxima, o que implica uma certa ausência da subjetividade por parte do pesquisador (CORRÊA, 2000).

Mais tarde a Geografia passa por uma influência mais crítica, sobretudo a partir da década de 1970, fruto de um olhar materialista histórico e dialético. Assim, a região começa a ser trabalhada vinculada às concepções de poder e totalidade. Dentro dessa perspectiva, algumas conceituações de região merecem atenção, podem-se citar autores como Duarte, Santos, Corrêa e Elias.

Para Duarte (1980), a região é uma dimensão espacial das especificidades sociais em uma totalidade espaço-social. Para Santos (1985, p. 16) a "regiao é o locus de determinadas funções da sociedade total em um momento dado". Para Corrêa (2000) a região é considerada uma entidade concreta, resultado da efetivação de mecanismos de regionalização sobre um território já ocupado, com heranças culturais, materiais e determinada estrutura socioespacial e seus conflitos. E por fim, Elias (2003, p. 56) expõe que a região é "resultado do impacto das forças externas/modernizantes e a capacidade de suas virtualidades, uma fração do espaço total do planeta, cada vez mais aberta às influências exógenas e aos novos signos do período atual”.

Elias (2003) trabalha o conceito de região de uma forma bastante interessante para a presente tese. Para ela, a região é objeto e sujeito da economia globalizada é um espaço que pouco possui de autônomo e interage de forma permanente com o mundo, visando a renovação tecnológica e a acumulação ampliada do capital. As reflexões de Elias contribuem para pensar a região pelo viés da globalização, realizada por meio do agronegócio, assim desta forma, muito contribuirá para auxiliar nas análises propostas.

Para essa discussão, o Estado tem papel fundamental, pois é agente da regionalização. Para Lipietz (1988), o Estado tem um papel de gerenciamento regional, e é responsável por remover as barreiras para o desenvolvimento do capitalismo, utilizando-se do planejamento de infrastrutura e a imposição de uma lógica capitalista avançada, através de uma nova divisão do trabalho. 
As ações de planejamento de modo geral e o planejamento regional de modo específico, são exemplos claros de que o Estado pensa a regionalização e intervem na mesma. Para as subdivisões regionais por exemplo é utilizada uma metodologia prenhe de intencionalidades geopolíticas e estratégicas, seja aprovando políticas públicas, atraindo infraestruturas, recursos e fomentos de modo geral.

Compreende-se que a regionalização tem papel importante para se pensar quais as melhores políticas de integração e desenvolvimento para o país e seus estados, principalmente com a extensão territorial brasileira e, em consequência, tentar compreender suas especificidades e singularidades que são perceptíveis nesse vasto e complexo território. A regionalização se pensada de forma coerente, buscando a efetivação das políticas públicas voltadas para as reais necessidades de cada região, pode ser uma forma eficiente para se compreender e desenvolver as potencialidades existentes e de mitigar as deficiências encontradas. Contudo, esclarece-se o olhar crítico para as regionalizações e para o planejamento regional, que como já exposto, são formas de intervir no território e mantê-lo sob controle.

O Brasil tem algumas experiências de regionalização antigas e que perduram até o momento. O IBGE é preponderante nos estudos da divisão regional brasileira e a partir dos anos 1940, passou a sistematizar a divisão regional do Brasil, em uma forma única, com o intuito de auxiliar o levantamento e a análise dos dados, bem como facilitar a divulgação das estatísticas levantadas por este Instituto ${ }^{11}$. No ano de 1942 foi aprovada pela Presidência da República, a primeira Divisão Regional do Brasil: Norte, Nordeste, Leste, Sul e Centro-Oeste. No ano de 1945, o Brasil é subdividido em zonas fisiográficas, baseadas em critérios econômicos, e a partir da década de 1960, inicia-se a divisão regional em macrorregiões.

A Divisão Regional do Brasil em mesorregiões (utilizada até hoje), partiu de determinações mais amplas em nível conjuntural e buscou identificar áreas individualizadas em cada uma das Unidades Federadas, e definiu as mesorregiões com base no processo social (como determinante), no quadro natural (como condicionante) e na rede de comunicação e de lugares (como elemento da articulação espacial) (IBGE, 2014).

\footnotetext{
${ }^{11}$ O IBGE foi criado em 1934 e instalado em 1936 com o nome de Instituto Nacional de Estatística. O nome atual data de 1938 (IBGE, 2014).
} 
Ao longo do tempo a regionalização tornou-se mais específica e além das mesorregiões foram criadas as microrregiões, portanto, cada estado brasileiro possui uma divisão em meso e microrregiões, definidas pelos critérios do IBGE. Desta forma, o estado de Goiás, por meio de uma Resolução da Presidência ( $\mathrm{N}^{\circ}$ 11, de 5 de junho de 1990) foi subdividido em 18 microrregiões geográficas, que são um conjunto de municípios, contíguos e definidos segundo a organização da produção econômica e sua integração.

A figura 11 ilustra a espacialização da Divisão Regional do estado de Goiás pelas microrregiões, segundo os critérios do IBGE. São ao total 18 microrregiões distribuídas pelas cinco mesorregiões goianas, a saber: Norte, Nordeste, Sul, Leste e Centro. Essa regionalização foi a escolhida para a pesquisa realizada na presente tese, será estudada a microrregião Ceres (ilustrada pelo número 6, na figura 11).

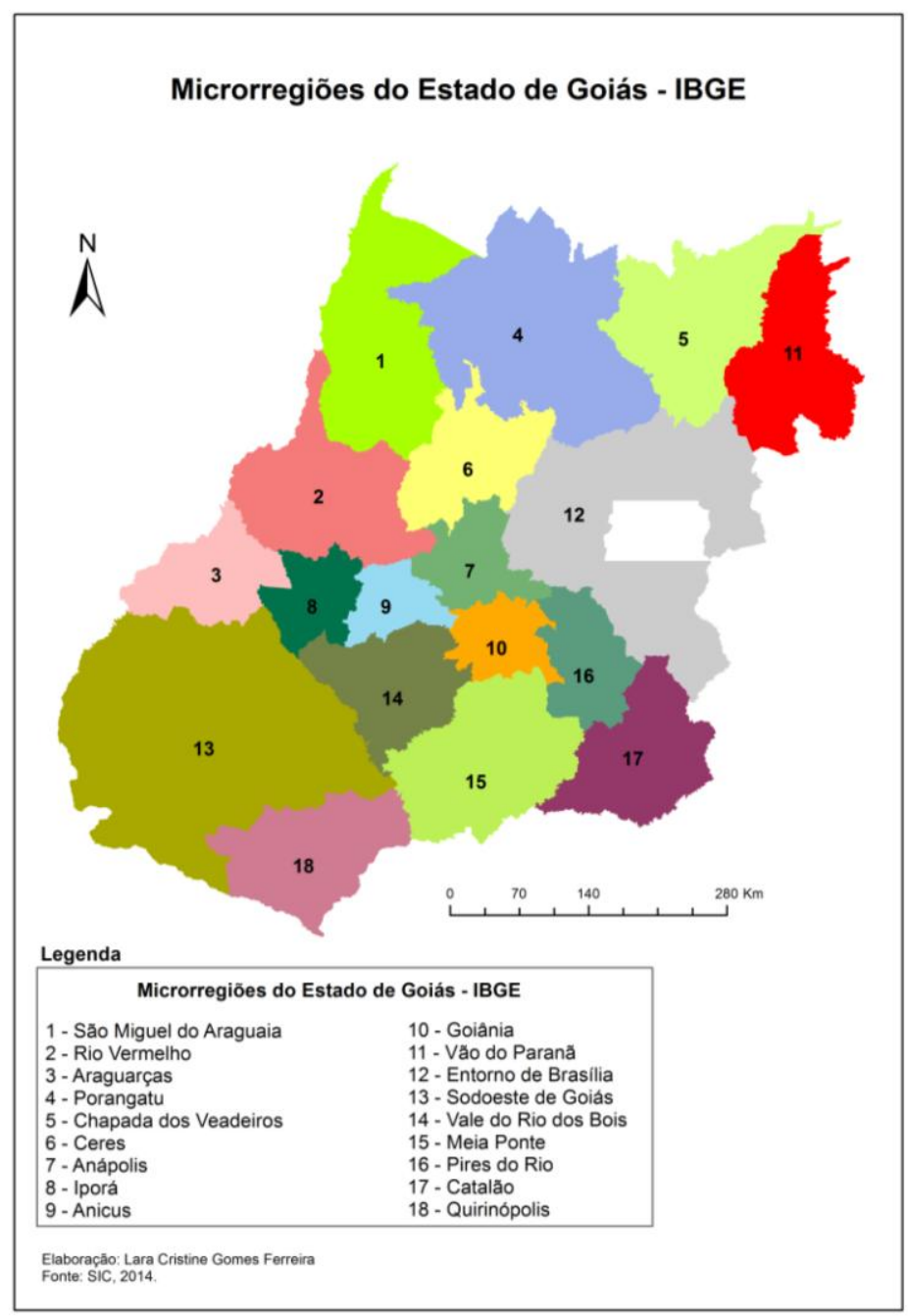

Figura 11 - Espacialização das 18 microrregiões do estado de Goiás, segundo o IBGE. 
Além da regionalização realizada pelo IBGE (oficial em nível Federal), o Governo Estadual também pode propor regionalizações próprias a fim de auxiliar e faciliar o ordenamento territorial e a efetivação das políticas estaduais. Assim, por meio da Secretaria de Estado de Gestão e Planejamento (Segplan), o estado de Goiás foi regionalizado em 10 Regiões de Planejamento (Lei do PPA 2002/2007) com base nos seguintes critérios (IMB, 2014):

a) A Região do Entorno do Distrito Federal foi definida conforme o estabelecido na Lei de criação da Ride: Região Integrada de Desenvolvimento do DF e Entorno - Lei Complementar (Constituição Federal) nº 94, de 19 de fevereiro de 1998 ;

b) A Região Metropolitana de Goiânia (Grande Goiânia mais Região de Desenvolvimento Integrado) é definida pela Lei Complementar Estadual no 27 de dezembro de 1999, alterada pela Lei Complementar Estadual no 54 de 23 de maio de 2005;

c) As Regiões do Norte Goiano e do Nordeste Goiano, constantes no primeiro PPA (2000-2003), foram delimitadas em função de sua homogeneidade em termos de condições socioeconômicas e espaciais e como estratégia de planejamento para investimentos governamentais tendo em vista minimizar os desequilíbrios regionais;

d) As outras seis Regiões (Centro, Noroeste, Oeste, Sudoeste, Sul e Sudeste) foram definidas tendo como critério os principais eixos rodoviários do estado. Todos os municípios cujas sedes utilizam o mesmo eixo rodoviário para o deslocamento à capital do estado foram considerados pertencentes a uma mesma região de planejamento.

As Regiões de Planejamento de Goiás, segundo critérios da Segplan, podem ser visualizadas pela figura 12 . 


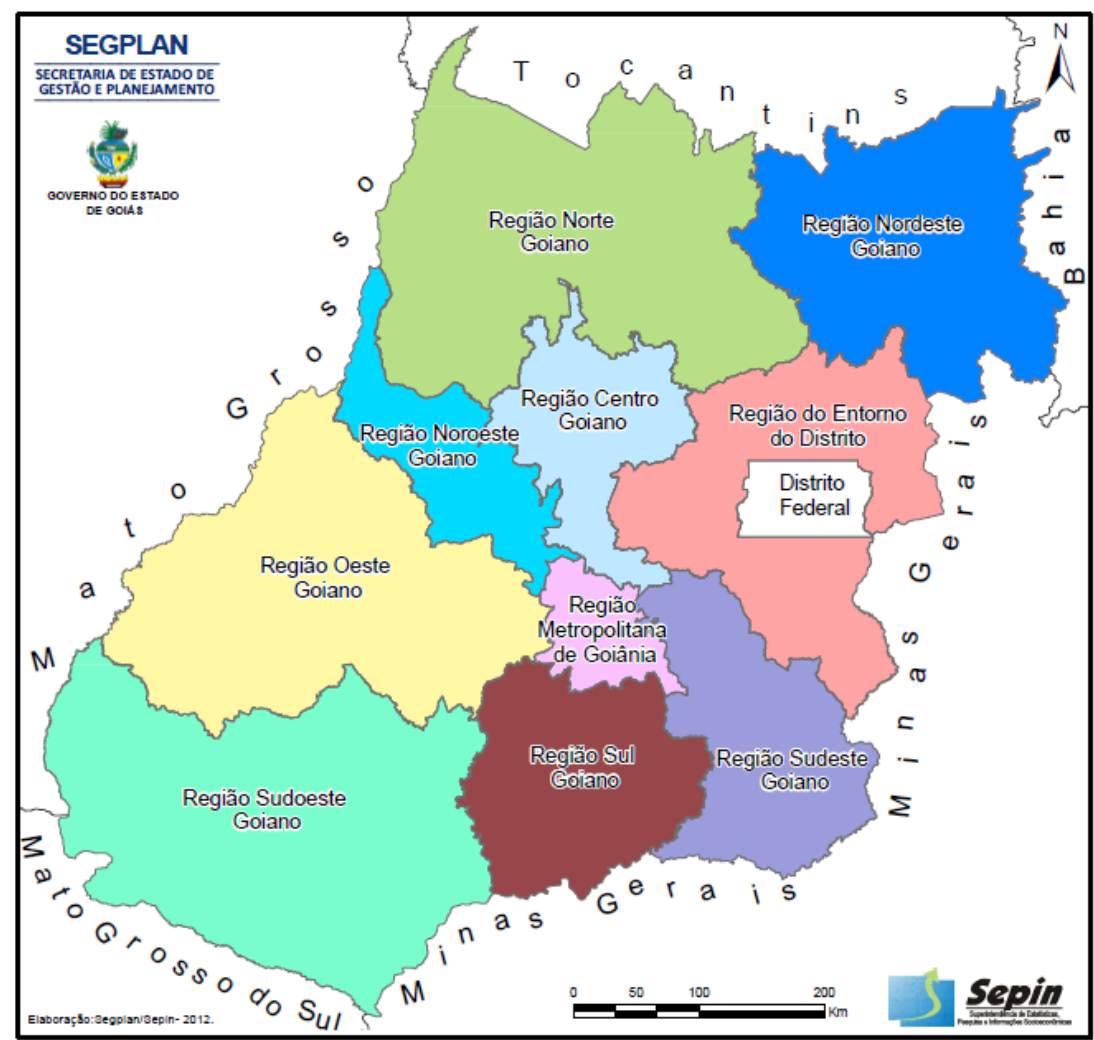

Figura 12 - Espacialização das 10 Regiões de Planejamento de Goiás, segundo a Segplan. Fonte: IMB, 2014.

Diante das duas propostas de regionalização apresentadas para o estado de Goiás, escolheu-se utilizar as microrregiões, proposta pelo IBGE. As Regiões de Planejamento de Goiás acabam englobando mais municípios que a proposta do IBGE, e no caso da região de Ceres (região de interesse nesse estudo) a regionalização da Segplan a insere na Região Centro Goiano, juntamente a municípios como Anápolis.

Acredita-se que o critério utilizado pela Segplan acaba por mascarar ainda mais as especificidades dos municípios, pois nesse caso, o critério adotado refere-se aos municípios em que a sede esteja vinculada ao mesmo eixo rodoviário para o deslocamento à capital. Considera-se assim equivocado, dentro dos estudos de região e da abordagem regional, aglutinar, por exemplo, o município de Anápolis junto aos municípios da Região de Ceres, devido às diferenças nas dinâmicas geoambientais, espaciais, históricas e, sobretudo, socioeconômicas.

A regionalização do IBGE, em microrregiões, também apresenta algumas contradições na escolha dos municípios. A microrregião Ceres, tem municípios com formação histórica muito diferente dos demais, por exemplo. Pode-se citar o município 
de Pilar de Goiás, criado no contexto aurífero em Goiás, no século XVIII, em contraposição ao município de Ceres, originado no contexto das Colônias Agrícolas Nacionais, ou a municípios com emancipação mais recente, como o município de São Patrício emancipado na década de 1990.

A partir do breve exposto, percebe-se que o conceito de região sempre teve importância considerável, não somente na ciência geográfica, mas também nos órgãos oficiais de regionalização do país. Contudo, a partir do processo de globalização o conceito de região foi talvez o que mais passou por críticas, falando-se até da não existência de regiões pela homogeneização do território fruto desse processo.

Contrária a essa afirmação, acredita-se que o grande motor de diferenciação de áreas e acentuação das desigualdades regionais é o modo de produção capitalista. Assim, o processo de globalização tende, na verdade, a acentuar as disparidades regionais, pois as regiões possuem potencialidades distintas e a atuação dos atores hegemônicos do capital também se dá de forma distinta, além da atuação do Estado, como agente regulador e financiador de empreendimentos do capital (nacional ou internacional) que também se dá de forma diferenciada.

Concorda-se com Pontes (2007) quando discute o carater dinâmico, múltiplo, complexo e instável das regiões. Elas são distintas, pois os aspectos que as estruturam são diversos, como os aspectos humanos, econômicos, históricos, sociais, políticos e culturais. A autora toca em um ponto fundamental na reflexão sobre o conceito de região, que é a escala. É fundamental considerar a escala, pois a delimitação da região jamais poderá ser rígida (mesmo compreendendo essa rigidez em termos oficiais, para facilitar o planejamento regional e a efetivação das políticas públicas), em termos científicos e acadêmicos é fundamental compreender que a dinâmica espacial não adimite cortes bruscos na definição de suas fronteiras. Para Pontes (2007, p. 497) a região é portanto, "uma dimensão escalar do espaço, que se concretiza mediante a funcionalização do poder no território".

Atualmente, um importante conceito dentro da abordagem regional é a Região Produtiva do Agronegócio (RPA) de Denise Elias. Há alguns anos essa autora vem construindo esse conceito, em Elias $(2011$; 2012) ela traz à discussão o conceito de Regiões Produtivas Agrícolas, e mais recentemente tem avançado nessa discussão, partindo do entendimento que o agronegócio é um agente produtor do espaço agrário e 
urbano. Assim, atualmente, a autora utiliza-se do conceito Região Produtiva do Agronegócio (RPA). Em síntese, as RPA's são os novos arranjos territoriais produtivos, os territórios das redes agroindustriais, escolhidos para receber vultosos investimentos ligados ao agronegócio globalizado (ELIAS, 2011).

Faz-se importante refletir sobre o conceito de RPA de Elias, por entender que o objeto de estudo dessa tese, está inserido em uma região permeada pela lógica do agronegócio sucroenergético, responsável por dinamizar e refuncionalizar a região, sendo perceptível em sua paisagem os (re) arranjos e as (re) funcionalizações, por meio da atividade sucroenergética e da relação campo-cidade.

As RPA's estão conectadas diretamente com os centros de poder e consumo, pois o agronegócio globalizado se realiza a partir da dialética entre o global e o local. Para a autora, as RPA's são híbridas e podem compor-se tanto de modernos espaços agrícolas, quanto de espaços urbanos não metropolitanos, principalmente as cidades pequenas, podendo também ser cidades médias.

As redes agroindustriais são compostas por inúmeras atividades que servem ao agronegócio, em prol da acumulação capitalista, podem-se citar as empresas agropecuárias, as indústrias de sementes selecionadas, de insumos químicos e implementos, os laboratórios de pesquisa, as prestadoras de serviço e comércio, as empresas de logística, as empresas de pesquisa em tecnologias, entre outras. Trata-se de uma rede complexa e para que se possa compreendê-la é preciso realizar estudos levando em consideração as diferentes escalas.

Segundo Elias (2012) as transformações ocorridas na atividade agropecuária no Brasil, sobretudo nas últimas cinco décadas, tem exercido profundos impactos na (re) organização do território brasileiro, o que resultou em distintos arranjos territoriais. Assim, a abordagem regional e no caso específico, as RPA's, são formas de se empreender a análise das tranformações e dos impactos da agropecuária e hoje do agronegócio no território brasilieiro, tão vasto e de grandes dimensões territoriais. Ainda para a autora, como a "globalização se realiza com a fragmentação do território, a RPA ganha força como uma das possibilidades para a percepção de tais processos" (ELIAS, 2012, p. 27).

É importante mencionar que o conceito de Região Produtiva do Agronegócio não se assemelha ao conceito clássico de região. As RPA's devem ser entendidas como 
lugares funcionais de circuitos espaciais da produção e círculos de cooperação da produção (conceitos de Milton Santos) de importantes commodities, que estão cada vez menos resistentes aos novos signos atuais e as novas forças externas, que são comandados pelas empresas hegemônicas do setor (ELIAS, 2011).

A metodologia para se chegar a uma RPA é bastante complexa e delicada, já que os processos são dinâmicos e as delimitações podem sofrer alterações constantemente. Podem-se destacar cinco eixos norteadores principais para a delimitação das RPA's: 1) Uso e ocupação do espaço agrário; 2) Setores industriais representativos das redes agroindustriais; 3) Economia urbana; 4) Mercado de trabalho e dinâmica populacional; 5) Infraestrutura e equipamentos urbanos.

É importante destacar que a própria autora enfatiza que a configuração das RPA's não respeitam os limites político-administrativos oficiais, sendo bastante comum que municípios de diferentes estados componham uma RPA. Diante disso, considera-se de suma importância os trabalhos de Elias, bem como sua contribuição no avanço da discussão sobre o conceito de região e sua reflexão crítica e construtiva para compreender as transformações e problemáticas postas, por meio da abordagem regional. Contudo, na presente tese, será utilizada a microrregião geográfica, pensada pelo IBGE, conforme já exposto.

Entente-se que a regionalização no Brasil é antiga e não acompanhou as transformações ocorridas ao longo do tempo, inúmeros e complexos foram os processos e, consequentemente, as formas e os efeitos materializadas no espaço geográfico brasileiro. Assim é muito comum perceber algumas discrepâncias nas regiões oficiais, sendo nítido, as vezes, perceber que determinado município não deveria estar "nessa" região ou que aquele município deveria estar "naquela" região, considerando é claro os mesmos critérios utilizados pelos órgãos oficias para realizar a regionalização.

Contudo, mesmo considerando os problemas existentes na forma de se regionalizar o Brasil, escolheu-se utilizar a forma oficial federal, até pelo fato de se objetivar compreender as transformações ocorridas, ao longo do tempo, com a microrregião Ceres (das Colônias Agrícolas ao momento atual) e, sobretudo, por entender que as pesquisas científicas podem subsidiar futuras discussões, planos, programas e políticas públicas que são, ainda, pensadas utilizando-se de critérios oficiais e geralmente exclusivas para determinado estado (principalmente os planos 
plurianuais dos Governos Estaduais), sendo complicado, sob esse viés, aglutinar em uma mesma região, municípios de estados distintos.

Portanto, parte-se da premissa que o Estado interfere diretamente na (re) produção do território e, consequentemente, nos arranjos regionais, no padrão de integração das regiões, na territorialização de agroindústrias e demais empreendimentos, bem como na materialização de infraestrutuas. Com isso intensificam-se as desigualdades regionais e, simultâneamente, o planejamento regional como forma de mitigar essas desigualdades. Arrais (2007) traz essa discussão para o estado de Goiás, o qual, pelo fato de estar em posição estratégica, no centro do país, e ter assumido o papel de fronteira agrícola foi fator decisivo na rapidez das transformações socioeconômicas e no consequente grau de desigualdade regional verificado.

O quadro 4 mostra os principais programas de intervenção do Estado no território goiano e o principal impacto regional verificado em cada período. É possível verificar que entre as décadas de 1930 e 1940 os programas do governo estavam direcionados para a expansão da fronteira agrícola e ocupação do que consideravam na época de vazios demográficos no Brasil. Nesse contexto, citam-se os programas vinculados ao projeto da Marcha para o Oeste (do Governo Vargas) e a construção de Goiânia e a transferência da capital do estado de Goiás para essa cidade.

A edificação de Goiânia, como nova capital do estado de Goiás, estimulou a migração para o centro do país. Segundo Teixeira (2013) a partir da criação de Goiânia, o estado de Goiás passou de uma região distante para uma região promissora para o desenvolvimento brasileiro, deixando, gradativamente, para trás o rótulo de estado isolado e pouco atuante no contexto nacional. Em síntese, Goiânia foi construída em um contexto que buscava a redução das disparidades regionais do Brasil, contudo acabou estimulando a intensa ocupação, pelo processo migratório, a fragmentação do centro goiano e alguns conflitos territoriais.

Pode-se destacar também as Colônias Agrícolas Nacionais, dentro da Marcha para o Oeste, que foi responsável por intenso processo migratório para a região centro goiano, região denominada Mato Grosso de Goiás. Esse programa teve o intuito de estimular a ocupação do centro goiano, por meio de colônias agrícolas. A CANG, como fícou conhecida a Colônia Agrícola Goiana, mesmo tendo grande parte de seus objetivos propostos frustrados, teve importância singular para a ocupação do território 
goiano, sobretudo para a região de estudo, a microrregião Ceres (essa discussão será realizada no próximo capítulo).

Quadro 4 - Principais Programas de Governo para o Estado de Goiás e os Impactos Regionais.

\begin{tabular}{|c|c|c|c|}
\hline \multicolumn{4}{|c|}{ O TERRITÓRIO GOIANO: ESTADO E A CAPITALIZAÇÃO DO TERRITÓRIO } \\
\hline \multicolumn{2}{|r|}{ Programas } & Período & Impacto Regional \\
\hline \multirow{2}{*}{ 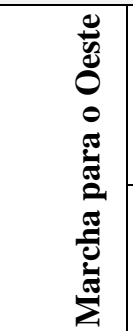 } & $\begin{array}{l}\text { Expedição Roncador } \\
\text { Xingu }\end{array}$ & 1943-1949 & $\begin{array}{l}\text { Ação de interesse militar, partindo de Aruanã com } \\
\text { destino ao Pará e ao Amazonas, tendo, entre outros } \\
\text { objetivos, a colonização pontual da vertente Oeste } \\
\text { do Araguaia. }\end{array}$ \\
\hline & $\begin{array}{l}\text { Fundação Brasil } \\
\text { Central }\end{array}$ & $1943-1967$ & $\begin{array}{l}\text { Substituiu a Expedição } \\
\text { intervindo, também, no território goiano, } \\
\text { do estímulo à colonizaçãão. }\end{array}$ \\
\hline \multicolumn{2}{|c|}{ Edificação de Goiânia } & 1933-1942 & $\begin{array}{l}\text { Estimulou a migração e mudou o eixo econômico } \\
\text { do Estado para Mato Grosso Goiano, reforçando as } \\
\text { desigualdades regionais entre o Norte e Sul. }\end{array}$ \\
\hline \multicolumn{2}{|c|}{$\begin{array}{l}\text { CANG (Colônia Agrícola } \\
\text { Nacional) }\end{array}$} & $1942-1945$ & $\begin{array}{l}\text { O programa de colonização federal causou impacto } \\
\text { na migração e alterou a estrutura agrária da porção } \\
\text { norte do Mato Grosso Goiano. }\end{array}$ \\
\hline \multicolumn{2}{|c|}{ Edificação de Brasília } & $1956-1960$ & $\begin{array}{l}\text { Estimulou a migração, a fragmentação municipal, o } \\
\text { mercado de consumo regional e a circulação } \\
\text { rodoviária, com impacto no Leste e Nordeste } \\
\text { Goianos. }\end{array}$ \\
\hline \multicolumn{2}{|l|}{ BR-153 } & $1958-1975$ & $\begin{array}{l}\text { Transformou-se na principal artéria de ligação entre } \\
\text { o Sudeste e o Norte brasileiro, redefinindo o eixo de } \\
\text { povoamento do Norte goiano para a vertente Oeste } \\
\text { do rio Tocantins. }\end{array}$ \\
\hline \multicolumn{2}{|c|}{ Cachoeira Dourada } & 1960 & $\begin{array}{l}\text { Atendeu a demanda de energia do Estado de Goiás } \\
\text { e do Distrito Federal. }\end{array}$ \\
\hline \multicolumn{2}{|c|}{ SUDECO } & $\begin{array}{l}1967-1990 \\
2006 \ldots\end{array}$ & $\begin{array}{l}\text { Programa do Governo Federal com o propósito de } \\
\text { intervir na Região Centro-Oeste, estimulando a } \\
\text { mudança no perfil econômico. Em } 1990 \text { a } \\
\text { SUDECO foi extinta. Em } 29 / 11 / 2006 \text { o projeto de } \\
\text { recriação da SUDECO foi aprovado por } \\
\text { unanimidade na Câmara Federal. }\end{array}$ \\
\hline \multirow{3}{*}{ 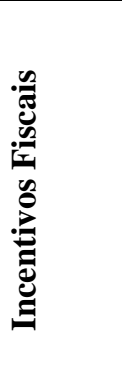 } & $\mathrm{FCO}$ & $1988 \ldots$ & $\begin{array}{l}\text { Fundo Constitucional do Centro-Oeste disponibiliza } \\
3 \% \text { do produto da arrecadação do Imposto Sobre } \\
\text { Renda e Proventos de Qualquer Natureza e do } \\
\text { Imposto Sobre Produtos Industrializados. }\end{array}$ \\
\hline & Fomentar & $\begin{array}{l}\text { 1996-2020 } \\
\text { (previsão de } \\
\text { término) }\end{array}$ & \multirow{2}{*}{$\begin{array}{l}\text { Estimularam a migração de empresas de diversos } \\
\text { ramos para o territórios goiano, especialmente o } \\
\text { Centro-Sul do Estado. }\end{array}$} \\
\hline & Produzir & $1999 \ldots$ & \\
\hline
\end{tabular}

Fonte: Adaptado de Arrais (2007). 
A construção de Brasília e a transferência da Capital Federal para a região Centro-Oeste brasileira, intensificou ainda mais o processo de ocupação do estado de Goiás e da fragmentação territorial, pois com a transferência da Capital, houve vultosos investimentos em infraestrutura viária, por exemplo, que correspondeu a um elemento fundamental para a criação de novos povoados, que posteriormente transformaram-se em cidades ao longo das rodovias, em destaque a rodovia BR 153, que começou a ser construída no final de década de 1950.

Ressalta-se então, que a construção das capitais Goiânia e Brasília foi fundamental para a consolidação do estado de Goiás e da região Centro-Oeste no processo de integração brasileira. Segundo Moysés e Silva (2007) a construção das capitais planejadas no planalto central possibilitou a formação do "eixo" GoiâniaAnápolis-Brasília, que se constitui em um espaço de grande concentração populacional, representando mais de 1/3 da população total do Centro-Oeste. Para Araújo Sobrinho (2008), o eixo Goiânia-Brasília configura-se em um sistema urbano-regional em expansão com inúmeras alternativas de crescimento econômico e populacional, além de ser atrativo em investimentos e apresentar incontáveis possibilidades de uso do território.

Nas décadas de 1980 e 1990 destacam-se os incentivos fiscais para atração de indústrias e agroindústrias para o território goiano. O FCO, o Fomentar e o Produzir são os principais exemplos de fundo, crédito e subsídios para a atração dos principais empreendimentos, que hoje estão implantados no estado de Goiás.

Buscou-se nesse primeiro capítulo trazer algumas discussões e reflexões sobre a produção do território goiano pelo agronegócio e já introduzir questões sobre o agronegócio sucroenergético. Essa discussão passou pelo entendimento da lógica capitalista, complexa e muitas vezes perversa, e pelo papel de agentes fundamentais para a territorialização e o funcionamento dos empreendimentos, como o Estado, por exemplo. Entende-se portanto, a abordagem regional como uma forma de se compreender as dinâmicas e os (re) arranjos materializados ao longo do tempo pela lógica do capital, que por meio de vários processos, frutos desse sistema, como a globalização por exemplo, acabaram por fragmentar e diferenciar os lugares.

No capítulo II será apresentada a microrregião Ceres, sua constituição história e suas principais características, além de buscar responder as seguintes questões: Porque a 
microrregião Ceres é interessante para a reflexão proposta? Quais as características socioeconômicas dessa microrregião? Quais as especificidades da Colônia Agrícola Nacional e como ela foi importante para a formação territorial da região estudada? 


\section{CAPÍtUlO II - A MICRORREGIÃo CERES (GO): DAS COLÔNIAS AGRÍCOLAS AO AGRONEGÓCIO SUCROENERGÉTICO}

A microrregião Ceres está localizada na mesorregião Centro Goiano e é constituída por 22 municípios: Barro Alto, Carmo do Rio Verde, Ceres, Goianésia, Guaraita, Guarinos, Hidrolina, Ipiranga de Goiás, Itapaci, Itapuranga, Morro Agudo de Goiás, Nova América, Nova Glória, Pilar de Goiás, Rialma, Rianápolis, Rubiataba, Santa Isabel, Santa Rita do Novo Destino, São Luiz do Norte, São Patrício e Uruana.

A microrregião tem o mesmo nome do município de Ceres, emancipado do município de Goiás no ano de 1953. A região de Ceres teve ocupação relevante durante o Governo de Getúlio Vargas que, com uma de suas frentes políticas, objetivou a ocupação dos "grandes vazios demográficos" do Brasil. Dentro da política que se denominou de "Marcha para o Oeste", criou-se o projeto das Colônias Agrícolas Nacionais, no ano de 1941, com o intuito de povoar o interior do Brasil, por meio de incentivos a pequena propriedade e ao produtor rural, com o discurso de incentivar a ocupação do interior do país, por meio da reforma agrária ${ }^{12}$.

Faz-se importante contextualizar, que nesse momento, o mundo passava pela segunda Guerra Mundial (1939 - 1945) e havia o temor da ocupação, por parte de outros países, de áreas pouco povoadas, estratégicas e com fronteiras desprotegidas. Desta forma, um dos motivos que incentivou a criação das colônias agrícolas no território nacional, foi político-estratégico, já que a Marcha para o Oeste também objetivava desbravar a Amazônia, dando início à ocupação pelo Planalto Central (TEIXEIRA; CAMPOS, 2011).

Assim, a Colônia Agrícola de Goiás, conhecida como CANG, foi a primeira de oito colônias idealizadas durante o Governo Vargas. Os outros locais escolhidos foram: Amazonas, Pará, Maranhão, Paraná, território de Ponta Porã (atual Mato Grosso), Piauí e Minas Gerais.

$\mathrm{Na}$ tentativa de compreender a região estudada na atualidade é preciso entender como se deu seu processo de constituição histórica e quais as principais políticas,

\footnotetext{
${ }^{12}$ A tese de que as Colônias Agrícolas Nacionais tiveram o intuito de realizar uma reforma agrária é defendida principalmente por Andrade (1990; 2006), contudo discorda-se aqui dessa ideia, os argumentos serão apresentados no decorrer da presente pesquisa.
} 
programas e incentivos do Estado. Para tanto, será realizada uma reflexão sobre os principais contextos de ocupação e suas repercussões quanto ao crescimento populacional e a expansão da fronteira agrícola para o centro goiano.

Escolheu-se retratar quatro momentos principais: primeiro, com a atividade mineradora, durante o século XVIII, responsável pela criação de vários povoados e vilas que deram origem as primeiras cidades de Goiás; segundo, pelo esvaziamento populacional que Goiás passou durante a crise da mineração (século XIX), o que deu início às produções agrícolas e a pecuária de subsistência; terceiro, no início do século XX, as principais políticas de interiorização do Brasil, sobretudo a Marcha para o Oeste e, dentro dela, o projeto das Colônias Agrícolas Nacionais; e por fim, os Planos Nacionais de Desenvolvimento (PND's) na década de 1970, que deram continuidade à expansão da fronteira agrícola e estimularam o uso de técnicas modernas e insumos.

A microrregião Ceres atualmente possui como principal atividade econômica o agronegócio vinculado ao setor sucroenergético, que se iniciou na região, sobretudo após os incentivos do Proálcool, em meados da década de 1970. São sete empreendimentos sucroenergéticos em funcionamento que são responsáveis por movimentar a economia local e regional, mas ao mesmo tempo, de forma geral, por não haver outro segmento do agronegócio em desenvolvimento ou outra atividade econômica autônoma à atividade canavieira, essa região pode desencadear problemáticas e graves efeitos socioeconômicos, devido à falta de dinamismo em relação a outros segmentos econômicos.

A produção de cana-de-açúcar também é verificada na maioria dos municípios da microrregião, não ficando circunscrita aos municípios que possuem usinas. Assim, busca-se aqui trazer elementos históricos para compreender o processo de ocupação da microrregião Ceres, bem como dados estatísticos, que em conjunto à análise, contribuirão para compreender a microrregião Ceres na atualidade, principalmente no que se refere às características socioeconômicas.

\subsection{O Processo de Constituição Histórica da Microrregião Ceres - GO}

A Capitania de Goiás foi criada no ano de 1749 originada da Capitania de São Paulo, em um contexto em que se objetivava levar a administração colonial às áreas 
auríferas do centro-oeste do país (TEIXERA NETO, 1982). Durante o século XVIII a ocupação da Capitania de Goiás se deu, sobretudo, por meio do povoamento de alguns núcleos devido a extração de ouro. Alguns núcleos merecem destaque, como Vila Boa (atual Cidade de Goiás) e Meia Ponte (atual Pirenópolis) que são as cidades mais conhecidas e diretamente identificadas, até por sua paisagem e patrimônio material, por sua constituição histórica vinculada ao período aurífero no Brasil, durante o século XVIII.

Outras cidades também tiveram seus primeiros núcleos de povoamento criados nesse contexto, como Niquelândia, Cavalcante, São Domingos, Pilar de Goiás (na época conhecida como Papuã), Crixás, Santa Cruz, Natividade, Arraias, entre outras (as duas últimas pertencem atualmente ao estado do Tocantins). Meia Ponte, Santa Cruz, Pilar e Crixás constituíram o pólo hegemônico da capitania, pois estavam mais próximas as decisões administrativas, possuíam atividades urbanas mais intensas e se aproximaram de um "conglomerado" devido ao fato de estarem mais perto das jazidas de ouro e por possuírem uma maior densidade populacional (ESTEVAM, 1997). Das vilas citadas, merecem detaque Vila Boa (Goiás) e Papuã (Pilar), no que se refere ao povoamento da região Mato Grosso de Goiás, denominada dessa forma, por conter uma extensa área florestal situada na porção centro-sul de Goiás. A microrregião Ceres está situada em parte dessa área.

O período mineratório teve um importante papel para a constituição histórica do que é hoje o município de Pilar de Goiás e, consequentemente, para o povoamento da região estudada. No século XIX, com o declínio das minas auríferas, houve um esvaziamento populacional de Pilar e os moradores passaram a sobreviver da agricultura e por aproximadamente um século a cidade ficou "isolada" (IPHAN, 2014). Hoje ainda é possível verificar as marcas desse período aurífero na paisagem da cidade, por meio de alguns monumentos e espaços públicos tombados pelo IPHAN, no ano de 1954. Entretanto, percebe-se o abandono por parte do poder público local e do próprio IPHAN para a preservação do patrimônio cultural (COSTA; STEIKE, 2013).

Com o esgotamento das minas de ouro na Capitania de Goiás, gradativamente a mineração foi sendo substituída pela lavoura e pela pecuária de subsistência, e aos poucos as diferenciações regionais foram surgindo. A região centro-sul de Goiás aproximava-se economicamente de Minas Gerais e São Paulo, enquanto a região centro- 
norte mantinha-se afastada. Segundo Estevam (1997), o século XIX amadureceu uma civilização sertaneja em Goiás, que se manteve afastada das rápidas transformações capitalistas do Sudeste do Brasil. Eram realizadas comercializações de gado, via triângulo mineiro, contudo eram feitas à base de troca, sem muita modernidade no que se refere aos negócios, podendo assim afirmar, que a província de Goiás esteve fracamente inserida e articulada ao contexto capitalista do país desde os primórdios.

O centro-norte goiano ficou durante longos anos (século XIX e início do século $\mathrm{XX}$ ) sem quase nenhuma interação com o dinâmica econômica do Sudeste brasileiro, o que era perceptível nas formas sociais e em sua estrutura fundiária, a qual era fracionada basicamente por questões familiares e de herança. O sul goiano, em contrapartida, intensificou ao longo dos anos, suas relações com o Sudeste brasileiro e já no ano de 1914 houve a implantação da primeira etapa da estrada de ferro "Mogiana", que estendeu-se de Araguari (MG) a Roncador (GO). A ferrovia possibilitou uma interrelação entre Goiás e os estados de Minas Gerais e São Paulo, o que acarretou algumas modificações nessa região goiana, como a ocupação, por meio de migrações, aumento da produção agrícola e uma relevante valorização fundiária.

A segunda etapa da ferrovia em Goiás data de 1935 e seu prolongamento chegou até a cidade de Anápolis, importante centralidade goiana da época. Nesse contexto, o Brasil passou por algumas mudanças, sobretudo relacionadas ao regime político fundado por Getúlio Vargas, denominado "Estado Novo". Dentro desse regime, foi criada a política da Marcha para o Oeste que objetivava, em síntese, ocupar os "vazios demográficos", por meio de uma política de ocupação e interiorização do Brasil. A Marcha para o Oeste promoveu a ocupação do interior brasileiro, por meio das migrações e visava a produção de matérias-primas e alimentos mais baratos para subsidiar o processo de industrialização do Sudeste brasileiro.

Dentro da Marcha para o Oeste, foi criado o projeto das Colônias Agrícolas Nacionais, também pensado como uma estratégia de ocupação do interior do Brasil, por meio de colônias agrícolas. A primeira colônia agrícola do Brasil foi implantada onde hoje está localizado o município de Ceres, no estado de Goiás. Primeiramente é importante ressaltar que quando se pesquisa sobre a Colônia Agrícola Goiana grande parte dos autores utilizam o termo "Mato Grosso Goiano", já mencionado, para designar a área escolhida para a implantação da colônia. A origem desse nome está relacionada 
ao tipo de vegetação, florestal, que se destaca em meio as áreas de Cerrado e foi dado pelos viajantes naturalistas do século XIX, como Auguste de Saint-Hilaire.

Um importante estudo para essa região foi realizado por Speridião Faissol, durante a década de 1950, intitulado O Mato Grosso de Goiás. Nesse estudo o autor aponta dois motivos principais para a ocupação humana na região: primeiro, pelo momento que o Brasil vivia, de expansão da ocupação do território nacional por meio das Colônias Agrícolas Nacionais, projeto orientado por técnicos em agricultura e colonização do Governo Federal; e, segundo, porque muitas áreas que estavam recebendo esse movimento pioneiro eram antigas áreas mineradoras, que ficaram decadentes por mais de um século. Durante a década de 1950, a exploração mineral não era mais considerada, pelo menos em grande escala, iniciava-se o momento de expansão das lavouras, principalmente de arroz, milho, feijão ou café (FAISSOL, 1952).

A base da ocupação do Mato Grosso Goiano deu-se pelas migrações, relacionadas ao processo de colonização da CANG. Segundo Faissol (1952) a migração estava sendo feita em uma escala nunca vista em Goiás até o momento. A maior parte dos migrantes era constituída por mineiros (das cidades de: Patos de Minas, Abaeté, Carmo da Paranaíba e outros municípios do oeste de Minas Gerais), mas também havia um número considerável de paulistas, baianos, maranhenses e mesmo goianos, de outras localidades do estado. Segundo Estevam (1997, p. 91) "na verdade, tratava-se de pessoas sem recursos, na maioria agregados de fazendas, meeiros e arrendatários, que marchavam em busca da terra prometida". Houve também um grande estímulo para a vinda de médicos e profissionais da saúde para a CANG e em pouco tempo foi construído o primeiro hospital da região, o hospital São Pio X.

A CANG foi criada pelo Decreto Lei № 6.882, de 19 de fevereiro de 1941, e fornecia aos colonos reconhecidamente pobres, mas trabalhadores e bem "comportados", lotes que variavam entre 26 e 32 hectares. Era uma exigência que os lotes só fossem distribuídos aos colonos que comprovassem ser casados, assim muitos migrantes que chegavam na colônia solteiros acabavam por contrair matrimônio para conseguirem terras.

Teixeira e Campos (2011) realizaram entrevista com uma pioneira da época da colônia, que afirmou que muitos burlavam as leis e se casavam somente para acessar terras ou quem já fosse casado em outro estado, casava-se novamente, pois era exigido 
somente a certidão de casamento. Tinham prioridade no acesso às terras, as famílias que possuíam filhos, nesse caso, a certidão de nascimento dos mesmos era exigida.

A Administração da Colônia doava também uma casa de alvenaria, além de um auxílio inicial aos colonos (a figura 13 mostra o escritório da CANG). Segundo Faissol (1952) na década de 1950, o número de casas já doadas era muito pequeno, devido a grande quantidade de migrantes, frente às verbas insuficientes do governo.

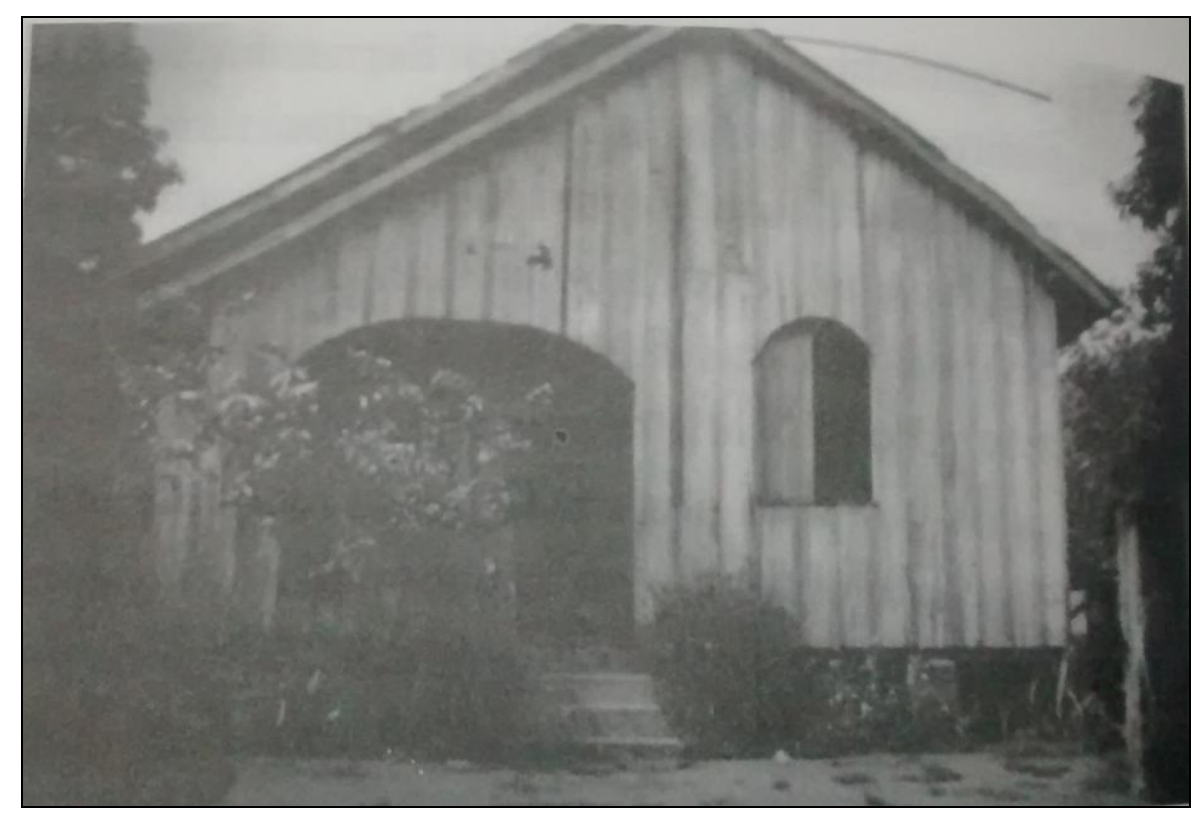

Figura 13 - Escritório da CANG. Fonte: Teixeira e Campos ( 2011).

A escolha da área para implantação da CANG foi estratégica, pois além de abranger terra fértil, situava-se ao norte de Goiânia e Anápolis. A escolha da área a qual a CANG seria implantada, contou com o apoio do Governo Estadual, pois o mandatário de Goiás mostrou a Getúlio Vargas, em mapa, uma ótima área para a implantação de tal empreendimento, já que ficava distante de Goiânia e mais perto de Anápolis, que nesse contexto, era a cidade mais populosa e progressista do estado de Goiás (ESTEVAM, 1997).

Assim, como a cidade de Anápolis era o principal centro regional e para que a produção de arroz, milho e feijão dos colonos pudesse ser comercializada, concluiu-se no ano de 1944, uma estrada de 142 Km que ligava a CANG à cidade de Anápolis. Isso indicaria fatores básicos para a modernização daquele período (CASTILHO, 2012). Essa estrada de rodagem, construída por intermédio do então administrador da CANG, 
o Engenheiro Bernardo Sayão, impulsionou certa integração territorial nesse trecho que futuramente seria a BR 153 (Belém-Brasília).

A colônia então, foi gradativamente apresentando incremento populacional, por meio das migrações, sendo que no ano de 1946 já contava com 1.600 famílias implantadas. No ano de 1950 a população era de quase 30 mil pessoas, o que conferia à colônia uma densidade demográfica de $35 \mathrm{hab} / \mathrm{Km}^{2}$. Grande parte das famílias habitavam a zona rural, que nessa época tinha aproximandamente $93 \%$ da população (ARANHA, 2001).

O fato é que mesmo a CANG apresentando objetivos relacionados a ocupação, por meio da colonização, concessão de terras, doação de casas e equipamentos para a produção agrícola, a realidade foi bem distinta. Há alguns relatos sobre a perversidade com os povos indígenas que habitavam aquela região, os quais tiveram que avançar para outros territórios ou se inserir na dinâmica da colônia, sendo inseridos também em novos costumes e na lógica capitalista. Portanto, na realidade, a CANG não apresentava uma proposta concisa de reforma agrária, somente apresentava um discurso nesse sentido, no intuito de aumentar as migrações para a região e propiciar a ocupação dos "vazios" no território brasileiro.

O modelo excludente da CANG e as exigências para o estabelecimento das famílias na colônia, bem como o atraso na construção das casas e na demarcação dos lotes, foram alguns motivos para que uma parte dos migrantes que lá chegavam, mas não conseguiam se inserir, fossem habitar outros núcleos. O exemplo mais claro do modelo excludente e seletista da CANG, foi o surgimento do povoado da Barranca, localizado na margem direita do Rio das Almas (importante rio, principalmente para o abastecimento da região). Foi o início do que hoje é o município de Rialma ${ }^{13}$. A figura 14 ilustra a construção da ponte sobre o Rio das Almas que ligaria (ou separaria) a CANG do povoado da Barranca. Antes da construção da ponte, era utilizada uma balsa para realizar a travessia, depois foi construída uma ponte de tambores e em seguida uma ponte semi-pênsil.

Segundo Silva (2002) o Rio das Almas separava dois mundos sociais distintos, de um lado a CANG, fruto de uma ocupação oficial, dentro de um discurso de

\footnotetext{
${ }^{13}$ Os povoados que hoje são os municípios de Carmo do Rio Verde e Uruana também surgiram com os migrantes que não conseguiram se inserir na CANG.
} 
colonização, vivendo nos lotes concedidos pelo Governo, mas recebendo auxílio precário e com uma política muito burocrática. No lado direito do rio, crescia a Barranca, que surgiu à margem da ocupação oficial e se constituiu "como uma extensão e, ao mesmo tempo, contraposição ao modelo de ocupação e implantação da CANG" (CASTILHO, 2012, p. 121). Na sede da CANG prezava-se pela ordem, assim era proibida a venda de bebidas alcoólicas e a instalação de casas de prostituição, mas na Barranca, não haviam proibições (SILVA, 2002). Desta forma, as duas localidades surgidas em uma mesma dinâmica de ocupação apresentavam, na época, organizações espaciais e funcionadades distintas.

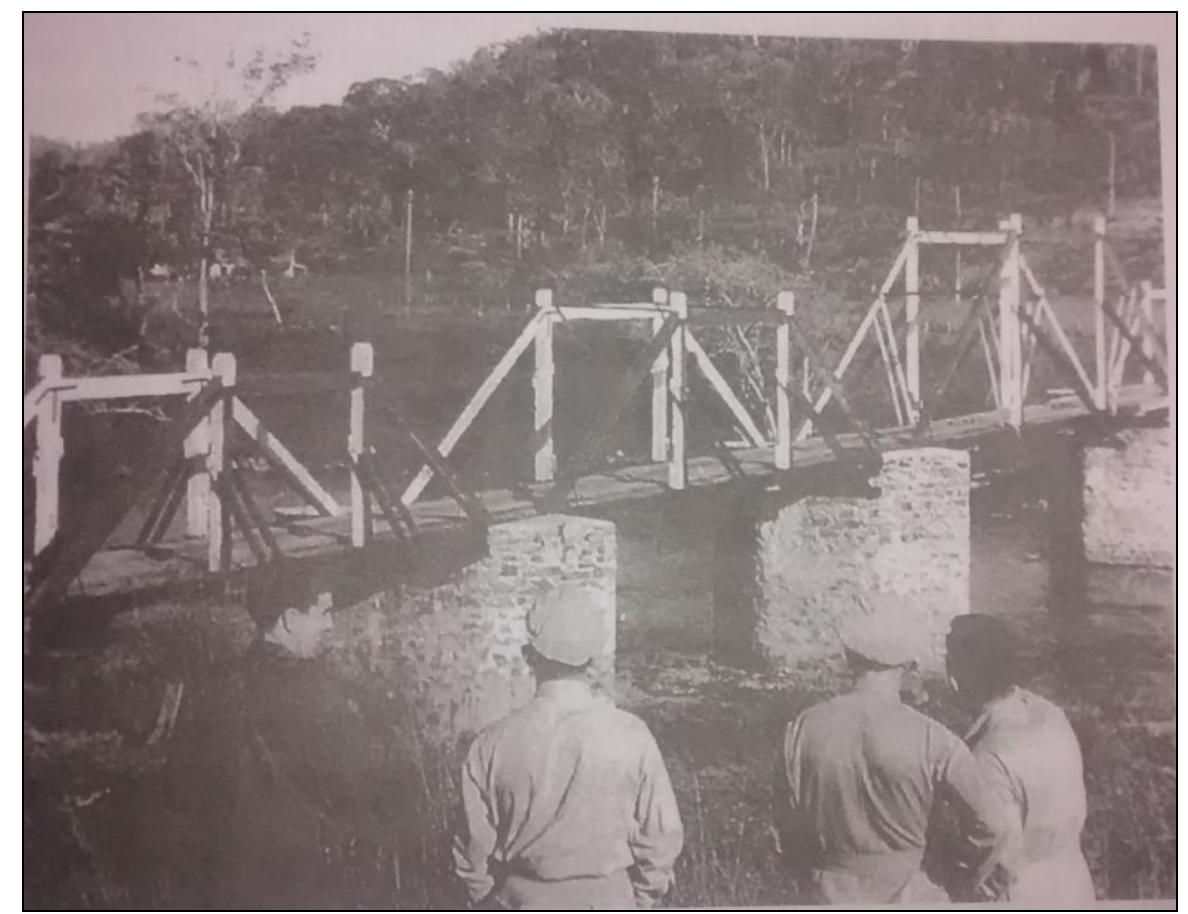

Figura 14 - Construção da ponte sobre o Rio das Almas, entre a CANG e o povoado de Barranca. Fonte: Teixeira e Campos (2011).

Com o passar do tempo, a falta de investimento e a insuficiência das políticas de apoio ao pequeno produtor, além da infraestrutura local e regional incipiente, foram fatores que levaram ao gradativo esvaziamento da colônia. A emancipação da colônia aconteceu no ano de 1953 e foi desmembrada das terras do município de Goiás, por meio da Lei № 767, e recebeu o nome de "Ceres" pelo administrador da Colônia, Bernardo Sayão, em homenagem a deusa da agricultura e dos cereais (Mitologia Romana). 
No ano seguinte o povoado de Barranca também foi emancipado, pelo DecretoLei $N^{o} 753$ de 1954, sendo desmembrado do município de Jaraguá. O povoado de Barranca recebeu o nome de "Rialma" em referência ao Rio das Almas, limite natural que separa os municípios de Ceres e Rialma. Segundo Castilho (2012) o núcleo urbano constituído pelas duas sedes municipais tinha, num primeiro momento, a função de servir ao campo, não havendo necessidade de emancipação. Mas, o quantitativo populacional que revelava uma representativa quantia de eleitores, fez com que lideranças políticas do estado de Goiás pressionassem pela emancipação, para que houvesse um desligamento da influência federal.

Em síntese, a má gestão da colônia, a lentidão em relação a legalização das terras e a falta de verbas e subsídios do governo, foram os principais motivos que fizeram alguns colonos abandonarem as terras e fossem habitar outras regiões ou outras localidades próximas a área da CANG, ou mesmo habitando o próprio sítio urbano de Ceres, após sua emancipação.

A CANG teve muitos de seus objetivos frustrados, mas obteve êxito em relação a ocupação, por meio das migrações, e a expansão da fronteira agrícola para a região, por meio de uma agricultura que já apresentava traços fortes de modernização. Assim, segundo Morais (2001), por meio da implantação da CANG o Governo Federal estava concretizando os principais objetivos da Marcha para o Oeste, que era fazer da região Centro-Oeste um pólo fornecedor de matérias-primas para a região Sudeste brasileira e, simultaneamente, ser consumidor dos produtos industrializados vindos de lá.

É importante destacar que a CANG entrou em crise no momento em que a região Centro-Oeste estava em evidência para o Governo Federal, com várias políticas de desenvolvimento agrícola e de malha viária voltadas para a região. Algumas dessas políticas estavam associadas à mudança da Capital Federal para o leste goiano e essa decisão só reforçaria a política de interiorização da economia, iniciada pelo Governo Vargas e prosseguida pelo Governo de Juscelino Kubitschek (1956 - 1961), como parte de um grande "Plano de Metas".

Após o golpe militar de 1964 no Brasil, os programas de desenvolvimento econômico e regional sofreram algumas mudanças, mas deram continuidade ao processo de modernização-centralização do Estado, inaugurado no regime do Estado Novo (COSTA, 2000). Nos anos pós 1964, algumas políticas de desenvolvimento foram 
propostas e executadas embasadas nas diferenças regionais do Brasil. Exemplo disso, foram as Superintendências e os Planos Nacionais de Desenvolvimento (PND's) criados nesse contexto.

O estado de Goiás, em decorrência de sua extensão territorial ${ }^{14}$ foi contemplado por programas governamentais de forma diferenciada. A parte norte foi incluída no contexto da "Amazônia Legal", que desde a década de 1960, foi alvo da Superintendência de Desenvolvimento da Amazônia (SUDAM). A porção centro-sul do estado de Goiás foi contemplada pela Superintendência do Desenvolvimento do CentroOeste (SUDECO). A instituição federal operadora das políticas de desenvolvimento regional tinham o intuito de estimular a produção agrícola, por meio de alta tecnologia e técnicas modernas de produção.

Na década de 1970 foram criados os Planos Nacionais de Desenvolvimento (PND’s), que dentre suas várias metas tinha como enfoque principal organizar o território brasileiro, com base em uma lógica geopolítica, que buscava a integração nacional, por meio da expansão da "fronteira econômica" do país a partir do centro-sul, em direção ao Centro-Oeste, Amazônia e Nordeste, de forma rápida e combinada. Segundo Costa (2000) o conceito de "fronteira econômica" era aplicado para várias instâncias, como fronteira agrícola, industrial, agroindustrial, urbana, de infraestrutura regional, etc., além disso, os planos de desenvolvimento regional eram direcionados tanto para as áreas mais desenvolvidas do país, quanto para áreas em desenvolvimento.

Os PND's foram divididos em três etapas: I PND (1972-1974), II PND (1975 1979) e III PND (1980-1985). O I PND teve por base o Plano de Integração Nacional (PIN) que destinou vultosos recursos para financiar o plano de obras e infraestrutura, nas regiões compreendidas nas áreas de atuação da Sudene e Sudam, na busca de promover a rápida integração da economia das regiões Nordeste e da Amazônia ao centro-sul brasileiro.

O II PND esteve mais voltado a dotar o Brasil de uma base industrial mais autônoma e, para tanto, era necessário obter maior contribuição ao PIB, da agricultura, pecuária, agroindústria e mineração. Na indústria, a ênfase foi dada aos setores de

\footnotetext{
${ }^{14}$ Até o ano de 1988 o atual estado do Tocantins pertencia ao estado de Goiás, o que conferia a Goiás uma grande extensão territorial.
} 
indústria de equipamentos e insumos básicos, e na parte de infraestrutura a preocupação maior era com área energética.

Os objetivos do III PND não diferiam muito dos anteriores, contudo não apresentou grande impacto na economia brasileira, pois na verdade não houve uma efetiva implementação do plano como os dois anteriores.

O II PND apresentou metas e programas voltados diretamente para a ocupação e desenvolvimento da região Centro-Oeste e para o Cerrado. Destacam-se então os programas: Programa de Desenvolvimento das Áreas de Cerrado (Polocentro), o Programa Especial da Região Geoeconômica de Brasília e o Programa de Cooperação Nipo-Brasileiro para o Desenvolvimento do Cerrado (Prodecer).

O Polocentro foi criado no ano de 1975, com objetivo de promover o desenvolvimento e a modernização das atividades agropecuárias da região Centro-Oeste e o oeste de Minas Gerais, mediante a ocupação das áreas de Cerrado e seu aproveitamento em escala empresarial com o desenvolvimento de linhas de financiamento rural, fortalecendo de maneira acelerada o processo de capitalização no campo, impondo a compra de insumos modernos, mecanização, aquisição de fertilizantes e outros insumos, concentrando-se portanto, no domínio das grandes propriedades.

O Polocentro também estimulou o desenvolvimento da infraestrutura de armazenagem, estradas e energia, contudo o crédito rural foi o segmento básico desse programa e fortaleceu o processo de capitalização do campo, já que para a concessão do crédito era exigido um padrão mínimo de tecnologia, mecanização e farta aquisição de fertilizantes e outros insumos (ESTEVAM, 1997).

Para efetivar os objetivos do Polocentro, utilizou-se a concepção de pólos de crescimento, por meio da seleção de doze áreas inseridas no domínio do Cerrado, espalhadas pelos estados de Mato Grosso, Mato Grosso do Sul, Goiás e Minas Gerais. Em Goiás, foram selecionadas cinco áreas: Gurupi, Pirineus, Paraná, Piranhas e Rio Verde, lembrando que naquela época ainda não havia ocorrido à subdivisão do estado para a formação do Tocantins. Essas áreas possuíam razoável potencial agrícola e receberam recursos para investir na construção de estradas, eletrificação rural, rede de estocagem e comercialização. Os benefícios incluíram sobremaneira, produtores de 
médio e grande porte e tinham como meta a destinação de $60 \%$ da área a ser explorada em lavouras e o restante (40\%) em pastagens (FARIA, 2006).

O Programa Especial da Região Geoeconômica de Brasília, foi proposto durante o I PND, mas foi executado no II PND. Ele objetivava um "desenvolvimento equilibrado" de Brasília, por meio do investimento em infraestrutura e visava uma ocupação ordenada, sobretudo no eixo Brasília - Anápolis - Goiânia. Na verdade, havia uma grande preocupação com a intensa migração para o Distrito Federal, o que acabaria por trazer efeitos "indesejáveis" sobre os equipamentos sociais da Capital. Assim, foram definidos cinco núcleos para investimento: o eixo Ceres - Anápolis, a área de influência das BR's 040 e 050, o Vale do Paranã, as áreas de mineração e os chapadões de Paracatu.

O eixo Ceres - Anápolis foi contemplado com $32 \%$ dos investimentos do programa aplicados principalmente em desenvolvimento industrial e rural; a área de influência das BR's 040 e 050 teve 14\% dos recursos, sendo que a maior parte foi aplicada em transportes, saneamento e melhorias urbanas (ESTEVAM, 1997). Este projeto influenciou diretamente no desenvolvimento de infraestrutura da microrregião Ceres, contudo a área que mais foi beneficiada no eixo Ceres - Anápolis foi, sem dúvida, o município de Anápolis, sobretudo onde hoje está implantado o Distrito Agroindustrial de Anápolis (DAIA).

Outro programa que contribuiu para a expansão da fronteira agrícola para o Centro-Oeste, foi o Programa de Cooperação Nipo-Brasileira para o Desenvolvimento do Cerrado (Prodecer), implementado a partir de 1978 com financiamento da agência japonesa - JICA e do governo brasileiro, em áreas dos estados de Minas Gerais, Bahia, Goiás, Mato Grosso e Mato Grosso do Sul. O principal instrumento utilizado pelo Prodecer foi o crédito supervisionado com empréstimos fundiários de investimento e de cobertura de despesas operacionais. O crédito era concedido a taxas de juros reais e atraiu um número significativo de agricultores (ALHO; MARTINS, 1995).

A cooperação entre Brasil e Japão apresentava interesses mútuos: o Brasil recebia investimentos japoneses a fim de subsidiar a pesquisa agropecuária e o Japão beneficiava-se da maior oferta de soja no mercado internacional. Segundo Inocêncio (2010) seria necessário expandir a área cultivada de soja no Brasil, para suprir as necessidades de uma população em expansão, ou seja, o Prodecer foi criado para 
atender aos interesses internacionais, por meio da venda de maquinários, insumos e cultivo de produtos destinados ao mercado internacional.

A década de 1970 consistiu em um marco da atuação do Estado para o ordenamento territorial do Brasil, já que todas as políticas tiveram em sua essência estratégias e intencionalidades, que direcionaram a expansão da fronteira agrícola para o centro do país, bem como estimularam a integração nacional, por meio da construção de rodovias. Como exposto, na década de 1970 várias políticas e programas foram criados para incentivar a ocupação do interior do país, expansão da fronteira agrícola e modernização da agricultura, com intensa capitalização do campo. Essas características acarretaram profundas transformações ambientais e socioeconômicas, como uma intensa fragmentação das fitofisionomias do Cerrado, por exemplo, como também um crescimento econômico acelerado e a gradativa intensificação do processo de urbanização, refletido na década 1990, quando os efeitos dessa ocupação se manifestaram, por meio da rápida e expressiva concentração urbana.

Em consequência a rápida ocupação do Cerrado, motivada pelas grandes extensões territoriais, principalmente nas áreas de fronteira, atraíram também as populações urbanas, dando início a um rápido processo de privatização das terras (em um ritmo até então nunca empregado), sobretudo por empresários sulistas, o que favoreceu a incorporação da região ao processo produtivo. Isso significou uma forte demanda de novos insumos, tecnologias, qualificação de mão-de-obra, maquinários, melhoramento genético, uso de calagem para os solos do Cerrado, entre outras características produzidas no âmbito da Revolução Verde. Além dessas, duas características se mantiveram inalteradas: o estímulo ao latifúndio e a concentração fundiária.

Simultaneamente a esse contexto efervescente de políticas e programas de integração nacional, o mundo vivia uma forte crise no modelo energético hegemônico, trata-se do choque do petróleo em 1973, sentido em todo o mundo. O Brasil então, propôs a criação do Proálcool, no ano de 1975, no intuito de tentar solucionar internamente o problema do abastecimento energético, por meio da produção de álcool carburante inicialmente e, posteriormente, de álcool anidro.

Os incentivos do Proálcool também foram responsáveis pela expansão da fronteira canavieira para o Centro-Oeste brasileiro, apesar que nesse contexto, todo o 
país viu a rápida territorialização das destilarias e a expansão da produção de cana-deaçúcar.

Em Goiás, várias destilarias foram implantadas. Na microrregião Ceres não foi diferente, foram instaladas as destilarias: Pite S/A, no município de Itapuranga; a Devale, no município de Itapaci; a Usina Goianésia e a Usina Jalles Machado, ambas no município de Goianésia; e, a Carval, no município de Carmo do Rio Verde, instaladas, a primeira, no final da década de 1970 e as demais no decorrer da década de 1980, fruto dos incentivos do Próalcool. Algumas dessas destilarias foram fechadas posteriormente, quando da crise desse Programa.

\subsection{Caracterização Socioeconômica da Microrregião Ceres}

Como discutido no subcapítulo anterior, o estado de Goiás passou por alguns contextos importantes que subsidiaram políticas e programas nacionais, os quais contribuíram para a expansão da fronteira agrícola e para a construção de infraestrutura básica, o que foi preponderante para a ocupação do território goiano e, consequentemente, do crescimento populacional.

Também relacionado aos contextos mencionados, verifica-se o processo de fragmentação territorial do centro goiano e, em especial, da microrregião Ceres. Destaca-se que a atual configuração territorial da microrregião Ceres, esteve originalmente vinculada a quatro núcleos principais: Goiás, Pirenópolis, Pilar de Goiás e Jaraguá, que foram núcleos populacionais consolidados durante o contexto de extração aurífera no século XVIII.

As emancipações municipais na microrregião Ceres começaram a se intensificar a partir da CANG, pois com o crescimento populacional, as migrações, somado ao insucesso de alguns objetivos da colônia agrícola, houve pressão por parte de lideranças políticas do estado de Goiás visando a autonomia da colônia frente ao Governo Federal. Assim, quatro municípios da microrregião tiveram sua emancipação diretamente vinculada ao contexto da CANG, são eles: Ceres, Rialma, Carmo do Rio Verde e Uruana.

Os municípios de Carmo do Rio Verde e Uruana, localizados bem próximos a antiga área da CANG (13 Km e $20 \mathrm{Km}$, respectivamente) receberam as pessoas que não 
conseguiram inserir-se na colônia, devido às exigências e a burocracia frente à concessão dos lotes. Outro município que teve aumento populacional devido à CANG foi Rianápolis, cujo povoado estava localizado entre Jaraguá e a colônia, assim servia muitas vezes de local de "pouso" para os viajantes e trabalhadores que iam para a colônia agrícola. Pode-se afirmar portanto, que a emancipação de Rianápolis esteve ligada à dinâmica estabelecida pela CANG, mesmo que indiretamente.

A figura 15 mostra o crescimento vertiginoso da população total da CANG, com destaque para a população rural, que era maioria nos tempos da colônia. Com a emancipação municipal de Ceres, em 1953, a população continua a crescer por algum tempo, mas a partir da década de 1970 há um declínio dessa população. O ápice populacional de Ceres foi nos anos 1968, pós CANG, quando chegou a quase 70 mil habitantes, atualmente sua população total não ultrapassa os 21 mil habitantes ${ }^{15}$.

As políticas e programas do Governo Federal, a partir da década de 1970, em prol da expansão da fronteira agrícola para áreas selecionadas, começaram a atrair população para outras localidades do estado de Goiás, principalmente para o sul e sudoeste de Goiás. Mas, isso foi perceptível também para os municípios da microrregião Ceres, que foram gradativamente atraindo população e se emancipando.

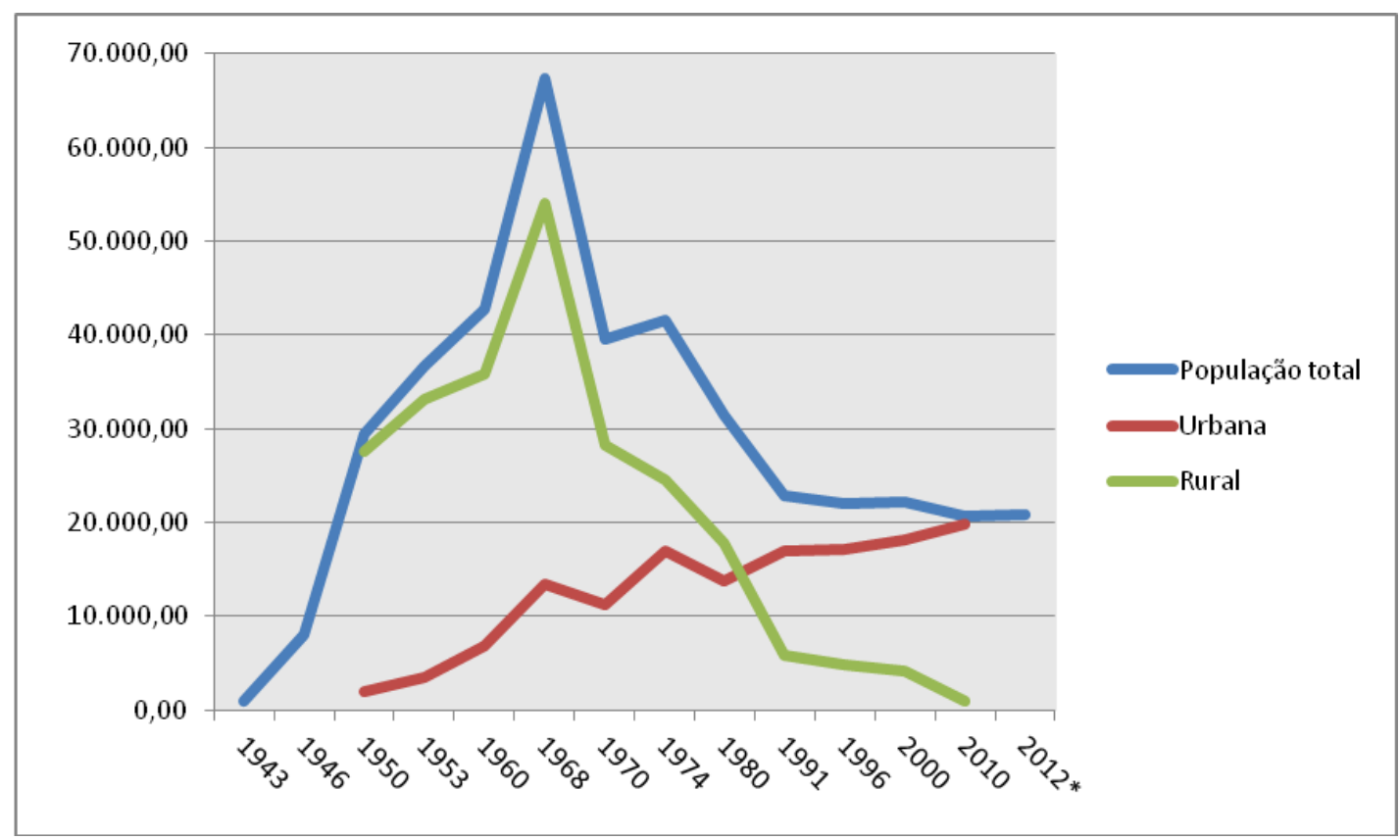

Figura 15 - População total, urbana e rural da CANG (até 1952) e Ceres (a partir de 1953). Fonte: Castilho (2012); IMB (2013). Organização: A autora.

\footnotetext{
${ }^{15}$ Segundo Censo Populacional, realizado no ano de 2010 (IBGE, 2010).
} 
Nas décadas de 1940 a 1960, durante e após a CANG, muitos povoados foram emancipados. O projeto das Colônias Agrícolas Nacionais muito contribuíram para a fragmentação da atual microrregião Ceres, somado aos programas de integração nacional, bem como à transferência da Capital Federal para Brasília, pois foram fundamentais para o intenso processo migratório para o centro-goiano naquela época.

Outro fator importante foi a construção de rodovias e a expansão da malha viária para o centro-norte do país. Destaca-se a BR 153 (Belém - Brasília) que trouxe, além de maior facilidade de deslocamento para áreas que até então apresentavam dificuldade de integração, maior fluidez para a circulação de produtos e pessoas. A BR 153 passa ao centro da microrregião Ceres, sendo a principal via de integração entre os municípios e outras localidades de Goiás e do Brasil. Confere-se assim, a essa rodovia, um protagonismo no processo de fragmentação territorial da microrregião Ceres. O quadro 5 mostra as datas de emancipação e a origem dos municípios da microrregião estudada.

Observa-se pelo quadro 5 que oficialmente Pilar de Goiás foi emancipada do município de Itapaci no ano de 1953, isso se deve ao fato de Pilar, nos séculos XVIII e XIX, ter passado pelas categorias de arraial, freguesia e por fim vila, a qual permaneceu com este status até o ano de 1935, quando foi transferida para o distrito de Vila Crixás. Em 1945 passou a ser distrito do município de Itapaci, pertencendo a este até o ano de 1953 quando houve a emancipação.

Durante os anos do Regime Militar no Brasil houve sérias restrições a fragmentação municipal, na microrregião Ceres somente dois municípios foram emancipados: Nova Glória e Santa Isabel, após o fím do Regime Militar as emancipações intensificaram-se novamente. Em estudo ao IPEA, Magalhães (2007), reflete sobre os principais motivos para a criação de novos municípios pós Regime Militar até o ano 2000 e, segundo este autor, os principais motivos referem-se ao descaso por porte da administração do município de origem e à extensão territorial do mesmo, pois quanto mais distante da sede municipal maiores são as dificuldades em se atender aos anseios da população, o que acaba por estimulá-los a busca pela emancipação. 
Quadro 5 - Data de Emancipação e Municípios de origem - Microrregião Ceres - GO

\begin{tabular}{|c|c|c|}
\hline \multicolumn{3}{|c|}{$\begin{array}{l}\text { DATA DE EMANCIPAÇÃO E MUNICÍPIO DE ORIGEM -MICRORREGIÃC } \\
\text { CERES - GO }\end{array}$} \\
\hline Municípios & Data da criação & Município de origem \\
\hline Barro Alto & 14-11-1958 & Pirenópolis \\
\hline Carmo do Rio Verde & 14-11-1952 & Goiás \\
\hline Ceres & 04-09-1953 & Goiás \\
\hline Goianésia & $24-06-1953$ & Jaraguá \\
\hline Guaraíta & 29-04-1992 & Itapuranga \\
\hline Guarinos & $11-05-1988$ & Pilar de Goiás \\
\hline Hidrolina & 14-11-1958 & Pilar de Goiás \\
\hline Ipiranga de Goiás & $21-07-1997$ & Ceres \\
\hline Itapaci & $19-07-1945$ & Pilar de Goiás \\
\hline Itapuranga & 03-07-1953 & Goiás \\
\hline Morro Agudo & $28-01-1988$ & Rubiataba \\
\hline Nova América & 14-11-1958 & Itapaci \\
\hline Nova Glória & $10-06-1980$ & Ceres \\
\hline Pilar de Goiás & $05-10-1953$ & Itapaci \\
\hline Rialma & $16-07-1953$ & Jaraguá \\
\hline Rianápolis & 18-12-1958 & Jaraguá \\
\hline Rubiataba & $12-10-1953$ & Goiás \\
\hline Santa Isabel & $14-05-1982$ & Jaraguá \\
\hline Santa Rita do N. Destino & $27-12-1995$ & Barro Alto \\
\hline São Luiz do Norte & $28-01-1988$ & Itapaci \\
\hline São Patricio & 27-12-1995 & Carmo do Rio Verde \\
\hline Uruana & 14-09-1948 & Jaraguá \\
\hline
\end{tabular}

Fonte: IMB (2013). Organização: A autora.

A figura 16 ilustra a fragmentação territorial da microrregião Ceres. Em primeira perspectiva, a configuração territorial ligada aos quatro núcleos centrais do contexto aurífero em Goiás ainda no século XVIII e, em segunda perspectiva, a configuração atual da microrregião, com seus vinte dois municípios. É possível verificar a atuação das políticas e programas do Governo (CANG, II PND e Proálcool) como agentes do "novo", que por meio de incentivos a ocupação do território, da implantação de rodovias e de destilarias, acabaram por estimular o crescimento populacional da região, o desenvolvimento econômico e o aumento de demandas socioespaciais, o que consequentemente contribuiu para a fragmentação dos municípios. 
FRAGMENTAÇÃO MUNICIPAL DA MICRORREGIÃO CERES - GO

Configuração Territorial dos municípios da microrregião Ceres - antes da CANG (anterior a 1940)

Goiás

Jaraguá

Pilar

Pirenópolis

Configuração atual da

Microrregião Ceres

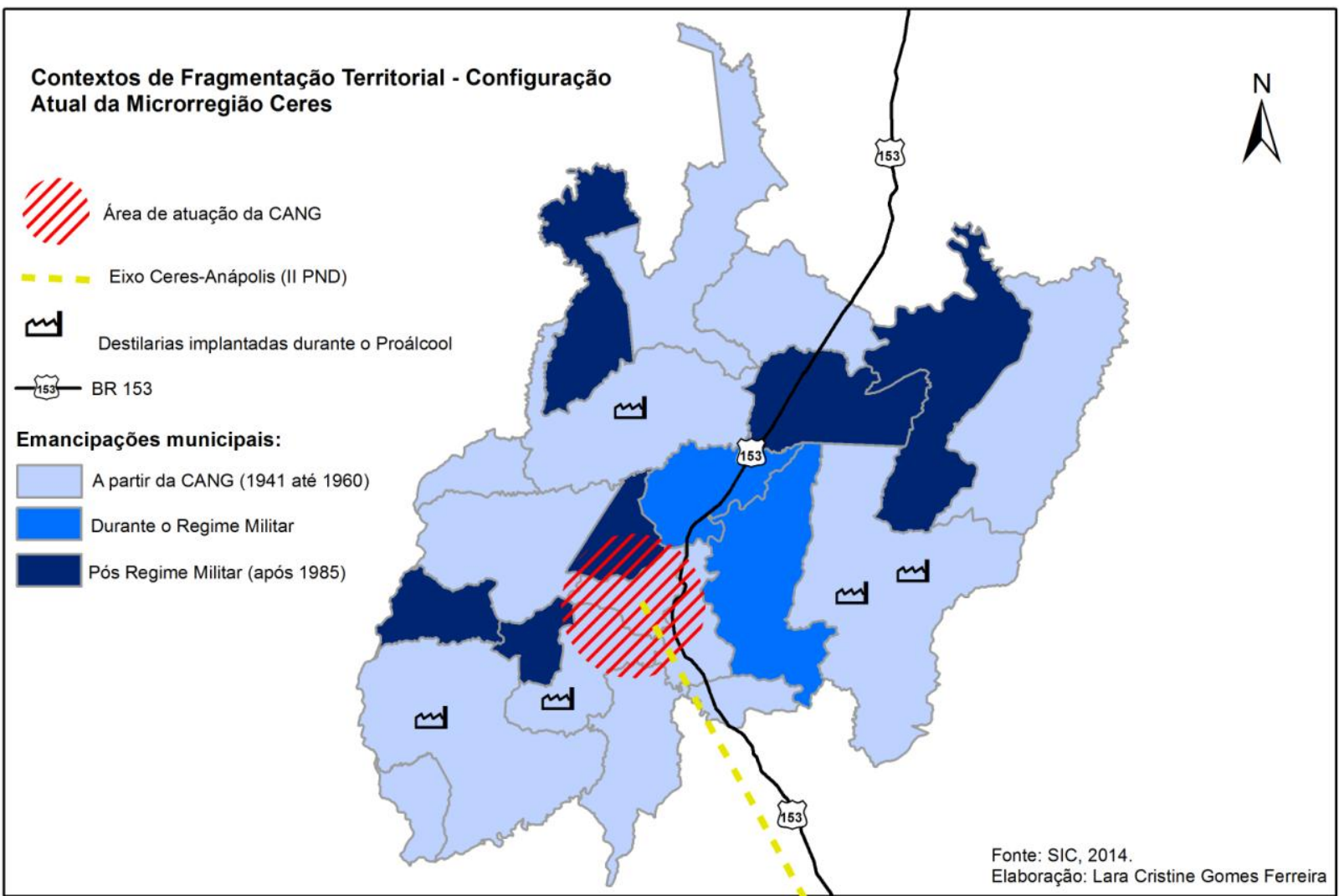

Figura 16 - Fragmentação territorial da microrregião Ceres e os principais contextos de emancipação. 
Ainda segundo Magalhães (2007) esse processo recente de emancipação municipal no Brasil, pós Regime Militar, alterou significativamente a configuração territorial dos municípios brasileiros, pois a maioria (94\%) dos municípios instalados no Brasil, entre os anos 1985 e 2000, possuem menos de 20 mil habitantes. Na microrregião Ceres isso não é diferente: dos vinte dois municípios, dezenove possuem menos de 20 mil habitantes.

Os programas de ocupação e desenvolvimento regional, bem como a fragmentação municipal contribuíram para uma inversão dos dados de população rural e urbana em Goiás. Como verificado, ainda no contexto da CANG, a microrregião Ceres possuía população rural bem superior a urbana. A partir dos fatores citados (políticas e programas de ocupação e a modernização da agricultura), juntamente à transferência da Capital Federal para Brasília, a urbanização foi gradativamente crescendo no centro do país.

A figura 17 ilustra o crescimento vertiginoso da população urbana da microrregião Ceres, em detrimento da população rural. É importante mencionar que até o início dos anos 1970 a população rural era superior na microrregião Ceres, mas a partir de meados dessa década gradativamente o campo vem perdendo população enquanto a cidade absorve. Ainda por meio da figura 17, observa-se que no ano de 1980 as populações rural e urbana ainda eram quase equivalentes, contudo a partir desse ano a urbanização passou a ser dominante nessa região.

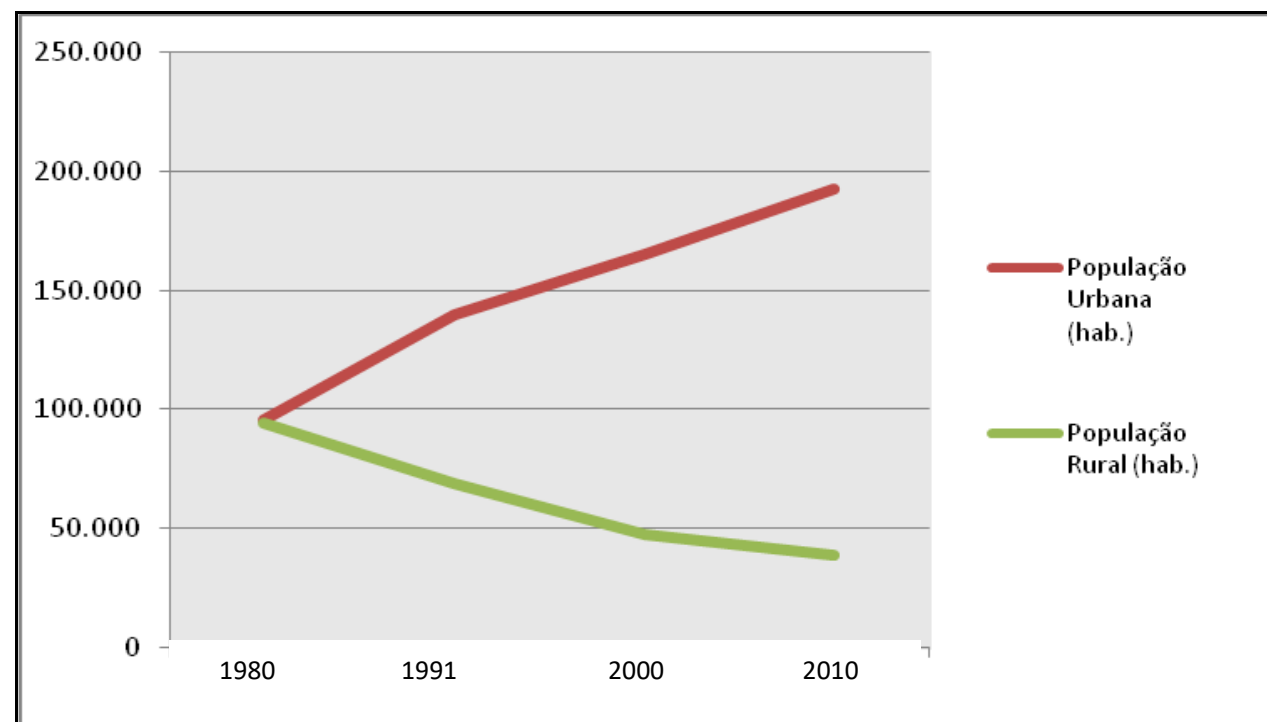

Figura 17 - População urbana e rural da microrregião Ceres - anos 1980 a 2010. Fonte: Censos populacionais do IBGE. 
A partir da tabela 3 pode-se verificar a população total da microrregião Ceres e dos municípios que a constituem para os últimos recenseamentos: anos 2000 e 2010. Observa-se que houve crescimento populacional para a microrregião Ceres, em relação aos anos analisados. No ano de 2010 a microrregião possuía 231.239 habitantes o que confere uma densidade populacional de $19,45 \mathrm{hab} / \mathrm{Km}^{2}$, sendo a quinta microrregião (das dezoito do estado de Goiás) em densidade demográfica.

O processo de fragmentação municipal da mesorregião Centro Goiano também justifica esses dados, pois as maiores densidades populacionais são verificadas nas microrregiões nela inseridas, como por exemplo, as microrregiões: Goiânia, Entorno de Brasília, Anápolis, Anicus e Ceres, as cinco maiores em densidade demográfica.

Os municípios de Goianésia (59.549 hab.), Itapuranga (26.125 hab.) e Ceres (20.722 hab.) são os que apresentam maior população da microrregião Ceres, respectivamente, (acima de 20 mil habitantes). Juntamente a esses três municípios, Rubiataba (18.915 hab.), Itapaci (18.458 hab.), Uruana (13.826 hab.) e Rialma (10.523 hab.) também são núcleos urbanos com relevância populacional, para a realidade da microrregião, bem como disponibilizam equipamentos e infraestrutura básica para a população das cidades vizinhas, com menos de 10 mil habitantes, que são maioria nessa região.

De modo geral, a microrregião Ceres atualmente possui municípios pequenos, com economia voltada, sobretudo para a agropecuária. Alguns municípios destacam-se na extração de minérios, como Barro Alto e Pilar de Goiás, por meio de mineradoras financiadas com capital externo, mas a principal atividade econômica da microrregião está voltada para a produção canavieira e seu beneficiamento em usinas sucroenergéticas.

A produção de cana-de-açúcar teve início na microrregião Ceres a partir do final da década de 1960 e se expandiu durante o Proálcool. A primeira destilaria implantada na região data de 1968 e se trata da Sociedade Açucareira Monteiro de Barros, instalada no município de Goianésia. Posteriormente foram instaladas a PITE S/A no município de Itapuranga (1979), a destilaria Carval, no município de Carmo do Rio Verde (1980), a Jalles Machado, no município de Goianésia (1980), a Devale, no município de Itapaci (1982), a Cooper Rubi, no município de Rubiataba (1984) e a usina Goianésia, no município de Goianésia (1989), todas relacionadas aos incentivos do Proálcool durante 
as décadas de 1970 e 1980. Das destilarias e usinas citadas, somente a usina Goianésia e a Jalles Machado ainda estão em funcionamento ininterrupto desde o momento de implantação, as demais foram desativadas, principalmente durante as crises do Proálcool.

Tabela 3 - População total dos municípios da microrregião Ceres - GO

\begin{tabular}{l|c|c}
\hline \multicolumn{1}{c}{ POPULAÇÃO TOTAL DOS MUNICÍPIOS DA MICRORREGIÃO } \\
CERES - GO / 2000 E 2010
\end{tabular}

Fonte: IBGE (2000; 2010). Legenda: ( - ) Dados não disponíveis.

A usina CRV Industrial foi implantada no município de Carmo do Rio Verde no ano 2000 e a usina Vale Verde em Itapaci, no ano de 2002. A usina Vale Verde instalada no município de Itapuranga e a usina Codora, uma filial da Jalles Machado, implantada em 2010 em Goianésia, estão relacionadas ao Plano Nacional da Agroenergia no Brasil (2006 - 2011), conforme já discutido.

Faz-se importante mencionar que durante o contexto do Plano Nacional da Agronergia foram solicitadas as licenças para a implantação de mais quatro usinas na 
microrregião Ceres: uma no município de Barro Alto, uma no município de Uruana e duas no município de Santa Isabel, mas nenhuma delas foi de fato construída. Os detalhes da implantação das destilarias e usinas da microrregião Ceres podem ser verificados no quadro 6, e a espacialização dos empreendimentos pode ser visualizada pela figura 18.

Quadro 6 - Histórico de Implantação dos Empreendimentos Canavieiros na Microrregião Ceres

\begin{tabular}{|c|c|c|c|}
\hline \multicolumn{4}{|c|}{$\begin{array}{l}\text { DETALHES DA IMPLANTAÇÃO DOS EMPREENDIMENTOS CANAVIEIROS NA MICRORREGIÃO } \\
\text { CERES }\end{array}$} \\
\hline Município & Empreendimento sucroalcooleiro & $\begin{array}{c}\text { Ano de } \\
\text { implantação }\end{array}$ & $\begin{array}{c}\text { Situação do } \\
\text { licenciamento }\end{array}$ \\
\hline Barro Alto & Destilaria Santa Rita Ltda. & $\begin{array}{l}\text { Em cadastro no } \\
\text { ano de } 2007\end{array}$ & Não implantada \\
\hline \multirow{2}{*}{$\begin{array}{l}\text { Carmo do Rio } \\
\text { Verde }\end{array}$} & Destilaria Carval & Anos 1980 & Desativada \\
\hline & CRV Industrial Ltda. & 2000 & Em funcionamento \\
\hline \multirow{4}{*}{ Goianésia } & Sociedade Açucareira Monteiro de Barros & 1968 & Desativada \\
\hline & Usina Goianésia & 1989 & Em funcionamento \\
\hline & Jalles Machado & 1980 & Em funcionamento \\
\hline & Codora Álcool e Energia Ltda. & 2010 & Em funcionamento \\
\hline \multirow{2}{*}{ Itapaci } & Grupo Devale & 1982 & Desativada \\
\hline & Vale Verde Empreendimentos & 2002 & Em Funcionamento \\
\hline \multirow[b]{2}{*}{ Itapuranga } & Pite S/A & 1979 & Desativada \\
\hline & Vale Verde Empreendimentos & 2007 & Em funcionamento \\
\hline Rubiataba & $\begin{array}{l}\text { Cooperativa Agroindustrial Rubiataba Ltda } \\
\text { (Cooper Rubi). }\end{array}$ & 1984 & Em funcionamento \\
\hline \multirow[b]{2}{*}{ Santa Isabel } & SAMB Agropecuária Ltda. & $\begin{array}{l}\text { Em cadastro no } \\
\text { ano de } 2007\end{array}$ & Não implantada \\
\hline & Destilaria Andradina Açúcar e Álcool & $\begin{array}{l}\text { Em cadastro no } \\
\text { ano de } 2007\end{array}$ & Não implantada \\
\hline Uruana & CRV Industrial Ltda. & $\begin{array}{l}\text { Em cadastro no } \\
\text { ano de } 2007\end{array}$ & Não implantada \\
\hline
\end{tabular}

Fonte: IMB (2014). 


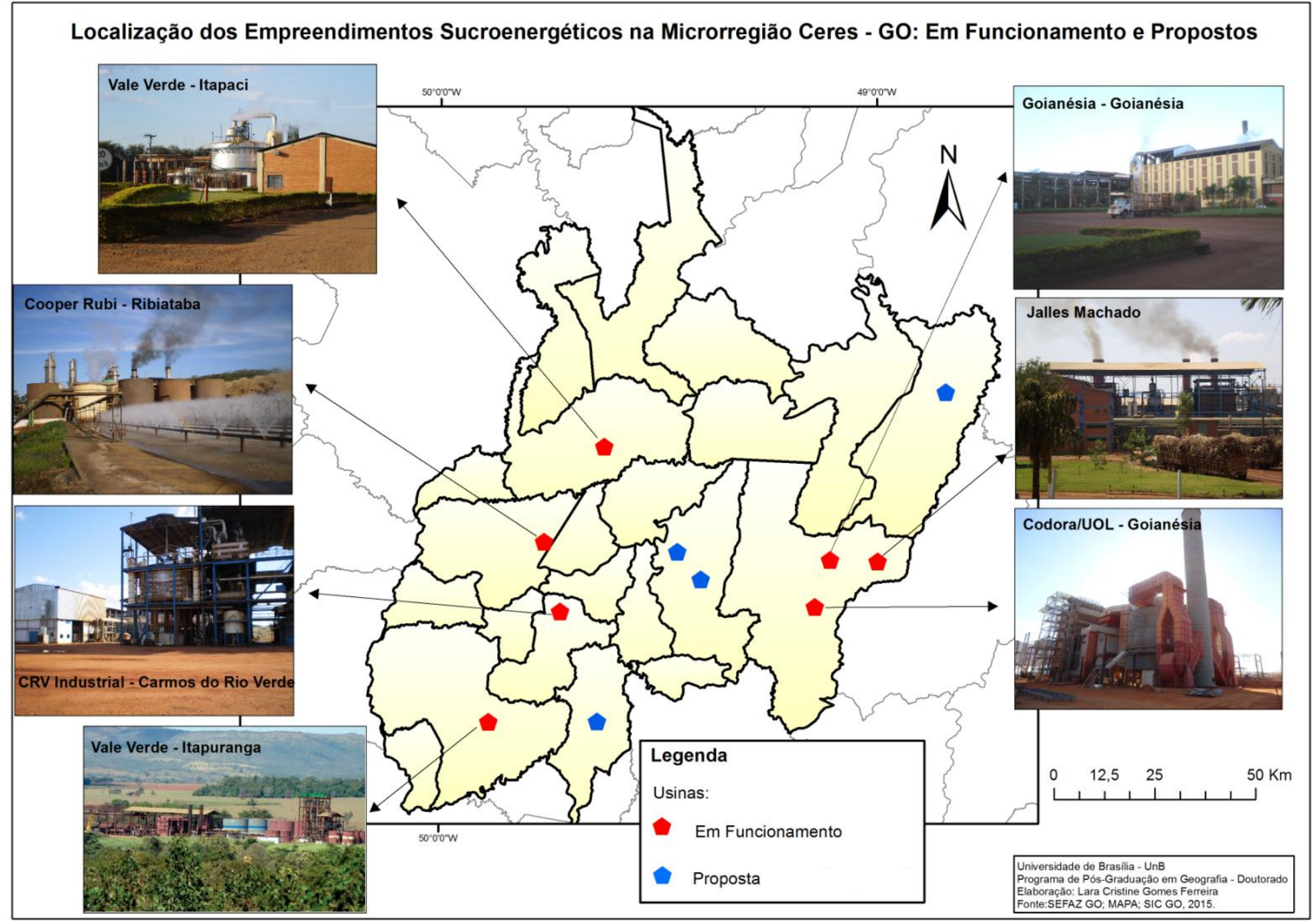

Figura 18 - Espacialização das usinas sucroenergéticas implantadas na microrregião Ceres, em funcionamento e propostas. 
A produção canavieira vem crescendo ao longo do tempo na microrregião Ceres: no ano 2000 a microrregião produzia 1.973 .500 toneladas de cana-de-açúcar e, em 2015, foram 7 002,324 toneladas. Os municípios que mais se destacam na produção canavieira são: Goianésia, Nova Glória, Itapuranga, Santa Isabel, São Luiz do Norte, Carmo do Rio Verde, Itapaci, Rubiataba e Barro Alto (tabela 4).

Dos nove maiores municípios em produção de cana-de-açúcar, cinco possuem usinas sucroenergéticas em funcionamento: Goianésia, Itapaci, Itapuranga, Carmo do Rio Verde e Rubiataba, os demais possuem uma alta produção canavieira que é transportada e beneficiada nos municípios vizinhos. Destaca-se a alta produção de cana nos municípios de Nova Glória (663.735 toneladas), Santa Isabel (491.643 toneladas), São Luiz do Norte (660.000 toneladas) e Barro Alto (553.800 toneladas), que mesmo não possuindo usinas, tem uma alta produção voltada para as usinas existentes na região. Diante disso, reitera-se a importância da abordagem regional, pois mesmo existindo usinas em somente cinco municípios, a produção canavieira é realizada de forma intensa em quase todos os municípios da microrregião.

O município de Carmo do Rio Verde, que possui uma usina em funcionamento, apresenta uma relevante produção de cana-de-açúcar (548.961 toneladas), contudo menor que outros municípios da região, conforme mencionado. Os municípios de Rialma e Uruana, vizinhos a Carmo do Rio Verde, produzem cana para a usina instalada neste município.

É possível verificar, por meio dos dados da tabela 4, o salto de produção de cana-de-açúcar nos municípios da microrregião Ceres, a partir dos anos 2000, sobretudo nos municípios de Santa Isabel e São Luiz do Norte. Ambos os municípios citados produziram no ano 2000 menos de 3.000 toneladas de cana, e em 2015 a produção foi superior a 1.000.000 toneladas juntos, e isso para servir aos municípios vizinhos que possuem usinas sucroenergéticas. 
Tabela 4 - Produção de cana-de-açúcar para os municípios da Microrregião Ceres 2000 a 2012 (toneladas).

\begin{tabular}{|c|c|c|c|c|c|c|}
\hline MUNICÍPIO & 2000 & 2003 & 2006 & 2010 & 2012 & 2015 \\
\hline Barro Alto & 176.000 & 224.000 & 306.000 & 473.000 & 513.566 & 553.800 \\
\hline Carmo do Rio Verde & 90.000 & 540.000 & 408.750 & 302.000 & 490.605 & 548.961 \\
\hline Ceres & 120.000 & 18.000 & 34.000 & 34.000 & 59.278 & 34.450 \\
\hline Goianésia & 1.040 .000 & 1.200 .000 & 1.020 .000 & 1.161.000 & 1.582 .600 & 1.440 .000 \\
\hline Guaraíta & 2.500 & 1.000 & 2.000 & - & - & - \\
\hline Guarinos & 800 & 500 & 800 & 1.350 & - & - \\
\hline Hidrolina & 1.200 & 450 & 80.500 & 105.000 & 98.600 & 88.400 \\
\hline Ipiranga de Goiás & - & 144.000 & 264.000 & 124.000 & 403.124 & 230.877 \\
\hline Itapaci & 2.000 & 320.000 & 339.200 & 180.000 & 531.978 & 461.242 \\
\hline Itapuranga & 800 & 90.000 & 208.000 & 272.541 & 570.125 & 302.801 \\
\hline $\begin{array}{l}\text { Morro Agudo de } \\
\text { Goiás }\end{array}$ & 1.200 & 1.500 & 4.000 & 5.000 & - & - \\
\hline Nova América & 800 & 8.000 & 26.250 & 19.000 & 29.672 & 47.825 \\
\hline Nova Glória & 184.000 & 384.000 & 701.250 & 350.000 & 782.318 & 663.735 \\
\hline Pilar de Goiás & 600 & 1.000 & 1.000 & 1.000 & - & - \\
\hline Rialma & 800 & 67.500 & 333.000 & 200.000 & 123.791 & 273.905 \\
\hline Rianápolis & 300 & 500 & 6.000 & 91.000 & 83.080 & 156.626 \\
\hline Rubiataba & 157.500 & 224.000 & 262.500 & 494.699 & $\mathbf{5 2 6 . 5 9 7}$ & 355.881 \\
\hline Santa Isabel & 1.000 & 400 & 60.000 & 170.000 & 553.330 & 491.643 \\
\hline $\begin{array}{l}\text { Santa Rita do Novo } \\
\text { Destino }\end{array}$ & 86.800 & 98.400 & 203.350 & 243.200 & 176.464 & 246.000 \\
\hline São Luiz do Norte & 1.200 & 600 & 395.500 & 540.000 & 540.000 & 660.000 \\
\hline São Patrício & 104.000 & 136.000 & 150.000 & 90.500 & 128.023 & 161.780 \\
\hline Uruana & 2.000 & 40.000 & 91.000 & 103.000 & 208.652 & 284.398 \\
\hline TOTAL & 1973.500 & 3499.850 & 4897.100 & 4960.290 & 7401.803 & 7002.324 \\
\hline
\end{tabular}

Fonte: IMB (2016). 
Percebe-se portanto, que a produção canavieira cresceu sobremaneira nos anos 2000 a 2012. Quando se analisa o ano de 2015, percebe-se uma tendência de queda em alguns municípios, bem como no montante geral da microrregião. Isso se deve principalmente ao contexto de crise política e econômica que tem se instalado no Brasil, bem como a alguns problemas financeiros verificados em alguns empreendimentos, como a usina Vale Verde de Itapuranga, que teve uma queda de produção de mais de 200 mil toneladas de cana-de-açúcar de 2012 a 2015.

A tabela 5 vem somar a análise posta, nela verificam-se os principais produtos agrícolas produzidos na microrregião Ceres, além da monocultura da cana-de-açúcar, no ano de 2015. Observam-se a produção em toneladas de arroz, feijão, soja, milho, tomate e melancia para a microrregião Ceres, destaca-se que todos esses produtos juntos não chegam a 324 mil toneladas, enquanto a produção canavieira, no mesmo ano, corresponde a mais de 7 milhões de toneladas.

A produção de melancia é importante na região, principalmente pelo município de Uruana, maior produtor de melancia do estado de Goiás. Além desse produto, a produção de grãos (principalmente milho e soja) também aparecem na microrregião Ceres. Já a produção de arroz e feijão são produzidos de forma bastante tímida.

Essa breve análise faz-se importante para ratificar a hegemonia da produção canavieira na microrregião Ceres e alertar o quanto a monocultura da cana-de-açúcar pode prejudicar a produção de alimentos e substituir culturas importantes, sobretudo para a agricultura familiar.

Desta disso, pode afirmar que a produção canavieira corresponde a principal produção agrícola e, junto aos empreendimentos canavieiros, à principal atividade econômica da microrregião Ceres. É a atividade que dinamiza socioeconomicamente a região, não somente com a monocultura da cana-de-açúcar, mas também com prestação de serviços e comércio para suprir algumas demandas da atividade sucroenergética. Contudo, ressalta-se que alguns serviços demandados pela atividade sucrorenergética são complexos e necessitam de tecnologias ainda não existentes na região, como por exemplo, mão-de-obra qualificada para consertar as colheitadeiras e os maquinários mais modernos.

Para isso, utilizam-se dos serviços de outras centralidades, principalmente da região Sudeste brasileira. Algumas indústrias, empresas e microempresas são 
observadas nos municípios da microrregião Ceres, sobretudo relacionadas a atividade mineradora, alimentícia e hospitalar.

Tabela 5 - Principais produtos agrícolas da microrregião Ceres - com exceção à canade-açúcar / 2015

\begin{tabular}{|c|c|c|c|c|c|c|}
\hline MUNICÍPIO & $\operatorname{Arroz}(t)$ & Feijão (t) & Soja $(t)$ & Milho (t) & Tomate (t) & Melancia (t) \\
\hline Barro Alto & 54 & - & 5.040 & 5.550 & 7.200 & - \\
\hline Carmo do Rio Verde & 360 & - & - & 7.200 & - & 14.571 \\
\hline Ceres & 270 & - & - & 2.400 & - & 2.100 \\
\hline Goianésia & 126 & - & 5.940 & 9.600 & 19.110 & - \\
\hline Guaraíta & 400 & - & - & 750 & - & - \\
\hline Guarinos & 46 & - & - & - & - & - \\
\hline Hidrolina & - & - & 9.000 & 1.050 & - & - \\
\hline Ipiranga de Goiás & 200 & - & - & 1.400 & - & 2.000 \\
\hline Itapaci & 63 & 216 & 2.160 & 2.400 & 7.200 & 5.750 \\
\hline Itapuranga & 72 & 11 & 720 & 1.980 & - & 17.500 \\
\hline $\begin{array}{l}\text { Morro Agudo de } \\
\text { Goiás }\end{array}$ & 156 & - & - & 300 & - & - \\
\hline Nova América & - & - & - & 150 & - & - \\
\hline Nova Glória & 300 & 40 & - & 5.600 & - & 4.000 \\
\hline Pilar de Goiás & 34 & - & - & 288 & - & - \\
\hline Rialma & 120 & - & 1.050 & 2.500 & - & 3.300 \\
\hline Rianápolis & - & 317 & 324 & 480 & - & 2.200 \\
\hline Rubiataba & 45 & - & - & 1.250 & - & - \\
\hline Santa Isabel & 300 & - & 2.100 & 2.160 & - & - \\
\hline $\begin{array}{l}\text { Santa Rita do Novo } \\
\text { Destino }\end{array}$ & 108 & - & 19.600 & 2.925 & - & - \\
\hline São Luiz do Norte & - & 122 & 5.400 & 455 & - & - \\
\hline São Patrício & 234 & - & - & 1.494 & - & - \\
\hline Uruana & 1.050 & 250 & 1.800 & 9.750 & - & 120.000 \\
\hline TOTAL & 3.938 & 956 & 54.134 & 59.682 & 33.510 & 171.421 \\
\hline TOTAL GERAL & $(A$ & +Feijão+S & Milho+T & +Melanci & 323.641 (ton & das) \\
\hline
\end{tabular}

Fonte: IMB (2016).

Por meio da tabela 6, pode-se verificar as principais atividades econômicas desenvolvidas na microrregião Ceres e os investimentos do Governo Estadual pela linha de financiamento do Produzir. Observa-se por essa tabela, que as atividades que 
receberam maiores montantes em investimento fixo e crédito foram as mineradoras e as usinas/destilarias. A mineradora Anglo American, instalada no município de Barro Alto, recebeu mais de dois bilhões de reais em investimento fixo do Produzir, e todas as usinas em funcionamento na microrregião também foram financiadas por este Programa.

É interessante mencionar que os empreendimentos sucroenergéticos propostos durante o Plano Nacional de Agroenergia, mas que não foram implantados na região, também tiveram o financiamento do Produzir aprovados, como pode ser verificado na tabela 6 em negrito, foram as usinas propostas para os municípios de Barro Alto (Destilaria Santa Rita), Santa Isabel (Destilaria Andradina) e Uruana (CRV Industrial).

Esse é mais um elemento que reforça o interesse do Estado em atrair e financiar esse tipo de empreendimento econômico, pois mesmo as usinas não tendo sido implantadas, tiveram altos valores de financiamento fixo (para construção do parque industrial) e crédito (para ser utilizado ao longo do tempo para compras, serviços, etc.) aprovados.

A tabela 6 também traz a quantidade de empregos que os empreendimentos propõem a oferecer, esse é um elemento utilizado pelo Estado para justificar o financimento de um empreendimento privado, pois segundo eles, trarão empregos diretos e indiretos para o local o qual está sendo implantado. 
Tabela 6 - Principais Atividades Econômicas Financiadas pelo Produzir na microrregião Ceres - GO.

\begin{tabular}{|c|c|c|c|c|c|c|}
\hline EMPREENDIMENTO & MUNICÍPIO & RAMO/ATIVIDADE & EMPREGOS & $\begin{array}{c}\text { INVESTIMENTO } \\
\text { FIXO }\end{array}$ & $\begin{array}{c}\text { INVESTIMENTO } \\
\text { CRÉDITO } \\
\end{array}$ & FINANCIAMENTO \\
\hline Anglo American Brasil Ltda. & Barro Alto & Minério & 619 & $2.319 .586 .613,22$ & $248.793 .646,82$ & Produzir \\
\hline Centro Oeste Latex Ind Com Ltda. & Barro Alto & Borracha & 82 & 7.957.745,99 & $49.570 .843,30$ & Produzir \\
\hline Destilaria Santa Rita Ltda & Barro Alto & Destilaria & 213 & 179.029.363,94 & $546.890 .390,41$ & Produzir \\
\hline Mineração Curimbaba Ltda. & Barro Alto & Minério & 50 & $15.386 .463,05$ & $45.723 .676,43$ & Produzir \\
\hline Biotêxtil Tecelagem I C R I E L & Carmo do Rio Verde & Hospitalar & 28 & $848.071,65$ & $2.058 .877,74$ & Produzir \\
\hline $\begin{array}{l}\text { CRV I C Imp. Exp. Produtos Químicos } \\
\text { Ltda. }\end{array}$ & Carmo do Rio Verde & Limpeza & 22 & $452.114,95$ & $2.046 .898,06$ & Produzir \\
\hline CRV Industrial Ltda. & Carmo do Rio Verde & Destilaria & 391 & $30.390 .660,14$ & $131.414 .453,14$ & Migração \\
\hline Ludan Indústria E Comércio Ltda. & Carmo do Rio Verde & Gaze & 24 & $229.997,86$ & $5.344 .716,20$ & Produzir \\
\hline Textilsan Ind Com Ltda & Carmo do Rio Verde & Têxtil & 26 & $1.487 .845,00$ & $10.554 .790,66$ & Microproduzir \\
\hline Cia Hidroelétria São Patrício & Ceres & Energia Elétrica & 2 & $23.562 .481,36$ & $129.336 .479,54$ & Produzir \\
\hline Cifensa C I Ferros N Sra Aparecida & Ceres & Esquadrias & 37 & $2.018 .007,79$ & $10.952 .894,60$ & Produzir \\
\hline $\begin{array}{l}\text { Cifensa Com.Ind. De Ferro } \\
\text { N.Sra.Aparecida }\end{array}$ & Ceres & Metalúrgico & 202 & $680.000,00$ & $33.390 .309,22$ & Produzir \\
\hline Edmar Vilela & Ceres & Sorvetes & 73 & $6.218 .422,47$ & $13.576 .506,37$ & Produzir \\
\hline Codora Álcool e Energia Ltda. & Goianésia & Destilaria & - & - & - & Produzir \\
\hline Goiás Alimentos Ltda. & Goianésia & Alimentício & 327 & $15.857 .310,40$ & $53.560 .528,06$ & Produzir \\
\hline Goiás Látex Ltda. & Goianésia & Borracha & 70 & 3.993.915,38 & $9.901 .389,89$ & Produzir \\
\hline Jalles Machado S/A & Goianésia & Destilaria & 853 & $98.756 .034,00$ & $615.762 .981,23$ & Produzir \\
\hline Lacerda \& Sá Ltda. & Goianésia & Cosméticos & 28 & $303.302,82$ & $726.134,39$ & Microproduzir \\
\hline Ind Pneus Marrige Ltda & Itapuranga & Pneus & 14 & $1.500 .073,49$ & $6.079 .232,87$ & Produzir \\
\hline Vale Verde Empreend. Agrícolas & Itapuranga & Destilaria & 314 & $37.003 .868,96$ & $435.178 .288,79$ & Produzir \\
\hline Kigut Alimentos Ltda. & Morro Agudo & Laticínios & 27 & $1.287 .916,66$ & $4.210 .666,18$ & Produzir \\
\hline Siderúrgica Goiana Ltda & Nova Glória & Siderúrgico & 135 & $199.871 .100,00$ & $2.768 .907 .306,59$ & Produzir \\
\hline Conprem Concreto Premoldado Ltda. & Rialma & Pré moldados & 99 & $5.881 .465,00$ & $80.447 .494,88$ & Produzir \\
\hline
\end{tabular}




\begin{tabular}{|c|c|c|c|c|c|c|}
\hline Dairy Partners Am. Man. Brasil L R & Rialma & Laticínios & 25 & $201.320,10$ & $162.851 .152,48$ & Produzir \\
\hline Nestlé Brasil Ltda. R & Rialma & Laticínios & - & $201.320,10$ & $127.999 .681,60$ & Produzir \\
\hline Bardusco Vasconcelos Ltda. & Rianápolis & Alimentício & 352 & $1.966 .885,96$ & $172.184 .619,15$ & Produzir \\
\hline Ind Bava Pr. Higiene E Limpeza L. & Rianápolis & Limpeza & 353 & 21.511.557,98 & $135.030 .687,03$ & Produzir \\
\hline Lacel Laticínios Ceres Ltda R & Rianápolis & Laticínios & 209 & $10.430 .139,01$ & $212.604 .114,73$ & Produzir \\
\hline Coop Agroi Rubiataba L & Rubiataba & Destilaria & - & $6.594 .166,23$ & $254.795 .526,79$ & Fomentar/Migração \\
\hline $\begin{array}{l}\text { Cooperativa Agroindustrial De } \\
\text { Rubiataba }\end{array}$ & Rubiataba & Destilaria & 187 & $55.677 .172,21$ & $246.003 .437,97$ & Produzir \\
\hline L'anno Ind Com Laticínios Ltda. & $\begin{array}{c}\text { Santa Rita do Novo } \\
\text { Destino }\end{array}$ & Laticínios & 16 & $487.715,47$ & $2.131 .712,31$ & Produzir \\
\hline $\begin{array}{l}\text { Destilaria Andradina Açúcar e } \\
\text { Álcool }\end{array}$ & Santa Isabel & Destilaria & 1.374 & 219.316.312,35 & 284.254.743,18 & Produzir \\
\hline Portugal Carnes Imp Exp Ltda & São Luiz Norte & Frigorífico & 50 & $335.010,20$ & $1.346 .129,14$ & Produzir \\
\hline CRV Industrial Ltda. - Uruana & Uruana & Destilaria & 1.374 & 219.316.312,35 & 208.172.306,46 & Produzir \\
\hline
\end{tabular}

Fonte: Secretaria de Indústria e Comércio - SIC Goiás (2014).

Org. Lara Cristine Gomes Ferreira (2014). 
O Produto Interno Bruto (PIB) da microrregião Ceres vem crescendo ao longo dos anos: no ano 2000 o PIB era de R\$704.205,48 e no ano de 2011 foi de R\$ 2.838.516,45. A maior contribuição para o aumento do PIB (a preços correntes) da microrregião está relacionada, sobretudo a atuação dos empreendimentos sucroenergéticos e da atividade mineradora crescente na região, nesses municípios o PIB apresentou crescimento sempre positivo nos anos analisados (tabela 7).

O maior PIB da microrregião Ceres é do município de Goianésia (R\$ 728.273,16) que possui três usinas em funcionamento. O segundo maior PIB ficou para o município de Ceres, que não possui usinas implantadas, mas é uma centralidade regional no que se refere aos serviços e comércio, bem como nas áreas de saúde e educação.

Outros municípios que se destacam em PIB estão diretamente relacionados à atividade sucroenergética, com usinas implantadas, como Itapuranga, Rubiataba, Itapaci e Carmo do Rio Verde; e com a atividade mineradora, como Barro Alto. Os valores do PIB podem ser verificados na tabela 7, onde os PIB's mais elevados encontram-se destacados em negrito.

O município de Rialma também possui um PIB relevante em relação aos municípios da microrregião Ceres. Reitera-se que esse município teve e tem a construção de sua estrutura urbana, bem como sua dinâmica socioeconômica diretamente vinculada ao município de Ceres, por meio de sua formação territorial. $\mathrm{O}$ limite municipal entre Rialma e Ceres é o Rio das Almas, assim há uma proximidade, não só geográfica entre os dois municípios, bem como uma dinâmica econômica muito semelhante, baseada em prestação de serviços e comércio, além de uma migração pendular entre seus habitantes.

Faz-se importante mencionar que os municípios de Nova Glória, Santa Isabel e São Luiz do Norte, que possuem grande produção canavieira, não se destacam em PIB, o que suscita alguns questionamentos: quais as consequências socioeconômicas podem ser acarretadas nesses municípios que possuem uma relevante quantidade de cana sendo produzida em seus territórios, mas para ser beneficiada em municípios vizinhos? Que tipo de efeitos podem ser observados, por meio dessa relação? 
Tabela 7 - Produto Interno Bruto (PIB) da Microrregião Ceres - GO.

\begin{tabular}{l|c|c|c|c}
\hline \multicolumn{5}{c}{ PRODUTO INTERNO BRUTO A PREÇOS CORRENTES - PIB (R\$ MIL) } \\
\hline MUNICÍPIO & $\mathbf{2 0 0 0}$ & $\mathbf{2 0 0 6}$ & $\mathbf{2 0 1 0}$ & $\mathbf{2 0 1 1}$ \\
\hline Barro Alto & $\mathbf{2 0 . 8 7 7 , 5 7}$ & $\mathbf{5 3 . 1 2 7 , 9 7}$ & $\mathbf{1 2 4 . 2 7 0 , 9 7}$ & $\mathbf{1 8 0 . 1 2 8 , 6 2}$ \\
\hline Carmo do Rio Verde & $\mathbf{2 5 . 5 1 6 , 6 8}$ & $\mathbf{9 7 . 8 8 3 , 2 0}$ & $\mathbf{1 5 1 . 7 1 1 , 4 0}$ & $\mathbf{1 7 3 . 7 0 0 , 2 6}$ \\
\hline Ceres & $\mathbf{8 1 . 8 2 3 , 3 3}$ & $\mathbf{1 5 2 . 5 0 2 , 2 5}$ & $\mathbf{2 2 1 . 4 4 6 , 3 1}$ & $\mathbf{2 4 4 . 9 1 1 , 2 4}$ \\
\hline Goianésia & $\mathbf{1 7 5 . 2 3 5 , 6 9}$ & $\mathbf{5 0 7 . 3 8 8 , 4 2}$ & $\mathbf{6 6 6 . 3 6 2 , 4 8}$ & $\mathbf{7 2 8 . 2 7 3 , 1 6}$ \\
\hline Guaraíta & $6.227,19$ & $11.452,54$ & $20.367,04$ & $18.840,53$ \\
\hline Guarinos & $5.728,93$ & $10.512,35$ & $20.957,01$ & $18.465,49$ \\
\hline Hidrolina & $10.574,79$ & $23.447,63$ & $37.265,57$ & $40.620,75$ \\
\hline Ipiranga de Goiás & - & $22.412,79$ & $24.741,26$ & $39.077,34$ \\
\hline Itapaci & $\mathbf{3 6 . 8 7 8 , 4 7}$ & $\mathbf{1 1 1 . 2 0 3 , 1 4}$ & $\mathbf{1 5 7 . 1 4 1 , 2 9}$ & $\mathbf{1 8 5 . 6 0 5 , 3 6}$ \\
\hline Itapuranga & $\mathbf{7 9 . 0 4 1 , 4 7}$ & $\mathbf{1 2 8 . 9 5 3 , 2 9}$ & $\mathbf{2 2 8 . 6 3 2 , 3 8}$ & $\mathbf{2 6 4 . 3 3 2 , 3 5}$ \\
\hline Morro Agudo de Goiás & $5.762,75$ & $12.336,65$ & $20.461,64$ & $21.134,24$ \\
\hline Nova América & $5.723,06$ & $12.041,46$ & $20.344,93$ & $21.616,62$ \\
\hline Nova Glória & $44.618,86$ & $55.680,10$ & $60.553,21$ & $85.057,16$ \\
\hline Pilar de Goiás & $7.470,97$ & $15.941,26$ & $27.385,09$ & $30.250,79$ \\
\hline Rialma $* *$ & $\mathbf{4 2 . 2 2 7 , 3 7}$ & $\mathbf{9 0 . 9 7 1 , 8 2}$ & $\mathbf{1 6 9 . 8 1 2 , 4 4}$ & $\mathbf{1 3 1 . 1 1 1 , 3 6}$ \\
\hline Rianápolis & $19.992,98$ & $38.573,38$ & $77.564,63$ & $80.810,00$ \\
\hline Rubiataba & $\mathbf{5 4 . 8 6 7 , 7 9}$ & $\mathbf{1 1 5 . 0 9 3 , 6 9}$ & $\mathbf{1 8 6 . 1 7 5 , 8 6}$ & $\mathbf{2 0 7 . 9 4 5 , 5 2}$ \\
\hline Santa Isabel & $10.801,56$ & $23.585,78$ & $44.489,96$ & $54.106,33$ \\
\hline Santa Rita do Novo Destino & $8.864,39$ & $22.336,31$ & $40.921,38$ & $41.166,86$ \\
\hline São Luiz do Norte & $13.268,78$ & $34.956,31$ & $58.651,96$ & $58.007,75$ \\
\hline São Patrício & $6.985,17$ & $15.964,74$ & $19.564,90$ & $22.964,07$ \\
\hline Uruana & $\mathbf{4 1 . 7 1 7 , 6 8}$ & $\mathbf{8 4 . 1 9 3 , 7 4}$ & $\mathbf{1 7 6 . 3 7 2 , 5 9}$ & $\mathbf{1 9 0 . 3 9 0 , 6 5}$ \\
\hline TOTAL & $\mathbf{7 0 4 . 2 0 5 , 4 8}$ & $\mathbf{1 . 6 4 0 . 5 5 8 , 8 2}$ & $\mathbf{2 . 5 5 5 . 1 9 4 , 3 0}$ & $\mathbf{2 . 8 3 8 . 5 1 6 , 4 5}$ \\
\hline Fon & & & & \\
\hline
\end{tabular}

Fonte: IBGE (2014).

Observar os dados do Índice de Desenvolvimento Humando (IDH), dos municípios da microrregião Ceres, auxilia na compreensão da realidade socioeconômica dessa região. O IDH é um índice que considera três aspectos principais: renda, longevidade e educação e oferece um panorama geral de como o município apresenta-se em relação a esses aspectos, bem como uma média global entre eles. Esses valores são enquadrados em baixo, médio e alto IDH.

Em observação aos valores de IDH para o ano de 2010 e os comparando com os dados do ano 2000, verifica-se que houve um relevante crescimento do IDH na microrregião Ceres. Para o ano de 2010, a microrregião apresentou todos os seus municípios com médio IDH, ou seja, entre o intervalo de 0,500 e 0,799. Novamente os municípios que apresentam os maiores valores de IDH são os municípios que possuem destaque em serviços, empreendimentos sucroenergéticos e mineração.

A tabela 8 apresenta os dados do IDH-Municipal (IDH-M - média entre os três aspectos) para todos os municípios da microrregião Ceres, referentes aos anos $2000 \mathrm{e}$ 
2010. Para o ano de 2010, além do IDH-M, podem-se verificar os IDH's 'Educação', 'Renda' e 'Longevidade' para todos os município da região.

É importante destacar que o município com maior IDH é Ceres, que se destaca em prestação de serviços na região e não na atividade canavieira. Ainda por meio da tabela 8, verifica-se que o município de Ceres apresenta os maiores índices em IDH Educação e IDH Renda. Ao realizar uma breve análise comparativa entre os municípios de Goianésia (maior PIB da região) e Ceres (maior IDH da região) pode-se inferir que mesmo o município de Goianésia apresentando a maior população da microrregião, o maior PIB regional, além de três usinas sucroenergéticas em funcionamento, essa lógica não acompanha o desenvolvimento humano, que pode ser verificado pelo IDH, um dos índices de referência para isso no Brasil.

O município de Ceres, mesmo com menos da metade da população de Goiânésia, possui alguns fatores socioculturais interessantes em comparação a Goianésia. Ceres funciona como um pólo regional, sobretudo em relação aos serviços de educação e saúde, fundamentais para os dados do IDH. Atualmente, Ceres possui mais de $93 \%$ da população alfabetizada, além da maior quantidade de Instituições de Ensino Superior (IES) da região, são oito IES ao total: Unievangélica, Faculdade de Ceres (FACER), Instituto Federal Goiano (IFGoiano), Universidade Estadual de Goiás (UEG), Universidade Anhanguera, Universidade Federal de Goiás (UFG), Universidade Metodista de São Paulo (UMESP) e Universidade Paulista (UNIP). Destas, as quatro primeiras possuem cursos presenciais e as quatro últimas cursos à distância. 
Tabela 8 - Dados do IDH dos Municípios da Microrregião Ceres - GO

\begin{tabular}{|c|c|c|c|c|c|}
\hline MUNICÍPIO & IDHM (2000) & IDHM (2010) & $\begin{array}{l}\text { IDHM Educação } \\
(\mathbf{2 0 1 0 )}\end{array}$ & $\begin{array}{l}\text { IDHM Renda } \\
(\mathbf{2 0 1 0})\end{array}$ & $\begin{array}{c}\text { IDHM Longevidade } \\
(\mathbf{2 0 1 0})\end{array}$ \\
\hline Barro Alto & 0.543 & 0.742 & 0.682 & 0.701 & 0.854 \\
\hline Carmo do Rio Verde & 0.578 & 0.713 & 0.649 & 0.677 & 0.824 \\
\hline Ceres & 0.654 & 0.775 & 0.733 & 0.753 & 0.842 \\
\hline Goianésia & 0.571 & 0.727 & 0.636 & 0.719 & 0.840 \\
\hline Guaraíta & 0.523 & 0.687 & 0.625 & 0.637 & 0.816 \\
\hline Guarinos & 0.505 & 0.652 & 0.563 & 0.604 & 0.815 \\
\hline Hidrolina & 0.545 & 0.677 & 0.577 & 0.652 & 0.824 \\
\hline Ipiranga de Goiás & 0.559 & 0.696 & 0.642 & 0.643 & 0.816 \\
\hline Itapaci & 0.557 & 0.725 & 0.626 & 0.720 & 0.844 \\
\hline Itapuranga & 0.593 & 0.726 & 0.653 & 0.700 & 0.837 \\
\hline Morro Agudo de Goiás & 0.535 & 0.695 & 0.630 & 0.644 & 0.826 \\
\hline Nova América & 0.514 & 0.678 & 0.604 & 0.647 & 0.796 \\
\hline Nova Glória & 0.557 & 0.681 & 0.589 & 0.657 & 0.816 \\
\hline Pilar de Goiás & 0.479 & 0.684 & 0.600 & 0.654 & 0.816 \\
\hline Rialma & 0.614 & 0.727 & 0.667 & 0.698 & 0.827 \\
\hline Rianápolis & 0.573 & 0.693 & 0.587 & 0.674 & 0.840 \\
\hline Rubiataba & 0.592 & 0.719 & 0.666 & 0.686 & 0.814 \\
\hline Santa Isabel & 0.566 & 0.683 & 0.593 & 0.658 & 0.818 \\
\hline Santa Rita do Novo Destino & 0.495 & 0.634 & 0.487 & 0.639 & 0.820 \\
\hline São Luíz do Norte & 0.494 & 0.669 & 0.581 & 0.643 & 0.801 \\
\hline São Patrício & 0.523 & 0.693 & 0.597 & 0.668 & 0.833 \\
\hline Uruana & 0.554 & 0.703 & 0.634 & 0.665 & 0.824 \\
\hline
\end{tabular}

Fonte: PNUD, 2014. 
Em contrapartida, o município de Goianésia, mesmo com o dobro da população de Ceres e apresentando o maior PIB regional, possui $90 \%$ da população alfabetizada e somente seis IES ao total: Faculdade Evangélica de Goianésia, Universidade Estadual de Goiás (UEG), Centro Universitário Internacional (UNINTER), Universidade Federal de Goiás (UFG), Universidade Norte do Paraná (UNOPAR) e Universidade Paulista (UNIP), sendo que somente as duas primeiras apresentam cursos presenciais.

O município de Ceres também se destaca na prestação de serviços na área da saúde, em número de hospitais, leitos e especialidades médicas variadas. Pode-se afirmar que isso tem uma estreita relação com uma "herança histórica" da CANG, já que nesse contexto, houve o estímulo para a vinda de muitos médicos para a colônia agrícola, com a doação de lotes, subsídios e construção de hospitais já na década de 1940, como o Hospital São Pio X (figura 19).

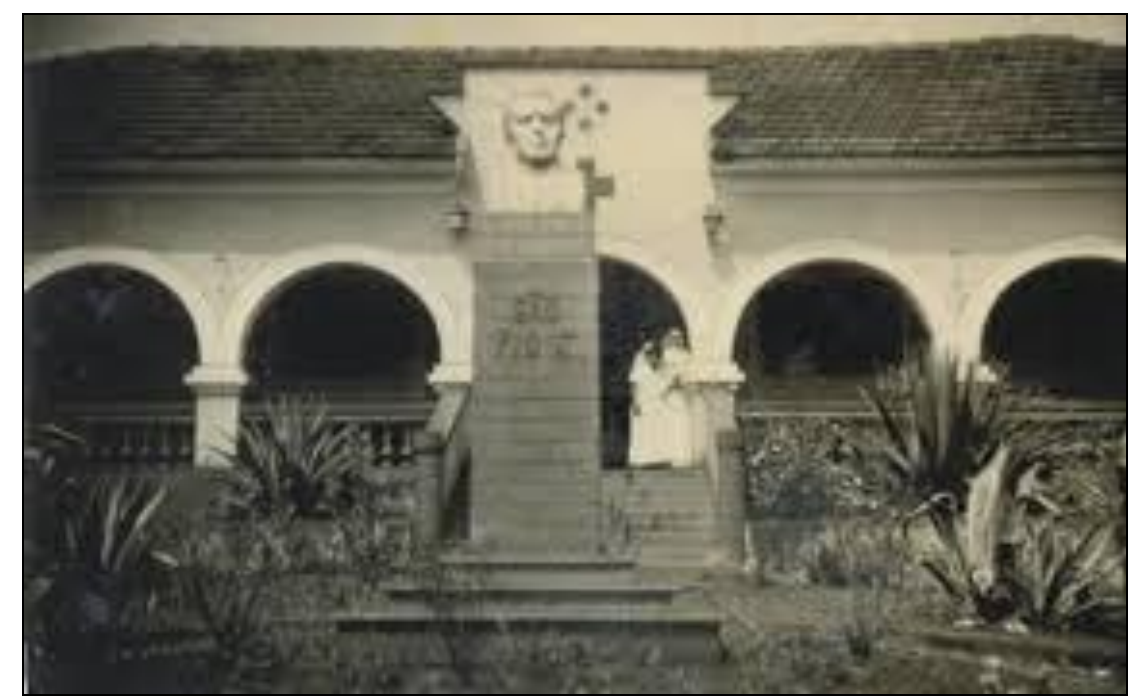

Figura 19 - Fachada do Hospital São Pio X em Ceres, nos anos 1950.

Fonte: http://www.hospitalsaopiox.org.br .

Assim, a comunidade médica instalada na colônia, mesmo com a crise da mesma, continuou habitando o município de Ceres após sua emancipação e foi gradativamente desenvolvendo a prestação de serviços médicos nesta cidade. $O$ município de Ceres possui oito hospitais com 294 leitos, enquanto o município de Goianésia somente cinco hospitais, com 220 leitos médicos (IMB, 2014).

Com a análise dos dados apresentados, pode-se inferir que a atividade canavieira contribui para o aumento do PIB dos municípios que possuem usinas implantadas e não 
para os municípios produtores de cana-de-açúcar, como Nova Glória, Santa Isabel e São Luiz do Norte. Esses municípios, além de possuírem um baixo PIB, possuem baixos valores de IDH, inferiores aos municípios com empreendimentos sucroenergéticos.

Faz-se importante refletir também sobre a relação entre uma rede de serviços associada a um maior IDH, como verificado no município de Ceres, em contrapartida aos municípios mais ricos, com alto valor do PIB, mas com baixo IDH. O que acontece nos municípios da microrregião Ceres é que os municípios que possuem usinas instaladas não apresentam diversidade econômica e acabam por se tornar "reféns" da atividade canavieira.

Os municípios de Goianésia, Carmo do Rio Verde, Rubiataba e Itapaci têm na atividade canavieira sua principal atividade econômica e apresentam pouco dinamismo econômico fora da lógica sucroenergética, o que leva a seguinte constatação: caso aconteça uma crise no setor sucroenergético tamanha ao ponto de se fechar as usinas implantadas, esses municípios passarão por grandes dificuldades socioeconômicas, pois se mantiveram por um longo período focados em somente um segmento do agronegócio, e não desenvolveram e consolidaram segmentos como serviços e comércio.

Talvez o município de Goianésia seja o único da microrregião Ceres, imerso na lógica sucroenergética, que tenha ao longo do tempo construído uma maior autonomia em relação a esse segmento. Como Goianésia é um importante nó na rede urbana da região de Ceres, construiu e desenvolveu infraestrutura e serviços básicos, apresentando um protagonismo socioeconômico na região, obviamente muito relacionado às três usinas em funcionamento no município, mas caso houvesse uma crise no setor, esse município teria mais facilidade em uma reconstrução econômica, devido a base consolidada existente, sobretudo relacionada aos equipamentos urbanos e infraestrutura local.

A constatação feita acima também é válida para os municípios da região que são grandes produtores de cana-de-açúcar, mas que não possuem as usinas para seu beneficiamento. Esses municípios ficam reféns não só da atividade econômica realizada no município vizinho, mas também por estarem dependentes de um segmento único do agronegócio, o qual apresenta oscilações periódicas, tanto relacionadas aos momentos de ápice e crises energéticas, quanto pelo mercado internacional do açúcar. A esses 
municípios restam a importância da administração pública para a geração de empregos e, consequentemente, renda para grande parte da população, o que é verificado muito comumente em municípios com menos de 20 mil habitantes em Goiás (como os municípios da microrregião Ceres), como bem refletiu Arrais (2011; 2013).

\subsection{A Configuração da Rede Técnica na Microrregião Ceres - A Importância da Malha Viária e da Energia Elétrica}

Para que a territorialização das agroindústrias sucroenergéticas se efetive é necessária a (re) configuração de alguns elementos no território, com a presença de objetos técnicos, que vão gradativamente conformando as redes e, consequentemente, as relações de poder são materializadas. A configuração desses elementos técnicos estabelecem uma relação dialética com o território: é a existência deles que são atrativos às agroindústrias? Ou são as agroindútrias que atraem os objetos técnicos?

Parte-se da premissa que a ocupação humana materializa no espaço as marcas de suas técnicas e isso é verificado em sua paisagem. Para Santos (2002), as técnicas são um conjunto de meios intrumentais e sociais, com os quais o ser humano produz o espaço e simultaneamente realiza sua vida. Assim, é importante asseverar que há uma intencionalidade, tanto para a determinação dos objetos técnicos a serem implantados, como na utilização dos mesmos. Ainda segundo Santos (2002) é o espaço que redefine os objetos técnicos, apesar de suas vocações originais, desta forma, a técnica é essencialmente humana e sua realização está diretamente relacionada a uma lógica prédeterminada.

Com a visível aceleração contemporânea, do tempo e das técnicas, a fluidez, a circulação e as redes tornaram-se exigências básicas do momento atual. Ao mesmo tempo em que as empresas e corporações exigem o mínimo de infraestrutura para sua territorialização, quando estas já estão implantadas, criam-se demandas cada vez mais complexas para que a estratégia e o sucesso econômico se efetivem. Para isso, além da ação empreendedora das empresas, o Estado muito contribui para que a circulação da produção, informação e dinheiro aconteça. Segundo Santos e Silveira (2001) cada empresa produz paralelamente uma lógica territorial que pode ser entendida por meio 
das redes, essa lógica é visível por meio de uma topologia, ou seja, a distribuição no território dos pontos de interesse para a operação do emprendimento.

A fluidez e a circulação da produção estão cada vez mais complexas. É bastante comum que a circulação seja pensada anterior à produção, no sentido de garantir o mercado e não permitir excedentes e prejuízos. Para isso, a fluidez contemporânea é baseada nas redes, que são cada vez mais globais, as redes técnicas, por exemplo, dão o suporte necessário para a competitividade e o sucesso econômico. De acordo com Santos (2002, p.185) "fluidez é, ao mesmo tempo, uma causa, uma condição e um resultado".

Com o decorrer da história, foram muitas as formas de redes criadas pelo ser humano para viabilizar a comunicação e as trocas. As invenções e inovações que visavam ampliar a capacidade produtiva e melhorar a circulação, viabilizaram o surgimento das redes (FRAGA, 2007). Dias (2007) ressalta que as redes não se inscrevem no vazio, mas em espaços geográficos plenos de história e destaca o papel das redes técnicas, tanto na criação de condições sociais inéditas, quanto na estruturação de territórios.

Assim, o estudo das redes tem se tornado bastante relevante na atualidade, sobretudo com o processo de globalização, onde ao mesmo tempo que algumas parcelas da sociedade encontram-se inseridas em mais de uma rede, também estão excluídas de várias outras, como bem explicitou Corrêa (1997), mas muitas vezes, mesmo excluída, a sociedade acaba sentindo as consequências fruto desse processo.

Benakouche (2005) faz um alerta sobre a dimensão política das técnicas. É fundamental entender o papel da técnica de modo integrado, considerando os aspectos socioeconômicos e polítcos e não somente a técnica pela técnica. Para essa autora, entender o significado da técnica é uma tarefa essencialmente política e responsabilizála pelos seus "impactos sociais negativos" ou mesmo "positivos" é desconhecer o quanto ela é construída por atores sociais, objetiva ou subjetivamente.

Desta forma, toda rede acaba por revelar as tessituras e a implantação dos pontos, bem como um domínio do espaço, da realidade (RAFFESTIN, 1993). Essa afirmação é importante para a reflexão de que não existe rede isenta das relações de poder, assim como a materialização dos objetos técnicos, que vão formar as redes 
técnicas, também estão prenhes de intencionalidades, fruto da lógica do mercado, seja nacional ou internacional.

Milton Santos trouxe a discussão de sistemas técnicos, para compreender as transformações no espaço geográfico, como sendo um conjunto de técnicas, ferramentas e conhecimentos que permitem a fluidez do território e contribuem para uma maior dinâmica do capital e da produção.

A criação e modernização da rede técnica em determinado território é fundamental para o sucesso econômico do agronegócio. Para as agroindústrias sucroenergéticas, por exemplo, é fundamental a materialização de determinadas técnicas e próteses (segundo Milton Santos) para a eficácia dessa atividade econômica, em termos de produção, produtividade e circulação dos produtos. Entende-se que o setor sucroenergético exige o mínimo de suporte técnico e logístico para sua implantação em determinado território e, ao mesmo tempo, após sua implantação demanda constantemente que esse território acompanhe as inovações e modernizações do mercado nacional e internacional.

São exigências técnicas mínimas para a territorialização do agronegócio sucroenergético: infraestrutura viária, para o escoamento da produção para o mercado consumidor; uma relativa proximidade aos centros que disponibilizem serviços e comércio básicos para a realização das atividades; e, o apoio do Estado, por meio de programas de atração e fomento às agroindústrias (essa última está relacionada à dimensão política da técnica explicitada por Benakouche).

O setor sucroenergético tem se tornado cada vez mais moderno, a cada ano surgem inovações tecnológicas e biogenéticas importantes para a dinamização desse setor. O melhoramento genético da cana-de-açúcar, a mecanização da produção (plantio e colheita da cana), a reutilização de subprodutos da cana para produção de fertilizantes e energia elétrica, entre outros, são exemplos da rapidez com que as novas técnicas e tecnologias são inseridas na lógica canavieira. Cada vez mais modernas e em rede, essas técnicas possibilitam a consolidação de novos instrumentos e produtos, como a cogeração de energia elétrica, por meio da biomassa da cana, que até pouco tempo era inutilizada ou comercializada somente para se tornar ração animal.

Atualmente muitos objetos técnicos são fundamentais para a formação da rede técnica de determinado local e região. Para a presente análise será realizada uma 
abordagem sobre a logística dos transportes, rodovias e ferrovias, e sua importância para o escoamento e circulação da produção sucroenergética para a microrregião Ceres; e, posteriormente, sobre o desenvolvimento de técnicas para a cogeração de energia elétrica, por meio da reutilização da biomassa da cana-de-açúcar.

\subsubsection{A Logística dos Transportes - Objetos Técnicos Fundamentais para a Circulação do Agronegócio}

A construção de rodovias e ferrovias foi muito importante para o processo de ocupação demográfica, expansão da fronteira agrícola e valorização econômica dos lugares. Ao longo do tempo são inúmeros os exemplos de povoados e cidades que foram criadas por meio da abertura de estradas, acompanhada geralmente de um considerável desenvolvimento regional. Essa dinâmica foi observada na região Mato Grosso Goiano após a chegada da ferrovia em Anápolis e da construção da BR 153.

Para Martins (1997) a abertura de estradas em determinada localidade era algo extremamente significativo, pois consistia em uma nova fase da expansão da fronteira agrícola no país e representava a chegada dos processos civilizatórios. Com a construção de estradas um novo tipo de economia se apresentava, uma economia voltada a atender o mercado, vinculada a circulação e escoamento da produção, em substituição a uma economia de subsistência.

Para a microrregião Ceres, a construção da BR 153 teve importância ímpar para a dinamização socioeconômica da região. A partir da década de 1950, alguns programas que incentivavam a política de integração nacional começaram a ser construídos em Goiás, sobretudo no centro goiano. Assim, juntamente à transferência da Capital Federal para o centro do país, houve a intensificação da construção da malha viária na busca de integração econômica ao sudeste brasileiro, bem como assegurar o intercâmbio nacional à Brasília.

Além da BR-153, que conecta o estado de Goiás no sentido norte-sul, destaca-se a construção das seguintes rodovias federais: BR-020 (Brasília - Formosa, na direção de Fortaleza - CE), a BR-040 (em direção ao Sudeste brasileiro), a BR-050 (com a intenção de encurtar a distância Brasília - São Paulo), a BR-060 (em direção ao Mato Grosso e Paraguai), a BR-364 (para Mato Grosso, passando pelo Sudoeste Goiano), e a BR-452 
(em conexão com o Sudoeste Goiano e Triângulo Mineiro), que foram fundamentais para ampliação da fronteira agrícola nacional, bem como facilitaram a integração intra e inter-regional (ESTEVAM, 1997).

Após esse efervescente contexto de integração nacional, o Brasil ficou por muito tempo sem grandes programas relacionados à rede de transportes, o que o deixou visivelmente à margem das reais necessidades de circulação e às novas lógicas impostas por um período de extrema demanda global, sobretudo por meio das corporações internacionais implantadas no país. Assim, na tentativa de ampliar a infraestrutura de transportes e readequá-la as novas exigências, o Governo Federal lançou o Programa de Aceleração do Crescimento (PAC 1 e 2) e o Programa de Investimentos em Logística e a participação na iniciativa para a integração da infraestrutura regional Sul-Americana IIRSA.

Em síntese, o PAC 1 (2007 - 2010) executou obras que representaram cerca de 94\% do que tinha sido previsto pelo Governo Federal. Nesse período, foram gastos $\mathrm{R} \$$ 444 bilhões em obras concluídas, o que equivale a $82 \%$ dos $\mathrm{R} \$ 541,8$ bilhões previstos. Grande parte dos investimentos do PAC 1 foi em transportes, com R\$ 65,4 bilhões destinados a: 1) Rodovias $(6.377 \mathrm{~km})$; 2) Marinha Mercante (financiamento de 301 embarcações e 5 estaleiros); 3) Ferrovias (909 km); 4) Aeroportos (12 empreendimentos em 10 aeroportos); 5) Portos (14 empreendimentos) e; 6) Hidrovias (10 terminais e as eclusas de Tucuruí) (SILVEIRA, 2013).

Ainda segundo essa autora, foram gastos no PAC 2 em transportes R\$24,4 bilhões, em 909 km de rodovias; 16 empreendimentos em aeroportos e 12 em portos; 71 $\mathrm{km}$ de ferrovias (Ferrovia Norte-Sul); além de 1.275 equipamentos para estradas vicinais. $\mathrm{O}$ valor estimado para investimentos em transportes no PAC 2 até 2014 é de R\$ 104 bilhões, ou seja, R \$ 24 bilhões a mais que o PAC 1.

O investimento em logística de circulação e escoamento da produção é fundamental para a redução dos gastos em transportes, o que influencia diretamente na competitividade do comércio internacional brasileiro, já que gastos muito altos em transporte influenciam na redução da produtividade e rentabilidade do agronegócio. Mesmo o estado de Goiás apresentando certa deficiência na logística de transportes, algumas regiões apresentam melhores condições de escoamento da produção, o que contribui para a efetivação da dinâmica do agronegócio. 
A microrregião Ceres possui algumas rodovias importantes, as quais facilitam a conexão da produção sucroenergética com os mercados consumidores nacionais e o acesso aos portos brasileiros. A figura 20 mostra as principais rodovias, estaduais e federais, da microrregião Ceres e os empreendimentos sucroenergéticos espacializados.

Observa-se com a figura 20 a proximidade das usinas às rodovias, sobretudo as estaduais, e a importância estratégica que a BR 153 tem para a região, já que essa importante rodovia federal passa ao centro da microrregião Ceres, ligando-a na direção norte-sul do país. O modal rodoviário é sem dúvida, até o momento, o mais importante para o escoamento da produção sucroenergética da microrregião Ceres. Nesse contexto, além da BR 153, destacam-se as GO’s 080, 438, 338, 334 e 230 e a BR 251.

Assim, os transportes tem papel fundamental para a implantação de indústrias e, no referido caso, de agroindústrias sucroenergéticas, pois a evolução da rede de transportes permitiu uma maior acessibilidade a todas as fontes e a todos os mercados, tornando o espaço muito mais flexível. Assim, com a evolução dos transportes a indústria adquiriu uma liberdade muito maior para a implantação de suas unidades no espaço geográfico (FISCHER, 1978).

O sistema de integração, por meio dos tranportes, ainda é ineficiente em Goiás, sobretudo quando se pensa em hidrovias e ferrovias. Com o PAC houve um maior investimento em ferrovias, mas ainda a fluidez do território pelo modal ferroviário encontra-se nas mãos da iniciativa privada, como refletiu Arrais (2013), já que algumas agroindústrias, principalmente beneficiadoras de grãos, possuem ferrovias integradas. 


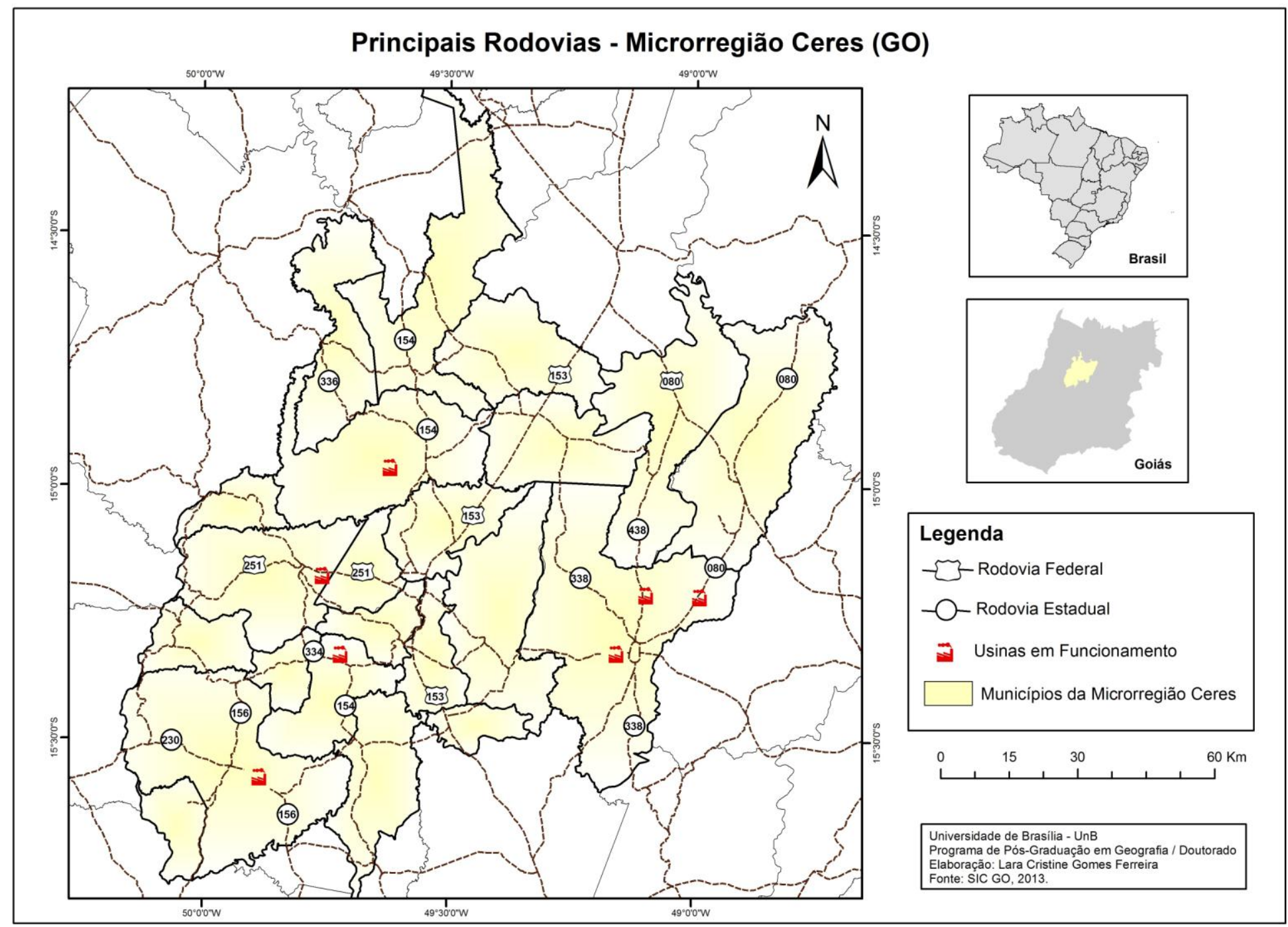

Figura 20 - Principais rodovias (estadual e federal) da microrregião Ceres e os empreendimentos sucroenergéticos. 
Segundo Fischer (1978) a ferrovia tem um papel histórico no processo de industrialização e é tecnicamente eficaz para a circulação em médias e grandes distâncias, além de possibilitar o transporte de todos os tipos de mercadoria. Dentro dessa discussão é importante mencionar que o Brasil encontra-se em um momento de estímulo a construção de ferrovias, interligando o país de norte a sul e de leste a oeste (figura 21). Para o estado de Goiás pode-se destacar duas ferrovias com trechos importantes: a ferrovia norte-sul, que irá conectar Belém (PA) a Panorama (SP), e a ferrovia transcontinental, que interligará o estado do Acre ao Rio de janeiro.

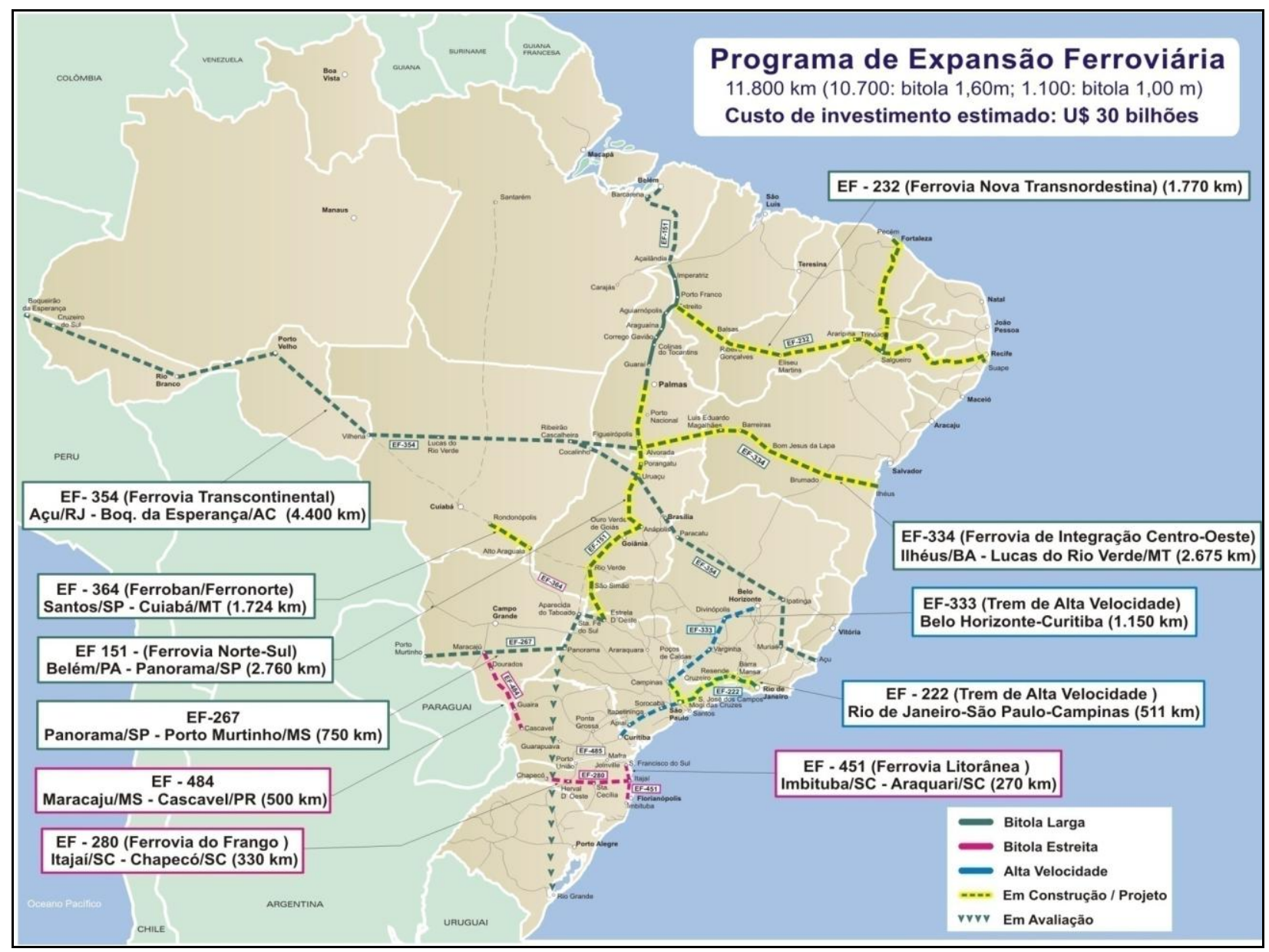

Figura 21 - Programa de expansão ferroviária - trechos de expansão. Fonte: Ministério dos Transportes/Brasil, 2014.

As duas ferrovias citadas passarão pelo estado de Goiás e possuirão trechos inseridos na microrregião Ceres ou muito próxima a ela. A ferrovia Norte-Sul terá um pátio localizado no município de Santa Isabel, pertencente à microrregião em estudo, 
que não possui usinas em funcionamento, mas é um dos principais municípios em produção de cana-de-açúcar. A construção da ferrovia Norte-Sul possibilitará uma maior fluidez na circulação da produção sucroenergética da microrregião Ceres.

A figura 22 mostra os trechos de ferrovias que passarão por Goiás. No sentido longitudinal, observa-se a ferrovia Norte-Sul e os pátios localizados em várias cidades goianas e transversalmente o traçado da ferrovia Transcontinental, que passa pelo município de Crixás, localizado bem próximo aos municípios da microrregião Ceres.

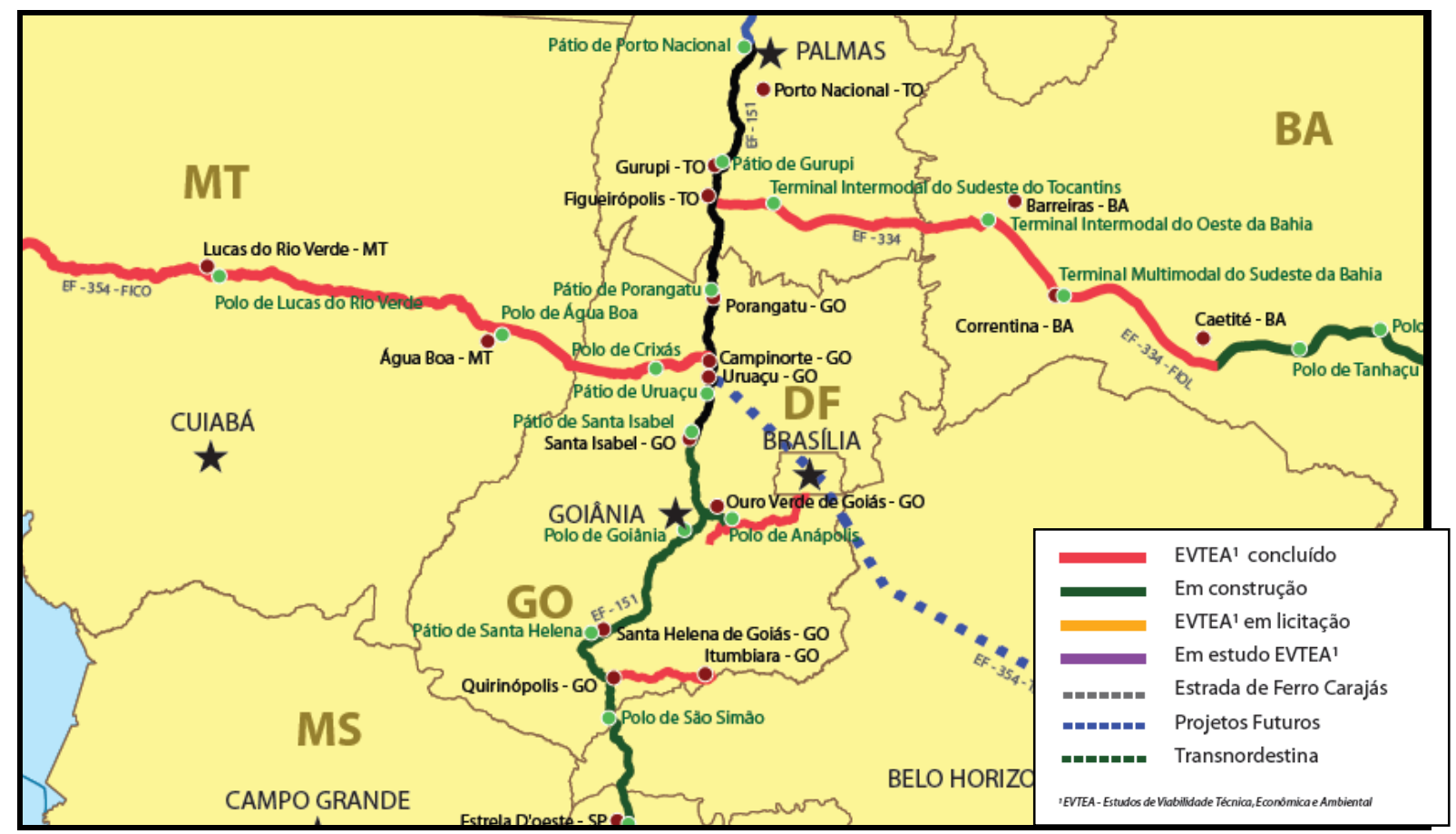

Figura 22 - Trechos das ferrovias concluídas e em construção - foco para Goiás. Fonte: Valec, 2014.

Verifica-se que o traçado da ferrovia Norte-Sul corta vários municípios estratégicos de Goiás, como o município de Anápolis (no centro goiano) que possui um Porto Seco e um Distrito Agroindustrial (DAIA), e alguns com ligação direta com a dinâmica do agronegócio sucroenergético, como são os casos dos municípios de Santa Isabel (microrregião Ceres), Santa Helena de Goiás (microrregião Sudoeste Goiano) e Quirinópolis (microrregião Quirinópolis).

\subsubsection{A Produção de Energia Elétrica pela Biomassa da Cana-de-açúcar - A Base Energética e a Cogeração de Energia}


Alguns elementos são basilares para a modernização dos territórios, pode-se citar a construção de uma rede técnica de eletrificação como uma demanda fundamental para a atração de agroindústrias para determinado lugar. Segundo Castilho e Arrais (2012) além de ser condição, a eletrificação é um elemento importante da infraestrutura produtiva que envolve um conjunto de políticas e estratégicas que corrobora em disputas e conflitos pela apropriação de um insumo estratégico.

Além disso, o desenvolvimento da técnica também possibilitou a inserção de novas especializações no setor sucroenergético. Atualmente não é mais possível pensar na dinâmica canavieira desassociando-a da produção de energia elétrica por meio da biomassa da cana-de-açúcar. Até pouco tempo, as usinas eram denominadas de "sucroalcooleiras", em referência à produção de açúcar e álcool, e, atualmente, as mesmas são denominadas de "sucroenergéticas" com o propósito de fazer alusão a crescente produção de energia elétrica através da cogeração de energia.

Muitas usinas sucroenergéticas são hoje verdadeiras biorrefinarias, que por meio da reutilização da biomassa da cana, preferencialmente o bagaço e, mais recentemente, a palha da cana (em alguns casos), produzem energia que será utilizada tanto para o próprio processamento industrial na usina, quanto, em alguns casos, para a comercialização do excedente com a central elétrica de energia.

A terminologia "cogeração" possui conceituações variadas, segundo a Agência Nacional de Energia Elétrica (ANEEL) cogeração é o processo operado numa instalação específica para fins da produção combinada das utilidades calor e energia mecânica, geralmente convertida total ou parcialmente em energia elétrica, a partir da energia disponibilizada por uma fonte primária. É importante mencionar que nas usinas sucroenergéticas a cogeração não é um processo muito novo, porém não havia uma preocupação em realizá-la de forma mais eficiente e, sobretudo, produtiva, como se tem hoje (QUEIROZ, et al, 2014).

Foi a partir do contexto da crise brasileira de energia no ano 2001, que levou ao racionamento de energia elétrica, que o Governo Federal implementou algumas regras no mercado energético, impulsionando o setor sucroalcooleiro a investir em técnicas mais modernas de produção de energia elétrica. Para isso, o Governo brasileiro lançou o Programa de Incentivo às Fontes Alternativas de Energia - Proinfa - por meio de um decreto no ano de 2004. 
O Proinfa foi criado com o intuito de aumentar a participação da energia elétrica produzida por empreendimentos concebidos com base em fontes eólica, biomassa e pequenas centrais hidrelétricas (PCH's) no Sistema Elétrico Interligado Nacional (SIN). Ele foi criado no âmbito do Ministério de Minas e Energia (MME) pela Lei $\mathrm{n}^{\circ}$ 10.438, de 26 de abril de 2002, e revisado pela Lei $\mathrm{n}^{\circ} 10.762$, de 11 de novembro de 2003 , com o intuito de promover a diversificação da Matriz Energética Brasileira, buscando alternativas para aumentar a segurança no abastecimento de energia elétrica, além de permitir a valorização das características e potencialidades regionais e locais (MME, 2014).

Ainda não é possível armazenar energia elétrica em grande escala, assim é fundamental investir nas linhas de transmissão da energia gerada, na busca de uma maior simultaneidade entre a produção e o consumo da energia. Destaca-se portanto, que para uma maior fluidez da rede de eletricidade, além da construção de usinas hidrelétricas, PCH's, produção de energia pela biomassa, etc., faz-se tão importante a construção das linhas de transmissão de energia elétrica, que propiciarão maior eficiência na transmissão dessa energia gerada, bem como a todo sistema energético, evitando maiores problemas no escoamento da energia e também de apagões e blecautes.

A figura 23 mostra a espacialização das linhas de transmissão de energia elétrica em Goiás: em vermelho as linhas já construídas e, em verde, as linhas de transmissão em projeto. Nessa figura também estão espacializadas as usinas sucroenergéticas de Goiás. Observa-se a importância da proximidade das usinas às linhas de transmissão de energia, no intuito de facilitar a comercialização do excedente energético, quando houver.

Tanto a geração de energia, quanto o desenvolvimento das linhas de transmissão estão sendo estimuladas pelo PAC 2. As linhas de transmissão em projeto, em verde no mapa, demonstram, em alguns casos, o reforço na interligação de alguns subsistemas a sistemas já consolidados, como observado no centro goiano e sudoeste goiano. Já o norte do estado de Goiás possui trechos mais extensos de projetos de linhas de transmissão, devido, sobretudo, por ser uma região com crescente aprovação de PCH's. Verifica-se que há um projeto de linha de transmissão muito extenso, ligando o nordeste 
goiano ao Distrito Federal, possibilitando o escoamento da energia produzida para esse grande centro populacional.

Observa-se também, por meio da figura 23, que há um extenso projeto de linhas de transmissão na região da Bacia do Rio Paranaíba, importante Bacia para o abastecimento hídrico e geração de energia elétrica, não só para Goiás e Triângulo Mineiro, mas também para outras regiões do Brasil.

Segundo Castilho (2013) o aumento da produção das linhas de transmissão de energia e, consequentemente, da rede técnica energética, nas divisas entre Goiás e Minas Gerais não se deve apenas ao aumento do consumo desses estados, mas à demanda nacional, em especial do Sudeste brasileiro. Além disso, o Sul Goiano assim como o Triângulo Mineiro tem apresentado crescimento na implantação de agroindústrias sucroenergéticas, o que acabam por demandar uma maior disponibilidade em energia elétrica, além da necessidade de uma rede técnica para o escoamento da energia produzida nas usinas, conforme já abordado.

No estado de Goiás a maior parte da distribuição de energia elétrica é realizada pela Central Elétrica de Goiás - CELG - que cobre cerca de $98 \%$ do território goiano. Os restantes $2 \%$ da distribuição é realizada pela Companhia Hidrelétrica São Patrício Chesp - que é responsável pela distribuição energética de alguns muncípios da microrregião Ceres. A Chesp foi construída no final de década de 1940, no contexto da implantação da CANG, liderada pelo Engenheiro Roland Martin, a construção teve início no ano de 1949 e foi finalizada em 1956.

Atualmente a Companhia tem a concessão para distribuição de energia elétrica para os municípios de Carmo do Rio Verde, Ceres, Ipiranga de Goiás, região do povoado de Monte Castelo (no Município de Jaraguá), Nova Glória, Rialma, Rianápolis, Santa Isabel, Uruana e São Patrício, perfazendo uma área de 3.394 km², e que conta com uma população de aproximadamente 80 mil habitantes (CHESP, 2014). 


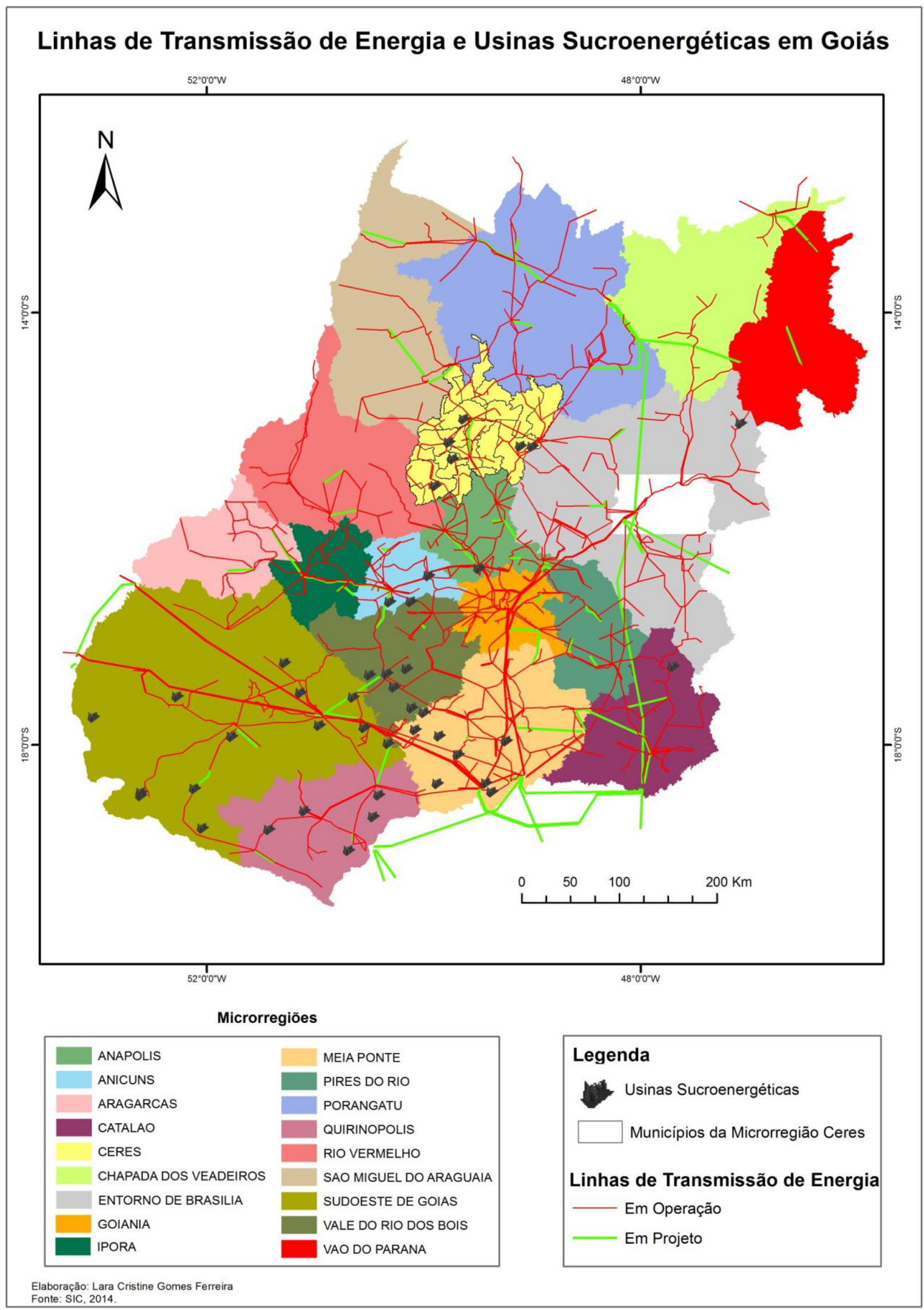

Figura 23 - Linhas de transmissão de energia elétrica em Goiás e as usinas sucroalcooleiras implantadas. 
As usinas sucroenergéticas acabaram por incorporar o discurso ambiental de reutilização de subprodutos e rejeitos da cana para a produção de energia para o consumo próprio na atividade industrial, bem como a comercialização de créditos carbono, por exemplo, com o mercado internacional. A produção de energia elétrica, por meio do bagaço da cana tem sido crescente em todos os empreendimentos. Todas as usinas canavieiras da microrregião Ceres produzem energia elétrica para consumo próprio da usina.

O quadro 7 mostra a potência em kw produzida pelas usinas canavieiras da microrregião Ceres, observa-se que as usinas Jalles Machado e a Unidade Otávio Lage (pertencente ao Grupo Otávio Lage, proprietários da Jalles Machado) ambas situadas em Goianésia apresentam as maiores produções de energia. As usinas Vale Verde (Itapaci) e Goianésia (Goianésia) apresentam uma produção de energia pequena, apresentando autosuficiência energética somente durante o período da safra na usina, nos demais meses necessitam comprar energia pela central elétrica local.

Quadro 7 - Potência de energia elétrica gerada pelos empreendimentos sucroenergéticos da microrregião Ceres - GO

\begin{tabular}{|l|l|c|}
\hline \multicolumn{1}{|c|}{ MUNICÍPIO } & \multicolumn{1}{|c|}{ EMPREENDIMENTO } & POTÊNCIA KW \\
\hline Carmo do Rio Verde & CRV Industrial Ltda. & 20.000 \\
\hline \multirow{3}{*}{ Goianésia } & Jalles Machado S/A & 40.000 \\
\cline { 2 - 3 } & Jalles Machado S/A - Unidade Otávio Lage & 48.000 \\
\cline { 2 - 3 } & Usina Goianésia S/A - Grupo J. Maranhão & 7.300 \\
\hline \multirow{2}{*}{ Itapaci } & Vale Verde Itapaci - Grupo Farias & 6.952 \\
\hline \multirow{2}{*}{ Rubiataba } & $\begin{array}{l}\text { Cooper Rubi - Cooperativa Agroindustrial } \\
\text { de Rubiataba Ltda }\end{array}$ & 21.000 \\
\hline
\end{tabular}

Fonte: SIFAEG; ANEEL, 2013.

Elaboração: Instituto Mauro Borges / SEGPLAN-GO / Gerência de Sistematização e Disseminação de Informações Socioeconômicas - 2013.

A usina Jalles Machado, além de utilizar a energia produzida, comercializa o excedente com a central elétrica local de Goianésia, além de comercializar crédito de carbono com o Governo Holandês. Essa usina foi a primeira do Centro-Oeste brasileiro 
a comercializar créditos carbono e tem capacidade para gerar $40.000 \mathrm{~kW}$, o que é suficiente para abastecer uma cidade com aproximadamente 150 mil habitantes.

A cogeração de energia pela biomassa da cana-de-açúcar é considerada uma tecnologia limpa, pois emite menos Gases do Efeito Estufa (GEE) se comparado às termoelétricas de gás natural ou a óleo. A redução na emissão dos gases GEE pode ser mensurada utilizando como base cada tonelada de Gás Carbônico $\left(\mathrm{CO}_{2}\right)$ que deixa de ser emitido à atmosfera. Esse cálculo é realizado a fim de conhecer a quantidade de crédito de carbono que poderá ser comercializado.

A usina Jalles Machado possui o certificado Bureau Veritas Quality International (BVQI), criado a partir da assinatura do Protocolo de Kyoto, o qual credencia o empreendimento a participar da comercialização de créditos de carbono no mundo. Desde o ano de 2001 essa usina comercializa créditos de carbono com o Governo Holandês, havendo uma redução de, aproximandamente, 220 mil toneladas de $\mathrm{CO}_{2}{ }^{16} \mathrm{em} 10$ anos.

O quadro 8 ilustra os dados aproximados referentes à cogeração de energia pela usina Jalles Machado. Observa-se que a usina produz o máximo da potência instalada, além disso utiliza, para consumo próprio, cerca de $13.000 \mathrm{~kW}$, entre indústria, parte agrícola e administrativa. Para exportação são utilizados cerca de $28.000 \mathrm{~kW}$, o que é bem superior à produção total de algumas usinas, como a CRV Industrial e a Cooper Rubi, na microrregião Ceres (conforme verificado no quadro 7).

Quadro 8 - Dados da Cogeração de Energia - Usina Jalles Machado

\begin{tabular}{|l|c|}
\hline \multicolumn{2}{|c|}{ DADOS DA COGERAÇÃO DE ENERGIA } \\
\hline Potência instalada & $40.000 \mathrm{~kW}$ \\
\hline Produção total & $40.000 \mathrm{~kW}$ \\
\hline Exportação & $28.000 \mathrm{~kW}$ \\
\hline Consumo Indústria & $10.000 \mathrm{~kW}$ \\
\hline Consumo Agrícola & $2.000 \mathrm{~kW}$ \\
\hline Consumo Administração & $1.000 \mathrm{~kW}$ \\
\hline
\end{tabular}

Fonte: Jalles Machado (2014). 16 Disponível em http://www.jallesmachado.com.br/portugues/meioambiente.php?creditos_carbono,
acesso em fevereiro de 2014 . 
A cogeração de energia pela biomassa da cana-de-açúcar vem sendo aperfeiçoada e desenvolvida por todas as usinas do setor canavieiro. Atualmente, a dinâmica desses empreendimentos, está associada a produção de energia elétrica, colocando em destaque três produtos principais: açúcar, etanol e energia. Hoje dificilmente as usinas se desassociariam da cogeração de energia, pois além de reutilizarem um subproduto da produção canavieira e produzirem energia para o consumo próprio (evitando gastos e reaproveitando rejeitos), podem comercializar o excedente com a central elétrica local ou mesmo estreitar ainda mais as relações finaceiras com o mercado internacional, por meio da venda dos créditos de carbono.

A figura 24 ilustra de forma simplificada o processo de cogeração de energia elétrica por meio da biomassa da cana-de-açúcar realizado pelas usinas sucroenergéticas. Em resumo, após a colheita da cana de açúcar, seja de forma manual ou mecanizada, a cana é levada do campo para a unidade industrial onde passará por um processo de lavagem e moagem, para extração do caldo que dará início a produção de açúcar ou etanol.

Com a moagem é produzida uma quantidade muito significativa de bagaço, que posteriomente é levado para caldeiras e incinerado para a geração de calor e energia elétrica. A foto 5 da figura em análise (figura 24), mostra a central de distribuição de energia, com a tubulação em evidência, dentro de uma usina, e a foto 6 mostra um sistema elétrico de transmissão de energia dentro da usina.

A cogeração de energia é mais um exemplo de como os empreendimentos agroindustriais estão se apropriando dos vários recursos, subprodutos, rejeitos, entre outros, para o reaproveitamento na unidade industrial ou para a criação de um novo mercado. A rede técnica vai ficando cada vez mais complexa, já que está essencialmente associada ao Capitalismo, assim com a modernização das técnicas e a fluidez das redes, essas relações ficam cada vez mais complexas e mais voltadas a atender ao processo de aceleração do tempo e ao mercado consumidor. 


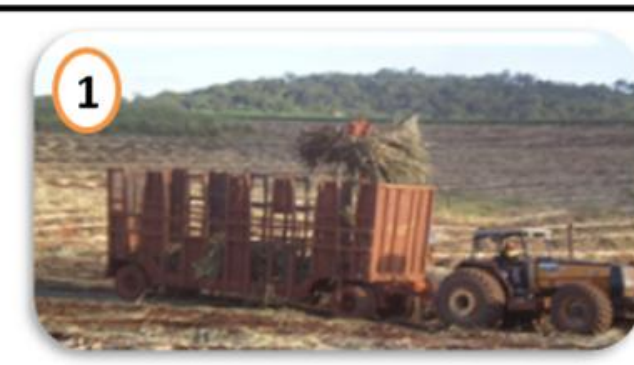

Transporte da cana-de-açúcar

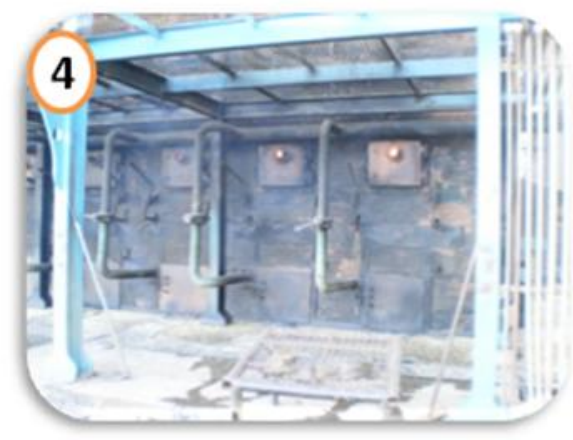

Caldeiras - Incineração do bagaço da cana

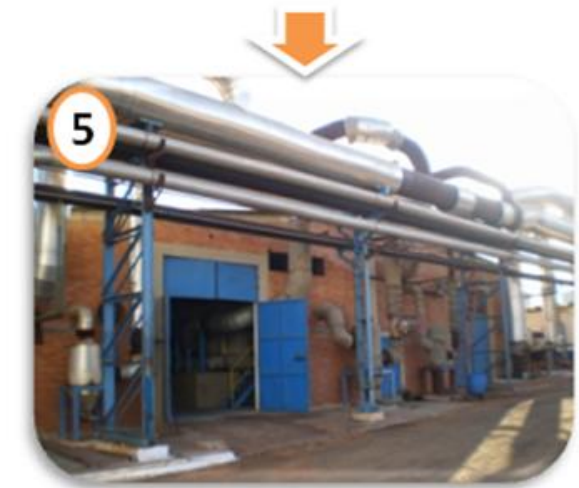

Central de distrib uição de energia na usina

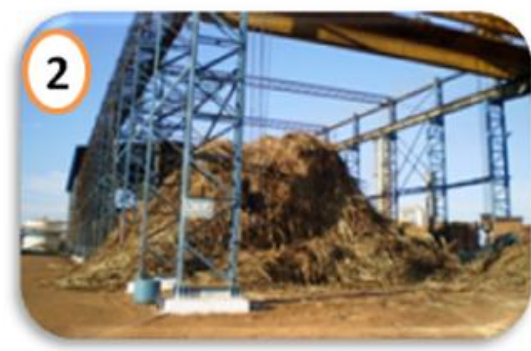

Início da moagem da Cana-de-açúcar

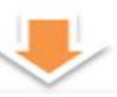

(3)
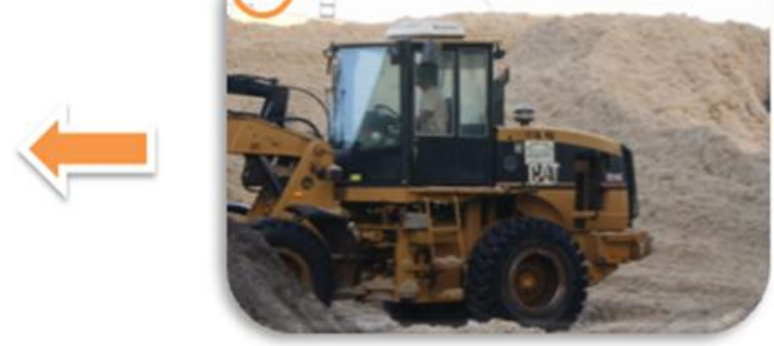

Bagaço da cana-de-açúcar - subproduto da moagem

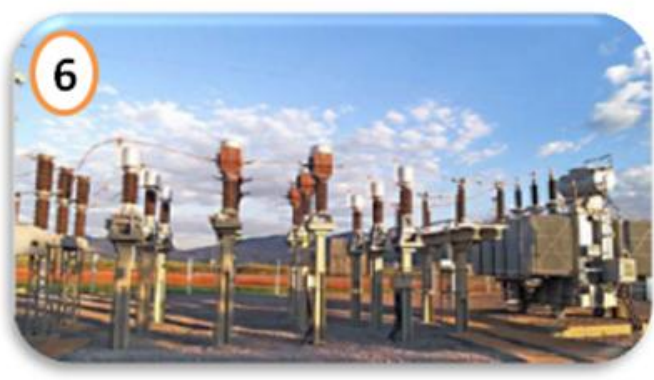

Sistema elétrico de transmissäo dentro da usina

Figura 24 - Ilustração simplificada do processo de cogeração de energia elétrica nas usinas sucroenergéticas. Fotos: A autora (2009).

Diante das reflexões propostas até aqui, entende-se como algo necessário abordar as principais características da atividade sucroenergética na região proposta, bem como verificar as principais formas espaciais e como se dá a relação campo-cidade, fruto do agronegócio sucroenergético. 


\section{CAPÍTULO III - A ATIVIDADE SUCROENERGÉTICA, SUAS FORMAS E A RELAÇÃO CAMPO-CIDADE NA MICRORREGIÃO CERES - GO}

A análise da territorialização das usinas sucroenergéticas no estado de Goiás permite identificar sua concentração no sentido sul-sudoeste e centro goiano. Como já exposto no capítulo 2, há uma relação muito próxima à infraestrutura e a logística de transportes para escoamento da produção, bem como aos melhores solos e topografia plana, em relação ao sul-sudoeste de Goiás.

E em relação ao centro goiano, mais precisamente a microrregião Ceres? Quais as especificidades dessa região frente à expansão do setor sucroenergético? As primeiras destilarias implantadas na microrregião Ceres remontam ao período de estímulo à implantação relacionado ao Proálcool. Atualmente há sete usinas em funcionamento, sendo que seis são de capital industrial oriundos do Nordeste brasileiro, tendo suas matrizes nos estados de Pernambuco, Paraíba e Alagoas, grandes produtores de cana-de-açúcar historicamente, e uma usina, a Jalles Machado (localizada em Goianésia) tem como proprietários uma histórica família política goiana, que inclusive ocupa a administração municipal no período atual (2013 - 2016).

Verificam-se que as usinas da microrregião Ceres oriundas do Nordeste brasileiro estiveram por muito tempo relacionadas a um modo de produção com menor competitividade e com forte tendência a colheita manual (se comparado à Jalles Machado e a outras usinas do sudoeste goiano, provindas, em sua maioria, do estado de São Paulo e com parcerias internacionais). Grande parte destas plantas industriais são de maquinário antigo e pouco eficiente e tiveram que se adaptar às normas de segurança

atuais, contudo, ainda hoje, percebe-se que apresentam dificuldades em renovar o maquinário, tornar mais produtiva a produção e colheita, bem como abolir o uso de mão de obra em situação precarizada frente a necessidade de mecanização da colheita da cana e competição no mercado internacional.

Silva (2016), propõe compreender porções do território goiano com relevante produção sucroenergética, para tanto apresenta duas divisões (Região Produtiva 1 e 2), que correspondem aproximadamente às microrregiões Sudoeste e Ceres. Para esse autor, a Região Produtiva 1 (Microrregião Sudoeste de Goiás) personifica a nova fase da agroindústria canavieira, que traz unidades agroindustriais novas (greenfields), e 
possuem grande capacidade de esmagamento, técnicas industriais e agrícolas mais eficientes no mercado e com capacidade de produzir etanol e gerar energia elétrica, bem como apresentam forte participação de capital externo. Já a Região Produtiva 2 (Microrregião Ceres) apresenta, em sua maioria, características de uma fase anterior, pois há o predomínio de unidades agroindustriais instaladas durante a fase áurea do Proálcool (brownfield). Nesta região é perceptível que a renovação técnica das operações agrícolas e industriais está em curso, a capacidade instalada é menor (se comparada a região 1) e a capacidade de cogeração de energia elétrica ainda é limitada.

A dificuldade em se mecanizar totalmente a colheita da cana na microrregião Ceres, esteve por muito tempo, associada a topografia relativamente acidentada que ela apresenta, o que impossibilita, em algumas áreas, a colheita pelo maquinário, sendo necessário o corte manual, pois geralmente o maquinário não acessa áreas com mais de $12 \%$ de declive.

Atualmente a única usina da região que possui a sua colheita $100 \%$ mecanizada é a Jalles Machado, as demais apresentam algum percentual de colheita manual. Assim, a microrregião Ceres ainda possui algumas características que expressam as "velhas" relações do setor sucroenergético, como o corte manual e, consequentemente, a queima da cana, bem como as migrações sazonais para essa atividade (ou a permanência do trabalhador migrante na cidade, o que demanda uma melhoria na infraestrutura básica para atendê-los) e todas as consequências estruturais, sociais e ambientais advindas desse contexto.

Nesse capítulo serão abordadas as principais características relacionadas à dinâmica sucroenergética na microrregião Ceres e como se pode compreender essas dinâmicas por meio da relação campo-cidade. Atualmente, sobretudo analisando as agroindústrias sucroenergéticas, torna-se cada vez mais difícil observar separadamente as dinâmicas, as demandas e os efeitos materializados no campo e na cidade. Portanto, parte-se da compreensão de que campo e cidade dialogam cada vez mais e estabelecem relações, redes e, muitas vezes, continuidades nas formas, que são verificadas, intensificadas e integralizadas na paisagem regional.

Ressalta-se a importância do campo e da cidade na compreensão das dinâmicas regionais e que não se trata do desaparecimento de um ou de outro, pois acredita-se que esses pares dialéticos, estão cada vez mais imbricados e prenhes do movimento 
estabelecido pela lógica do capital canavieiro, sendo difícil delimitar as fronteiras materiais de um e de outro, as relações, os "jogos" de poder estabelecidos entre ambos, bem como os papéis desempenhados.

\subsection{A Dinâmica Sucroenergética na Microrregião Ceres e a Relação Campo- Cidade}

A partir principalmente do contexto do Proálcool (anos 1970), a produção canavieira começou a crescer e a ser incorporada pela dinâmica socioeconômica da microrregião Ceres. Ao longo dos anos a área plantada com cana-de-açúcar e a produção canavieira, em toneladas, cresceu substancialmente e veio delineando as formas, demandas e as relações na região, o que é facilmente verificado pelas formas espaciais, como será verificado no decorrer do subcapítulo.

Observa-se um incremento de aproximadamente 86 mil hectares plantados com cana-de-açúcar na região, em 29 anos. A produção em toneladas de cana também cresceu ao longo dos anos, salvo alguns anos em queda, mas nenhuma queda muito relevante. Outro dado interessante a se analisar é a produtividade, que corresponde à razão entre a produção (t) e a área (ha). Os empreendimentos sucroenergéticos têm apostado, na atualidade, no crescimento da produtividade por meio da utilização de terras com melhores solos, com topografia plana e, sobretudo, com a inserção de insumos e maquinários nas etapas de plantio, colheita, transporte e produção sucroenergética.

Contudo, como bem explicitou Pires (2014), a difusão de tecnologia no setor sucroenergético tem se instalado de forma lenta e heterogênea, pois existem grandes diferenças entre o padrão técnico das usinas, que variam de acordo com seu período de implantação, origem da planta industrial e gestão organizacional, capital investido, disputas territoriais e exigências ambientais do poder público.

O aumento da produtividade da cana tem justificado sua expansão, pois com o incremento de técnicas e tecnologias capazes de aumentar a produtividade, sem ser preciso expandir a área plantada, tem sido uma justificativa utilizada pelo setor sucroenergético, pois assim não seriam necessárias novas áreas para plantio de cana, o qual normalmente necessita de desmatamentos ou substituição de culturas ou pastagens. 
O discurso das usinas, junto à União da Indústria de Cana-de-açúcar (UNICA, 2016) é que mais de $60 \%$ da expansão recente de cana-de-açúcar na região Centro-Sul ocorreu em áreas de pastagens, em sua maioria pastos degradados. Afirmam também que os novos plantios de cana estão ocorrendo em áreas já consolidadas, como as utilizadas pela pecuária, que são ineficientes e vem sofrendo um processo de intensificação.

Contudo, a microrregião Ceres demonstra outra realidade, verificada por meio dos dados: a produtividade não é muito alta e oscila bastante, principalmente por ter uma topografia acidentada, com relevantes áreas com declives acima de 12\%, o que inviabiliza o incremento de alguns maquinários modernos para plantio e colheita da cana. A figura 25 mostra a declividade da microrregião Ceres, por meio desse mapa é possível verificar que a região possui relevantes áreas com classe acima de 9 - $12 \%$ de declive. 


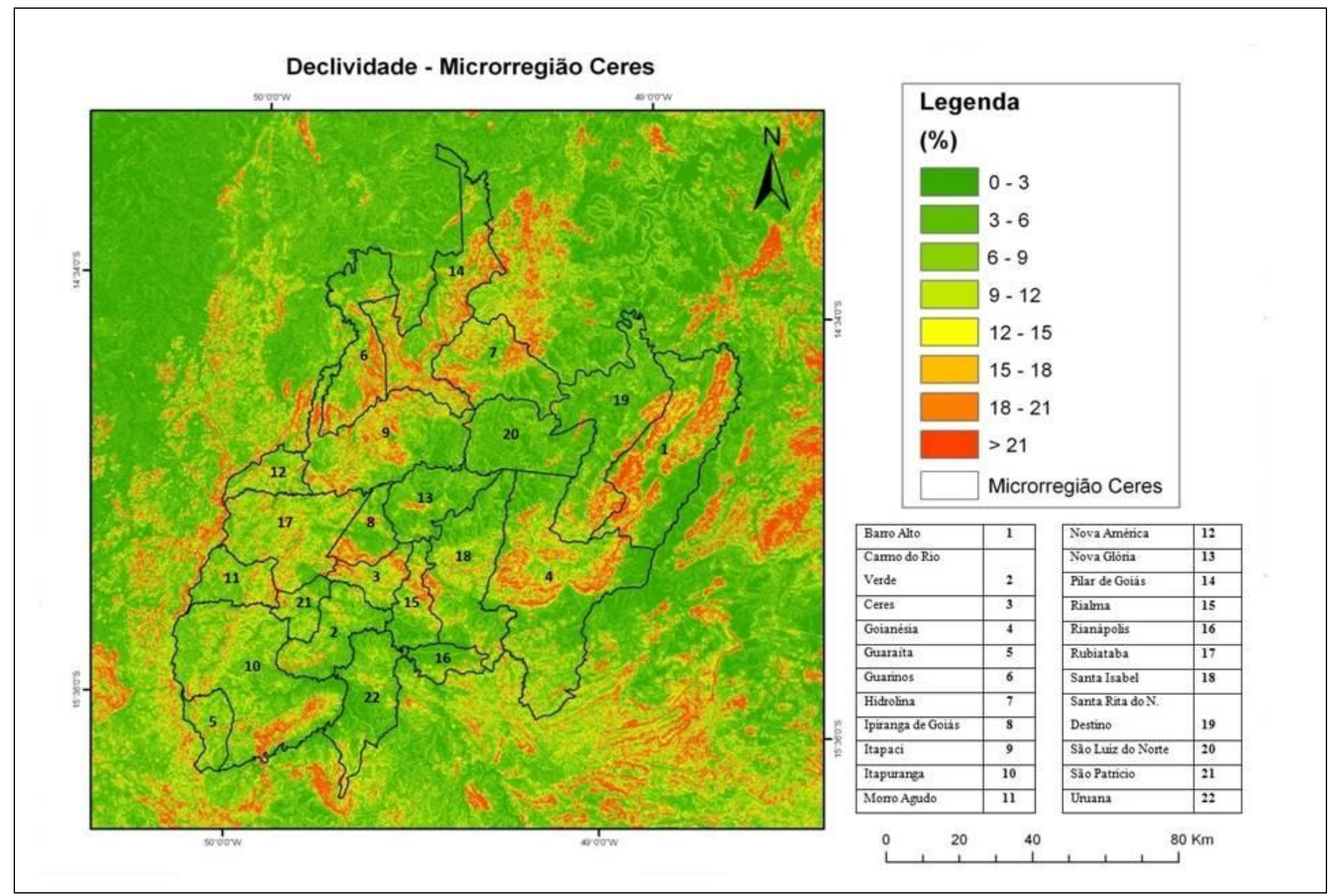

Figura 25 - Classes de declividade na microrregião Ceres. Fonte: Ferreira (2010), Org. A autora (2016). 
Essa oscilação nos dados pode ser verificada na tabela 9, a área plantada de cana-de-açúcar apresentou crescimento na região, o que justifica a queda da produtividade em alguns anos, como 2010 e 2011, pois quanto maior a área em relação à produção, menor tende a ser a produtividade. Porém, observa-se que no ano de 2013 houve queda na área plantada de cana-de-açúcar, mas aumento da produção em toneladas. Isso é explicado justamente pela produtividade pois, com certeza, no ano de 2013, houve incremento de técnicas, insumos, mecanização, etc., para justificar a redução em área e crescimento na produção canavieira.

Tabela 9 - Área, Produção e Produtividade de cana de açúcar, em série histórica Microrregião Ceres.

\begin{tabular}{c|c|c|c}
\hline Anos & Área (ha) & Produção (t) & Produtividade (t/ha) \\
\hline 1984 & 16.056 & $1.191,440$ & 74,5 \\
\hline 1988 & 20.434 & $1.626,040$ & 79,5 \\
\hline 1993 & 20.192 & $1.619,830$ & 80,2 \\
\hline 2000 & 25.115 & $1.973,500$ & 78,5 \\
\hline 2001 & 25.885 & $2.017,200$ & 77,9 \\
\hline 2002 & 28.190 & $2.299,100$ & 81,5 \\
\hline 2003 & 42.805 & $3.499,850$ & 81,7 \\
\hline 2004 & 53.770 & $4.341,570$ & 80,7 \\
\hline 2005 & 61.510 & $5.080,200$ & 82,5 \\
\hline 2006 & 68.958 & $4.897,100$ & 71,0 \\
\hline 2007 & 84.532 & $6.580,805$ & 77,8 \\
\hline 2008 & 78.990 & $6.253,720$ & 79,2 \\
\hline 2009 & 71.480 & $6.332,320$ & 88,6 \\
\hline 2010 & 70.766 & $4.960,290$ & 70,1 \\
\hline 2011 & 101.286 & $6.834,103$ & 67,5 \\
\hline 2012 & 109.395 & 7.401 .803 & 67,7 \\
\hline 2013 & 102.398 & 7.543 .328 & 73,7 \\
\hline
\end{tabular}

Fonte: Instituto Mauro Borges / Segplan-GO - Goiás em Dados, 2013.

Apesar da microrregião Ceres iniciar seu processo de expansão canavieira durante os anos 1970/1980, faz-se importante ratificar que o principal contexto de expansão da cana para essa região foi a partir do Plano Nacional da Agroenergia, em 2006. Até esse contexto, os principais municípios produtores de cana restringiam-se aos que possuíam usinas instaladas, como: Goianésia, Itapaci, Itapuranga, Carmo do Rio Verde e Rubiataba ou municípios muito próximos a esses. 
A partir do ano 2006, percebeu-se o aumento da produção de cana em quase todos os municípios da microrregião Ceres, que produzem cana-de-açúcar para ser beneficiada nos municípios onde se localizam as usinas da região. As figuras 26, 27, 28 , 29 e 30 mostram a expansão da produção canavieira para os municípios da microrregião Ceres, por meio delas é possível verificar a rápida expansão canavieira que se estabeleceu na região, principalmente após o Plano Nacional de Agroenergia (20062011).

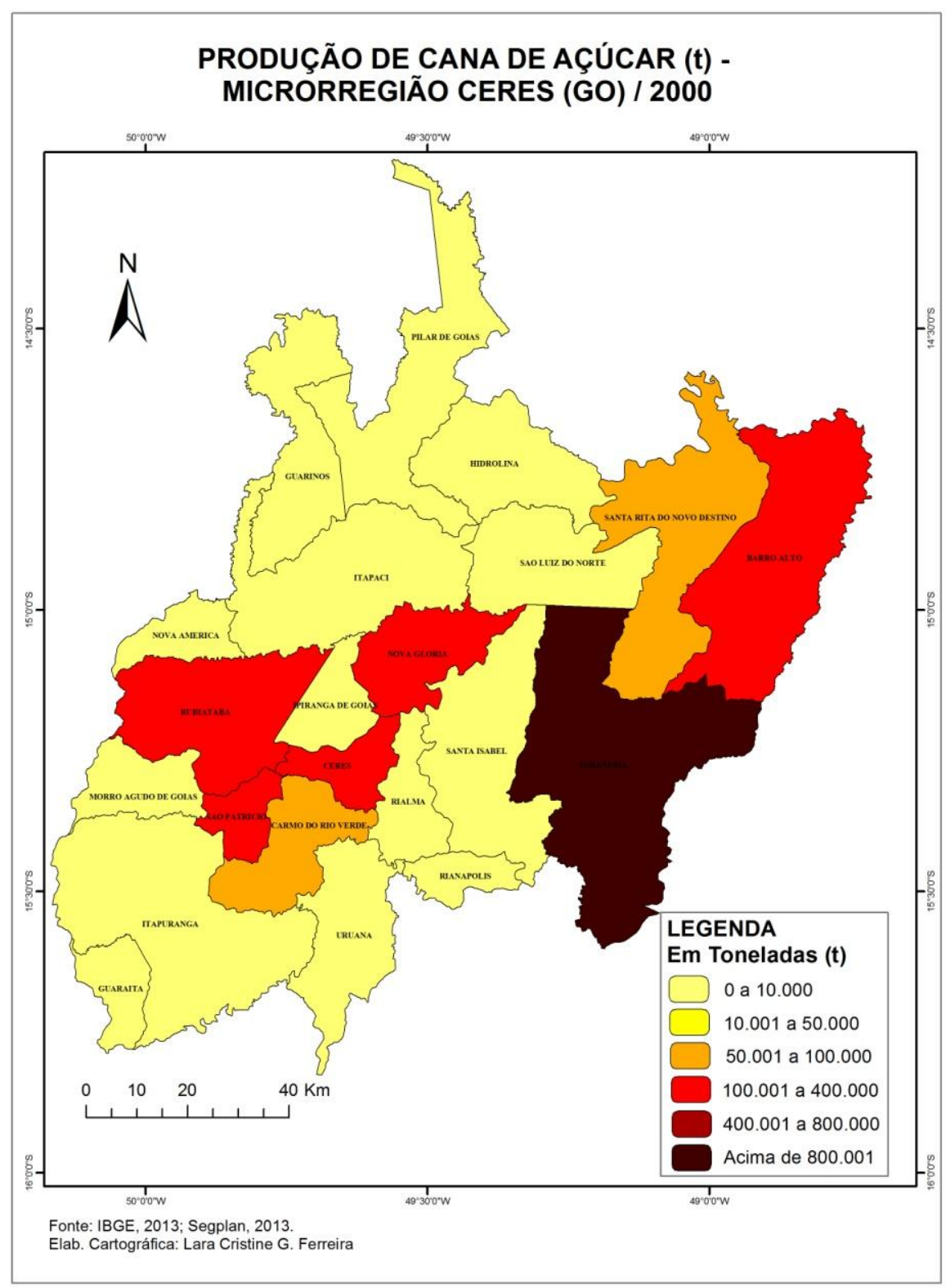

Figura 26 - Produção de cana-de-açúcar - Microrregião Ceres, 2000. 


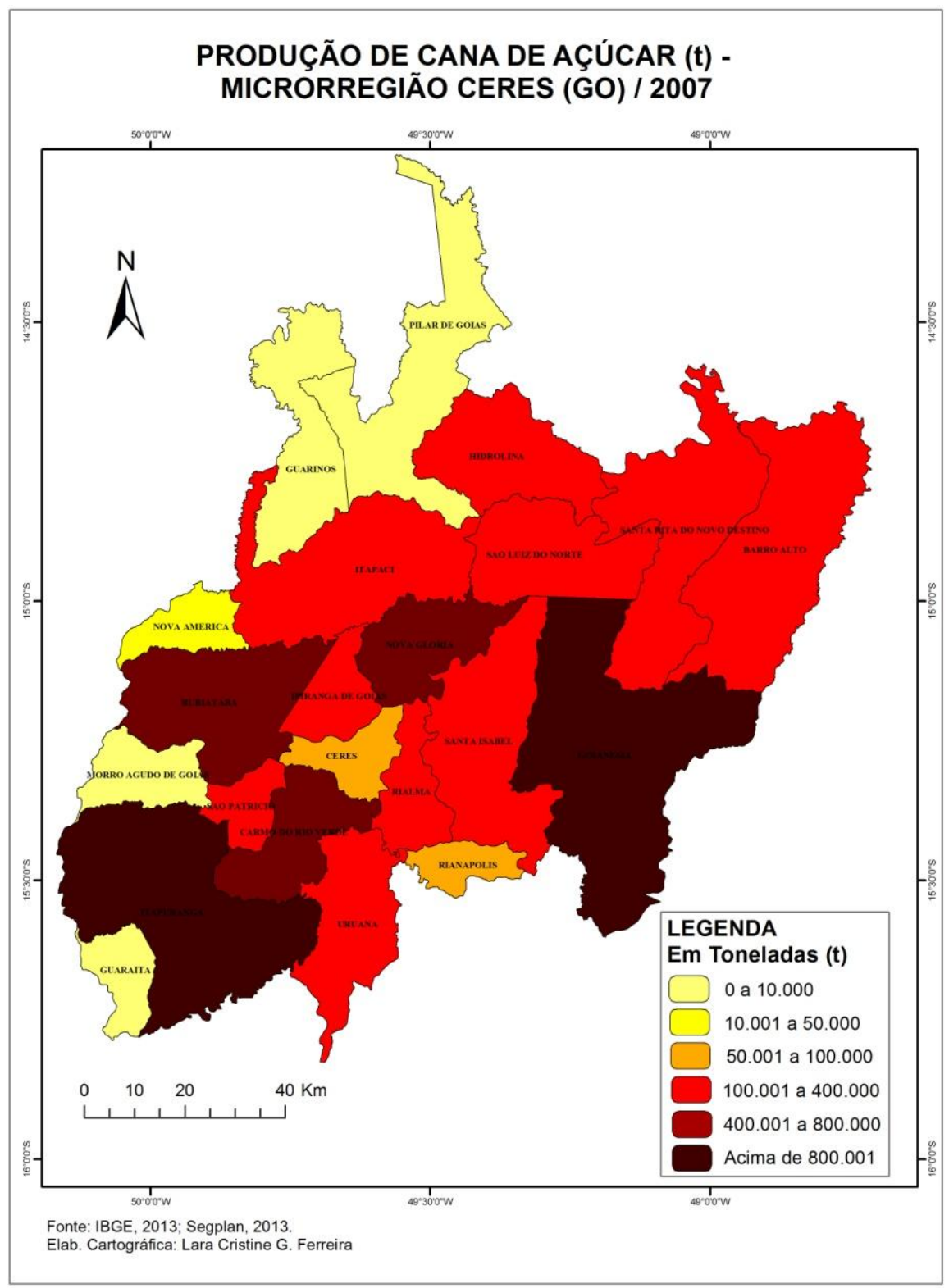

Figura 27 - Produção de cana-de-açúcar - Microrregião Ceres, 2007. 


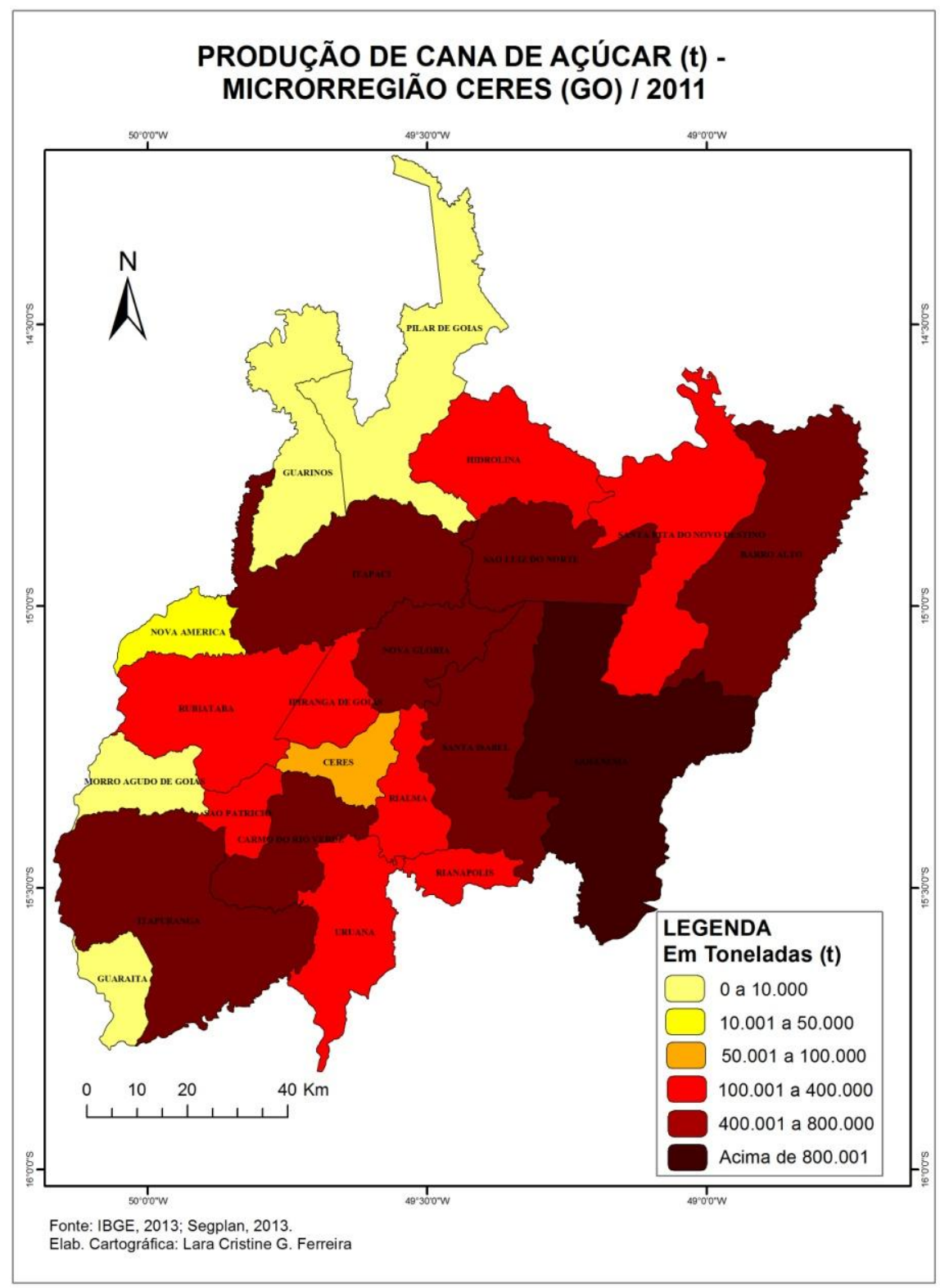

Figura 28 - Produção de cana-de-açúcar - Microrregião Ceres, 2011. 


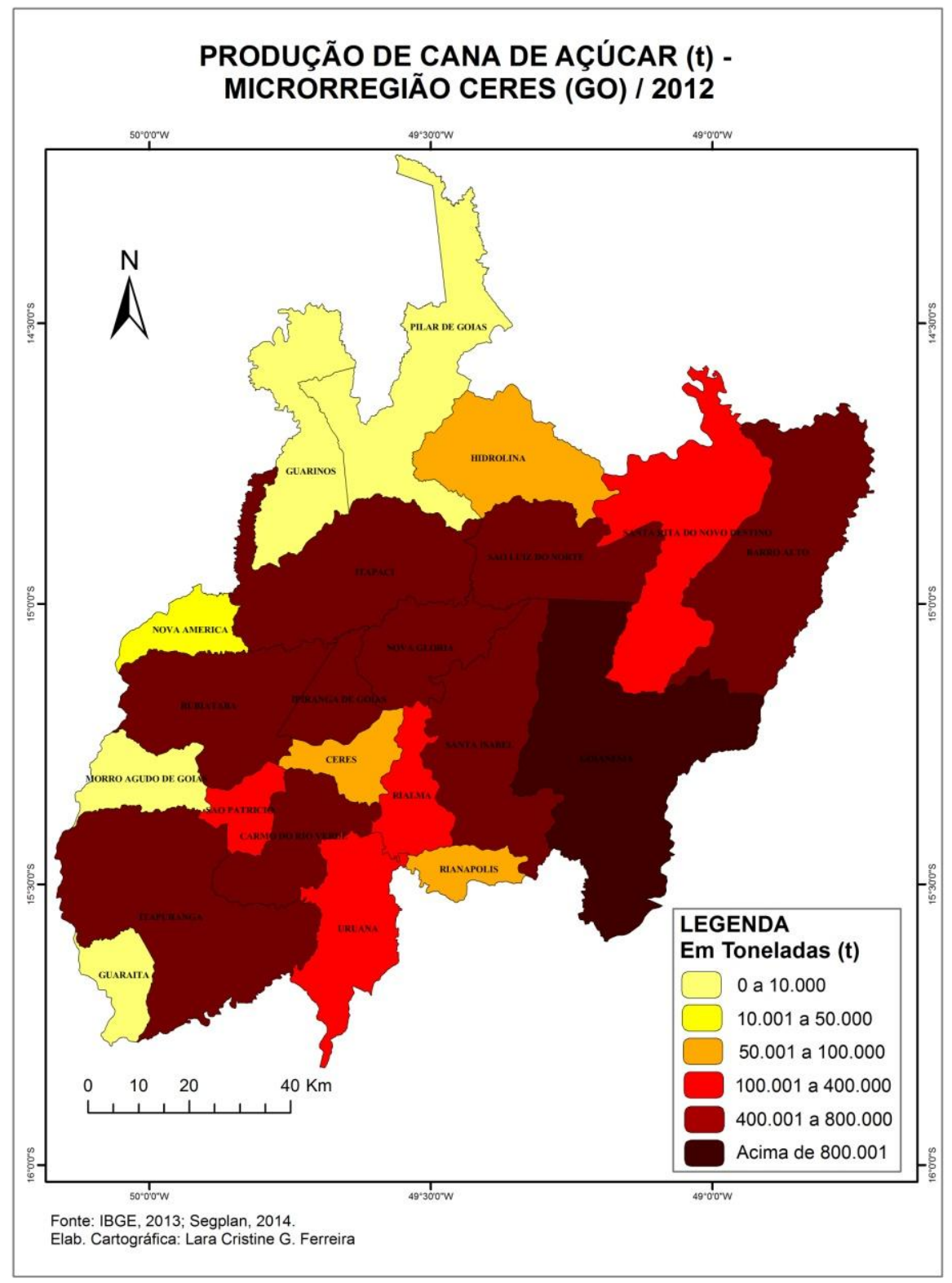

Figura 29 - Produção de cana-de-açúcar - Microrregião Ceres, 2012. 


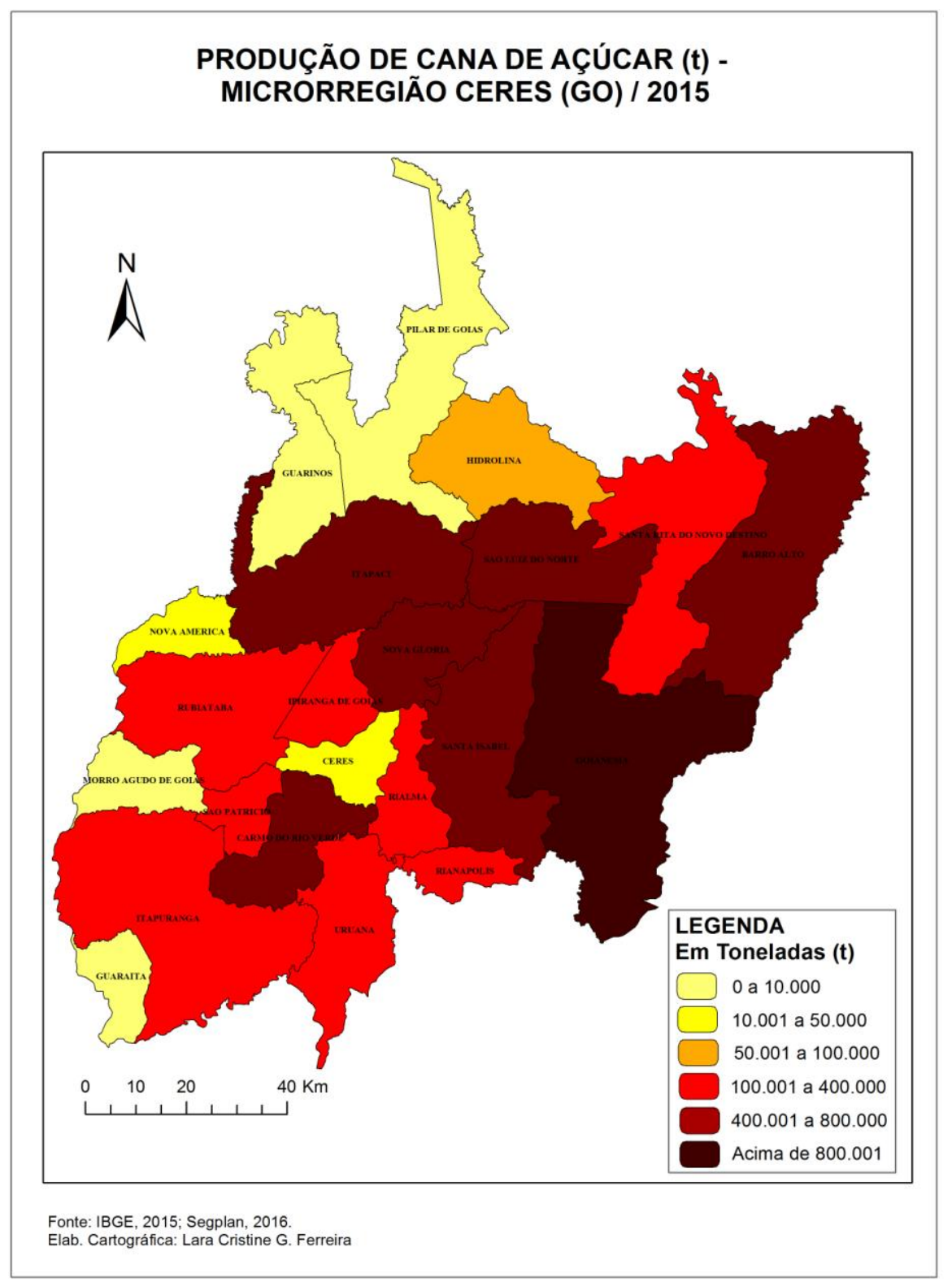

Figura 30 - Produção de cana-de-açúcar - Microrregião Ceres, 2015.

Destacam-se na dinâmica canavieira não somente os municípios onde se localizam as usinas, como: Goianésia, Rubiataba, Carmo do Rio Verde, Itapaci e Itapuranga, mas vários outros municípios da região, que em alguns casos, são grandes produtores de cana-de-açúcar. É comum, ao visitar a região verificar, impressas na paisagem, as marcas da dinâmica sucroenergética, mesmo em municípios que não são usineiros, tais como: a vastidão das áreas cultivadas de cana, os caminhões de transporte da produção, os ônibus de transporte de trabalhadores das usinas, entre outros.

Em pesquisa ao Instituto Nacional de Pesquisas Espaciais (INPE) foi possível encontrar dados mais atualizados de área plantada de cana-de-açúcar. Trata-se do sistema Canasat que 
monitora as áreas com cana no Brasil, por meio de imagens de satélite. Para a safra 2013/14 o Canasat/INPE divulgou que a microrregião Ceres teria 128.261 ha em área plantada, o que ratifica a tendência de expansão canavieira para a região.

Os municípios de Goianésia, São Luiz do Norte, Nova Glória e Santa Isabel são os que apresentam maior área plantada com cana-de-açúcar na microrregião Ceres, com 21.253 ha, 16.649 ha, 14.221 ha e 14.093 ha, respectivamente. Dos quatro maiores produtores de cana da região somente Goianésia possui usina implantada (são três usinas), os outros três municípios apresentam uma alta produção canavieira, para ser beneficiada nas usinas vizinhas. A figura 31 mostra o gráfico de área plantada com cana-de-açúcar, por municípios, na microrregião Ceres.

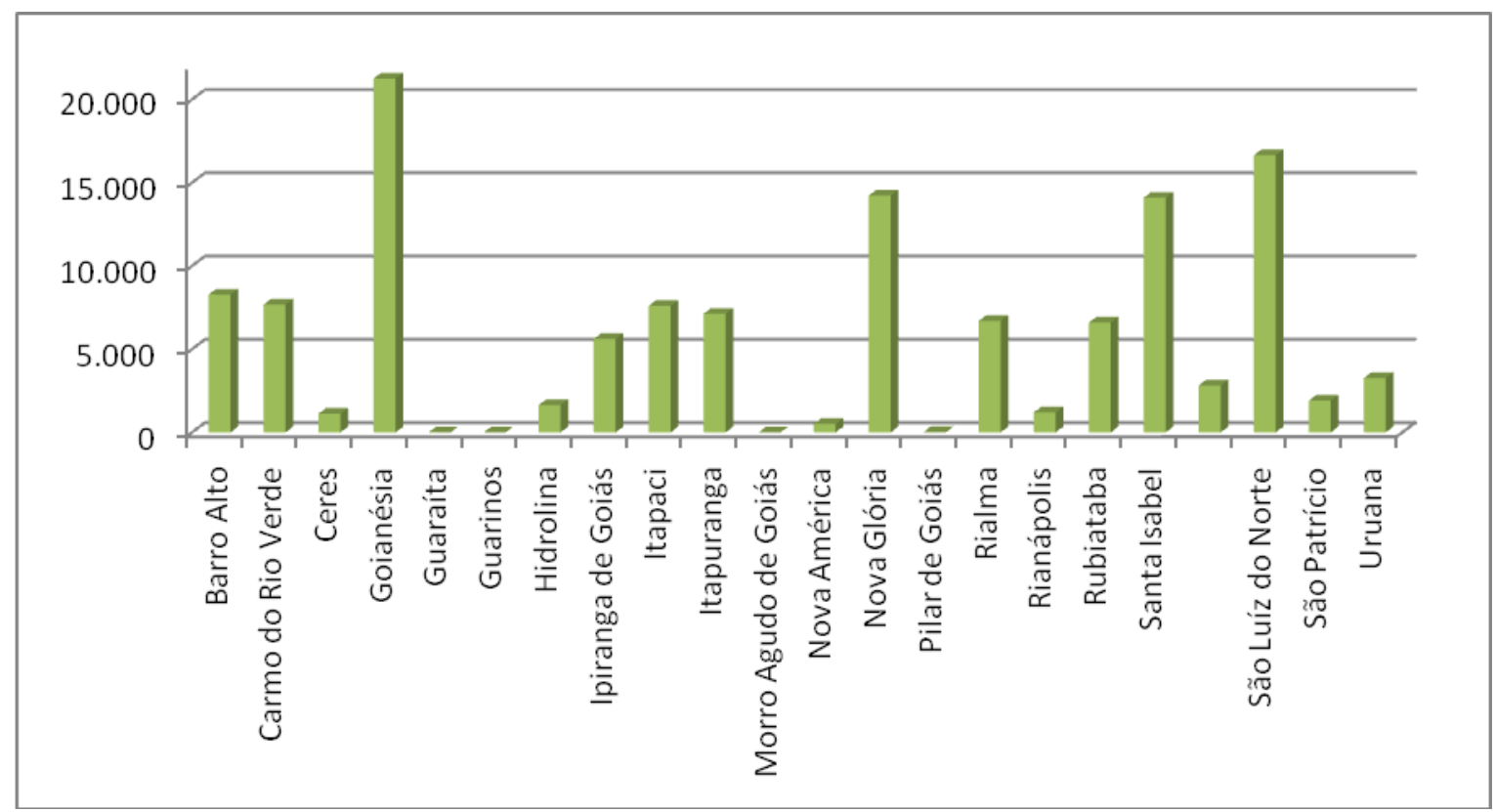

Figura 31 - Área plantada (ha) com cana-de-açúcar na microrregião Ceres - 2013/2014. Fonte: CANASAT, INPE, 2014.

A partir da análise dos dados, somado às atividades de campo, fica evidente que para tentar compreender a dinâmica sucroenergética posta é necessário considerar a relação campocidade. A relação campo-cidade tem sido bastante utilizada nos estudos da Geografia, sobretudo quando o objeto de análise está relacionado à modernização da agricultura, agronegócio e suas dinâmicas no campo e na cidade.

Há hoje no Brasil duas linhas teóricas que se destacam nessa temática: a linha que entende o campo e a cidade como duas materialidades distintas e que assim não podem estabelecer uma relação, a não ser por meio dos sujeitos e/ou atores sociais ali envolvidos; e 
outra linha, que compreende a relação campo-cidade como um continuum, ou seja, reconhecendo a constituição de um contínuo entre as formas e as relações entre o campo e a cidade.

Suzuki (2007) trabalha com a primeira linha apresentada e entende que a relação agricultura-urbanização é a melhor maneira para se compreender as problemáticas e dinâmicas entre o campo e a cidade. Contudo, esse autor utiliza a terminologia "relação campo-cidade", na busca de entender, além das relações, complementaridades que se estabelecem entre esses dois espaços, por meio dos sujeitos envolvidos. Já autores como Sposito (2010) e Rosa e Ferreira (2010) entendem a relação campo-cidade como um continnum, pois a oposição cidade e campo cede lugar, do ponto de vista analítico, para o enfoque da unicidade e complementaridade existente nesse par dialético.

Segundo Sposito (2010) reconhecer a continuidade entre campo e cidade não pressupõe o desaparecimento de nenhum deles, mas a constituição de áreas de transição e contato entre eles, com práticas socioespaciais, interesses políticos e estratégicas econômicas associadas tanto ao campo, quanto à cidade.

Essa imbricação entre campo e cidade é bastante recente e remonta ao processo de modernização da agricultura, devido, sobretudo, à aceleração da urbanização no Brasil. O processo de modernização ao mesmo tempo em que implica a integração técnica intra-setorial e a mercantilização da agricultura, promove a substituição de elementos internos do complexo rural para compras extra-setoriais, como máquinas e insumos, abrindo espaço para a criação de indústrias de bens de capital, insumos para a agricultura e redes de comercialização (GRAZIANO DA SILVA, 1996).

Os efeitos da modernização e a evolução das técnicas perpassam todos os aspectos dos circuitos espaciais de produção, desde os mais sofisticados, como o da cana-de-açúcar que utiliza equipamentos de alta precisão ou como o da mandioca, que utiliza força de tração animal e humana em quase todas as etapas da produção (LOCATEL, 2012).

Antes do processo de modernização do campo e industrialização da agricultura, os papéis, as funções, relações estabelecidas e a paisagem eram bem definidos. Com a intensificação do padrão consumista da sociedade do século XXI, baseado nas atividades capitalistas, alguns elementos como: as articulações estratégicas e econômicas, os fluxos e redes estabelecidas, a indústria e a especialização do trabalho, são identificados tanto no campo, quanto na cidade (ROSA; FERREIRA, 2010). 
As dinâmicas da cidade interferindo no campo, intensificaram-se no Brasil, sobretudo com a introdução do pacote técnico e tecnológico na agricultura em meados dos anos 1960, como já mencionado, principalmente durante a chamada "Revolução Verde". Diante disso é perceptível a influência da cidade no campo e do campo na cidade, principalmente quando se avalia as cidades pequenas que possuem nas agroindústrias sucroenergéticas, sua principal atividade econômica.

Para se compreender a configuração de uma pequena cidade canavieira, por exemplo, faz-se fundamental analisar a relação campo-cidade. Problemáticas como segregação socioespacial, (re) arranjos na infraestrutura da cidade, (re) configuração da rede urbana, entre outras, verificadas na cidade, somente são possíveis de ser compreendidas observando as dinâmicas da agricultura capitalista, suas relações e complementaridades.

Diante das duas linhas citadas, concorda-se com o entendimento da relação campocidade como um continnum, pois diante da problemática estudada entende-se que a atividade sucroenergética não vai (re) configurar somente as formas e a paisagem do campo, mas também a cidade; entende-se que os sujeitos envolvidos, tanto no campo quanto na cidade, são afetados pela atividade sucroenergética.

Concorda-se com Sposito (2010) quando esta diz que na atualidade, está cada vez mais difícil distinguir onde acaba a cidade e começa o campo. E isso está relacionado tanto à proximidade dos empreendimentos agroindustriais (que ficam na zona rural do município) com a cidade, quanto da continuidade das relações, da paisagem, do movimento pendular dos trabalhadores rurais (que moram na cidade), no transporte da cana colhida para o beneficiamento na usina (os caminhões muitas vezes passam dentro do perímetro urbano para se chegar à usina), enfim, em um município em plena atividade sucroenergética são facilmente verificáveis esses elementos na paisagem, seja campo ou cidade.

Pensar a relação campo-cidade como um continuum está vinculado também a pensar os diálogos que são postos entre a população, a economia, os papéis e funções do campo e da cidade: eles se relacionam e se aproximam cada vez mais, por meio de fluxos vindos tanto da cidade para o campo, quanto o contrário.

Surge assim uma nova relação campo-cidade, não mais baseada nas contradições, mas sim na complementaridade e na dependência. Cada vez mais as fronteiras são difusas e de difícil identificação. Pode-se considerar que as áreas urbanas na atualidade englobam espaços urbanos e rurais e os limites entre esses espaços não coincidem com o recorte utilizado para levantamentos de dados estatísticos (MARAFON, 2014). 
Para complementar a discussão sobre a relação campo-cidade na microrregião Ceres, far-se-á importante conhecer primeiramente as usinas em funcionamento na região, para posteriormente abordar as formas, demandas, infraestruturas urbanas e os arranjos territoriais construídos em prol da realização do capital sucroenergético.

\subsection{As Usinas Sucroenergéticas da Microrregião Ceres - Semelhanças e Especificidades}

Conforme já mencionado, existem hoje sete usinas em funcionamento na microrregião Ceres e, de forma geral, pode-se afirmar que grande parte delas possuem características de produção e organização muito semelhantes, contudo faz-se importante abordar algumas especificidades de produção, comercialização e diversificação organizacional.

Para se conhecer os empreendimentos canavieiros implantados na região estudada, sua lógica de produção, características gerais e sua relação com o município e região o qual está inserido, foram necessárias diversas atividades de campo, que foram realizadas no período de julho de 2014, dezembro de 2015 e maio de 2016, para verificar essas dinâmicas durante períodos distintos, principalmente de safra e entressafra. Foram realizadas entrevistas às Secretarias de Agricultura (Secretários de Agricultura ou Diretores de Agricultura) de alguns municípios da região de Ceres e visitas técnicas, com entrevistas, a algumas usinas da região.

Foram visitadas no mês de maio de 2016 as usinas Cooper Rubi, CRV Industrial, Jalles Machado e Vale Verde Empreendimentos, localizadas nos municípios de Rubiataba, Carmo do Rio Verde, Goianésia e Itapaci, respectivamente. É importante mencionar que a usina Goianésia, localizada no município de mesmo nome, não aceitou realizar a visita e entrevista, com a justificativa de estarem muito ocupados com as contratações referentes ao início da safra.

Outra usina não visitada, foi a Unidade Otávio Lage (UOL/Codora), pertencente ao mesmo grupo da usina Jalles Machado, assim os questionamentos referentes a essa unidade foram realizados durante a visita à Jalles Machado. E por fim, a usina Vale Verde Empreendimentos, localizada em Itapuranga, mesmo constando em status de funcionamento, abriram recuperação judicial e no ano de 2016 não irá moer a cana para produção de etanol, 
assim, a cana que for produzida por essa usina será moída em outras usinas do Grupo Farias, nos municípios de Uruaçu e Itapaci ${ }^{17}$.

Em princípio pode-se distinguir os empreendimentos da microrregião Ceres em quatro grupos: Grupo Japungu (Paraíba), responsável pelas usinas CRV Industrial e Cooper Rubi; Grupo Farias (Pernambuco), responsável pelas usinas Vale Verde Empreendimentos; Grupo Otávio Lage (Goiás), responsável pelas usinas Jalles Machado e UOL/Codora; e a usina Goianésia, que pertence a um Grupo de Pernambuco (figura 32). Percebeu-se, sobretudo durante as visitas, que as usinas pertencentes a um mesmo Grupo possuem características gerais, lógica de produção e relações trabalhistas e comerciais muito semelhantes entre si, mesmo porque sua lógica organizacional e política dentro das empresas é a mesma.

Quando se observa de forma mais aproximada, percebe-se que as usinas vinculadas a grupos nordestinos possuem características muito semelhantes, bem como dificuldades em se relacionar de forma propositiva e colaborativa com o município no qual encontra-se implantada. O Grupo Otávio Lage, responsável por duas usinas no município de Goianésia, diferencia-se bastante das outras usinas, tanto por sua dinâmica empresarial, já que não trabalha somente com o setor sucroenergético, quanto pela diversidade de produtos dentro da usina e pelas relações comerciais diversas, inclusive com exportação.

As usinas da microrregião Ceres, possuem de modo geral, duas características que ocorrem em todas elas: a principal forma de obtenção de terras para a produção canavieira é por meio dos arrendamentos de terras ${ }^{18}$, possuindo poucas terras pertencentes aos empreendimentos e poucos fornecedores; outra característica é que o etanol produzido por essas usinas não conseguiu atingir mercados externos, a totalidade do etanol produzido é vendido principalmente para a Petrobrás (Goiânia e Brasília, principalmente), que por sua vez, distribui aos postos de combustível.

\footnotetext{
${ }^{17}$ Informações obtidas através de telefonema para a Usina Vale Verde e em entrevista com o Secretário de Agricultura de Itapuranga no mês de maio de 2016.

${ }^{18} \mathrm{O}$ arrendamento é, de forma geral, uma forma de aluguel da terra, por meio de contrato estabelecido entre o empreendimento e o proprietário da terra, por tempo determinado em contrato. Embora oficialmente se fale em arrendamento a opção utilizada em Goiás é contrato de parceria que tem como motivação, sobretudo, o aspecto fiscal (menos oneroso para efeito de Imposto de Renda).
} 

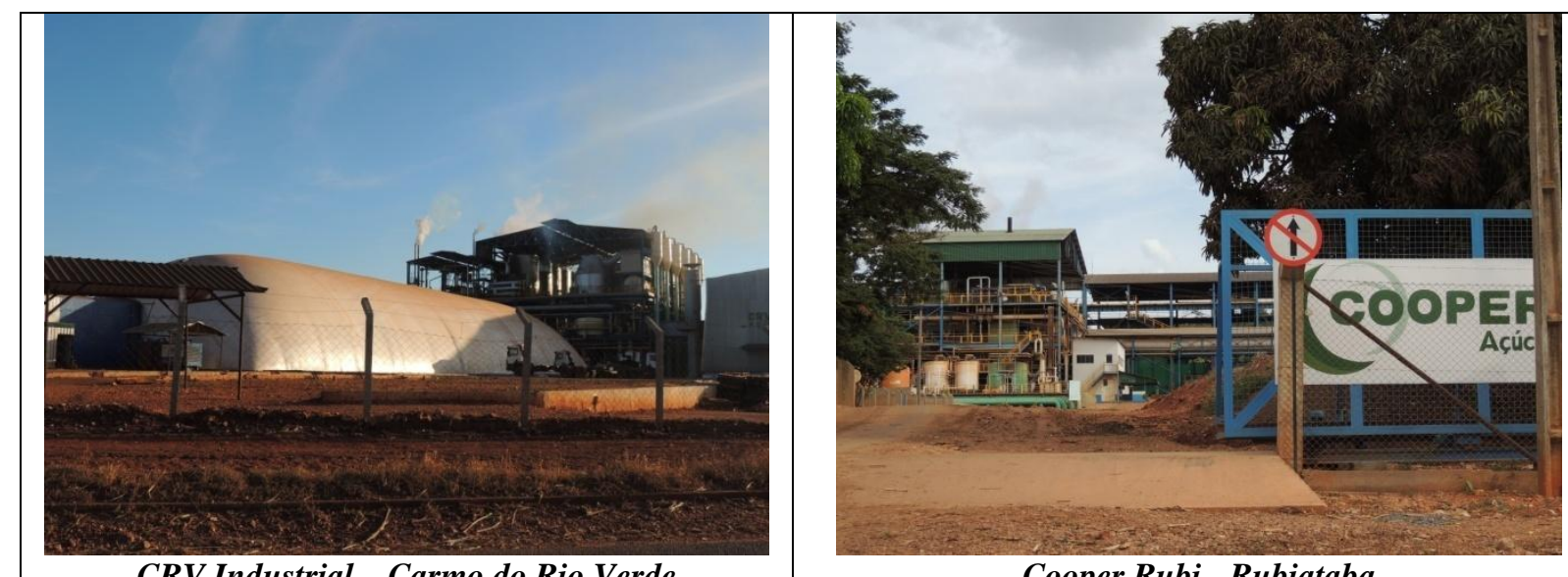

CRV Industrial - Carmo do Rio Verde

Cooper Rubi - Rubiataba

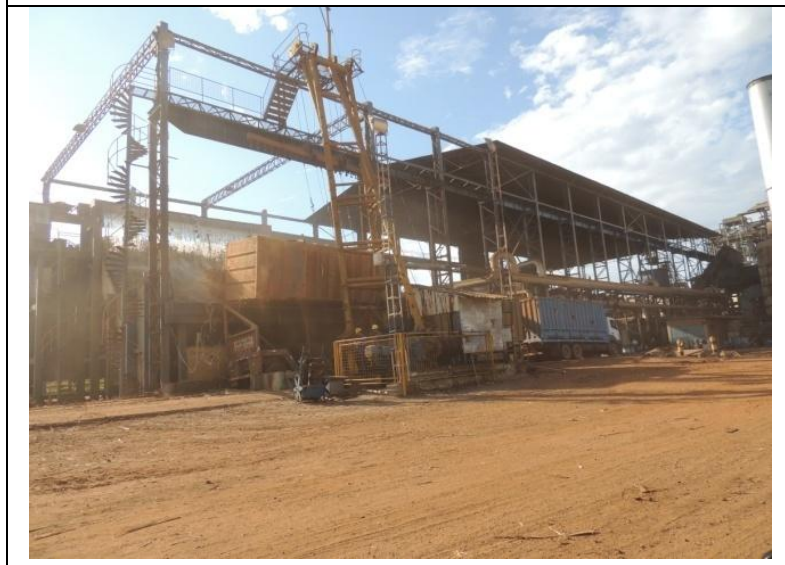

Vale Verde - Itapaci

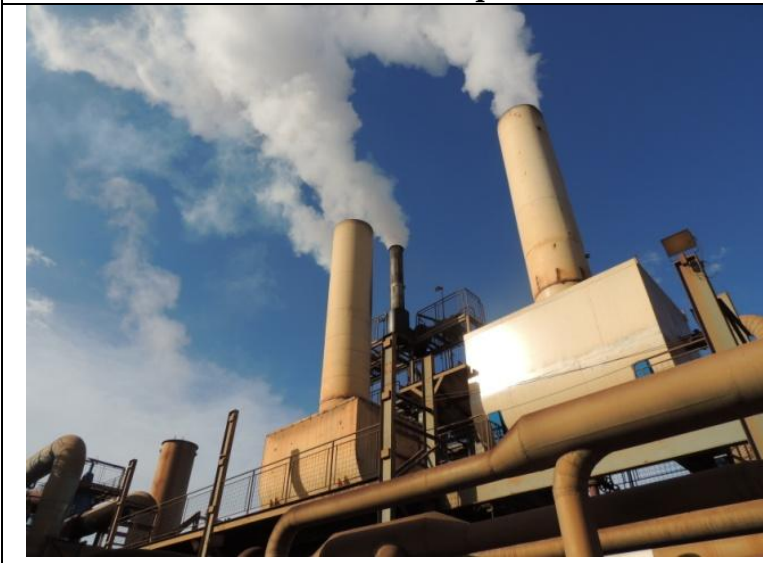

Jalles Machado-Goianésia

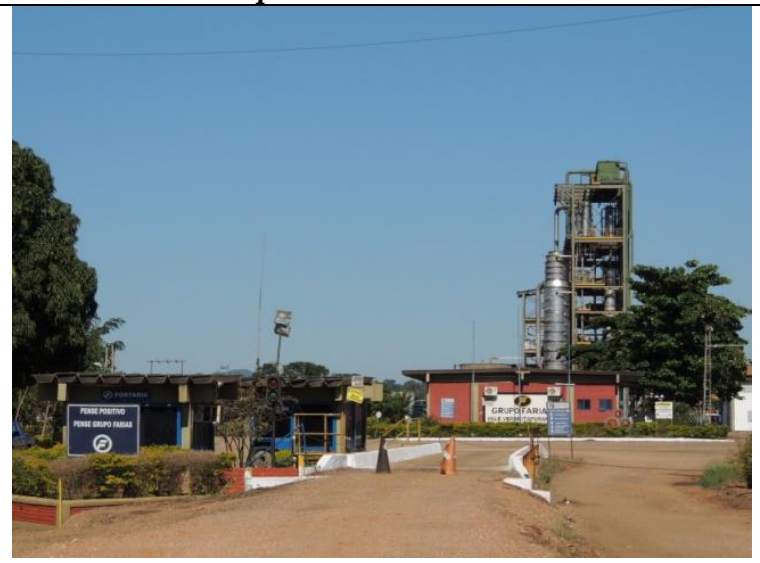

Vale Verde - Itapuranga

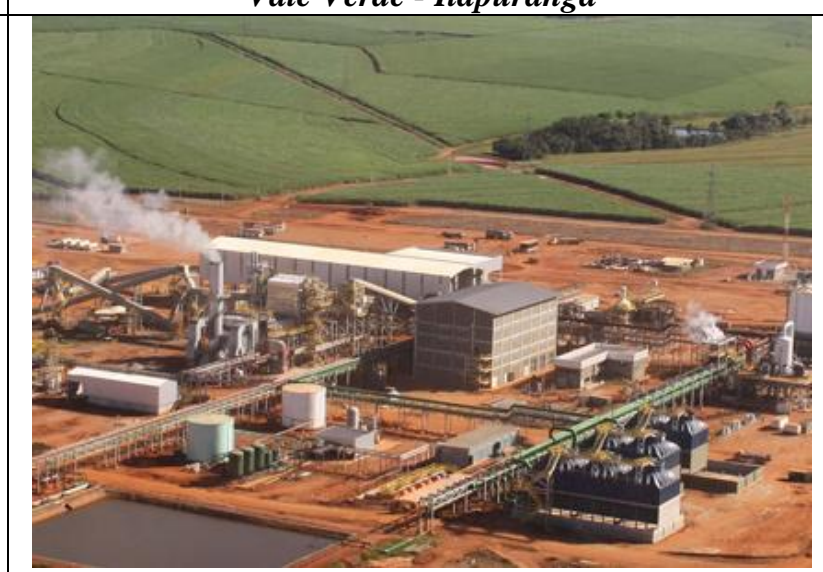

UOL / Codora - Goianésia

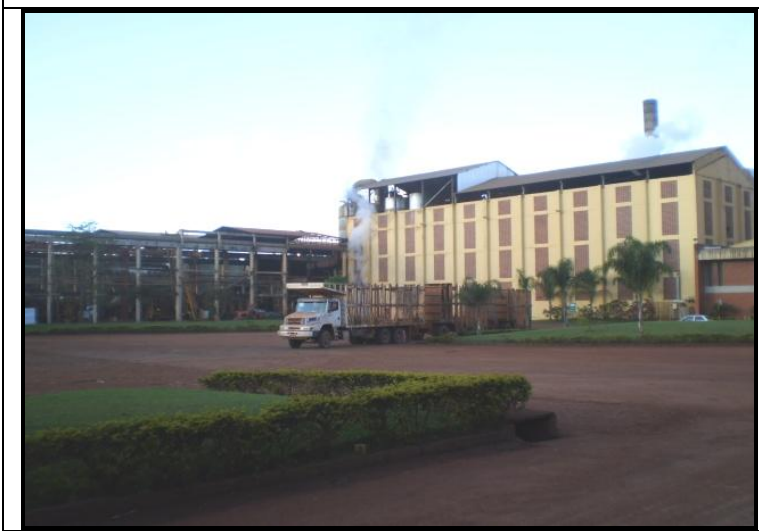

Goianésia-Goianésia

Figura 32 - Usinas localizadas na Microrregião Ceres (período de 2009 a 2016). Fotos: Acervo da autora e www.codora.com.br, acesso em junho de 2016. 
As usinas do Grupo Japungu e a usina Goianésia produzem etanol e açúcar cristal. O açúcar em sua maioria é vendido no mercado interno, contudo a usina Cooper Rubi já apresenta comercialização com o mercado externo, sobretudo a China. Já o Grupo Farias produz somente etanol. Durante entrevista realizada a usina Vale Verde do município de Itapaci, foi relatado que há dois anos iniciaram o processo de produção de açúcar cristal, mas não obtiveram sucesso.

Já o Grupo Otávio Lage apresenta uma grande variedade de produtos, além do etanol e do açúcar cristal, produzem álcool em gel, açúcar orgânico e levedura (fruto da fermentação na produção do etanol), além da produção de energia térmica e elétrica através da queima do bagaço. A Jalles Machado exporta açúcar orgânico e levedura para mais de 20 países, dentre os principais estão Estados Unidos, China, Canadá, Emirados Árabes, entre outros.

Com exceção ao Grupo Otávio Lage, as demais usinas ainda possuem duas formas de colheita da cana: manual e mecanizada (figuras 33 e 34). O Grupo Otávio Lage já se adequou $100 \%$ para a colheita mecanizada, o que reduz a queima da cana para o processo de corte manual. As demais usinas, com exceção à CRV Industrial, possuem elevado percentual de colheita manual, com queima da cana, tendo como principal exemplo as usinas do Grupo Farias com $65 \%$ e $90 \%$ de colheita manual, para as usinas dos municípios de Itapaci e Itapuranga, respectivamente.

Outra diferença entre as usinas do Grupo Otávio Lage e as demais da região, é a comercialização do excedente de energia elétrica produzida pela usina à central elétrica local e a venda de créditos carbono, entre a Jalles Machado e o Governo da Holanda (quadro 9). 


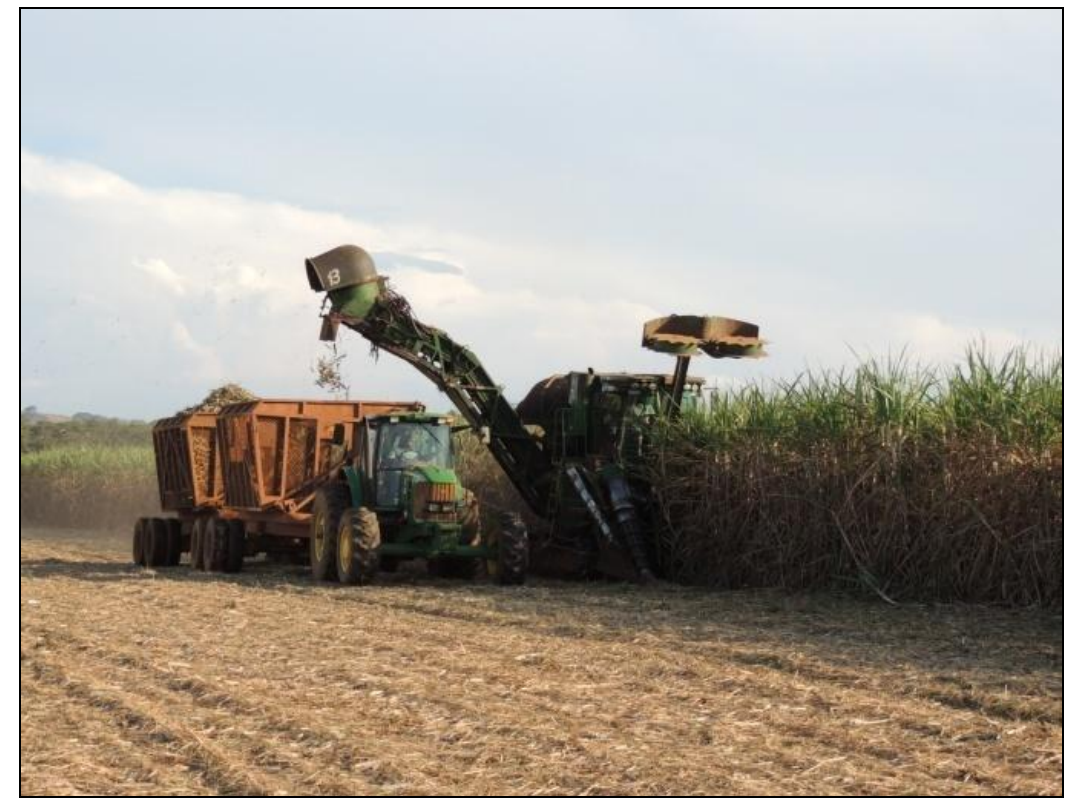

Figura 33 - Colheita mecanizada no município de Itapaci. Foto: A autora, maio de 2016.

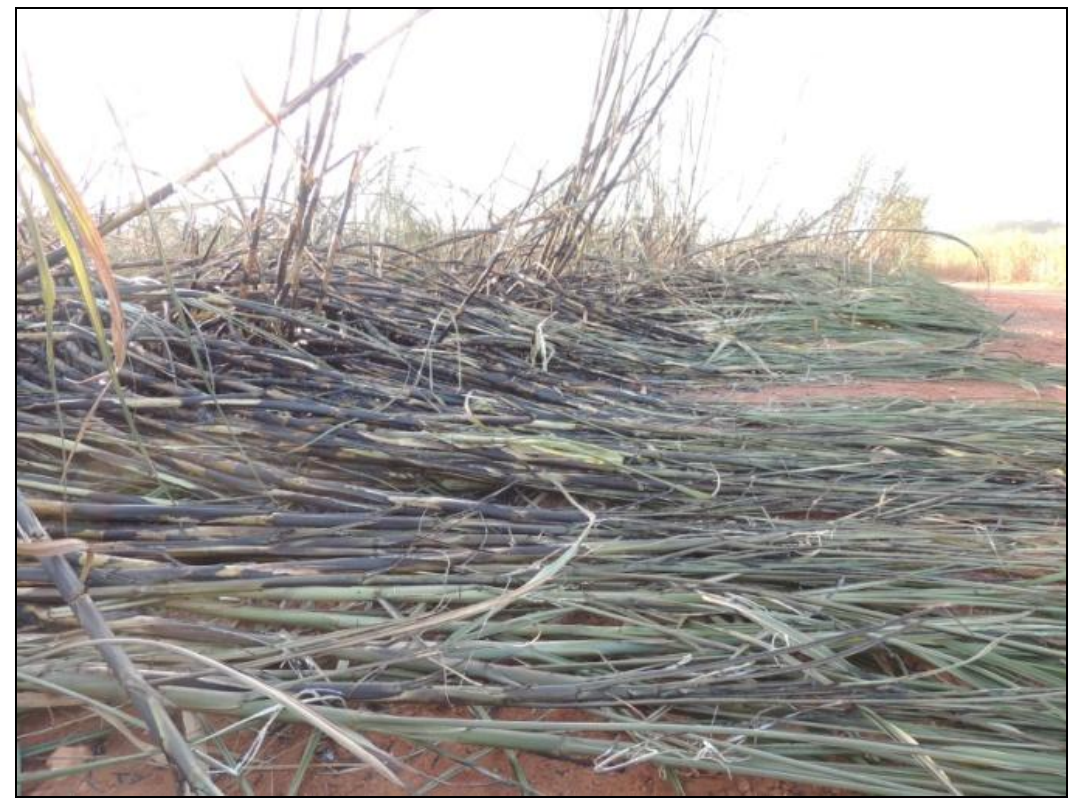

Figura 34 - Cana queimada para colheita manual no município de Carmo do Rio Verde. Foto: A autora, maio de 2016. 


\begin{tabular}{|c|c|c|c|c|c|c|}
\hline \multicolumn{7}{|c|}{ Quadro 9 - Detalhes de Produção - Usinas da Microrregião Ceres / GO } \\
\hline Usina & Origem & Produtos & Forma de colheita & $\begin{array}{c}\text { Principal forma de } \\
\text { obtenção / produção } \\
\text { de cana }\end{array}$ & Destino da Produção & $\begin{array}{c}\text { Cogeração de energia } \\
\text { elétrica }\end{array}$ \\
\hline $\begin{array}{l}\text { Cooper Rubi / } \\
\text { Grupo Japungu } \\
\text { (Rubiataba) }\end{array}$ & Paraíba & $\begin{array}{l}\text { Açúcar cristal e } \\
\text { etanol }\end{array}$ & $\begin{array}{l}\text { Aprox. } 40 \% \\
\text { mecanizada }\end{array}$ & Arrendamento & $\begin{array}{l}\text { Interno para etanol. } \\
\text { Exportação de açúcar para a } \\
\text { China. }\end{array}$ & $\begin{array}{l}\text { Autossuficiência durante a } \\
\text { safra }\end{array}$ \\
\hline $\begin{array}{l}\text { CRV Industrial / } \\
\text { Grupo Japungu } \\
\text { (Carmo do Rio } \\
\text { Verde) }\end{array}$ & Paraíba & $\begin{array}{l}\text { Açúcar cristal e } \\
\text { etanol }\end{array}$ & $\begin{array}{ll}\text { Aprox. } & 75 \% \\
\text { mecanizada } & \end{array}$ & Arrendamento & Interno & $\begin{array}{l}\text { Autossuficiência durante a } \\
\text { safra }\end{array}$ \\
\hline $\begin{array}{l}\text { Goianésia } \\
\text { (Goianésia) }\end{array}$ & Pernambuco & $\begin{array}{l}\text { Açúcar cristal e } \\
\text { etanol }\end{array}$ & - & Arrendamento & Interno & $\begin{array}{l}\text { Autossuficiência durante a } \\
\text { safra }\end{array}$ \\
\hline $\begin{array}{l}\text { Jalles Machado / } \\
\text { Grupo Otávio } \\
\text { Lage } \\
\text { (Goianésia) }\end{array}$ & Goiás & $\begin{array}{l}\text { Açúcar (cristal e } \\
\text { orgânica), Etanol, } \\
\text { Álcool em gel e } \\
\text { levedura }\end{array}$ & $100 \%$ mecanizada & Arrendamento & $\begin{array}{l}\text { Interno para etanol. } \\
\text { Exportação de açúcar } \\
\text { orgânico para EUA, Canadá, } \\
\text { China e alguns países da } \\
\text { Europa e Ásia. } \\
\text { Exportação de levedura } \\
\text { Hidrolisada e Autolisada para } \\
\text { países da Europa. }\end{array}$ & $\begin{array}{l}\text { Autossuficiência durante a } \\
\text { safra e quase toda } \\
\text { entressafra. } \\
\text { Comercializa uma parte da } \\
\text { energia com a central elétrica } \\
\text { local. créditos } \\
\text { Comercializa } \\
\text { carbono com a Holanda. }\end{array}$ \\
\hline $\begin{array}{l}\text { Vale Verde / } \\
\text { Grupo Farias } \\
\text { (Itapaci) } \\
\end{array}$ & Pernambuco & Etanol & $\begin{array}{l}\text { Aprox. } \\
\text { mecanizada }\end{array}$ & Arrendamento & Interno & $\begin{array}{l}\text { Autossuficiência durante a } \\
\text { safra }\end{array}$ \\
\hline $\begin{array}{l}\text { Vale Verde / } \\
\text { Grupo Farias } \\
\text { (Itapuranga) }\end{array}$ & Pernambuco & Etanol & $\begin{array}{l}\text { Aprox. } \\
\text { mecanizada }\end{array}$ & Arrendamento & Interno & $\begin{array}{l}\text { Autossuficiência durante a } \\
\text { safra }\end{array}$ \\
\hline
\end{tabular}

Fonte: Trabalhos de campo nas usinas e Secretarias municipais (2016); Sites das usinas (2015; 2016). Org. Lara Ferreira (2016).

Legenda: ( - ) Sem informações. 
Faz-se importante um rápido resgate sobre o papel do Estado para a territorialização das agroindústrias canavieiras. Todas as usinas da microrregião Ceres receberam auxílios do Governo Estadual. É corriqueiro deparar-se, na entrada dos empreendimentos, com as placas dos programas Fomentar e Produzir, conforme pode ser visualizado por meio da figura 35 e 36.

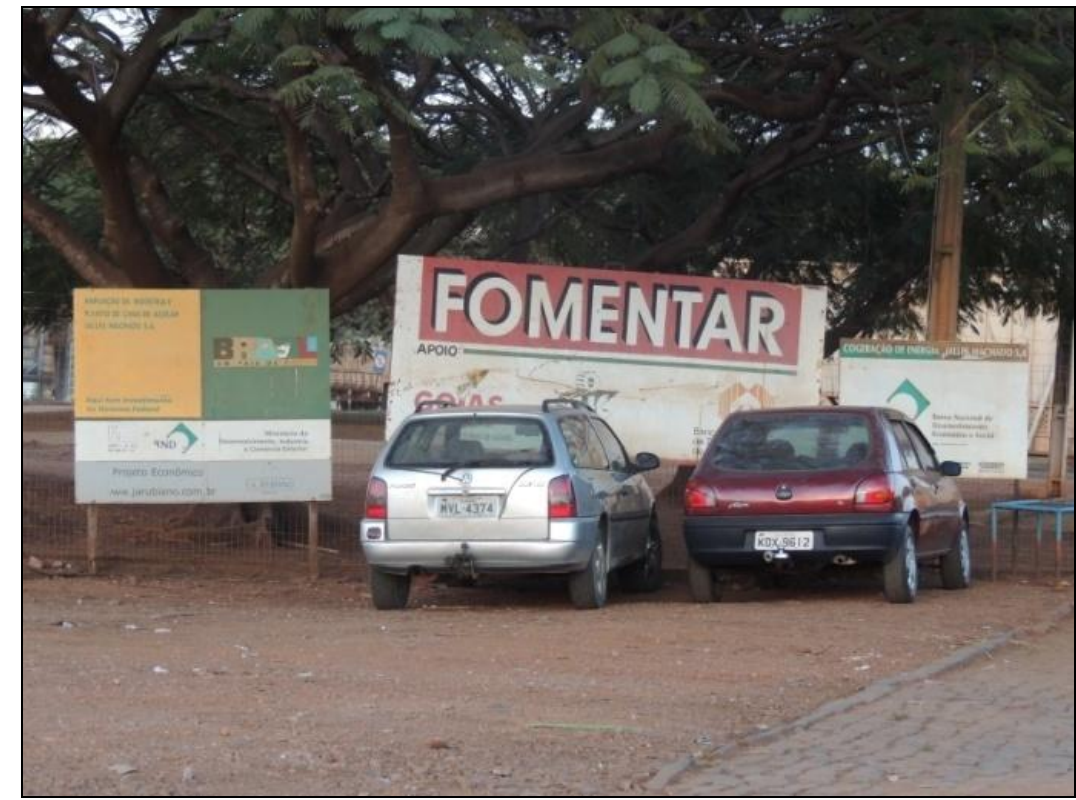

Figura 35 - Placa do Fomentar na usina Jalles Machado em Goianésia. Foto: A autora, maio de 2016.

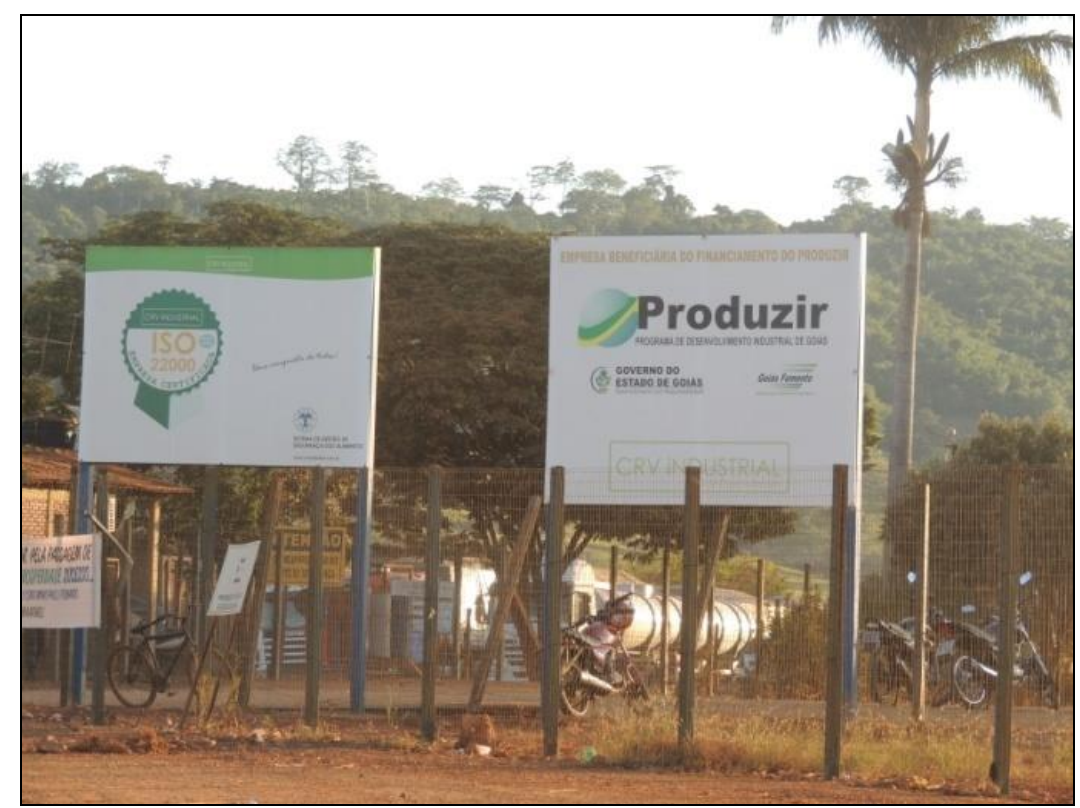

Figura 36 - Placa do Produzir na usina CRV Industrial em Carmo do Rio Verde. Foto: A autora, maio de 2016. 
Outra característica produtiva comum entre as usinas é o uso da vinhaça ou vinhoto como fertilizante na produção de cana-de-açúcar. Ela corresponde a um resíduo da produção do etanol e é utilizada para a fertirrigação das próprias lavouras canavieiras. É considerada uma rica fonte de nutrientes, principalmente matéria orgânica e potássio. A figura 37 mostra a fertirrigação do campo com vinhaça.

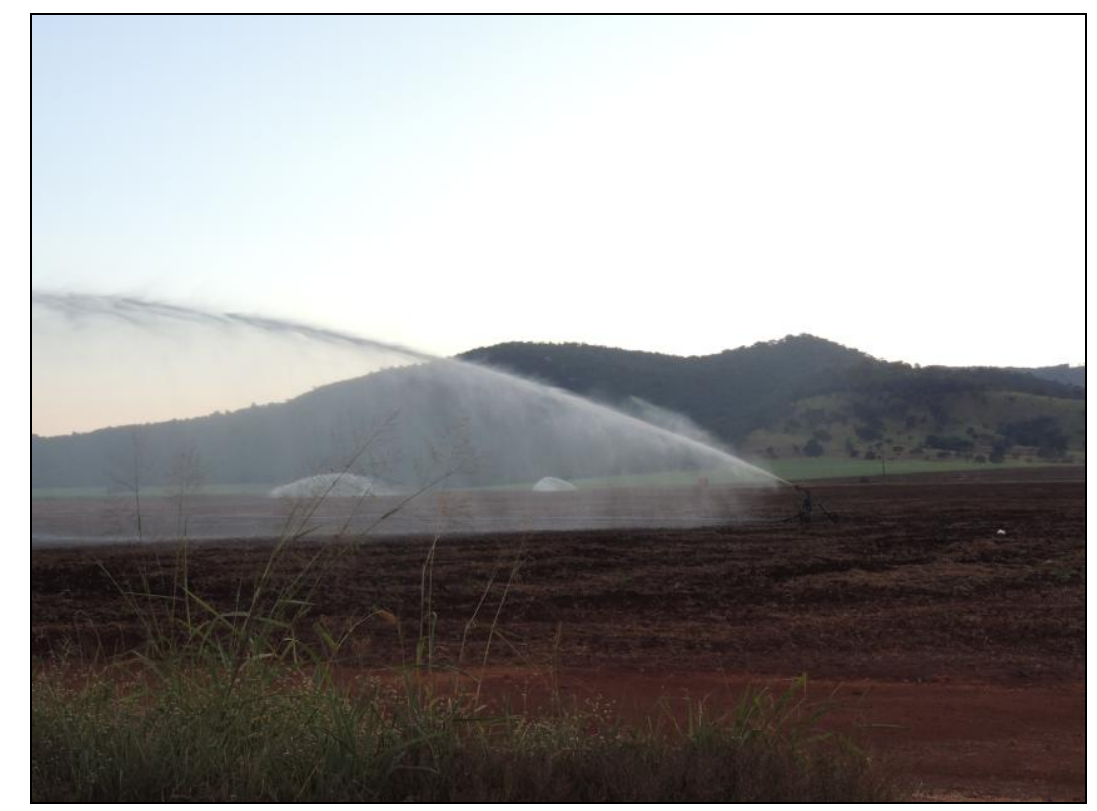

Figura 37 - Uso da vinhaça para fertirrigação em Goianésia. Foto: A autora, maio de 2016.

A vinhaça pode trazer vantagens para a cultura canavieira, como a elevação do $\mathrm{pH}$, a disponibilidade de certos nutrientes (como magnésio, cálcio e potássio), melhoria da estruturação do solo, aumento na retenção de água e desenvolvimento da microflora e microfauna do solo. Contudo, o uso da vinhaça deve obedecer a limites baseados em normas técnicas, pois sua sobrecarga pode trazer sérios impactos como salinização e contaminação do lençol freático (SOUZA, 2005).

O uso da vinhaça para a fertirrigação por todas as usinas confere um odor característico a todas as cidades produtoras de cana. Mesmo que não se visualize os canhões de irrigação ou os canais da vinhaça sente-se logo seu cheiro característico (a figura 38 mostra um canal de vinhaça da usina Cooper Rubi onde pode se verificar o escoamento superficial deste rejeito.

No campo verificou-se que a vinhaça expelida pela usina, encontra-se em elevadas temperaturas e que em contato com o ar atmosférico produz vapores que se dispersam nas áreas 
próximas. Hoje as usinas reaproveitam muito dos seus subprodutos, como a vinhaça, a levedura, a torta de filtro, o bagaço da cana, entre outros, isso tem sido um dos resultados mais vantajosos obtidos pelo setor sucroenergético, por meio do desenvolvimento de técnicas e tecnologias capazes de transformar o lixo industrial das agroindústrias canavieiras em subprodutos economicamente rentáveis (ELIAS, 2003).

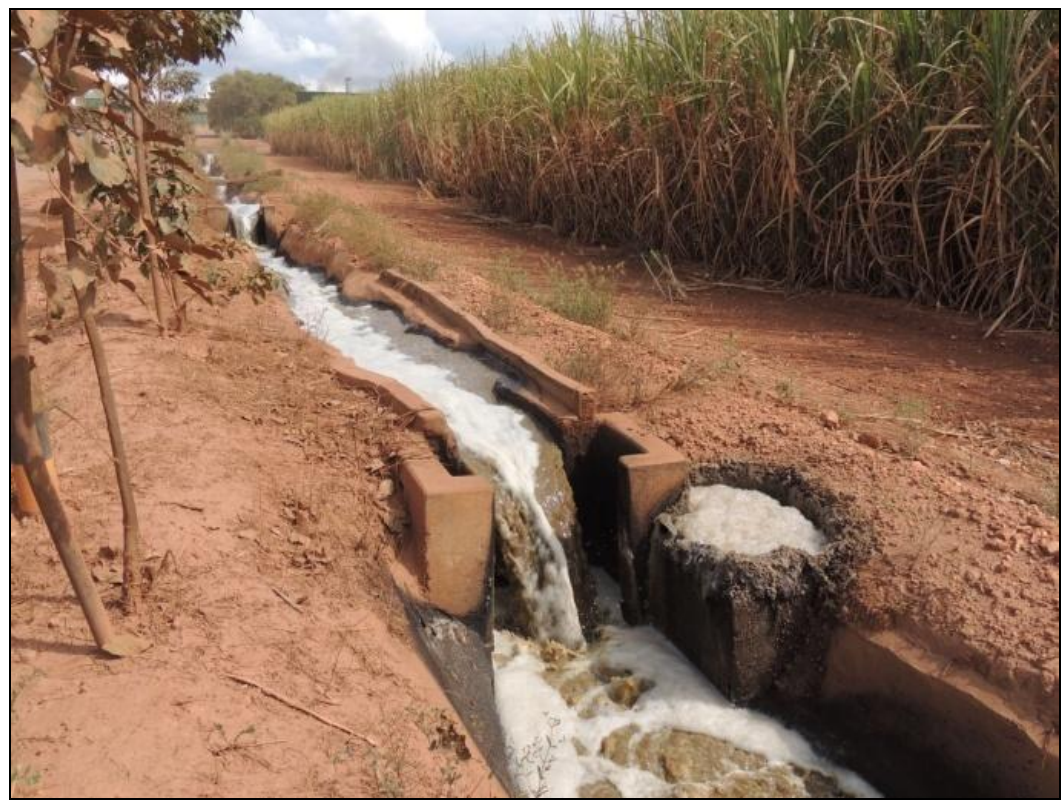

Figura 38 - Canal de vinhaça na usina Cooper Rubi. Foto: A autora, maio de 2016.

Além da vinhaça, outros dois subprodutos são reaproveitados e muito utilizados pelas usinas da região: a torta de filtro e o bagaço da cana. A torta de filtro corresponde ao resíduo proveniente da produção de açúcar, rico em material orgânico e mostra elevada capacidade de retenção de água a baixas tensões, essa propriedade contribui tanto para aumentar a produtividade da cana-de-açúcar, especialmente em regime não irrigado, como para assegurar melhor brotação em plantios realizados em épocas desfavoráveis (SACAROSE ON LINE, 2009). ${ }^{19}$

Já o bagaço da cana é bastante utilizado para a cogeração de energia térmica e elétrica, bem como também é vendido para compor rações animais. Em várias entrevistas realizadas nas usinas, foi relatado a importância que o bagaço da cana-de-açúcar tanto para a usina, para a produção de energia, quanto como um produto para comercialização, além dos produtos usuais,

\footnotetext{
${ }^{19}$ Disponível em http://sacaroseonline.blogspot.com.br/. Acesso em dezembro de 2015.
} 
como etanol e açúcar. A figura 39 mostra um amontoado de bagaço da cana, que será levado para as caldeiras e posteriormente para produção de energia.

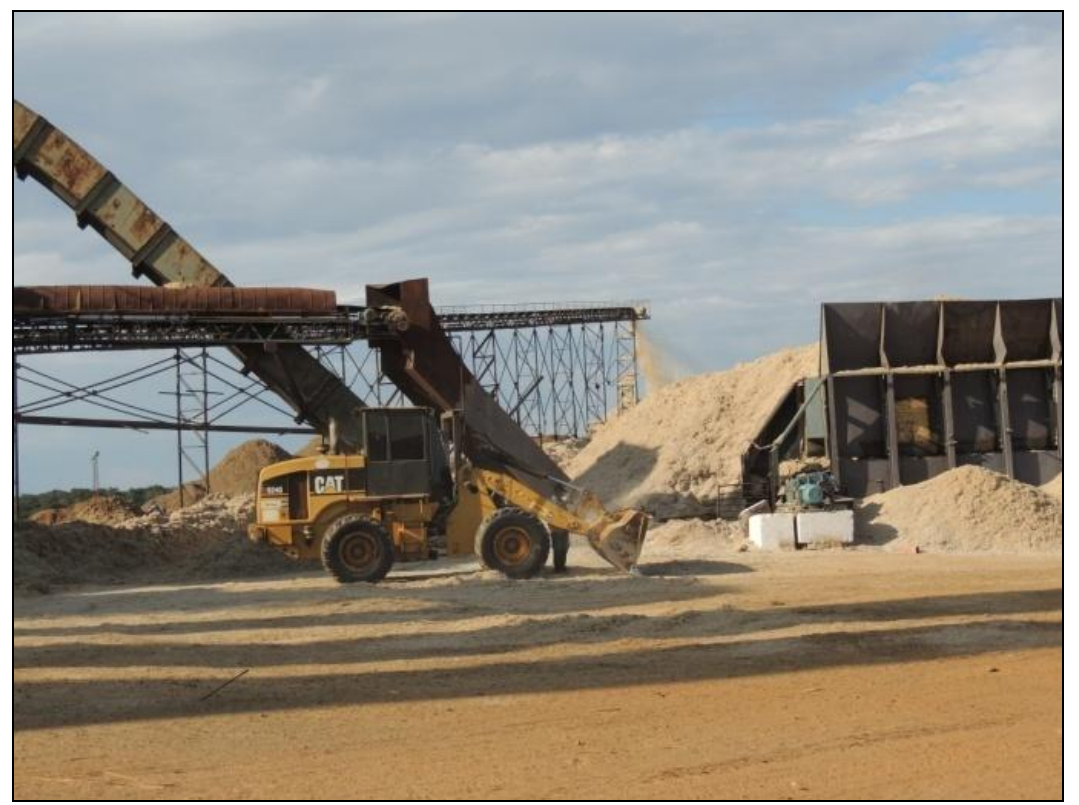

Figura 39 - Bagaço de cana na Vale Verde em Itapaci. Foto: A autora, maio de 2016.

Nessa pesquisa, parte-se do pressuposto que a microrregião Ceres, por ter a sua sustentação produtiva em segmento hegemônico do agronegócio e não apresentar outra atividade econômica forte na região, apresenta dificuldades em manter uma dinâmica socioeconômica equilibrada, pois torna-se refém do mercado sucroenergético, econômica e socialmente, pois a maioria dos municípios da região tem nas usinas canavieiras sua principal atividade econômica, geração de empregos e impostos.

Essas características das usinas da microrregião Ceres acabam por refletir na pouca dinamização financeira da indústria, o que também reflete nos municípios em que estão inseridas. $\mathrm{O}$ grupo que se globaliza e que consegue variar os produtos e os mercados consegue também se manter no mercado e superar as crises financeiras. Esse é o caso do Grupo Otávio Lage, proprietário da usina Jalles Machado, que acaba refletindo no município de Goianésia. Verificou-se nesse município uma diferenciação em relação aos demais, e isso está diretamente relacionado às características da empresa global (verificadas na Jalles Machado, por exemplo), e a um conjunto de serviços e empreendimentos mais variados existentes em Goianésia e que não ocorrem nos outros municípios da região. 
O Grupo Otávio Lage, em Goianésia, de todos os grupos é o único que possui produção diversificada, tanto dentro da agroindústria canavieira, quanto na quantidade de empresas, com diferentes fins e produtos, dentro do mesmo grupo empresarial. O Grupo Otávio Lage teve sua origem com o político, nascido em Goianésia, Otávio Lage, que foi prefeito do município de Goianésia (1962 - 1965) e Governador do estado de Goiás por dois mandatos entre a década de 1960 e 1970. Além do mandato de Otávio Lage, seus dois filhos também assumiram a prefeitura da cidade: Jalles Fontoura de Siqueira, assumiu o primeiro mandato entre 1977 e 1982 e está em seu segundo mandato (2013 - 2016); e Otávio Lage de Siqueira Filho, que esteve à frente da prefeitura de Goianésia em dois mandatos consecutivos, entre os anos $2001 \mathrm{e}$ 2008.

Além das duas usinas implantadas hoje em Goianésia sob gestão desse Grupo, há também outras propriedades e empresas pertencentes ao Grupo Otávio Lage, como: a Vera Cruz Agropecuária, empresa de confinamento de gado, com cerca de 28 mil cabeças de gado (figura 40); fazendas Covoá, Porteiras e Bandeirantes, produtoras de seringueira (heveicultura); são proprietários de duas emissoras de rádio, uma em Goianésia e outra no município de Barro Alto; e atuam no ramo imobiliário, possuem dois loteamentos em Goianésia, os Residenciais Parque das Palmeiras I e II.

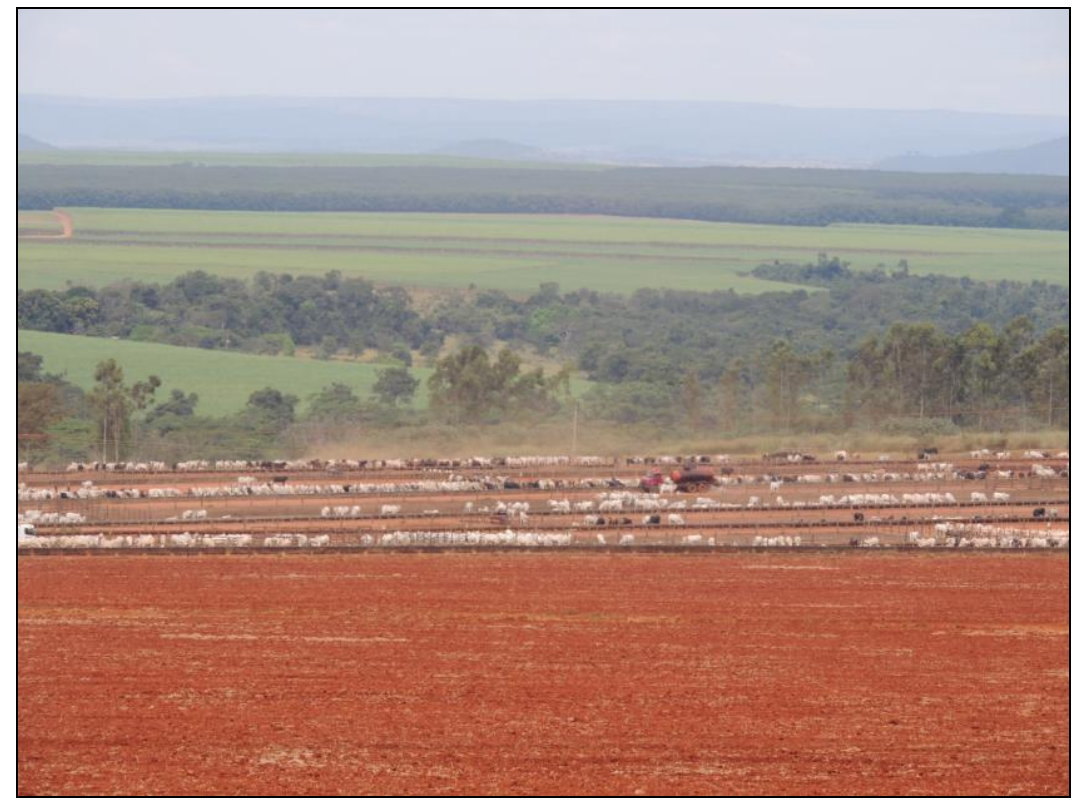

Figura 40 - Confinamento de gado pela Vera Cruz Agropecuária em Goianésia. Foto: A autora, maio de 2016. 
A usina Jalles Machado é hoje uma das principais usinas do Brasil, ela possui relações comerciais com vários países do mundo, além de ter uma marca própria de seus produtos: Itajá. Como mencionado, a Jalles Machado exporta alguns produtos, um dos principais é o açúcar orgânico. Para que essa empresa consiga exportar orgânicos, ela passa por várias especificações e fiscalizações até obter os selos de segurança, como o USDA Organic (padrão orgânico dos Estados Unidos) e o JAC (padrão orgânico do Japão).

A figura 41 mostra as certificações da Usina Jalles Machado, o que revela a estratégia de reconhecimento e estabelecimento de redes comerciais com várias empresas do mundo, dentre os selos há os de responsabilidade ambiental, comércio justo, agricultura orgânica, entre outros, além dos selos que regem dietas específica de certos povos, como a comunidade Islâmica e a judaica ortodoxa, por exemplo. Ressalta-se que esses selos de certificação, correspodem a signos do mito do progresso, muito frequentes no discursos do agronegócio, além de outros que serão discutidos posteriormente.

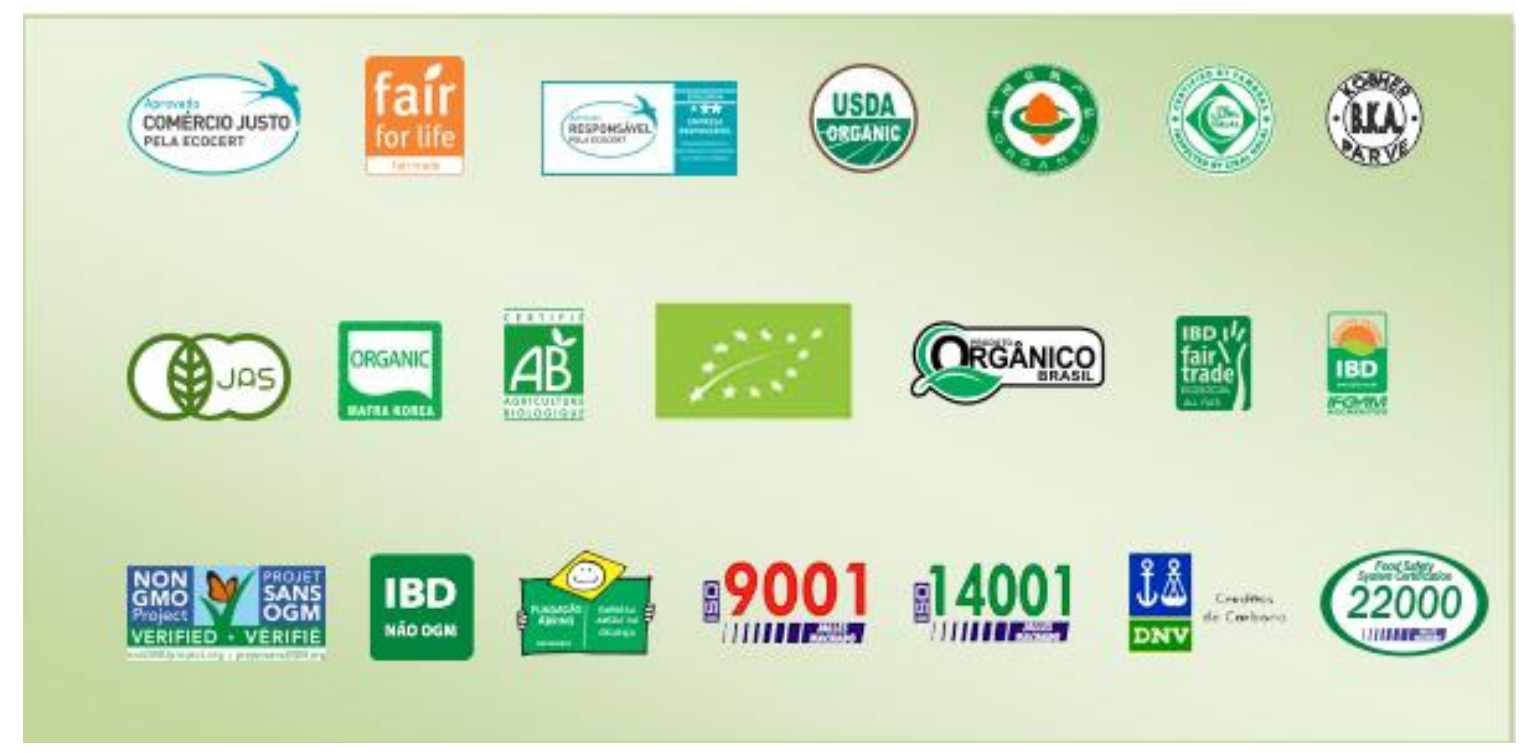

Figura 41 - Selos de certificação da Usina Jalles Machado. Fonte: wwww.jallesmachado.com. Acesso em julho de 2016.

Para a produção de açúcar orgânico a usina teve de adequar as áreas de plantio, o controle de pragas e até mesmo o processo de empacotamento, que não pode conter componentes químicos. As figuras 42 e 43 mostram a área de produção de cana orgânica da usina Jalles Machado e os pacotes da marca Itajá como o açúcar orgânico e suas derivações (Bio, Demerara e Orgânico Cristal). 


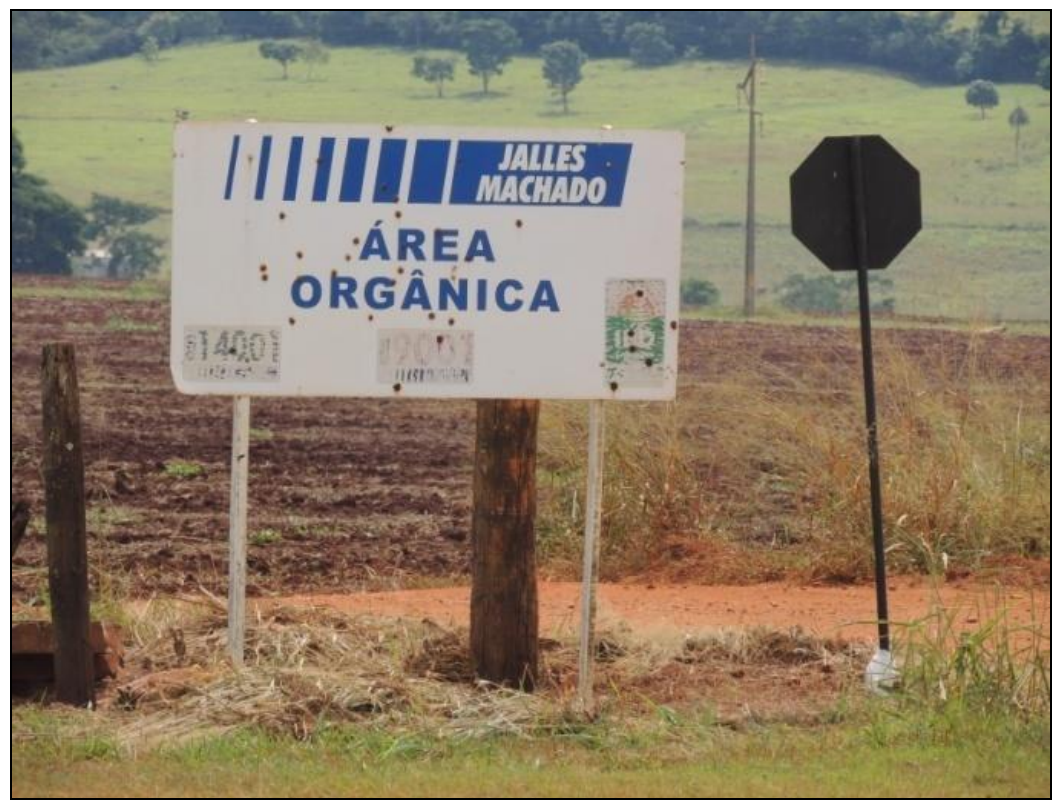

Figura 42 - Área de produção orgânica da usina Jalles Machado em Goianésia. Foto: A autora, maio de 2016.

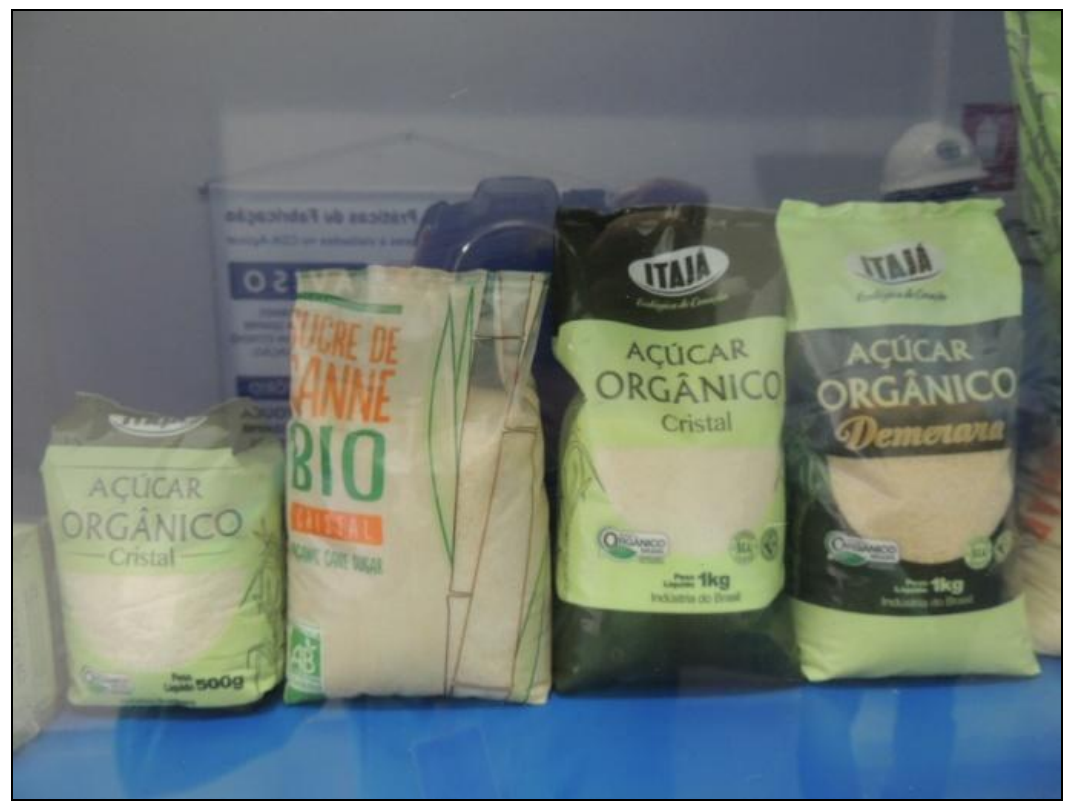

Figura 43 - Pacotes com derivações de açúcar orgânico da marca Itajá. Foto: A autora, maio de 2016.

Outras atividades que o Grupo Otávio Lage encontra-se diretamente envolvido, são as fazendas de confinamento de gado, como mencionado, por meio da Vera Cruz Agropecuária (figura 44) e, sobretudo, com a produção de seringueiras. O município de Goianésia é hoje o maior produtor de seringueira do estado de Goiás (a figura 45 mostra um seringal próximo a 
uma estrada em Goianésia). A princípio, a heveicultura começou a ser desenvolvida pelo Grupo com o intuito de empregar a mão de obra dispensada devido a mecanização da colheita da cana pela Jalles Machado.

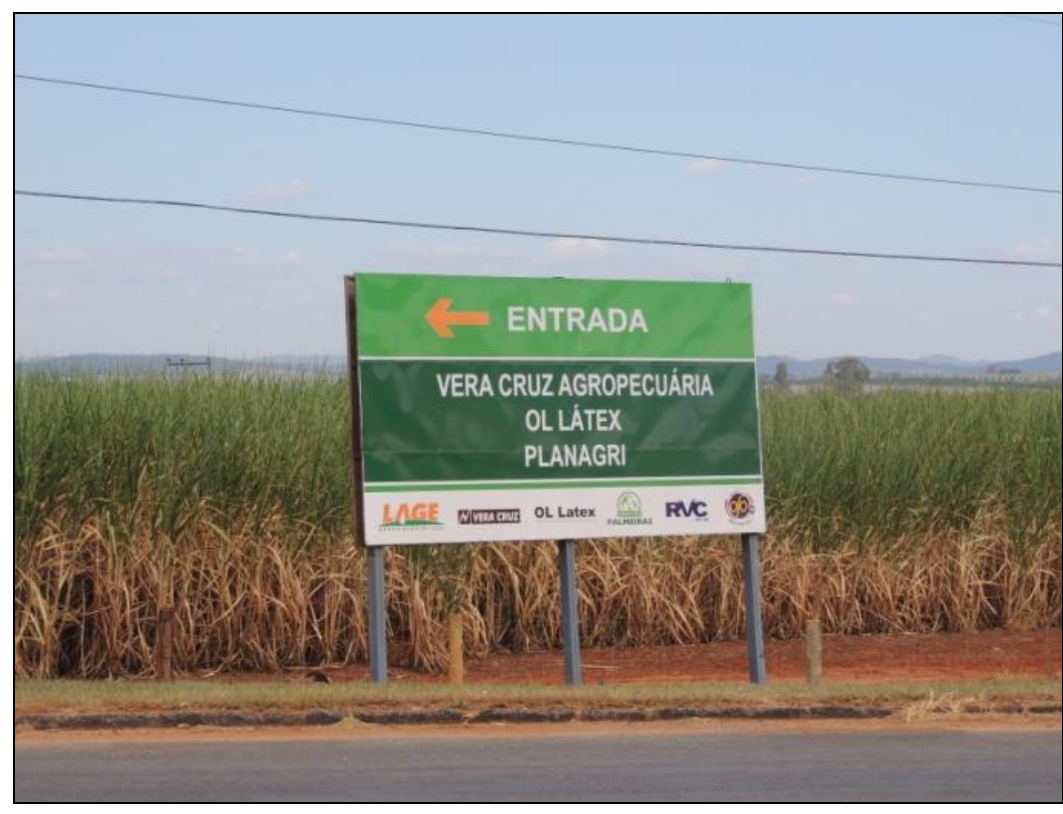

Figura 44 - Vera Cruz Agropecuária, em Goianésia. Foto: A autora, maio de 2016.

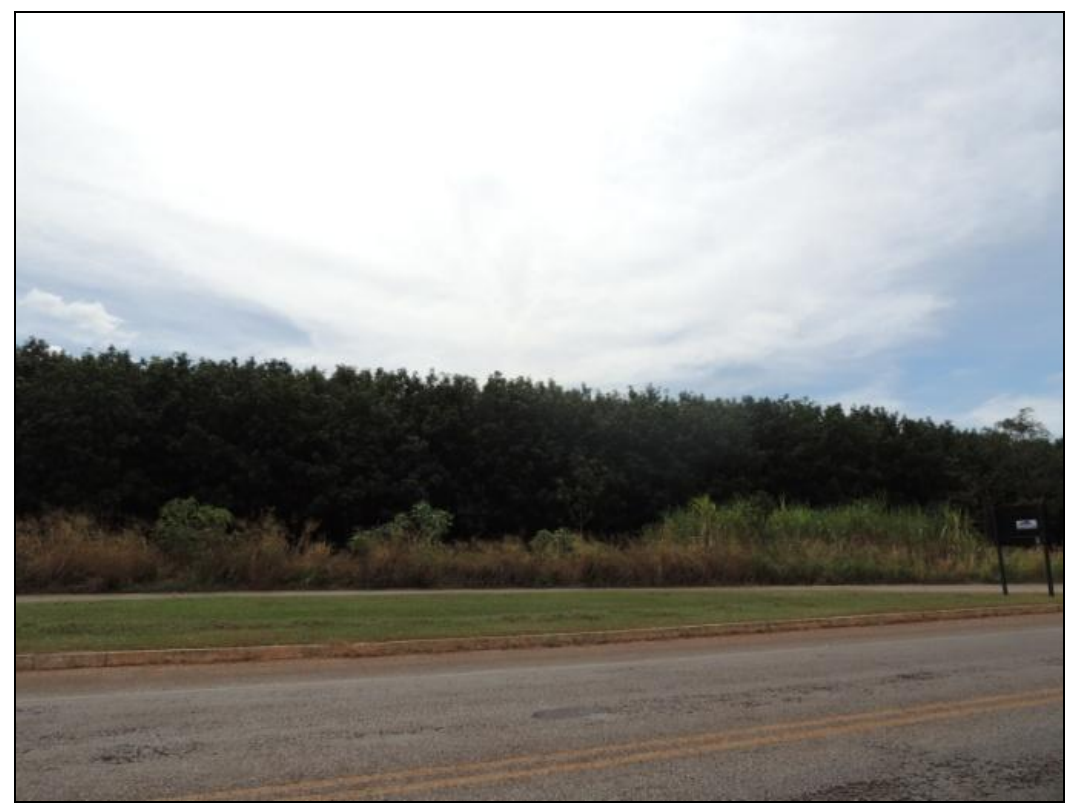

Figura 45 - Produção de seringueira, em Goianésia. Foto: A autora, maio de 2016.

Está prevista para o município de Goianésia a instalação de duas montadoras de carros, a Zotye Motors e a Electro Motors do Brasil, estas empresas utilizarão o latex produzido em 
Goianésia na confecção de pneus. A Zotye Motors do Brasil é uma montadora de veículos automotores chinesa, os investimentos serão da ordem de R \$ 88.642.791.00 milhões, com previsão de geração de 700 empregos diretos e indiretos. Além da Zotye, também será instalada uma unidade da Electro Motors do Brasil, montadora de veículos automotores de propulsão elétrica, com previsão de geração de 700 empregos diretos e indiretos, com investimentos na ordem de $\mathrm{R} \$ 82.136 .945 .00^{20}$.

A diversificação econômica verificada em Goianésia, mesmo sendo várias empresas pertencentes ao mesmo grupo/empresa, aliada à estreita ligação existente entre o grupo Otávio Lage e o poder político local e estadual (já que o atual prefeito de Goianésia é um dos donos do Grupo) faz com que esse município seja diferenciado dentro da lógica estudada na microrregião Ceres. Os demais municípios canavieiros da região possuem forte dependência da atividade sucroenergética, além de não possuírem diálogo próximo com o poder público local.

O fato de a família Lage ser de Goianésia e proprietária de um grande grupo econômico local e ainda estar diretamente relacionada ao poder político local e estadual, faz com que a população tenha uma relação de respeito com esse Grupo, já que a maioria dos moradores da cidade já trabalhou em uma de suas empresas. Isso foi verificado em algumas situações durante a realização de trabalho de campo ao município, a Diretora de Agricultura do município de Goianésia, por exemplo, havia trabalhado durante anos na Jalles Machado e assim focou seu discurso sobre a importância dessa usina para a cidade, mesmo quando questionada sobre a outra usina existente (de outro grupo). Em visita a Jalles Machado verificou-se também muitos funcionários que trabalham desde a década de 1980 na empresa, observação realizada pelo próprio gerente responsável pela visita guiada.

O contrário também é verificado, pois como o grupo tem uma relação de pertencimento com o município, além do prefeito atual ser um dos proprietários do mesmo, geralmente se interessam por parcerias e diálogos com outras esferas (mesmo porque necessitam de um feedback positivo da população nas eleições locais), o que normalmente não acontece com os grupos canavieiros externos, como os verificados nos outros municípios da microrregião Ceres.

\footnotetext{
${ }^{20}$ Informações obtidas em campo, em entrevista à Diretora de Agricultura de Goianésia, em maio de 2016, e no Jornal Diário do Norte, disponível em http://www.jornaldiariodonorte.com.br, acesso em junho de 2016.
} 


\subsection{As Formas e as Demandas vinculadas ao Setor Sucroenergético na Microrregião Ceres}

Para que a vida se realize em sociedade são necessárias múltiplas funções e quanto maiores as funções, mais diversas são as formas e os atores sociais envolvidos. Assim, quanto mais complexa é a vida em sociedade, mais distantes os seres humanos ficam do mundo natural e caminham para um mundo artificial (SANTOS, 1988). Desta forma, para que a atividade sucroenergética se desenvolva em determinado território e região são necessários vários elementos, cada vez mais artificiais, que contribuem para a realização dessa atividade.

As "velhas" formas podem ser utilizadas, (re) arranjadas ou não, bem como "novas" formas espaciais podem ser criadas. Segundo Santos (1978) as formas espaciais, criadas por uma geração ou herdadas das anteriores, têm como característica singular o fato de que, como forma material, tem uma autonomia de existência, o que lhes confere e assegura uma maneira original, de entrar em relação com os outros dados da vida social.

As formas espaciais, fruto da dinâmica canavieira, são verificadas no campo e na cidade, o que se configura em mais um elemento importante para se considerar a relação campo-cidade na análise proposta. Há algumas usinas da microrregião Ceres que estão localizadas muito próximas às sedes municipais, isso faz com que sejam mais facilmente verificadas as formas criadas ou reaproveitadas por essa atividade.

O principal exemplo é a usina CRV Industrial, no município de Carmo do Rio Verde. Por medida de segurança há algumas normativas, que podem variar de acordo com as leis municipais ou estaduais, que delimitam a distância de segurança entre a localização da usina e o perímetro urbano municipal, que é de $10 \mathrm{~km}$, o que evitaria, em caso de explosões ou acidentes mais graves nas caldeiras, alcançar a cidade e, sobretudo, a população local. No município de Carmo do Rio Verde, a usina CRV Industrial dista somente 2,5 km da cidade, isso pode ser justificado também pelo processo de expansão urbana ocorrido ao longo dos anos, pois percebeu-se uma tendência de expansão urbana, especialmente em direção a área em que a usina está implantada, como será visualizado na figura a seguir.

Conforme Sposito (2010) é importante se considerar que a cidade cresce transformando terra rural em terra urbana, contudo no caso analisado, a expansão urbana para essa região, não poderia ser aprovada, pois a proximidade à usina oferece perigo à sociedade, já que se trata da produção de um produto altamente inflamável, como o etanol, sendo necessário manter a distância de segurança. 
Com essa proximidade física da usina ao perímetro urbano, fica mais fácil perceber as relações estabelecidas entre campo e cidade, já que é rotina verificar próximo ao perímetro urbano: cortadores de cana, caminhões transportando a cana cortada, a fuligem da cana queimada e, até mesmo, o cheiro marcante da vinhaça. A figura 46 mostra a área urbana edificada de Carmo do Rio Verde e onde está localizada a usina CRV Industrial. As fotos numeradas na figura mostram a planta industrial, a proximidade da usina à rodovia, o tráfego de caminhões transportando a cana e o asfalto com muitos "remendos" no perímetro urbano, devido ao intenso tráfego de veículos pesados na cidade.

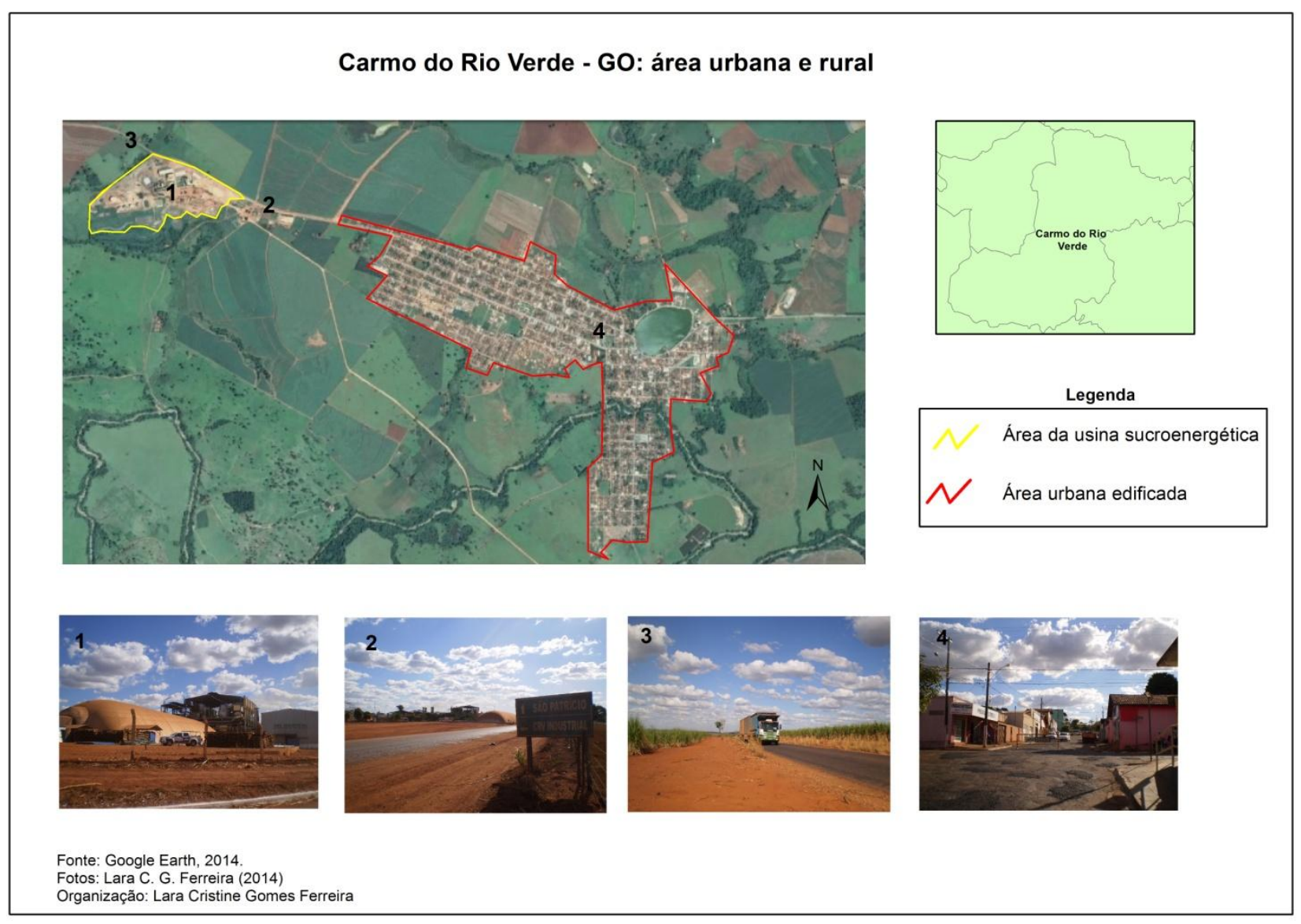

Figura 46 - Área urbana edificada de Carmo do Rio Verde e a usina CRV Industrial. Fotos: A autora, 2014.

Algumas formas espaciais podem ser verificadas por meio da figura 46 e também se repetem em outros municípios canavieiros. A forma mais contundente nos municípios usineiros são as plantas industriais, nelas se observam a indústria, os galpões, a fumaça, elementos indicativos de uma usina em funcionamento (figura 47). Em toda região é possível verificar lavouras de cana-de-açúcar, principalmente quando se trafega nas rodovias que ligam os 
municípios. É fácil perceber a atividade canavieira, seja no período de safra, com as colhedoras, caminhões, tratores e trabalhadores rurais, ou seja na entressafra, com o período de rebrota e desenvolvimento da cana (figura 48).

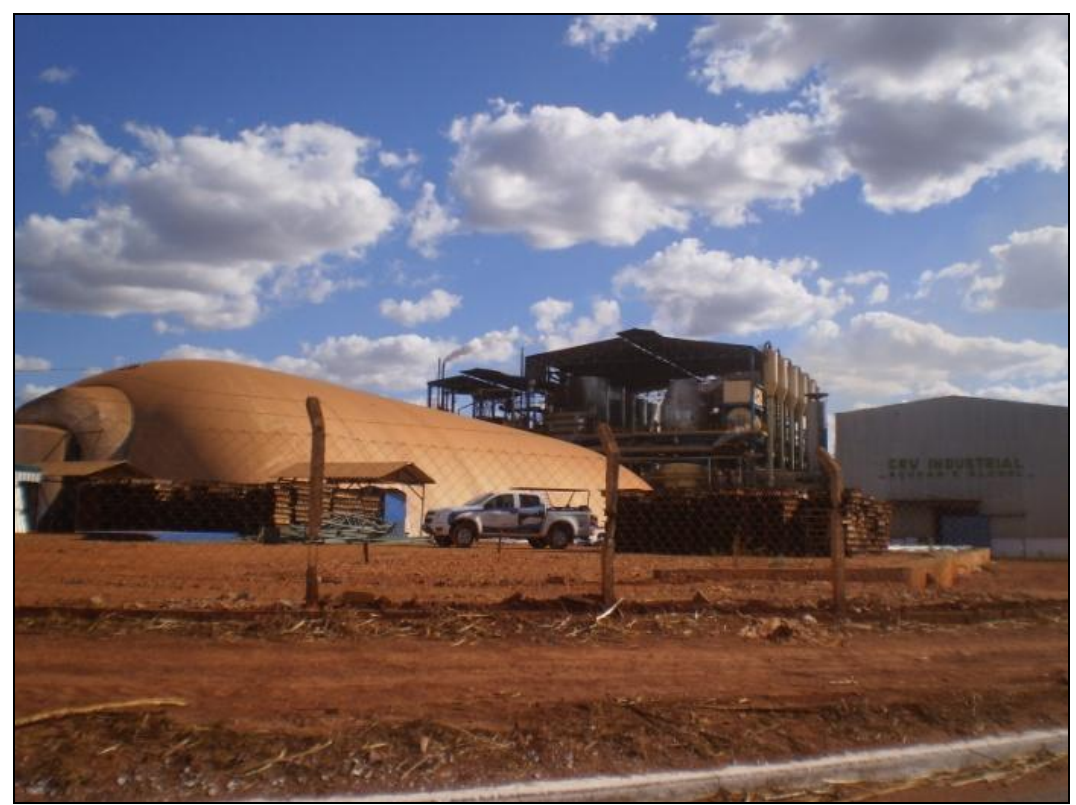

Figura 47 - Planta industrial da CRV Industrial, Carmo do Rio Verde. Foto: A autora, maio de 2016.

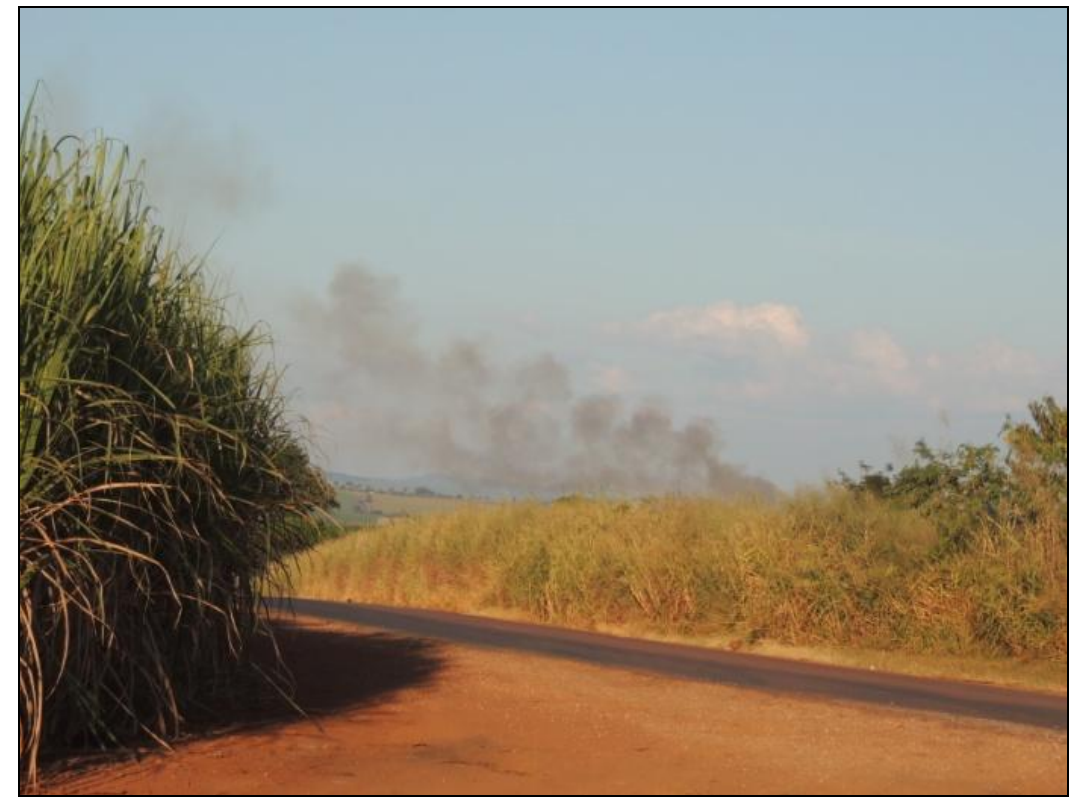

Figura 48 - Lavoura de cana, rodovia e fumaça ao fundo, em Carmo do Rio Verde. Foto: A autora, maio de 2016.

A monocultura de cana-de-açúcar é muito mais que uma forma espacial, ela revela a progressiva substituição dos sistemas técnicos agrícolas e uma profunda mudança das formas 
de uso e ocupação do espaço, com forte substituição da produção de alimentos ou da pecuária, pela produção de cana e derivados. Quando se adentra à microrregião Ceres fica perceptível que a cultura canavieira é dominante, o que acaba por substituir possíveis vocações naturais pelas imposições econômicas, difundindo especializações produtivas, como bem explicitou Elias (2011).

Destaca-se também que as rodovias, que são utilizadas por carros de passeio, ônibus e outros, também são utilizadas para transportar a cana-de-açúcar, entre as lavouras canavieiras e as usinas (figura 49). O raio médio de distância entre as áreas de produção e as usinas é de 50 $\mathrm{km}$, pois acima disso acaba por onerar o processo produtivo devido aos altos custos de transporte. Contudo, durante entrevista ao Agrônomo da Usina Vale Verde de Itapaci, o mesmo relatou que esse raio de $50 \mathrm{~km}$ pode ser facilmente ultrapassado para plantio e colheita de canade-açúcar, em busca de terras disponíveis, principalmente mais planas para a colheira mecanizada.

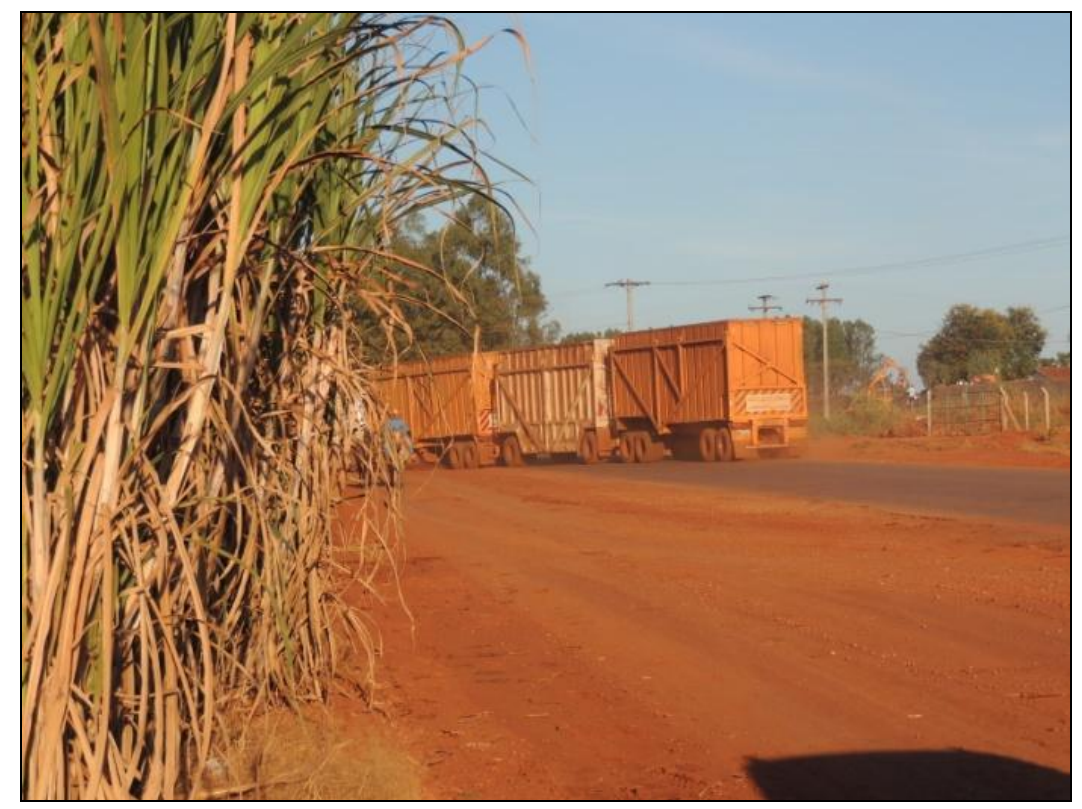

Figura 49 - Treminhões para colheita de cana, Carmo do Rio Verde. Foto: A autora, maio de 2016.

A cana transportada, somada ao peso do treminhão, ultrapassa facilmente 100 toneladas o que acaba sobrecarregando e estragando o asfalto com mais rapidez. Assim é bastante comum observar, junto à paisagem canavieira, às margens das rodovias, vários buracos e falhas no asfalto, além de acidentes envolvendo os treminhões, como pode ser observado pela figura 50. 


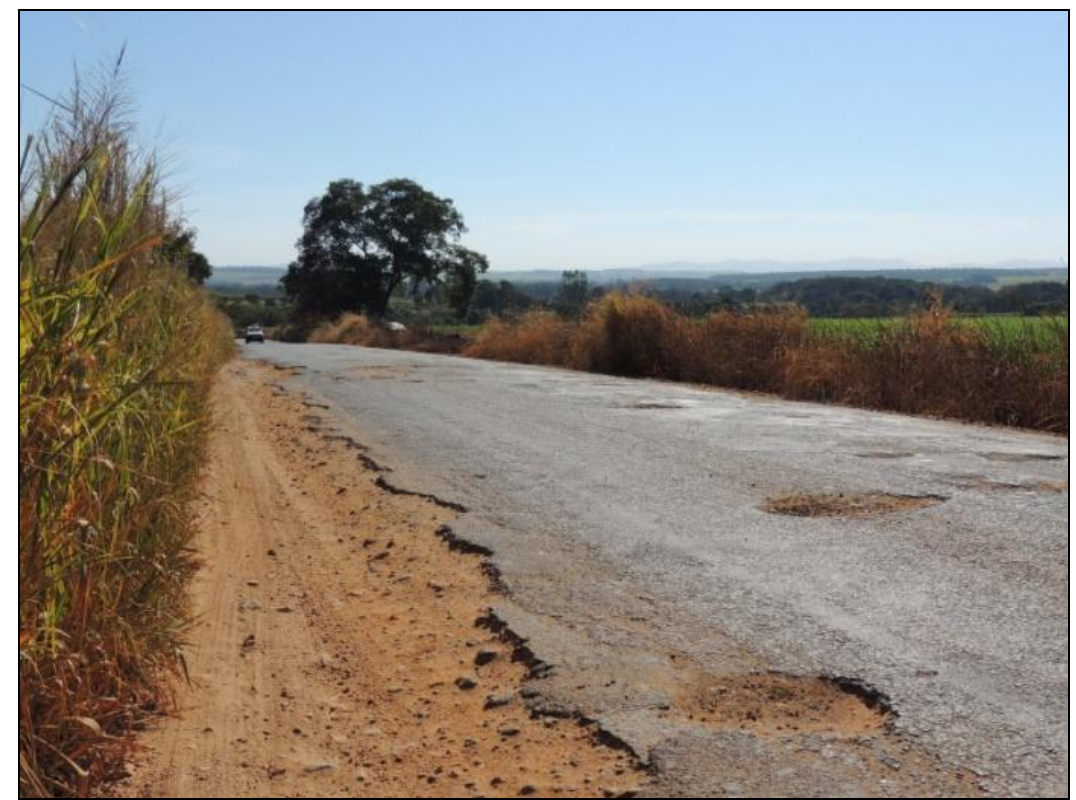

Figura 50 - Rodovia em péssimas condições devido o transporte de treminhões, Rubiataba. Foto: A autora, maio de 2016.

Além das formas espaciais mais comuns fruto da atividade sucroenergética, podem-se observar várias demandas desse setor, que são perceptíveis no campo e, sobretudo na cidade, que também acabam compondo a paisagem regional. Como já mencionado, as usinas se relacionam de distintas formas com o poder público e com a população local. Percebeu-se, de modo geral nas atividades de campo, que com exceção à usina Jalles Machado, as demais possuem uma relação conflituosa com o poder público local, mas estes consideram as usinas de grande importância socioeconômica, apesar de reconhecerem os problemas relacionados a esse empreendimento.

Normalmente as usinas utilizam-se de serviços e comércios locais e regionais demandados pela atividade agrícola e industrial. Contudo, observou-se que demandas mais complexas como: manutenção das máquinas agrícolas e colhedoras de cana e/ou suplementos mais específicos, são adquiridos de outras cidades, principalmente São Paulo e Goiânia. Os serviços e comércios que se desenvolvem nas cidades canavieiras da microrregião Ceres são mais simples e imediatos, como itens de supermercado, alugueis de ônibus para transporte de trabalhadores, manutenção em ar condicionados, entre outros.

Ao contrário de várias cidades que se organizam para servir ao agronegócio, tornandose verdadeiras cidades funcionais para o desenvolvimento dessas atividades modernas do campo, as cidades da microrregião Ceres apresentam poucas prestadoras de serviços e 
comércio especializado, devido à característica que essa região apresenta de estar focada no segmento canavieiro.

O município de Goianésia, que é o único da região que apresenta certa diversificação em atividades, com outros segmentos econômicos fortes (mesmo apresentando um monopólio relacionado ao Grupo Otávio Lage), também não apresenta grandes lojas de maquinários, quantidade relevante de agências bancárias e, principalmente, não é sede de grandes escritórios de empresas agroexportadoras, como é bastante comum nas cidades baseadas em vários segmentos do agronegócio, como grãos, carne e energia.

Para Frederico (2011), a presença de escritórios exportadores nas cidades do agronegócio tem uma função estratégica, são pontos de uma rede mundial que interliga desde as cidades do agronegócio, dispersas pela fronteira agrícola moderna, passando pelos principais portos exportadores e centros financeiros do país, até a bolsa de valores de Chicago (CBOT) e os países importadores de commodities agrícolas. Assim, as cidades da microrregião Ceres, mesmo apresentando uma estreita relação com o agronegócio canavieiro, estão muito distantes das chamadas cidades do agronegócio trabalhadas por autores como Frederico (2011) e, sobretudo, Elias (2011; 2012; 2013).

O comércio voltado para as atividades agrícolas, verificado nas cidades da microrregião Ceres, é muito simples, geralmente focado em ração, ferramentas, adubos, sementes, entre outros produtos de menor complexidade (figura 51). O único município da região estudada que apresenta loja de comercialização de tratores é Goianésia. Esta apresenta uma loja da Valtra Borgato, grande empresa multinacional especializada na comercialização de tratores e máquinas agrícolas (figura 52). 


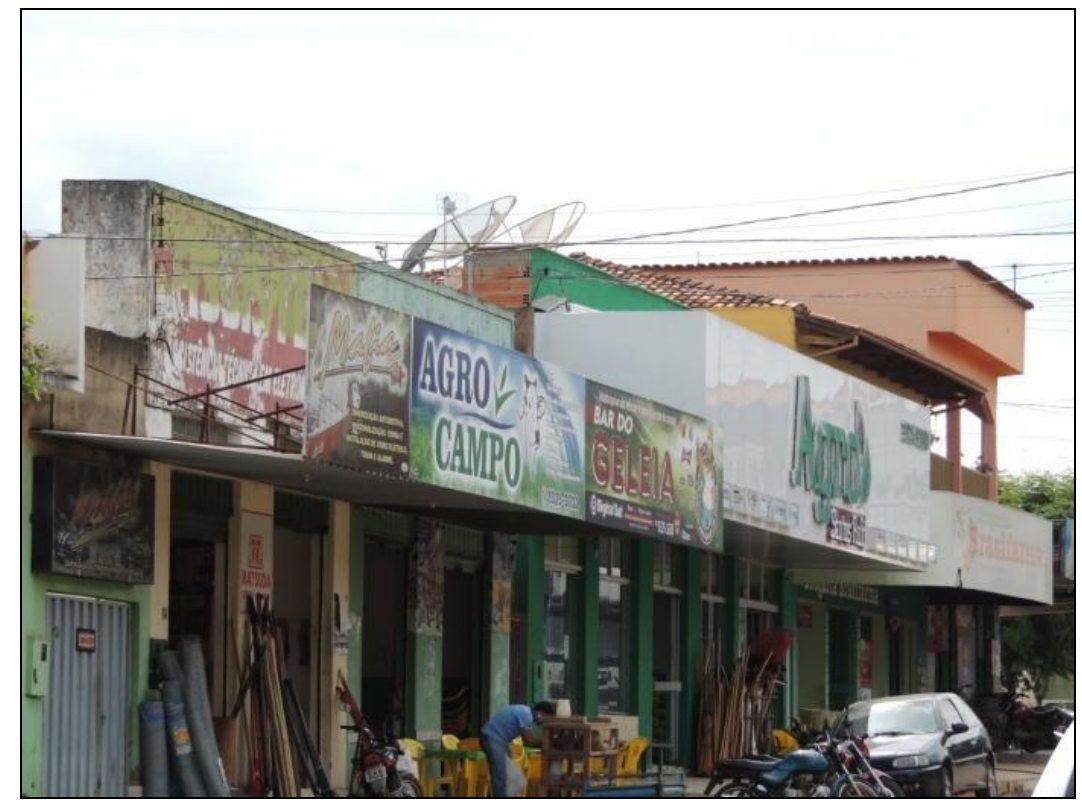

Figura 51 - Lojas de produtos agropecuários, em Rubiataba. Foto: A autora, maio de 2016.

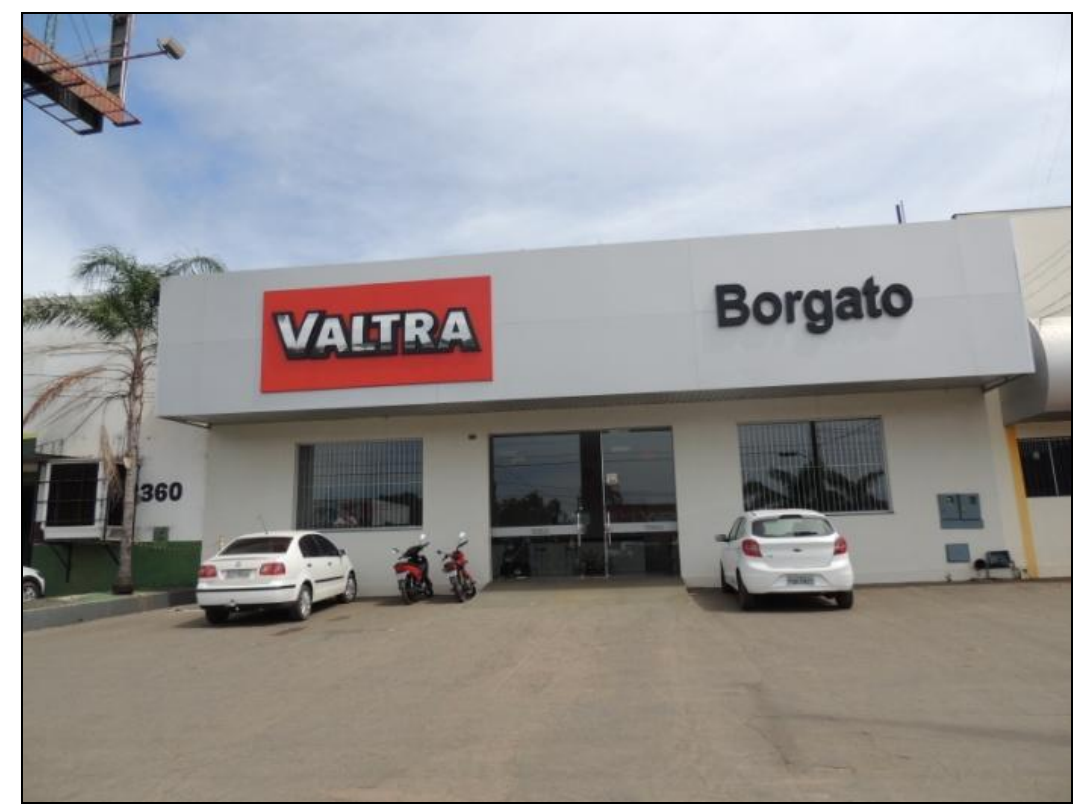

Figura 52 - Presença de loja Valtra Borgato, em Goianésia. Foto: A autora, maio de 2016.

Em relação à prestação de serviços, percebeu-se que as usinas utilizam principalmente, o serviço terceirizado de alugueis de ônibus para o transporte dos trabalhadores rurais (figura 53). Em todos os municípios que possuem usinas em funcionamento e até alguns municípios vizinhos que possuem moradores que trabalham nessas usinas, apresentam em sua paisagem os 
ônibus de transporte rural. Como a usina funciona 24 horas por dia é muito comum visualizar os ônibus transitando pela cidade para cumprir os turnos matutino, vespertino e noturno.

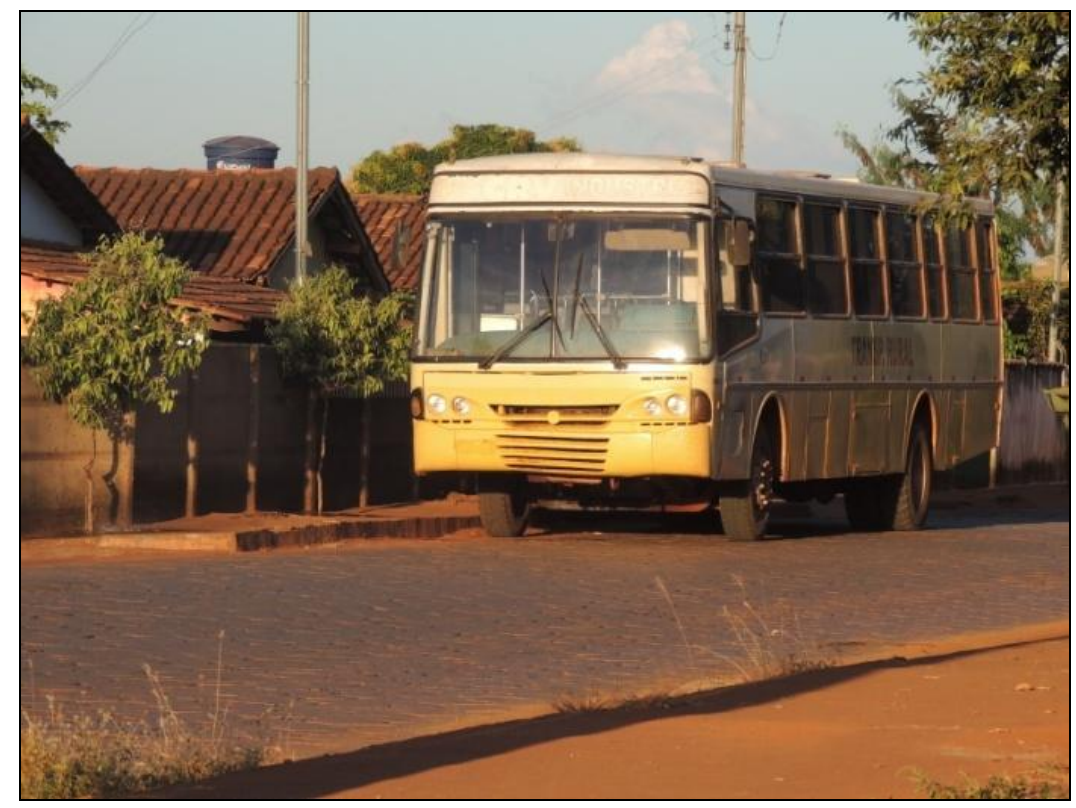

Figura 53 - Ônibus utilizado para transporte rural, em Carmo do Rio Verde Foto: A autora, maio de 2016.

Outro serviço importante para os municípios que possuem grandes empresas instaladas são as hospedagens, já que geralmente recebem representantes comerciais, visitas técnicas, etc.. Esse serviço está diretamente relacionado à complexidade econômica do município, o município de Goianésia, por exemplo, possui muitos hotéis, com tamanhos e qualidade variada, já o município de Carmo do Rio Verde, tem somente uma pousada muito simples. A figura 54 mostra um dos hotéis localizados em Goianésia, que atendem as demandas de hospedagem do município. 


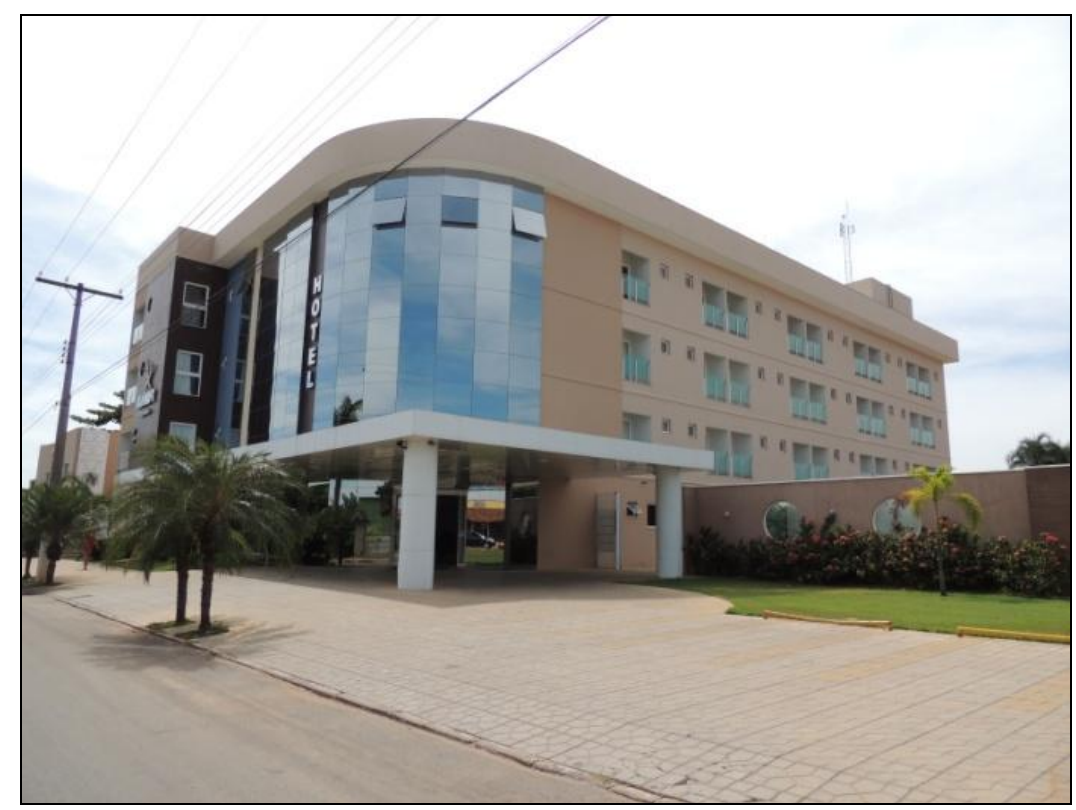

Figura 54 - Hotel em Goianésia. Foto: A autora, maio de 2016.

Obviamente, o que fica claro na relação estabelecida entre as usinas e as demandas criadas por elas, que inicialmente poderiam contribuir para o desenvolvimento do comércio e prestação de serviços local e regional, é que as usinas da microrregião Ceres não fazem grandes compras nesses municípios, pois esses não apresentam comércio especializado de maquinários, por exemplo, muito menos utilizam mão de obra local para a manutenção das máquinas e colhedoras de cana, geralmente os serviços mais simples são realizados por uma mecânica existente dentro da usina, e para os serviços de manutenção e consertos mais complexos recorre-se a centros maiores, como Goiânia, Brasília e São Paulo.

Outra questão que reforça essa discussão são as formações realizadas pelo SENAI (Serviço Nacional de Aprendizado Industrial), principalmente com cursos nas áreas industriais, em parceria com as usinas ou prefeituras. Os cursos ofertados pelo SENAI chegam em estruturas móveis nas cidades e promovem as formações.

Ressalta-se que a parceria feita entre o SENAI e as usinas e prefeituras são de suma importância para as formações profissionais, contudo entende-se que na maioria das cidades canavieiras da microrregião Ceres, não há escolas de formação e cursos técnicos, o que seria o ideal, pois estimularia a formação profissional local, além de gerar emprego para a população. As figuras 55 e 56 mostram os ônibus do SENAI que estavam no município de Carmo do Rio Verde, em maio de 2016, ofertando cursos de manutenção em máquinas agrícolas e de manutenção mecânica. 


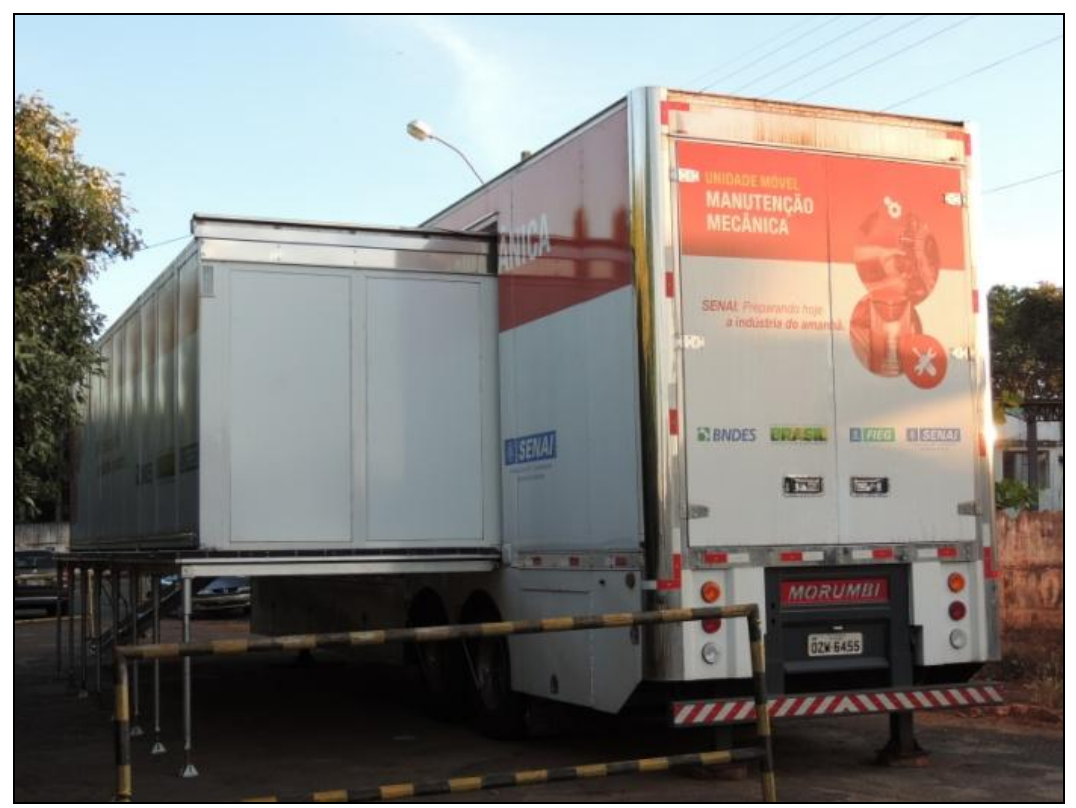

Figura 55 - Ônibus do SENAI, manutenção mecânica, em Carmo do Rio Verde. Foto: A autora, maio de 2016.

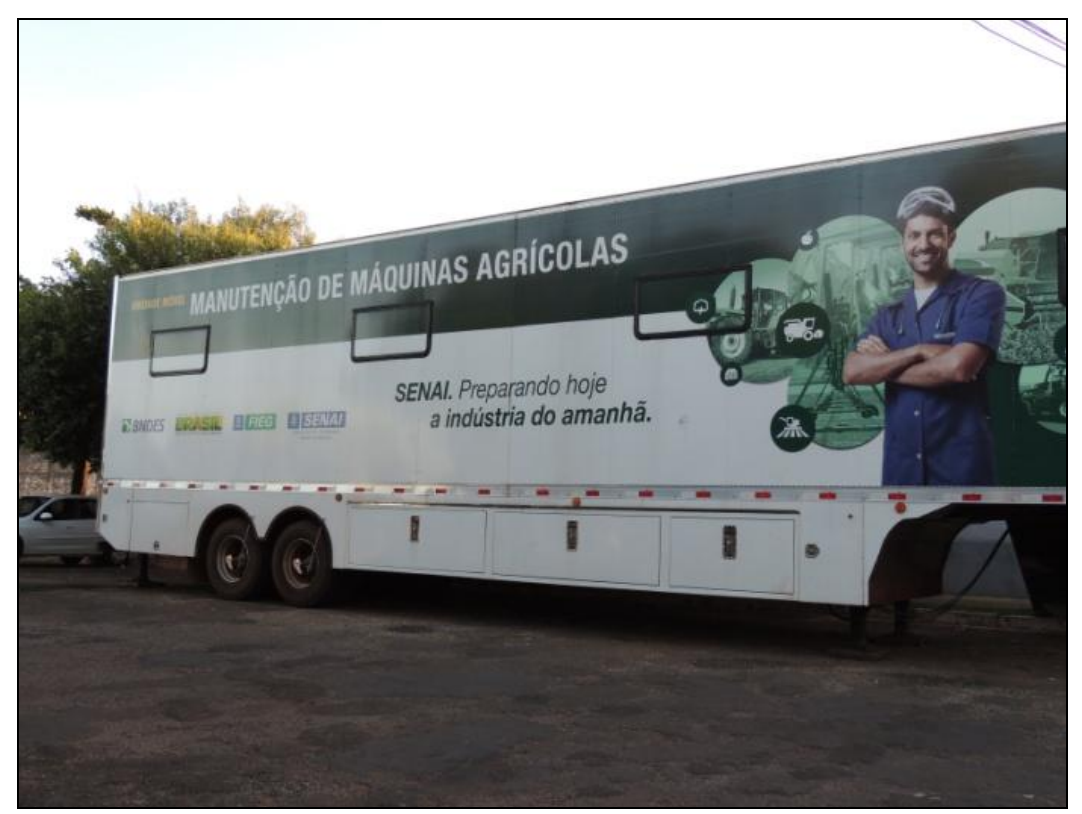

Figura 56 - Ônibus do SENAI, manutenção de máquinas agrícolas, em Carmo do Rio Verde. Foto: A autora, maio de 2016.

Por meio das observações de campo, leituras e entrevistas realizadas nas prefeituras e nas usinas da região estudada, pode-se inferir que as formas espaciais e as demandas criadas pelo setor sucroenergético na microrregião Ceres são menos expansivas, no sentido de possuir menos alcance, sobretudo internacional (se comparado a outras cidades baseadas no 
agronegócio), já que são pouquíssimas as empresas de capital estrangeiro implantadas nesses municípios, além de trazer poucos signos da modernidade, que geralmente são atribuídos ao agronegócio.

Isso não significa dizer que não há formas espaciais e elementos na paisagem regional vinculados a dinâmica do agronegócio, pelo contrário, eles existem e são simultaneamente ligados à dinâmica canavieira quando observados, contudo percebe-se que de forma bem mais marginal e fragilizada, que se comparado às cidades do agronegócio. As formas e elementos mais perceptíveis estão relacionados aos efeitos da atividade sucroenergética nesses municípios, que confirmam a concentração de renda e a desigualdades socioeconômicas fruto dessa atividade.

Frederico (2011) apontava que, nas cidades do agronegócio, são facilmente verificados fluxos de toda ordem perpassando os territórios, desde aqueles promovidos e controlados pelas grandes empresas, como fluxos de mercadorias, dinheiro, informação e profissionais qualificados, até a migração de trabalhadores não qualificados atraídos pelos signos da modernidade. Não que isso seja demasiadamente positivo, mas a sensação que se tem quando se conhece uma cidade canavieira da microrregião Ceres é que elas não apresentam essa dinâmica de capital internacional, fluxos de todas as ordens, enfim essa efervescência econômica verificada nas cidades do agronegócio, o que demonstra um intenso uso do território pelas agroindústrias, mas pouco retorno socioeconômico, poucas relações financeiras e redes estabelecidas.

Com exceção ao município de Goianésia, os demais municípios da região demonstraram-se muito preocupados quando questionados sobre uma possível grave crise na atividade canavieira e fechamento das usinas ${ }^{21}$. Os agentes do poder público local entrevistados, preocupam-se com as consequências socioeconômicas locais, como um grave quadro de desemprego e a iminente necessidade que algumas cidades teriam em descobrir outras vocações econômicas (alternativas à "tradicional" atividade canavieira) para tentarem se reestruturar economicamente.

Faz-se importante ressaltar, que tanto as cidades do agronegócio, citadas por Frederico e Elias, quanto as cidades canavieiras da microrregião Ceres, possuem bônus e vários ônus frutos dessa atividade, entretanto defende-se aqui a evidência da vulnerabilidade econômica e,

\footnotetext{
${ }^{21}$ Foram realizadas entrevistas a todos os municípios que possuem empreendimentos canavieiros na microrregião Ceres: Carmo do Rio Verde, Goianésia, Itapaci, Itapuranga e Rubiataba. As entrevistas foram focadas nos Secretários de Agricultura ou Diretores Agrícolas desses municípios, como representantes do poder público local.
} 
consequentemente social, das cidades voltadas para a atividade canavieira, principalmente as que não apresentam diversificação nas atividades econômicas, de forma geral, e mesmo dentro do agronegócio, como se verifica em grande parte dos municípios da microrregião Ceres.

No próximo capítulo, será apresentada a (re)configuração da rede urbana da microrregião Ceres, utilizando-se sobretudo, dos dados da Regic - Região de Influência das Cidades (IBGE). Por meio dessa análise, foi possível observar o papel dos empreendimentos canavieiros na rede urbana microrregional, além de introduzir a discussão iminente de um “ordenamento territorial da cana" nessa microrregião. 


\section{CAPÍTULO IV - A FORMAÇÃO DA REDE URBANA E O ORDENAMENTO TERRITORIAL PELA DINÂMICA CANAVIEIRA: A "NOVA" CONFIGURAÇÃO SOCIOESPACIAL}

Para se compreender a dinâmica e os efeitos da atividade sucroenergética na microrregião Ceres é preciso verificar sua influência na rede urbana regional. Entende-se que as agroindústrias canavieiras e a rede estabelecida, funcionam como elementos importantes para o ordenamento territorial e contribuem para sua reconfiguração socioespacial, bem como para mudanças nos papéis desempenhados pelos centros urbanos em rede e também na relação campo-cidade.

A partir da década de 1970, por meio da política de modernização agropecuária, viabilizada pela política de integração nacional, a agricultura do estado de Goiás passou por transformações significativas, com o objetivo de estreitar as relações entre o setor agrícola e o urbano-industrial (FERREIRA; MENDES, 2009). São as transformações ocorridas a partir desse período, do processo de modernização agrícola, que estão mais latentes na paisagem, podem-se citar: as relações de trabalho estabelecidas (e as várias especializações), as técnicas e tecnologias disponíveis (implementos, maquinários), os fixos e as redes estabelecidas pelos complexos agroindustriais, dentre outros.

Assim, nesse capítulo, buscam-se elementos para compreender como a dinâmica sucroenergética, por meio de um "ordenamento territorial da cana", pode ter influenciado uma "nova" configuração socioespacial. Esse Capítulo busca compreender como se comporta a rede de cidades da microrregião Ceres, como a atividade sucroenergética pode influenciar na reconfiguração da rede urbana, como se comportam os diferentes municípios, eles são distintos na rede ou desempenham o mesmo papel e função?

Procura-se também discutir nesse capítulo, quais são os efeitos verificados em municípios que possuem uma extensa área em plantação de cana-de-açúcar na região, mas não possuem usinas para o processamento. Como essas cidades, que servem ao agronegócio, como fornecedoras de cana, participam ou se inserem na lógica do agronegócio sucroenergético da microrregião Ceres.

Parte-se da afirmação de Egler (2011), o qual entende que a rede urbana tem importância decisiva para a dinâmica espacial e, portanto, para o desenvolvimento regional, considerado em sua dimensão territorial. A manifestação mais concreta dos níveis de integração territorial em uma determinada região é a estruturação de seu sistema urbano. 
Ainda para Egler (2011), o estágio de desenvolvimento da rede urbana revela os níveis de integração produtiva e financeira entre as regiões em âmbito nacional e até internacional. Assim, procurar-se-á entender, por meio da análise da evolução da rede urbana da microrregião Ceres, bem como de dados socioeconômicos e financeiros, a realidade da rede urbana regional; as desigualdades entre os municípios, frente à disponibilidade de serviços financeiros e renda, além de discutir sobre as fragilidades encontradas, fruto do desenvolvimento incompleto relacionado ao agronegócio sucroenergético nessa região.

O ordenamento territorial da cana acaba por dinamizar algumas cidades, principalmente as cidades que sediam usinas, por meio da geração de empregos, atração de prestadoras de serviços e renda. Contudo, os empregos são sazonais, devido aos períodos de safra e entressafra das usinas, as prestadoras de serviços são concentradas e, na maioria das vezes, localizadas em cidades voltadas aos serviços e não ao agronegócio; e a renda é extremamente concentrada em pequena parcela da população. Assim, é perceptível a relação dialética estabelecida na região: simultaneamente a uma dinamização socioeconômica, há também o reforço da desigualdade entre os municípios pertencentes à região, o que gera um pseudo desenvolvimento regional.

\subsection{A Rede Urbana e o Ordenamento Territorial - Alguns Apontamentos}

A estruturação da rede urbana do que hoje corresponde à microrregião Ceres é recente, contudo cabe destacar que o processo de interiorização e construção de uma rede urbana pretérita em Goiás é bem anterior e remonta ao período imperial no Brasil. Segundo Ferreira e Mendes (2009), um período de decadência econômica em Minas Gerais e no nordeste brasileiro, fomentou deslocamentos para o centro oeste brasileiro contribuindo para a ampliação do sistema econômico agrícola, pecuarista e comercial, desde o começo do século XIX.

Ainda segundo Ferreira e Mendes (2009), os primeiros núcleos populacionais de Goiás foram constituídos por duas frentes colonizadoras, uma pelo sul, por meio dos bandeirantes paulistas que atravessaram o Rio Paranaíba e outra pelo norte, formada pelos migrantes da Bahia, Pará e Maranhão, que vieram pelo vale do Rio Tocantins. É importante mencionar a importância dos rios para os primeiros povoamentos no centro do país, anterior a abertura de estradas, eram nas proximidades dos rios que os povoados se constituíam (isso ainda é perceptível em algumas cidades do estado de Goiás, como característica marcante da rede urbana pretérita). 
Até o início do século XX, após o período aurífero do século XVIII, a província de Goiás passou a apresentar um forte caráter pecuarista e já apresentava uma estrutura fundiária extremamente concentrada. A difícil fiscalização das terras e dos documentos, somado ao coronelismo existente na região, fez com que houvessem grandes extensões de terras nas mãos de poucas famílias tradicionais.

O desenvolvimento dos meios de transporte e a abertura e estradas e ferrovias, foi fundamental para diversificar e aumentar a produção, principalmente a partir dos anos 1920, e mais focado no sul goiano. Foi a partir da década de 1930 que a a Estrada de Ferro Goiás chegou até o município de Anápolis (ESTEVAM, 2004). A partir daí intensificou-se o processo de ocupação e povoamento do centro oeste brasileiro, sobretudo após a política da "Marcha para o Oeste" na década de 1940.

Diante dessa breve síntese, pode-de afirmar que a formação da rede urbana da microrregião Ceres é muito recente (já que grande parte da estruturação da rede urbana dessa região inicia-se a partir dos anos 1940) e teve como principais agentes o Estado e o capital privado (ou o articulação entre esses dois agentes), principalmente vinculada às agroindústrias canavieiras em período mais recente.

O papel do Estado é fundamental para a formação e (re) configuração da rede urbana, já que por meio de políticas públicas, programas governamentais e a construção de infraestruturas, acaba direcionando a ocupação da região, intensificando a atividade produtiva e a geração de diversos fluxos (capitais, matéria prima, mão de obra) e consequentemente o uso da mesma.

Para a região de Ceres as principais políticas e programas que contribuíram, sobremaneira, para a configuração da rede urbana foram realizadas durante os anos 1940 e 1970, especialmente. A década de 1940, com a "Marcha para o Oeste" e o projeto das Colônias Agrícolas Nacionais foram, de fato, muito importantes para a ocupação do centro brasileiro e da região estudada. O município de Ceres, porção principal que abrigou a CANG nos anos 1940, recebeu investimentos na área de saúde e educação que até os dias atuais o configuram como principal centralidade vinculada à prestação de serviços.

A década de 1950, com a emancipação do município de Ceres e o fim da CANG, bem como com o início da construção da BR 153, foi um contexto fundamental para a fragmentação territorial e consequente conformação da rede urbana regional. A construção de Goiânia e de Brasília, bem como as transferências da Capital do estado de Goiás, na década de 1930, e da Capital Federal, na década de 1960, além do conjunto de Programas Federais voltados à 
modernização da agricultura, na década de 1970, com o objetivo de "desenvolvimento" do Cerrado foram responsáveis por um contexto de grande ocupação da região Centro-Oeste brasileira e expansão da fronteira agrícola, além da criação do Proálcool, que foi responsável pela expansão das lavouras de cana-de-açúcar pelo Brasil e implantação de destilarias para a produção de álcool combustível, no contexto da crise mundial do petróleo, conforme já mencionado.

As ações do Estado, com ou sem parcerias com o capital privado (ou no caso estudado, com a lógica do agronegócio sucroenergético), são fundamentais para o ordenamento do território. A escolha de onde seria implantada a primeira Colônia Agrícola Nacional, no centro do Brasil, onde hoje é o município de Ceres, não foi aleatória, bem como a construção de uma rodovia que ligasse o país de norte a sul e os altos investimentos em técnicas e tecnologias agrícolas, no contexto da modernização da agricultura.

Todas essas ações foram responsáveis por direcionar a migração interna e consequente ocupação dos "vazios demográficos" de um país com dimensões continentais como o Brasil, além de expandir a fronteira agrícola para o centro-oeste brasileiro, criando novos municípios em áreas de ocupação rarefeita, até então.

Segundo Martins (2014) a ocupação do oeste brasileiro, acelerada pelo regime militar, tinha objetivos econômicos, mas, sobretudo, geopolíticos. Falava-se muito em "vazios demográficos", contudo a região já estava ocupada por diversos grupos indígenas, além de uma população camponesa, mesmo que ainda dispersa, desde o século XVIII, pelo menos.

No Brasil, o Estado acaba sendo o principal agente de planejamento do território e, consequentemente, de como acontecerá seu ordenamento ou organização espacial. Cada vez mais o Estado se associa a grandes empresas e tende a se apoderar de funções, atributos e prerrogativas da sociedade urbana, retirando dela poder político, desvalorizando-a. Segundo Marques (2002), a cidade é transformada em meio, dispositivo material a serviço da organização da produção, do controle da vida cotidiana e da programação do consumo.

Em termos genéricos a rede urbana constitui-se como um conjunto de centros urbanos funcionalmente articulados entre si, sendo um produto social cujo principal papel é o de garantir a existência da sociedade articulada numa dada porção do espaço e sua reprodução (CORRÊA, 2005). Dessa forma, o espaço urbano é fragmentado e articulado, decorrentes dos agentes modeladores que produzem e consomem o espaço urbano.

De modo geral, os estudos de rede urbana no Brasil são muito recentes e se intensificaram com o processo de urbanização nacional, principalmente após os anos 1970. 
Como o Brasil não possuía Universidades até o início do século XX e para tentar compreender os desafios do desenvolvimento urbano-industrial, o Estado brasileiro apoiou a vinda de pesquisadores estrangeiros ao Brasil, para auxiliar na construção de um ambiente acadêmico e de pesquisa.

Podem-se destacar Pierre Deffontaines e Pierre Monbeig, nos anos 1930, e Jean Tricart e Michel Rochefort, nos anos 1950 (EGLER, et al, 2011). Esses pesquisadores contribuíram para a construção da Universidade do Estado de São Paulo e da atual Universidade Federal do Rio de Janeiro, além de contribuir sobremaneira para a criação do atual Instituto Brasileiro de Geografia e Estatística - IBGE. Outro autor bastante utilizado para entender a rede urbana brasileira foi Walter Christaller, que realizou a Teoria das Localidades Centrais, um estudo baseado no sul da Alemanha, na década de 1930.

Segundo a Teoria das Localidades Centrais de Christaller, existem princípios gerais que regulam o número, distribuição e tamanho dos povoamentos. Há núcleos semi rurais, pequenos, médios e grandes núcleos urbanos, que são considerados localidades centrais. Todos esses possuem funções centrais para uma população externa, residente na hinterlândia (região de influência). A centralidade de determinado núcleo está diretamente relacionado ao grau de importância que desempenha a partir de suas funções centrais, como: maior região de influência, maior população atendida pela localidade central, funções mais complexas, entre outras (CORRÊA, 1994).

Dentro da teoria de Christaller, ainda pode ser destacado os conceitos de alcance espacial máximo, que corresponde à área determinada por um raio a partir da localidade central; e alcance espacial mínimo, que compreende a área que engloba um número mínimo de consumidores, assim, por meio do alcance espacial máximo e mínimo, pode-se verificar uma diferenciação da oferta de bens e serviços.

Essa teoria embasou vários estudos brasileiros e até hoje é considerada como base para o entendimento das redes urbanas, contudo é importante salientar que essa teoria foi realizada para uma realidade européia da década de 1930. Considera-se portanto sua importância para os estudos de redes, fluxos, centralidades, mas entende-se a importância de adaptação à realidade brasileira, por seu contexto de formação, (re) produção e complexidade, distintos da realidade alemã do início do século XX.

O IBGE tem um papel fundamental nos estudos relacionados à rede urbana brasileira, são várias pesquisas e estudos que demonstram a velocidade e a instabilidade da configuração da rede urbana do Brasil, além dos fluxos migratórios muito relacionados às frentes pioneiras 
que se instalaram no Brasil ao longo do tempo. Destaca-se o estudo "Região de Influência das Cidades" - REGIC, que buscou analisar as centralidades, os fluxos e as transformações registradas na rede urbana brasileira ao longo dos anos (foram realizados três estudos do REGIC, nos anos 1978, 1993 e 2007, que foram publicados em 1987, 2000 e 2008, respectivamente).

Diante do breve exposto, entende-se que os principais agentes, que acabam por modelar e reconfigurar o espaço geográfico, acabam por realizar um ordenamento do território, sobretudo em tempos de complexa estrutura capitalista. Tanto o Estado, por meio das políticas e programas, quanto às indústrias, grandes empresas e corporações acabam ordenando o território e fomentando a reconfiguração da rede urbana de acordo com os variados interesses.

No Brasil, por exemplo, é comum observar o deslocamento da fronteira agrícola para determinada região (estrategicamente pensada) e o consequente deslocamento da pecuária para outros estados e regiões, bem como a substituição de lavouras de alimentos por commodities, entre outros. Isso tem acontecido no Brasil, onde tem ocorrido uma intensa expansão das monoculturas agrícolas, sobretudo as lavouras de grãos e cana-de-açúcar, para o Centro-Oeste brasileiro, e tem-se empurrado as grandes pastagens pecuaristas para a região norte do Brasil, incluindo áreas da Amazônia Legal. Castro (2005, p. 15), explicita bem essa dinâmica:

\begin{abstract}
As atividades econômicas responsáveis pelos desmatamentos e pela incorporação de novas áreas na Amazônia - voltadas para a expansão da produção agropecuária - têm relação com a dinâmica econômica de outras regiões do país. Não é possível entender esse processo sem ligá-lo às dinâmicas do mercado nacional, como a fronteira consolidada do Norte do Mato Grosso, de Goiás, do Maranhão e do Tocantins, espaços de reprodução de agentes econômicos que se deslocam, capitalizados ou não, para a Amazônia.
\end{abstract}

Assim, para Silva (2007), o ordenamento territorial é uma forma singular de uso do território que apresenta um arranjo de objetos naturais, sociais e culturais historicamente estabelecidos. Esse autor entende as transformações e os conflitos como inerentes ao ordenamento territorial e, que por isso, deve-se pensá-lo para além de um arranjo espacial, pois como se trata de um sistema aberto, revela um movimento dialético das contradições do modelo de reprodução do capital na sociedade moderna.

Nos países da União Européia com destaque para Portugal, Espanha, França, Alemanha e Reino Unido, há variados estudos envolvendo Geografia, paisagem e ordenamento territorial. No ano de 1983, foi escrita a Carta Europea de Ordenación del Territorio, a qual constitui um instrumento importante de desenvolvimento econômico. A Carta Europea tem como objetivo 
central promover estratégias que permitam reduzir ao máximo os conflitos que surgem entre as crescentes necessidades de uso dos recursos naturais e a exigência de sua conservação, trata-se de assegurar uma administração responsável entre os recursos do solo, subsolo, ar, água, recursos energéticos, entre outros (CONSEJO DE EUROPA, 1983).

Para eles, o ordenamento territorial persegue paralelamente o desenvolvimento socioeconômico equilibrado das regiões, tendo em conta as peculiaridades regionais e a importância do papel dos eixos de desenvolvimento que buscam controlar o crescimento demasiado de regiões mais adensadas e adaptar as infraestruturas indispensáveis para permitir um novo impulso para as regiões em decadência socioeconômica ou ameaçadas por graves problemas de emprego, principalmente pelas migrações de mão de obra em nível europeu.

Assim, o Conselho Europeu busca controlar a implantação, organização e o desenvolvimento dos grandes complexos urbanos e industriais e das grandes infraestruturas, assim como a proteção das zonas agrícolas e florestais. Tem também a função de organizar a coordenação e a cooperação entre os diversos níveis de decisão e a distribuição equitativa dos recursos financeiros. Há graus de organização, que vão do nível local ao europeu, no intuito de por em prática o ordenamento territorial nesses três patamares, buscando um desenvolvimento geral equilibrado.

Recentemente foi aprovada a chamada estratégia Europa 2020, no ano de 2010, com o intuito central de que a Europa deve seguir até o ano 2020, em uma trajetória de crescimento inteligente baseado no conhecimento e na inovação, que seja inclusivo socialmente e ambientalmente sustentável (COMISSÃO EUROPÉIA, 2010). O crescimento deve desenvolver uma economia voltada para o conhecimento e a inovação, criando condições para ampliar a pesquisa e aumentar o nível geral de educação.

A estratégia Europa 2020 foi pensada e concebida também para enfrentar o contexto de crise econômica, principalmente após 2008. Foram introduzidos alguns melhoramentos para tornar mais eficaz a aplicação dos fundos, com maior ênfase nos resultados, tais como: estabelecimento de objetivos claros, transparentes e mensuráveis; introdução de condições prévias ao investimento dos fundos; redução da burocracia e simplificação das regras; alocação de recursos para o desenvolvimento urbano; reforço da cooperação entre regiões em nível nacional e internacional (ROLIM, 2015). Em síntese, as principais metas estão relacionadas a: emprego, inovação, mudanças climáticas, educação e redução da pobreza. 
Ressalta-se que é evidente que há países com níveis de desenvolvimento desiguais na Europa, mas busca-se com essa reflexão, exemplificar como o ordenamento territorial é visto em alguns países europeus, e como trabalham na tentativa de minimizar as disparidades socioeconômicas entre os países que compõem o Conselho Europeu para o ordenamento territorial $^{22}$.

Destaca-se também que não há aqui o intuito de trazer as estratégias ou mesmo metodologias realizadas em território Europeu para o Brasil, pois sabe-se das diferenças históricas e socioeconômicas entre ambas. Contudo, parte-se da importância de se conhecer a política regional Europeia e até mesmo, com todos os devidos cuidados e adaptações, servir de embasamento para a construção de estratégias para o desenvolvimento econômico brasileiro, mais integrado e voltado para a abordagem regional.

Segundo Siqueira e Diniz (2010), as estratégias européias de desenvolvimento regional apresentaram poucos avanços, pois o princípio de subsidiariedade que pressupunha um certo recorte na margem de manobra da Comissão acabou acentuando uma política regional fragmentada em territórios, o que acabou não seguindo a concepção clara do desenvolvimento territorial, objetivo da União Européia (UE).

No Brasil, por mais que hajam programas e políticas públicas no intuito de promover estratégias de ordenamento territorial de forma equilibrada entre as regiões e reduzir os conflitos, a realidade é bem distinta, até pela extensão territorial do país e pela riqueza em terras e recursos naturais, que acabam por gerar disputas e conflitos territoriais de diversas ordens.

Segundo Freitas et al (2014), na atual ordem internacional de liberalização dos mercados, o "ordenamento territorial do Estado" é progressivamente substituído pelo "ordenamento territorial do mercado", ou seja, a organização espacial tende a favorecer cada vez mais os atores corporativos em detrimento da coletividade. Para os autores, cada vez mais "é produzido aquilo que é lucrativo para as empresas nos mercados e não o que permite garantir a soberania alimentar local e regional, pelo menos nos países semi-periféricos do sistema internacional" (FREITAS et al, 2014, p. 3).

\footnotetext{
${ }^{22}$ A "Carta Europea de Ordenación del Territorio" e outras ações referentes a temática do ordenamento territorial, Paisagem e Geografia foram temas discutidos em algumas conferências assistidas, durante a experiência de estágio doutoral (com Bolsa CAPES) realizado na Universidade de Santiago de Compostela, na Espanha.
} 
Concorda-se com a ideia trazida por esses autores, contudo acredita-se que o Estado e o mercado não são tão dissociados, no sentido de haver uma substituição do ordenamento territorial do Estado pelo do mercado, tampouco ingênuos no sentido de serem forças antagônicas nesse processo. Acredita-se que cada vez mais haja um diálogo entre Estado e mercado, sendo duas forças convergentes e atuantes para o ordenamento territorial. Os empreendimentos sucroenergéticos, por exemplo, tem lugar certo para serem implantados e isso com o aval do Estado, que por meio de políticas de fomento atraem as agroindústrias (como já citado anteriormente).

Verifica-se que na microrregião Ceres, o Estado e o agronegócio canavieiro são os grandes responsáveis pelo ordenamento territorial atual. O Estado por meio, tanto do Governo Federal, como do governo do estado de Goiás, garante subsídios para a territorialização das agroindústrias canavieiras, exemplo disso foi a aprovação do financiamento, via Fomentar ou Produzir, das usinas implantadas e propostas na microrregião. Ressalta-se que mesmo antes de algumas usinas propostas terem tido a licença funcionamento aprovada pelo órgão competente ou a viabilidade econômica dos Grupos para serem construídas, o Estado já havia liberado o financiamento de milhões de reais para a construção dos empreendimentos e crédito agrícola ${ }^{23}$.

Cada vez mais se abre à discussão de que as grandes empresas e corporações são as principais financiadoras de campanhas políticas no Brasil. Assim, além de se discutir que o Estado atrai e financia as agroindústrias, devido à dinamização urbana e regional e atração de mão de obra direta e indireta para a região envolvida, deve-se atentar para as manobras financeiras e geopolíticas que estão por trás das ações, programas e cooperações.

\subsection{A "Nova" Configuração Socioespacial pela Dinâmica Sucroenergética na Microrregião Ceres}

A partir da década de 1970 até o momento atual, a atividade canavieira passou a ser um elemento importante para a dinâmica socioeconômica da região. Atualmente são sete empreendimentos sucroenergéticos em funcionamento na microrregião Ceres, mas alguns foram fechados, tiveram a licença funcionamento cassada e depois foram reabertos, durante esse tempo.

\footnotetext{
${ }^{23}$ Informações disponibilizadas pela Secretaria de Indústria e Comércio de Goiás - SIC, com valores aprovados pelo Programa Produzir.
} 
Essa dinâmica trouxe repercussões na estrutura urbana e regional, além de trazer elementos "novos" e outros "velhos" para a microrregião Ceres que colaboram com a realização da dinâmica sucroenergética na região e simultaneamente acabam por reforçar a "nova" configuração socioespacial estabelecida pela atividade canavieira.

É importante ressaltar que como a microrregião Ceres tem uma rede urbana pretérita baseada em pequenas cidades e atividades agropecuaristas e, atualmente, está vinculada a somente um ramo do agronegócio (o sucroenergético) não se percebe nessa região médias ou grandes cidades (população numerosa) ou uma estrutura efervescente do agronegócio, com relevante comércio de máquinas agrícolas, tratores, fertilizantes químicos ou centros biotecnológicos. Mas, uma região que possui a dinâmica canavieira como principal atividade, porém que apresenta um desenvolvimento marginal e fragilizado devido a essa especificidade.

Desta forma, como a microrregião Ceres encontra-se relacionada a somente um ramo do agronegócio, não apresenta prestadoras de serviços e comércios altamente modernos e especializados, quando necessitam de alguma atividade mais complexa ou da aquisição de alguma ferramenta mais moderna isso é realizado em outras cidades, como Goiânia e, sobretudo, São Paulo, ficando para a região de Ceres, serviços e comércios mais emergenciais e simples, além da principal marca na paisagem da região: as extensas monoculturas canavieiras.

Para entender melhor a configuração da rede urbana da microrregião Ceres, será utilizado o estudo da Região de Influência das Cidades - REGIC, realizado pelo IBGE. As figuras 57, 58 e 59 mostram três momentos dessa pesquisa, o primeiro realizado para o ano 1978 (publicado em 1987), o segundo para o ano de 1993 (publicado em 2000) e o último realizado em 2007 (publicado em 2008). O REGIC tem como finalidade classificar e hierarquizar as cidades brasileiras segundo seus níveis de centralidade, bem como verificar como são definidas suas ligações espaciais e mapear suas áreas de atuação e mercado (IBGE, 2000).

Primeiramente é importante destacar que a nomenclatura das categorias de cidades foi alterada nos três REGIC's realizados. Para a região analisada, destacamos que no ano de 1978 as categorias variavam entre Metrópole Regional e municípios subordinados; já em 1993, variavam entre máximo e muito fraco; e, em 2007, entre Metrópole e centro local. O quadro 10 mostra a correspondência entre as categorias de centros do REGIC para a microrregião Ceres, para os anos de 1978, 1993 e 2007. 
Quadro 10 - Correspondência entre Categorias de Centros do REGIC para a Microrregião Ceres / 1978, 1993 e 2007

\begin{tabular}{|c|c|c|}
\hline \multicolumn{3}{|c|}{ CORRESPONDÊNCIA ENTRE CATEGORIAS DE CENTROS DO REGIC } \\
\hline REGIC 1978 (1987) & REGIC 1993 (2000) & REGIC 2007 (2008) \\
\hline Metrópole Regional & Máximo & Metrópole \\
\hline Capital Regional & Forte & - \\
\hline Centro Sub-regional & Médio & Centro de Zona A \\
\hline Centro de Zona & Fraco & Centro de Zona B \\
\hline Municípios Subordinados & Muito fraco & Centro local \\
\hline
\end{tabular}

Fonte: REGIC (1987; 2000; 2008). Org. A autora.

Por meio da análise dos três estudos da rede urbana brasileira, realizado pelo IBGE, fazse possível verificar a evolução da rede urbana da microrregião Ceres. O REGIC de 1978, mostra que a microrregião Ceres possuía uma rede urbana mais simplificada, com a participação de poucos municípios. O município de Ceres já se destacava na região como um centro sub-regional, porém como poucas ligações. O município de Anápolis, que já apresentava uma centralidade importante para o estado de Goiás à época, apresentava-se relevante para as conexões entre a região de estudada e Goiânia, pois funcionava como intermediário entre a Metrópole Regional (Goiânia) e o município de Ceres e os centros de zona: Goianésia, Itapuranga, Itapaci, Rubiataba e Uruana. Nesse momento, tem-se somente seis municípios que aparecem como subordinados aos outros centros de maior hierarquia, conforme pode ser visualizado na figura 57.

Já na década de 1990, verifica-se com o REGIC realizado em 1993, que a rede urbana da microrregião Ceres já se apresenta de forma um pouco mais complexa. É possível verificar a consolidação da centralidade do município de Ceres, como um centro sub-regional (médio). O município de Ceres apresenta muitas ligações com municípios de hierarquia inferior na rede, sobretudo com os de categoria "muito fraco", pois, nesse contexto, já apresenta importância regional em relação à educação, saúde e prestação de serviços. O município de Goianésia aparece como um centro local (fraco) e, além desses, aparecem 13 municípios subordinados (muito fraco) que se conectam a Ceres ou Goianésia na rede. 
Microrregião Ceres e a Região de Influência de Goiânia - REGIC (1978)
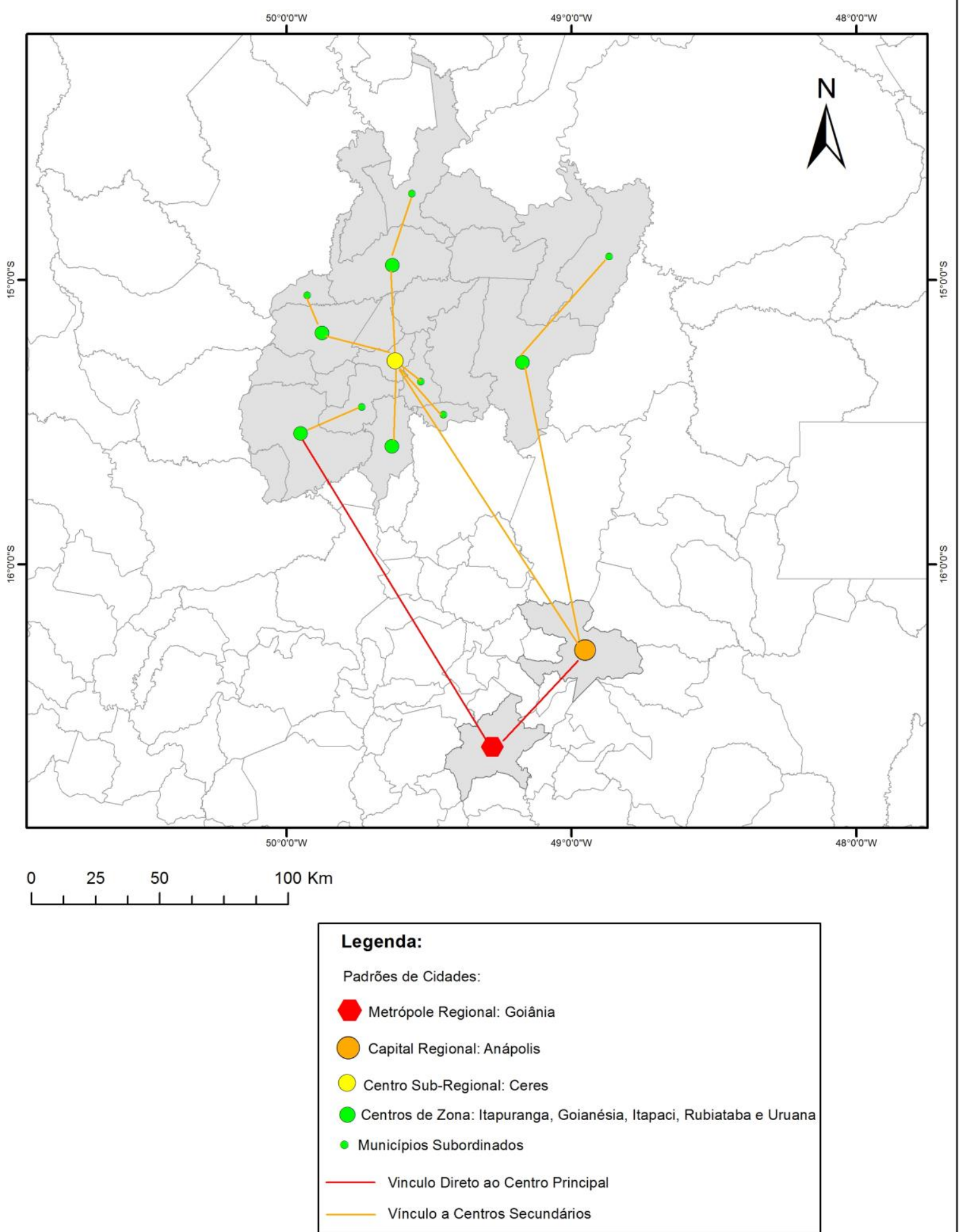

Elaboração: Lara Cristine Gomes Ferreira Fonte: REGIC, 1978 (1987); SIC, 2016.

Figura 57 - A microrregião Ceres e a região de influência de Goiânia - REGIC 1978. 
Verifica-se também que nenhum dos municípios da microrregião de Ceres conecta-se diretamente à Goiânia, que correspondia à centralidade máxima metropolitana, mas continuavam possuindo uma ligação direta com Anápolis (capital regional), o que demonstrava, ainda na década de 1990, a importância e a centralidade de Anápolis para Goiás e, no caso, para a região estudada (figura 58).

Anápolis aparece como importante nó na rede urbana da microrregião Ceres nas décadas de 1970 e 1990, devido a proximidade física e sua importância em termos de logística, política, prestação de serviços e comércios. Anápolis nesses contextos funcionava como importante nó na rede urbana, sobretudo relacionada ao centro-norte do estado de Goiás. É importante destacar que a cidade de Anápolis ainda possui papel e funções importantíssimas na rede urbana goiana, mas após os anos 2000, percebeu-se que a rede urbana microrregional passou a ser mais articulada e complexa, estabelecendo conexões diretas com a Metrópole.

Com o último REGIC, realizado em 2007, já percebe-se nitidamente uma maior complexidade e articulações entre os municípios da microrregião Ceres, além de algumas alterações na rede urbana microrregional. O município de Ceres ainda permanece com principal centralidade da região (centro de zona A), e têm-se quatro cidades que aparecem como centro de zona B: Goianésia, Itapaci, Itapuranga e Rubiataba, que acabam se consolidando com o tempo entre as cidades que receberem mais fluxos dos centros locais, depois de Ceres.

Outra alteração na rede urbana da microrregião Ceres em 2007 é que a própria região conecta-se à metrópole Goiânia, não sendo mais necessário outro centro como Anápolis, para fazer a intermediação. Além de Ceres como principal centro da região e Goianésia, Rubiataba, Itapaci e Itapuranga como centros menores, há 14 outros centros locais que se conectam ao centro de zona A e aos centros de zona B (figura 59). 


\section{Microrregião Ceres e a Região de Influência de Goiânia - REGIC (1993)}
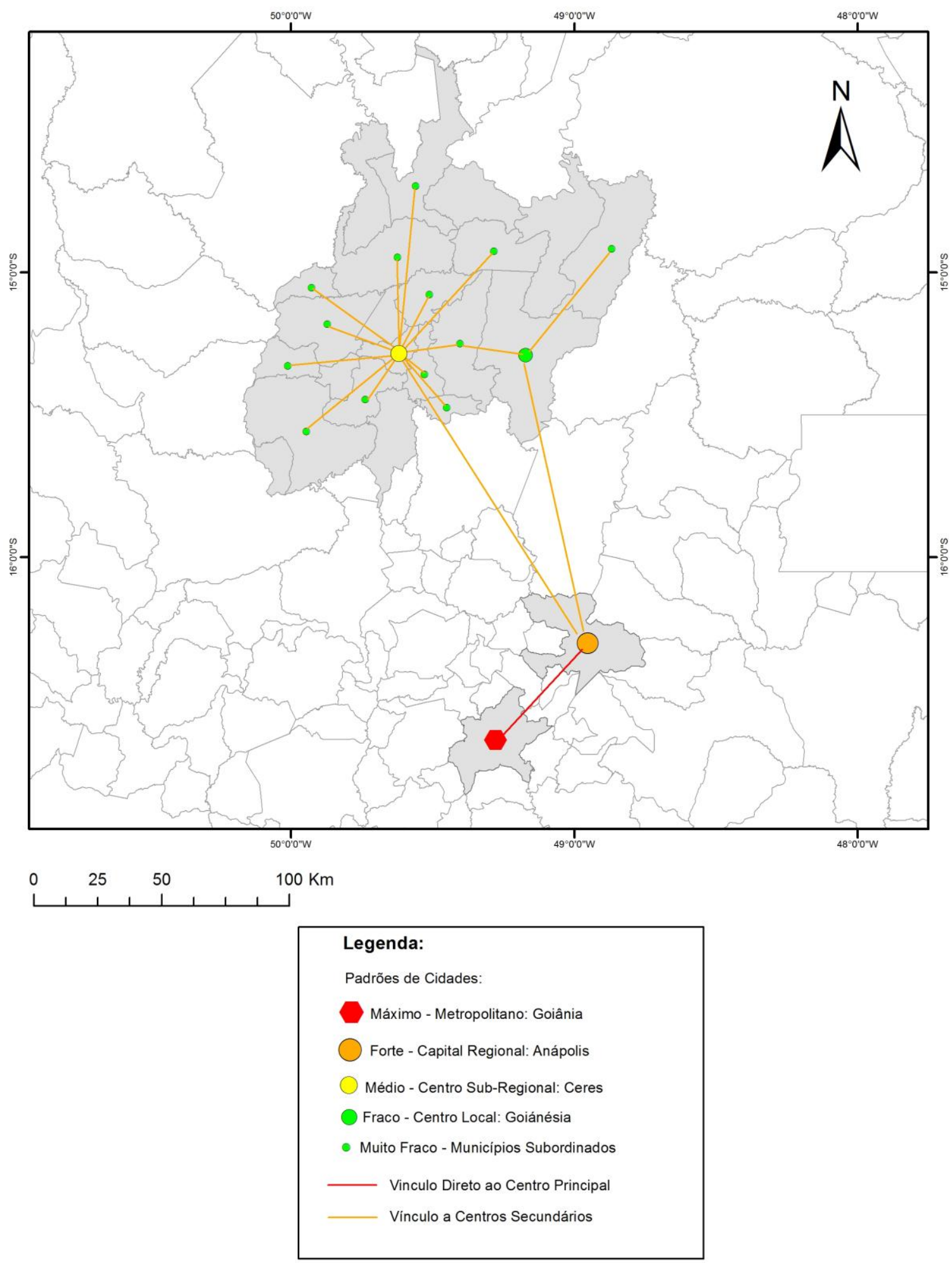

Elaboração: Lara Cristine Gomes Ferreira Fonte: REGIC, 1993 (2000); SIC, 2015.

Figura 58 - A microrregião Ceres e a região de influência de Goiânia - REGIC 1993. 


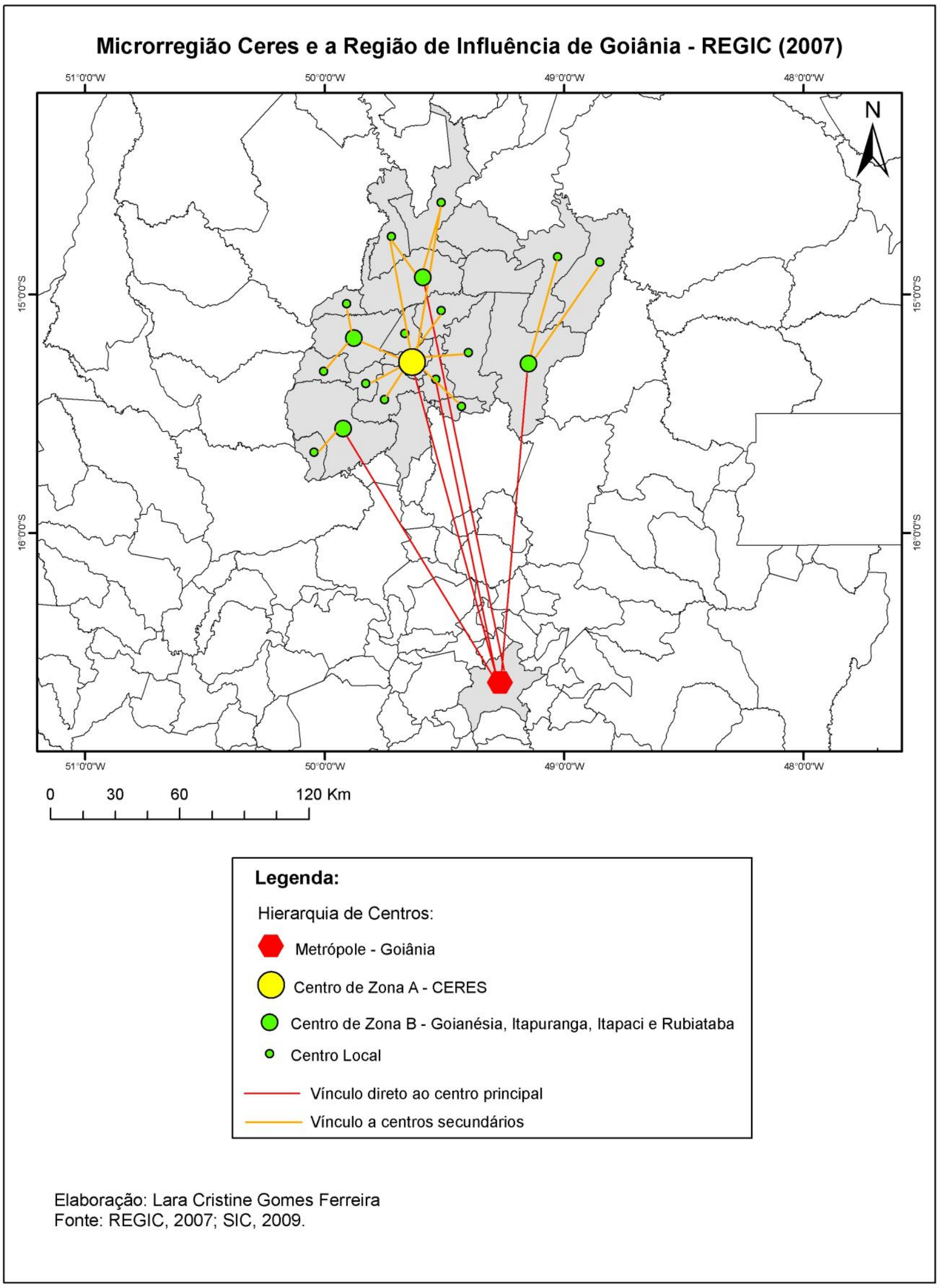

Figura 59 - A microrregião Ceres e a região de influência de Goiânia - REGIC 2007. 
Por meio da análise dos REGIC's foi possível observar que a microrregião Ceres não apresenta grandes centralidades para Goiás, pois são centros menores, em geral municípios de pequeno porte (demograficamente), contudo é importante ressaltar que para a dinâmica microrregional, o papel e a função de municípios como Ceres, Goianésia, Itapaci, Itapuranga e Rubiataba, principalmente, são fundamentais. Como a metodologia do REGIC é baseada, sobretudo, na definição de centros a partir de diferentes equipamentos e serviços na cidade, isso ratifica a ideia de que o município de Ceres funciona como um pólo de serviços na microrregião, assumindo papel importante na dinâmica socioeconômica regional.

Com os três REGIC's foi possível perceber que mais cidades emergiram na rede urbana da microrregião Ceres, mesmo como hierarquias menores, como os centros locais e os municípios subordinados. Foi possível observar também a emergência na hierarquia de cidades como Rubiataba, Itapaci e Itapuranga, que juntos a Goianésia, possuem agroindústrias canavieiras em funcionamento na região.

Pode-se inferir que o estabelecimento de ligações diretas entre Goianésia, Itapaci, Itapuranga e Rubiataba, com a metrópole Goiânia, está diretamente vinculada também à dinâmica construída pelas agroindustrias sucroenergéticas ao longo do tempo, pois com elas são necessárias cada vez mais articulações político-financeiras, com centros maiores e de hierarquia máxima na rede urbana do estado de Goiás. Assim, municípios que têm sua economia baseada na lógica do agronegócio necessitam estabelecer redes cada vez mais estreitas, com centros comerciais mais desenvolvidos e centros financeiros mais dinâmicos.

Desta forma, mesmo a microrregião Ceres apresentando uma rede urbana mais simplificada em relação a outras regiões goianas e brasileiras, foi possível verificar alterações substanciais entre os REGIC's. Em praticamente 30 anos, a rede urbana da microrregião apresentou aumento de centros locais participantes, além de quatro centros de zona B, que juntos a centralidade principal da região, que é Ceres, auxiliam na interconexão entre os centros locais e a metrópole.

Entende-se que a dinâmica sucroenergética tem auxiliado para o aumento da complexidade da rede urbana da microrregião Ceres, pois mesmo a região sendo focada em segmento único do agronegócio, tem a necessidade de interconectar-se a outros centros urbanos: seja pela busca de um comércio e prestadoras de serviços mais modernas e especializadas; pelo diálogo financeiro, circulação da produção e comercialização dos produtos; ou também, pela própria articulação política, por meio do diálogo constante com o Estado, na busca de parcerias, recursos, subsídios, etc. centralizado na Capital Goiânia. 
Assim, infere-se que, para que a dinâmica canavieira aconteça é necessário uma rede de cidades articuladas em função da dinâmica sucroenergética, que vai desde a produção de cana-de-açúcar até a comercialização dos produtos finais.

Ampliando um pouco esse debate, faz-se importante destacar que historicamente a constituição da rede urbana brasileira foi marcada pela conjugação dos processos de urbanização e de integração do mercado nacional. As causas do processo de urbanização no Brasil já são amplamente conhecidas, como por exemplo, a intensificação da industrialização e o êxodo rural. A microrregião Ceres acompanhou a lógica de urbanização brasileira e a partir dos anos 1970 começou a inverter a dinâmica populacional: a população urbana passou a crescer em detrimento da população rural.

Segundo Soares e Bessa (1999), a partir da década de 1970 tem-se uma nova urbanização, que se caracteriza como uma verdadeira revolução urbana no Brasil, relacionada à generalização do processo de urbanização, pela expansão do meio técnico científico informacional e pela nova divisão territorial do Trabalho, o que tornou o sistema urbano brasileiro mais complexo e diferenciado.

Mesmo tendo pequenas cidades em sua maioria, a microrregião Ceres apresenta população urbana maior que a rural, apesar de existir uma ruralidade ${ }^{24}$ muito presente nessa região, mesmo que apresente elementos ligados ao agronegócio canavieiro. Os municípios canavieiros e os municípios que representam as principais centralidades da região, sobretudo pela presença de prestadoras de serviços, comércios, saúde e educação, apresentam-se mais densamente povoados. A tabela 10 mostra a densidade demográfica dos municípios pertentencentes à microrregião Ceres.

\footnotetext{
${ }^{24}$ Aqui se entende ruralidade como Villa Verde (2004): um modo de ser rural que se faz presente no campo e na cidade.
} 
Tabela 10 - Densidade Demográfica da Microrregião Ceres.

\begin{tabular}{l|l|l|l|l}
\hline \multicolumn{5}{c}{ DENSIDADE DEMOGRÁFICA (HAB/KM $)$} \\
\hline MUNICÍPIO & $\mathbf{1 9 9 1}$ & $\mathbf{2 0 0 0}$ & $\mathbf{2 0 0 6}$ & $\mathbf{2 0 1 0}$ \\
\hline Barro Alto & 9,07 & 5,72 & 5,04 & 7,97 \\
\hline Carmo do Rio Verde & $\mathbf{2 2 , 5 7}$ & $\mathbf{1 7 , 4 2}$ & $\mathbf{1 6 , 5 6}$ & $\mathbf{2 1 , 3 3}$ \\
\hline Ceres & $\mathbf{1 0 7 , 1 4}$ & $\mathbf{1 0 4 , 0 2}$ & $\mathbf{8 8 , 8 1}$ & $\mathbf{9 6 , 6 9}$ \\
\hline Goianésia & $\mathbf{2 8 , 1 3}$ & $\mathbf{3 1 , 7 6}$ & $\mathbf{3 4 , 4 5}$ & $\mathbf{3 8 , 4 9}$ \\
\hline Guaraíta & - & 13,61 & 13,84 & 11,57 \\
\hline Guarinos & 6,23 & 4,77 & 3,7 & 3,86 \\
\hline Hidrolina & 8,58 & 7,84 & 7,29 & 6,94 \\
\hline Ipiranga de Goiás & - & - & 11,42 & 11,79 \\
\hline Itapaci & $\mathbf{1 3 , 2 3}$ & $\mathbf{1 4 , 5 7}$ & $\mathbf{1 5 , 5 6}$ & $\mathbf{1 9 , 3 1}$ \\
\hline Itapuranga & $\mathbf{2 4 , 4 4}$ & $\mathbf{2 0 , 9 4}$ & $\mathbf{1 9 , 9 3}$ & $\mathbf{2 0 , 4 7}$ \\
\hline Morro Agudo de Goiás & 8,94 & 8,81 & 8,71 & 8,34 \\
\hline Nova América & 9,54 & 10,31 & 10,87 & 10,65 \\
\hline Nova Glória & 20,6 & 21,66 & 22,44 & 20,6 \\
\hline Pilar de Goiás & 5,34 & 3,68 & 2,46 & 3,06 \\
\hline Rialma & $\mathbf{3 3 , 1 4}$ & $\mathbf{3 7 , 9 6}$ & $\mathbf{4 1 , 5 3}$ & $\mathbf{3 9 , 2}$ \\
\hline Rianápolis & 26,92 & 27,39 & 27,73 & 28,67 \\
\hline Rubiataba & $\mathbf{2 2 , 3}$ & $\mathbf{2 4 , 1 7}$ & $\mathbf{2 5 , 5 5}$ & $\mathbf{2 5 , 2 8}$ \\
\hline Santa Isabel & 4,82 & 4,45 & 4,18 & 4,57 \\
\hline Santa Rita do Novo Destino & - & 3,16 & 3,29 & 3,32 \\
\hline São Luiz do Norte & 7,1 & 6,98 & 7,12 & 7,88 \\
\hline Uruana & 26,35 & 26,69 & 26,95 & 26,46 \\
\hline Fo: IBGE/ IMB 2015$)$ & & & & \\
\hline
\end{tabular}

Fonte: IBGE / IMB (2015).

Os municípios com maior densidade demográfica são Ceres e Rialma, com 96,69 e 39,2 hab. $/ \mathrm{km}^{2}$, respectivamente. Esses municípios tem sua economia baseada principalmente na prestação de serviços e estão conurbados, sendo separados apenas por uma ponte sobre o Rio das Almas. Os municípios que possuem usinas canavieiras também apresentam uma alta densidade demográfica, muito relacionada ao processo de expropriação do pequeno e médio produtor rural, sobretudo para o arrendamento das terras para a produção de cana-de-açúcar. Segundo Elias (2003) em estudo a região de Ribeirão Preto (SP), centenas de pequenos agricultores não resistiram às pressões econômicas e venderam suas terras aos usineiros, abandonando a policultura e propiciando a expansão da monocultura canavieira.

Outra característica relacionada à evolução da rede urbana é a quantidade de agências bancárias. A quantidade de bancos revela a rede de investimentos e a possibilidade 
de acesso a créditos para as empresas e agroindústrias implantadas, bem como a integração desse município e região ao mercado nacional. Segundo Matias e Carmo (2012, p. 93),

As redes bancárias correspondem a nós do sistema financeiro e as finanças são um dos motores mais importantes da dinâmica territorial. Fluxos financeiros nacionais-territoriais e internacionais-extraterritoriais articulam diversos pontos (re) configurando escalas de atuação no território a partir de uma lógica políticofinanceira.

Esse dado revela muito a realidade da microrregião Ceres, percebe-se que a região apresenta-se bastante desigual em relação à quantidade de agências bancárias e, consequentemente, acesso a créditos diversos e integração financeira. A metade dos municípios da microrregião (50\%) não possui nenhuma agência bancária, sendo os serviços bancários básicos realizados em agências dos correios (pagamentos, depósitos, recebimento de salários, etc.). A tabela 11 mostra a quantidade de agências bancárias disponíveis nos municípios da microrregião Ceres, e a figura 60 espacializa as agências, por tipos, nos municípios da microrregião Ceres.

Tabela 11 - Agências bancárias nos municípios da Microrregião Ceres - 2014

\begin{tabular}{l|c||l|c}
\hline \multicolumn{1}{c|}{ MUNICÍPIO } & $\begin{array}{c}\text { Agências } \\
\text { Bancárias }\end{array}$ & \multicolumn{1}{|c}{ MUNICÍPIO } & $\begin{array}{c}\text { Agências } \\
\text { Bancárias }\end{array}$ \\
\hline Barro Alto & 1 & Nova América & 0 \\
\hline Carmo do Rio Verde & $\mathbf{2}$ & Nova Glória & 1 \\
\hline Ceres & $\mathbf{4}$ & Pilar de Goiás & 0 \\
\hline Goianésia & $\mathbf{5}$ & Rialma & 1 \\
\hline Guaraíta & 0 & Rianápolis & 0 \\
\hline Guarinos & 0 & Rubiataba & $\mathbf{4}$ \\
\hline Hidrolina & 1 & Santa Isabel & 0 \\
\hline Ipiranga de Goiás & 0 & Santa Rita do Novo Destino & 0 \\
\hline Itapaci & $\mathbf{4}$ & São Luíz do Norte & 0 \\
\hline Itapuranga & $\mathbf{4}$ & São Patrício & 0 \\
\hline Morro Agudo de Goiás & 0 & Uruana & $\mathbf{4}$ \\
\hline
\end{tabular}

Fonte: Instituto Mauro Borges - IMB / Goiás.

Os municípios que possuem empreendimentos sucroenergéticos acabam se destacando na quantidade de agências bancárias (Goianésia, Rubiataba, Itapaci, Itapuranga e Carmo do Rio Verde), elas são fundamentais para pagamentos, investimentos e concessão de créditos mais complexos vinculados a realidade do agronegócio local. Quanto mais 
dinâmica é a cidade ligada ao agronegócio, mais agências existem na cidade, como pode ser verificado no município de Goianésia, que possui 5 agências bancárias e corresponde ao município com maior quantidade de usinas em funcionamento.

O município de Carmo do Rio Verde, dos cinco municípios que possuem usinas, é o que apresenta menor dinamicidade em relação ao agronegócio sucroenergético, e isso é verificado também em relação à quantidade de agências bancárias, apresentando somente duas em seu território.

É interessante perceber que o município de Barro Alto, que possui uma importante mineradora em funcionamento, a Anglo American (extração de minério de ferro e níquel), possui somente uma agência bancária. Mesmo a atividade mineradora sendo altamente rentável, que faz como que o município de Barro Alto tenha um alto valor de PIB em relação a outros municípios da microrregião, isso não reflete em algumas infraestruturas básicas, como na quantidade de agências bancárias.

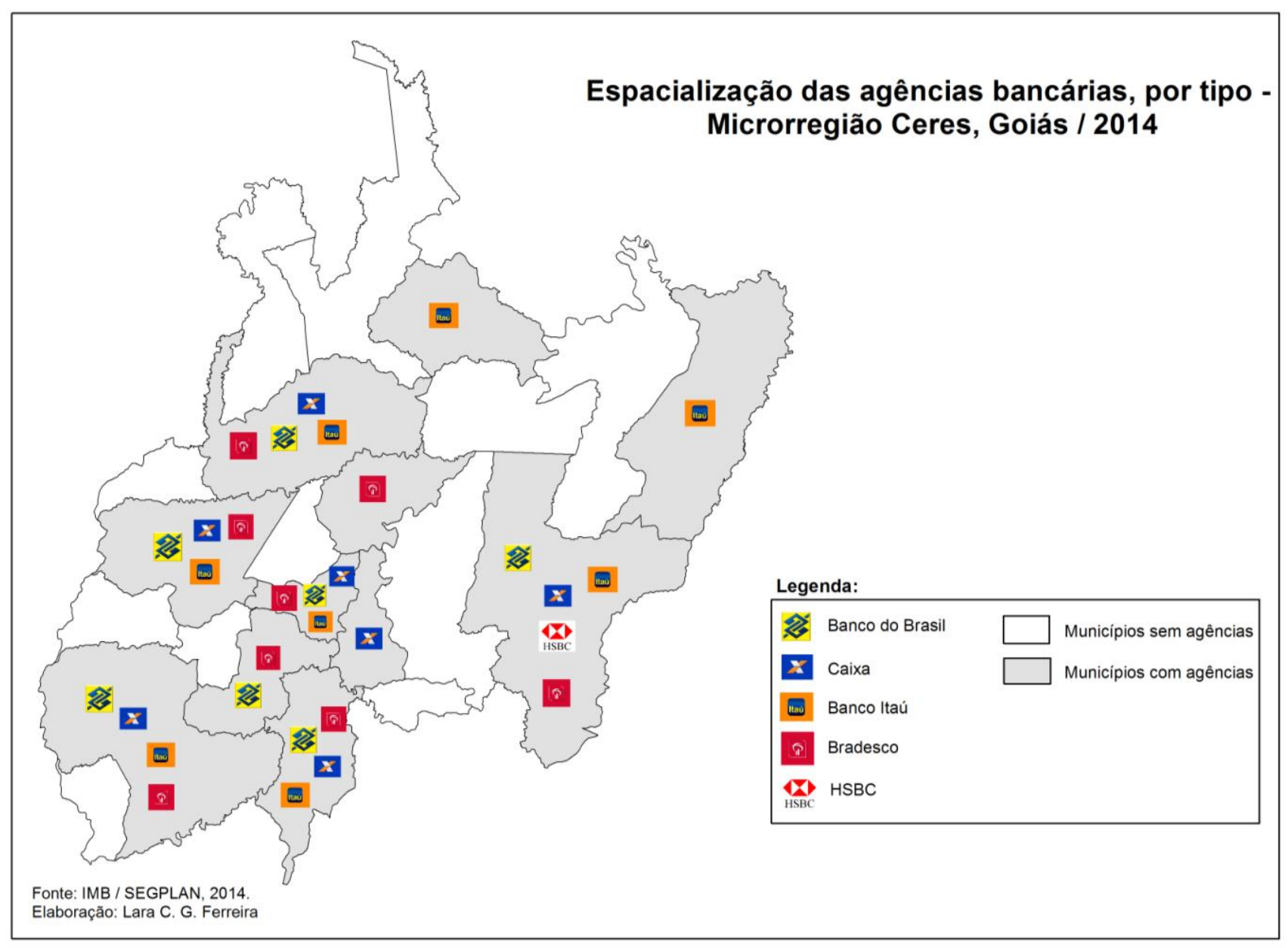

Figura 60 - Espacialização das agências bancárias da microrregião Ceres - 2014. 
Nesse sentido, o agronegócio acaba por estabelecer uma rede financeira mais ampla, extremamente necessária para a realização das redes de comercialização do agronegócio. Desta forma, mesmo a microrregião Ceres sendo vinculada a apenas um segmento do agronegócio, tem a necessidade de acessar várias opções de créditos, agências de financiamento, empréstimos, entre outros.

A rede de agências bancárias gera espaços de valores diferenciados dentro do território, o que remete diretamente ao significado de poder, principalmente quando associada à divisão do trabalho que atribui papéis diferenciados na organização do espaço. Assim, grandes corporações aproveitam-se da estrutura de redes para maximizar seus lucros e o poder pode ganhar uma dimensão local ou regional dependendo de suas interações (MATIAS; CARMO, 2012).

Outra forma para aquisição de créditos agrícolas e financiamento que tem crescido muito nos municípios da microrregião Ceres é via SICOOB, que corresponde a um sistema financeiro cooperativo composto por cooperativas financeiras e empresas de apoio, que em conjunto, oferecem aos associados serviços de conta corrente, crédito, investimento, cartões, previdência, consórcio, seguros, cobrança bancária, adquirência de meios eletrônicos de pagamento, dentre outros ${ }^{25}$. Exemplo disso é o município de Carmo do Rio Verde, que além de ter duas agências bancárias tradicionais, contém um SICOOB, como pode ser visualizado na figura 61.

\footnotetext{
${ }^{25}$ Disponível em http://www.sicoob.com.br.
} 


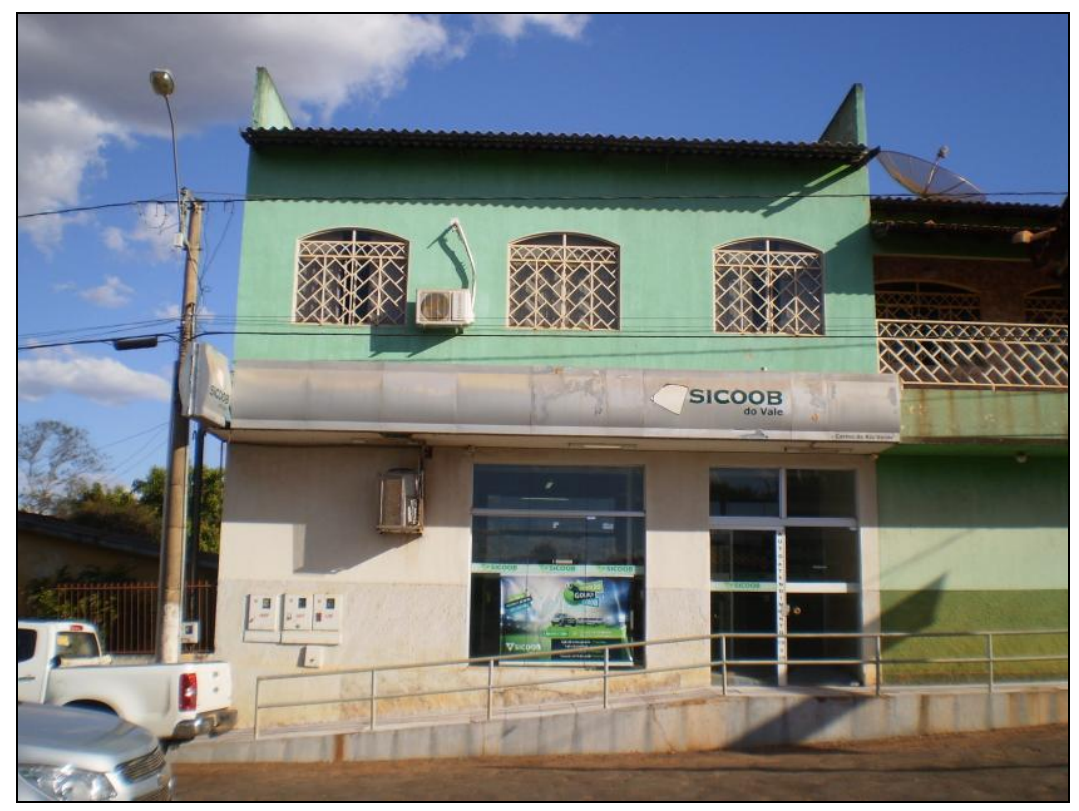

Figura 61 - Presença de SICOOB em Carmo do Rio Verde, Goiás. Foto: A autora, 2015

Outra forma de compreender a rede urbana é observando os dados de Valor Adicionado (V.A) do PIB, neles observam-se os valores adicionados à agropecuária, à indústria e aos serviços, além do valor dos impostos gerados sobre essas rubricas. Por meio da tabela 12 é possível perceber que o Valor Adicionado à Agropecuária é relativamente menos desigual que os valores adicionados à indústria e aos serviços. Isso se justifica pela história agropecuária da região, que ainda possui áreas relevantes em pecuária, além de ser grande produtor agrícola, sobretudo de cana-de-açúcar.

Como já mencionado, não só os municípios com usinas implantadas possuem áreas em monocultura de cana, há vários outros municípios que contribuem para a dinâmica canavieira. Há também na região, outros municípios que se destacam em outras culturas, como é o caso de Uruana (maior produtor de melancia de Goiás).

Já os dados de V.A. Indústria e V.A. Serviços revelam uma concentração maior em alguns municípios específicos da microrregião Ceres. Na indústria, destacam-se principalmente os municípios de Goianésia, que possui três usinas sucroenergéticas em funcionamento, e Barro Alto, com a mineradora Anglo American. Os demais municípios que possuem usinas vem logo em seguida no ranking: Rubiataba, Itapaci e Carmo do Rio Verde. Destaca-se que no ano de 2012, a usina Vale Verde do município de Itapuranga, estava com a licença funcionamento cassada, o que justifica o baixo valor do V.A industrial para esse município no ano analisado. 
Tabela 12 - Valor Adicionado Bruto a Preços Básicos (R \$ mil) / 2012

\begin{tabular}{l|r|r|r|r}
\hline \multirow{2}{*}{ MUNICÍPIO } & \multicolumn{4}{|c}{ Valor Adicionado Bruto a Preços Básicos (R\$ mil) / 2012 } \\
\cline { 2 - 5 } Barro Alto & Agropecuária & \multicolumn{1}{c}{ Indústria } & \multicolumn{1}{c}{ Serviços } & \multicolumn{1}{c}{ Impostos } \\
\hline Carmo do Rio Verde & $\mathbf{4 2 . 3 9 0 , 8 0}$ & $\mathbf{1 5 7 . 2 2 0 , 4 9}$ & $\mathbf{1 1 5 . 9 5 5 , 9 1}$ & $\mathbf{3 8 . 9 1 8 , 5 0}$ \\
\hline Ceres & $\mathbf{2 8 . 6 4 1 , 4 9}$ & $\mathbf{4 8 . 2 6 6 , 7 6}$ & $\mathbf{5 4 . 3 6 0 , 4 4}$ & $\mathbf{2 5 . 9 8 8 , 2 0}$ \\
\hline Goianésia & $\mathbf{8 . 5 9 6 , 8 2}$ & $\mathbf{3 8 . 9 0 5 , 6 6}$ & $\mathbf{2 0 4 . 2 5 6 , 0 6}$ & $\mathbf{3 7 . 5 0 4 , 5 1}$ \\
\hline Guaraíta & $\mathbf{9 2 . 0 8 0 , 0 8}$ & $\mathbf{1 7 3 . 9 4 1 , 5 4}$ & $\mathbf{4 2 9 . 8 8 6 , 4 8}$ & $\mathbf{8 2 . 3 7 1 , 2 1}$ \\
\hline Guarinos & $5.951,63$ & $1.717,86$ & $11.450,57$ & 693,81 \\
\hline Hidrolina & $8.927,68$ & $1.531,61$ & $10.891,32$ & $1.013,01$ \\
\hline Ipiranga de Goiás & $17.095,23$ & $3.655,23$ & $21.160,35$ & $1.815,16$ \\
\hline Itapaci & $14.550,67$ & $2.151,64$ & $14.279,10$ & $1.232,02$ \\
\hline Itapuranga & $\mathbf{2 8 . 2 5 6 , 9 1}$ & $\mathbf{4 9 . 7 0 9 , 9 2}$ & $\mathbf{1 0 5 . 0 2 6 , 6 7}$ & $\mathbf{1 3 . 9 4 3 , 2 5}$ \\
\hline Morro Agudo de Goiás & $\mathbf{5 3 . 4 5 0 , 2 6}$ & $\mathbf{3 0 . 2 7 6 , 0 0}$ & $\mathbf{1 5 9 . 5 4 2 , 0 2}$ & $\mathbf{1 6 . 3 9 6 , 8 7}$ \\
\hline Nova América & $7.685,51$ & $1.795,63$ & $12.611,11$ & $1.004,75$ \\
\hline Nova Glória & $6.381,79$ & $2.035,26$ & $12.277,29$ & 936,81 \\
\hline Pilar de Goiás & $14.735,11$ & $6.725,84$ & $39.868,25$ & $4.167,53$ \\
\hline Rialma & $14.161,65$ & $3.756,73$ & $14.310,23$ & $2.814,36$ \\
\hline Rianápolis & $6.602,33$ & $30.123,93$ & $81.278,49$ & $14.505,56$ \\
\hline Rubiataba & $6.224,06$ & $31.795,44$ & $30.548,11$ & $7.003,12$ \\
\hline Santa Isabel & $24.295,36$ & $55.037,71$ & $122.290,55$ & $17.273,28$ \\
\hline Santa Rita do Novo & $21.704,96$ & $3.050,36$ & $19.326,62$ & $1.802,88$ \\
\hline Destino & $28.300,24$ & $2.316,85$ & $16.276,11$ & $1.529,94$ \\
\hline São Luíz do Norte & $26.423,66$ & $3.928,30$ & $25.508,30$ & $2.830,67$ \\
\hline São Patrício & $6.756,14$ & $1.640,56$ & $10.876,12$ & 820,33 \\
\hline Uruana & $\mathbf{8 2 . 1 0 6 , 1 1}$ & $\mathbf{1 1 . 1 8 9 , 8 5}$ & $\mathbf{8 3 . 7 2 9 , 4 9}$ & $\mathbf{8 . 7 5 1 , 6 6}$ \\
\hline Foryyyyyyy & & & \\
\hline
\end{tabular}

Fonte: IBGE, 2012. Acesso em dezembro de 2015.

Para o V.A Serviços, observa-se que há uma tendência semelhante ao V.A Indústria, já que geralmente há demandas, mesmo que mínima, por prestação de serviços por parte das indústrias implantadas. Contudo, destaca-se o município de Ceres, que não possui indústrias de grande porte, mas se configura como uma centralidade de serviços na região e, o município de Carmo do Rio Verde, que mesmo possuindo uma usina em funcionamento não se destaca em serviços, a usina supre suas demandas em municípios vizinhos maiores e, sobretudo, em cidades de outros estados.

Carmo do Rio Verde é uma cidade pequena, com menos de 10 mil habitantes, que não apresenta grande dinamização com a agroindústria implantada, ela é um dos principais exemplos da microrregião Ceres que reforça a concentração de renda e a desigualdade social 
fruto da lógica canavieira, além de confirmar o mito do progresso que existe por trás do discurso para atrair os empreendimentos sucroenergéticos.

Segundo Fresca (2010), a rede urbana possibilita reinvestimentos do excedente acumulado em outras atividades produtivas, sejam no campo ou na cidade, visando ampliar a reprodução do capital e que novos excedentes sejam gerados. Entretanto, isso não se realiza de forma homogênea, acorrendo desigualmente em uma rede urbana, que internamente também é diferenciada. Para essa autora,

Esta desigualdade de investimentos privilegia determinados lugares, gerando diferenciações cada vez mais acentuadas; determinados centros urbanos tornam-se capazes de apropriar, por processos, mecanismos e agentes diversos, de valor excedente que circula e cria novos valores, enquanto outros centros urbanos tem menores possibilidades de apropriação do valor excedente, aí permanecendo pequena parcela de mais-valia (FRESCA, 2010, p. 121).

Na rede urbana da microrregião Ceres é perceptível a desigualdade em investimentos e arrecadações, como bem explicitou Fresca (2010). Dos 22 municípios pertencentes à região, geralmente seis deles, sempre se destacam em termos financeiros. Mesmo a região possuindo vários municípios produtores de cana-de-açúcar, quando se analisa dados econômicos têm-se os mesmos municípios em evidência na região: Goianésia, Ceres, Rialma, Itapaci, Itapuranga, Rubiataba e Carmo do Rio Verde. Mas, quando se verifica com mais proximidade a possibilidade de apropriação do valor excedente, acredita-se que somente dois municípios estão dentro dessa realidade: Goianésia e Ceres, o primeiro possui três empreendimentos canavieiros em pleno funcionamento e, o segundo, é a grande referência em termos de serviços, comércio, saúde e educação da região.

Os demais municípios da microrregião podem até apresentar dados financeiros relativamente relevantes, mas não apresentam infraestrutura ampla, prestadoras de serviços ou comércio especializado, nem desenvolvimento humano, o que evidencia a concentração de renda nas mãos do capital sucroenergético, a diferenciação entre os municípios da microrregião (que é visível na paisagem) e o desenvolvimento marginal fruto do agronegócio da cana.

Em observação ao percentual de ocupados na microrregião Ceres, por setores da economia (pessoas com 18 anos ou mais), tem-se que a maioria dos empregos gerados na região estão relacionados ao setor agropecuário e serviços, respectivamente (figura 62). Mesmo a região tendo sete agroindústrias canavieiras em funcionamento, elas não empregam muito no setor industrial. Como o processamento industrial é muito 
informatizado, são necessárias poucas pessoas para o controle das máquinas, nos laboratórios bioquímicos e na parte administrativa da usina, ficando para a área agrícola a maioria das vagas de emprego: nas áreas de plantio, irrigação, tratoristas e, principalmente, na colheita da cana, seja ela manual ou mecanizada.

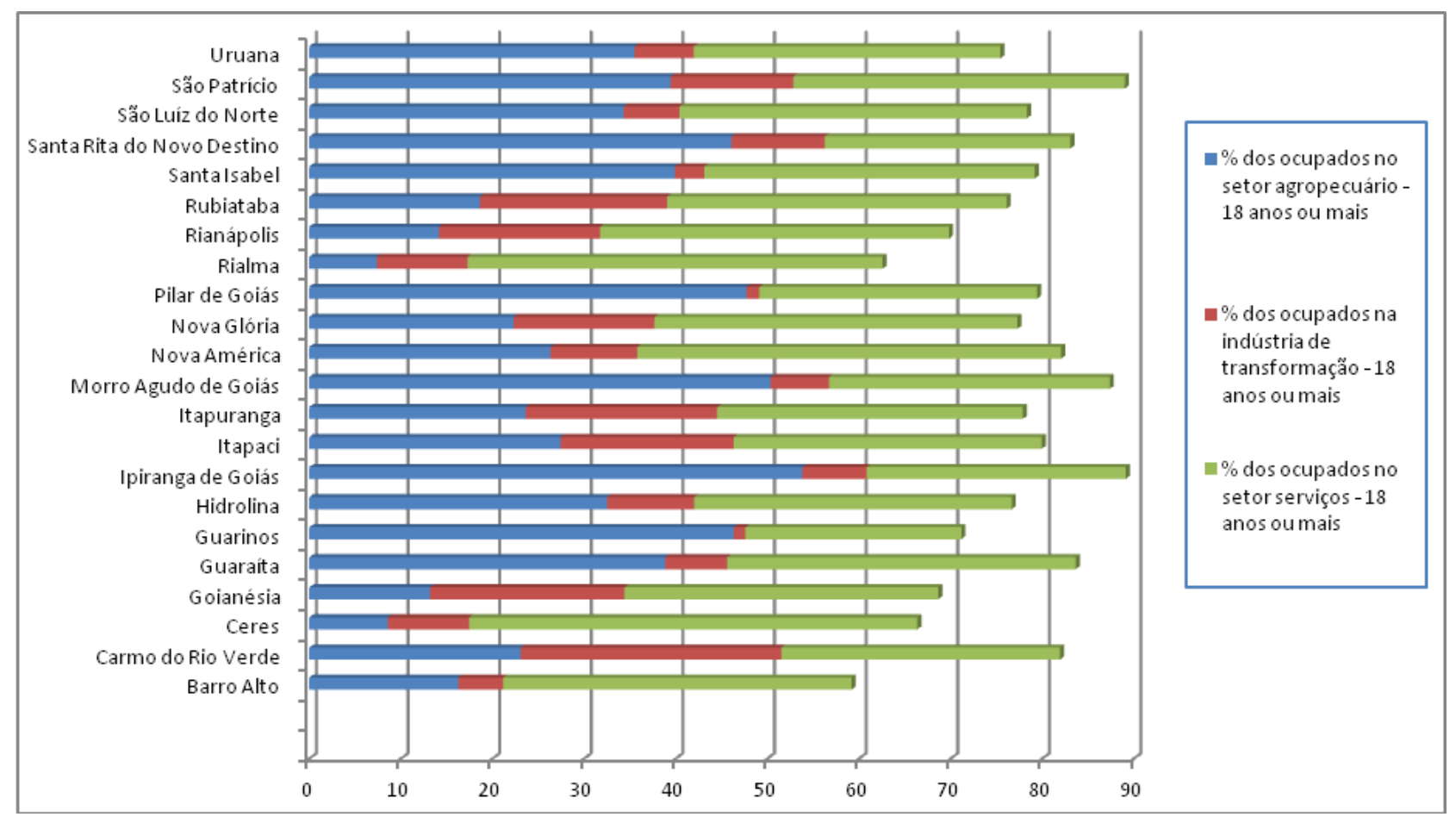

Figura 62 - Gráfico com o percentual dos ocupados nos setores agropecuário, industrial e serviços, municípios da Microrregião Ceres, GO - 2010. Fonte: Atlas do Desenvolvimento Humano.

Ressalta-se que há geração de empregos, sobretudo para o setor agrícola nas usinas canavieiras, porém a maioria desses empregos é somente para o período da safra nas usinas (março a outubro), sendo que durante o período da entressafra (novembro a fevereiro) muitos trabalhadores perdem seus empregos, pois a usina fica cerca de quatro meses sem atividades de colheita e produção de etanol e açúcar.

Infere-se então que a maioria dos empregos gerados estão diretamente vinculados a uma lógica sazonal e relacionado a um trabalho pouco especializado e muitas vezes precarizado, especialmente durante a colheita da cana-de-açúcar. Segundo Elias (2003), a proletarização do trabalhador agrícola, especialmente com a proliferação do trabalhador que reside na cidade e tem emprego temporário, corresponde a mais devastadora das consequências sociais da marcha de modernização da produção e do consumo da atividade agropecuária na atualidade. 
A cana colhida não pode ser estocada, seu recebimento pela indústria deve ocorrer em até 72 horas após sua colheita, para evitar perda de qualidade pela ação de bactérias e fermentos. A cana colhida há mais de 5 dias geralmente não é aceita pelas indústrias, por isso a produção de etanol a partir da cana ocorre apenas durante 8 meses do ano, quando há oferta de cana (ÚNICA, 2007). Nos outros 4 meses a indústria pára e passa por procedimentos de manutenção (na área industrial) e por plantio, irrigação, controle de pragas, etc. (na área agrícola). Como não há colheita de cana no período da entressafra, as vagas de empregos reduzem-se muito, gerando um alto número de desemprego, ficando empregados alguns trabalhadores para a realização desses tratos culturais.

Assim, verifica-se nos municípios da microrregião Ceres um relevante percentual de pessoas (com 18 anos ou mais) com baixa escolaridade e vinculados a ocupação informal. É importante destacar que geralmente a informalidade nos empregos relaciona-se a cidades grandes e médias, devido ao quantitativo populacional e ao desemprego estrutural, o que não é a realidade da microrregião Ceres, onde a maioria das cidades enquadram-se na categoria de pequenas cidades.

Contudo, como várias cidades da microrregião Ceres estão vinculadas às monoculturas de cana-de-açúcar, verificou-se ao longo dos anos, um processo de expropriação dos pequenos e médios produtores rurais para o arrendamento das terras para as usinas, o que faz com que os trabalhadores rurais, quando chegam à cidade, sejam desempregados estruturais, o que aumentam os casos de informalidade para a complementação da renda familiar. Além disso, tem crescido a quantidade de desempregados estruturais devido à mecanização da colheita da cana-de-açúcar.

Há também uma alta taxa de analfabetismo na região, que segue uma lógica espacial bastante semelhante ao nível de escolaridade e de ocupação informal, considerando o ano de 2010. Com exceção aos municípios de Ceres e Rialma, todos os demais municípios possuem taxa de analfabetismo maior que a média nacional, ou seja, mais que 10,19\% das pessoas com 18 anos ou mais são analfabetas.

Ceres e Rialma, representam a centralidade regional em termos de prestação de serviços, o que inclui disponibilidade de escolas, cursos técnicos e cursos superiores (Ceres principalmente, mas como Rialma está conurbada a Ceres, acaba muitas vezes, por refletir a lógica desse município), mesmo com essa característica e os dois municípios apresentando média de analfabetismo inferior a média nacional, considera-se elevada, na atualidade, a 
taxa de cerca de $8 \%$ (as informações de baixa escolaridade, informalidade e analfabetismo podem ser verificadas por meio da figura 63) .

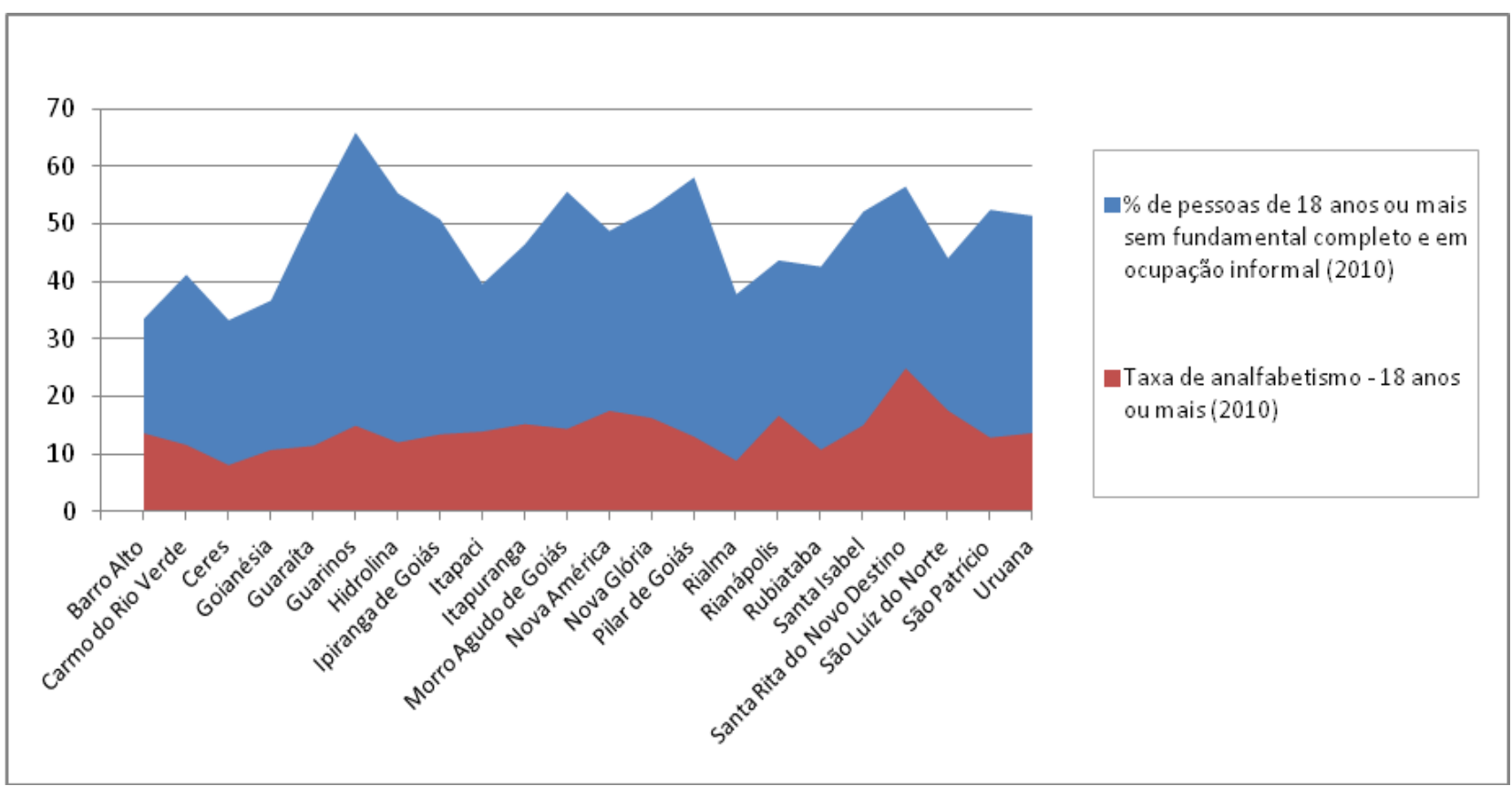

Figura 63 - Taxa de analfabetismo e percentual de pessoas sem fundamental completo e em ocupação informal - microrregião Ceres / 2010. Fonte: Atlas do Desenvolvimento Humano.

A partir dos dados apresentados, pode-se inferir que a territorialização das usinas canavieiras na microrregião Ceres, contribuiu para a intensificação de alguns processos na rede urbana regional, como: a urbanização, principalmente com a lógica da capitalização no campo que acaba por expulsar os pequenos e médios produtores para a cidade, sobretudo pela grande quantidade de terras arrendadas para a monocultura da cana-de-açúcar; a industrialização, que nesse caso, passa pela agroindustrialização do campo e com reflexo na cidade; além da desigualdade social, revelada pelos altos índices de analfabetismo (ainda na atualidade) e da informalidade conjunta ao baixo nível de escolaridade.

A tabela 13 traz dados que corroboram com a afirmativa acima, por meio dela podeser verificar a desigualdade social existente na região como um todo, onde todos os municípios pertencentes à microrregião têm mais de $40 \%$ da renda apropriada pelos $20 \%$ mais ricos. Em alguns municípios, a desigualdade é mais acentuada, como nos municípios que possuem usinas (Goianésia, Carmo do Rio Verde, Itapaci, Itapuranga e Rubiataba) e alguns municípios que servem à lógica do agronegócio sucroenergético, por meio da alta produção de cana-de-açúcar para o beneficiamento na usina do município vizinho, como são os casos de Nova Glória, São Patrício e Uruana. 
Tabela 13 - Percentual da Renda Apropriada pelos 20\% mais ricos e Percentual de Pobreza Microrregião Ceres / 2010

\begin{tabular}{l|c|c}
\hline \multicolumn{1}{c|}{ Município } & $\begin{array}{c}\text { Percentual (\%) da renda } \\
\text { apropriada pelos 20\% mais ricos }\end{array}$ & Percentual (\%) de pobres \\
\hline Barro Alto & 49,87 & 6,44 \\
\hline Carmo do Rio Verde & 50,4 & 7,81 \\
\hline Ceres & 58,37 & 4,43 \\
\hline Goianésia & 52,81 & 4,61 \\
\hline Guaraíta & 45,77 & 14,98 \\
\hline Guarinos & 45,94 & 22,00 \\
\hline Hidrolina & 47,16 & 11,56 \\
\hline Ipiranga de Goiás & 47,35 & 14,96 \\
\hline Itapaci & 60,77 & 8,42 \\
\hline Itapuranga & 54,06 & 8,79 \\
\hline Morro Agudo de Goiás & 47,53 & 11,09 \\
\hline Nova América & 42,93 & 10,91 \\
\hline Nova Glória & 52,03 & 14,49 \\
\hline Pilar de Goiás & 57,25 & 19,75 \\
\hline Rialma & 51,08 & 5,45 \\
\hline Rianápolis & 47,49 & 8,09 \\
\hline Rubiataba & 49,52 & 7,47 \\
\hline Santa Isabel & 44,67 & 8,58 \\
\hline Santa Rita do Novo Destino & 47,07 & 16,14 \\
\hline São Luíz do Norte & 44,37 & 11,15 \\
\hline São Patrício & 50,16 & 9,57 \\
\hline Uruana & 51,49 & 13,89 \\
\hline Fona Atas & & \\
\hline
\end{tabular}

Fonte: Atlas do Desenvolvimento Humano.

Os municípios de Ceres e Rialma, que têm sua economia baseada nos serviços, também apresentam uma alta concentração de riqueza nas mãos de poucos, nesses municípios há algumas prestadoras de serviços, pequenas e médias empresas, bem como pequenas e médias indústrias, que acabam concentrando a renda, além da presença de muitos médicos e donos de clínicas e hospitais em Ceres, que corresponde a um polo médico regional, como já abordado. A figura 64 mostra a empresa Saborelle, localizada em Rialma, que corresponde a uma distribuidora de produtos alimentícios (sucos, biscoitos, condimentos, achocolatados, dentre outros produtos) de porte médio (no Brasil há 14 empresas Saborelle distribuídas pelo país). 


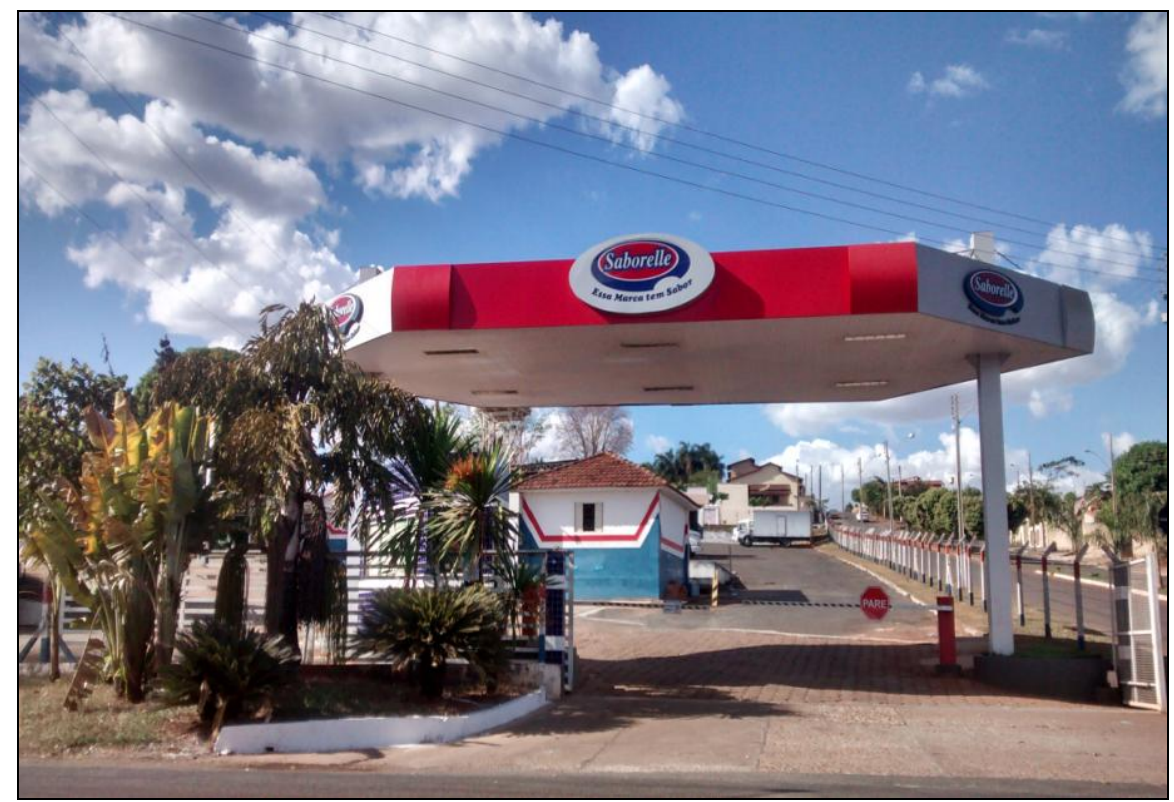

Figura 64 - Empresa/Distribuidora Saborelle - Rialma, Goiás. Foto: A autora, 2015.

A rede urbana da microrregião Ceres foi ao longo do tempo se reconfigurando a partir de alguns processos e contextos importantes. Dentre eles a implantação das usinas sucroenergéticas e suas demandas contribuíram para a atual estrutura da região e sua reconfiguração territorial. A microrregião Ceres é exemplo latente de como a dinâmica agroindustrial pode contribuir para a atração de elementos básicos que servem ao agronegócio, como agências bancárias, infraestrutura viária, investimentos e arrecadações tributárias e, ao mesmo tempo, apresentar desigualdade social, concentração de renda e fragilidade socioeconômica, principalmente devido ao fato de a maioria da região possuir certa dependência da atividade sucroenergética, salvo algumas exceções, como abordado.

No próximo subcapítulo será verificado como se comportam os municípios que são grandes produtores de cana-de-açúcar, mas não possuem empreendimentos sucroenergéticos em seus territórios, como Santa Isabel, São Luiz do Norte e Nova Glória, quais são as consequências e os efeitos verificados nos municípios que servem ao agronegócio canavieiro e o que pode ser visualizado em sua paisagem. 


\subsection{As Cidades que servem ao Agronegócio Sucroenergético: O Caso de Santa Isabel, São Luiz do Norte e Nova Glória}

Dentro do ordenamento territorial impulsionado pelo capital canavieiro, podem-se citar três municípios da microrregião Ceres que apresentam uma dinâmica diferenciada nesse processo, que são: Santa Isabel, São Luiz do Norte e Nova Glória. Esses três municípios estão entre os maiores produtores de cana-de-açúcar na região estudada. Juntos correspondem a mais de $23 \%$ da produção em toneladas de cana e mais de $25 \%$ em área colhida, em hectares (a tabela 14 mostra os detalhes da produção e área colhida de cana-deaçúcar nesses três municípios).

Quando se adentra à área municipal de Santa Isabel, São Luiz do Norte e Nova Glória, têm-se a certeza de que correspondem a municípios canavieiros, sobretudo por visualizar a grande extensão territorial dos mesmos em plantio de cana-de-açúcar (a figura 65 mostra a localização desses municípios na microrregião estudada).

Tabela 14 - Produção de cana-de-açúcar e área colhida nos município de Santa Isabel, São Luiz do Norte e Nova Glória - 2013

\begin{tabular}{l|c|c}
\hline \multicolumn{1}{c|}{ Município } & $\begin{array}{c}\text { Produção de cana-de-açúcar } \\
(\mathbf{t})\end{array}$ & Área colhida (ha) \\
\hline Nova Glória & 709.278 & 11.766 \\
\hline Santa Isabel & 471.527 & 7.128 \\
\hline São Luiz do Norte & 570.000 & 9.500 \\
\hline Total da Microrregião Ceres & 7.543 .328 & 102.398 \\
\hline Percentual dos três municípios & $\mathbf{2 3 , 2 \%}$ & $\mathbf{2 5 , 9 \%}$ \\
\hline
\end{tabular}

Fonte: Instituto Mauro Borges / Segplan-GO, 2015.

O grande diferencial é que nenhum dos três municípios possuem empreendimentos sucroenergéticos implantados e quando se chega às respectivas sedes municipais e se pesquisa as estatísticas socioeconômicas, percebe-se que a estreita ligação desses municípios com a atividade canavieira está praticamente circunscrita à disponibilização de terras para o cultivo, que se dá, em sua maioria, por meio dos arrendamentos de terras para as usinas vizinhas (e todas as mazelas relacionadas a isso, como será discutido a seguir). 


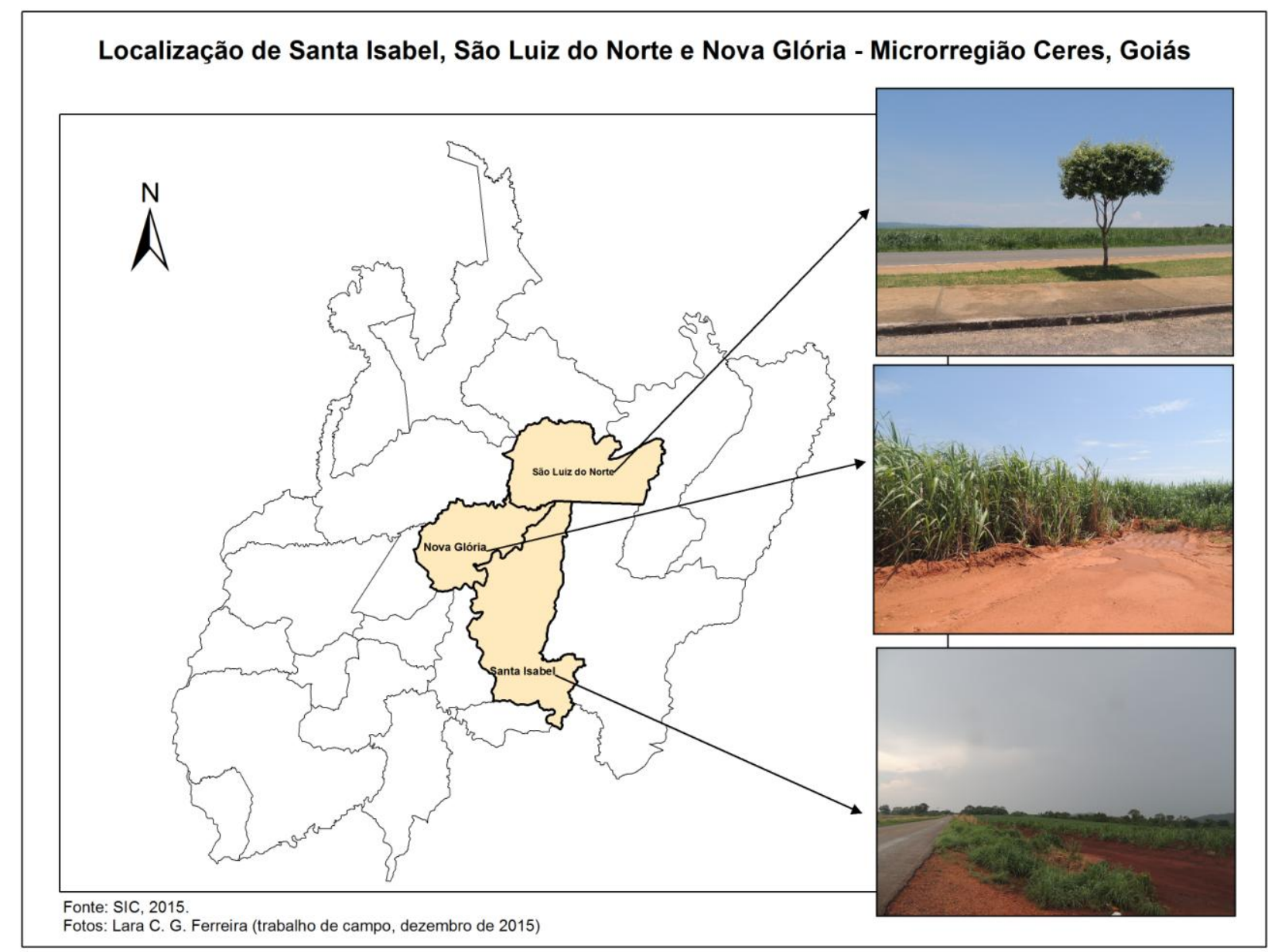

Figura 65 - Localização dos municípios de Santa Isabel, São Luiz do Norte e Nova Glória na Microrregião Ceres, Goiás.

Quando se avalia as sedes municipais desses três municípios, elas podem ser consideradas cidades pequenas e que ainda possuem características rurais muito fortes. $\mathrm{Na}$ microrregião Ceres a maioria das cidades que a compõe são consideradas pequenas, já que possuem população inferior a 10 mil habitantes. A discussão sobre o conceito de cidades pequenas está relacionada à região em que tal cidade está inserida, por exemplo, para Gohn (2007) cidades pequenas seriam aquelas com população até 50 mil habitantes, contudo, essa autora utiliza a escala nacional como análise (o sistema urbano brasileiro).

Autores como Deus (2004), conceituam cidades pequenas como sendo aquelas com até 20 mil habitantes, sendo um conceito mais apropriado para a realidade do estado, já que Goiás possui mais de $80 \%$ de seus municípios com população até 20 mil habitantes. Nesse sentido, a expressão "pequenos municípios" utilizada por Arrais (2004) é considerada apropriada para a realidade da microrregião Ceres, pois segundo este autor, pequenos 
municípios são os que apresentam população igual ou inferior a 10 mil habitantes, ou seja, a maioria dos municípios que configuram a microrregião estudada.

Santa Isabel, São Luiz do Norte e Nova Glória são consideradas cidades pequenas e as áreas que hoje formam esses municípios foram mais amplamente ocupadas durante a década de 1940 (segundo relatos locais colhidos em trabalho de campo), juntamente ao processo de ocupação do interior do país, durante a Marcha para o Oeste. Nesses municípios a principal atividade econômica era a agropecuária, mas sem grandes destaques. Com a construção da Belém-Brasília (BR 153) e com a expansão do agronegócio para o CentroOeste brasileiro, esses municípios passaram a incorporar população e elementos que os configuraram com um caráter fundamentalmente agrário.

As marcas do agronegócio sucroenergético são bem visíveis na paisagem desses três municípios. Já durante o deslocamento para eles, são verificadas extensas lavouras canavieiras ao longo das rodovias. Contudo, quando se adentra ao perímetro urbano desses municípios verificam-se poucos elementos relacionados à dinâmica sucroenergética (se comparados aos municípios com usinas implantadas), bem como quando se analisa os dados de PIB, impostos, arrecadações, empregos, entre outros. Percebe-se portanto, que o município participa da atividade canavieira, mas basicamente como coadjuvante, praticamente como um mero fornecedor de terras para a produção de cana.

Geralmente quando se analisa os dados brutos de cidades relacionadas ao agronegócio, percebe-se uma dinamização socioespacial e um crescimento econômico dos mesmos. Mas, isso não é observado nos municípios como Santa Isabel, São Luiz do Norte e Nova Glória, que são grandes produtores de cana-de-açúcar, mas não possuem empreendimentos sucroenergéticos em seus territórios.

Ao conhecer essas cidades surgem vários questionamentos: como se encontra o município inserido na lógica sucroenergética? Há no município, trabalhadores rurais ou prestadoras de serviço para as usinas vizinhas? Em termos econômicos, o que há de retorno da usina para os municípios produtores de cana? E por fim, quanto o município está vinculado à lógica canavieira de uma agroindústria implantada em outro município, quais os efeitos disso?

O município de Santa Isabel produz cana-de-açúcar para as usinas: CRV Industrial (Carmo do Rio Verde), Jalles Machado e Uol/Codora (ambas de Goianésia). Segundo o 
Secretário de Agricultura do município ${ }^{26}$, essas áreas substituíram principalmente áreas de pastagens e houveram muitas áreas desmatadas para o plantio de cana. A maioria das áreas em produção de cana-de-açúcar nesse município é arrendada e se tratam de médias e grandes propriedades.

Segundo o Secretário de Agricultura de Santa Isabel, a grande maioria dos proprietários de terras que arrendam para as usinas, não vivem no município e possuem outras fontes de renda, são fazendeiros em sua maioria, e moram em cidades vizinhas com maior infraestrutura. A figura 66 mostra uma lavoura de cana no município de Santa Isabel, durante o período de entressafra.

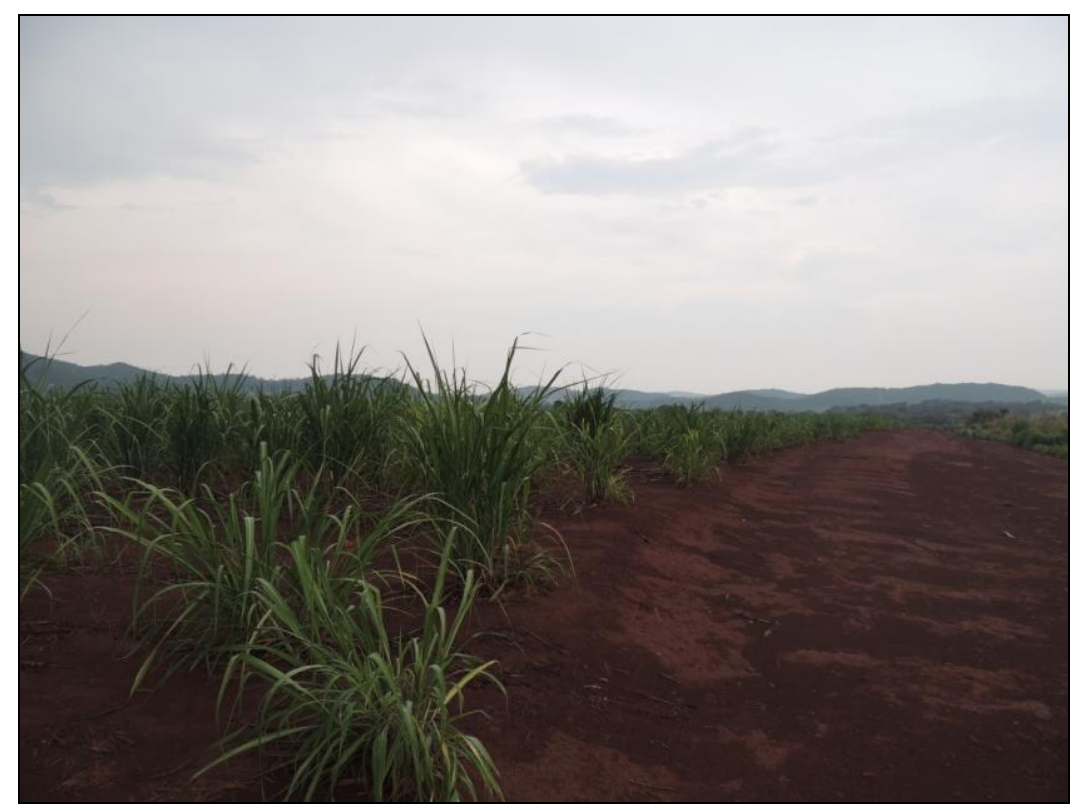

Figura 66 - Cultivo de cana-de-açúcar em Santa Isabel no período da entressafra - Santa Isabel, Goiás. Foto: A autora, dezembro de 2015.

Não há em Santa Isabel prestadoras de serviço, comércio especializado e nem um número considerável de trabalhadores da cana. Segundo entrevista ao representante do poder público local, a cana traz mais efeitos negativos (erosões, contaminações, poluição do ar pela queima da cana, concentração de terras e renda, trabalho precarizado, etc.) que positivos (geração de empregos e impostos e dinamização econômica local/regional) para o

\footnotetext{
${ }^{26}$ Entrevista realizada no dia 08 de dezembro de 2015, com os Secretários de Agricultura e Finanças do município de Santa Isabel.
} 
município, pois não há nenhuma devolutiva social por parte da usina. A prefeitura já tentou algumas parcerias com essas usinas que utilizam as terras do município para plantio de cana, sobretudo para realizar ações na busca de mitigar os impactos ambientais fruto da atividade canavieira em Santa Isabel, mas não obtiveram sucesso.

Em termos econômicos, há dois impostos principais que as usinas deveriam pagar para esses municípios que são fornecedores de cana-de-açúcar: o ICMS e o ISSQN. O ICMS (Imposto sobre Circulação de Mercadorias e Serviços) é um imposto estadual brasileiro, somente os governos dos estados têm competência para instituí-lo. Para atrair os empreendimentos sucroenergéticos para o estado de Goiás, uma das estratégias do Governo foi a de isentar as agroindústrias de alguns impostos, inclusive o ICMS, e o fomento por meio de programas como o Produzir, como já exposto.

Desta forma, os municípios ficam a mercê do governo do estado, que por interesses que as vezes não perpassam as necessidades municipais, isentam as usinas por um longo período. Quando esse tempo se finda, o ICMS é pago pelo empreendimento diretamente para o governo do estado e este retorna somente depois para os cofres municipais e não na mesma proporção.

O ISSQN (Imposto sobre Serviços de Qualquer Natureza) pode ser recolhido mensalmente a partir de uma alíquota que varia de acordo com o serviço prestado, pelo valor estimado pela fiscalização ou ainda de forma anual, a partir de um valor fixo atribuído a cada atividade. Esse imposto deve ser pago diretamente para o município (diferentemente do ICMS).

Durante a entrevista realizada na Prefeitura de Santa Isabel, os Secretários de Agricultura e Finanças do município, mostraram-se muito indecisos e inseguros quanto aos impostos que de fato recebiam das usinas que produzem cana-de-açúcar no município. Segundo eles, o município de Santa Isabel tem uma extensa área territorial, o que dificulta a fiscalização da real área utilizada para produção de cana e qual o percentual utilizado pelas três usinas.

Outro conflito verificado no município está relacionado ao terminal / Porto Seco da Ferrovia Norte-Sul previsto para ser instalado em Santa Isabel. Segundo os Secretários entrevistados, o terminal começou a ser construído, porém atualmente a obra está paralisada. Segundo eles há rumores que o terminal da ferrovia vá para o município de Goianésia, pois neste município além de conter três empreendimentos sucroenergéticos implantados, há também uma centralização do poder político e estratégico regional relacionado a atividade 
canavieira. Quando se verifica o site da Valec (empresa responsável pela construção da Ferrovia Norte-Sul) o terminal está previsto realmente para Santa Isabel.

Já o município de São Luiz do Norte está praticamente ilhado nas lavouras de cana, quando se entra no município é possível ver canaviais muito próximos ao perímetro urbano (figura 67), além de observar claramente elementos na paisagem que remetem à atividade canavieira.

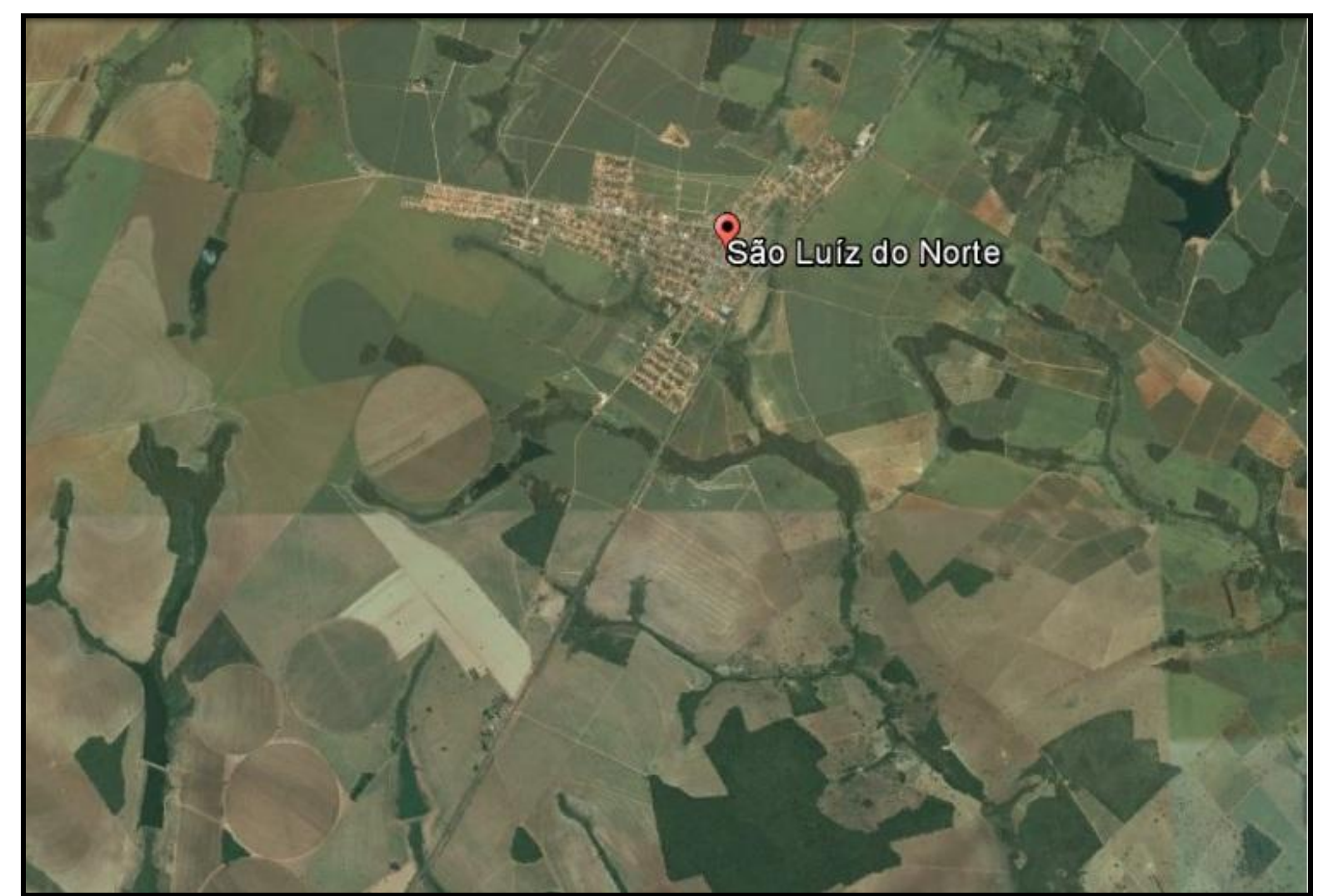

Figura 67 - Imagem de São Luiz do Norte e os talhões de cana-de-açúcar e pivôs centrais. Fonte: Google Earth, 2016.

Foi possível verificar treminhões carregados de cana-de-açúcar passando pelo perímetro urbano do município, mesmo durante o período da entressafra da cana, pois esses treminhões estavam carregados de cana para o plantio (a figura 68 registra o momento em que o treminhão passava pelo perímetro urbano de São Luiz do Norte). 


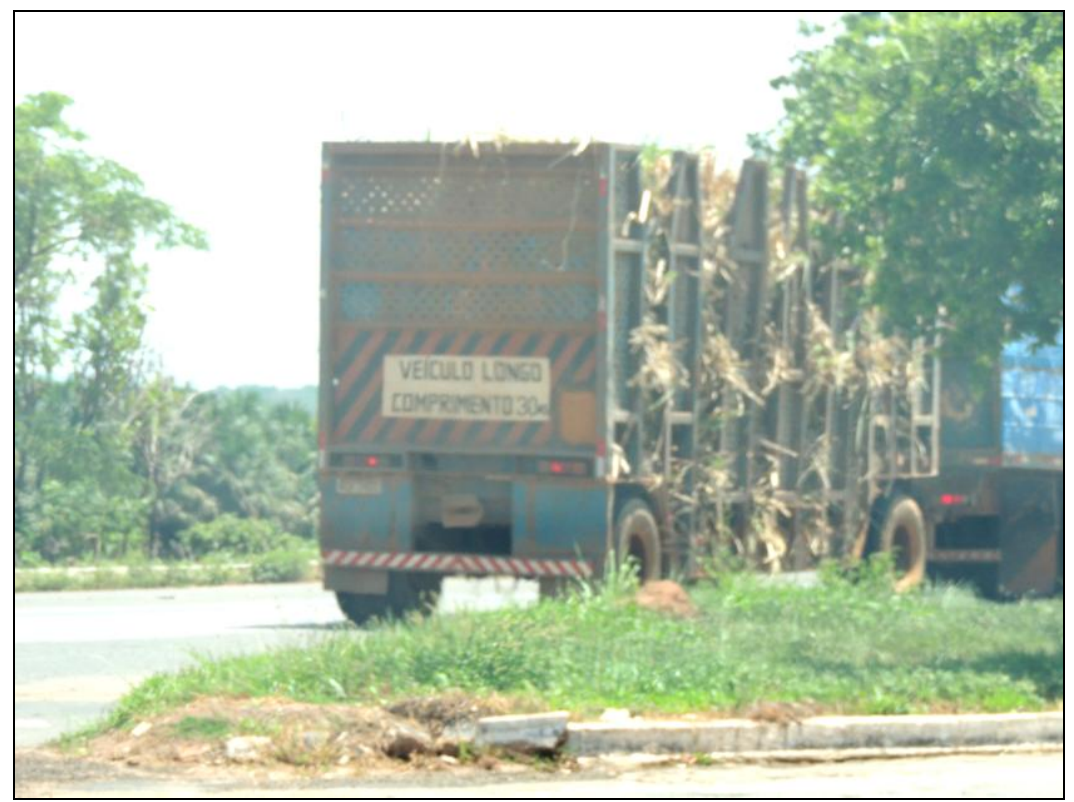

Figura 68 - Treminhão no perímetro urbano - São Luiz do Norte, Goiás. Foto: A autora, dezembro de 2015.

O município de São Luiz do Norte produz cana-de-açúcar para cinco usinas de municípios vizinhos, quatro usinas localizadas na microrregião Ceres (Usina Goianésia, UOL/Codora, Cooper Rubi e Vale Verde) e uma usina localizada no município de Uruaçu (Uruaçu Açúcar e Álcool).

São mais de 9 mil hectares de cana-de-açúcar produzidas por ano em São Luiz do Norte. Dessa área a maioria está arrendada pelas usinas, mas há três fazendas fornecedoras de cana para as usinas. Trata-se da LOER - Locadora Entre Ríos, uma empresa Colombiana que produz cana em terras próprias e revende para as usinas vizinhas. Além disso, a LOER também trabalha com a locação de veículos para o transporte da cana-de-açúcar para as agroindústrias.

No município de São Luiz do Norte observa-se a presença de algumas prestadoras de serviço voltadas para a atividade canavieira, além de algumas mecânicas (simples, nenhuma especializada ou muito moderna) e um percentual considerável de habitantes do município que trabalham na atividade canavieira, especialmente nas lavouras e como motoristas e tratoristas, segundo o Secretário de Agricultura do município ${ }^{27}$.

Em termos econômicos e fiscais a mesma problemática verificada em Santa Isabel se repete em São Luiz do Norte. Segundo o representante do poder público local entrevistado é

\footnotetext{
${ }^{27}$ Entrevista realizada com o Secretário de Agricultura de São Luiz do Norte, no dia 09 de dezembro de 2015.
} 
muito difícil fiscalizar a quantidade de área que é produzida por cada uma das cinco usinas que produzem cana-de-açúcar no município, essa tarefa é realizada pela própria usina e não há um esforço ou pessoal técnico capacitado, por parte da prefeitura, para realizar a fiscalização.

Por fim, o município de Nova Glória é o segundo maior município com área plantada de cana-de-açúcar da microrregião Ceres, são mais de 11 mil hectares em lavouras canavieiras, o que corresponde a mais de $70 \%$ da área municipal em plantação de cana (a figura 69 mostra o perímetro urbano da cidade e a área circundante em plantação de cana).

A cana produzida em Nova Glória vai para as usinas Cooper Rubi (Rubiataba) e Vale Verde (Itapaci). Todas as terras em produção de cana são arrendadas pelas usinas, sendo que muitos fazendeiros arrendatários não vivem em Nova Glória, mas em cidades vizinhas, como Ceres, por exemplo.

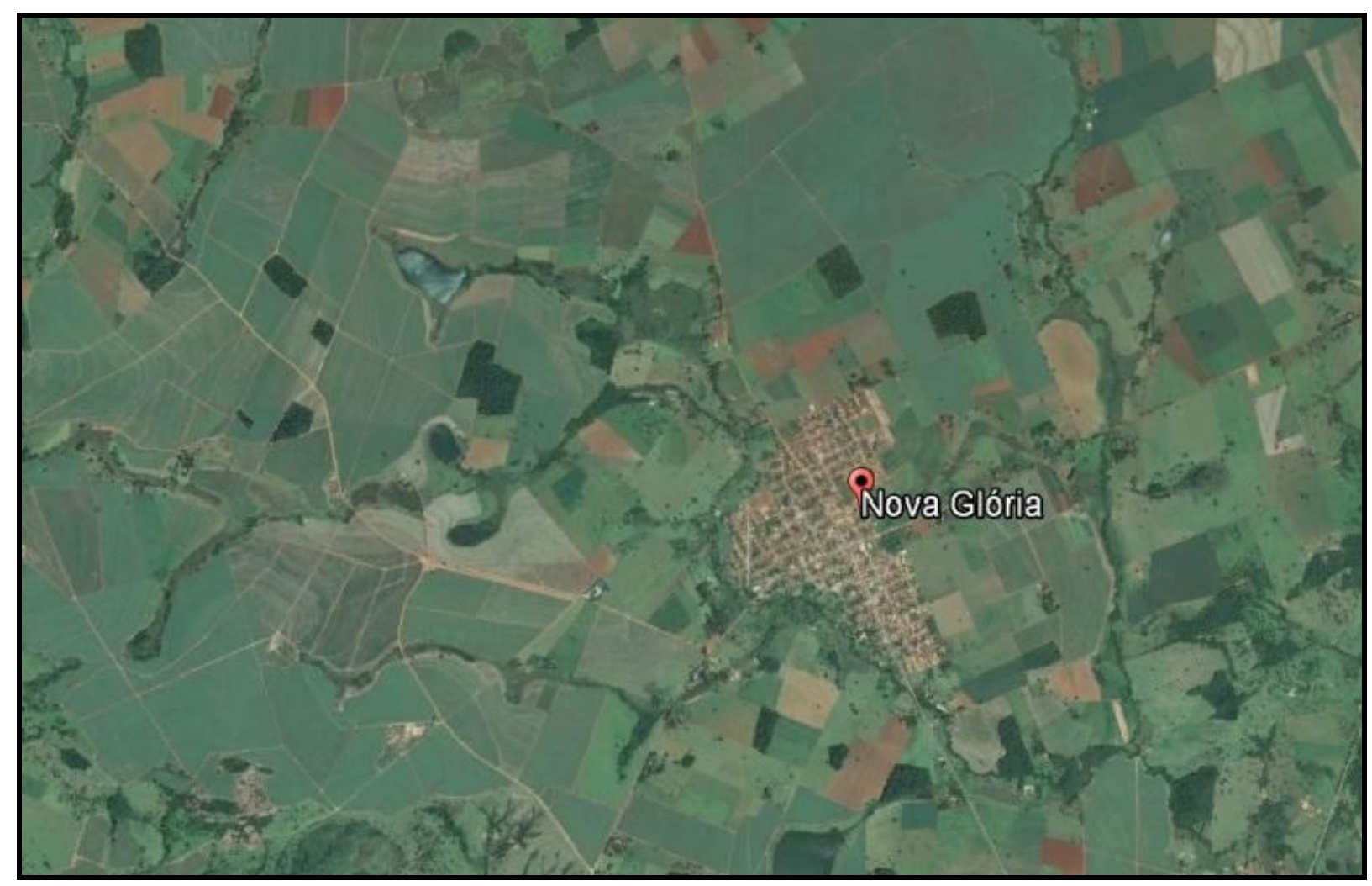

Figura 69 - Imagem de Nova Glória e os talhões de cana-de-açúcar. Fonte: Google Earth, 2016.

Em Nova Glória, apesar de ser grande produtora de cana-de-açúcar, verifica-se poucas prestadoras de serviços voltadas a atividade canavieira. Segundo o Secretário de 
Meio Ambiente do município ${ }^{28}$ tem poucas empresas que prestam serviços, principalmente de transporte para as usinas, sobretudo durante o período da safra. Há também alguns moradores de Nova Glória que trabalham em atividades braçais na usina (plantio e corte da cana, por exemplo), o Secretário enfatizou que nas "melhores" funções da usina (funções relacionadas ao escritório e indústria) não há nenhum trabalhador de Nova Glória.

Destaca-se que mesmo Nova Glória sendo o segundo maior produtor de cana da região estudada, não existe uma Secretaria de Agricultura no município, ficando para a Secretaria de Meio Ambiente os encargos desta pasta. Isso mostra a falta de prioridade junto ao desenvolvimento agrário municipal e, sobretudo, a fragilidade técnica e política frente a uma realidade latente e preocupante e que pode desencadear grandes impactos caso não haja minimamente um acompanhamento técnico, bem como as fiscalizações necessárias.

Durante a entrevista, o Secretário de Meio Ambiente de Nova Glória relatou o quão danosa tem sido a atividade canavieira no município, pois as atividades realizadas pelas usinas não respeitam as áreas de nascentes e ultimamente tem-se retirado as curvas de nível das lavouras para a entrada de máquinas para a colheita mecanizada. Essas duas ações tem ocasionado degradação nas nascentes de rios e córregos, bem como erosões pela retirada das curvas de nível. Nesse sentido, a prefeitura criou o projeto "Ser Natureza" na tentativa de mitigar os impactos ambientais já existentes, diretamente relacionados ao plantio de canade-açúcar. Para o projeto "Ser Natureza" a Secretaria de Meio Ambiente solicitou parceria com as usinas, contudo não obteve sucesso.

Outro grave problema socioambiental verificado em Nova Glória (mas que é realidade em todos os municípios envolvidos com o agronegócio) é a "chuva" de veneno que acessa a população da cidade, não só pelo ar, mas também por meio da contaminação de solos e recursos hídricos.

Durante a realização de trabalho de campo em Nova Glória, foi possível verificar a pulverização aérea de veneno nas lavouras (que acontece durante o período da entressafra plantio e desenvolvimento da planta). Segundo o Secretário de Meio Ambiente é muito comum nessa época, o aumento de alguns sintomas na população, como: diarréia e dores de cabeça, o que os leva a crer que há alguma relação com a pulverização aérea das lavouras,

\footnotetext{
${ }^{28}$ Entrevista realizada ao Secretário de Meio Ambiente de Nova Glória, no dia 09 de dezembro de 2015.
} 
que estão muito próximas ao perímetro urbano de Nova Glória. A figura 70 mostra o avião utilizado para a pulverização das lavouras de cana em Nova Glória.

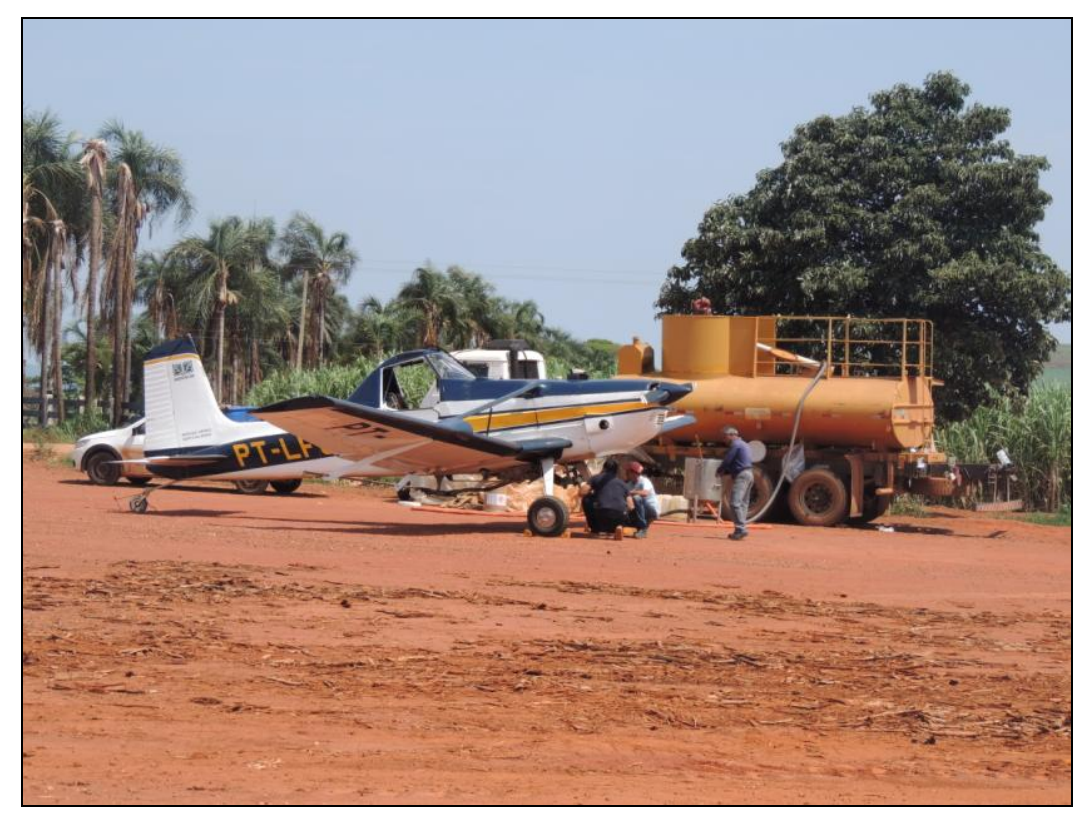

Figura 70 - Avião pulverizador de veneno utilizado nas lavouras de cana-de-açúcar - Nova Glória, Goiás. Foto: A autora, dezembro de 2015.

Em termos econômicos, novamente observou-se que o poder público local perdeu as "rédeas" do que deve ser devolvido ao município pelas usinas, em forma de impostos. Em Nova Glória o Secretário de Finanças do município disse claramente, durante uma entrevista, que somente a usina Vale Verde (Itapaci) paga periodicamente o ISSQN (que deveria ser pago mensalmente) e a Cooper Rubi (Rubiataba) nunca pagou qualquer imposto ao município.

Ter escolhido os municípios de Santa Isabel, São Luiz do Norte e Nova Glória para verificar como se comportam os municípios que têm grandes lavouras de cana, mas que não possuem empreendimentos implantados, foi fundamental para se compreender a lógica do setor sucroenergético. A demanda por áreas para o plantio de cana para servir poucas usinas, acaba por envolver quase toda a região. É comum estudos com a temática canavieira focar somente os municípios usineiros, mas isso mascara toda uma complexa realidade do setor sucroenergético em Goiás e, mais especificamente, na região de Ceres. 
Observou-se de perto três grandes produtores de cana, que não têm praticamente nenhum retorno social, ambiental e, sobretudo, econômico dos empreendimentos. Grandes e graves são os efeitos nesses municípios, bem como o desconhecimento dos direitos fiscais e/ou os acordos políticos existentes entre poder público e usineiros para que a efetiva fiscalização e a cobrança de tributos não aconteçam.

Nos três municípios quando deles se aproxima é visível a imersão na atividade canavieira, nem que seja somente como mero fornecedor de cana-de-açúcar para as usinas vizinhas. Foi unânime também o descontentamento dos Secretários frente à lógica canavieira, que é de muita expropriação e pouco retorno aos municípios. Poucas são as prestadoras de serviços, pouco é utilizado do comércio local e poucos são os trabalhadores envolvidos nas atividades das usinas dos municípios vizinhos, e quando existem estão vinculados a atividades braçais e como motoristas ou tratoristas.

Para a paisagem regional, vários são os elementos materializados, mesmo quando são municípios que não possuem usinas e que não veem quase nenhum retorno direto dessa atividade. Mesmo sem usinas implantadas são comuns treminhões dentro do perímetro urbano dessas cidades; os efeitos da queima da cana, como a fuligem nas casas durante o período da safra (antes a queima da cana acontecia somente para a colheita manual, atualmente a queima da cana está sendo utilizada também, em alguns casos, para a colheita mecanizada, pois a queima aumenta os teores de sacarose ${ }^{29}$ ); além de aviões pulverizadores das lavouras, como verificado anteriormente.

Talvez o mais grave verificado nesses municípios seja o poder público local, principalmente o materializado nas pessoas dos prefeitos, apropriarem-se do mito do progresso, que acompanha o discurso das agroindústrias sucroenergéticas, e não buscarem efetivamente o mínimo retorno financeiro, que é de direito desses municípios, que deveriam ser retornados em ações para a cidade e, principalmente, para os moradores.

Foi perceptível e até relatado por alguns Secretários durante os trabalhos de campo, que os grandes financiadores das campanhas eleitorais municipais são os usineiros. De posse dessa informação dá para se compreender muitas vezes o silêncio, os acordos realizados, a falta de fiscalização, entre outras atitudes, que poderiam culminar com a devolução aos municípios produtores de cana de, pelo menos, o elemento financeiro.

\footnotetext{
${ }^{29}$ Informações obtidas em trabalho de campo.
} 
Arrais (2013) afirma que o agronegócio (carnes, cana-de-açúcar, grãos) conta com a maior influência econômica e destina o maior montante de financiamento de campanhas políticas. Segundo o mesmo autor, “é nesse contexto de conflitos muitas vezes dissimulados que o território é produzido. As mudanças na paisagem regional são expressão formal, visível, de um processo que oculta problemas sociais e ambientais próprios da nossa matriz de desenvolvimento" (ARRAIS, 2013, p. 198). Desta forma, pode-se inferir que a dimensão política, o poder que envolve as relações, influenciam direta e indiretamente na (re) produção do território e nos efeitos causados e que são verificados nas paisagens regionais.

Diante do exposto, o capítulo 5 trás à discussão o mito do progresso, tão presente nos discursos do agronegócio brasileiro, além disso questiona-se: como fica o desenvolvimento econômico frente à realidade socioeconômica dessa região? O próximo capítulo discute também o conceito de Paisagem Regional, importante para se compreender os elementos e as formas espaciais materializadas na paisagem da microrregião Ceres. 


\section{CAPÍtUlo V - A PAISAGEM REgIONAL E O MITO DO PROGRESSO - O DESENVOLVIMENTO INCOMPLETO DA MICRORREGIÃO CERES}

Nesse último capítulo, após conhecer o processo histórico de formação e a realidade atual da microrregião Ceres, como uma região regida pelo agronegócio sucroenergético, bem como após conhecer a formação da rede urbana e sua evolução, que esteve muito relacionada à política de colonização e ocupação do oeste brasileiro, por meio das Colônias Agrícolas Nacionais, intenta-se discutir o que ficou de herança dessa política e o que pode ser desvelado por meio de sua paisagem regional.

Um conceito que pode somar à abordagem das paisagens regionais é conceito de rugosidades de Santos (2002), o qual representa o que fica do passado como forma, espaço construído, o que resta do processo de supressão, acumulação, superposição, na paisagem. Assim, as rugosidades podem se apresentar como formas isoladas ou como arranjos territoriais.

Faz-se importante também discutir quais as consequências do mito do progresso, muito diretamente relacionado às políticas desenvolvimentistas do Estado e das promessas de progresso atrelado ao agronegócio e que realidades podem estar vinculadas ao discurso do desenvolvimento econômico, também muito presente.

Com o desenvolvimento da tese, viu-se o quanto a atividade sucroenergética está vinculada à dinâmica socioeconômica da microrregião Ceres e quais problemáticas podem estar relacionadas a essa atividade, sobretudo em uma região que não possui outra atividade econômica forte ou outro setor do agronegócio para contrabalancear e diversificar a economia regional. Assim, de forma sintética, verificou-se uma região com altos PIB's e valores adicionados à agropecuária e serviços, mas com índices de desenvolvimento humano deficientes, além de uma paisagem regional muito vinculada ao "mar" de cana e todas as problemáticas que essa atividade pode acarretar.

A política das Colônias Agrícolas Nacionais trouxe um verdadeiro boom populacional para a região de Ceres durante a década de 1940, com o discurso de ocupação do que na época era considerado um verdadeiro "vazio" demográfico, por meio de doação de lotes e subsídios para uma produção agrícola familiar. Após alguns objetivos frustrados da CANG, municípios foram criados, emancipados e, com o passar dos anos, com a ação de programas que propiciaram a expansão da fronteira do agronegócio canavieiro, essa região alterou sua paisagem, antes vinculada às colônias, à produção de alimentos, aos comércios em feiras, para uma paisagem fortemente relacionada a extensas monoculturas de cana-de- 
açúcar, plantas agroindustriais de processamento sucroenergético, colhedoras, treminhões, trabalhadores rurais, cortadores de cana, fuligem, entre outros elementos e formas espaciais, conforme já abordado.

Mesmo conhecendo a realidade dessa região, pode-se questionar: como se configuram as lutas de acesso à terra atualmente? O que pode estar por trás da paisagem da cana nessa região, no que se refere à luta pela reforma agrária e acesso às políticas de desenvolvimento da agricultura familiar? O que existe hoje nessa região, que se encontra na contramão da lógica do capital sucroenergético?

Sabe-se dos problemas do cerne da política das Colônias Agrícolas no Brasil, e discorda-se de alguns autores que a entenderam como uma política relacionada à reforma agrária. Contudo, entende-se que a região estudada possui uma história muito relacionada a agricultura, à terra e com sujeitos sociais com raízes rurais muito fortes. Assim, nesse Capítulo entende-se a importância de trazer alguns dados atuais sobre a reforma agrária nessa região: famílias assentadas, dados de área reformada, bem como números do Programa de Fortalecimento à Agricultura Familiar na microrregião Ceres.

Além disso, tenta-se compreender a paisagem regional da microrregião Ceres e o que elas podem revelar, além de uma discussão, considerada aqui muito importante, sobre o mito do progresso e suas reais consequências para o desenvolvimento econômico da região, muito relacionados ao discurso do agronegócio.

\subsection{A Paisagem Regional da Microrregião Ceres - Da CANG ao Setor Sucroenergético}

Nesse último Capítulo, após serem conhecidos dados, estatísticas, levantamentos, mapas, etc., sobre a realidade da microrregião Ceres frente à dinâmica sucroenergética, parte-se para a tentativa de compreender, por meio da paisagem regional, as formas, as dinâmicas e as contradições socioespaciais verificadas na região estudada, a partir das Colônias Agrícolas Nacionais aos dias atuais. Para isso, entende-se que, aliada a abordagem regional, tem-se a categoria paisagem que contribui sobremaneira, para desvelar as marcas históricas incrustadas no espaço geográfico.

Para Santos (1985), a paisagem é como um palimpsesto, ou seja, resulta de acumulações, nas quais algumas construções permanecem intactas ou modificadas, enquanto 
outras desaparecem para ceder lugar a novas edificações. Assim, a paisagem revela um mosaico de relações, formas, funções e sentidos.

Santos, em outra obra, formula talvez o conceito de paisagem mais utilizado nos trabalhos geográficos, para ele "a paisagem é tudo aquilo que nós vemos, o que nossa visão alcança é a paisagem. Esta pode ser definida como o domínio do visível, aquilo que a vista abarca" (SANTOS, 1988, p. 21).

Outros importantes autores trazem concepções de paisagem que complementam as de Milton Santos. Para Corrêa (2000), as desigualdades que aparecem, caracterizam-se pela combinação de aspectos distintos dos diversos momentos históricos, o que acaba por imprimir marcas na paisagem, que nada mais é que uma expressão dos modos de vida humanos. Corrêa (2014) também discute que a paisagem é constituída por um conjunto articulado de formas materiais que podem ser criadas tanto pela natureza, quanto pela ação humana, atribuindo funcionalidades e impregnando significados.

Para Naranjo (2002), a paisagem contêm materializadas, distintas soluções que as distintas gerações (em diferentes condições técnicas), têm dado à ocupação e ao uso de um território. As transformações técnicas, políticas, econômicas e sociais vem crescendo, principalmente após o século XVI, e vem alterando o sentido da paisagem, introduzindo um valor de troca e novos signos e sentidos (CORRÊA, 2014).

A sociedade capitalista, sobretudo nas últimas décadas, na ânsia de progresso somado à capacidade tecnológica, que vem evoluindo sobremaneira ao longo do tempo, modifica a natureza cada vez mais rapidamente, incorporando arranjos e estruturas artificiais discordantes com a paisagem, e muitas vezes numa velocidade tão grande que a própria sociedade tem dificuldade em assimilar.

Essas novas transformações e possibilidades modificaram radicalmente a relação entre o ser humano e a natureza, de modo que o ser humano passa a ser o agente transformador e a construir, muito rapidamente, uma segunda natureza, cada vez mais artificializada e com um grande número de fixos artificiais (SANTOS, 2002).

A paisagem concede personalidade ao espaço, considerando como uma totalidade que resulta da combinação de múltiplos elementos, físicos e humanos, além de uma trajetória histórica (RODRIGUEZ, 2006). E é essa personalidade, concedida pela paisagem ao espaço, que revela os efeitos e os conflitos acumulados ao logo do tempo. Assim, quando se observa a paisagem não se vê somente elementos simples, como sua fisionomia, relevo ou vegetação, mas sobretudo como tem se dado seu uso ao logo do tempo. 
Para essa noção, o que está materializado na paisagem, está carregado também de sentido político, pois o que está visível acaba por desvelar as políticas aplicadas no lugar, os agentes com interesses diversos que se inseriram, além da permissão (e estímulo) do Estado na territorialização dos empreendimentos, empresas, corporações, agronegócios, entre outros exemplos.

Concorda-se com Santos (1988), quando esse diz que a paisagem é um conjunto heterogêneo de formas naturais e artificiais, e é formada por frações de ambas. Segundo ele, quanto mais complexa a vida social mais distantes os sujeitos estão de um mundo natural, e mais próximos a um mundo artificial. A paisagem é heterogênea porque corresponde a uma "escrita" sobre a outra, além de conter objetos e elementos materializados, com idades diferentes. Ainda para Santos (1988, p. 24), “a paisagem não é dada para todo o sempre, é objeto de mudança. É um resultado de adições e subtrações sucessivas. É uma espécie de marca da história do trabalho e das técnicas".

A esse conceito de paisagem de Milton Santos, pode-se dialogar com o conceito de rugosidades, também dele autor, o qual reflete que os conjuntos de formas espaciais ficam à espera, prontos para eventualmente exercer funções, ainda que limitadas por sua própria estrutura. Assim, “o trabalho já feito se impõe sobre o trabalho a fazer. A atual repartição territorial do trabalho repousa sobre as divisões territoriais do trabalho anteriores. E a divisão social do trabalho não pode ser explicada sem a explicação da divisão territorial do trabalho, que depende, ela própria, das formas geográficas herdadas" (SANTOS, 2002, p. 92).

Para analisar e compreender a paisagem é necessário também ter em mente a importância do tempo. Toda ação humana está inscrita no espaço e no tempo, incorporando e criando elementos e atributos. Segundo Corrêa (2014), a espacialidade refere-se à distribuição dos processos e formas, o que permite identificar seções do espaço dotadas de diferentes conteúdos e limites, e a temporalidade refere-se às origens, desenvolvimento e transformação dos processos e formas.

Além do tempo, a escala também é muito importante nessa análise, pois os objetos ganham ou perdem visibilidade ao se alterar a escala espacial. A paisagem local não exibe os mesmos objetos da paisagem regional. Segundo Corrêa (2014), com a escolha da escala, a problemática e os questionamentos podem variar, além de que os processos que atuam na escala regional podem ser mais amplos que na escala local, por exemplo.

Assim, faz-se importante discutir sobre a paisagem tendo em mente a abordagem regional, tão importante nesse trabalho. Pode-se dizer que a região é uma entidade concreta, 
resultado de múltiplas determinações, ou seja, por meio da efetivação de políticas, ações e mecanismos relacionados à regionalização, tem-se um quadro territorial caracterizado por uma natureza já modificada, heranças culturais e determinada estrutura socioespacial (CORRÊA, 2000).

Desta forma, quando um empreendimento se instala em determinada região, acaba por criar uma organização espacial própria, mas também relaciona-se com uma organização previamente existente. $\mathrm{O}$ empreendimento pode alterar parcialmente a realidade regional, e isso pode ser verificado por meio de sua paisagem.

Com a intensificação do processo de globalização, o conceito de região passou a ser questionado, sobretudo porque alguns autores entendiam que a globalização seria responsável por uma homogeneização espacial. Nessa discussão sobre globalização e região, dois pontos merecem destaque: primeiro, a ideia do seu potencial homogeneizador, pois no mundo globalizado não haveria espaço para a diferenciação e isso aconteceria também com a região, já que essa guarda em sua essência, a noção de singularidade. O segundo ponto está centrado no discurso que prega o fim do "Estado-Nação", pois tem-se de um lado, a emergência de uma cultura global e, de outro, uma economia também global (ARRAIS, 2007).

Concorda-se com Pontes (2007), a qual defende que a globalização pode não significar homogeneização total, mas sim diferenciação de partes, isso ocorre devido as diferentes potencialidades regionais e dos vários agentes que atuam com forças desiguais no território. Para Haesbaert e Limonad (2007, p. 40),

Se muitos autores afirmam que o mundo contemporâneo vive uma era de globalização, outros, por sua vez, enfatizam como característica principal do nosso tempo a fragmentação. Globalização e fragmentação constituem de fato os dois pólos de uma mesma questão que vem sendo aprofundada, seja através de uma linha de argumentação que tende a privilegiar os aspectos econômicos - e que enfatiza os processos de globalização inerentes ao capitalismo, seja através do realce de processos fragmentadores de ordem cultural.

Para Elias e Pequeno (2007) a reestruturação do agronegócio e da agropecuária não homogeneizou a produção ou os espaços agrícolas nem os espaços urbanos que cresceram com este processo. O que de fato acontece é um intenso processo de fragmentação da produção e do espaço agrícola, em contraposição ao processo de globalização da produção e do consumo agropecuário. 
Assim, entendendo a paisagem e a região como categorias fundamentais para a leitura e compreensão dos processos ocorridos ao longo do tempo e da realidade atual da microrregião Ceres, propõe-se pensar na noção de paisagem regional, que não seria somente a junção dessas duas importantes categorias, mas uma forma mais ampla e complexa de verificar ao mesmo tempo as problemáticas postas pela dinâmica sucroenergética e as diferenciações que esse processo acarreta na região e que se apresenta visível por meio de sua paisagem.

Desta forma, entende-se paisagem e região como conjuntos heterogêneos, sobretudo quando se considera a intensificação da globalização, que atua de diferentes formas. Na região estudada pode-se destacar a reestruturação produtiva, a inserção de técnicas modernizantes, bem como a atuação de distintos agentes, que contribuem para diferentes construções socioespaciais.

Além de serem conjuntos heterogêneos, entende-se que paisagem e região podem ser conceitos complementares, já que um auxilia na compreensão do outro. Oliveira (1981) já apontava que as diversas formas de reprodução do capital, conformaria "regiões" distintas e que algumas regiões seriam hegemonicamente controladas pelos setores mais avançados da produção capitalista. Os produtos e as formas, consequências das diferentes ações e atuações dos agentes do capital sobre as regiões, estão materializados na paisagem regional.

A paisagem regional está diretamente relacionada ao contexto histórico que se vive. Em temporalidades distintas, têm-se paisagens regionais também distintas. E em uma mesma região têm-se paisagens muito parecidas, fruto de processos e formas semelhantes e, ao mesmo tempo, podem-se ter paisagens diferentes, já que a produção capitalista se realiza de modo diferente nos lugares, além de algumas rugosidades presentes. Assim, a análise da microrregião Ceres contribuirá para compreender essas afirmações.

$\mathrm{Na}$ presente tese, entende-se as Colônias Agrícolas Nacionais como o principal contexto de formação territorial da microrregião Ceres. Durante essa Política, na década de 1940 e início de 1950, a região foi largamente ocupada e utilizada para produção agrícola familiar e com a comercialização do excedente em feiras e mercados locais. A paisagem regional nessa época estava voltada para a produção de alimentos, principalmente arroz, feijão, abóbora, milho, etc., e os trabalhadores eram moradores, junto às suas famílias, da Colônia Agrícola (figura 71 e 72). 


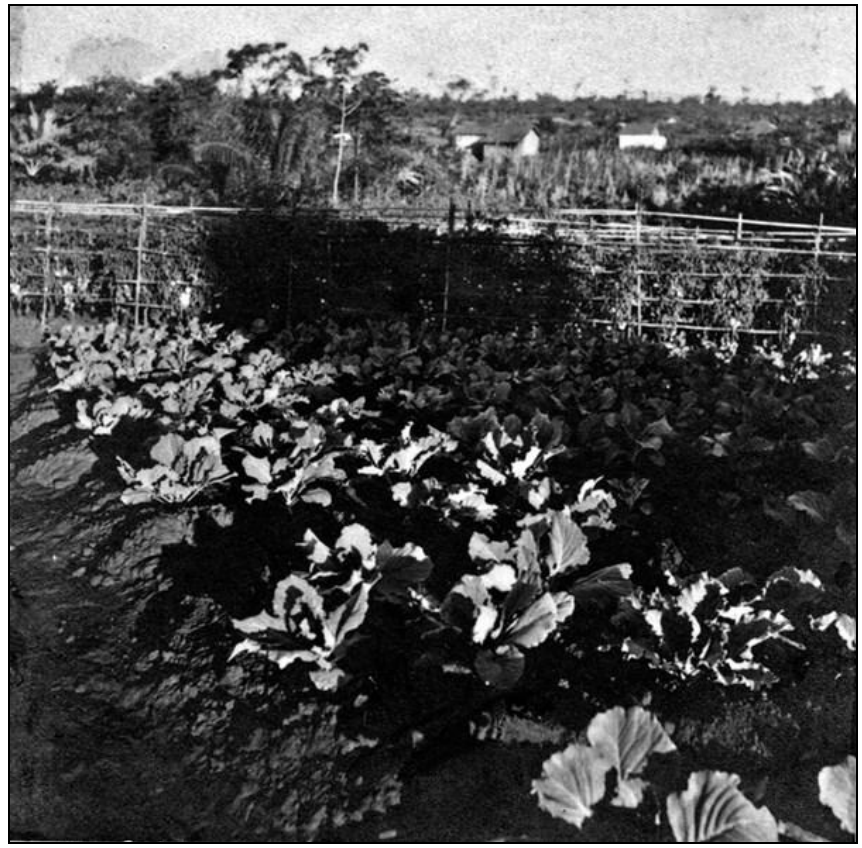

Figura 71 - Plantio de hortaliças na CANG. Fonte: IBGE cidades, 2016.

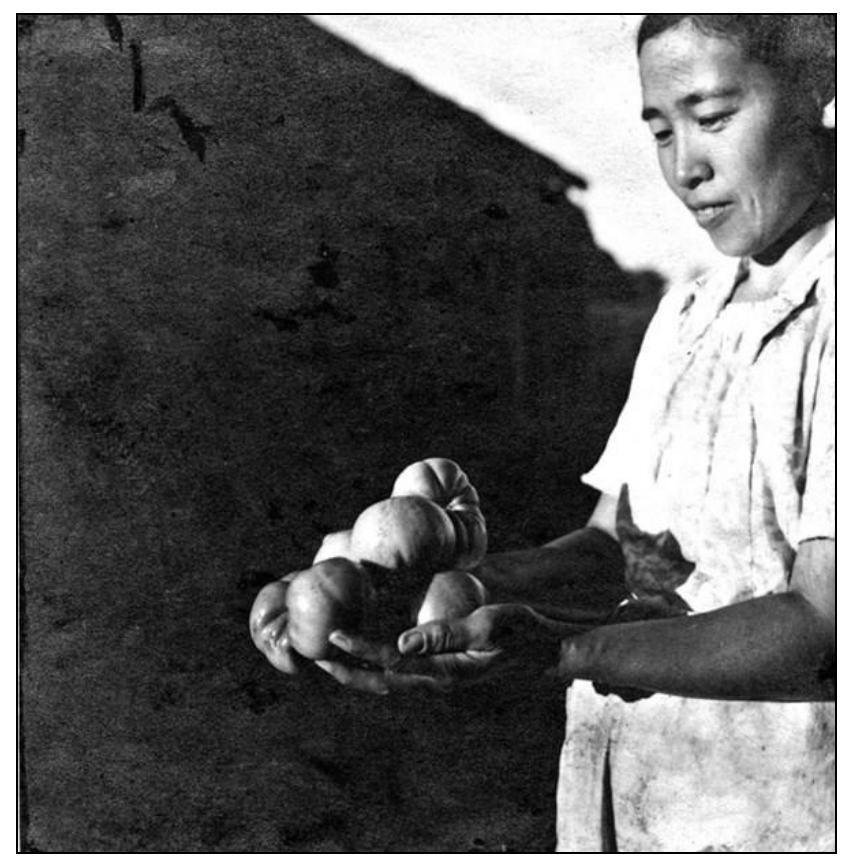

Figura 72 - Produção de alimentos na CANG. Fonte: IBGE cidades, 2016.

Segundo Castilho (2012), a marcha em direção à CANG significou mais que uma aventura, uma ampliação econômica do território nacional e a ligação com o mercado consumidor de São Paulo, por exemplo. Além da expansão do comando federal, o projeto de 
modernização da agricultura na região estudada significou também a criação de demanda para a indústria paulista.

Percebe-se que ao longo do tempo essa lógica foi alterada e, consequentemente, a paisagem foi modificada. A produção de alimentos na região de Ceres foi sendo reduzida ao longo dos anos, e isso pode ser verificado tanto por meio de dados, quanto por meio de algumas formas espaciais. O mercado municipal de Ceres, criado posterior à emancipação do município, sempre foi destaque na região como espaço de comercialização de produtos ligados à agricultura familiar, seja hortifrutigranjeiros e/ou carnes. Atualmente quando se visita o mercado municipal de Ceres verifica-se a decadência do mesmo, com pouquíssimos boxes ocupados, como pode ser verificado nas figuras 73 e 74 .

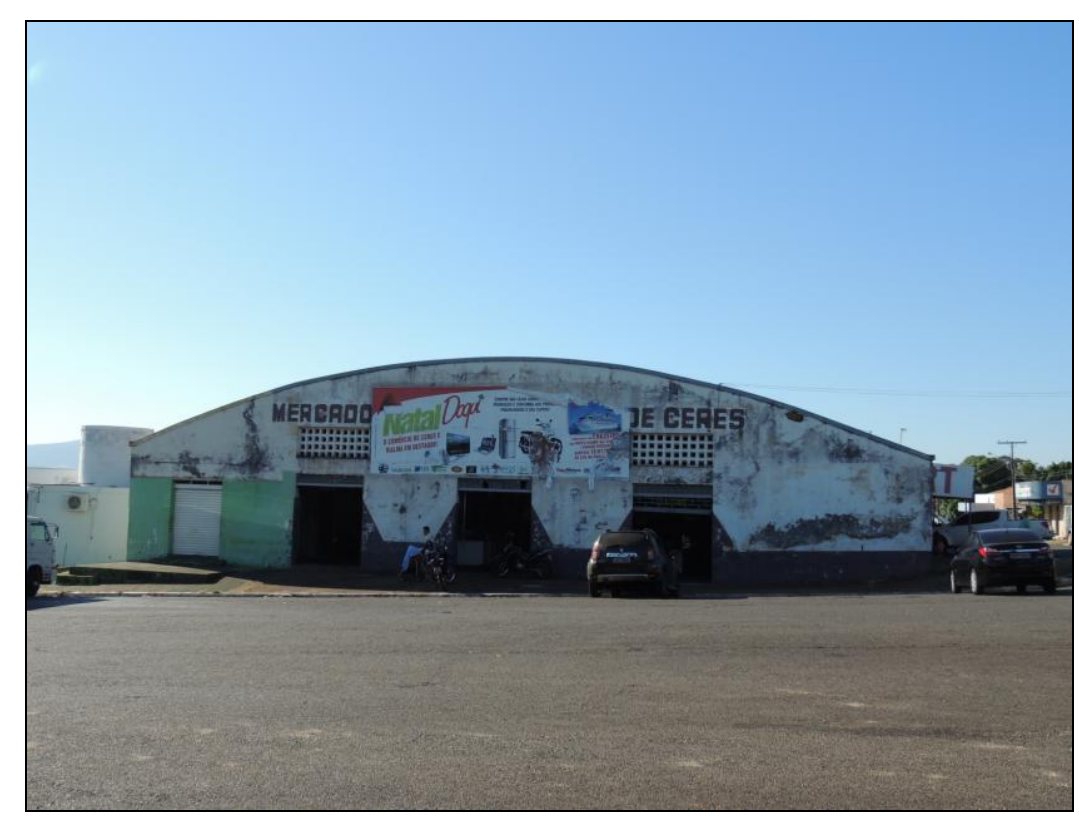

Figura 73 - Mercado municipal de Ceres, GO. Foto: A autora, maio de 2016. 


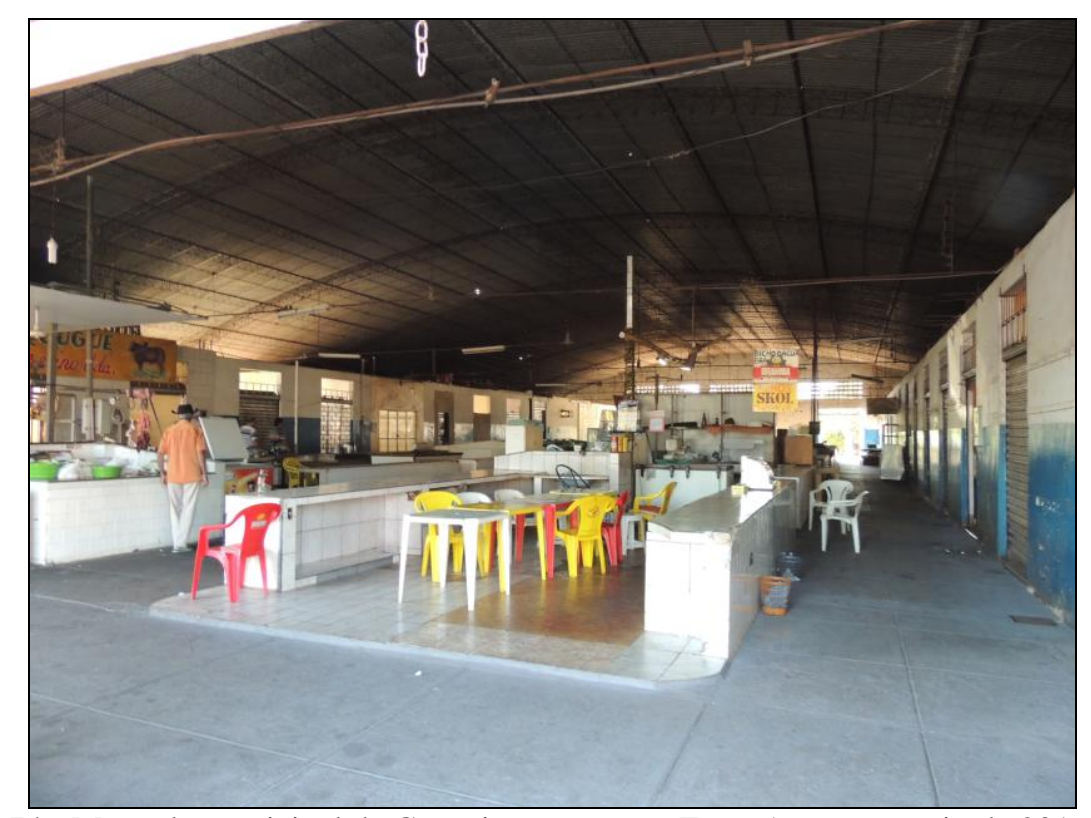

Figura 74 - Mercado municipal de Ceres internamente. Foto: A autora, maio de 2016.

A realidade atual do mercado de Ceres retrata a falta de investimentos e incentivos do poder público local e de políticas públicas voltadas ao pequeno produtor. A região possui uma grande relação de dependência com a atividade canavieira e, mesmo em municípios como Ceres, cuja atividade econômica dominante é a prestação de serviços, percebe-se o pouco incentivo à produção familiar.

A paisagem regional, que durante a CANG, era voltada para a diversidade em produção de alimentos, técnicas mais simples de produção e famílias envolvidas no plantio, colheita e comercialização nas feiras locais; hoje predomina as extensas lavouras de canade-açúcar, modernas máquinas para a colheita mecanizada e ainda a presença de trabalhadores cortadores de cana. A figura 75 mostra um exemplo recorrente na paisagem canavieira na microrregião Ceres, a constante presença das lavouras canavieiras nas rodovias e estradas vicinais, bem como no perímetro urbano em algumas cidades.

Como grande parte das terras da microrregião Ceres estão voltadas para a produção de cana é muito comum verificar a produção de alimentos, como mandioca, milho, quiabo, alface, entre outros, nos quintais, nos lotes baldios e nas calçadas das casas nessas cidades. Isso revela resquícios do modo de vida rural, já que nos últimos anos houve uma intensificação do êxodo rural, devido aos contextos já mencionados, e nessa região ainda verifica-se essa realidade, pois são comuns os casos de arrendamentos de terras para a usina, mesmo de pequenos proprietários. 


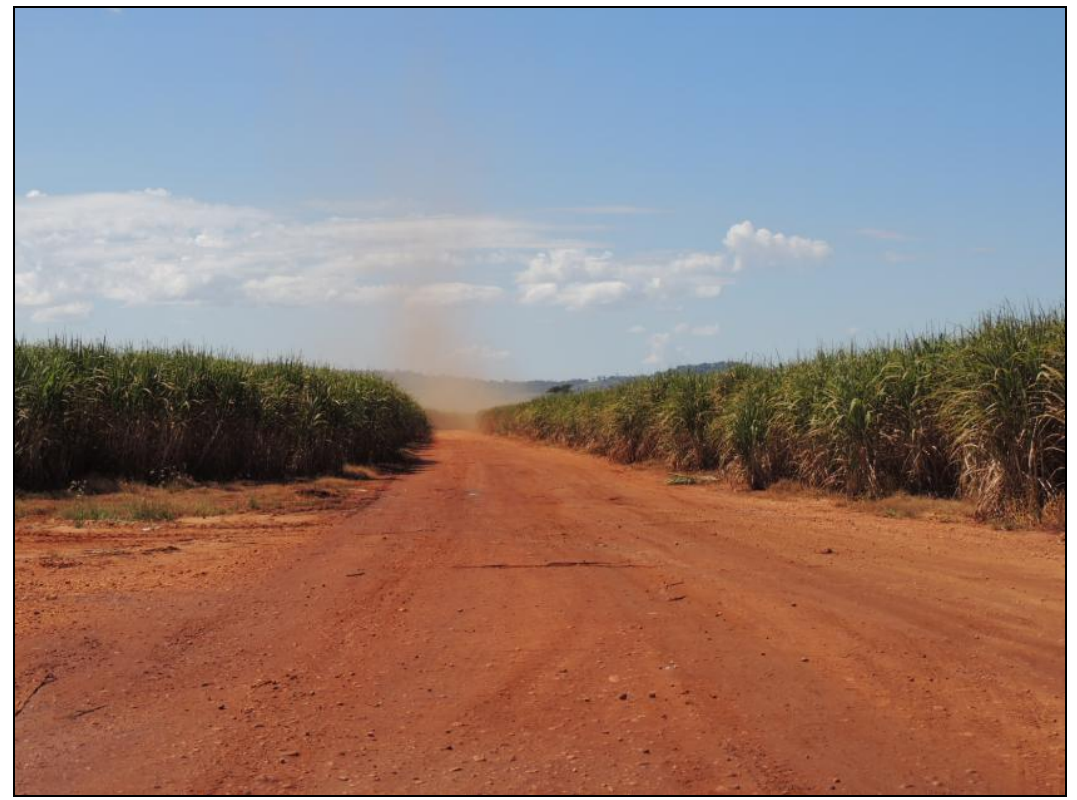

Figura 75 - Lavoura de cana-de-açúcar na Microrregião Ceres. Foto: A autora, maio de 2016.

A figura 76 e 77 mostram o plantio de mandioca em lote baldio e nas calçadas do município de Itapaci, muito comumente verificado nos municípios da microrregião Ceres. Destaca-se que os sujeitos levam para a cidade, alguns elementos do modo de vida do campo, suas heranças e costumes, além de ser um auxílio para a alimentação familiar.

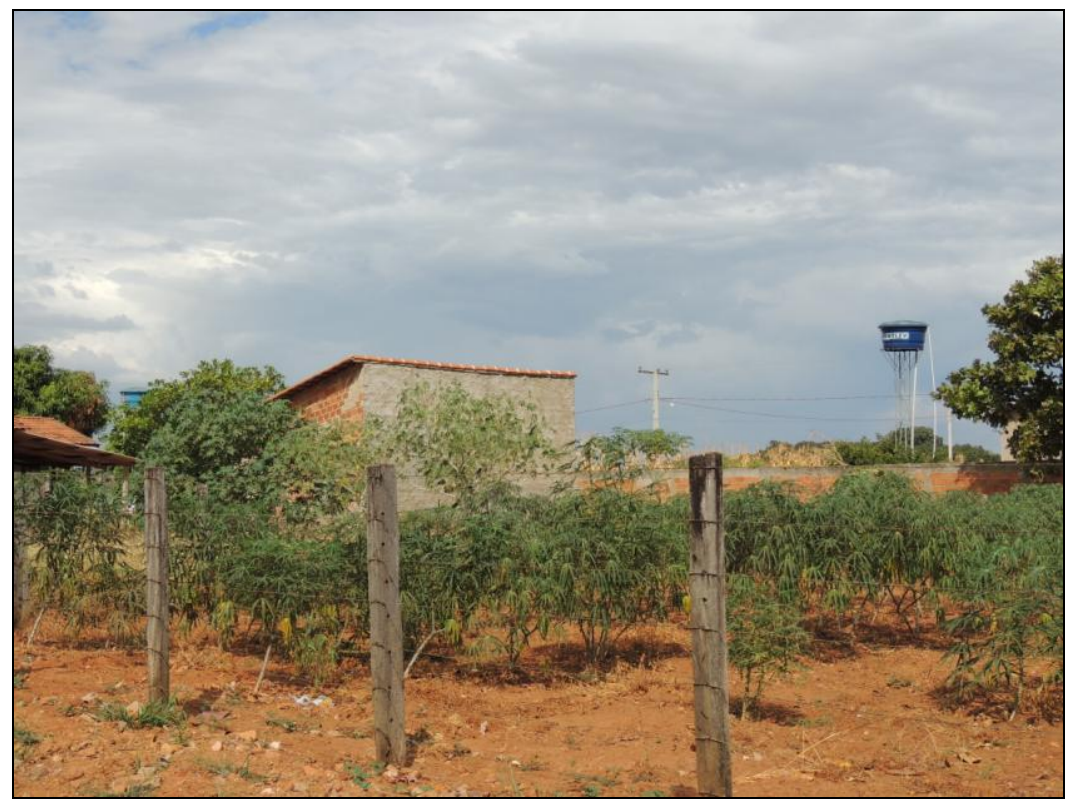

Figura 76 - Plantio de mandioca em lote baldio, no município de Itapaci. Foto: A autora, maio de 2016. 


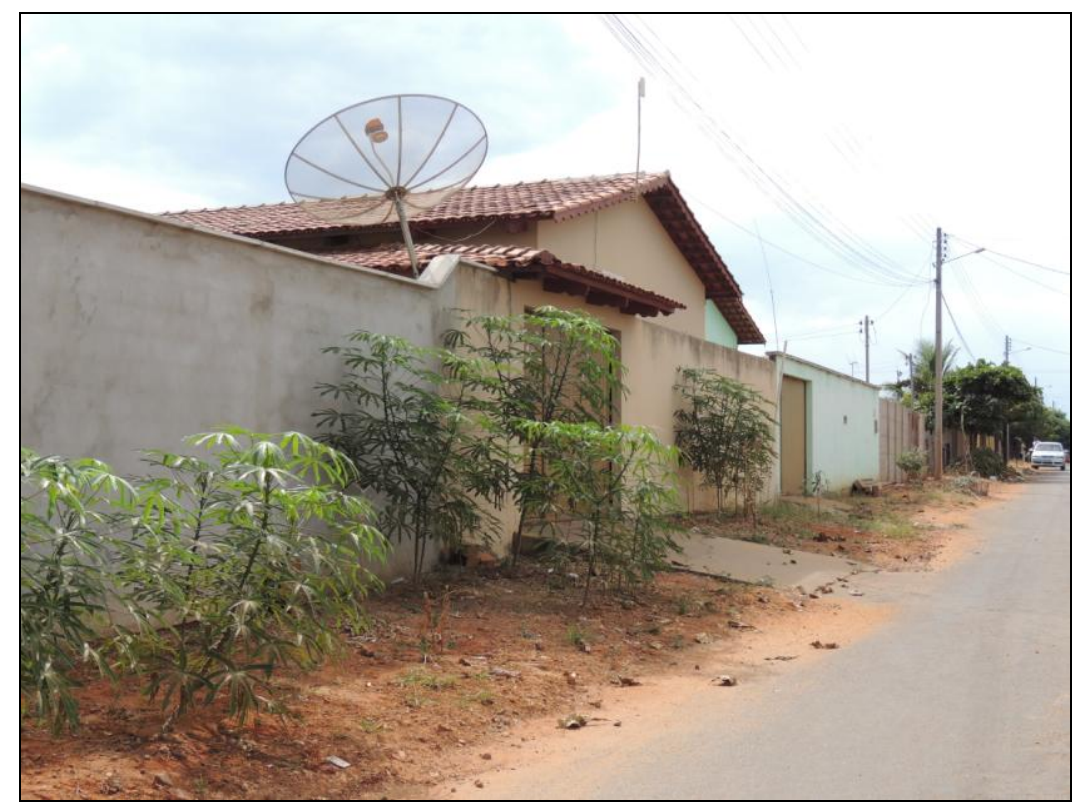

Figura 77 - Produção de mandioca na calçada em Itapaci. Foto: A autora, maio de 2016.

Verifica-se também na paisagem regional uma intensa alteração nas técnicas de produção, principalmente quando se observa o recorte temporal da pesquisa. Durante a CANG as técnicas agrícolas eram mais rudimentares e o trabalho era, em grande parte, manual, com o envolvimento de toda a família, portanto com pouca relação assalariada.

Segundo Elias e Pequeno (2007), com o processo de globalização e a intensa capitalização na agricultura há relevante reestruturação da produção e do território preexistentes, o que acaba por desorganizar as estruturas, as funções e as formas antigas. Diante disso, quando há alguma refuncionalização ou reestruturação do território para atender à produção globalizada, superpõem-se novos fixos artificiais, aumentando a complexidade dos seus sistemas técnicos e de suas rugosidades (ELIAS; PEQUENO, 2007),

A figura 78 mostra o envolvimento das mulheres durante a colheita do café produzido na região, e a forma bem rudimentar que o trabalhador arava a terra durante a Colônia Agrícola (figura 79). 


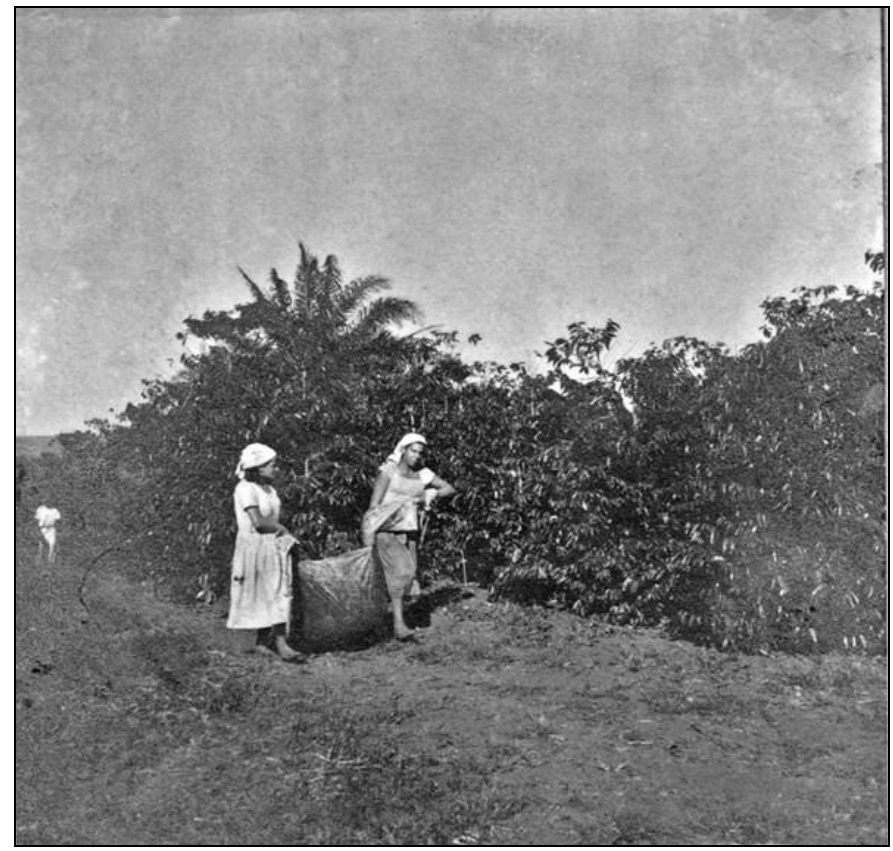

Figura 78 - Colheita de café feita por mulheres, na CANG. Fonte: IBGE cidades, 2016.

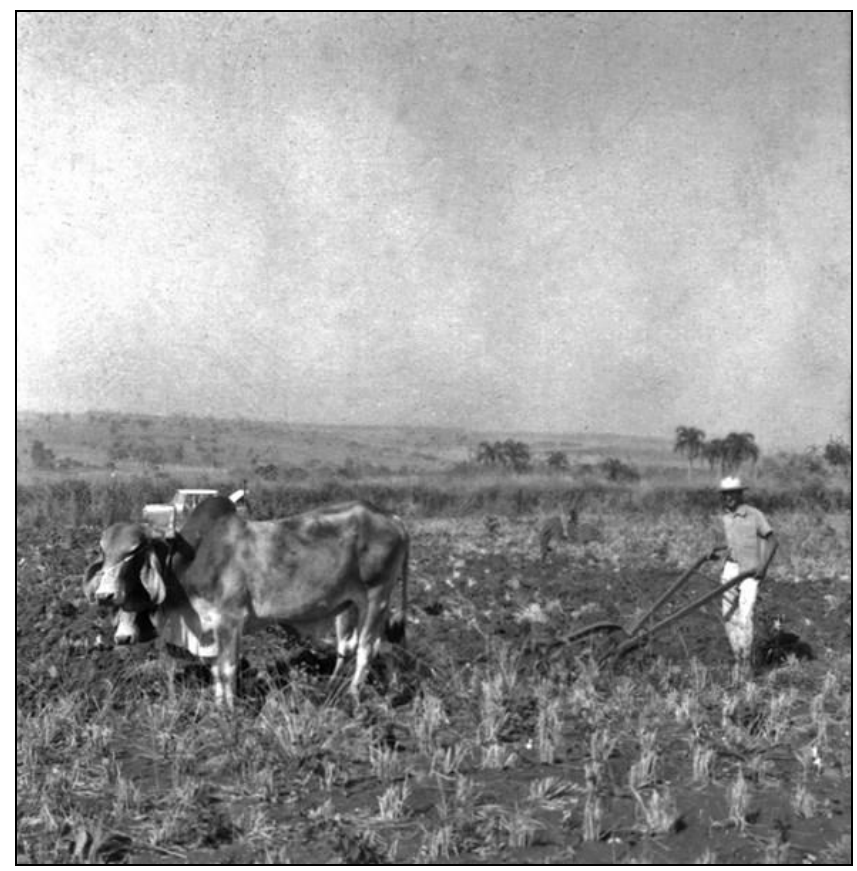

Figura 79 - Técnicas rudimentares utilizadas na CANG. Fonte: IBGE cidades, 2016.

Atualmente, mesmo com a presença de usinas não tão modernas na microrregião Ceres (se comparadas aos empreendimentos do sudeste brasileiro por exemplo), verificamse a presença de caríssimos maquinários com tecnologia avançada, como por exemplo, as 
colhedoras de cana altamente eficientes, que simultaneamente ao corte da cana, alinham e cortam separadamente a palha.

As figuras 80 e 81 mostram o transporte da cana colhida de forma totalmente mecanizada e o transbordo da cana colhida que chega à usina para a etapa de lavagem e posterior processamento da cana-de-açúcar em etanol, açúcar ou outros produtos.

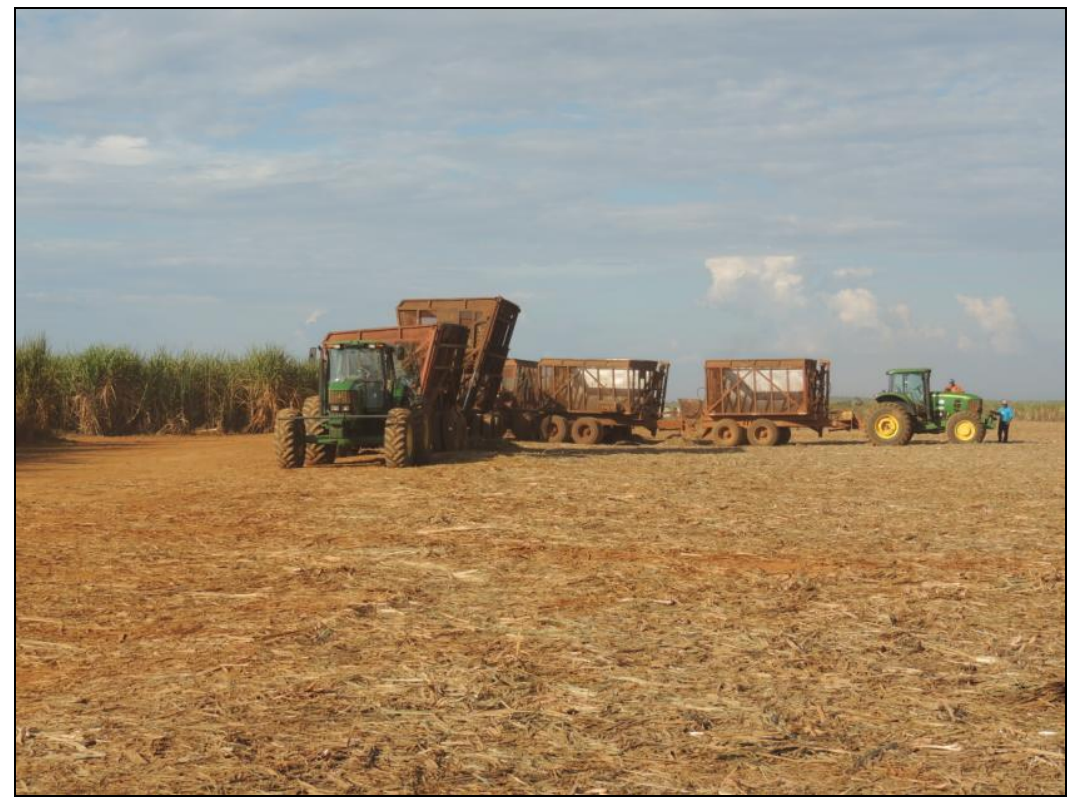

Figura 80 -Transporte da colheita de forma mecanizada em Itapaci - GO. Foto: A autora, maio de 2016.

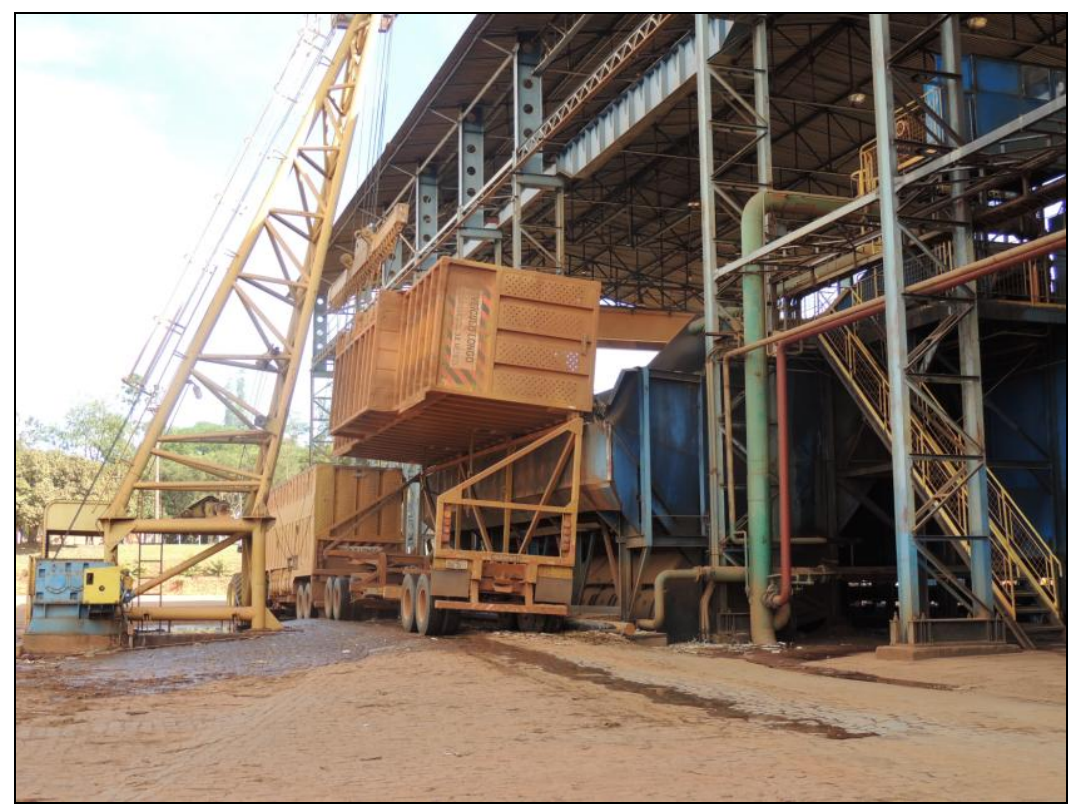

Figura 81 - Transbordo da cana colhida na usina Jalles Machado, Goianéisa, Goiás. Foto: A autora, maio de 2016. 
Geralmente uma colhedora de cana faz o trabalho equivalente a 100 trabalhadores rurais, isso gera aumento dos dados de produtividade na área agrícola. Na área industrial, também observa-se a redução gradativa de trabalhadores, pois há modernos equipamentos e etapas quase totalmente mecanizadas, quando se adentra à área industrial das usinas, percebe-se que a mão de obra existente é praticamente para o monitoramento das máquinas.

Segundo Barreto e Thomaz Júnior (2016), a reestruturação produtiva a partir das modificações técnico-organizacionais incorporadas a produção sucroenergética, principalmente no setor agrícola, com a mecanização da colheita da cana-de-açúcar tem gerado desemprego e competição entre os trabalhadores canavieiros, sobretudo os mais jovens em busca da capacitação profissional. Ainda segundo esses autores,

Nesse caso, é importante ponderar que a substituição do homem pela máquina, tem de fato proporcionado mudanças para o ambiente de trabalho oferecido pelo capital canavieiro, mas isso não significa que as condições de trabalho vivenciadas pelos trabalhadores tenham necessariamente melhorado (BARRETO; THOMAZ JÚNIOR, 2016, p. 4).

Na microrregião Ceres, como ainda existem as duas formas de colheita da canade-açúcar é muito comum verificar na paisagem regional, tanto os maquinários, quanto os cortadores de cana, seja durante o corte nas lavouras mais próximas às rodovias e ao perímetro urbano, ou durante o deslocamento dos trabalhadores para as lavouras, por meio dos ônibus de transporte que saem das cidades.

Como utiliza-se aqui de um dos conceitos de paisagem formulados por Milton Santos, onde a paisagem é como um palimpsesto, ou seja, resulta de acumulações e revela um mosaico de relações e formas, faz-se importante mencionar que a paisagem regional atual revela elementos, formas, sentidos, relacionados predominantemente com a atividade sucroenergética. A paisagem regional, fruto do período das colônias agrícolas, está quase que totalmente suprimida pelas paisagens da cana.

Há alguns elementos da paisagem que revelam a importância da CANG para a formação territorial da microrregião Ceres, como alguns bustos e nomes de avenidas em homenagem ao Bernardo Sayão, engenheiro e gestor da CANG, e o próprio hospital Pio $\mathrm{X}$, construído durante à colônia agrícola e que ainda está em funcionamento na cidade de Ceres. Contudo, poucas formas e elementos fixos são 
verificados na paisagem regional da microrregião Ceres que remetam à CANG, hoje predominam as paisagens canavieiras e os fixos e fluxos frutos dessa dinâmica.

Para compreender como eram as paisagens durante as Colônias Agrícolas Nacionais de Ceres foi necessário remeter a alguns textos do Geógrafo Alemão Léo Waibel, que esteve no Brasil durante os anos 1940 e escreveu vários textos na Revista Brasileira de Geografia do IBGE. Parte de seus estudos estavam relacionados à ocupação do planaldo central brasileiro, bem como trabalhava as paisagens do "mato grosso de Goiás" e descrevia as formas e atividades provindas da intensa migração causada pela CANG.

Segundo Waibel (1948), a paisagem da CANG era formada por uma vegetação característica de florestas, por isso chamaram a região de "mato grosso de Goiás". Durante a estação seca era comum o fogo nas matas, de acordo com as "informações do Dr. Sayão, diretor da Colônia Agrícola Nacional, o fogo invade até as partes mais remotas dessas florestas, destrói a vegetação original e causa uma mata secundária, rica em bambus altos, muito semelhante à que cresce nas roças abandonadas" (WAIBEL, 1948, p 11). A figura 82 mostra a vegetação existente na área da CANG na década de 1940.

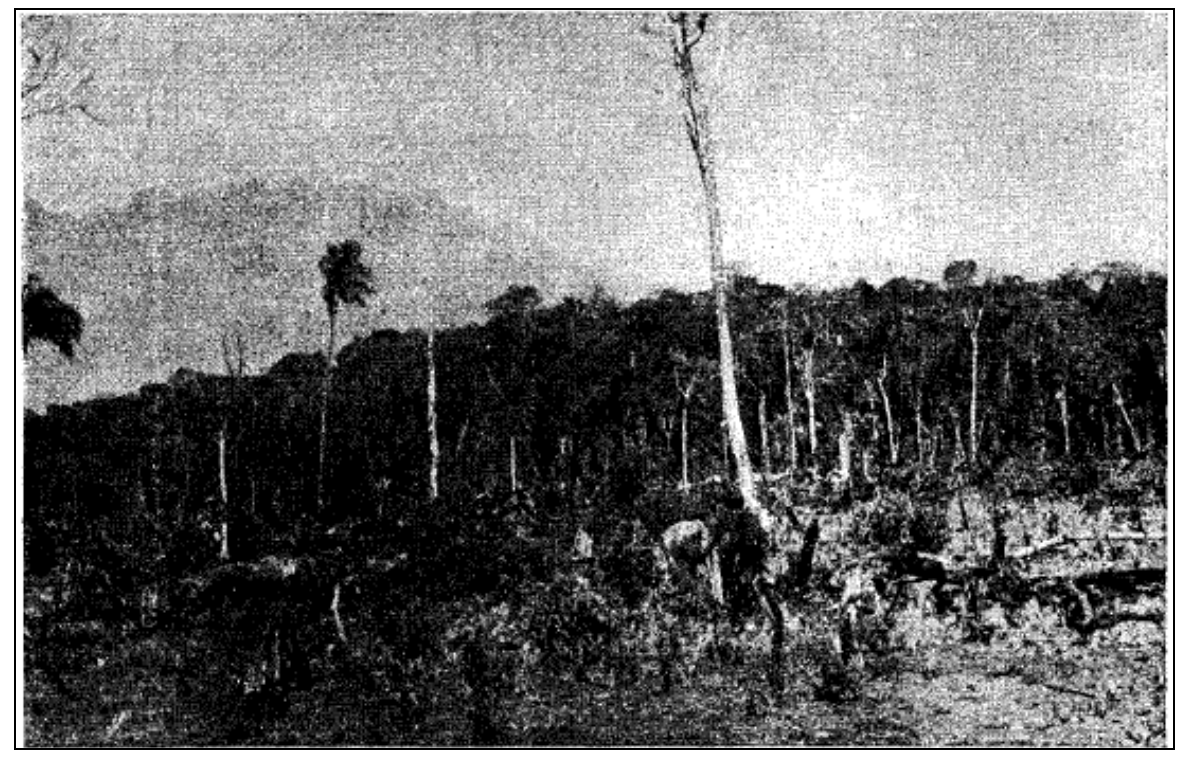

Figura 82 - Vegetação típica do “mato grosso de Goiás”. Fonte: Waibel, 1948. 
Nesse artigo da Revista do IBGE, Waibel ainda relatou que a atual região de Ceres não tinha agricultura bem sucedida, indicando que,

A agricultura em terras de cerrado, caso seja bem sucedida, mudará por completo a situação social e econômica do Planalto Central. Tornar-se-ia, entretanto, necessária uma mudança total dos métodos agrícolas, uma mudança da agricultura nômade para a permanente, da cultura de enxada para a cultura de arado e da rotação de terras para a rotação de culturas (WAIBEL, 1948, p. 32).

A leitura dos artigos de Léo Waibel contribuem para ratificar o quão diferente se tornou a paisagem da região de Ceres ao longo dos contextos estudados e como as formas e os elementos materializados hoje na paisagem estão muito vinculados à lógica da agricultura capitalista. As figuras 83 e 84 mostram exemplos de elementos da paisagem que introduzem ao morador, visitante ou pesquisador à lógica socioeconômica da região.

A figura 83 mostra uma placa na rodovia, muito comum ao logo das estradas da microrregião Ceres, sinalizando o intenso tráfego de treminhões nos próximos quase $50 \mathrm{~km}$ de pista. Já a figura 84 mostra parte de um treminhão abandonado em um lote baldio em Itapaci, indicando por meio da paisagem urbana, que a atividade canavieira é bastante presente na cidade.

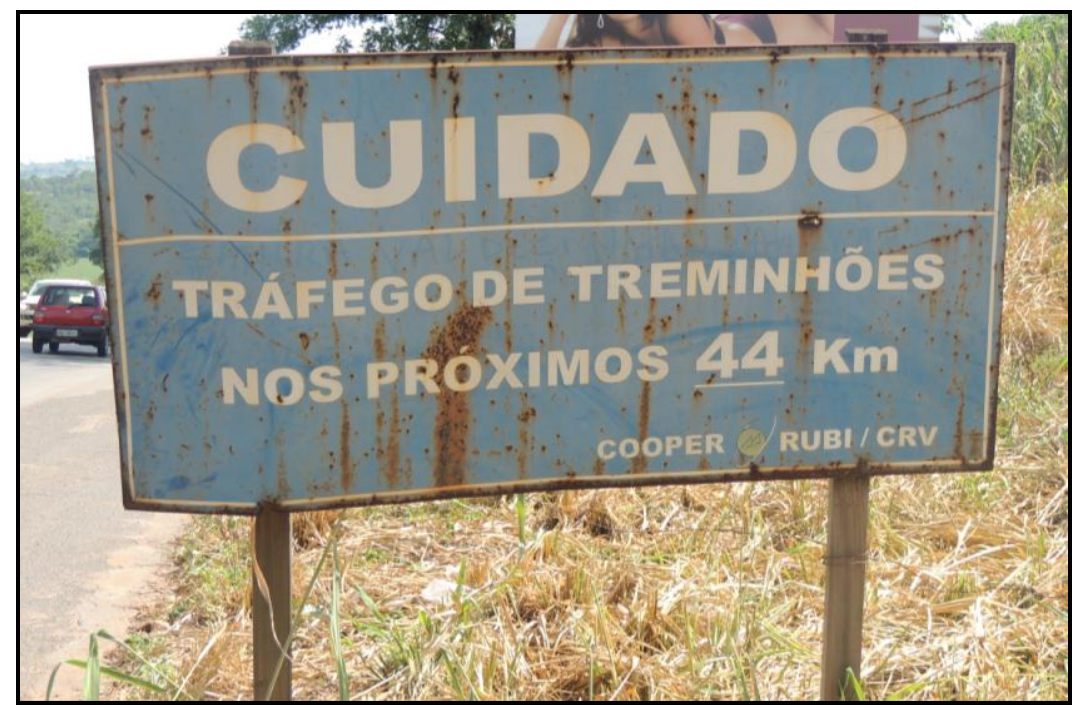

Figura 83 - Placa na rodovia indicando o intenso tráfego de treminhões entre os municípios de Rubiataba e Carmo do Rio Verde. Foto: A autora, maio de 2016. 


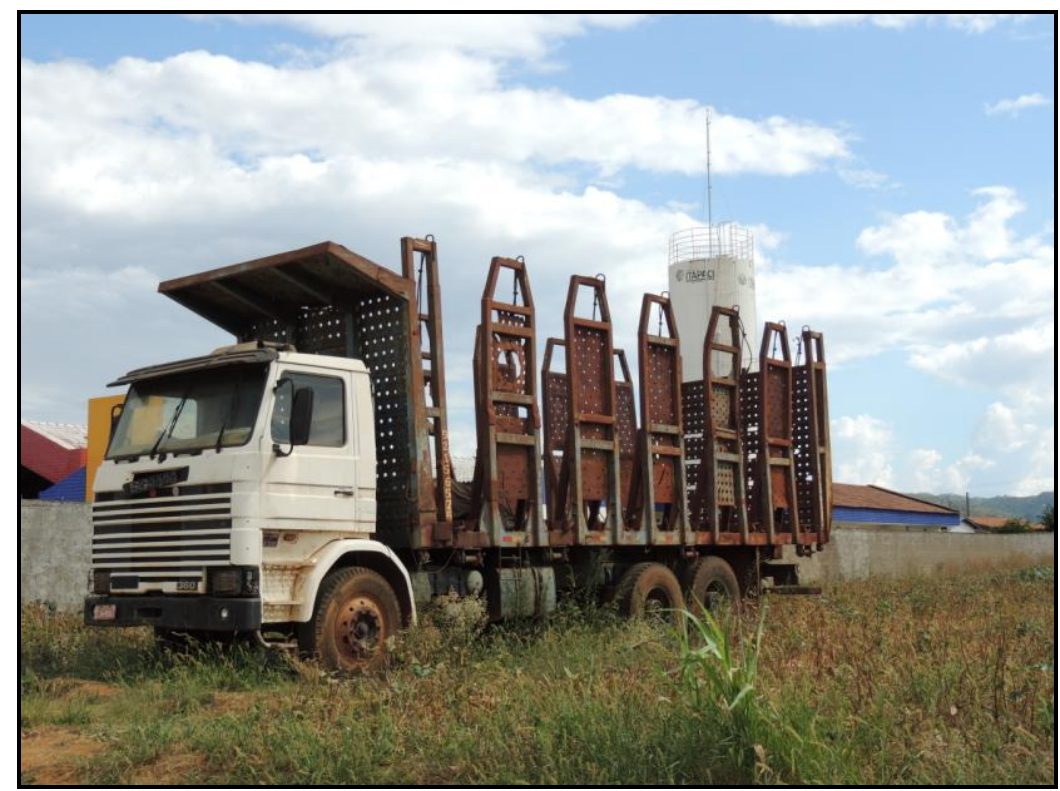

Figura 84 - Parte de um treminhão abandonado em lote baldio, em Itapaci. Foto: A autora, maio de 2016.

Faz-se importante destacar um elemento, na paisagem do município de Goianésia, bastante interessante e que confirma a importância do papel político para a monopolização do Grupo Otávio Lage nas atividades econômicas do município. Na praça principal da cidade há algumas placas de agradecimento aos membros da família Lage, que estiveram diretamente vinculados à gestão do município e do estado de Goiás. A figura 85 mostra duas placas que existem na praça principal de Goianésia em agradecimento aos trabalhos de Otávio Lage e Jalles de Siqueira (pai e filho, respectivamente). Vale salientar que atualmente (gestão 2012 - 2016) o prefeito de Goianésia é novamente o Sr. Jalles de Siqueira.

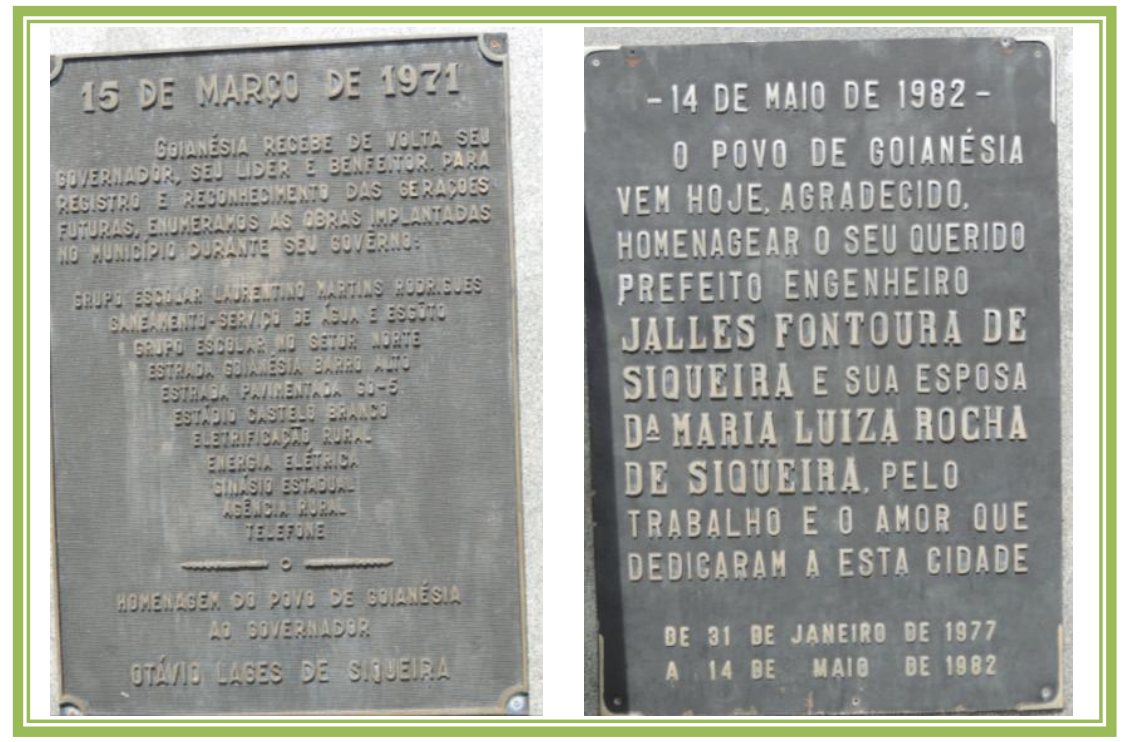

Figura 85 - Placas em agradecimento à família Lage em Goianésia. Foto: A autora, maio de 2016. 
Assim, diante da pesquisa realizada, com grande importância e destaque para os trabalhos de campo, que muito contribuíram para a análise da paisagem, foi possível pensar no delineamento de um conceito de paisagem regional, fundamental para a compreensão da microrregião Ceres, frente à dinâmica sucroenergética e a lógica do agronegócio canavieiro, que ao longo de aproximadamente 60 anos, das Colônias Agrícolas Nacionais ao agronegócio canavieiro, praticamente dominam a região estudada.

Ressalta-se a importância da paisagem regional para se compreender e desvelar as contradições existentes em determinada região, bem como a incipiente discussão existente dentro desse conceito nas pesquisas brasileiras, assim, intenta-se contribuir com o delineamento desse conceito. Diante disso, entende-se aqui como paisagem regional, o conjunto visível de formas, elementos fixos, artificiais e relacionais (redes comerciais e relações de trabalho) materializados na paisagem de determinada região, fruto da atuação conjunta do capital privado e do Estado.

A figura 86 traz um mapa, que representa a dífícil tentativa, de sintetizar as paisagens regionais da microrregião Ceres atualmente. Por meio dele, pode-se verificar os empreendimentos sucroenergéticos implantados e em funcionamento na região, elementos fixos visíveis e presentes na paisagem regional.

Observam-se elementos como a maciça presença de treminhões e colhedoras de cana, além das monótonas lavouras de cana-de-açúcar presentes na região, não só nos municípios que possuem usinas, mas também em vários municípios próximos a esses. No mapa das paisagens regionais da microrregião Ceres, também é possível verificar uma imagem que mostra a próximidade das casas às lavouras de cana no perímetro urbano de Goianésia, o que demostra essa dinâmica sempre presente, vinculada ao setor canavieiro, tanto no campo, quanto na cidade. 


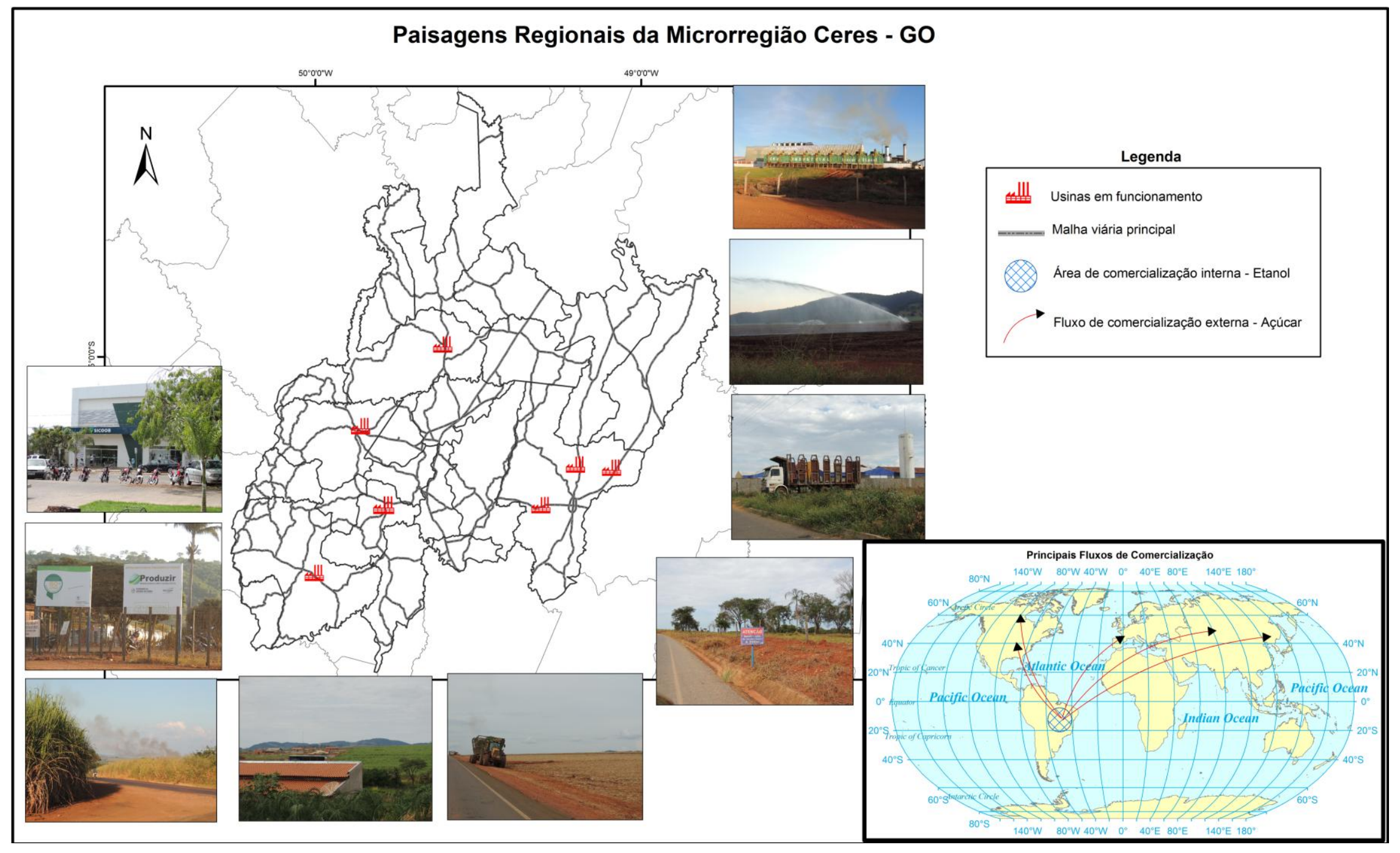

Figura 86 - Mapa síntese das Paisagens Regionais da Microrregião Ceres, Goiás. 
Várias formas e elementos fazem parte do cotidiano dos moradores das cidades canavieiras, sobretudo durante o período da safra nas usinas. Observam-se também na figura 85 as principais malhas viárias que são fundamentais para o escoamento e circulação da produção, bem como imagens que mostram as formas presentes e materializadas nessa paisagem, destacam-se: a presença do Estado, por meio das placas dos programas de fomento à industrialização; do capital privado, com os maquinários, insumos, cooperativas de crédito; e, as redes estabelecidas, que não são visíveis na paisagem, mas que são fundamentais para a realização da lógica do agronegócio, como as redes relacionais e de comercialização, internas, no caso do etanol, e externas, em sua maioria, com a comercialização do açúcar, levedura e créditos carbono com vários países do hemisfério norte.

\subsection{As Políticas de Acesso à Terra na Microrregião Ceres: Alternativas ao Agronegócio Canavieiro}

Sabe-se da complexidade das lutas e da história da reforma agrária no Brasil, bem como dos conflitos inerentes a essa temática. Aqui far-se-á um panorama geral da reforma agrária no Brasil, a título de contextualização, para por fim apresentar os dados do acesso à terra e do Programa de Fortalecimento Familiar na microrregião Ceres.

Parte-se do entendimento que atualmente o agronegócio é o modelo hegemônico de desenvolvimento da agricultura, baseado nas monoculturas, em grandes corporações, no trabalho assalariado e num discurso progressista que tem contagiado o Estado, as corporações e a população em geral.

Segundo Fernandes (2015), o agronegócio procura subordinar a todos, inclusive o campesinato, contudo estes têm procurado construir outro modelo desenvolvimentista baseado na agricultura familiar, associações ou cooperativas, em economias solidárias, entre outros. Ainda segundo esse autor, "esses dois modelos são inconciliáveis, o que explica os permanentes confrontos, conflitos e conflituosidades que formam a conjuntura agrária e transforma a questão agrária de tempos em tempos" (FERNANDES, 2015, p. 159).

Algumas ações e políticas foram elaboradas ao longo da história recente do Brasil em prol da reforma agrária. Pode-se citar o Estatuto da Terra (Lei n ${ }^{\circ}$ 4.504) de 1964, que definia como objetivo central da reforma agrária, estabelecer um sistema de relações entre o ser 
humano, a propriedade rural e o uso da terra, capaz de promover a justiça social, o progresso e o bem-estar do trabalhador(a) rural e o desenvolvimento econômico do Brasil.

Contudo, as décadas que se seguiram à criação do Estatuto da Terra estiveram fortemente vinculadas ao processo de modernização da agricultura, nos moldes da Revolução Verde, o que atuou no sentido de transformar os capitalistas industriais e urbanos em proprietários de terra, em latifundiários (OLIVEIRA, 2001).

Diante disso, entende-se que o projeto de desenvolvimento rural adotado ao longo da história do país está relacionado diretamente à expansão e consolidação do agronegócio. $\mathrm{O}$ discurso vincula-se aos efeitos positivos, relacionados ao aumento da produtividade agrícola e geração de divisas para o Brasil, devido ao perfil agroexportador. Mas, não se pode esquecer do ônus socioambiental por trás dessa realidade.

Marques (2002), destaca a necessidade de se elaborar uma estratégia de desenvolvimento para o campo que priorize o desenvolvimento social e não somente o econômico e setorial. Essa realidade do Brasil, tem trazido como consequência, o avanço dos movimentos sociais no campo e a intensificação das lutas, no intuito de buscar formas de se organizar socialmente na terra e produzir alimento.

Até a década de 1990, pouco tinha sido feito pelo Estado Brasileiro em prol da reforma agrária. O Governo Tancredo Neves idealizou o I Plano Nacional de Reforma Agrária (I PNRA), mas com sua morte em 1985, José Sarney assumiu a presidência e o I PNRA teve seus objetivos frustrados, com apenas $6 \%$ de seus objetivos atingidos.

O Governo Collor promoveu uma das maiores perseguições ao Movimento dos Sem Terra (MST) da história do Brasil e somente a partir do primeiro mandato do Governo FHC (1995 - 1998) houve uma política considerável de assentamentos de famílias rurais, sendo considerado o segundo maior Governo em criação de assentamentos (atrás somente do primeiro mandato do Governo Lula), foram 2.345 assentamentos, com 300.654 famílias (FERNANDES, 2015).

Apesar disso, destacam-se dois conflitos sangrentos, entre a polícia e agricultores sem terra, que marcaram esse período: o massacre de Corumbiara, em Rondônia no ano de 1995, e o massacre de Eldorado dos Carajás, no Pará no ano de 1996. Com o discurso de que a reforma agrária já havia sido realizada, o segundo mandato do Governo FHC (1999 2002) reduziu drasticamente o número de assentamentos rurais, publicando inclusive, medidas provisórias de criminalização das ocupações. 
Com a eleição do Governo Lula (2003 - 2006) tem-se a elaboração do II Plano Nacional de Reforma Agrária (II PNRA) e com ele 2.381 assentamentos, com 303.187 famílias. Esse primeiro mandato foi o maior da hístoria brasileira em número de assentamentos rurais. Já o segundo mandato apresentou declínio e frustração nos objetivos propostos. Segundo Fernandes (2015, p. 172) "o primeiro e segundo Planos Nacionais de Reforma Agrária tiveram suas metas executadas, o que explica o fato da luta pela terra e pela reforma agrária continuarem na pauta política”.

O estado de Goiás seguiu essa tendência, até o ano de 1994 somente 430 famílias tinham sido assentadas. Os dois momentos mais relevantes em Goiás estão relacionados aos primeiros mandatos dos Governos Lula e FHC, respectivamente, com 3.036 e 2.303 famílias assentadas (figura 87). O primeiro mandato do Governo Dilma (2011 - 2014) também seguiu esse declínio. Segundo a Comissão Pastoral da Terra - CPT, foram assentadas 103.746 famílias entre os anos 2011 e 2014, contudo somente 28.313 famílias estão ligadas aos processos de assentamentos originados no Governo Dilma ${ }^{30}$.

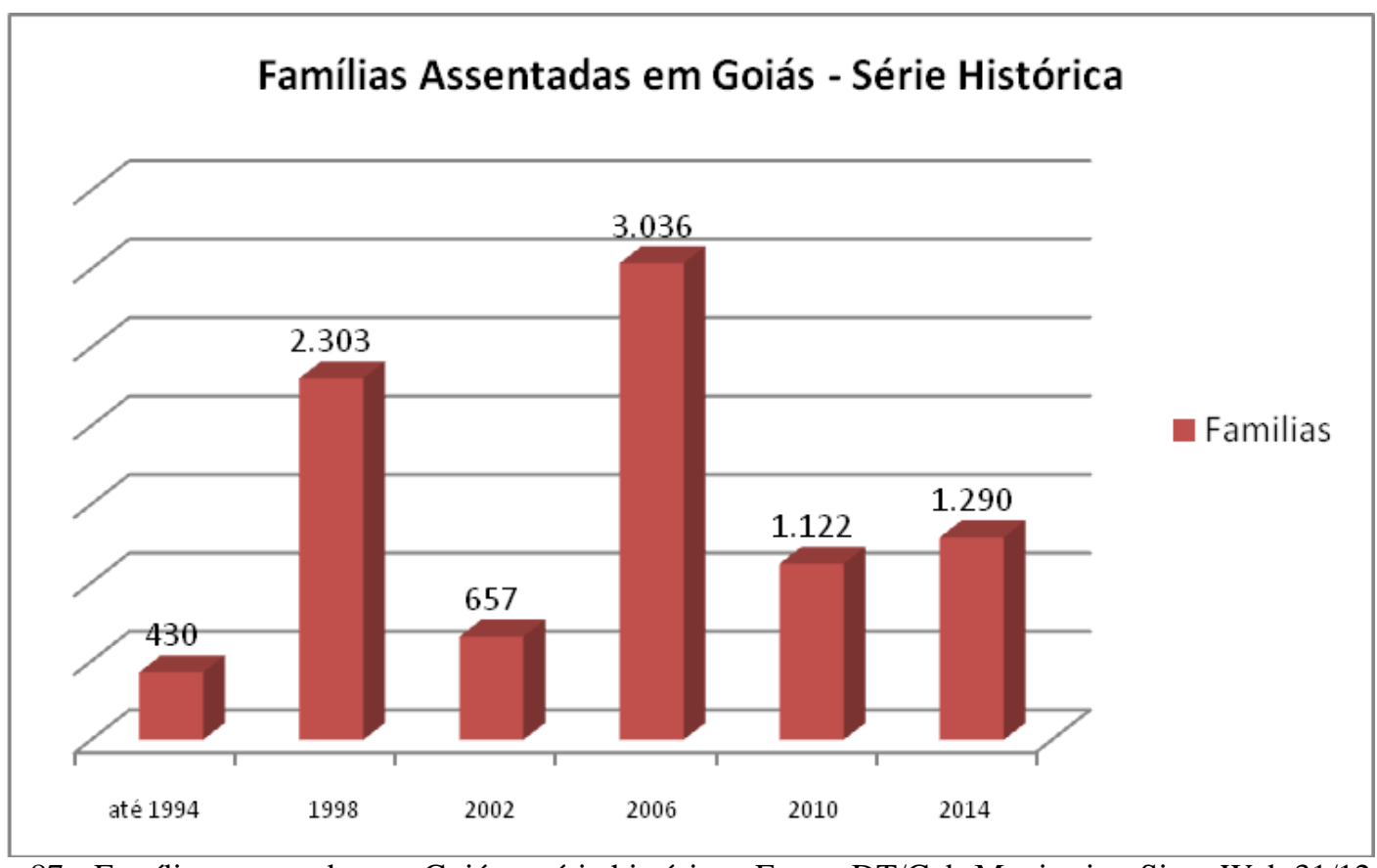

Figura 87 - Famílias assentadas em Goiás - série histórica. Fonte: DT/Gab-Monitoria - Sipra Web 31/12/2014 - INCRA Goiás.

\footnotetext{
${ }^{30}$ Disponível em http://www.cptnacional.org.br. Acesso em janeiro de 2016.
} 
Os últimos governos de Lula e Dilma criaram alguns programas e políticas que têm contribuído para a melhoria de renda das famílias assentadas, podem-se citar: o Programa de Aquisição de Alimentos (PAA), o Programa Nacional de Alimentação Escolar (PNAE) e o Programa de Agroindustrialização em Assentamentos da Reforma Agrária (Terra Forte).

A tabela 15 mostra a realidade da microrregião Ceres dentro desse contexto. Observam-se os dados de agricultores familiares (Censo Agropecuário de 2006) e de área e famílias assentadas (2015). A microrregião Ceres, com seus vinte e dois municípios, possuía em 2006, somente 7.513 agricultores familiares, e em 2015 somente 664 famílias assentadas, com uma área reformada de 32.043 ha. Por meio da análise dos dados, observase que os municípios que possuem a maior quantidade de agricultores familiares são Itapuranga, Guarinos e Rubiataba, destes os dois últimos não tiveram famílias assentadas em 2015, e Itapuranga somente 13 famílias.

A microrregião Ceres apresentou ao total, 664 famílias assentadas, no ano de 2015, o que corresponde a uma área reformada de 32.043 ha. Os dados da tabela 14 representam mais um indício da realidade fundiária da microrregião Ceres e revelam a concentração de terras nas mãos do agronegócio canavieiro e pouco investimento em políticas alternativas às monoculturas, bem como ineficiência em relação à reforma agrária.

Segundo Abramovay (1999), há um vasto segmento da agricultura familiar que não consegue afirmar-se economicamente em função do ambiente social que a vincula ao mercado e, consequentemente, coloca as famílias em reduzidas margens de escolha na comercialização de seus produtos, na obtenção de insumos e acesso à finaciamentos. Ainda segundo esse autor,

\footnotetext{
Nos poucos casos em que o crédito agrícola formal chega a estas famílias, não só a resposta em termos de produção é imediata, como também - mesmo nos produtos convencionais - é nítida a elevação da renda: é que neste caso, a família consegue emancipar-se do círculo de dependência clientelista a que está ligada e, por aí, abre a via para inserir-se em mercados competitivos - mesmo que sejam nos produtos que vinham praticando até então (ABRAMOVAY, 1999, p. 14).
}

Em relação aos assentamentos rurais, o acesso aos financiamentos são fundamentais, além da eliminação dos riscos por parte do sistema financeiro, para que seja não só um instrumento de crédito, mas também, de desenvolvimento rural. De acordo com Abramovay (1999), Os financiamentos deixam de integrar-se a projetos economicamente sustentáveis e tendem a tornar-se formas de complementação da renda, perpetuando a situação de pobreza em que se encontram as famílias assentadas. 
Tabela 15 - Agricultores familiares e reforma agrária na microrregião Ceres - GO.

\begin{tabular}{|c|c|c|c|}
\hline \multirow[b]{2}{*}{ Municipio } & \multirow[b]{2}{*}{$\begin{array}{c}\text { Agricultores } \\
\text { Familiares } \\
\text { (Censo Agro./06) }\end{array}$} & \multicolumn{2}{|c|}{ Reforma Agrária } \\
\hline & & $\begin{array}{c}\text { Famílias } \\
\text { Assentadas } \\
(\text { nov/15) }\end{array}$ & $\begin{array}{c}\text { Área reformada } \\
\text { (ha) }(\text { nov/15) }\end{array}$ \\
\hline Barro Alto & 176 & 39 & 2.991 \\
\hline Carmo do Rio Verde & 431 & - & - \\
\hline Ceres & 288 & - & - \\
\hline Goianésia & 452 & 213 & 10.452 \\
\hline Guaraíta & 257 & - & - \\
\hline Guarinos & 605 & - & - \\
\hline Hidrolina & 218 & - & - \\
\hline Ipiranga de Goiás & 353 & - & - \\
\hline Itapaci & 289 & 43 & 2.261 \\
\hline Itapuranga & 1.121 & 13 & 773 \\
\hline Morro Agudo de Goiás & 267 & - & - \\
\hline Nova América & 199 & - & - \\
\hline Nova Glória & 374 & 34 & 909 \\
\hline Pilar de Goiás & 291 & - & - \\
\hline Rialma & 161 & 66 & 3.063 \\
\hline Rianápolis & 69 & - & - \\
\hline Rubiataba & 572 & - & - \\
\hline Santa Isabel & 390 & 47 & 1.461 \\
\hline Santa Rita do Novo Destino & 345 & 143 & 7.730 \\
\hline São Luiz do Norte & 71 & 66 & 2.403 \\
\hline São Patrício & 219 & - & - \\
\hline Uruana & 365 & - & - \\
\hline Microrregião Ceres & 7.513 & 664 & 32.043 \\
\hline
\end{tabular}

Fonte: Bacen/Derop/Sicor/MDA - Ministério do Desenvolvimento Agrário; DATALUTA, 2015.

Um outro programa que é considerado a principal política agrícola para a agricultura familiar (tanto em número de beneficiários, capilaridade nacional e recursos aplicados) é o Programa Nacional de Fortalecimento da Agricultura Familiar - PRONAF, que historicamente, tem contado com um montante crescente de recursos disponibilizados, atingindo, no Plano Safra da Agricultura Familiar 2014/2015, o valor de R \$24,1 bilhões de reais (GRISA; SCHNEIDER, 2015).

Ressalta-se que a noção de agricultura familiar foi mais difundida após o Decreto $\mathrm{N}^{\circ}$ 1.946, de 28 de junho de 1996, que instituiu o Programa Nacional de Fortalecimento da 
Agricultura Familiar, com a finalidade de "promover o desenvolvimento sustentável do segmento rural constituído pelos agricultores familiares, de modo a propiciar aumento da capacidade produtiva, geração de empregos e melhoria na renda" ${ }^{31}$.

Sabe-se que a melhor forma para designar os pequenos produtores rurais é utilizar o conceito de campesinato, já que a noção de agricultura familiar veio para tentar incorporar os camponeses à lógica da agricultura capitalista. Na presente pesquisa foi utilizada algumas vezes a noção de agricultura familiar, pois é a forma utilizada pelas políticas públicas que serão aqui mencionadas, contudo sabe-se da importância política do conceito de campesinato, sobretudo no sentido de rompimento dos sujeitos do campo com a lógica hegemônica da agricultura capitalista e, de forma propositiva, pensar em uma perspectiva emancipatória dos trabalhadores do campo.

Assim, o PRONAF foi criado em 1996 com o objetivo de conceder créditos para os agricultores familiares e contribuir para a redução das desigualdades sociais. O Programa financia projetos, individuais ou coletivos, que gerem renda aos agricultores familiares e assentados da reforma agrária, com baixas taxas de juros dos financiamentos rurais ${ }^{32}$.

Apesar da importância do Programa e do aumento do montante investido na agricultura familiar nos últimos 20 anos, sabe-se dos problemas e contradições inerentes ao debate agronegócio versus agricultura familiar. Concorda-se com Alentejano quando esse apresenta duas problemáticas vinculadas a isso: primeiro, relacionado à ilusão da igualdade dos mercados, que acaba por ignorar a diferença entre grandes e pequenos na competição.

Também não há consideração relativa à atuação das agroindústrias na formação dos preços agrícolas, "assim como à recente tendência das grandes empresas agroindustriais de mudar o perfil da integração, excluindo os pequenos produtores, em função de exigências tecnológicas e de escala” (ALENTEJANO, 2000, p. 92). E, em segundo lugar, há o problema da disponibilidade de recursos, que mesmo tendo acesso a programas como o PRONAF, são valores muito pequenos diante da realidade das famílias e, sobretudo, dos assentados.

A tabela 16 mostra que no ano de 2015, 2.499 famílias foram contratadas pelo PRONAF na microrregião Ceres, o que corresponde a um valor de R\$ 64.525.601,00. Se

\footnotetext{
${ }^{31}$ Disponível em http://www.planalto.gov.br/ccivil 03/decreto/D1946.htm. Acesso em agosto de 2016.

${ }^{32}$ Informações disponíveis em http://www.brasil.gov.br/economia-e-emprego/2015/08/entenda-o-programa-defortalecimento-da-agricultura-familiar-pronaf. Acesso em julho de 2016.
} 
compararmos aos altíssimos investimentos no agronegócio sucroenergético esses valores se mostram muito pequenos.

Tabela 16 - Programa Nacional de Fortalecimento da Agricultura Familiar - PRONAF (2015)

\begin{tabular}{|c|c|c|}
\hline \multicolumn{3}{|c|}{$\begin{array}{l}\text { Programa Nacional de Fortalecimento da Agricultura Familiar - PRONAF } \\
\text { (Safra / Ano 2015) }\end{array}$} \\
\hline Municipio & $\begin{array}{l}\text { Quantidade de } \\
\text { Contratos }\end{array}$ & Valor em R\$ \\
\hline Barro Alto & 37 & $1.091 .648,00$ \\
\hline Carmo do Rio Verde & 163 & $4.699 .899,00$ \\
\hline Ceres & 69 & $1.859 .675,00$ \\
\hline Goianésia & 88 & $2.490 .063,00$ \\
\hline Guaraíta & 82 & $1.490 .974,00$ \\
\hline Guarinos & 164 & $3.529 .601,00$ \\
\hline Hidrolina & 128 & $2.092 .900,00$ \\
\hline Ipiranga de Goiás & 80 & $2.319 .468,00$ \\
\hline Itapaci & 109 & $2.359 .278,00$ \\
\hline Itapuranga & 547 & $13.384 .078,00$ \\
\hline Morro Agudo de Goiás & 68 & $2.360 .651,00$ \\
\hline Nova América & 39 & $1.509 .304,00$ \\
\hline Nova Glória & 34 & $849.710,00$ \\
\hline Pilar de Goiás & 201 & $5.359 .974,00$ \\
\hline Rialma & 39 & $1.115 .452,00$ \\
\hline Rianápolis & 11 & $261.796,00$ \\
\hline Rubiataba & 220 & $6.803 .943,00$ \\
\hline Santa Isabel & 50 & $1.576 .470,00$ \\
\hline Santa Rita do Novo Destino & 56 & $1.746 .585,00$ \\
\hline São Luiz do Norte & 20 & $524.584,00$ \\
\hline São Patrício & 74 & $2.266 .537,00$ \\
\hline Uruana & 220 & 4.833.011,00 \\
\hline Microrregião Ceres & 2.499 & 64.525.601,00 \\
\hline
\end{tabular}

Fonte: Bacen/Derop/Sicor/MDA - Ministério do Desenvolvimento Agrário.

Como um exercício comparativo, pode-se observar os dados do programa Produzir (fomento à industrialização) do estado de Goiás para as usinas sucroenergéticas em funcionamento na região estudada (tabela 17). Enquanto o PRONAF investe cerca de 64 milhões por ano na região (vinte e dois municípios), somente o Produzir investiu mais de 1 
bilhão e seissentos mil reais em investimento fixo e crédito agrícola para a implantação de seis usinas na região.

Tabela 17 - Recursos Produzir para as usinas da Microrregião Ceres - GO

\begin{tabular}{|c|c|c|c|}
\hline \multicolumn{4}{|c|}{ Usinas implantadas na Microrregião Ceres / GO - Recursos Produzir } \\
\hline Empreendimento & Município & $\begin{array}{l}\text { Investimento } \\
\text { Fixo R\$ }\end{array}$ & Crédito $R \$$ \\
\hline Jalles Machado & Goianésia & $98.756 .034,00$ & $615.762 .981,23$ \\
\hline Goianésia & Goianésia & $59320.019,00$ & $170871.851,54$ \\
\hline Vale Verde & Itapaci & $48068.941,00$ & $193921.019,06$ \\
\hline CRV Industrial & Carmo do Rio Verde & $30.390 .660,14$ & $131.414 .453,14$ \\
\hline Vale Verde & Itapuranga & $37.003 .868,96$ & $435.178 .288,79$ \\
\hline Cooper Rubi & Rubiataba & $55.677 .172,21$ & $246.003 .437,97$ \\
\hline \multicolumn{2}{|c|}{ Total } & 221.827.735,31 & $1.428 .359 .161,13$ \\
\hline Total F & 0 + crédito & \multicolumn{2}{|c|}{$1.650 .186 .896,40$} \\
\hline
\end{tabular}

É importante mencionar que essa comparação é somente com o Produzir, que corresponde a um programa do governo do estado de Goiás, assim, várias são as opções de crédito rural do Governo Federal para a agricultura comercial (além de outros do governo estadual que não serão destacados aqui), com vários projetos de investimentos que as usinas podem solicitar, como: Programa de Incentivo à Irrigação e à Armazenagem, Programa de Desenvolvimento Cooperativo para Agregação de Valor à Produção Agropecuária, Programa de Capitalização das Cooperativas de Produção Agropecuária, entre outros disponíveis, a cada ano, por meio do Plano Agrícola e Pecuário, disponibilizado pelo Ministério da Agricultura, Pecuária e Abastecimento - MAPA.

Pode-se utilizar as palavras de Alentejano (2000) para afirmar que, tanto ao nível das políticas quanto dos processos em curso no campo brasileiro, há profundas contradições que podem apontar para a constituição de um novo mundo rural, como para a perpetuação das velhas tendências da realidade agrária do Brasil. E infelizmente, a realidade verificada, no caso específico da microrregião Ceres, tem apontado para a segunda tendência: da perpetuação da concentração, de terra e de renda, nas mãos da agricultura comercial voltada para o agronegócio sucroenergético.

Outro breve exemplo para se compreender a realidade da microrregião Ceres é a existência de associações e cooperativas voltadas para o desenvolvimento da agricultura comercial. Segundo Oliveira (2010), o modelo de associativismo pautado no cooperativismo 
agrícola manteve-se distante da realidade dos pequenos produtores rurais, pois a necessidade de competição fez com que as cooperativas mais ativas e dinâmicas funcionassem como espaços de mediação para os médios e grandes produtores vinculados ao agronegócio.

Um exemplo contundente na microrregião Ceres é a Cooper Rubi, emprendimento sucroenergético implantado no município de Rubiataba. A Cooper Rubi foi criada na década de 1980, fruto dos incentivos do Proálcool, e funcionava como uma destilaria dentro de uma cooperativa local, que também trabalhava com produção leiteira. Durante quase 20 anos, a destilaria ficou sob direção integral de produtores locais, mas a partir do ano 2003, o Grupo Japangu da Paraíba comprou sua maior parte, passando a ser os donos majoritários da Cooper Rubi.

A microrregião Ceres também apresenta algumas cooperativas voltadas para a agricultura familiar, o que é fundamental para fortalecer os pequenos produtores sejam eles proprietários de terra ou assentados. Contudo, concorda-se com Oliveira (2010), quando esse coloca que o formato de associativismo que vem sendo implementado no país de modo geral, acaba por intensificar a fragmentação existente entre os pequenos produtores, em vez de fortalecer uma identidade de classe da produção familiar. Ainda segundo esse autor,

[...] tal processo está inserido numa conjuntura, na qual os gastos públicos com a agricultura familiar são inversamente proporcionais a sua expressividade numérica na geração de postos de trabalho e abastecimento do mercado interno, quando comparada à agricultura empresarial (OLIVEIRA, p. 196).

Essa breve discussão é importante para se entender os conflitos de interesses latentes na região estudada, entre a lógica dominante do agronegócio canavieiro e a agricultura familiar e, consequentemente, a produção de alimentos, tão importante para as pequenas cidades.

A presente pesquisa aponta para uma verdadeira fragilização dos produtores familiares, ou seja, pouco ficou da intenção política da CANG, não que o projeto das colônias agrícolas fosse a melhor solução para a realidade do campo brasileiro, mas porque compreende-se a importância da produção de origem familiar (introduzida na região pela CANG) para a constituição histórica da microrregião Ceres e para a valorização dos camponeses da região.

A realidade socioeconômica atual da região está muito vinculada à atividade sucroenergética, sua paisagem regional demostra paisagens relacionadas à dinâmica 
sucroenergética, tanto em municípios com usinas implantadas, quanto em municípios vizinhos a estes. Poucas ações são realizadas atualmente em prol da agricultura familiar (e quando existem, estão diretamente vinculadas à agricultura comercial), e poucas são as alternativas ao agronegócio latente na região. São realizadas ações vindas das secretarias municipais e, sobretudo, da Emater, contudo, ainda de maneira tímida frente ao agronegócio canavieiro.

A maioria dos municípios da microrregião Ceres, possui hoje elementos que os traduzem como produto de um agronegócio que segrega e marginaliza, principalmente porque está vinculado somente ao segmento canavieiro e possui poucas alternativas para a produção de alimentos e inclusão social em outras atividades, que não sejam, direta ou indiretamente, relacionadas a atividade canavieira.

Durante as atividades de campo realizadas na microrregião Ceres, foi possível conhecer a Cooperativa de Agricultores Familiares de Itapuranga, a Cooperafi ${ }^{33}$, criada no município de Itapuranga no ano de 1998 (figura 88). A Cooperafi é um exemplo de alternativa viável frente ao agronegócio da cana na região, o município de Itapuranga possui uma usina implantada, mas esta há alguns anos passa por dificuldades financeiras e judiciais, sendo que nesse ano de 2016 plantaram cana, mas não haverá a moagem nessa usina, como já mencionado no Capítulo 3.

\footnotetext{
${ }^{33}$ Visita e entrevista à Cooperafi, realizada no mês de maio de 2016.
} 


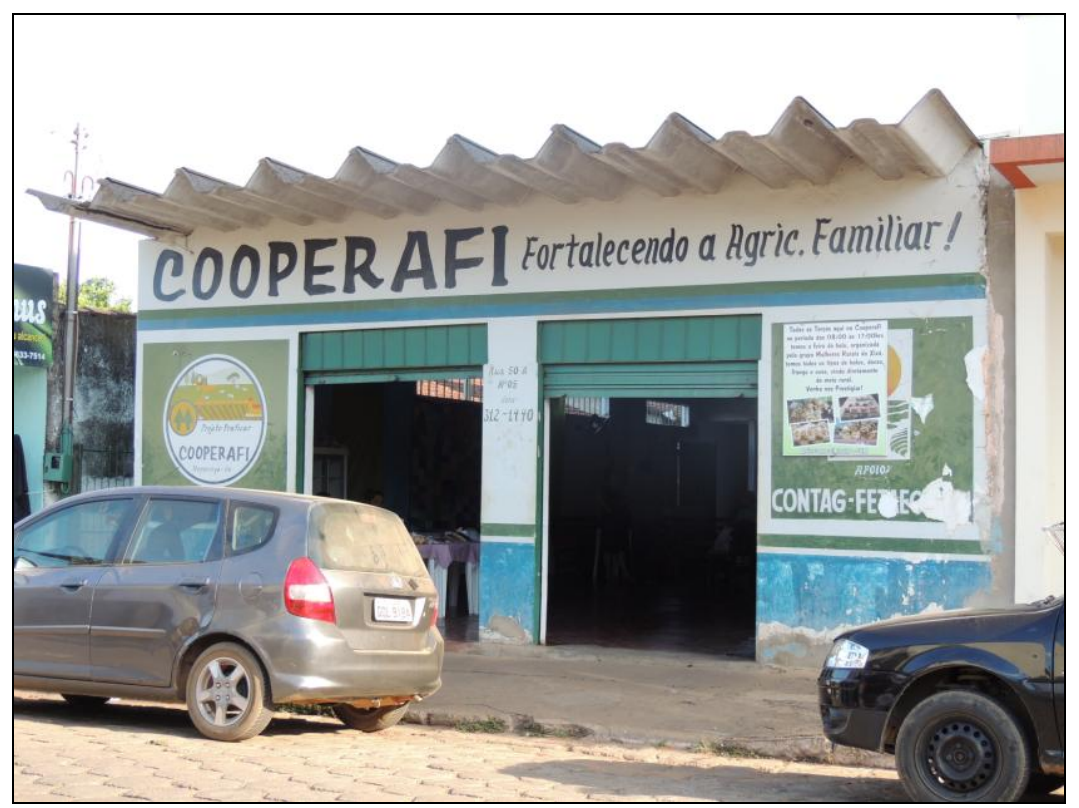

Figura 88 - Sede da Cooperativa de Agricultores Familiares - Cooperafi, Itapuranga. Foto: A autora, maio de 2016.

O município de Itapuranga possui, em sua maioria, pequenas propriedades que acabam por não se adaptar à lógica de arrendamento das usinas canavieiras, assim, uma alternativa bastante interessante é trabalhar de forma coletiva e garantir a permanência à terra, trabalho, dignidade e renda para os pequenos agricultores.

A Cooperafi tem atualmente 230 cooperados, que iniciaram os trabalhos com a produção de leite, e hoje já acessam o Programa de Aquisição de Alimentos (PAA) e o Programa Nacional de Alimentação Escolar (PNAE). A cooperativa familiar é bastante ativa em Itapuranga e já possui uma marca associada à produção de polpas de frutas PRAFICAR. As polpas de frutas são vendidas para as escolas de municípios vizinhos, além de Itapuranga, como: Guaraíta, Heitoraí, Itaberaí, Faina e Morro Agudo de Goiás, por meio do PNAE.

Outros alimentos são produzidos e comercializados na cidade, na sede da Cooperafi, ou na feira do produtor rural de Itapuranga. Alimentos, como: mamão, laranja, abóbora, mexerica e melancia são produzidos e vendidos nas feiras e também diretamente aos centros de abastecimentos (CEASA's) de Goiânia e Brasília, principalmente. Há também, dentro da Cooperativa, um grupo de mulheres, denominado "Mulheres Rurais do Xixá34" que

\footnotetext{
${ }^{34}$ A palavra Xixá foi a primeira denominação de Itapuranga, quando ainda era somente um povoado. Dizem que o povoado recebeu o topônimo de Xixá, em virtude da celebração da primeira missa campal à sombra de um enorme Xixazeiro - uma árvore do Cerrado também conhecida por Caliandra do Cerrado.
} 
produzem bolos, doces, frangos, ovos e artesanatos e os vendem, todas as terças-feiras, na sede da Cooperafi, como pode ser visualizado na figura 89.

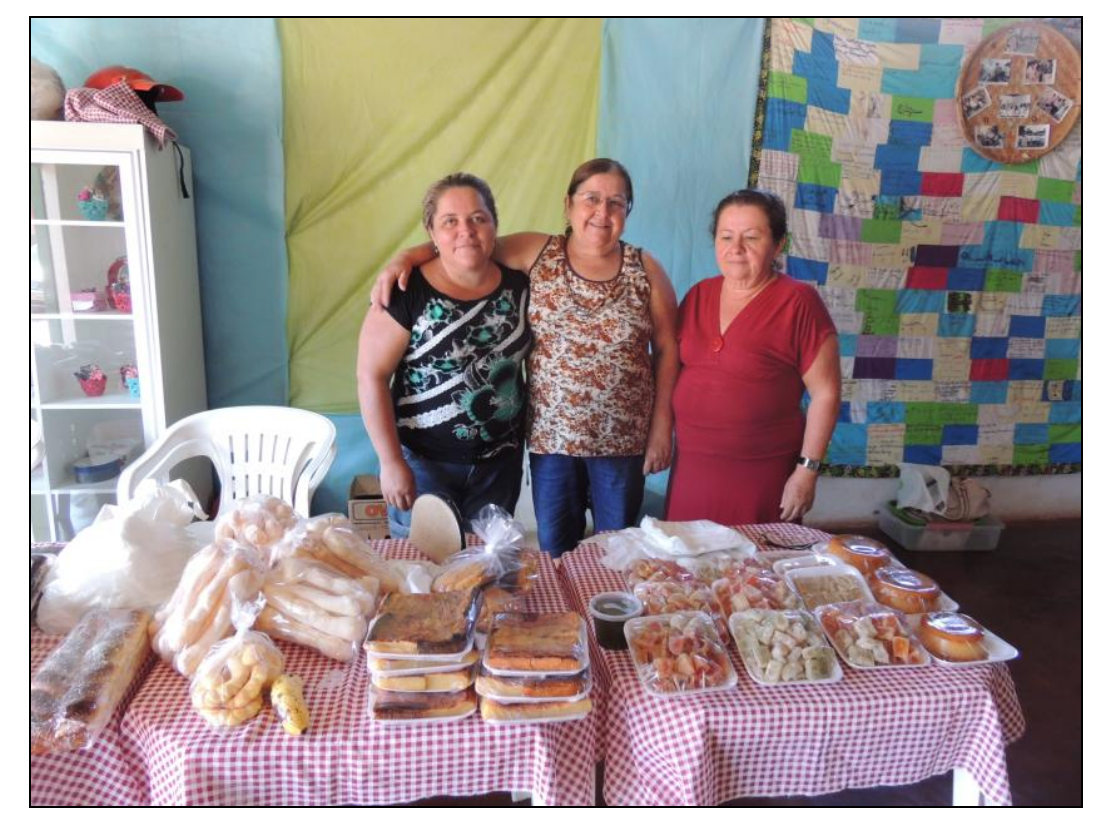

Figura 89 - Mulheres Rurais do Xixá, na Cooperafi, Itapuranga. Foto: A autora, maio de 2016.

Experiências como as verificadas durante a visita na Cooperafi são entendidas aqui como uma alternativa para a inclusão dos pequenos agricultores e acesso mais facilidado à créditos agrícolas, por meio da cooperativa, além da possibilidade de estimular o trabalho coletivo e a agricultura familiar, tão importantes para a produção alimentos, bem como a possibilidade de permanência na terra aos camponeses da região.

Essas alternativas são de suma importância para a microrregião Ceres, a qual possui grande parte de suas terras em pequenas propriedades rurais, que estão arrendadas para o agronegócio sucroenergético. É sabido por todos que os agricultores familiares são os excluídos do processo vivenciado na região e, consequentemente, do desenvolvimento econômico e do progresso que são "vendidos" pelo agronegócio e "comprados" pela iniciativa privada, pelo Estado e por grande parte da população. 


\subsection{A Microrregião Ceres e o Desenvolvimento Econômico - O Mito do Progresso}

Com a presente pesquisa pôde-se compreender a microrregião Ceres e como sua paisagem foi sendo remodelada de forma tão rápida no tempo e intensa no espaço, por meio do recorte temporal utilizado pela pesquisa: das Colônias Agrícolas Nacionais ao agronegócio sucroenergético atual. A paisagem regional modificou-se rapidamente e trouxe consigo marcas visíveis do processo de capitalização da agricultura, estabelecido ao longo do tempo na região e fruto do discurso de progresso, vinculados às agroindústrias e ao agronegócio como um todo.

Faz-se importante entender aqui como esse discurso, aliado à concepção de desenvolvimento, podem ser importantíssimos para a estratégia de territorialização das agroindústrias sucroenergéticas, por exemplo. O que é propagandeado pelo agronegócio tem o intuito direto de se promover e de vender a máxima que agronegócio é sinônimo de progresso e isso acaba por legitimar as desigualdades e os efeitos do agronegócio.

É muito comum as grandes empresas e corporações propagarem o discurso de que os empreendimentos implantados trarão rapidamente: empregos, diretos e indiretos; reestruturação do espaço urbano dos municípios; dinamismo econômico; entre outros, ou seja, acabam por difundir fortemente a ideia de progresso, modernização e desenvolvimento econômico.

Com a pesquisa realizada percebeu-se que o discurso de progresso difundido pelo setor sucroenergético rapidamente conquista vários adeptos, entre eles: o Estado, que apoia e fomenta a territorialização dos empreendimentos; o poder público local, não é raro ver prefeitos e secretários defendendo o desenvolvimento local e regional provindos das agroindústrias canavieiras; e, por fim, conquistam grande parte da população, que acredita que o progresso está atrelado a ideia de modernização, grandes indústrias e corporações, mesmo conhecendo todas as mazelas e efeitos dessa atividade.

Dentro do exposto, faz-se importante trazer autores como Dupas (2006) que traz uma rica discussão sobre o mito do progresso, muito presente atualmente, nas elites e nos atores hegemônicos. Segundo esse autor, as inovações tecnológicas foram ao longo do tempo adquirindo um teor qualitativo intrínseco, o que gerou rotulações de "progressistas" para quem as aprovava e de "reacionários" para seus críticos.

Dupas (2006) dialoga bastante com Barzun (2002), o qual recorda que a doutrina do progresso foi incorporada à filosofia do século XVIII e "foi se convertendo em um credo 
que os constantes avanços tecnocientíficos ratificavam ao criar produtos e serviços que se transformaram em objeto de desejo e símbolos do progresso" (BARZUN, 2002, p.100).

Concorda-se com Dupas (2006) quando esse esclarece que não é pretensão negar ou desqualificar os benefícios da evolução tecnológica ocorrida na história mundial, mas de compreender quais as dimensões desse progresso e, sobretudo, a quem ele serve e quais seus reais objetivos. É preciso ter em mente que a capacidade de produzir mais e melhor também traz exclusão, segregação, concentração de renda e terras, subdesenvolvimento e subalternidades.

Mendonça (2015, p. 392), confirma que “o conceito de agronegócio no Brasil está baseado em uma perspectiva que adota a ideia de desenvolvimento como sinônimo de progresso tecnológico". Além disso, a autora traz à discussão a ideia de "vocação", que muitas vezes é usada para justificar certas práticas, como por exemplo, o discurso sobre uma suposta vocação agrícola brasileira, que viria para justificar a defesa do modelo econômico baseado na monocultura para exportação, sendo utilizado para manter o caráter extensivo do agronegócio, por meio de sua aliança com a oligarquia latifundista.

Muitos autores trabalharam a noção de progresso em vários contextos históricos, seja aliado ao poder, às conquistas e às inovações técnicas ou tecendo críticas, no intuito de desconstruir o discurso do progresso. Aqui é interessante perceber o quanto a ciência moderna está relacionada definitivamente ao capital e o quanto o ser humano está dependente de símbolos aliados ao progresso: próteses, máquinas, medicamentos, avião, computador, internet, entre outros.

O que deve-se ater é que hoje a ideia de progresso é bastante utilizada como estratégia de convencimento nos discursos hegemônicos, principalmente no caso estudado, dos atores envolvidos com o agronegócio. O que se observa é que os impactos socioeconômicos e ambientais são aceitáveis diante da promessa de progresso e de crescimento econômico que será trazido pelas grandes empresas e corporações.

O discurso utilizado pelas usinas canavieiras, por exemplo, e apropriado pelas elites locais e pelo poder público convence a população, que mesmo insatisfeita com os efeitos negativos gerados, os serviços incipientes criados e a qualidade questionável do urbano proposta pelos empreendimentos, acabam por acreditar e defender a atividade canavieira e não ver outras alternativas e possibilidades. A região fica portanto, refém ideologicamente do mito do progresso. 
Autores como Elias e Pequeno (2007) abordam a realidade do que denominam de "cidades do agronegócio", sobretudo discutindo como a intensificação do capitalismo no campo torna as cidades mais urbanas e as relações campo-cidade mais complexas. Esses autores também discutem o quanto o agronegócio globalizado contribui para a formação de redes agroindustriais globalizadas que acabam se associando a empresas agroecuárias, fornecedores de insumos e implementos mecânicos, laboratórios biotecnológicos, além de grandes empresas de marketing.

Todos esses elementos discutidos por Elias e Pequeno (2007), levam a inferir que o resultado dessa intensa dinâmica entre o agronegócio, as cidades e a região o qual está inserido, resultam na intensificação de trocas intersetoriais e a criação de diferentes arranjos territoriais produtivos no campo e na cidade, o que acaba por evidenciar "uma significativa remodelação do território e na organização de um novo sistema urbano, com a multiplicação de pequenas e médias cidades, que compõem lugares importantes para a realização do agronegócio globalizado" (ELIAS; PEQUENO, 2007, p. 29).

Com base nas leituras desses autores e de outros que pesquisam as "cidades do agronegócio" e fazendo a análise da região estudada, afirma-se que nenhuma cidade da microrregião Ceres, mesmo sendo uma grande produtora de cana-de-açúcar em Goiás e apresentando uma relação praticamente de dependência com a atividade sucroenergética, pode ser considerada um "cidade de agronegócio", dentro do conceito de Elias e/ou Elias e Pequeno.

Verifica-se na microrregião Ceres a territorialização de usinas sucroenergéticas e, no caso do município de Goianésia, até uma monopolização do Grupo Otávio Lage. Contudo, a realidade observada está longe de ser comparada a uma região com amplas e complexas redes agroindustriais, principalmente porque o que predomina na região é o segmento canavieiro, não há outros arranjos produtivos do agronegócio que poderiam unir-se a essa atividade, como as empresas agropecuárias, para estabelecer uma rede de consumo para o bagaço da cana (ração animal) ou compra da energia gerada, por exemplo.

O agronegócio sucroenergético verificado na microrregião Ceres, de forma geral, é bastante simplificado em termos das redes que poderiam ser formadas, além dos serviços e das empresas presentes serem muito incipientes, necessitando acessar mercados maiores para certas demandas, como São Paulo, Goiânia e Brasília, conforme já mencionado.

O que se observa na microrregião Ceres é que mesmo não apresentando características econômicas e estruturais das "cidades do agronegócio", acaba por exibir os 
efeitos negativos fruto dessa atividade. Sabe-se que o agronegócio globalizado acontece de forma excludente e seletista, o que promove, além da concentração de renda, uma intensificação das desigualdades socioespaciais e de impactos sociais e ambientais.

Elias e Pequeno (2007) ainda fazem uma reflexão bastante válida para as "cidades do agronegócio" e que também serve para a região estudada. Essas cidades, que em sua maioria são pequenas e médias, apresentam problemas urbanos de grandes cidades, como: deficiências nos serviços de saúde e infraestrutura social (principalmente cidades que possuem alojamentos para os cortadores de cana), aumento no preço dos aluguéis, surgimento de áreas de ocupação de risco e periferização, entre outros.

Diante dessa breve análise, questiona-se: qual é a dimensão do desenvolvimento que é produzida pelo mito do progresso vinculado ao agronegócio e, consequentemente, aos empreendimentos sucroenergéticos, verificada na microrregião Ceres?

Antes de fazer o recorte para a microrregião Ceres e para a atividade canavieira, cabe retomar brevemente a discussão proposta por Léo Waibel quando escreveu sobre suas expedições durante a Marcha para o Oeste e a CANG. Alguns elementos são visíveis na descrição e análise desse Geógrafo: primeiro a visão cética, como ele mesmo diz, sobre a possibilidade de desenvolvimento para o oeste brasileiro; e a visão pré concebida sobre o oeste do Brasil, que o levou muitas vezes a uma análise muito reducionista, quando compara o leste "com as melhores áreas" ao oeste brasileiro "sem promissão".

A visão apresentada por Waibel está diretamente vinculada a uma noção progressista. Isso fica evidente em seu texto, sobretudo quando após suas discussões, trabalhos de campo e análises, o mesmo infere:

Tudo isso me leva à conclusão de que o oeste do Brasil não é uma terra da promissão. (...) Para mim, em todo caso, não restam dúvidas de que as melhores áreas do Brasil já foram ocupadas e que, mesmo no futuro, o país não assistirá a uma "marcha para o oeste" (WAIBEL, 1955, p. 415 ).

Essa retomada é importante para entendermos o quanto a ideia de progresso está presente em várias esferas e acaba por ratificar e legitimar algumas atividades e o alto índice produtivo, que muitas vezes é nocivo social e ambientalmente. Percebe-se no Brasil uma ideia muito forte de que o progresso está diretamente vinculado ao agronegócio e que consequentemente traria um desenvolvimento territorial e regional.

Hespanhol (2008), afirma que a operacionalização do desenvolvimento territorial é praticamente impossível de ser implementada quando perduram a elevada concentração da 
propriedade da terra (ou o alto número de arrendamentos de terras para as usinas canavieiras), a grande concentração social e regional da renda, o esgarçamento do tecido social e a falta de dinamismo econômico. Essas características são facilmente perceptíveis na microrregião Ceres, principalmente a falta de dinamismo econômico, devido ao foco produtivo estar quase que unicamente vinculado a atividade canavieira.

Quando se analisam os números de PIB e IDH por exemplo, mesmo com as críticas que envolvem esses indicadores, pode-se verificar um crescimento econômico nos números, mas concentração de renda e deficiências nos indicadores sociais. As observações realizadas em campo, somadas às entrevistas ao poder público local, contribuíram para ratificar a omissão dos empreendimentos canavieiros frente aos problemas socioambientais gerados e a falta de parcerias com as prefeituras e instituições locais, bem como com a sociedade, conforme previstas durante o processo de implantação das usinas, pelo menos entre as agroindústrias provindas do nordeste brasileiro, que são maioria na região.

Segundo Hespanhol (2008), a permanência de problemas estruturais relacionados a ineficiência das instituições, a concentração de riqueza e das relações de poder, a persistência de práticas clientelistas e, principalmente, o despreparo da população para participar de maneira autônoma ou a sua co-dependência a esses empreendimentos, acabam por dificultar a implementação de abordagens qualificadas de desenvolvimento.

Quando se discute desenvolvimento, sobretudo relacionado à abordagem econômica no Brasil, tem-se que fazer referência à importante obra de Celso Furtado. Esse autor aborda em síntese, a alta concentração do excedente na atividade industrial brasileira, a crescente hegemonia das grandes empresas e um distanciamento das formas de vida de uma minoria privilegiada em relação à massa populacional.

De acordo com Furtado (1983), deve-se estar atentos ao aumento da renda de determinada comunidade, pois esta pode ser resultado de pelo menos três processos distintos: 1) o desenvolvimento econômico, isto é, a acumulação do capital e a adoção de processos produtivos mais eficientes; 2) a exploração de recursos naturais não renováveis, e; 3) a realocação de recursos visando a uma especialização num sistema de divisão internacional do trabalho. Diante do exposto, o aumento da renda implica em diversificação do consumo, introdução de novos produtos, entre outros, assim esse aumento pode ocorrer numa comunidade sem desenvolvimento econômico.

Destaca-se, portanto, que é bastante comum, com o incremento de atividades agroindustriais, verificar aumentos nos indicativos econômicos e nas estatísticas financeiras, 
contudo pode somente representar a exploração dos recursos naturais e realocação de recursos, o que mascara a não introdução de processos produtivos mais eficientes e uma desigualdade na distribuição de renda.

Furtado (1983) defende a ideia de que o desenvolvimento econômico é um simples mito e que isso tem justificado ações para mobilizar a população a aceitar os problemas, os efeitos negativos e a legitimar a destruição do meio físico para permitir as formas de dependência que reforçam o caráter predatório do sistema produtivo. Reforça-se aqui também a ideia de progresso, para legitimar os problemas e desigualdades da exploração do agronegócio na microrregião Ceres.

Diante do entendimento da irrealização do desenvolvimento econômico, sobretudo quando se parte da ideia de Furtado (1983), de que as economias da periferia nunca serão desenvolvidas e que os povos pobres não poderão disfrutar algum dia das formas de vida dos atuais povos ricos, alguns autores começaram a propor discussões sobre o desenvolvimento.

Atualmente no Brasil, verificam-se discussões sobre desenvolvimento territorial, regional e rural, relacionadas aos efeitos do processo de capitalização da agricultura. Não se propõe aqui aprofundar nesses conceitos e suas especificidades, mas discutir o quanto as noções de progresso e de desenvolvimento econômico, difundidos nos discursos do agronegócio, podem justificar as mazelas e as desigualdades verificadas.

Assim, os problemas sociais e ambientais relacionados à agroindústria da cana já são velhos conhecidos no Brasil. O importante a ser destacado é que os problemas socioambientais, são geralmente experimentados por toda a sociedade, sobretudo aqueles com rendimentos mais baixos, entretanto os benefícios econômicos e a acumulação do capital são vivenciados por poucos, conforme explicitou Martinelli e Filoso (2008).

Isso é verificado nos municípios da microrregião Ceres, em escalas diferentes. Quando se observa os municípios que possuem usinas em pleno funcionamento, vê-se mais nitidamente as formas e os elementos da atividade sucroenergética, muito presentes em sua paisagem. Contudo, quando se adentra aos municípios que são grandes produtores de canade-açúcar, mas não possuem usinas, percebe-se outra escala de efeitos do agronegócio canavieiro. Municípios como Nova Glória, Santa Isabel e São Luiz do Norte acabam sendo reféns de uma atividade que não traz quase nenhum retorno para seus municípios, sequer os impostos que deveriam ser pagos, o que reforça uma situação de subalternidade dentro da rede urbana da microrregião Ceres. 
Esta análise envolve várias dimensões e esbarra na dimensão política: os usineiros dos grupos nordestivos normalmente não se envolvem com programas locais e não desenvolvem parcerias com as prefeituras, contudo durante as eleições acabam sendo os principais investidores de campanhas. A dimensão política é muito importante na análise proposta, pois quando se analisa a usina do grupo goiano, em Goianésia, também se percebe uma relação intrínseca entre os usineiros e a política local. Diante disso, como pensar no desenvolvimento econômico, como este deve ser, envolvendo toda a sociedade, com tantos interesses envolvidos?

Araújo (1999), defende que a fragmentação espacial do Brasil, frente à globalização, pode ser contrabalançada por uma nova política nacional de desenvolvimento regional semelhante à praticada por outros países e até por Blocos Econômicos, como a União Européia. Essa autora também acredita que a dinâmica regional entregue apenas às decisões do mercado tende a exacerbar seu caráter seletivo, ampliando as fraturas herdadas do passado.

Favareto (2010) propõe que para haver uma estratégia de desenvolvimento rural seria necessário pensar em uma agenda que abrangesse diversificação e dinamização das economias interioranas, sendo fundamental diversificar as economias locais, e buscar uma paridade entre as regiões rurais e urbanas, principalmente no que tange às políticas de saúde e educação.

Assim, os entraves percebidos na microrregião Ceres e que muito dificultam a busca por um real desenvolvimento econômico, estão relacionados à falta de diversificação das atividades econômicas, muito voltadas para o setor sucroenergético. Entretanto, destaca-se que não se trata somente de diversificar a produção agrícola, mas também os serviços, às redes estabelecidas, o acesso a educação e, sobretudo, pelas características históricas e socioeconômicas da região, o acesso à terra e a políticas de permanência das famílias no campo.

A análise proposta contribuiu para ratificar que não é a modernização da agricultura ou a incorporação de técnicas ou maquinários que vão contribuir para o desenvolvimento econômico de determinada região. O acesso à terra, ferramentas de trabalho e incentivo, por meio de políticas públicas eficientes, contribui de forma muito mais eficaz com o desenvolvimento, que deve perpassar a dimensão econômica.

Concorda-se com Locatel (2014), quando este destaca que a modernização da agricultura brasileira, não foi um elemento homogeneizador das condições técnicas e 
socioeconômicas. Ao contrário, em relação as condições sociais, esse processo serviu para agravar ainda mais as desigualdades já existentes e as condições de vida de uma significativa parcela das famílias trabalhadoras rurais. E em relação à tecnificação do território, o mesmo autor, ressalta que se trata de um processo seletivo e desigual espaçotemporalmente.

Com o desenvolver da presente tese, observou-se que a microrregião Ceres é uma região que vivenciou ao longo do tempo importantes contextos históricos que trouxeram refuncionalizações na rede urbana regional, além de se tornar mais complexa. As colônias agrícolas nacionais representaram o grande "pontapé" para as migrações e o desenvolvimento da produção familiar. Com as ações de programas governamentais e políticas públicas a região absorveu muito rapidamente a lógica capitalista e atraiu algumas usinas canavieiras que atualmente representam a principal atividade socioeconômica da região, inclusive sendo as principais fornecedoras de empregos.

Essa realidade é facilmente observada pela paisagem regional, as formas, os elementos fixos e fluxos, as redes estabelecidas, estão materializadas na paisagem, além dos conflitos e problemáticas que acompanham o setor sucroenergético. A microrregião Ceres ainda possui um relevante quantitativo de trabalhadores manuais na colheita da cana, isso trouxe alguns problemas para a região como a refuncionalização de escolas ou espaços públicos para servir de alojamentos para os trabalhadores migrantes. Atualmente, grande parte dos trabalhadores migrantes já se incorporaram aos municípios, não regressando mais para as suas cidades no período da entressafra, como bem reforçaram os representantes do poder público local, entrevistados nas atividades de campo.

Assim, observa-se na microrregião Ceres insuficiência de serviços, comércios, hospitais e escolas (de nível básico e superior), principalmente nas cidades que servem ao agronegócio sucroenergético. O município de Ceres, que não participa da dinâmica canavieira, ainda é a grande centralidade da região em relação a esses serviços. Destaca-se que o município de Goianésia também apresenta relativa diversidade em serviços, contudo sua centralidade ainda está circunscrita ao próprio município e a municípios muito próximos a ele. Atribui-se a isso à importância histórica do município de Ceres, bem como à sua localização geográfica: o perímetro urbano de Ceres está localizado praticamente no centro da região, enquanto o de Goianésia está bem mais distante, inclusive das principais malhas viárias, como a BR 153, principal via de circulação e escoamento da região que está muito próxima à Ceres. 
A atividade canavieira na microrregião trouxe incremento de novos elementos técnicos, além de empregos diretos e indiretos, contudo a falta de diversidade nas atividades econômicas e a falta de acesso e permanência dos pequenos agricultores à terra, deixa a região refém do setor sucroenergético, além do poder público local e a população, o que faz com que essa dinâmica se processe de forma extremamente frágil.

Grande parte das terras da microrregião Ceres estão arrendadas para a produção de cana, lembrando que a região possui parte relevante de sua estrutura fundiária em pequenas e médias propriedades. Para os pequenos proprietários a rentabilidade frente ao arrendamento é praticamente irrisória, além de estimular a expropriação do produtor rural e o desemprego estrutural nas cidades. Outro grave problema é que o contrato entre as usinas e os arrendatários costuma ser longo, por no mínimo 5 anos, dessa forma o agricultor fica muito tempo longe do trabalho na terra, além da cultura canavieira exaurir bastante o solo, inviabilizando ou onerando o trato do solo após a finalização do contrato com a usina.

Segundo Elias (2006) a presença do trabalhador assalariado temporário não representa somente aqueles não detêm a propriedade da terra, como também incluem os pequenos proprietários que são obrigados a se assalariar em determinados períodos do ano (durante a safra). A afirmação de Elias é bastante pertinente, pois mostra que muitas vezes aquele pequeno proprietário, que arrendou suas terras para a usina e foi expropriado para a cidade, acaba trabalhando na própria usina como assalariado (em várias funções / especializações), já que o valor pago ao arrendamento das pequenas propriedades é muito baixo, não sendo suficiente para a sobrevivência das famílias.

Diante dessa breve explanação, somada aos cinco Capítulos apresentados na presente tese, defende-se que, o fato da microrregião Ceres não apresentar diversificação econômica e estar focada em segmento único do agronegócio, o canavieiro, acaba por intensificar a fragilidade socioeconômica, associada a uma co-dependência das usinas sucroenergéticas, o que é fortalecido pelo mito do progresso, difundido pelas agroindústrias, e absorvido pelo poder público local e por parte da população.

As regiões que servem ao agronegócio geralmente acabam associando-se a outras redes comerciais, como os frigoríficos, agropecuárias, cooperativas de beneficiamentos de grãos ou de ração animal, entre outras, como observado no sudoeste de Goiás, por exemplo. A microrregião Ceres não apresenta essa característica, o que acaba por fragilizar ainda mais a economia local e regional e, em consequência, as relações em sociedade. 
Durante a realização das entrevistas aos secretários de agricultura ou similares, nas prefeituras municipais, todos os representantes mostraram-se preocupados quando questionados sobre um possível fechamento das usinas, pois como a maioria delas foi implantada nas décadas de 1980 e 1990, já há uma dependência socioeconômica dessa atividade. O único município que possui certa diversidade nas atividades econômicas é Goianésia, contudo há uma monopolização do Grupo Otávio Lage, proprietário de duas usinas localizadas no município e de praticamente todas as principais empresas.

Atrelados a isso têm-se o Estado, como agente fundamental, e a dimensão política que se fazem importantíssimos, tanto para a territorialização das agroindustrias canavieiras, quanto para sua permanência. Os vultosos recursos e o acesso facilitado a créditos para seu funcionamento, movimentam a dinâmica canavieira na microrregião Ceres e ditam as principais regras, já que os usineiros são os principais financiadores de campanhas políticas, quando não são os próprios candidatos, como no caso da prefeitura de Goianésia.

Em contrapartida aos vultosos investimentos no agronegócio estão as pequenas parcelas direcionadas aos agricultores familiares da microrregião Ceres. Como exposto, essa região teve importante contexto de formação territorial e ocupação por meio da política de colonização durante a "marcha para o oeste", entretanto atualmente não há quase nada na região que identifique essa política que contou com a doação de lotes e incentivos durante a década de 1940.

A maior crítica talvez deva estar na consecução da política das Colônias Agrícolas Nacionais, que buscou a atração de migrantes, doação de lotes e ferramentas, mas sem procurar realizar a reforma agrária tão importante para a realidade fundiária brasileira. Assim, das colônias agrícolas ao agronegócio sucroenergético pouco foi feito para o acesso efetivo à terra, com condições eficazes para a permanência dos produtores familiares. Alguns municípios da microrregião Ceres, como Itapuranga, caminham na direção do cooperativismo, que dá possibilidades, mesmo que ainda pequenas, de autonomia frente ao agronegócio canavieiro, bem como dignidade ao pequeno produtor e a sua família.

Acredita-se portanto, que há uma dinamização socioeconômica provinda da atividade sucroenergética, mas essa é altamente concentrada e causa uma co-dependência social e econômica, devido ao fato de estar focada no segmento canavieiro e não criar redes autônomas a este. Essa dinamização concentrada e altamente dependente acaba por contribuir com um desenvolvimento econômico incompleto, bem como por construir um elo legitimador das contradições socioespaciais e ambientais, fruto do agronegócio 
sucroenergético, verificadas na microrregião Ceres e que são, muitas vezes, mascaradas pelos mitos do progresso e do desenvolvimento econômico, mas que são facilmente verificadas pelas formas espaciais, pelas fragilidades verificadas e pelas desigualdades materializadas, ou seja, pelo que revela sua paisagem regional.

Por fim, entende-se que a proposta de desenvolvimento econômico ideal para compreender a realidade verificada na microrregião Ceres deve estar atrelada a quatro principais pontos: primeiro, faz-se fundamental partir da dimensão do desenvolvimento integrado à relação campo-cidade, já que dentro da análise posta não é possível separar campo e cidade; segundo, deve-se considerar a abordagem regional para a análise do agronegócio sucroenergético, já que desconsiderar os municípios que servem à lógica canavieira, mas que não possuem usinas em funcionamento, é um grave erro, já que muitas vezes os efeitos e impactos nesses municípios podem ser muito mais fortes e gerar uma dependência aos municípios vizinhos; terceiro, deve-se buscar a diversificação das atividades econômicas desses municípios e região, para que os mesmos não fiquem reféns da atividade sucroenergética; e, por último, é necessário e iminente o acesso à terra, por meio da realização da reforma agrária, e a promoção de políticas públicas e programas para a permanência dos produtores familiares, além de cursos de formação, para que os mesmos possuam instrumentos reais para uma autonomia mínima frente ao agronegócio sucroenergético e não necessitem arrendar suas terras para as lavouras de cana.

Acredita-se que para uma região que possui grande quantidade de pequenos produtores familiares, pensar na dimensão do desenvolvimento pautado no incentivo a terra, créditos rurais e investimento em uma efetiva extensão rural, para estimular não só a produção "clássica" de alimentos, mas também a agroecologia, a produção de orgânicos, bem como artesanatos e produtos tradicionais, já é um grande avanço inicial para se enfrentar os desafios postos em uma região com tantos conflitos socioecononômicos relacionados ao agronegócio sucroenergético. 


\section{CONSIDERAÇÕES FINAIS}

O tema pensado para a presente tese, durante a apresentação do projeto de doutorado, versava sobre A Produção do Espaço e a Relação Campo-Cidade nos Municípios Sucroenergéticos na Microrregião Ceres - GO, no intuito inicial de compreender como se deu a produção do espaço pela dinâmica canavieira ao longo do tempo, por meio da relação campo-cidade. Cabe ressaltar que a microrregião Ceres, teve no projeto das Colônias Agrícolas Nacionais (CANG) grande importância para sua formação territorial, crescimento populacional, por meio de migrações e (re) configuração urbana e regional. Dessa forma, ao longo do desenvolver da tese, houve necessidade de se compreender a microrregião Ceres também pelo contexto das CANG e não somente pelo sucroenergético, que é mais atual.

Além de partir do contexto das Colônias Agrícolas, percebeu-se a importância metodológica de se utilizar os conceitos de território e paisagem, para somar à abordagem regional proposta. Assim, com os ajustes baseados em leituras e trabalhos de campo, que muito contribuíram para se melhor delinear os objetivos a serem propostos e as hipóteses a serem comprovadas ou refutadas, chegou-se ao título atual da pesquisa, que buscou compreender As Paisagens Regionais na Microrregião Ceres (GO) - das Colônias Agrícolas Nacionais ao Agronegócio Sucroenergético.

Ressalta-se também, que há poucos estudos sobre a microrregião Ceres (ou dos municípios que a constituem) dentro dos estudos da Geografia Agrária goiana, principalmente quando se compara ao sul goiano, sobretudo à microrregião sudoeste de Goiás. Sabe-se das diferenças existentes entre as duas microrregiões em relação à formação territorial e até mesmo concorda-se que o sul goiano possui uma maior quantidade de plantas agroindustriais e a configuração do agronegócio muito mais dinâmica e, em termos numéricos, mais expressivo. Contudo, defende-se a importância em se ampliar as áreas e escalas de análise dentro dos estudos agrários no estado de Goiás.

A microrregião Ceres apresenta-se bastante interessante, traz em sua formação histórica contextos fundamentais e que revelam problemáticas complexas, além de trazer, materializados em sua paisagem, elementos e formas espaciais nítidas da principal atividade socioeconômica da região na atualidade: o agronegócio sucroenergético.

Cabe aqui resgatar, que o estado de Goiás consolida-se hoje como um dos principais produtores de cana-de-açúcar do Brasil e apresenta um número relevante de 
empreendimentos sucroenergéticos em funcionamento. A cana-de-açúcar no Brasil faz parte da sua história, desde o período colonial brasileiro foi considerada uma importante atividade econômica, principalmente para a comercialização do açúcar com o mercado Europeu, algo bastante vantajoso economicamente para a coroa Portuguesa.

Contudo, para a análise proposta, há alguns contextos mais recentes que merecem destaque para a compreensão da territorialização do setor canavieiro no Brasil e, consequentemente, no estado de Goiás, como: o Programa Nacional do Álcool (Proálcool), criado na década de 1970 no Brasil, durante a crise internacional do petróleo e, mais recentemente, o Plano Nacional de Agroenergia, criado pelo Governo Federal brasileiro, no ano de 2006.

O estado de Goiás é hoje o terceiro maior produtor de cana-de-açúcar do Brasil, atrás somente dos estados de São Paulo e Minas Gerais. Em Goiás, algumas regiões destacam-se na produção canavieira e em empreendimentos sucroenergéticos implantados. Percebe-se que há um eixo preferencial de espacialização das usinas, que coincide com uma malha viária desenvolvida e disponível (principais BR's e GO's) e com as melhores terras agricultáveis. Esse eixo corresponde ao centro norte e ao sul / sudoeste do estado de Goiás.

A microrregião Ceres, focada nessa pesquisa, está localizada no eixo citado, no centro goiano, e chama à atenção quando se pretende analisar o setor canavieiro. Não se pode esquecer de mencionar o papel que às Colônias Agrícolas Nacionais tiveram para a formação territorial da região, que tinha como objetivo central povoá-la, por meio da doação de lotes e introduzir a produção agrícola de base familiar.

Entretanto, a Colônia não apresentou muitos êxitos nesse sentido, além de em menos de dez anos ter sua emancipação para o município de Ceres (e outros que seriam emancipados posteriormente). Assim, não se pode negar a importância da CANG para essa região e como esta poderia ser planejada para estimular a introdução dos valores relacionados à divisão de terras, à pequena produção agrícola, à produção familiar e, principalmente, ao acesso à terra, por meio de uma reforma agrária eficaz e não somente doação de lotes, sem o apoio e o acesso a recursos fundamentais para a autonomia das famílias.

A CANG falhou, não se fortaleceu enquanto Colônia Agrícola voltada aos pequenos produtores e apresentou muitos problemas e conflitos. Assim, abriu possibilidades para que outras atividades e dinâmicas surgissem totalmente fora da lógica objetivada inicialmente e isso de forma muito rápida e concentrada. 
Diante disso, a região foi rapidamente direcionada para a grande produção, para as monoculturas, principalmente a canavieira, já a partir do final da década de 1960. As primeiras destilarias implantadas na microrregião Ceres, estão relacionadas ao Proálcool e, a partir daí, a atividade canavieira passou a fazer parte da realidade da região. Com a introdução do Plano Nacional de Agroenergia, em 2006, vários investimentos foram realizados, o que contribuiu para a ampliação da produção sucroenergética.

Atualmente são sete usinas em funcionamento: a CRV Industrial (Carmo do Rio Verde), a Cooper Rubi (Rubiataba), a Vale Verde (Itapaci), a Vale Verde (Itapuranga) e as usinas Jalles Machado, Goianésia e Codora/Unidade Otávio Lage - UOL (localizadas em Goianésia). Essas usinas criaram uma dinâmica própria dentro da lógica sucroenergética, o que acaba por gerar demandas, fluxos, redes, fragilidades, conflitos e efeitos, que são verificados não só nos municípios que possuem usinas instaladas, mas em toda a região.

A principal atividade econômica hoje na microrregião Ceres é sem dúvida a canavieira. A região de Ceres configura-se como uma das principais regiões goianas em produção de cana-de-açúcar, e isso é verificado não somente nos municípios com usinas implantadas, mas também em vários outros municípios que participam da lógica canavieira, por meio da produção de cana para ser beneficiada nas usinas vizinhas. Destacam-se portanto, além dos municípios que possuem usinas, os municípios de Nova Glória, Santa Isabel e São Luiz do Norte, especialmente, que juntos ao município de Goianésia, são os maiores produtores de cana-de-açúcar da microrregião Ceres.

Um elemento muito importante para o desenvolvimento da lógica do agronegócio é a malha viária e a rede de transportes, que são fundamentais em várias fases da atividade canavieira, como a colheita e o transporte da cana-de-açúcar colhida nos canaviais, muitas vezes distantes cerca de $50 \mathrm{~km}$ da sede das usinas, bem como para a circulação e o escoamento dos produtos derivados do setor sucroenergético. No Brasil e, consequentemente, no estado de Goiás o principal modal utilizado pelo agronegócio é o rodoviário. Houve, principalmente, nos últimos anos, um pequeno desenvolvimento do modal ferroviário, mas as rodovias são a principal forma utilizada para a circulação da produção agronegocista no Brasil.

Para a microrregião Ceres, destaca-se a importância da rodovia BR 153, que passa ao centro dessa região, sendo a principal rodovia utilizada para o escoamento dos produtos: o etanol é comercializado nacionalmente, assim é levado das usinas para os centros de distribuição, localizados, sobretudo, em Goiânia e Brasília; o açúcar é em grande parte 
exportado, saindo das usinas para os principais portos do Brasil (Porto de Santos e Porto de Itaqui, por exemplo), via rodovias brasileiras, para então ser exportados.

Faz-se importante destacar a proporção que a cogeração de energia, por meio do bagaço da cana-de-açúcar, tomou nos últimos anos. Quando se adentra em todas as usinas é facilmente perceptível as verdadeiras "montanhas" de bagaço de cana, que serão utilizados para a produção de energia térmica e elétrica. Todas as usinas da microrregião Ceres produzem energia que são suficientes para o funcionamento da indústria, principalmente durante o período da safra.

Várias usinas no Brasil já comercializam o excedente de energia produzida com a central elétrica local, como é o caso da usina Jalles Machado, no município de Goianésia. Durante a realização dos trabalhos de campo nas usinas da região, alguns representantes dos empreendimentos, reforçaram a importância da reutilização do bagaço da cana, seja para produção energética ou para ração animal, tendo, em muitos casos, um mercado muito mais certo e rentável que o próprio etanol, por exemplo.

Com o desenvolver da pesquisa, pôde-se inferir que para a realização do agronegócio sucroenergético, além das usinas (lavouras e indústria) os empreendimentos acabam por demandar alguns setores nos municípios envolvidos, como: prestadoras de serviços, comércios, redes bancárias, transportes, entre outros. Contudo, na microrregião Ceres, percebeu-se uma fragilidade na prestação de serviços, sendo que as principais demandas das usinas são resolvidas em grandes centros, como São Paulo, Brasília ou Goiânia. Assim, há inegavelmente a construção de uma rede minimamente dinâmica para a realização da atividade sucroenergética, mas, na região estudada, ela se mostra muito pontual e focada em serviços mais básicos.

Verificou-se também que os municípios que possuem usinas em funcionamento apresentam PIB's maiores, contudo quando se verifica dados relacionados ao desenvolvimento humano, como o IDH, os municípios que têm economia baseada em serviços, apresentam melhores índices, como Ceres e Rialma, por exemplo. Desta forma, as agroindústrias contribuem para o crescimento econômico e arrecadação financeira nos municípios que têm usinas implantadas, mas verifica-se uma alta concentração dessa renda, o que gera pobreza, desigualdades sociais e uma falsa sensação de estar em uma cidade "rica" e progressista.

Os municípios que são grandes produtores de cana-de-açúcar, vizinhos aos municípios usineiros, apresentam problemas e efeitos socioeconômicos muito complexos. 
Durante os trabalhos de campo para os municípios de Santa Isabel, São Luiz do Norte e Nova Glória (grandes produtores de cana na região), verificou-se o quanto esses municípios estão reféns da lógica canavieira, sem simplesmente terem usinas implantadas. Esses municípios estão diretamente vinculados à lógica econômica estabelecida pelas usinas vizinhas, estas não pagam os tributos que deveriam, além de não manterem nenhuma parceria com o poder público local, no sentido de minimizar os efeitos ambientais e socioeconômicos fruto da dependência estabelecida.

Hoje, a usina Vale Verde do município de Itapaci, mantém um alojamento de trabalhadores rurais, migrantes, em uma fazenda do município de Nova Glória. Essa prática é comum na microrregião Ceres, em outros momentos alguns alojamentos eram mantidos pelas usinas em municípios vizinhos, o que acaba por transferir responsabilidades básicas para as cidades que recebem os trabalhadores, já que estes demandam por serviços de saúde, alimentação, infraestrutura, entre outros, do município em que está vivendo.

Atualmente, como muitos migrantes optaram por morar definitivamente nos municípios da microrregião Ceres, reduziu-se bastante a quantidade de alojamentos mantidos pelas usinas, pois os trabalhadores, muitas vezes, optam por trazerem suas famílias e a demandar por moradias fixas, que geralmente são por meio de casas e barracões alugados ou mesmo a construção da casa própria em áreas periféricas das cidades.

Outro elemento emblemático, que se verificou durante as entrevistas concedidas nas atividades de campo, foi que essa dependência estabelecida entre os municípios produtores de cana com as usinas vizinhas, dá-se devido aos usineiros serem os principais financiadores das campanhas políticas municipais. Assim, o poder público local acaba por aceitar a lógica determinada, bem como não questionar e não buscar os direitos relacionados ao pagamento de impostos ou devolutivas para essas cidades, pois acabam sendo parceiros políticos e criando uma co-dependência entre eles.

Diante do exposto, ressalta-se que as quatro hipóteses levantadas inicialmente na pesquisa foram confirmadas. É inegável que a dinâmica sucroenergética influencia diretamente os municípios da microrregião Ceres, tanto os municípios com usinas, quanto os municípios sem usinas, mas que servem à lógica canavieira. O importante nessa discussão é enfatizar a importância da abordagem regional nessa análise, pois avaliar somente os municípios com usinas implantadas empobreceria sobremaneira a análise, pois os efeitos, conflitos e contradições perpassam os municípios que sediam as usinas, vide os municípios de Santa Isabel, São Luiz do Norte e Nova Glória, já mencionados. 
A segunda hipótese confirmada está circunscrita à nova função na divisão territorial do trabalho na microrregião Ceres, após a implantação das agroindústrias canavieiras e a realização da lógica sucroenergética. Foi perceptível que novos elementos e novas formas foram incorporadas ao espaço urbano e rural da região estudada, frutos da atividade canavieira; e que "velhas" formas ainda são realizadas e, muitas vezes, reforçadas nas usinas, como o corte manual, as especializações do trabalho canavieiro, a queima da canade-açúcar, entre outros exemplos.

Para se compreender melhor os efeitos e os conflitos da dinâmica sucroenergética, partiu-se da importância da relação campo-cidade, a partir do entendimento de um continuum, pois o agronegócio canavieiro acaba por reconfigurar as formas, as paisagens e envolver os sujeitos, tanto do campo, quanto da cidade. Destaca-se que está cada dia mais difícil, diferenciar quais relações são puramente do campo e quais são puramente da cidade, ou seja, quando se adentra a uma região canavieira tem-se dificuldade em distinguir campo de cidade, mesmo porque os vários elementos associados à lógica sucroenergética estão intensamente presentes na paisagem regional como um todo.

Observaram-se também, durante os trabalhos de campo, as semelhanças e as especificidades de cada empreendimento sucroenergético da região. Destaca-se que a maioria do capital industrial é oriundo do nordeste do Brasil (as usinas de Carmo do Rio Verde, Rubiataba, Itapaci, Itapuranga e uma usina de Goianésia), e as outras duas usinas pertencem ao Grupo Otávio Lage, uma família política goiana de Goianésia (as usinas Jalles Machado e Codora/UOL).

Verificaram-se semelhanças, sobretudo, entre as usinas dos Grupos relacionados ao nordeste do Brasil e diferenças entre esses grupos e o grupo goiano. As usinas oriundas do Nordeste brasileiro apresentam um parque industrial mais envelhecido e práticas de trabalho e produção canavieira mais obsoletas se comparado às usinas oriundas do sudeste do Brasil (localizadas em outras regiões goianas), ou às usinas que possuem parcerias internacionais, como a Jalles Machado. Atribui-se isso também, ao fato da usina do Grupo goiano (Otávio Lage) ter uma estreita relação com o município que está localizado, pois além de serem um grupo familiar pertencente a esse município, são políticos e dependem diretamente da população para se elegerem. O atual prefeito de Goianésia (gestão 2012 - 2016) é um dos proprietários do Grupo Otávio Lage, donos das usinas Jalles Machado e Codora/UOL.

Pôde-se constatar também, que houve uma evolução na rede urbana da microrregião Ceres ao longo dos anos analisados, apesar de que para a realidade do estado 
de Goiás, os municípios da região estudada não são tão representativos, já que são municípios pequenos demograficamente e não apresentam grandes centralidades estaduais. Porém, deve-se ressaltar que para a dinâmica microrregional, o papel e a função de municípios como Ceres, Goianésia, Itapaci, Itapuranga e Rubiataba são fundamentais.

Por meio da análise aos três REGIC's (Região de Influência das Cidades - IBGE), verificou-se que os municípios com empreendimentos canavieiros passaram a ter certa centralidade na região e certa autonomia, já que precisam dialogar diretamente com a capital do estado de Goiás (Goiânia), sobretudo, por questões financeiras, de compras e acesso a serviços que não são disponibilizados na região.

A terceira hipótese confirmada está relacionada às deficiências socioeconômicas verificadas nos municípios canavieiros e na região. Há atração de alguns equipamentos urbanos e infraestruturas devido às demandas dos empreendimentos, contudo o aparato técnico, as prestadoras de serviços, o comércio especializado e, principalmente, a mão de obra qualificada vem de outras cidades e estados ou são realizados fora da região. E as consequências disso são verificadas por meio da paisagem regional, junto às formas, aos elementos fixos e fluxos e as relações, que de alguma forma são materializadas e visíveis na paisagem.

Faz-se importante reiterar algo bastante interessante verificado, especialmente, nos trabalhos de campo, que foram os efeitos negativos da atividade canavieira nos municípios que não possuem usinas. Municípios como Nova Glória, Santa Isabel e São Luiz do Norte, entre outros, produzem cana-de-açúcar em grandes quantidades na microrregião Ceres, para serem beneficiadas nas usinas dos municípios vizinhos. Além de todos os efeitos negativos observados nos municípios com usinas, esses municípios citados não recebem as devolutivas sociais e ambientais, tampouco os impostos que lhes são de direito. Verificou-se uma fortíssima co-dependência desses municípios com as usinas vizinhas, seja por empregos, diretos e indiretos e, sobretudo, uma dependência política, já que os usineiros são os principais financiadores das campanhas eleitorais, conforme já explicitado.

A paisagem tornou-se muito importante ao longo da pesquisa, especialmente com a realização dos trabalhos de campo, onde se percebia nitidamente as formas espaciais estabelecidas pela atividade sucroenergética na região, bem como os efeitos e as desigualdades materializadas. Acredita-se que para as pesquisas que utilizem essa abordagem, partir do conceito de paisagem regional, pode ser bastante enriquecedor, pois pode-se compreender o "conjunto visível de formas, elementos fixos, artificiais e relacionais 
(redes comerciais e relações de trabalho) materializados na paisagem de determinada região, fruto da atuação conjunta do capital privado e do Estado", conforme se explicitou no decorrer do capítulo 5.

A última hipótese vai ao encontro de uma realidade bastante evidenciada quando se estuda municípios ou regiões voltadas para a lógica da agricultura capitalista: o mito do progresso largamente difundido pelas empresas, corporações, agroindústrias e, na maioria das vezes, com o apoio do Estado. Este acaba por atrair e financiar os empreendimentos sucroenergéticos, assegurados pelo discurso de progresso e de desenvolvimento econômico que essas empresas trazem, além do discurso de geração de empregos, diretos e indiretos, que são os que geralmente mais chamam à atenção da população, que também acaba por reproduzir o discurso do progresso e, em alguns casos, até defender esses empreendimentos.

É comum observar a falta de senso crítico do poder público local dos municípios que servem ao agronegócio sucroenergético, bem como a ausência de conhecimento aos direitos, à legislação cabível e mesmo uma fácil aceitação dos efeitos negativos fruto da atividade canavieira, em prol de uma ideia de progresso.

Percebeu-se uma forte dependência econômica, social e, atreve-se aqui a dizer, muitas vezes, "cultural” em relação a atividade canavieira nesses municípios. Como essa atividade já está na região desde a década de 1970, e como não há outra atividade econômica forte na maioria dos municípios, percebe-se que muitos ficam reféns desses empreendimentos, e os agentes sociais como o Estado acabam por reforçar essa lógica, não apresentando alternativas de inclusão de outros setores econômicos.

Verificou-se também na microrregião Ceres, municípios que apresentam altos PIB's, mas são bastante empobrecidos, o que é facilmente perceptível pela paisagem regional. Pode inferir que os altos PIB's estão diretamente relacionados aos municípios com empreendimentos sucroenergéticos implantados e que essa alta arrecadação fica concentrada nesse setor e não é distribuída para a população, tampouco revertida em projetos e programas sociais como deveria.

Municípios como Carmo do Rio Verde, Itapaci, Rubiataba, Itapuranga (para citar alguns municípios com usinas) e Santa Isabel, São Luiz do Norte e Nova Glória (que não têm usinas) demonstram em suas paisagens elementos que revelam a concentração da renda, as desigualdades sociais e a dependência em relação às vagas de empregos nas usinas, principalmente porque a microrregião Ceres está voltada para o segmento canavieiro, não apresentando outras atividades econômicas alternativas ao agronegócio sucroenergético. 
Nessa região, um município que destoa um pouco dessa realidade é Goianésia, no sentido de que se apresenta com uma dinâmica maior em relação aos outros municípios da microrregião Ceres, pois não está focado somente no segmento canavieiro, apesar de conter três usinas em funcionamento, sendo que uma delas, a Jalles Machado, é uma das mais importantes do estado de Goiás.

Outra especificidade em relação à Goianésia é que duas usinas desse município são propriedades do atual prefeito da cidade (e sua família), conforme mencionado, o que revela uma estreita relação com o poder público local (destaca-se que outros membros dessa família também já ocuparam cargos públicos em Goianésia e no estado de Goiás). O Grupo Otávio Lage, composto por essa família de políticos goianos, acaba por monopolizar a cidade de Goianésia, pois além de duas usinas canavieiras, são proprietários de todas as principais empresas do município (produção de seringueiras, confinamento de gado, construtoras, etc.).

Para além das hipóteses, verificou-se que pouco ficou dos objetivos do projeto das Colônias Agrícolas Nacionais da década de 1940, a não ser uma quantidade relevante de pequenos produtores que precisam de terra para produzir, mas que estão sendo, atualmente, "afogados" pelo "mar" de cana presente na região. Hoje, existem algumas políticas e programas que buscam fortalecer o pequeno produtor e a agricultura familiar, mas ainda são bastante incipientes, e os recursos aplicados vão na contramão dos vultosos investimentos do agronegócio.

Ressalta-se que a paisagem regional da microrregião Ceres alterou-se muito rapidamente ao longo de quase 80 anos. Na paisagem regional, veem-se as formas espaciais e as consequências do agronegócio sucroenergético, principalmente pela região não apresentar uma diversificação econômica, para além da cana-de-açúcar. A microrregião Ceres se apresenta altamente concentrada e dependente das usinas implantadas, socioeconomicamente. Essa característica é extremamente prejudicial, pois acaba por não criar redes autônomas ao segmento canavieiro e, somado ao apoio político das usinas no financiamento de campanhas eleitorais, deixa a região refém (também) ideologicamente dos empreendimentos em funcionamento.

Diante disso, mesmo com a população insatisfeita com os efeitos do setor canavieiro, o poder público local acaba não apoiando alternativas ao agronegócio implantado e, quando ocorrem, passam por muitos problemas e dificuldades, como 
verificado na Cooperativa de Agricultores Familiares de Itapuranga - Cooperafi, durante visita ao município de Itapuranga.

Acredita-se que por ser uma região com pequenos proprietários rurais, que estão perdendo suas terras para o arrendamento das usinas, o ideal seria buscar o incentivo ao acesso à terra e a permanência dos pequenos nela. Não se pode esquecer que a produção de alimentos no Brasil necessita dos pequenos produtores, já que o agronegócio não está pautado na produção de alimentos, mas, sobretudo, em produção de energia e ração animal ou outros produtos voltados para a exportação. Quem alimenta os brasileiros são os agricultores familiares, e isso é um detalhe muito importante que não pode ser desconsiderado e desvalorizado no Brasil.

Para além dos resultados e das discussões aqui apresentadas referentes à presente tese, destaca-se que, para a microrregião Ceres, ainda se faz necessário pensar e verticalizar em próximas pesquisas:

1) Nos efeitos negativos aos pequenos produtores e os conflitos travados entre eles e o agronegócio canavieiro;

2) Os reais efeitos na saúde da população frente à pulverização de agrotóxico nas lavouras de cana-de-açúcar, muito próximas ao perímetro urbano e aos recursos hídricos (como relatado na atividade de campo no município de Nova Glória);

3) Os impactos do agrohidronegócio na região, principalmente porque em períodos de seca a população chega a ficar sem água em suas casas, mas as usinas não (viu-se relatos e denúncias em jornais da região sobre a usina bombear água diretamente dos rios);

4) Verificar se há algum tipo de oposição na implantação de assentamentos rurais de reforma agrária nessa região, devido à força econômica e política do agronegócio canavieiro;

5) E por fim, para além da microrregião Ceres, verificar se há distinção entre o agronegócio canavieiro e o agronegócio grãos-carnes para o processo de desenvolvimento regional incompleto.

Essas e outras questões são importantes para se compreender de forma mais abrangente a microrregião Ceres (ou outras regiões voltadas para a atividade sucroenergética em Goiás e no Brasil como um todo). Essas perguntas não se configuravam inicialmente questões de pesquisa da presente tese, mas podem subsidiar e auxiliar a pensar, futuras pesquisas dentro dessa temática. 
Ressalta-se que os objetivos propostos, as hipóteses delineadas e a execução das etapas metodológicas foram fundamentais para entender a tese da pesquisa. $\mathrm{O}$ agronegócio sucroenergético, na microrregião Ceres, trouxe uma dinamização regional concentrada e gerou uma co-dependência da população e do poder público local em relação aos empreendimentos canavieiros.

Essa relação trouxe claramente um desenvolvimento econômico incompleto, que é legitimado pelo mito do progresso, vinculado ao discurso do agronegócio no Brasil, o que acaba por justificar várias ações perversas desse setor na região, como os efeitos sociais e ambientais negativos, além das contradições e desigualdades que são próprias da agricultura capitalista no Brasil e que foram fácil e perfeitamente verificadas na paisagem regional da microrregião Ceres. 


\section{REFERÊNCIAS}

ABRAMOVAY, R. Agricultura familiar e desenvolvimento territorial. In: Revista da Associação Brasileira de Reforma Agrária. v. 28 ns 1, 2, 3 e 29, nº1, Jan/dez 1998 e jan/ago, 1999.

ALENTEJANO, P. R. R. O que há de novo no rural brasileiro? In: Terra Livre. São Paulo, n. $15,2000$.

ALHO, C. J. R.; MARTINS, E. de S. De Grão em Grão o Cerrado perde Espaço. Cerrado: impactos do processo de ocupação. WWF, 1995.

ANDRADE, Manuel Correia de. A terra e o homem no Nordeste: contribuição ao estudo da questão agrária no Nordeste. 5. ed. São Paulo: Atlas, 1986.

ANDRADE, N. L. História e Histórias da CANG: Meu Rincão por Adoção. Goiânia: Kelps, 1990.

Kelps, 2006.

Reforma Agrária: Colônia Agrícola Nacional de Goiás. 2. Ed. Goiânia:

ARANHA, B. da S. Eu vi Ceres nascer: A saga do bandeirante Bernardo Sayão. Goiânia: Grafia O Popular, 2001.

ARAÚJO, T. B. de. Por uma Política Nacional de Desenvolvimento Regional. In: Revista Econômica do Nordeste. Fortaleza, v. 30, n. 2, 1999.

ARAÚJO SOBRINHO, F. L. Turismo e Dinâmica Territorial no Eixo Brasília - Goiânia. Tese (Doutorado em Geografia). Universidade Federal de Uberlândia - UFU, 2008.

ARRAIS, T.P.A. Goiás: novas regiões, ou novas formas de olhar velhas regiões. In: ALMEIDA, M. G. de (Org.). Abordagens Geográficas de Goiás: o natural e o social na contemporaneidade. Goiânia: IESA, 2002.

Geografia Contemporânea de Goiás. Goiânia: Vieira, 2004.

O Território Goiano: uma abordagem quase contemporânea do desenvolvimento regional. In: XII Encontro da Associação Nacional de Pós-Graduação e Pesquisa em Planejamento Urbano e Regional. Belém (PA), 2007.

As Políticas Governamentais e Transferências Federais de Recursos Financeiros no Território Goiano. In: Revista da ANPEGE, v. 7, n. 1, 2011.

A Produção do Território Goiano: economia, urbanização, metropolização. Goiânia: Editora UFG, 2013.

BARRETO, M. J.; THOMAZ JÚNIOR, A. O Trabalho nos Canaviais Paulistas no Contexto da Reestruturação Produtiva. In: Anais do X Seminário do Trabalho: trabalho, crise e políticas sociais na América Latina. Marília: Unesp, 2016. 
BARZUN, J. Da Alvorada à Decadência: A História da Cultura Ocidental de 1500 aos Nossos Dias. Rio de Janeiro: Campus, 2002.

BENAKOUCHE, T. Tecnologia é sociedade: contra a noção de impacto tecnológico. In: DIAS, L.C.;SILVEIRA, R. L. L. (Orgs.). Redes Sociedades e Território. Santa Cruz do Sul: EdUnisc, 2005.

BENETTI, M. D. A internacionalização recente da indústria de etanol brasileira. In: Revista Fundação de Economia e Estatística (FEE), Rio Grande do Sul, v. 36, n. 4, 2009.

BRASIL. Plano Nacional de Agroenergia 2006-2011. Ministério da Agricultura, Pecuária e Abastecimento, Secretaria de Produção e Agroenergia. 2. ed. rev. - Brasília, DF : Embrapa Informação Tecnológica, 2006.

BRASIL. Ministério da Agricultura, Pecuária e Abastecimento. Anuário estatístico de agroenergia 2012: statistical yearbook of agrienergy / Ministério da Agricultura, Pecuária e Abastecimento. Secretaria de Produção e Agroenergia. Bilíngüe. - Brasília : MAPA/ACS, 2013.

CANASAT/INPE. Monitoramento da cana-de-açúcar via satélite. Disponível em http://www.dsr.inpe.br/laf/canasat. Acesso em setembro de 2014.

CASTILHO, D. A Colônia Agrícola Nacional de Goiás (CANG) e a Formação de CeresGO. In: Revista Élisée - UEG: Goiânia, v.1, n.1, p.117-139, 2012.

As redes de energia elétrica em Goiás e os padrões espaciais de produção, transmissão e distribuição. In: II Simpósio Internacional Eletrificação e Modernização Social. Universidade de São Paulo - USP, 2013.

CASTRO, E. Dinâmica Socioeconômica e Desmatamento na Amazônia. In: Novos Cadernos - NAEA. UFPA, v. 8, n. 2, 2005.

CHESP. Companhia Hidrelétrica de São Patrício. Disponível em http://www.chesp.com.br. Acesso em junho de 2014.

CLEPS JÚNIOR, J. Questão Agrária, Estado e Território em Disputa: os enforques sobre agronegócio e a natureza dos conflitos no campo brasileiro. In: SAQUET, A.; SANTOS, R. A. (Orgs.). Geografia Agrária, Território e Desenvolvimento. São Paulo: Expressão Popular, 2010.

COMISSÃO EUROPEIA. (2010). Europa 2020: Estratégia para um crescimento inteligente, sustentável e inclusivo. Bruxelas: União Europeia.

CONSEJO DE EUROPA. Carta Europea de Ordenación del Territorio. Torremolinos, Espanha, 1983.

COPERSUCAR. Disponível em: http://www.copersucar.com.br/historico.html. Acesso em dezembro de 2013. 
CORRÊA, R. L. A Rede Urbana. São Paulo: Ática, 1994.

Corporação e Espaço: uma nota. In: Trajetórias Geográficas. Rio de Janeiro: Bertrand Brasil, 1997.

. Região e Organização Espacial. 7 Ed. São Paulo: Editora Ática, 2000.

.Estudos sobre a Rede Urbana. Rio de Janeiro: Bertrand Brasil, 2005.

Paisagem: Algumas reflexões sobre sua natureza e conexões. In: ALVES, I.; LEMOS, M.; NEGREIROS, C. (Orgs.). Estudos de Paisagem: Literatura, viagens e turismo cultural - BR, FR, PT. Ed. Rio de Janeiro: Oficina Raquel, 2014.

COSTA. W. M. da. O Estado e as Políticas Territoriais no Brasil. São Paulo: Contexto, 2000 .

COSTA, E. B.; STEIKE, V. A. Cidades históricas do estado de Goiás, Brasil: uma agenda de pesquisa. In: Ateliê Geográfico. Goiânia-GO, v. 7, n. 2, p.164-195, ago/2013.

DATALUTA. Banco de Dados da Luta pela Terra: Relatório Brasil. NERA - Núcleo de Estudos, Pesquisas e Projetos de Reforma Agrária - FCT/ UNESP: Presidente Prudente, São Paulo, 2015.

DEUS, J. B. de. O Sudeste Goiano e a Desconcentração Industrial. Brasília: Ministério da Integração Nacional. Universidade Federal de Goiás, 2004.

DIAS, L. C. Redes de Informação, grandes organizações e ritmos de modernização. In: Revista etc Espaço, Tempo e Crítica. n 2 (1), v. 1, jun. 2007.

DUARTE, A.C. Regionalização: Considerações Metodológicas. Boletim de Geografia Teorética. Rio Claro, v. 10, n 20, 1980.

DUPAS, G. O Mito do Progresso: Ou Progresso como Ideologia. São Paulo, UNESP, 2006.

EGLER, C. A. G. A Formação da Rede de Cidades na América do Sul. In: IX Encontro Nacional da Associação Nacional de Pós-Graduação e Pesquisa em Geografia (Enanpege). Anais. Goiânia, 2011.

EGLER, C. A. G.; MENDES, C. C.; FURTADO, B. A.; PEREIRA, R. H. M. Bases Conceituais da Rede Urbana Brasileira: análise dos estudos de referência. In: Pereira, R. H. M.; Furtado, B. A. (Orgs). Dinâmica Urbano-Regional: rede urbana e suas interfaces. Brasília: IPEA, 2011.

ELIAS, D. Globalização e Agricultura: A Região de Ribeirão Preto-SP. São Paulo: EDUSP, 2003. 
. Ensaios Sobre os Espaços Agrícolas de Exclusão. Revista NERA. Unesp/Presidente Prudente, v. 1, n. 8, 2006.

Agronegócio e Novas Regionalizações no Brasil. In: Revista Brasileira de Estudos Urbanos e Regionais. V. 13, N 2, Novembro de 2011.

. Relações Campo-Cidade, Reestruturação Urbana e Regional no Brasil. In: XII Colóquio Internacional de Geocrítica. Bogotá - Colômbia, 2012.

- Globalização, Agricultura e Urbanização no Brasil. In: Revista ACTA Geográfica. Boa Vista: Ed. Esp. Geografia Agrária, 2013.

ELIAS, D; PEQUENO, R.. Desigualdades Socioespaciais nas Cidades do Agronegócio. Revista Brasileira de Estudos Urbanos e Regionais. ANPUR, v. 9, 2007.

EMBRAPA. Zoneamento Agroecológico da Cana-de-açúcar (2009). Disponível em www.embrapa.br/zoneamento_cana_de_açúcar. Acesso em maio de 2014.

ESTEVAM, L. A. O Tempo da Transformação: Estrutura e Dinâmica da Formação Econômica de Goiás. Tese em Economia, Universidade Estadual de Campinas: Campinas, 1997.

Tempo da transformação: estrutura e dinâmica econômica de Goiás. Goiânia: Ed. da UCG, 2004.

FAISSOL. E. O Mato Grosso de Goiás. Rio de Janeiro: Biblioteca Geográfica Brasileira IBGE, 1952.

FARIA, K. M. S. de. Caracterização dos remanescentes de cerrado e suas relações como ouso e ocupação das terras da Alta bacia do rio Araguaia. Dissertação em Geografia, Universidade Federal de Goiás: Goiânia, 2006.

FAVARETO, A. As políticas de desenvolvimento territorial rural no Brasil em perspectiva: uma década de experimentações. In: Revista Desenvolvimento em Debate. Rio de Janeiro, v.1, n.2, 2010.

FERLINI, Vera Lúcia Amaral. A civilização do açúcar. 11 ed. 1 reimp. São Paulo: Ed. Brasiliense, 1998.

FERNANDES, B. M. Reforma Agrária no Brasil, para além de um projeto: uma luta permanente. In: MITIDIERO, JUNIOR, M. A.; GARCIA, M. F.; VIANA, P. C. G. (Orgs.). A Questão Agrária no Século XXI: escalas, dinâmicas e conflitos territoriais. São Paulo: Outras expressões, 2015.

FERNANDES, B. M.; WELCH, C.A. Campesinato e Agronegócio da Laranja nos EUA e Brasil. In: FERNANDES, B. M (Org.). Campesinato e agronegócio na América Latina: A questão Atual. São Paulo: Expressão Popular, 2008. 
FERREIRA, L. C. G. A Evolução do Setor Sucroalcooleiro na Microrregião Ceres (GO): Dinâmica Espacial e Impactos Socioeconômicos. Dissertação (mestrado em Geografia). Universidade Federal de Goiás: Goiânia, 2010.

FERREIRA, I. M.; MENDES, E. P. P. In: XIX Encontro Nacional de Geografia Agrária (Anais), São Paulo, 2009.

FISCHER, A. (1978). Indústria, Ordenamento do Território e Transportes: a contribuição de André Fischer. FIRKOWSKI, O.L.C.F; SPOSITO, E.S. (Org.). São Paulo: Expressão Popular, 2008.

FRAGA, N. C. Território, Região, Poder e Rede: Olhares e Possibilidades Conceituais de Aproximação. In: Relações Internacionais no Mundo Atual. Curitiba, n. 7, p. 9-31, 2007.

FREDERICO, S. As Cidades do Agronegócio na Fronteira Agrícola Moderna Brasileira. In: Caderno Prudentino de Geografia. Presidente Prudente, n.33, v.1, p.5-23, jan./jul.2011.

FREITAS, R.L.; CLEPS JÚNIOR, J. A Territorialização do Setor Sucroenergético e o Agrohidronegócio no Triângulo Mineiro/Alto Paranaíba. In: Revista Pegada. Presidente Prudente, SP, v. 13, n.1, 2012.

FREITAS, E. P.; ROSSINI, R. E.; QUEIRÓS, M. O Poder das Empresas Transnacionais sobre o Território Brasileiro. Reflexões a Partir do Sector Sucroenergético. In: XIII Colóquio Internacional de Geocrítica: El control del espacio y los espacios de control Barcelona, 2014.

FRESCA, T. M. Rede Urbana e Divisão Territorial do Trabalho. In: Revista Geografia (Londrina) v. 19 n. 2, 2010.

FURTADO, C. O Mito de Desenvolvimento Econômico. 6. Ed. Rio de Janeiro: Paz e Terra, 1983.

GASQUES, J. G. et al. Desempenho e crescimento do agronegócio no Brasil. Brasília: IPEA/DISET/Diretoria de Políticas e Estudos Setoriais, 2004. Disponível em: http://www.ipea.gov.br/TemasEspeciais/agronegocio. Acesso em: março de 2014.

GIRARDI, E. P.; FERNANDES, B. M. Territorialização da produção de soja no Brasil: 1990-2002. In: Anais $1^{\circ}$ Encontro Nacional de Geografia Agrária, Gramado. XVII ENGA tradição $X$ tecnologia: as novas territorialidades do espaço agrário brasileiro. Gramado-RS: UFRGS, 2004.

GONÇALVES, C. W. P. A Luta pela Apropriação e Reapropriação Social da Água na América Latina. In: FERNANDES, B. M (Org.). Campesinato e agronegócio na América Latina: A questão Atual. São Paulo: Expressão Popular, 2008.

GOHN, M. da G. O futuro das cidades. Disponível em www.lite.fae.unicamp.br/revista/gohn.html. Acesso em junho de 2007. 
GRAZIANO DA SILVA, J. A Nova Dinâmica da Agricultura Brasileira. 2. ed. Campinas, São Paulo: UNICAMP, 1996.

GRISA, C.; SCHNEIDER, S. Três gerações de políticas públicas para a agricultura familiar e formas de interação entre sociedade e Estado no Brasil. In: Políticas públicas de desenvolvimento rural no Brasil. GRISA, C.; SCHNEIDER, S (Orgs.). Porto Alegre: UFRGS, 2015.

HAESBAERT, R.; LIMONAD, E. O Território em Tempos de Globalização. In: Revista etc Espaço, Tempo e Crítica. No 2(4), v. 1, 2007.

HARVEY. David. A Produção Capitalista do Espaço. São Paulo: Annablume, 2005.

Boitempo, 2011.

O enigma do capital: e as crises do capitalismo. São Paulo, SP:

HESPANHOL, A. N. Modernização da Agricultura e Desenvolvimento Territorial. In: $\mathbf{4}^{\mathbf{0}}$ Encontro Nacional de Grupos de Pesquisa. ENGRUP: São Paulo, 2008.

HIRSCH. J. ¿Qué Significa Estado? Reflexiones Acerca de la Teoría del Estado Capitalista. In: Revista de Sociologia Política. Curitiba, 2005.

IBGE. Instituto Brasileiro de Geografia e Estatística. Censo Demográfico 2000. Disponível em www.ibge.com.br, acesso em julho de 2013.

Instituto Brasileiro de Geografia e Estatística. Censo Demográfico 2010. Disponível em www.ibge.com.br, acesso em julho de 2013.

Produção Agrícola Municipal: Culturas Temporárias e Permanentes / IBGE. Rio de Janeiro, v. 41, p.1-100, 2014.

IMB / SEGPLAN. Instituto Mauro Borges. Programa Fomentar/Produzir Informações e Análises para o Estado e Microrregiões de Goiás. SEGPLAN, 2012.

Instituto Mauro Borges / Secretaria de Estado de Gestão de Planejamento de Goiás. Goiás em Dados - 2012. Goiânia: SEGPLAN, 2013.

Instituto Mauro Borges / Secretaria de Estado de Gestão de Planejamento de Goiás. Goiás em Dados - 2013. Goiânia: SEGPLAN, 2014.

Instituto Mauro Borges / Secretaria de Estado de Gestão de Planejamento de Goiás. Goiás em Dados - 2014. Goiânia: SEGPLAN, 2015.

Instituto Mauro Borges / Secretaria de Estado de Gestão de Planejamento de Goiás. Perfil dos municípios goianos. Disponível em http://www.imb.go.gov.br/. Acesso em julho de 2014.

INCRA. Instituto Nacional de Colonização e Reforma Agrária. Sipra Web. Disponível em www.incra.gov.br. Acesso em dezembro de 2014. 
INOCÊNCIO. M. E. As Tramas do Poder na Territorialização do Capital no Cerrado: O Prodecer. Tese (Doutorado em Geografia). Universidade Federal de Goiás: Goiânia, 2010.

JALLES MACHADO. Disponível em www.jallesmachado.com.br/creditos_carbono. Acesso em junho de 2014.

KAGEYAMA, A; BUAINAIN, A.M; REYDON, B.P; GRAZIANO DA SILVA, J; SILVEIR, J.M.J; FONSECA, M da G.D; RAMOS, R; FONSECA, R.B; BELIK, W. O Novo Padrão Agrícola Brasileiro: Do Complexo Rural aos Complexos Agroindustriais. DELGADO, G.C; GASQUES, J.G; VILLA VERDE, C.M (Org.). Agricultura e Políticas Públicas. 2.ed. Brasília: IPEA, 1996.

LIMA, A. A. de. A Agroindústria Canavieira Alagoana: da criação do IAA à desregulamentação na década de 1990. Dissertação em Economia, Universidade Estadual de Campinas: Campinas, 2001.

LIPIETZ, A. O Capital e seu espaço. Tradução: Manuel Fernando Gonçalves Seabra. São Paulo: Nobel, 1988.

LOCATEL, C. Tecnificação dos territórios rurais no Brasil: políticas públicas e pobreza. In: Scripta Nova. Revista Electrónica de Geografía y Ciencias Sociales. [En línea]. Barcelona: Universidad de Barcelona, vol. XVI, nº 418 (66), 2012.

MAGAlHÃES, J. C. Emancipação Político-Administrativa de Municípios no Brasil. In: CARVAlHO, A. X. Y. et al. (Org.). Dinâmica dos Municípios. Instituto de Pesquisas Econômicas Aplicadas - IPEA: Brasília, 2007.

MAGDOFF, H. Imperialism: From the Colonial age to the Present. London: Monthly Review Press, 1978.

MARAFON, G. J. Territorialidades, Ruralidades e as Relações Campo-Cidade. In: CampoTerritório. Edição especial do XXI ENGA-2012, p. 1-13, jun., 2014.

MARQUES, M. I. M. O Conceito de Espaço Rural em Questão. In: Revista Terra Livre (São Paulo) Ano 18, n. 19, 2002.

MARTINELLI, L. A.; FILOSO, S. Expansion of Sugarcane Ethanol Production In Brazil: Environmental and Social Challenges. In: Ecological Applications. Washington, EUA, v. 18, Issue 4, 2008.

MARTINS, J. de. S. Fronteira: A degradação do outro nos confins do humano. São Paulo: Hucitec, 1997.

MATIAS, V. R. S.; CARMO, A. M. R. Dinâmica Territorial da Rede de Agências Bancárias da Região Metropolitana de Belo Horizonte. In: Revista Caminhos de Geografia. Uberlândia (MG), v. 13, n. 42, 2012. 
MDA. Ministério do Desenvolvimento Agrário. Bacen/Derop/Sicor. Disponível em www.mda.gov.br. Acesso em fevereiro de 2015.

MENDONÇA, M. L. O Papel da Agricultura nas Relações Internacionais e a Construção do Conceito de Agronegócio. In: Revista Contexto Internacional. Rio de Janeiro, v. 37, n. 2, maio/agosto, 2015.

MENDONÇA, M. R. As Transformações Espaciais no Campo e os Conflitos pelo Acesso a Terra e a Água: As Novas Territorialidades do Agrohidronegócio em Goiás. In: Revista Pegada. vol. 16, n. Especial, 2015.

MENDONÇA, M. R.; MESQUITA, H. A. O Agro-hidro-negócios no Cerrado Goiano: A Construção das (re)sistências. Anais (...) II Encontro Brasileiro de Ciências Sociais e de Barragens. Salvador, Bahia, 2007.

MÉSZÁROS, I. Para Além do Capital: Rumo a Uma Teoria da Transição. Tradução Paulo Cezar Castanheira, Sérgio Lessa. 1.ed. revista. São Paulo: Boitempo, 2011.

MINISTÉRIO DOS TRANSPORTES. Disponível em http://www.transportes.gov.br/. Acesso em abril de 2014.

MOYSÉS, A.; SILVA, E.R. Ocupação e Urbanização dos Cerrados do Centro-Oeste e a Formação de uma Rede Urbana Concentrada e Desigual. In: XII Encontro da Associação Nacional de Pós-Graduação e Pesquisa em Planejamento Urbano e Regional. Belém, PA, 2007.

NARANJO, F. Z. Aspectos Conceptuales, de Conocimiento Y Fundamentos Legales. In: NARANJO, F. Z.; MORENO, C. V. (Orgs.). Paisaje y Ordenación del Territorio. Junta de Andalucía, España, Consejería de Obras Públicas y Transportes, 2002.

NOVA CANA. Disponível em http://www.novacana.com. Acesso em abril de 2014.

OLIVEIRA, A. R. de. O associativismo na região do Pontal do Paranapanema-SP: limites e possibilidades para o desenvolvimento rural. Tese (Doutorado em Geografia) Faculdade de Ciências e Tecnologia, Unesp / Presidente Prudente, 2010.

OLIVEIRA, A. U. de. A geografia agrária e as transformações territoriais recentes no campo brasileiro. In. CARLOS, A. F. A. (Org). Novos Caminhos da Geografia. São Paulo: Contexto, 1999.

A longa marcha do campesinato brasileiro: movimentos sociais, conflitos e Reforma Agrária. In: Revista Estudos Avançados. São Paulo, v. 15, n. 43, 2001.

OLIVEIRA, F. de. Elegia para uma re(li)gião: Sudene, Nordeste, Planejamento e Conflitos de Classe. 4. Ed. Rio de Janeiro: Paz e Terra, 1981.

PINHEL JUNIOR, D. Apontamentos sobre a expansão do setor sucroalcooleiro. In: Núcleo de Apoio Técnico do Setor Sucroalcooleiro (CD-ROM): Ministério Público, 2007. 
PIRES, W. R. O (uso do) Discurso Ambiental como Elemento para a Consolidação do Setor Agroenergético no Sudoeste de Goiás. Dissertação (Mestrado em Geografia). Universidade Federal de Goiás: Jataí, Goiás, 2014.

PITTA, F. T.; XAVIER, C.V.; NAVARRO, C.; MENDONÇA, M.L. Empresas Transnacionais e Produção de Agrocombustíveis no Brasil. São Paulo: Editora Outras Expressões, 2014.

PNUD. Programa das Nações Unidas para o Desenvolvimento. Atlas do Desenvolvimento Humano no Brasil. Disponível em http://www.pnud.org.br/. Acesso em maio de 2014.

. Atlas do Desenvolvimento Humano. Disponível em www.pnud.org.br/atlas. Acesso em janeiro de 2016.

PONTES, B. M. S. Região e regionalização no contexto da globalização: a região sob diferentes óticas, no contexto do método dialético. In: Cronos. Natal-RN, v. 8, n. 2, p. 489499, jul./dez. 2007.

QUEIROZ, G. M. de O. R.; PASCHOARELI JR, D.; FARIA JR, M, J, de A. Geração e Exportação de Energia Elétrica por Usinas Sucroalcooleiras. Disponível em http://www.nipeunicamp.org.br/agrener/anais/2008/Artigos/82.pdf Acesso em junho de 2014.

RAFFESTIN, C. Por uma Geografia do Poder. São Paulo: Ática, 1993.

REGIC. Região de Influência das Cidades (1978). Instituto Brasileiro de Geografia e Estatística - IBGE, 1987.

Região de Influência das Cidades (1993). Instituto Brasileiro de Geografia e Estatística - IBGE, 2000.

Região de Influência das Cidades (2007). Instituto Brasileiro de Geografia e Estatística - IBGE, 2008.

RODRIGUEZ, J. M. M. La Concepción sobre los paisajes vista desde la geografia. In: Boletim de Geografia. Maringá, v. 24, n. 1, 2006.

ROLIM, C. F. C. Política Regional na União Europeia e na América Latina. In: Relatório de Pesquisa. Brasília: Instituto de Pesquisa Econômica Aplicada - ipea, 2015.

ROMANATTO, E.; ARRIEL, M. F., LIMA, W. M. O Programa FOMENTAR/PRODUZIR - Informações e Análises para o Estado de Goiás e suas Microrregiões. In: Conjuntura Econômica Goiana, Goiânia, n. 22. Segplan-GO, set. 2012. Disponível em: www.segplan.go.gov.br. Acesso em fev. de 2014.

ROSA, L. S.; FERREIRA, D. A. O. As categorias rural, urbano, campo e cidade: a perspectiva de um continnum. In: SPOSITO, M. E. B e WHITACKER, A. M. (Orgs.). Cidade e Campo: Relações e Contradições entre o Rural e o Urbano. 2. Ed. São Paulo: Expressão Popular, 2010. 
SACAROSE ON LINE. Resíduos da cana-de-açúcar: Torta de filtro. Disponível em www.sacaroseonline.com.br. Acesso em novembro de 2009.

SANTOS, B. de. S. Estado, Direito e a Questão Urbana. In: Revista Crítica de Ciências Sociais. Coimbra/Portugal, $\mathrm{n}^{\circ}$ 09, 1982.

SANTOS, M. Por uma Geografia Nova. Hucitec-Edusp, São Paulo, 1978.

Espaço e método. São Paulo: Nobel, 1985.

. Metamorfoses do Espaço Habitado: fundamentos Teórico e metodológico da Geografia. Hucitec. São Paulo 1988.

Hucitec, 2002.

A Natureza do Espaço: técnica e tempo, razão e emoção. São Paulo:

SANTOS, M.; SILVEIRA, M. L. O Brasil: Território e Sociedade no Início do Século XXI. Rio de Janeiro: Record, 2001.

SIC. Secretaria de Indústria e Comércio de Goiás. Disponível em http://www.sic.goias.gov.br/. Acesso em abril de 2014.

SILVA, C. A. F. da. Grupo André Maggi: Corporação e Rede em Áreas de fronteira. Cuiabá: Entrelinhas, 2003.

Fronteira agrícola capitalista e ordenamento territorial. In: SANTOS, Milton. et al. (Org.) Território, territórios: ensaios sobre ordenamento territorial. 3. ed. Rio de Janeiro: Lamparina. 2007.

SILVA, E. R. da. A Economia Goiana no Contexto Nacional: 1970-2000. Dissertação em Economia, Universidade Estadual de Campinas: Campinas/São Paulo, 2002.

SILVA, W. F. da. Da Agroindústria Canavieira ao Setor Sucroenergético em Goiás: a questão técnico-gerencial e as estratégias de controle fundiário. Tese (Doutorado em Geografia). Universidade Federal de Goiás: Goiânia, Goiás, 2016.

SIQUEIRA, T.; DINIZ, F. A Política de Desenvolvimento Regional Europeia: Um Caminho para a Coesão Econômica e Social? In: Revista Nexus Econômicos. UFBA, v. Iv, n. 6, 2010 .

SMITH, N. Desenvolvimento Desigual: natureza, capital e a produção do espaço. Rio de Janeiro: Bertrand Brasil, 1988.

SOJA, E. W. Geografias Pós-Modernas: A Reafirmação do Espaço na Teoria Social Crítica. Rio de Janeiro: Jorge Zahar, 1993.

SOUZA, S. A. V. Vinhaça o avanço das tecnologias de uso. In: A energia da cana-deaçúcar: doze estudos sobre a agroindústria da cana-de-açúcar no Brasil e sua 
sustentabilidade. São Paulo: Berlendis \& Vertecchia: UNICA - União da Agroindústria Canavieira do Estado de São Paulo, 2005.

SPOSITO, M. E. B. A questão cidade-campo: perspectivas a partir da cidade. In: SPOSITO, M. E. B e WHITACKER, A. M. (Orgs.). Cidade e Campo: Relações e Contradições entre o Rural e o Urbano. 2. Ed. São Paulo: Expressão Popular, 2010.

SUZUKI, J. C. Modernização, território e relação campo-cidade: uma outra leitura da modernização da agricultura. In: Revista Agrária. São Paulo, n. 6, pp. 83 - 95, 2007.

TEIXEIRA, R. A. No Descompasso da Metrópole: um estudo sobre a dinâmica espacial da Região Metropolitana de Goiânia a partir do município de Inhumas. IFG, 2013.

TEIXEIRA, L. B.; CAMPOS, L. R. Ceres: Olhares sobre sua Trajetória. Goiânia: Kelps, 2011.

TEIXEIRA NETO. Formação territorial: considerações sobre alguns aspectos geográficos, históricos e políticos. In: Boletim Goiano de Geografia. V. 2 (2):137-163. Julh./ dez. 1982.

THOMAZ JÚNIOR, A. A classe trabalhadora no Brasil e os limites da teoria - qual o lugar do campesinato e do proletariado? In: Campesinato e agronegócio na America Latina: a questão agrária atual. (Org). FERNANDES, B. M. 1'a .ed. São Paulo: Expressão Popular, 2008.

. O agrohidronegócio no centro das disputas territoriais. In: Campo-

Território: Revista de Geografia Agrária, v.5, n.10, p. 92-122, ago. 2010.

ÚNICA. (UNIÃO NACIONAL DA INDÚSTRIA DE CANA-DE-AÇÚCAR). Produção e uso do etanol combustível no Brasil. São Paulo, 2007.

Disponível em www.unica.com.br. Acesso em setembro de 2013.

- Unica rebate estudo internacional que sugere expansão da cana sobre vegetação nativa. Disponível em www.unica.com.br. Acesso em abril de 2016.

VALEC. Ações e Programas - Ferrovias Valec. Disponível em http://www.valec.gov.br . Acesso em maio de 2014.

VIAN, C. E. F. Agroindústria canavieira: estratégias competitivas e modernização. São Paulo: Átomo, 2003.

VILLA VERDE, V. Territórios, Ruralidade e Desenvolvimento. Curitiba: Ipardes, 2004.

WAIBEL, L. Vegetação e o uso da Terra no Planalto Central. In: Revista Brasileira de Geografia. Rio de Janeiro, Ano X, n. 3, 1948.

As Zonas Pioneiras do Brasil. In: Revista Brasileira de Geografia. Rio de Janeiro, Ano XVII, n. 4, 1955. 


\section{APÊNDICES}

Apêndice 1 - Modelo de entrevista semi-estruturada para as usinas canavieiras.

Usina:

Município:

\section{Características da indústria (usina) e produção da cana:}

a) Data de implantação da usina:

b) Produtos da cana que produzem:

( ) Açúcar ( ) Etanol. Outro? (Qual?)

c) Qual a quantidade produzida de álcool e açúcar (a partir da safra 2006/07)?

d) Recebeu ou recebe auxílio de algum Programa/Projeto do Governo do estado de Goiás:

( ) FOMENTAR ( ) PRODUZIR ( ) Outros.

e) Sobre a colheita da cana, acontece de forma:

( ) Manual ( ) Mecanizada ( ) Ambas. Por favor, aproxime o percentual de cada uma?

f) Qual a quantidade aproximada de trabalhadores da usina?

g) Há trabalhadores migrantes na usina?

Quantos aproximadamente?

h) há alojamentos para os trabalhadores da usina no município?

i) Qual a estrutura de obtenção de terras para o cultivo da cana:
( ) Terras próprias da usina
( ) Arrendamento
( ) Terceiros

Aproxime o percentual de cada uma?

j) Quais os municípios vizinhos que participam da dinâmica de produção de cana para a usina? 
1) Se caso houver arrendamento como forma de obtenção de terras para o cultivo da cana, há estimativa do percentual de propriedades pequenas, médias e grandes que são arrendadas?

m) Destino da Produção (diferencie por favor, açúcar e etanol):

( ) Estado de Goiás . Vendido para quais cidades?

( ) Exportação.

Destino?

n) Há co-geração de energia através do bagaço / palha da cana?

( ) Não ( ) Sim. Autossuficiente ou há venda do excedente?

\section{Relação usina / dinâmica socioeconômica do município:}

a) Qual a perspectiva de geração de empregos diretos e indiretos no município pela usina?

b) A usina utiliza algum tipo de serviço terceirizado do município ou município vizinho/outros estados do Brasil?

( )Não ( ) Sim. Se sim, quais estados e municípios e quais serviços?

c) A usina utiliza serviços de manutenção de seus maquinários do município ou municípios vizinhos:

( ) Sim ( ) Não. Se não, esse serviço é realizado por outros estados do Brasil? Quais?

d) Existe relação entre a usina e o comércio local? A usina compra algum produto do comércio local ou vizinho?

( ) Não ( ) Sim.

Se sim, quais produtos?

e) Existe algum projeto social desenvolvido pela usina?

( ) Não ( ) Sim. Há parcerias, nesses projetos, com órgãos públicos e/ou privados? 
Por favor, especifique esses projetos?

Apêndice 2 - Modelo de entrevista semi-estruturada para municípios com usinas implantadas:

\section{Prefeitura do Município:}

1. Qual a principal atividade econômica do município? Pode-se dizer que é a atividade canavieira?

2. Como a atividade canavieira é vista hoje no município? Qual seu nível de importância? Está em ascenção ou crise no município?

3. O que foi alterado na infraestrutura da cidade após a implantação da usina? Que elementos surgiram na paisagem da cidade em função da usina? Serviços, comércio, bancos, etc?

4. Quais impactos, positivos e negativos, a prefeitura observa na cidade - campo e cidade - em decorrência dessa atividade? (aumento no preço dos aluguéis, alimentos, etc)

5. Ainda vêm trabalhadores de outros estados trabalharem na usina? A colheita ainda é manual?

6. A prefeitura tem os dados de estrutura fundiária? Qual percentual de arrendamentos, terras próprias da usina, etc?

7. Existe algum projeto social entre a usina e a prefeitura?

8. Quais as principais potencialidades e problemas do município? 
9. Há um discurso de progresso/desenvolvimento vinculado ao setor sucroenergético. Caso a usina fechasse hoje, como a prefeitura enxerga que ficaria a cidade em termos sócioeconômicos?

Apêndice 3 - Modelo de entrevista semi-estruturada com os municípios que possuem alta produção canavieira, mas não possuem usinas implantadas (Nova Glória, Santa Isabel e São Luiz do Norte)

\section{Município:}

1. Ao longo do tempo a região de Ceres foi se configurando como uma região ligada ao agronegócio sucroenergético. Como se encontra o município inserido nessa lógica/realidade?

2. Qual a relação do município dentro da lógica canavieira da região? Econômica, de produção de cana, trabalhadores da cana, logística, serviços, mercado, alojamento (os usineiros utilizam a infraestrutura do município)?

3. Quais as principais potencialidades e problemas do município? Essas potencialidades e problemas tem alguma relação, direta ou indireta, com a atividade canavieira?

4. Em termo econômicos o que a produção de cana retorna para o município? Impostos, a usina ou o Estado investe no município?

5. O quanto o município está vinculado a atividade canavieira? Em termos sociais (empregos, etc) e econômicos (produção de cana)? 
Apêndice 4 - Modelo de entrevista semi-estruturada para o município de Ceres (centralidade da CANG na década de 1940 e de serviços na Região atualmente)

\section{Município: CERES}

1. Fale um pouco sobre a formação histórica de Ceres, por meio da CANG?

2. Qual a importância da CANG para a formação da região de Ceres?

3. Quais os pontos positivos e negativos da implantação da CANG em Ceres?

4. A CANG teve início com o discurso da reforma agrária, com doação de lotes para os colonos, como isso foi se dando ao longo do tempo?

5. Ainda há algumas pessoas ou locais que guardem a memória da CANG? Material, livros ou fotos?

6. O que ficou na Ceres de hoje das colônias agrícolas? O que pode ter ficado materializado na paisagem da época da CANG?

7. O que tem hoje construído no lugar de implantação da CANG?

8. Ao longo do tempo a região de Ceres foi se configurando como uma região ligada ao agronegócio sucroenergético. Como Ceres ficou nesta realidade?

9. Qual a relação do município de Ceres dentro dessa lógica canavieira da região?

10. Econômica, de produção de cana, trabalhadores da cana, logistica, serviços e mercado e bancos (os usineiros utilizam a infraestrutura de Ceres)? 
11. Como está a relação IDH X PIB no município de Ceres? Quais os principais problemas e potencialidades do município?

12. Qual a importância hoje de Ceres para a microrregião Ceres? 